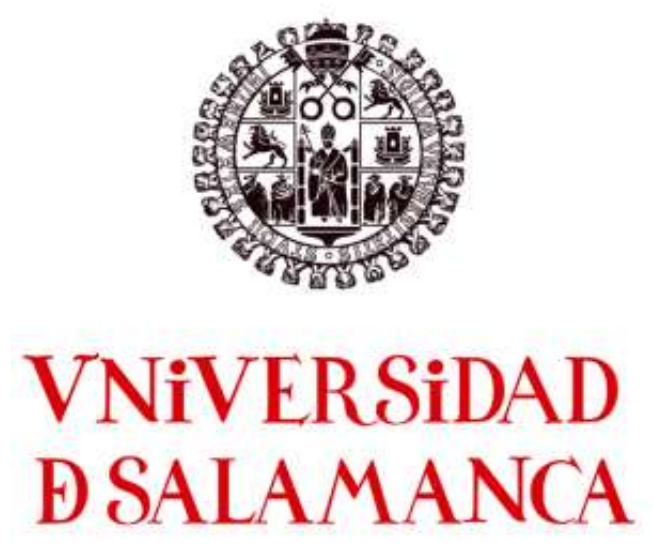

LA HORIZONTALIDAD DE LA MIRADA DE ORIENTE EN OCCIDENTE

(De la Construcción a la Composición del Espacio Pictórico)

Tesis Doctoral presentada por MARÍA DEL MAR SUEIRAS PRIETO

Dirigida por

MANUEL LUCA DE TENA NAVARRO 


\section{LA HORIZONTALIDAD DE LA MIRADA DE ORIENTE EN OCCIDENTE}

(De la Construcción a la Composición del Espacio Pictórico)

Tesis Doctoral presentada por:

María del Mar Sueiras Prieto

Universidad de Salamanca

Facultad de Bellas Artes

Departamento Historia del Arte-Bellas Artes

Director

Manuel Luca de Tena Navarro

Salamanca 2021 


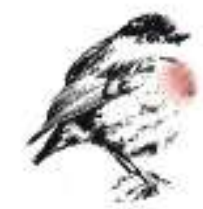


“¿Qué mundo tan extraño! Pocos se acuerdan de aquel “¡ah!” emocionado de que nos hablaba no hace mucho Joan Teixidor y que todos deberíamos poder y saber emitir cada día al abrir la ventana por la mañana. O de aquel canto de los pájaros con el que Picasso comparaba las obras de arte y que sería ridículo querer "dirigir" con teorías."

\footnotetext{
${ }^{1}$ Tàpies, Antoni, El arte contra la estética, Barcelona, 1986, p. 19.
} 


\section{ÍNDICE}

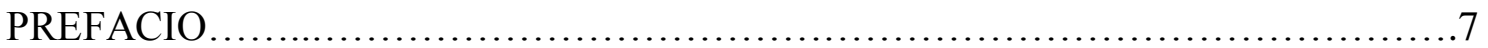

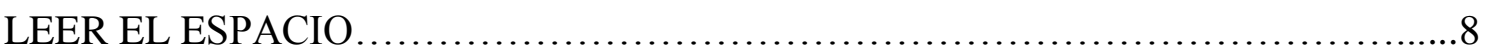

1.- CUESTIONES METODOLÓGICAS.......................................... 15

1.1.- Antecedentes y estado de la cuestión..................................17

1.2.- Definición del Problema............................................ 18

1.3.- Objetivos del estudio ............................................20

1.4.- Hipótesis y Variables............................................23

1.5.- Metodología.....................................................25

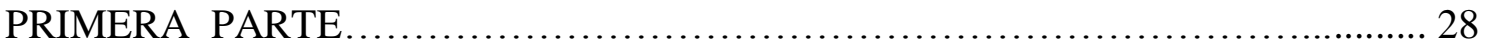

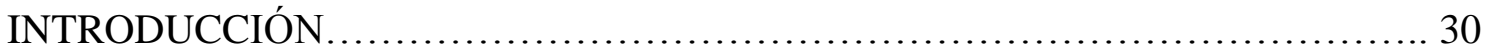

LA ACTIVIDAD DE LA MIRADA............................................. 31

EL ESPACIO PICTÓRICO EXTREMO ORIENTAL Y EUROPEO: Una comparativa entre la noción de Horizonte y de Horizontalidad.....................................40

2.- UNA APROXIMACIÓN A LA COMPRENSIÓN DEL ESPACIO PICTÓRICO...45

2.1.- .- La Gramática Visual del Arte: Cultura Estética y Valores Culturales en el Extremo Oriente y en Occidente.......................................55

2.2.- I, II, III como paradigma del sistema vertical de la cosmovisión occidental

.3.- - (1), 二 (2), 三 (3) como paradigma del sistema horizontal de la cosmovisión extremo oriental.................................................66

3.-LA TEORÍA COGNITIVA DE LA MIRADA................................... 74

3.1.- La Representación del espacio. La dimensión mensurable del espacio de la pintura de la edad moderna europea...................................78

3.1.2.- Perspectiva: La teoría científica de la visión. Los Dípticos y Trípticos en la pintura europea.

3.2.- La Composición del espacio. La dimensión temporal del espacio pictórico

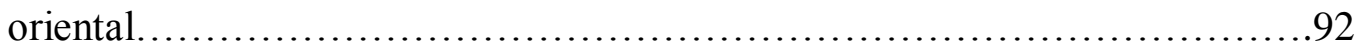


3.2.1.- Narración Continua: La teoría intuitiva de la mirada. Del emakimono (絵

巻物) a los biôbu (屏風) 99

APÉNDICE DE IMÁGENES................................................. 110

SEGUNDA PARTE...................................................... 138

LA IMAGEN Y SU SINTAXIS ............................................ 139

4.- LA FORMA Y EL CONTEXTO (formas simbólicas)..........................146

4.1.- Nuevos sistemas de representación.................................152

4.2.- Claude Monet y las Ninfeas................................................................161

4.3.- Las Neovanguardias americanas .................................... 173

5.- LOS DÍPTICOS, TRÍPTICOS Y POLÍPTICOS EN LA PINTURA.................188

5.1.- La Tradición: Francis Bacon y Hiroshi Senju............................195

FRANCIS BACON/HIROSHI SENJU .................................198

Francis Bacon...................................................... 199

Hiroshi Senju..................................................... 206

5.2.- La Narración Continua en la obra de Cy. Twombly, Joan Mitchel, Antoni Tàpies......................................................... 213

Cy TWOMBLY, JOAN MITCHELL, ANTONI TÀPIES................... 215

Cy. Twombly. Obras .................................................. 216

Joan Mitchell. Obras........................................................ 221

Antoni Tàpies. Obras...................................................... 229

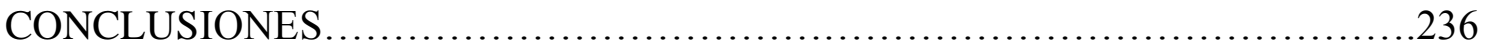

APÉNDICE DE IMÁGENES ..................................................245

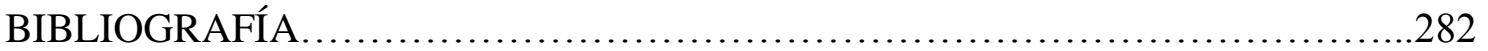

Bibliografía general de arte...........................................283

Bibliografía sobre arte oriental........................................286

Bibliografía sobre pintura contemporánea.................................293 
A los que están y permanecen... a los que se fueron y siempre quedarán.

Mi eterna gratitud. 
PREFACIO 
"Por la pintura circulan sin cesar códigos de reconocimiento y la historia del arte ha de tener estos en cuenta. El espectador es un intérprete, y el asunto es que puesto que la interpretación cambia conforma cambia la realidad, la historia del arte no puede pretender un conocimiento definitivo o absoluto de su objeto $[\ldots]^{2,}$

\section{LEER EL ESPACIO}

- Qué es la pintura? ¿Cómo se comprende en ella el espacio? En el sistema identitario contemporáneo ¿cuál es su relación con la tradición en la percepción? El espacio pictórico está sujeto a unos códigos sociales de representación y reconocimiento. Más que como una dimensión mensurable del tema representado se comprende como un asunto relacionado con la percepción y, por lo tanto, con la relación que se establece entre el sujeto y el mundo. Por eso, como señala Bryson, no podemos solo decir que vemos, sino que culturalmente reconocemos ${ }^{3}$. A partir de esta afirmación y tomando como referencia las primeras preguntas claves, he desarrollado mis dos proyectos actuales - esta tesis doctoral y un proyecto pictórico - esgrimiendo para ambos la siguiente hipótesis principal: la influencia de la pintura de Asia Oriental ha sido un factor clave para el cambio de paradigma en la comprensión del espacio de la pintura contemporánea.

¿Por qué, desde diversas culturas y periodos de la historia, se ha comprendido el espacio pictórico de manera tan distinta? aunque, a pesar de la certeza que subyace bajo esta interrogante, el tiempo nos ha demostrado que no todo son diferencias. ¿Puede sólo ser casualidad las coincidencias en la resolución del problema del espacio de algunas manifestaciones pictóricas, realizadas en contextos culturales diferentes y en distintos

\footnotetext{
${ }^{2}$ Bryson, Norman, Visión y Pintura. La lógica de la mirada, Madrid, 1991, p. 15.

${ }^{3}$ Véase, Bryson, Norman, Visión y Pintura. La lógica de la mirada, Madrid: Alianza Editorial, S.A. 1991.
} 
períodos de la historia? ¿Puede ser aleatoria esta circunstancia? Lo cierto es que el Arte precisa de un ajuste sensorial que depende de unos factores psicológicos y de un contexto cultural que en su conjunto son los que en gran parte le dan forma. Una tarea que persigue visibilizar el mundo mediante la creación de imágenes, es decir, mediante una representación que está sujeta a unos códigos que rigen a su vez el conjunto de normas sobre las que en mayor o menor medida se estructura la forma artística. Porque, como bien señala Francastel:

[...] Se ha podido decir justamente que todas las obras de arte, todos los objetos de civilización de la historia, constituían los archivos del mensaje o de la acción humanos. Va implícito que, como tales, ellos están determinados por un sistema de ideas y de lenguaje localizado en el espacio y el tiempo y que este sistema no constituye una construcción gratuita, sino que corresponde a un cierto tipo de civilización, es decir, a una manera de abordar y de resolver los problemas de la condición humana $[\ldots]^{4}$.

Efectivamente, el Arte precisa de un ajuste sensorial directamente relacionado con ese contexto cultural que le da forma y que, a decir de Heidegger ${ }^{5}$, transita entre lo presente y lo ausente. En concreto para este estudio, entre la presencia explícita de la representación del espacio de la pintura moderna de Occidente y la inmanente de la pintura extremo oriental ${ }^{6}$. Porque, el Arte precisa de un ajuste de las percepciones que en el contexto de la idea de un pensamiento rememorante - trata de borrar, o al menos de suavizar, esa sutil línea que separa al objeto del sujeto, ideando para ello una retórica capaz de invocar aquella presencia que se encuentra implícita siempre en el origen de una representación. Una tautología al fin y al cabo con la que, en particular la pintura lejos de limitarse a una mera representación - trata de dar vida y emoción a todo cuanto está representado. Tal vez por eso se pueda entender el Arte como la expresión de una sensibilidad que depende en mayor o menor medida del contexto cultural en el que se origina y que - como tal manifestación cultural - conforma el leguaje sensible del que se sirve una sociedad, aunque - a decir de Fenollosa - puesto que "ninguna civilización es un fenómeno aislado" es necesario entender este arte desde la riqueza que nos ofrece toda diversidad y todo pluralismo social e individual. Así “[...] Los orígenes de cualquier civilización están envueltos en un manto de misterio y, por poco que nos remontemos en el tiempo, nos abismamos desde la atalaya de lo conocido a la densa niebla de lo ignoto [...]" de manera que, los fenómenos "[...] que parecen desconectados, manifestaciones artísticas atribuidas a la evolución paralela son causadas, en realidad, por contactos subterráneos, rutas migratorias ancestrales, inverosímiles vías comerciales"7.

\footnotetext{
${ }^{4}$ Francastel, Pierre, Sociología del arte, Madrid, 1984, p. 28.

${ }^{5}$ Véase Cortés, Helena y Leyte, Arturo, trans : Heidegger, Martin, Caminos de bosque, Madrid, 1996.

6 Énfasis propio.

${ }^{7}$ Fenollosa, Ernest, Introducción a la Cultura China, 2011, p.13.
} 
Desde Occidente, se ha dicho en numerosas ocasiones que el arte es un espejo en una alusión directa a Leonardo y su Trattato - puesto que "[...] las obras de arte no son solo espejos, pero comparten con los espejos esa inaprehensible magia de transformación, tan difícil de expresar en palabras [...]"8. Efectivamente, para algunos un espejo del artista y de la sociedad o contexto en el que se origina, para otros un medio que permite calibrar la catadura psíquica del hombre y de su época. Pero más allá de aquella primera dimensión especular o de la otra comprensión más empírica - que se basa en el razonamiento de los hechos para un análisis social - necesitamos comprender que el arte es, además, un emocionado ejercicio de la memoria. El registro de una serie variada de factores de índole psicológico, histórico, filosófico y social que nos permiten dilucidar que miramos con la memoria. Así, en la imagen pictórica - como en una cápsula del tiempo - se condensa una experiencia y, por lo tanto, también un proceso. Es decir, se evoca un tiempo y un espacio representado - real o imaginado - al tiempo que - como tal proceso - se evoca el momento en el que se ha realizado, conllevando igualmente un tiempo determinado para su contemplación. Descrito en palabras de Francastel,

[...] La inserción del tiempo en la visión implica la intervención de la memoria. Pero esta memoria posee un carácter diferente de aquel que se acuerda habitualmente a la reminiscencia o al recuerdo de acontecimientos del pasado. Se trata, por así decirlo, de una memoria actual, inmediata, y de una micro-memoria, más exactamente de una memoria donde el tiempo interviene a velocidad fenomenológica y no histórica o simplemente consciente $[\ldots]^{9}$.

Esto tal vez explica por qué, al buscar en la realidad de un cuadro - como en la realidad de la memoria - encontramos una contradicción temporal entre el tiempo presente de quien mira y la inmanencia del tiempo que se representa. Un paradójico juego temporal que de la misma manera parece relacionar la memoria de la pintura contemporánea con el olvido voluntario de gran parte de la tradición del arte occidental, donde el espacio ha dejado de ser la mímesis de una dimensión para convertirse una percepción más intuitiva de esta. Y es que el arte no es un acontecimiento estático sino que, por el contrario, es un proceso y como tal es dinámico - fluctúa como resultado de los vaivenes de la sociedad y de su época - y está sujeto a los caprichos de las influencias foráneas tanto como a la ruptura y consecuente revisión de la tradición que supone el descubrimiento de cualquier novedad. Por ello, la manera de comprender, representar y contemplar el espacio en la pintura nos dice tanto de una obra y, al mismo tiempo, de una sociedad. Entendemos entonces que, como bien indica Bryson, “[...] la realidad experimentada por los seres humanos es siempre producida históricamente: no existe una Realidad transcendente y naturalmente dada". En este contexto, como indica

\footnotetext{
${ }^{8}$ Gombrich, E.H, Arte e Ilusión. Estudio sobre la psicología de la representación pictórica, Barcelona, 1979, p. 21.

${ }^{9}$ Francastel, Pierre, Sociología del arte, Madrid, 1984, pp.49-50.
} 
este autor, es preciso comprender la imagen como un "[...] vehículo para la expresión de lo que una determinada comunidad visual conoce como realidad. El término 'realismo' no puede, por tanto, referirse a una concepción absoluta de 'lo real', porque tal concepción no puede dar cuenta del carácter histórico y cambiante de 'lo real' dentro de los diferentes periodos culturales".

[...] sería más exacto decir que "realismo" consiste en la coincidencia entre una representación y lo que una determinada sociedad propone y supone como realidad: una realidad que implica un complejo agregado de códigos de comportamiento, leyes, psicologías, usos sociales, modas, gestos, actitudes, todas aquellas normas prácticas que gobiernan la instalación del ser humano en su particular entorno histórico $[\ldots]^{10}$.

Al hilo de esta idea observamos cómo durante el Renacimiento y la Edad Moderna en Europa la pintura ha estado permanentemente sujeta a una misma realidad; es decir, a un mismo patrón visual. A pesar de las diferentes corrientes estilísticas que se habían adoptado - asimilando recursos artísticos y valores estéticos propios y ajenos - se conservó invariable el mismo sistema de representación que la mantuvo encorsetada durante un periodo que, desde el Renacimiento hasta finales del siglo XIX, se impuso y se mantuvo. Un aspecto sobre el que ya hace hincapié Francastel en el libro Sociología del arte.

[...] Durante este periodo, habitaron un cierto espacio, físico, geográfico, imaginativo, sometido a leyes fijas de representación. Pudieron cambiar las leyendas, pudieron acentuar tal o cual parte nueva de la técnica, pero sin dejar nunca de aceptar esas leyes fundamentales que he tratado de recordar en lo que concierne a la pintura. $\mathrm{Y}$ es un hecho que en determinado momento este sistema, basado en un cierto equilibrio entre las ideas y los signos figurativos, se quebró. Los artistas y su público se encontraron, entonces, hablando con propiedad, fuera del espacio plástico tradicional ${ }^{11}$.

Una manera de mirar - hasta entonces nunca cuestionada - cuya quiebra ha supuesto la revisión de la tradición de una secular comprensión del espacio pictórico, retomando desde ese momento planteamientos que por la época estaban considerados como más arcaicos y hasta incluso primitivos ${ }^{12}$. Un cisma de la mirada que ha supuesto para la pintura un ejercicio necesario de la memoria. Pero ¿podemos fundamentar este cambio solo en el retorno a las antiguas leyes de representación? Lo cierto es que en el origen y las consecuencias del giro que se ha producido en la comprensión del espacio pictórico - de esta crisis que ha tocado los que parecían inamovibles cimientos del arte occidental - parece que no solo se encuentra la recuperación o redescubrimiento del pasado visual europeo. Por el contrario, el cambio en el paradigma de la representación

\footnotetext{
${ }^{10}$ Bryson, Norman, Visión y Pintura. La lógica de la mirada. Madrid, 1991, p. 31.

${ }^{11}$ Francastel, Pierre, Sociología del arte, Madrid, 1984, p. 157.

${ }^{12}$ Énfasis propio.
} 
del espacio pictórico ha sido, sobre todo, el resultado de la influencia que supuso el descubrimiento del arte de otras culturas y que, a nuestro juicio ¿fue en particular de la pintura china y sobre todo de la japonesa? Una disquisición sobre la que, en definitiva, girará esta investigación.

Efectivamente, parece que este descubrimiento ha supuesto para la pintura contemporánea la adopción de una serie de recursos artísticos y - aunque de calado mucho más lento - de valores estéticos que han derivado en un nuevo, sutil y más rico lenguaje expresivo. Porque, al fin y al cabo, el arte es un palimpsesto que se hace y se deshace, abandonando, retomando e incluso adoptando o reinventando caminos ya trazados, para crear una ambigua cartografía que llega mucho más allá de la semiótica de cualquier lenguaje artístico: es decir, más allá de la creación, de la contemplación y de la experimentación. Tres prácticas que se encuentran, cómo no, en el origen y condición polisémica de la pintura y que también nos permiten transcender su condición ontológica. En este sentido, en este estudio nos interrogaremos sobre las diferentes formas de representación del espacio pictórico - y en consecuencia sobre distintas actitudes para su contemplación - y la relación de todo ello con las diferentes teorías elaboradas en la actualidad sobre la imagen y sus condicionantes culturales.

Sobre cuáles fueron las condiciones en las que se produce este cambio; en qué medida han influido en las ideas de la pintura de la modernidad - en la nueva comprensión del espacio pictórico - y en la recuperación de los dípticos y trípticos para la pintura contemporánea tras el abandono de la perspectiva, se centrará nuestra investigación. Siguiendo estas premisas, esta tesis se cuestiona sobre la nueva comprensión del espacio en la pintura contemporánea, surgido tras el abandono de la perspectiva y la adopción y puesta en práctica del llamado Principio de la Narración Gráfica Continua o Foco Móvil característico de la pintura de Asia Oriental. Pero, llegados a este punto, ha sido preciso insistir sobre el evidente paralelismo encontrado entre la distribución espacial de muchas de las obras abstractas de las neovanguardias americanas - y posteriores - y de las pinturas de los biombos y otros soportes utilizados en Asia Oriental. Por eso, en esta investigación proponemos analizar estas coincidencias, interrogándonos sobre su posible relación con la recuperación de los polípticos como recurso visual y estrategia artística para la pintura contemporánea. Una similitud o coincidencia que, a pesar de la complejidad que implica su verificación o refutación ¿podría evidenciar esta relación?

Una investigación cuyo objetivo no solo es realizar un estudio cronológico e históricamente pormenorizado de la Historia del Arte de una determinada época o cultura - aunque es indudable que se requieren fuentes y datos históricos para su contextualización y argumentación - sino que pretende ampliar algunas nociones sobre una problemática que atañe particularmente a la comprensión del espacio pictórico - y por lo tanto de la mirada - y que nos desvelará, por lo tanto, su implicación como condicionante cultural. Para ello, en esta investigación pretendemos ampliar más que cerrar unas nociones sobre la evolución del espacio en la pintura para, en palabras de 
Bryson, estudiarlo como el "registro de una percepción explicándolo desde su dimensión social, es decir desde la imagen y su realidad como signo"13. Porque, como afirmaba Francastel,"el problema del espacio es doble. Exige que se tenga en cuenta, a la vez lo que se representa y la manera en que se representa"14.

[...] Pero introducir la historia en la descripción del espectador es como el riesgo de producir una historia del arte determinista en que se da por supuesto que una cierta base social engendrará una cierta superestructura como impronta o reflejo ideológico. De hecho, la historia social del arte se ha hecho en esos términos de causalidad $[\ldots]$

Lo que tenemos que entender es que en el acto de reconocimiento que la pintura galvaniza el significado es producido, más que percibido. La actividad del espectador es la de transformar el material de la pintura en significados y esa transformación es perpetua: nada puede detenerla ${ }^{15}$.

Una investigación cuya estructura y posterior desarrollo se encuentra totalmente alejada de la idea de compartimentos estancos. Al contrario; teoría y obras, textos e imágenes, se encuentran y conectan como una caja de resonancia para, así, ayudarnos a comprender las teorías estéticas de la contemporaneidad. Por eso, como en un flash back, en esta tesis retomaremos el fenómeno visual de la narración gráfica continua para enlazarlo con la comprensión del espacio en la pintura contemporánea. Un déjà vu, al fin y al cabo, al que podríamos calificar de historicista - porque la historia forma parte de cualquier posible estudio o teoría relacionada con la cultura - pero que, en cualquier caso, no persigue reducirse a una estricta relación causa - efecto.

Una tesis, en definitiva, donde elucidaremos sobre la dialéctica que se establece entre la mirada, el espacio pictórico y sus diferentes modos de representación y contemplación. Sobre la implicación que supone la realidad ausente de quien mira que, en el contexto de la pintura contemporánea - tras el rechazo y parcial abandono de la perspectiva - ha dado lugar a una comprensión de un espacio pictórico más intuitivo y lírico. Un estudio - y esto es importante - donde cada apartado se comprenda mirando a la otra cultura para que, de esta manera - si ambas se contemplan desde una cierta distancia cultural - nos resulte más sencillo comprenderlas como unidad," [...] sin que una parezca más o menos valiosa que la otra. Sólo así se soslayará, o en todo caso se limitará, el de otro modo inevitable etnocentrismo que desde hace tiempo caracteriza a la mirada occidental cuando contempla otras culturas [... $]^{\prime 16}$. De esta manera, las líneas de la investigación podrán cambiar de punto de vista, realizando unos cambios de óptica que nos permitirán comprender el tema desde ángulos distintos. Por eso recurriremos a las comparaciones como un medio para realizar un estudio sobre culturas en apariencia

\footnotetext{
${ }^{13}$ Bryson, Norman, Visión y Pintura. La lógica de la mirada, Madrid, 1991, p. 14.

${ }^{14}$ Francastel, Pierre, Sociología del arte, Madrid, 1984, p. 172.

${ }^{15}$ Ibídem, p. 15.

${ }^{16}$ Belting, Hans, Florencia y Bagdad: Una historia de la mirada entre Oriente y Occidente, Madrid, 2012, p. 10.
} 
tan dispares como las orientales y las occidentales, aunque cuestionando la validez de esta binaridad en las relaciones actuales. En este sentido, se recurrirá a nociones tales como diferencias y confluencias para, de este modo, poder describir más acertadamente el encuentro de cada cultura comparada; un enfoque que, a nuestro juicio, hará sin duda este estudio mucho más interesante ${ }^{17}$.

Así, hablando tanto de elementos comunes como de diferencias podremos acercar ambas culturas, partiendo siempre de la base de un concepto de cultura que no esté entendido como una idea de enfrentamiento cultural. No obstante, inevitablemente nos encontraremos con un amplio y variado espectro de referencias culturales para las que - para no ser generalista - precisaremos de un hilo conductor que las conecte y sirva de apoyo. En esta tesitura, sin querer ser prejuicioso, es necesario señalar que aunque puedan parecernos tópicas las continuas alusiones al Extremo Oriente y Occidente, estas nos ayudarán a distinguir el asunto del que se va a tratar. En definitiva, entender las diferencias como un juego de posibilidades que enriquezcan la singularidad de ambas culturas para, de este modo, superar el remanente que aún nos queda de aquel absolutista pensamiento eurocentrista que se impuso durante el periodo colonial. Porque, todos los fenómenos culturales son, al fin y al cabo, fenómenos locales potencialmente globales, por lo que para su comprensión y estudio necesitamos, en palabras de Frazer "[...] descubrir el camino seguido por el pensamiento que fundamenta la práctica del arte, [...] desenredar los hilos que en reducido número forman la embrollada madeja; aislar los principios abstractos de sus aplicaciones concretas; en suma, discernir la ciencia espuria tras el arte bastardo" $" 18$.

\footnotetext{
${ }^{17}$ Énfasis propio.

${ }^{18}$ Frazer, G.F, La Rama Dorada. Magia y Religión, México, D.F, 2014, p. 24.
} 


\section{1.- CUESTIONES METODOLÓGICAS}

$\mathrm{E}$

1 fundamento y principal propósito de esta tesis es plantear un estudio que nos permita investigar los posibles condicionantes culturales que los soportes de la pintura hayan podido tener y su repercusión en la construcción simbólica del espacio pictórico - desde su naturaleza y su alcance -, utilizando para su análisis una metodología ajena a cualquier juicio de valor. Por ello, en su esencia hemos querido hacer una reflexión sobre las distintas interpretaciones culturales a las que inevitablemente está abocada la mirada, para detenernos en la experiencia física del espacio pictórico contemporáneo a la luz del encuentro del arte del Extremo Oriente y el europeo. Es decir que, más allá de buscar un enfoque oriental u occidental, se ha querido comprender cómo, en la confluencia de estas dos maneras distintas de comprender el espacio en la pintura, se ha llegado a la comprensión espacial de la pintura contemporánea donde estas gregarias diferencias ya no están delimitadas. En cualquier caso, aunque no se trata de realizar una distinción entre espacio y mirada ambos aspectos no se pueden considerar separados - el foco de atención del presente estudio recaerá en el espacio, en sus diferentes modos de representación y de contemplación y en el papel que en todo ello juega la cultura.

Desde mi propia experiencia personal, he podido comprobar cómo los estudios sobre Arte y Estética abordan la cuestión artística desde un análisis cultural que obvia cualquier consideración ajena a los patrones de las corrientes artísticas occidentales. Unas consideraciones que - desde la filosofía hasta las diferentes prácticas artísticas conforman el sustrato sobre el que se estructuran las diferentes teorías estéticas del arte europeo en general y han sido, en gran medida, el fundamento de la pintura moderna europea en particular. No obstante, con demasiada frecuencia se olvida que la diversidad es una condición implícita en el origen de nuestra creatividad, por lo que 
debemos tener presente que a pesar de nuestra actual globalización no se puede hablar de una homogeneidad cultural. Es por este motivo por el que, previamente, para poder realizar una crítica o un análisis sobre los diferentes discursos que nos ofrece la pintura contemporánea - y superando nuestros secular eurocentrismo - necesitamos conocer los distintos valores que sobre arte y estética ha ido adoptando de diferentes pueblos y culturas. Es decir, como se han ido recuperando recursos del arte considerados primitivos $^{19}$ dentro del mismo seno de Europa o, como en el caso de este estudio, de lugares tan distantes como Japón, China y el Extremo Oriente en general.

$\mathrm{Y}$ es que, si para comprender una determinada cultura resulta imprescindible conocer los factores ambientales e históricos - así como la tradición filosófica y religiosa - de las sociedades que la conforman, para entender una forma necesitamos contextualizarla para llegar a comprender su significado, como transmisora de una serie de valores culturales que le dan sentido a la vez que ella los elabora y también transmite. Por este motivo, para articular nuestra investigación recurriremos a una dicotomía o, lo que es lo mismo, a un estudio comparado entre el modelo de la mirada occidental y la técnica de la perspectiva - donde, mediante una representación científica, las líneas de los rayos visuales convergen en un único punto de fuga que se encuentra en la línea del horizonte - y el modelo de la mirada oriental y el recurso visual del foco móvil o principio de la narración gráfica continua - donde las líneas de los rayos visuales convergen en el ojo del espectador favoreciendo un desplazamiento de la mirada al contemplar una imagen y logrando, así, la comprensión de lo que Belting ha denominado "espacio narrativo" ". Lo que se puede denominar como una narración continua que transciende y se extiende, superando el espacio pictórico, y prolongando la narración más allá de los límites de la obra.

[...] la narración se propaga en varias etapas más allá de la imagen, pues estas utilizan un "espacio narrativo", que no debe confundirse con un espacio arquitectónico o natural [...] Lo conocemos como "principio de la narración gráfica continua", que no necesita atenerse a la moderna unidad del espacio y el tiempo subyacente en la perspectiva ${ }^{21}$.

Una investigación que - para comprenderla más fácilmente - establece una serie de relaciones holísticas entre los aspectos objetivos y subjetivos de la pintura, realizando para ello un recorrido que nos permitirá pasar de la globalidad a la particularidad y que, mediante la descripción de lo visible - y a través de las diferencias, semejanzas y de las relaciones - nos ayudará a descubrir las distintas vías internas subyacentes en el espacio pictórico. Pero además, proponemos otro punto de vista sobre la que se ha dado en llamar crisis de la mirada ${ }^{22}$, sobre cómo el espacio pictórico ha devenido en abstracto y sobre cómo - y en consecuencia - al perder este toda relación

\footnotetext{
${ }^{19}$ Énfasis propio.

${ }^{20}$ Belting, Hans, Florencia y Bagdad: Una historia de la mirada entre Oriente y Occidente, Madrid, 2012, p. 70.

${ }^{21}$ Ibídem, p. 70.

${ }^{22}$ Énfasis propio.
} 
con la observación real ha provocado lo que ha sido considerado como una crisis en el seno de la pintura.

Una problemática cuya investigación nos llevará - mediante la comparación y el acercamiento - a interrogarnos sobre la cuestión de la mirada y sobre la representación de un espacio pictórico que, tradicionalmente, ha sido muy diferente en Occidente y en el Extremo Oriente. Por eso, más allá de proponer certezas ya mitificadas sobre la experiencia de Oriente y sus artistas, para desarrollar la investigación partiremos de una serie de interrogantes, tales como ¿Se pueden comprender las prácticas de Oriente con los ojos de Occidente? ¿Se puede restringir lo problematizado a presupuestos culturales?

\section{1.- Antecedentes y Estado de la Cuestión}

El nexo de toda esta investigación se encuentra en el conjunto de pinturas de Los Nenúfares de Claude Monet, planteadas y expuestas como una banda continua horizontal. En este proyecto pictórico se ha eliminado física y conceptualmente el recurso del horizonte - desde el punto de vista de la mirada occidental - dando lugar así a unos campos de color, compuestos por sutiles matices, que se desenvuelven mediante el desarrollo horizontal de una secuencia móvil.

Esta nueva manera de concebir la superficie pictórica, a nuestro juicio, terminará por ejercer una influencia definitiva sobre los pintores abstractos de las neovanguardias americanas y, además, será la inspiración y punto de partida para las pinturas a gran escala y el estilo color field de muchas de sus obras. Una incorporación del denominado Foco Móvil o Principio de la Narración Gráfica Continua que facilita el desarrollo horizontal de la obra y que podría estar en el origen de la recuperación para la pintura occidental de los dípticos, trípticos y de los polípticos compuestos por más de tres paneles.

En este contexto debemos destacar que la novedad que supuso para la pintura europea la nueva comprensión del espacio representado en las Nymphéas de Monet, ha sido transcender la percepción espacial de la pintura occidental - dogmatizada hasta entonces por la perspectiva - para recrear una sucesión de superficies bidimensionales que se resuelven mediante una secuencia horizontal. Una idea de foco móvil que ¿es posible que conociese Monet a través de los emakimono y byôbu japoneses? ¿Un tipo de representación heredado de los panoramas y cicloramas del siglo XIX? Es decir, una herencia de la otrora herencia oriental - permítaseme este juego de palabras - de estas 
peculiares representaciones que estaban a medio camino entre el espectáculo y el arte. Una estrategia artística a caballo entre el ciclorama y el panorama que por otra parte, parece ser, estaban de moda por entonces y a las que recurrieron otros pintores de la época, como constatan los proyectos que Sorolla y Casas realizaron en Nueva York y Barcelona respectivamente a principios del pasado siglo XX. Pero, a diferencia de estos, en sus Nenúfares Monet concibió el espacio pictórico como una secuencia horizontal, apoyándose para ello en el formato apaisado de unos lienzos que hacían así más fácil su lectura $^{23}$. Una novedad soterradamente revolucionaria que dejó además una notable huella en los grupos de artistas Simbolistas, Postimpresionistas y Nabis.

Efectivamente, Claude Monet proyectará el diseño de la habitación oval de la Orangerie para exponer sus pinturas, yuxtaponiendo una serie de cuadros - sobre el tema del estanque de su jardín japonés - como una banda horizontal continua que envuelve al espectador mientras los contempla. Un conjunto de pinturas que, como una bisagra, articularán nuestra investigación, permitiéndonos interrelacionar la posible influencia que haya podido ejercer sobre estas la comprensión espacial de la pintura oriental y - a través de ellas - la influencia que esta última haya podido ejerce sobre los pintores de las neovanguardias americanas en particular y sobre los de la segunda mitad del siglo $\mathrm{XX}$ en general para, después, indagar sobre sus huellas en los polípticos de Cy Twombly, Antoni Tàpies y Joan Mitchell, todos ellos pintores coetáneos.

\section{2.- Definición del Problema}

La hegemonía de los medios de comunicación de masas - principalmente de la televisión y prensa escrita - ha sido, en gran medida, un vehículo para la globalización de la perspectiva y, por consiguiente, para una actualidad homogeneizada en lo que se refiere a los usos de la imagen ${ }^{24}$. Una actividad de la mirada que, sin embargo, tradicionalmente ha tenido un cariz muy diferente en el Extremo Oriente y en Occidente. He aquí, pues, una problemática que - en su relación con la imagen - atañe a dos culturas: a sus actuales y mutuas influencias y, así mismo, a las influencias que sobre cada una de ellas haya podido tener las particularidades de su idiosincrasia, especialmente en su relación con el arte y la filosofía. Una serie de distinciones culturales que en este estudio en general se han centrado en el tema de la imagen

\footnotetext{
${ }^{23}$ Énfasis propio.

${ }^{24}$ Véase Belting, Hans, Florencia y Bagdad: Una historia de la mirada entre Oriente y Occidente, Madrid: Akal /Estudios Visuales, 2012.
} 
pictórica y, en particular, sobre su comprensión espacial. Sobre la práctica social implícita en su concepción, representación y contemplación, que establece unas diferencias culturales que, en el caso de Occidente - tras el desarrollo del sistema de representación en perspectiva - trocó la cultura visual de toda una época, dando lugar con ello a esa idea tan occidental de la pintura como una actividad intelectual que hizo suya una teoría matemática de la percepción visual.

Así, en este estudio reflexionaremos sobre aquellas circunstancias que nos han permitido elaborar la hipótesis principal y las secundarias de la investigación - además de sus consiguientes variables - lo que nos avocará necesariamente hacia una retrospectiva histórica. Esto nos permitirá estudiar no sólo cómo, cuánto y donde contra los hábitos visuales y filosóficos del Extremo Oriente - se impuso la enseñanza y difusión de la perspectiva por parte de la política colonialista y de las órdenes religiosas europeas; sino también cómo, cuándo y dónde se estableció la verdadera influencia de la estética oriental en general y japonesa en particular sobre la pintura occidental. Es decir, realizar un estudio sobre el origen de unos gregarios límites culturales que durante generaciones, además de significar o identificar, han dogmatizado las distintas maneras de mirar.

Por otra parte debemos insistir en que, como se ha señalado anteriormente, para el desarrollo de esta tesis - y para comprender nuestra actualidad artística globalizada se ha necesitado recurrir a unas determinadas comparaciones culturales que en ningún momento han considerado ninguna cultura la luz de la otra sino que, por el contrario, han querido equipararlas. Con ello, como ha dicho Belting, hemos querido dar a esta investigación un enfoque que ha buscado "[...] comprender ambas culturas en su singularidad en vez de aumentar aún más su separación [...]" para de esta manera convertir las diferencias en "[...] una ocasión para la interpretación. Pero la interpretación presupone que no se considere la cultura occidental como cultura universal ni se reduzcan todas las demás culturas a un estatus local $[\ldots]^{\natural 25}$. Por consiguiente, como bien señala el autor, hemos colocado "[...] ambas culturas una junto a otra a la misma altura de visión, sin que una parezca más o menos valiosa que la otra $[\ldots]^{\prime 26}$ para así poder realizar este estudio y elaborar una teoría sobre la imagen y su representación espacial, la cual precisa - además de un sujeto incluido en el proceso de la mirada - de los condicionantes culturales que se presuponen en el proceso. De este modo - desde el momento en el que en nuestra contemporaneidad se significan lo que Belting denomina "zonas limítrofes y elementos comunes" ${ }^{\text {,2 }}$ - necesitamos señalar las diferencias que se encuentran en el origen de nuestro patrimonio global, para plantear esta investigación desde la diversidad y el pluralismo - indagando sobre todas aquellas distinciones necesarias para una articulación cultural - y estableciendo, así, un diálogo flexible y permeable con otras culturas. A decir de este autor:

\footnotetext{
${ }^{25}$ Belting, Hans, Florencia Bagdad:Una Historia de la Mirada entre Oriente y Occidente, Madrid, 2012, p. 217.

${ }^{26}$ Ibídem, p. 10

${ }^{27}$ Ibídem, p. 11.
} 
[...] El filósofo Régis Debray ha calificado recientemente el diálogo entre las culturas de "mito de nuestro tiempo" 28 . Aunque la ciencia y la técnica puedan moldear nuestro mundo común, "la cultura es un lugar natural de confrontación, pues es una forja de identidades y supone un mínimo de disensión”. Debray considera hoy más necesario que nunca abrir puertas y derribar muros hechos de prejuicios. Pero la máxima comunidad posible no constituiría un punto controvertido, pues sólo la diversidad podría preservarnos de los malentendidos ${ }^{29}$.

\section{3.- Objetivos del Estudio}

En este contexto, nos interrogamos sobre ¿cómo y cuánto, la nueva comprensión del espacio que ha venido a sustituir a la perspectiva ha podido definir el ámbito en el que se despliega la pintura contemporánea y ha enriquecido, a decir de Francastel, “[...] la visión y la representación plástica del espacio mediante la introducción de una cuarta dimensión, yuxtaposición, etc. [...] "30 ${ }^{3}$ Y Y, en ese caso ¿cómo, cuánto y donde se ha adoptado la estrategia visual de la narración continua o foco móvil característico de la pintura de Asia Oriental? Una novedad en Occidente, sustentada en un viejo recurso, que precisa de un desglose del espacio pictórico, recurriendo para ello a formatos horizontales o a la yuxtaposición de un número determinado de soportes ¿Una coincidencia con la recuperación para la pintura contemporánea de los dípticos, trípticos y polípticos de más de tres paneles?

Por consiguiente, con esta investigación hemos querido arrojar un poco de luz sobre las diferencias entre la manera de mirar del Extremo Oriente y de Occidente, y el alcance que todo esto haya podido tener en la manera de comprender y representar el espacio en la pintura contemporánea. Para ello ha sido preciso profundizar en el estudio de determinados conceptos y términos recurrentes, como Oriente, Occidente, Pintura, Cultura, Espacio, Tiempo, etc. abordando el estudio de la evolución, etapas y desarrollo del problema para poder llevar a cabo un análisis de los significados en su contexto, además de sus implicaciones artísticas, culturales e históricas. Señalar que para muchos de estos términos se ha recurrido a la denominación y escritura de su país de origen ${ }^{31}$.

\footnotetext{
${ }^{28}$ Régis Debray, Un Mythe contemporain. Le dialogue des civilisations, Paris, 2007. En Belting, Hans, Florencia Bagdad. Una Historia de la Mirada entre Oriente y Occidente, Madrid, 2012, p. 11.

${ }^{29}$ Belting, Hans, Florencia Bagdad: Una Historia de la Mirada entre Oriente y Occidente, Madrid, 2012, p. 11.

${ }^{30}$ Francastel, Pierre, Sociología del arte, Madrid, 1984, p. 198.

${ }^{31}$ En el caso del vocabulario chino o coreano se ha hecho una transcripción alfabética de los mismos. Se observará que no se ha hecho lo mismo con las palabras de origen japonés, transcritas en caracteres kanji. Una licencia tomada dados los estudios aún elementales que está realizando la autora sobre este idioma.
} 
Desde estos presupuestos, se ha hecho un estudio comparado sobre las diferentes maneras de comprender, representar y contemplar el espacio pictórico en Oriente y en Occidente, realizando una investigación sobre las dos miradas: particularmente la extremo oriental - que recoge la pintura china, coreana y japonesa - y la de la pintura del Renacimiento de la Edad Moderna europea. Por otra parte, se han definido los factores y resultados formales que a nuestro juicio han influido en estas diferentes maneras de percibir el espacio: cuáles han sido las causas explicativas que han dado lugar al fenómeno de la perspectiva en Europa y al método continuo en Oriente, entendiéndolos en su sentido artístico como modelos de percepción. Además, hemos cotejado estas diferentes maneras de percibir el espacio - definiéndolas y después verificando y analizando su presencia en la obra de Monet - para, posteriormente, investigar las aportaciones de estas influencias sobre la pintura contemporánea, poniéndolas en discusión y realizando un análisis crítico de las mismas.

Es decir, comprender y estudiar el diálogo bidireccional que se establece entre la pintura oriental y la occidental, desde lo que podríamos llamar el momento de inflexión $^{32}$ de las pinturas de Los Nenúfares de Monet y su instalación en la Orangerie. Para ello nos hemos interrogado sobre las variables que hayan podido influir en las diferentes maneras de percibir el espacio, para así intentar dar respuesta a la cuestión de ¿cómo y cuánto ha podido influir la representación espacial de la pintura extremo oriental sobre la nueva comprensión del espacio pictórico europeo y en la recuperación de los polípticos para el arte contemporáneo? Pero además, de manera tangencial, valorar su influencia sobre la consagración de la abstracción como lenguaje pictórico.

Pero, consignar todo esto nos ha obligado a detenernos en las diferencias que encontramos en la comprensión del concepto de horizontalidad en la pintura, basándonos en una comprensión del espacio pictórico muy diferente en ambas culturas. Es decir, la línea del horizonte en Occidente y el despliegue horizontal en Oriente, y las diferencias implícitas y explícitas en lo que respecta a la concepción del espacio ${ }^{33}$. Por eso, debemos insistir, este estudio se ocupará de estudiar lo que en principio entendemos como dos sistemas de representación - la técnica cultural de la perspectiva occidental y el recurso de la narración continua oriental - no solo como recursos útiles para representar el espacio pictórico, sino como enfoques significativos de una particular forma de mirar.

Nuestra propuesta se apoya en cuatro razones básicas: la falta de estudios sobre el tema, el interés de los conocimientos a adquirir, los resultados que se obtendrán en esta línea de trabajo y la necesidad de estudiar las causas y consecuencias del cambio que se ha producido en la mirada de la pintura contemporánea. Actualmente no tenemos constancia de ningún estudio o publicación específico sobre la manera de representar el espacio pictórico en Asia Oriental. Solo algunas publicaciones lo mencionan tangencialmente. Por ejemplo, G. Rowley - en un capítulo de su libro Principios de la

\footnotetext{
${ }^{32}$ Énfasis propio

${ }^{33}$ Énfasis propio.
} 
Pintura China - nos habla del Principio de la Narración Gráfica Continua. De cómo el ojo percibe la escena representada: es decir de cómo capta un tiempo que se desarrolla a través del movimiento lateral de las líneas compositivas y no en profundidad como ha venido sucediendo en el arte moderno occidental a partir del desarrollo de la perspectiva $^{34}$.

Efectivamente, escasean publicaciones que aborden un análisis profundo sobre este recurso visual y, por otra parte, no tenemos constancia de que se haya realizado ningún estudio comparativo entre las dos maneras de mirar, interpretar y contemplar el espacio - entre el del Extremo Oriente y el de Occidente - ni sobre la repercusión que el primero haya podido tener en la pintura contemporánea ${ }^{35}$. A pesar del interés que pueda suscitar el tema, los artículos o libros sobre esta cuestión - u otros trabajos relacionados con el tema principal de esta tesis - son pocos, muchos de ellos se han publicado hace más de 30 años y solo abordan el asunto de manera tangencial, por eso, nos ha parecido necesaria su revisión y su ampliación.

En cuanto a la problemática de la influencia de Monet sobre la comprensión del espacio en la pintura contemporánea, ya se ha evidenciado en importantes exposiciones como Monet y la Abstracción (2010), siendo una tesis recogida anteriormente en publicaciones de Greenberg y Steinberg, quienes ya en su momento se aproximaron a este asunto en algunos de sus ensayos ${ }^{36}$. Todos ellos hablan del redescubrimiento de la obra de Monet por parte de los pintores norteamericanos de las Neo Vanguardias y la consiguiente influencia sobre su trabajo. Pero ninguno hace mención a la adopción de la narración continua o foco móvil de la pintura japonesa; a su presencia tanto en las obras tardías de Monet como en las de los pintores de neovanguardia norteamericanos. Una falta de estudios y publicaciones específicas sobre esta cuestión que, a nuestro juicio, justifican la preocupación y necesidad de llevar a cabo esta investigación y que ponen de manifiesto la relevancia del tema a través de sus diversos aspectos históricos, artísticos e iconográficos. Estos, tal vez, podrán constituir un soporte científico para futuros estudios, aportando una valiosa información histórica, artística y social que nos permitirá crear un archivo de datos tanto documental como gráfico.

Porque, para dar respuesta a la cuestión de ¿cómo y cuánto ha influido la comprensión y representación espacial de la pintura de Asia Oriental en el cambio de paradigma del espacio pictórico europeo? Y ¿cómo y cuánto ha influido en la recuperación de los polípticos para el arte contemporáneo? debemos analizar qué factores y, a decir de Vives, qué "resultados formales - consecuencia de planteamientos basados en una especial concepción vital" $" 37$ - han influido en estas diferentes maneras

\footnotetext{
${ }^{34}$ Véase Rowley. George, Principios de la Pintura China, Madrid: Alianza Editorial S.A, 1981.

${ }^{35}$ Véase Rowley. George, Principios de la Pintura China, Madrid: Alianza Editorial S.A, 1981. Corsi. Elisabetta, La fábrica de Ilusiones. Los Jesuitas y la difusión de la perspectiva lineal en China, 16981766. México: El Colegio de México, Centro de Estudios de Asia y África, 2004. Belting. H, Florencia y Bagdad. Una Historia de la Mirada entre Oriente y Occidente, Madrid: Akal /Estudios Visuales, 2012.

${ }^{36}$ Véase Greenberg. Clement, Arte y Cultura, 2002. Steinberg. L, Other Criteria. Confrontations with Twentieth-century Art, 2007. Alarcó. P, Monet y la Abstracción, 2010.

${ }^{37}$ Vives, Javier, El teatro japonés y las artes plásticas, Gijón, 2010, p. 12.
} 
de percibir el espacio. Por ello, a partir de su análisis, estudiaremos: la dimensión del contexto cultural que los origina y, posteriormente, su posible repercusión en la obra de determinados pintores contemporáneos.

\section{4.- Hipótesis y Variables}

Partiendo de la cuestión ¿Cuánto debe nuestra actual cultura visual a la estrategia artística de la Narración Gráfica Continua característica de la pintura oriental? - como pregunta clave para la investigación - hemos valorado cuales son las causas explicativas que definen tanto a este fenómeno como al de la perspectiva, entendiendo ambos recursos como modelos de percepción que nos remiten al contexto cultural donde se han desarrollado.

Para ello, proponemos un recorrido que tenga en cuenta el contexto cultural y la preeminencia de unos determinados códigos de percepción. Así, en la Primera parte de esta Tesis, ha sido necesario comenzar acotando un estudio que, desde el contexto de Asia Oriental, analiza la comprensión del espacio de la pintura china desde la Dinastía Ming 大明 (1368 - 1644) hasta mediados de la dinastía Qing 清朝 (1644 - 1911), que se corresponde temporalmente en Corea con la primera mitad de la dinastía Joseon (1392 - 1897), y en Japón con el periodo Muromachi 室町 (1392 - 1568), AzuchiMomoyama 安土桃山 (1568-1615) y la primera mitad del periodo Edo 江戸時代 (16031868). En lo que respecta a Occidente, hemos tenido en cuenta las pinturas renacentistas y las obras representativas de la Quadratura entre los siglos XVII y XVIII. Después, en la Segunda parte, se ha confrontado y cuestionado la herencia de ambas percepciones espaciales en las pinturas de los Nenúfares de Claude Monet y su posterior influencia sobre los polípticos de la pintura contemporánea, analizando las obras de algunos pintores que hayan desarrollado su trabajo a partir de 1950. Concretamente, la obra de J Mitchell como pintora representativa de las vanguardias de Estados Unidos, Antoni Tàpies de la pintura española y Cy Twombly como representativo de la pintura de la segunda mitad del siglo XX. Además, hemos estudiado algunas obras de Francis Bacon y Hiroshi Senju como modelos que ejemplifican la vigencia de la tradición del espacio pictórico occidental y oriental sobre los dípticos, trípticos y polípticos.

Una investigación organizada según un itinerario que va desde el estudio comparado de la representación y sus condicionantes - tanto culturales como históricos - hasta el estudio de la imagen como signo y su significación. Así, para comenzar, la hipótesis principal de la investigación es la que sigue: 
La influencia de la pintura de Asia Oriental ha sido un factor clave en el cambio de paradigma en la comprensión del espacio de la pintura contemporánea.

En lo que respecta a las hipótesis secundarias se han planteado las siguientes:

1) El desarrollo horizontal del espacio en la pintura contemporánea - mediante la recuperación de los dípticos y trípticos - viene dado tanto por el descubrimiento del foco móvil o narración continua de la pintura extremo oriental - de los emakimono 絵 巻物 y de los byôbu 屏風 - como por una suerte de emancipación del arte respecto a la perspectiva.

$\left.2^{\circ}\right)$ La recuperación de los dípticos y trípticos para la pintura contemporánea ha sido una consecuencia de la adopción de los soportes y del sistema de representación de la narración continua de la pintura china y japonesa.

$3^{\circ}$ ) La repercusión de la percepción espacial de la pintura extremo oriental ha dado lugar a las representaciones bidimensionales y secuenciales de la pintura contemporánea.

Unas hipótesis que, a nuestro juicio, solo se podrán verificar mediante un estudio comparado de la evolución del espacio pictórico, por medio de una serie de variables cualitativas y cuantitativas, y de sus respectivos indicadores. Los datos documentales han sido la recogida de información a través del estudio de documentos relacionados con el tema, consulta de exposiciones y colecciones que alberguen obras relacionadas con la investigación, además de archivos fotográficos y otras publicaciones que arrojen luz sobre esta cuestión. Así, se ha llevado a cabo la presentación de las distintas influencias y aportaciones de las maneras de mirar de ambas culturas, poniéndolas en discusión y haciendo un análisis crítico de las mismas, basándonos para ello en información recabada de diferentes fuentes especializadas.

En lo que respecta a las variables explicativas o variables dependientes estas se han agrupado en dos tipos: las que afectan al contexto y las de carácter individual. En el primer grupo se encuentran tanto las de carácter histórico como aquellas que están en relación con el espectador y la conexión con el marco social, mientras que en el segundo se encuentran aquellas que hacen alusión a la obra y a todo su proceso de creación: a los recursos artísticos, los tipos de soporte, el contenido icónico, composición y estructura. Para medir las variables históricas y culturales se ha recurrido a la literatura existente con el fin de identificarlas en los diferentes casos. En lo que respecta a la información relativa a las variables sobre el autor y la obra, se ha recurrido a la documentación y al análisis literario y crítico. Con esta metodología se tomará como variable dependiente el desarrollo horizontal de la pintura tanto extremo oriental como contemporánea a través de la recuperación de dípticos, trípticos y polípticos de más de tres paneles. Como indicadores de esta variable dependiente se ha cuantificado la presencia de esta particularidad en las obras de los pintores antes mencionados. 
Todo un conjunto de variables que han sido estudiadas rigurosamente explorando todas sus posibles combinaciones. Por eso, mediante la selección de un número concreto de casos, hemos realizado una comparación sistemática que nos ha permitido verificar los datos, estableciendo estrategias de comparación mediante una metodología específica adaptada a las particularidades de esta investigación. Para ello, hemos empleado técnicas históricas - que estudian la evolución, etapas y desarrollo del proceso - y sintéticas - que nos han ayudado a buscar una posible conexión entre sucesos aparentemente aislados - para, así, poder analizar las variables que han influido en estas diferentes maneras de comprender e interpretar el espacio pictórico y responder a la siguiente cuestión ¿Pudo el diálogo entre el espacio pictórico de Oriente y Occidente influir en las pinturas de Los Nenúfares de Claude Monet? Unos ineludibles preliminares que nos han ayudado a estructurar el marco de estudio para esta investigación y que - desde el contexto artístico e histórico de las obras tardías de Monet - nos han permitido especular sobre cuánto ha podido influir la pintura de Asia Oriental en nuestra actual comprensión del espacio pictórico.

En definitiva, un estudio que, en palabras de Gombrich, más allá de “[...] establecer una conexión entre los experimentos de los artistas del siglo XX y los problemas que planteó el triunfo de la habilidad representativa en los descubrimientos visuales de los impresionistas [... $]^{, 38}$ busca la posible vinculación entre el espacio en la pintura europea y el espacio pictórico del Extremo Oriente donde, finalmente, lo que se representaba era lo que se intuía y no lo que se veía.

\section{5.- Metodología}

Lejos de una imagen teórica unificada, para organizar esta investigación hemos preferido proponer una serie de relaciones a partir de determinadas preguntas. De este modo, se ha tomado como unidad de análisis las obras de Cy Twombly, Antoni Tàpies y Joan Mitchell, además de Francis Bacon y Hiroshi Senju, y su conexión con las obras europeas y orientales de las épocas ya señaladas, además de la última etapa de la obra de Monet. Aunque sabemos que es tarea compleja - establecer una relación completa entre la obra de todos y cada uno de los artistas seleccionados - sí podremos reconocer un cierto paralelismo que, como un eco, resuena repitiendo algunos rasgos específicos.

\footnotetext{
${ }^{38}$ Gombrich, E. H, Arte e Ilusión. Estudio sobre la psicología de la representación pictórica, Barcelona, 1979, p. 334.
} 
Reconocerlos y evaluarlos requiere de dos niveles de investigación: por un lado, el del contexto en el que se han realizado las obras y por el otro, las posibles concomitancias con la pintura de Asia Oriental y las características de cada creador. Es decir, atender a las características que definen a cada autor, al contexto cultural en el que se han desarrollado sus obras y a la influencia del método de la narración gráfica continua de la pintura extremo oriental como nexo. Para ello, recurriendo a un análisis metodológico y conceptual, hemos estudiado el sistema de representación utilizado en cada espacio cultural. Un aspecto significativo que nos permitirá concluir con el estudio de unas pinturas que - como el caso de gran número de las realizadas en la segunda mitad del siglo XX- han logrado transformarse en un espacio/tiempo ${ }^{39}$ que sutilmente se desplaza.

En lo que respecta a la selección de estas obras, se han tomado aquellas que utilizan los polípticos como recurso plástico - para así valorar cómo y en cuantas de ellas se recoge la idea del método continuo - mediante un desarrollo horizontal del tema. De esta manera, partiendo de los posibles antecedentes de las obras analizadas, nos hemos propuesto llegar a lo particular, sin olvidarnos de plantear determinadas preguntas como duda razonable ${ }^{40}$. Una investigación regida por un principio inductivo: es decir, por una suerte de observaciones mensurables que nos permitan elaborar un archivo de datos exactos y fiables. Su registro permite observar una serie de constantes que - al ser abstraídas - nos ofrecen unas proposiciones que a su vez también nos permiten elaborar una determinada teoría hipotética, dando lugar a unas afirmaciones que aunque no pueden verificarse - como proposiciones de ley - si pueden refutarse; en el sentido formulado por Bryson de que "[...] las afirmaciones empíricas no pueden nunca ser verificadas de forma que produzcan proposiciones con carácter de ley; pero si se puede llegar a tales proposiciones por la vía, no de la verificación, sino de la refutación [...]"41. Con esto queremos insistir sobre la idea de que las observaciones recogidas para esta investigación deben ser consideradas como hipótesis comprobables mediante un sistema de refutación. En este contexto, las hipótesis propuestas son la solución provisional más apropiada al problema que nos ocupa: es decir, lo que en palabras del propio Bryson podríamos definir como una "doble entidad: la hipótesis en interacción - con - la - realidad"42.

Por lo tanto, hemos planteado una estrategia metodológica que define nuestro punto de vista - explicitando desde que posición estamos realizando la observación y desde que presupuestos - mediante un estudio interdisciplinar que enriquezca el análisis realizado. Así, se analizará cómo desde un fenómeno particular establecemos una hipótesis que pueda explicarlo - acercándonos a nuevas ideas y conceptos que nos permitan avanzar en la investigación - examinando cómo este fenómeno interfiere en la presencia de determinadas variables y observando si ciertos valores contextuales afectan a los valores promedio de las obras y a las asociaciones entre variables individuales.

\footnotetext{
${ }^{39}$ Énfasis propio.

40 Ibídem.

${ }^{41}$ Bryson, Norman, Visión y Pintura. La lógica de la mirada, Madrid, 1991, p. 37.

${ }^{42}$ Ibídem. p. 40.
} 
Señalar que el hecho de optar por un análisis multinivel de estos referentes sociales, culturales y técnicos de la práctica de la pintura contemporánea, nos permitirá tomar los estudios culturales y visuales como modelos metodológicos flexibles y contextualizadores. Por eso, se ha valorado su origen como enfoque metodológico para el análisis de la forma de representación elegida y para un estudio de los discursos visuales e iconográficos de la pintura contemporánea. 
PRIMERA PARTE 
La Horizontalidad de la mirada de Oriente en Occidente 
INTRODUCCIÓN 
"[...] dos procesos de tiempo real, el del trazo y el de la inspección se encuentran en el plano pictórico, lugar fronterizo. La pintura de la Mirada rompe con el tiempo real, con la duración de la ejecución [...] en la Mirada, la imagen tiene a la vez la profundidad de la percepción inicial y la planitud de la superficie pictórica" ${ }^{\text {43. }}$.

\section{LA ACTIVIDAD DE LA MIRADA}

A

1 terreno de lo invisible, de lo suprasensible, además de nuestros mitos y de algunos ritos, pertenece el arte. Lo ausente-presente o lo inmanente; un espacio poblado de sombras que es el punto de partida para toda creación. Un espacio conceptual e imaginario sujeto a una serie de códigos de representación al que - en el juego de relaciones que se establece entre espacio y arte - podemos considerar como aquella forma primigenia que, condicionada por la subjetividad del contexto cultural que la conforma, dará lugar a un espacio físico que - como lugar - se abrirá a un paraje.

Pero, un espacio no puede existir sin una mirada y, por lo tanto, tampoco sin aquellas conductas que la acompañan. Es entonces cuando, en palabras de Bryson, tiene lugar la "observancia" que no solo es "retiniana" - puesto que "involucra los reductos más íntimos de la sensibilidad" - envolviendo su aparente subjetividad con una serie de "códigos de reconocimiento" socialmente "construidos y mantenidos por la sociedad" y que son los que darán forma a nuestra sensibilidad ${ }^{44}$. Una observación y un reconocimiento ante los que todo individuo se posiciona. La contemplación de un espacio siempre sujeto a unos códigos sociales de identificación, de carácter cultural y material - construidos en el seno de una sociedad -que, como nos recuerda Gauthier, en el terreno de la pintura están "adaptados al sistema dominante de la representación

\footnotetext{
${ }^{43}$ Norman Bryson, Visión y Pintura. La lógica de la mirada, Madrid, 1991, pp. 127- 128.

${ }^{44}$ Ibídem, p. 58
} 
pictórica" ${ }^{45}$. Por eso, como ya se ha señalado, no podemos decir solo que vemos sino que culturalmente reconocemos.

A partir de estos argumentos, para cualquier investigación que verse sobre el desarrollo del lenguaje pictórico, será preciso hacer hincapié en dos aspectos fundamentales: documentar las diferentes vías seguidas en la evolución del espacio en la pintura y su articulación a partir de sus múltiples influencias culturales; sus diferencias y sus equivalencias. En palabras de Gauthier:

Para apreciar hasta qué punto somos tributarios de toda una concepción del espacio, es mejor ir más lejos en la búsqueda de contra-ejemplos. Además, tenemos de sobra donde escoger: la pintura prehistórica, nuestras imágenes medievales, los dominios amerindianos o extremorientales ofrecen, entre otros, una reserva inagotable ${ }^{46}$.

En esta tesitura, reconocemos que las relaciones que tradicionalmente Oriente y Occidente han establecido con el espacio pictórico han sido muy distintas. Dos posicionamientos directamente vinculados con la relación que se ha dado desde estos ámbitos culturales entre lo que entendemos como dentro y fuera. Dos posicionamientos diferentes que conllevan además dos maneras de mirar distintas, a pesar de que el impulso escópico es una cualidad común a los individuos de todas las culturas y de todas las épocas ${ }^{47}$. Una problemática que según Guy Gauthier atiende al sujeto en tanto en cuanto "[...] éste hace suya la imagen a partir de la pulsión escópica [...]"48. Aunque, a decir de Bryson, no obstante "[...] Hablar de una cultura escópica sólo tiene sentido si existen normas colectivas para la mirada que puedan explicarse históricamente [...]"49. Por eso, puesto que tanto Oriente como Occidente han recurrido a sistemas de representación codificados, entendemos que ambas son culturas escópicas que, por lo tanto, han desarrollado sus propias normas sociales de percepción. Es decir, sus propios códigos culturales de reconocimiento, que han dado lugar a una serie de hábitos visuales implícitos en la sociedad y que, como señala Belting, han permitido teorizar sobre una "historia de la mirada"

Pero, al amparo de estas normas que evidencian diferencias notables, también podemos encontrar confluencias. Así, - parafraseando las argumentaciones que George Rowley hace sobre la pintura china - mediante la conjunción de las "comparaciones

\footnotetext{
${ }^{45}$ Guy Gauthier, Veinte lecciones sobre la imagen y el sentido, Madrid, 2008, p. 29

${ }^{46}$ Ibídem. p 30

47 Es interesante que nos aproximemos a una definición más clarificadora del término cultura, categorizándolo bajo dos distintas apreciaciones. Así, por un lado está la denominada cultura materialista relacionada con el pragmatismo de sus fines y, por otro, la cultura espiritual estrechamente vinculada con el desarrollo de la conciencia de los individuos que la conforman. Precisamente, dentro de esta última se encuentra la denominada cultura estética - que aglutina aquellos ideales de belleza que germinan dentro de una sociedad - y que, como es evidente, establece tantos y diversos parámetros como tantos y diversos sean los ámbitos en los que se desarrolla.

${ }^{48}$ Guy Gauthier, Veinte lecciones sobre la imagen y el sentido, Madrid, 2008, p. 8.

${ }^{49}$ Hans Bryson, Norman, Visión y Pintura. La lógica de la mirada, Madrid, 1991, p. 220.

${ }^{50}$ Belting, Florencia Bagdad: Una Historia de la Mirada entre Oriente y Occidente, Madrid, 2012, p. 9.
} 
internas" que buscan la "[...] coherencia a través de la interdependencia de los opuestos $[\ldots]^{51}$ podemos establecer algún nexo entre Occidente y Asia Oriental. Entre la cultura europea y la china y la japonesa en particular - que serán sobre las que principalmente se centrará esta investigación - ya que, las dos son fundamentalmente culturas visuales donde, desde cada particular marco social y filosófico, existe un claro predominio de la imagen. Sobre este particular, Gombrich señala:

$\mathrm{Al}$ investigar el desarrollo del lenguaje de la representación, puede ser que hayamos ganado cierta comprensión de cómo se articulan otros lenguajes de equivalencias. Y es que, en el fondo, el verdadero milagro del arte no es que permita al artista crear la ilusión de la realidad. Es el hecho de que, bajo las manos de un gran maestro, la imagen se hace translúcida. Al enseñarnos a mirar al mundo con ojos frescos, nos da la ilusión de que miramos a los invisibles reinos de la mente, a condición de que supiéramos, como dice Filostrato, servirnos de nuestros ojos $[\ldots]^{52}$.

Un contexto de coherencias y equivalencias donde - tanto en el Extremo Oriente como en Europa - observamos la intervención de un elemento horizontal ${ }^{53}$ en el campo pictórico que, como tal, interviene en la comprensión del espacio. Sin embargo, en su génesis, en ambas culturas este concepto difiere según las leyes de la percepción bajo las que el sujeto lo contempla. Así, mientras en Occidente el espacio se comprende desde una escala humana que precisa de un punto de referencia fijo en la línea del horizonte - que a su vez focaliza la mirada de un observador - en muchas de las pinturas chinas, coreanas y japonesas la mirada se desplaza de manera lineal y con ella también la posición del sujeto que las contempla [Figura 1]. Es decir: mientras en la pintura de los rollos de mano y biombos - al estar liberada de un punto de vista fijo - la mirada realiza un recorrido horizontal para leer un espacio que, al ser menos cartesiano, resulta ser más sugerido, en Europa la mirada se extiende en profundidad hacia un horizonte conceptual, ideado por y para un punto de fuga fijo y ubicado en una línea del horizonte, es decir, en una línea horizontal [Figura 2].

En este contexto, como señala Belting, podemos añadir que si "[...] el arte es nativamente una forma simbólica, esto vale particularmente para el arte occidental de la Edad Moderna, el cual fundamentalmente se distingue por la invención de la perspectiva del arte de otras culturas y también de su prehistoria medieval [...]" $]^{, 54}$. Pero, debemos tener presente que en la pintura europea - en la Antigüedad Clásica y en la Edad Media - al igual que sucede en la tradición de la pintura de Asia Oriental, ya se utilizaban las secuencias espaciales y temporales como recurso para unir varios

\footnotetext{
${ }^{51}$ George Rowley, Principios de la Pintura China, Madrid, 1981, p, 79.

${ }^{52}$ E. H, Gombrich, Arte e Ilusión. Estudio sobre la psicología de la representación pictórica, Barcelona, 1979, p. 333.

53 Énfasis propio.

${ }^{54}$ Hans Belting, Florencia Bagdad: Una Historia de la Mirada entre Oriente y Occidente, Madrid, 2012, p. 19 .
} 
elementos mediante agrupaciones rítmicas [Figura 3$]^{55}$. Una circunstancia que hizo posible el planteamiento de un espacio pictórico más expresivo e intuitivo, que lejos de focalizar la pintura alrededor de un centro unitario, interpretaba las representaciones mediante una yuxtaposición de espacios, dando así lugar a una sucesión temporal que desapareció en el siglo XV con el desarrollo científico de la perspectiva. Así:

En Europa, desde el Renacimiento, un paisaje era una ventana abierta a un punto particular del mundo. En China era una interpretación del macrocosmos. Este universo representado bajo este aspecto no resulta estático; está animado por un ritmo, esencia misma de la vida cósmica, ritmo que el hombre aprehende contemplando la naturaleza e identificándose con ella. La búsqueda de este ritmo no estaba, pues, centrada en torno a un punto fijo, la ausencia de perspectiva geométrica no era debida a la ignorancia o a la casualidad. El cuadro mismo de una pintura china implica movimiento: rollos que ni a lo largo ni a lo ancho pueden ser aprehendidos en su conjunto de una sola ojeada ${ }^{56}$.

He aquí, en gran medida, un aspecto que ha marcado las notables diferencias que encontramos entre estas dos maneras de mirar. Distintas actitudes que así mismo se encuentran en el origen de cada particular comprensión espacial. Es decir, un juego recíproco donde el espacio y la mirada son, mutuamente y a la vez, origen y causa; diferentes visiones de un mundo construido a la medida de imperativos y sensibilidades culturalmente distintas ${ }^{57}$. En cualquier caso, una combinación y una dualidad que nos permitirá establecer un doble conocimiento: el de la "forma simbólica" de la que, parafraseando a Cassirer, nos hablaba Panofsky ${ }^{58}$ - que entiende la perspectiva como emblema del Renacimiento y, posteriormente, como rasgo cultural de Occidente - y el de la relación simbólica ${ }^{59}$ de Oriente que - mediante el recurso visual del foco móvil o narración gráfica continua - recurre a la lectura de una secuencia de formas esquematizadas que serán interpretadas como símbolos, en el ámbito de un rico sincretismo donde se unen arte y rito.

Así, encontramos cómo en la explicación de la pintura moderna europea el espacio se comprende como un espacio mensurable que - bajo aquella idea de escala que calcula una distancia - se nos revela como aquel principio que la sociedad ha dado en llamar realidad y que, a decir de Bryson, no se corresponde con aquella "realidad

\footnotetext{
55 En este caso, nos hemos tomado la licencia de comparar dos imágenes con ciertas similitudes compositivas y cierto paralelismo en el tiempo: Los mosaicos de San Apolinar Nuevo, en concreto La procesión de los Santos Mártires ( s.VI- VII d. C) y el Rollo de los Trece Emperadores (歴代帝王圖) [Figura 4] pintado por Yan Liben $(600-673$ d. C)

${ }^{56}$ Noticias sobre la exposición "Montagnes et eaux" (Paisajes chinos de los siglos XIV al XVIII) Museo Guimet, París 1957. En Michel Courtois, Pintura China, Madrid, 1969, p. 111-112.

${ }^{57} \mathrm{La}$ lectura horizontal de la pintura está relacionada con la escritura. Mientras que los textos occidentales - su estructura, desarrollo y lectura - se desarrollan de izquierda a derecha, los chinos y japoneses se desenvuelven de derecha a izquierda, en unos párrafos que antiguamente se escribían en este sentido y de arriba abajo. Esta particularidad mantiene su vigencia en el mundo editorial del Japón de hoy en día, otorgando en sus libros la condición de portada a lo que para los occidentales es la contra portada y, por lo tanto, desplegando su diseño, maquetación y lectura de derecha a izquierda.

${ }^{58}$ Véase Panofsky, Erwin, La Perspectiva como forma simbólica, Barcelona: Tusquets Ediciones, 2003.

${ }^{59}$ Énfasis propio.
} 
noúmenicamente revelada"60. De este modo, en Occidente el espacio pictórico se reflexiona desde el factor de un horizonte donde está situado el punto de fuga. De aquí esa idea europea del cuadro como ventana que se manifiesta en el Renacimiento, y que en su evolución como metáfora - que también connota la contemplación - supuso una doble separación: la que se dio entre el significante y el significado, y entre el plano conceptual y el pictórico. Es decir, la denotación frente a la connotación, que ha dado lugar a una paradoja, enfrentando la observación empírica y su propio esquema o estructura en la pintura mediante la perspectiva. Como ha dicho Norman Bryson:

[...] La imagen realista disfraza su condición de lugar de producción; y en ausencia de indicios visibles de que se esté produciendo desde dentro, el significado se concibe como algo que penetra en la imagen desde un espacio imaginario exterior a ella. El hecho de que se hayan desarrollado códigos de perspectiva significa que el cultivo de ese espacio imaginario ha sido, en el caso de la pintura europea, especialmente intenso. Aunque la metáfora del cuadro como ventana no madura hasta el Renacimiento, su existencia está anticipada desde el principio, pues desde el momento en que el significado se concibe como algo separado y exterior al significante, existe un segundo espacio conceptual que no se identifica con el plano pictórico; un espacio imaginario que los códigos de perspectiva, por así decirlo, sujetan y enfocan, desarrollando su construcción hasta que llega un punto en que la "ventana" se abre a su perfecto mundo sucedáneo $[\ldots]^{61}$.

Y es que, en el desarrollo del espacio pictórico europeo se ha establecido una clara oposición entre dentro y fuera, dando lugar a la apertura de un mundo virtual detrás de esa ventana metafórica. Lo que podríamos llamar un oculocentrismo, que ha encontrado su significación cultural en la perspectiva y que ha favorecido la creación de un espacio interior, en el cual se encuentra encerrado el observador, mientras el mundo que contempla permanece en el exterior $^{62}$. Es decir, un retiro interior desde donde contemplar un exterior que se comprende como el espacio del mundo. Una "experiencia de la morada" que, a decir de Belting probablemente "haya determinado en algún punto esencial la experiencia del yo en la cultura occidental"63.

La res extensa cartesiana; la dimensión de un mundo extenso ante el cual el observador, como tal, se posiciona desde fuera, de manera que el interior pasa a ser el espacio del sujeto frente a ese exterior que es aquel espacio del mundo que este sujeto contempla.

Concentrada en la mirada y, con el propósito de adquirir más objetividad, remontando hasta la formación retiniana de la visión, la reflexión europea sobre la pintura se preocupó poco de lo que sería su condición de posibilidad, no por fijación de un afuera

\footnotetext{
${ }^{60}$ Norman Bryson, Visión y Pintura. La lógica de la mirada, Madrid, 1991, p. 68.

${ }^{61}$ Ibídem, p. 71.

${ }^{62}$ Énfasis propio.

${ }^{63}$ Hans Belting, Florencia Bagdad: Una Historia de la Mirada entre Oriente y Occidente, Madrid, 2012, pp. 204-205
} 
sino por depuración en lo "interno". Por recogimiento deberá entenderse aquí, en primer lugar, frente a la mirada, la conjunción de esos dos significados: recogimiento de sí mismo, liberado de las inoportunidades y de las impurezas, y recogimiento en sí (del paisaje). Se trata de ese ángulo del recogimiento a partir del cual el arte letrado chino decidió, cada vez más explícitamente, en el curso de los siglos, abordar y pensar la pintura $[\ldots]^{64}$.

Por lo tanto, como ya hemos dicho, en lo que respecta a Oriente tradicionalmente el espacio se ha reflexionado desde el desarrollo lineal que podemos encontrar en muchas de sus pinturas. Una factura horizontal - que es la que compete a este estudio - o en ocasiones vertical, en cuyo espacio se comprende el vacío el cual, en vez de entenderse como carencia - como ha venido sucediendo en la tradición occidental - se comprende en sí mismo como creación y origen de lo que se entiende como el espacio/sitio ${ }^{65}$. Una manera de comprender, representar y contemplar el espacio pictórico que, como señala Elisseeff, estaba sujeta a unos códigos de reconocimiento que, en este caso, se habían desarrollado en un contexto muy diferente al de la escritura alfabética occidental.

Efectivamente, esta circunstancia ha sido definitiva en la configuración de la sensibilidad estética extremo oriental en general. Así, señala Elisseeff “[...] Hasta el mundo hindú, uno vive en el mundo de la escritura alfabética, lo cual es muy importante desde el punto de vista artístico: de alguna manera se da una total separación entre la expresión gráfica y la expresión pictórica, plástica. En el mundo chino, incluyendo en él Corea y Japón, no ocurre lo mismo: un arte del pincel unifica los modos gráficos, plásticos y poético [...]"66. Por ello, para apreciar un poema no solo es preciso valorar su ritmo y su rima sino que, además, inevitablemente necesitamos apreciar la imagen que ofrece el trazo de sus caracteres; unos ideogramas que establecen así un equilibrio de fuerzas que dan a la obra, parafraseando a Elisseeff, un "inusitado aspecto audiovisual". Es decir, lo que en Oriente se ha considerado como la más elevada expresión del hombre, permitiendo que los eruditos/pintores chinos del siglo XVI elaborasen una teoría del arte propia. Un aspecto transcendental, continúa este autor:

[...] desde el punto de vista de la flexibilidad mental. Conviene no olvidar, por ejemplo, que para apreciar debidamente una poesía china, ya fuera en la época de los T'ang o en la de los Sung, e incluso en nuestros días, hay que valorar las rimas, los ritmos y la imagen misma de los caracteres. La grafía entraña a veces un juego de líneas más fácil de realizar, como tránsito de un carácter a otro, que otro tipo de combinaciones. Se tiene, instantáneamente, un aspecto visual, o más exactamente "audiovisual" integral, en el que la palabra no sobra. No hay primacía de lo visual sobe lo auditivo, ni tampoco de lo auditivo sobre lo visual ${ }^{67}$.

\footnotetext{
${ }^{64}$ Ibídem, p. 242

${ }^{65}$ Énfasis propio.

${ }^{66}$ Vadime Ellisseeff, en Jean Riviére, El arte oriental, Barcelona, 1973, p. 11.

${ }^{67}$ Ibídem, p 14.
} 
Por lo tanto, la oriental y la occidental son dos maneras de comprender el espacio pictórico que están enmarcadas en culturas eminentemente visuales, aunque han evolucionado con matices y hacia formas distintas ${ }^{68}$. Porque lo cierto es que si Occidente focaliza la mirada pictórica en tanto en cuanto lo que se pretende es la reproducción de un espacio, en Oriente, por el contario, la representación de ese espacio se percibe desde la dimensión espiritual del proceso

En cualquier caso, cabe preguntarse si ¿se pueden establecer categorías geográficas tan generales sobre estos sistemas de representación? Porque, aunque estamos hablando de lo que se podrían considerar dos sistemas representativos ${ }^{69}$ es necesario recordar que dentro del ámbito europeo los artistas bizantinos y los pintores medievales recurrieron tanto a la llamada perspectiva inversa - que estaba directamente relacionada con el observador - como a la perspectiva isométrica; un sistema de representación que por otra parte fue también utilizado además de en la Indica y Persia, en Japón y China. Es decir que estas culturas, de alguna manera, sí mostraban un cierto interés por captar una idea de la profundidad espacial en la pintura, aunque prescindiendo de un único punto de fuga por lo que, podríamos decir, no se da un paralelismo en el planteamiento de sus respectivos universos. No obstante, nos recuerda Gauthier, debemos tener presente que no hay "[...] una inspiración común de todos los sistemas de representación no occidentales: entre la pintura mural cingalesa del s. XVIII, la miniatura de la escuela mogol en el s XVII y la pintura china clásica, las diferencias son considerables. A lo máximo, tienen en común el hecho de cuestionar la doxa occidental de la figuración $[\ldots]^{\prime 70}$. Y he aquí que, de nuevo, nos encontramos dentro del ámbito de la representación de un espacio pictórico, lo que a decir de este mismo autor "[...] nos invita a explorar presupuestos - pulsiones, rasgos de cultura interiorizados - que guían, generalmente sin él saberlo, al sujeto enunciador [...]"71.

A tenor de este punto de vista, debemos añadir que un rasgo definitivamente característico de una cultura es la manera de comprender y de relacionarse con su entorno. En este contexto, sabemos que en Europa no fue hasta tiempo después que la perspectiva lineal entró a formar parte de una teoría oficial sobre cómo se deben representar las imágenes. Una, podríamos llamar, alienación que hace que nos planteemos la siguiente pregunta ¿ha influido este dogma de la representación, en la separación psicológica del sujeto - de la cultura de la Edad Moderna europea - respecto a los demás y también con respecto al mundo natural? ya que, en cualquier caso, parece que la imagen construida de acuerdo a la perspectiva de Alberti nos separa del espacio que nos rodea.

En esta tesitura, encontramos como desde la tradición extremo oriental la relación con la naturaleza se expresa a través de la filosofía, de la religión o del arte.

\footnotetext{
${ }^{68}$ Énfasis propio.

${ }^{69}$ Énfasis propio.

${ }^{70}$ Guy Gauthier, Veinte lecciones sobre la imagen y el sentido, Madrid, 2008, p. 33.

${ }^{71}$ Ibídem, p. 14.
} 
Una actitud que ha encontrado como símbolo el Tao (道) o el Camino - que, en este caso, es también el camino a la naturaleza - estableciendo de esta manera una vinculación con el medio muy distinta a la que se ha dado en Occidente, donde - desde una relación más práctica con el medio natural - este se ha comprendido como fin o como objeto. Un punto de vista más utilitario y pragmático que la ha entendido como conquista o recurso. No obstante, sería un error aceptar sin más una explicación tan reduccionista ya que, detrás de gran parte de la tradición del paisajismo - tanto de Occidente como de Oriente - subyace una idea religiosa imbuida de un cierto misticismo. Aun así, ambas actitudes son en sí mismas experiencias sujetas a nociones abstractas, patrones de creencias profundamente arraigadas en unas sociedades a las que han definido y que, a su vez, les ha dado forma. Un juego de complejas relaciones, que así expresa Guy Gauthier:

[...] Para nosotros, todo empieza como Dios manda, por el caos: debemos trabajar a partir de la complejidad del mundo visible, introducir en él nuestro orden, y entresacar de él nuestros signos. Cuando esta tarea está ya realizada y sólo queda un único trazo, entonces éste, por oposición a la tradición china, nos aparece como un fin. [...] Siempre se repite el mismo gesto corrigiéndolo sin cesar. El chino empieza por la forma para llegar al objeto, nosotros empezamos por el objeto para llegar a la forma. Por donde lo cojamos no salimos de esta dualidad $[\ldots]^{72}$.

Son, al fin y al cabo, distintas maneras de interactuar con el espacio que encuentran su correlato en el conflicto que se origina entre la ideación y la representación de las imágenes. Pero ¿cómo se refleja esto en la representación pictórica del espacio? Y así, de nuevo, nos encontramos inmersos de lleno en el ámbito de la percepción visual. Un ámbito espaciotemporal sobre el que Francastel opinaba “[...] Se puede considerar, de manera general, que la percepción del espacio -tiempo, sobre la que reposa toda figuración, implica siempre una atención simultáneamente concedida a por lo menos dos órdenes de consideraciones. El lugar es el presente, el tiempo es la memoria. El tiempo es diferencial; el espacio, unificante; el tiempo son las ocasiones, los acontecimientos, la problemática. El espacio es el acto, el tiempo la causalidad $[\ldots]^{, 73}$.

Así, mientras que en la pintura china, coreana y japonesa el espacio fluye y con ello nuestra mirada se desplaza, en la pintura de la Época Moderna europea se da una percepción estático- espacial, dando la impresión de que el tiempo se congela. En definitiva, si la perspectiva es un recurso neoplatónico y, por lo tanto, construye racionalmente un espacio - al que podemos definir como cartesiano -, el recurso del foco móvil - mediante la expresión de una abstracción psicofisiológica - compone un espacio pictórico que toma sus fuentes de un sincretismo religioso-filosófico que tiene como principales influencias al Taoísmo, al Budismo, Confucianismo y - dependiendo

\footnotetext{
${ }^{72}$ Ibídem, p. 15.

${ }^{73}$ Pierre Francastel, Sociología del arte, Madrid, 1984, p. 51.
} 
de cada contexto - a otras religiones autóctonas como el Sintoísmo (shintô 神道), el Chamanismo y el Shenismo (神教 Shénjiào) ${ }^{74}$. Aun así, como, señala Francastel en su Sociología del arte, "[...] creer que captamos de un solo golpe de vista una imagen fija con nuestro ojo es pura fábula [...] La imagen figurativa es fija, pero su percepción es móvil. Ver es una acción. El espíritu no es el registrador pasivo de una representación que, además, es diferente para cada observador [...]"75.

En cualquier caso, entendemos que la cuestión de la representación del espacio pictórico define e identifica a ambas culturas ya que su concepción y representación enuncia sus distintas maneras de percibirlo y de representarlo. Una problemática que llega mucho más allá de una cuestión artística puesto que nos revela, además, aquellas peculiaridades que - en cuanto a la comprensión del mundo - subyacen en cada cultura: su cosmovisión o metafísica y, por ende, la manera de pensar de sus sociedades que, tanto desde las diferencias como desde las similitudes, nos permitirán avanzar en este estudio.

¿Qué tienen en común la pintura extremo oriental, la serie de Los Nenúfares de Monet y muchas de las pinturas realizadas en el siglo XX a partir del expresionismo abstracto? ¿Encontramos en estas un desarrollo temporal del espacio, al igual que sucede con la pintura de Asia Oriental? ¿En su composición, mediante una relación con el $Q i$ (氣) $)^{76}$ - al igual que sucede con la pintura china y japonesa - encontramos alguna resonancia musical, agrupando y alternando elementos y silencios/vacíos? ¿Cuánta influencia ha podido tener esto en el desarrollo horizontal de la pintura? ¿Se encuentra aquí el origen de la recuperación de los polípticos en la pintura contemporánea? ¿Cuánto debe.....? Con este enfoque comenzamos a transitar el camino que seguiremos en este estudio.

\footnotetext{
${ }_{75}^{74}$ Énfasis propio.

${ }^{75}$ Pierre Francastel, Sociología del arte, Madrid, 1984, p. 45.

${ }^{76} \mathrm{Qi}$ : Pneuma o soplo vital.
} 
"Verdaderamente el poder de la pintura es inmenso. No hay nada que viva en el Cielo y la Tierra cuyos misterios no escrute y cuyos múltiples aspectos no muestre" 77

\section{EL ESPACIO PICTÓRICO EXTREMO ORIENTAL Y EUROPEO: Una comparativa entre la noción de Horizonte y de Horizontalidad ${ }^{78}$}

$\mathrm{E}$ ste título define el asunto alrededor del cual gira la primera parte de esta tesis doctoral, planteada como una investigación transcultural sobre el espacio pictórico y sus formas de percepción en los lenguajes de la pintura extremo oriental y occidental: la noción de horizontalidad de la primera y su comparativa con la de la línea del horizonte de la perspectiva europea ${ }^{79}$. Al hilo de esta idea se han querido ampliar algunas nociones sobre el concepto del espacio en la pintura y sobre la dialéctica que se establece entre la mirada la obra y el espectador. Así, hemos planteado un estudio comparado de la estructura de ambos espacios pictóricos - de sus sistemas de representación $\mathrm{y}$, tangencialmente, de sus constantes estéticas, fundamentos psicológicos y su cosmovisión - para abordarlo como un asunto relacionado con la percepción y, por consiguiente, con la relación que se establece entre el sujeto y el mundo. Es decir, entendiendo ambos espacios como experiencias sujetas a nociones y patrones de creencias profundamente arraigadas que no constituyen una construcción gratuita sino que se corresponde con un cierto tipo de civilización.

En consecuencia - dando por hecho que la organización del espacio plano de la imagen ha constituido desde siempre una preocupación común a todas las culturas para abordar su problemática hemos comenzado determinando los sistemas de ideas y de lenguaje que competen a este estudio, localizándolos en el espacio y el tiempo, y

\footnotetext{
${ }^{77}$ Teng Ch'un (dinastía Sung). En François Cheng, Aliento y Espíritu. Textos teóricos chinos sobre el arte pictórico, 2017, p. 30.

${ }^{78}$ Extraído del ensayo publicado por la autora en el libro Eurasia: Avances de Investigación, del GIR Humanismo Eurasia (HUME). Ediciones de la Universidad de Salamanca, 2021.

${ }^{79}$ Énfasis propio.
} 
analizando los códigos sociales adaptados al sistema dominante de la representación en cada contexto. Por lo tanto, hemos acotado el marco de la investigación al estudio del espacio en el género de paisaje de la pintura china, coreana y japonesa - entre los siglos XIV y XVII - y de la pintura del Renacimiento y de la Edad Moderna en Europa - desde el s XIV hasta las obras de la Quadratura del s. XVII - realizando un recorrido por algunos de aquellos aspectos que hemos considerado claves y que nos han permitido conocer las particularidades del contexto cultural en el que se ha dado la representación.

A partir de esta comparativa, por una parte nos hemos detenido en el concepto occidental del formato del cuadro y por la otra en el de los formatos de la pintura extremo oriental que recurren a un desarrollo lineal comprendido como una experiencia continua espacial y temporal. De este modo, en el contexto cultural del formato de sus característicos soportes, si en el caso europeo para la representación del espacio la pintura recurre a la Perspectiva, en el de Asia Oriental se aplicará el denominado Principio de la Narración Gráfica Continua: recurso sobre el que George Rowley nos habla en Principios de la pintura china, donde nos explica cómo expresa un tiempo que se desarrolla a través de un movimiento lateral de las líneas compositivas y no en profundidad como sucede con la perspectiva en la pintura del Renacimiento y de la Edad Moderna europea ${ }^{80}$. Pero, consignar esta diferencia nos obliga a detenernos en la distinta comprensión del concepto de lo horizontal en la pintura y nos plantea una serie de preguntas. Para empezar, la primera cuestión sería: ¿cuáles han sido las causas explicativas que han dado lugar al fenómeno de la perspectiva en Europa y al método continuo en Oriente, entendiendo ambos en el sentido artístico como modelos de percepción? Pero, asumir ambos modelos de percepción como sistemas de representación - con acepciones artísticas y filosóficas - nos obliga a deducir unas normas destinadas a la construcción de ambos espacios pictóricos que, a su vez, han estructurado tanto sus modos de representación como de contemplación. Una problemática que atiende al sujeto en la medida en que, aludiendo a una pulsión escópica, éste hace la imagen suya; entendiendo esta pulsión como una cualidad común a todas las culturas y todas las épocas. En consecuencia, si entendemos que tanto el Extremo Oriente como Occidente han recurrido a sistemas de representación codificados, asumimos que ambas son culturas escópicas que, por lo tanto, han desarrollado sus propias normas colectivas de percepción.

Aceptar este supuesto nos permite, pues, hacer uso del concepto de forma simbólica de la que - parafraseando a Cassirer - nos hablaba Panofsky ${ }^{81}$ : la perspectiva como forma simbólica y como emblema del Renacimiento, para posteriormente convertirse en el rasgo cultural de Occidente. Entonces ¿podemos interpretar el recurso de la narración gráfica continua como la forma simbólica de Oriente? Pero, si damos a este sistema de representación dicha categoría ¿por qué no hemos encontrado en Oriente ningún término que lo defina como tal? Si nos consta el manejo de términos para definir los diferentes enfoques en profundidad de un paisaje - Gâoyuân (高遠), Shênyuân (深

\footnotetext{
${ }^{80}$ Véase Rowley, George, Principios de la Pintura China, Madrid: Alianza Editorial S.A, 1981.

${ }^{81}$ Véase Panofsky, Erwin, La Perspectiva como forma simbólica, Barcelona: Tusquets Ediciones, 2003.
} 
遠), Píngyuân (平遠) - y se han publicado adaptaciones sobre la perspectiva - véase el Shixue jingyung (視學精蘊), sobre el método Xianfa (線法) de 1729 - ¿por qué no hemos encontrado ninguna publicación extremo oriental sobre el sistema de la representación gráfica continua?

Por lo tanto, una pregunta importante para esta investigación sería la que sigue: ¿Podemos entender la perspectiva y la representación gráfica continua como los sistemas representativos de dos ámbitos culturales? Una cuestión que en el contexto occidental nos remiten al Renacimiento cuando la pintura, al estar necesitada de certezas, terminó por acuñar un nuevo concepto de espacio: métrico y siempre reflexionado desde una escala humana. Efectivamente - al estar necesitado de un punto de referencia fijo en la línea del horizonte - el espacio pictórico occidental ha hecho posible que la mirada se extendiese en profundidad, dando lugar a lo que entendemos hoy como el origen del oculocentrismo europeo que, entre otras cosas, encontró su significación cultural en la perspectiva y fue el origen de un nuevo formato para la pintura, el cuadro. Mientras, la pintura extremo oriental ha recurrido a unos soportes que ni a lo alto ni a lo largo pueden ser aprehendidos de una sola ojeada dando lugar a su característica dimensión espaciotemporal. Así, a diferencia de la pintura europea, su universo no es estático ni está centrado en un único punto de vista fijo, estableciendo de este modo una relación espacio/tiempo que se expresa a través del concepto $M a$ (間) ${ }^{82}$ que al fragmentar el espacio establece una relación secuencial, yuxtaponiendo y alternando motivos y silencios/vacíos. Es decir, la "lectura" de una factura "horizontal" cuyo espacio comprende una noción de vacío que suscita la impresión de resonancia numinosa y que - en el contexto del formato de estas pinturas - entendemos como una "horizontalidad dilatada", en el sentido formulado por Otto que la define como lo "sublime puesto en sentido horizontal" $"$.

Y este asunto nos lleva al siguiente punto de nuestra investigación: señalar la influencia de los sistemas de pensamiento sobre la concepción del espacio pictórico. En el caso extremo oriental, es sabida la influencia de China sobre gran parte de las ideas fundamentales de Japón y Corea. Por ejemplo, la composición de los colores o la ley de la proporción numérica de su pintura, pasando por algunos de sus principales valores culturales o un sincretismo estético y religioso que, en este último caso, comprende también la tradición de unas divinidades relacionadas con los fenómenos y con las fuerzas de la naturaleza. Es decir, una común "correspondencia con las impresiones mágicas en las que es muy rico y profundo el arte prescrito por el taoísmo y el budismo en China, Japón y Tíbet" que ya señalaba Rudolf Otto ${ }^{84}$, que no obstante se enriqueció en cada contexto: en China con las creencias populares o shenismo (神教 Shénjiào), con el chamanismo en Corea y con el shintô (神道) en Japón. No obstante, señala Yoshitsugu Sawai, esta cosmovisión no sería ajena a "una concepción religiosa contemplativa y no teísta de la naturaleza, tal y como sucede con el taoísmo,

\footnotetext{
${ }^{82}$ Ma: Concepto budista asociado a un intervalo entre varios objetos que se relacionan en continuidad.

${ }^{83}$ Rudolf Otto, Lo santo. Lo racional y lo irracional en la idea de Dios, Madrid, 2016, p. 154.

${ }^{84}$ Ibídem, p. 149.
} 
confucianismo o el budismos Hua Yen y el Zen"85. En cualquier caso, todos ellos han tenido en común la práctica de lo que podríamos entender como un ejercicio espiritual del arte $^{86}$. En otras palabras, la experiencia religiosa a través de la relación armoniosa del hombre, la naturaleza y el arte, que nos remite a su vez a la creencia mutua de la reciprocidad entre el sujeto, los dioses y la naturaleza, estableciendo así una relación horizontal que conserva un indiscutible paralelismo con la armonía que recoge el Libro de las Mutaciones entre el hombre, la tierra (el espacio) y el cielo (el tiempo).

No parece entonces descabellado vincular la concepción espaciotemporal de la pintura extremo oriental con las ideas del I Ching - ya durante la dinastía Han, encontramos en el Huai-nanzi (淮南子) ${ }^{87}$ el término yuzhou (宇宙) ${ }^{88}$, espacio-tiempo donde, paradójicamente, se trata de traducir lo intemporal en términos de tiempo. Una concepción que, a nuestro juicio, tiene una clara similitud con el desarrollo lineal de unas pinturas representadas mediante el Principio de la Narración Gráfica Continua, y organizadas a partir del Principio de la Comparación Interna ${ }^{89}$. Un enfoque que, por otra parte, está totalmente alejado de la realidad pictórica occidental a la que, en palabras de Bryson, se le ha quitado "la duración; las posturas de los cuerpos y los gestos están congelados en puntos que la visión normal es incapaz de inmovilizar"90.

Pero en alusión a ese Principio de la Comparación Interna surge otro aspecto a destacar: para estudiar la concepción del espacio en la pintura oriental debemos tener en cuenta que la comprensión de su construcción - como sustrato y como fundamento ontológico - se estructura a partir de la expresión de dos aspectos dentro de un mismo universo; es decir, su comprensión se basa en la interdependencia de opuestos complementarios, ya que atañe a una dualidad que sin dejar de serlo conforma una sola realidad. Un equilibrio de tensiones - que entiende que el mundo de los fenómenos descansa sobre una oposición polar de fuerzas asociadas al Yin-Yang - expresadas a través de la composición de binomios como espacio/ tiempo, composición/ sugestión y silencios-vacíos/formas. Un planteamiento espacial completamente distinto al occidental que recurre a una teoría científica de la visión para reconstruir el espacio. Y de aquí, otro punto esencial de esta investigación que nos advierte de otra comparativa: construcción y composición. Una composición espacial en la pintura extremo oriental que mantiene profundos vínculos con lo sagrado, mientras que la occidental ha

\footnotetext{
${ }^{85}$ Yoshitsugu Sawai, "Perspectivas de la naturaleza en culturas de Asia Oriental", Universidad de Tenri, Nara. Galicia y Japón del sol naciente al sol poniente, 2008, p. 257.

$<\quad$ https://ruc.udc.es/dspace/bitstream/handle/2183/12905/CC-98_art_13.pdf?sequence=1\&isAllowed=y (Consultado el 23 de mayo 2020)

${ }^{86}$ Énfasis propio.

${ }^{87}$ Colección de ensayos sobre mitología, historia, astronomía, filosofía, ciencia, metafísica, naturaleza y política. Consta de 21 capítulos inspirados en los debates literarios y filosóficos entre en príncipe de Huainan, Liu An (179-122) y sus invitados durante la mitad del período Han.

${ }^{88}$ Yuzhou: (Espacio/Tiempo - cosmos) Término, acuñado durante la dinastía Han (漢) para designar el concepto espacio-tiempo

${ }^{89}$ Véase Rowley, Goerge. Principios de la pintura china. Madrid: Alianza Editorial S.A, 1981.

${ }^{90}$ Norman Bryson, Visión y Pintura. La lógica de la mirada, Madrid, 1991, p.106.
} 
evolucionado desde un estricto sentido cartesiano hacia la mimética construcción de su espacio $^{91}$.

En definitiva, entendemos que la visión naturalista extremo oriental del cosmos explica la existencia de múltiples verdades dentro de un sistema horizontal de las relaciones. Una cosmovisión, por otra parte, muy diferente al monoteísmo antropocéntrico característico de Occidente que nos remite, a su vez, a un sistema vertical de las relaciones. Llegados a este punto, parece inevitable preguntarse la lógica de si la relación horizontal de cielo/ tierra/arte extremo oriental puede plantear la alteralidad de la horizontalidad de sus pintura con respecto a la cosmovisión de sus sociedades. Y, al hilo de esta idea viene nuestro siguiente interrogante: esa visión monoteísta occidental que jerarquiza la separación de la divinidad, la naturaleza y el hombre ¿ha podido tener relación con la verticalidad compositiva con respecto a la línea del horizonte que encontramos en la pintura europea? Y, en este caso ¿podría, entonces, cada sistema cultural encontrar su correlato en la estructura espacial de sus pinturas?

\footnotetext{
${ }^{91}$ Énfasis propio.
} 
"Ya conoces el célebre adagio: "antes de dibujar un bambú, que haya crecido ya en tu interior" 92

\section{2.- UNA APROXIMACIÓN A LA COMPRENSIÓN DEL ESPACIO PICTÓRICO}

$\mathrm{E}$ n esta investigación, como principio, hemos eludido cualquier enfoque que desde un punto de vista conceptual único - permanezca sujeto al yugo impuesto por una única perspectiva ${ }^{93}$. Un doble sentido para un término que, como una metáfora, nos sirve para expresar cómo frecuentemente se ha devaluado cualquier imagen que la excluya como sistema de representación, entendiendo entonces su ausencia más como un error o una desviación. Porque, tenemos que recordar que en la mayoría de las culturas - incluidas la europea hasta el Renacimiento y las de Asia Oriental - tradicionalmente las imágenes se han organizado según el significado interno de cada uno de sus elementos, de tal manera que la imagen pictórica - en consonancia con sus propias convenciones y orden interno - no ha tenido que depender del punto de vista fijo de un observador. En cualquier caso, eso no quiere decir que no existiese una preocupación por la representación del espacio, sino que se recurría a unos principios diferentes a los de la pintura de la Europa moderna. Así, como indica Gauthier:

[...] Encontramos otros ejemplos sin dificultad, particularmente en la pintura china que presenta la ventaja de haber sido objeto de una verdadera doctrina - así como la pintura occidental, y con ella, en estrecha relación con todo el trasfondo ideológico. El pintor no ignora la perspectiva; al contrario, en la pintura de paisaje, es excelente

\footnotetext{
${ }^{92}$ Tung Ch`i (dinastía Ts’ing), en François Cheng, Aliento y Espíritu. Textos teóricos chinos sobre el arte pictórico, Valencia, 2017, p. 56.

${ }^{93}$ Énfais propio.
} 
traduciendo el infinito de las lejanías. Sencillamente, construye el espacio según principios diferentes a los del pintor occidental ${ }^{94}$.

Por otra parte es importante señalar dos aspectos fundamentales. En primer lugar, para realizar una aproximación a la comprensión del espacio de la pintura europea y extremo oriental, debemos comprender que son dos culturas visuales donde la combinación entre percepción y arte ha dado lugar a unas particularidades que, no obstante, evidencian diferencias entre ambos modelos visuales. En segundo lugar, debemos tener presente que en la actualidad - debido en gran medida a la intervención de los medios de comunicación globalizados - sus diferencias se han ido difuminando, aunque de alguna manera permanezcan aún codificadas en el subconsciente cultural. Pero, vayamos por partes. Para empezar, al estudiar la concepción del espacio en la pintura oriental, debemos tener en cuenta que la comprensión de su construcción - como sustrato y como fundamento ontológico - se estructura a partir de la expresión de dos aspectos dentro de un mismo universo. Es decir, que su comprensión atañe a una dualidad que sin dejar de serlo conforma una sola realidad. Así, Cheng nos habla de cómo ya en la dinastía Qing 清朝, Wuang Yü - s. XVII - XVIII - en su Tung-chuang lunhua (Palabras sobre la pintura del Pabellón del Este) ${ }^{95}$ hablaba de la importancia que tiene para la composición tener presente:

[...] el par complementario Yin-Yang, es decir, el tratamiento de la "cara" y el "dorso" de la escena representada; la secuencia rítmica subida-descenso, ch'i-fu, es decir, la disposición de las estructuras en su movimiento horizontal; la oposición orgánica apertura-cierre, k’ai-ho, es decir, la disposición de los conjuntos altos o bajos, alejados o próximos; y después todo lo tocante a la relación sutil entre diversas figuras pintadas [...] En cuanto al manejo del pincel -tinta, es necesario que el pintor se esfuerce por rebuscar los efectos contrastantes siguientes: apoyado-levantado, lento-rápido, continuo-sincopado, seco-mojado, concentrado-diluido, oscuro-claro $[\ldots]^{96}$.

Lo que podemos entender como un equilibrio de tensiones ${ }^{97}$ expresado a través de los binomios composición - sugestión y silencios/vacíos - formas, reforzados por la coherencia de la interdependencia de los opuestos: es decir, basados tanto en las diferencias como en las semejanzas y que, como señala el Tung-chuang lun-hua, en su movimiento horizontal organizan la composición mediante una secuencia rítmica, ondulante, expresada en con el término chino Qifú (起伏). Es decir, la noción culturalmente extendida del desarrollo del formato horizontal que, como el término

\footnotetext{
${ }^{94}$ Guy Gauthier, Veinte lecciones sobre la imagen y el sentido, Madrid, 2008, pp. 31-32.

95 Tung-chuang lun-hua, de Wang Yü (1680 - 1729), es un tratado de pintura que reúne una serie de unas 30 expresiones no conectadas y sin ningún orden en particular,

${ }^{96}$ François, Cheng, Aliento-Espíritu. Textos teóricos chinos sobre el arte pictórico, 2017, p. 55.

${ }^{97}$ Idea que ya recoge el I Ching, El libro de las mutaciones. Este antiguo libro de oráculos que impregnan la cosmovisión china, es un tratado filosófico - ético para el que la esencia del mundo no es un estado estático, sino que, por el contrario, está en perpetua mutación y cambio.
} 
japonés fûkeigashyoshiki (風景画書 式) - que designa un formato de escritura - se ha registrado como característico de la pintura de paisaje extremo oriental ${ }^{98}$.

Una dualidad que llevada al contexto de la cultura europea se podría entender como una polaridad, representada mediante aquella metáfora sobre el alcance finito de la mirada que se orienta hacia el punto infinito en el que convergen las líneas de la perspectiva. La "polaridad entre el aquí y el allí, del dentro - fuera" ${ }^{99}$ de la cultura occidental. Como recoge Belting:

La mirada con su alcance finito, se orienta a este punto infinitamente lejano en el que las líneas convergen. Se llega a una polaridad entre el aquí y el allí. [...] En la mirada el espectador adquiere la prerrogativa de observar el mundo desde una posición externa. No puede estar con su cuerpo allí donde fija su mirada ${ }^{100}$.

Así, por un lado nos encontramos con una polaridad de fuerzas complementarias y por el otro con una polaridad de fuerzas excluyentes. Es decir, la dualidad extremo oriental como un equilibrio de tensiones complementarias y la polaridad occidental como tensiones opuestas enfrentadas. En este punto, cabe hacerse una pregunta relevante ¿Explican estos dos diferentes planteamientos los distintos conceptos del espacio de la pintura europea y extremo oriental? ¿Explican éstos, dos diferentes planteamientos de modernidad? Y, si fuese este el caso ¿Toda modernidad aspira a romper con ciertos formalismos culturales? Así, continua Belting:

[...] en el arte moderno se produjo un curioso movimiento contrario cuando, por una parte, el realismo europeo se introducía en la cultura asiática al tiempo que, por otra, el arte occidental sentía una gran afinidad con el libre "subjetivismo" y los gestos creativos del pincel en el mundo artístico oriental. La estampa japonesa, con su perspectiva tan curiosa y en cierto modo ingenua, características que la hacían tan expresiva, despertó gran entusiasmo en el mundo artístico parisino. [...] Se estaba iniciando una revuelta estética con la que se deseaba sacudirse la obligación académica de la perspectiva como herencia no estimada. Mientras Japón introducía en aquellos años el cuerpo extraño de la pintura al óleo occidental, el encuentro con el arte tradicional japonés en los círculos artísticos parisinos llevaba el signo contrario [... $]^{101}$.

\footnotetext{
${ }^{98}$ En cualquier caso, no debemos olvidar que el género del paisaje sufre una notable transformación durante la dinastía Song $(960$ - 1279), qué para su representación pasará del foco panorámico al foco parcial.

${ }_{99}$ Véase Belting, Hans, Florencia Bagdad. Una Historia de la Mirada entre Oriente y Occidente, Madrid: Akal /Estudios Visuales, 2012, p. 28.

100 "Según Gottfried Bochm esta contradicción se parece a la que se encuentra en el giro copernicano 'De quien reflexiona sobre su propia visión puede decirse que es dueño de su mirada. Pero al mismo tiempo debe reconocer su impotencia. Pues en cualquier cosa que mire, verá los límites de su percepción. El mundo que ven los ojos se oscurece, lo invisible es su horizonte visible' (Bochm, 1995, p. 28)". En Belting, Hans, Florencia Bagdad: Una Historia de la Mirada entre Oriente y Occidente, Madrid, 2012, p. 28 .

${ }^{101}$ Ibídem, p. 43.
} 
Efectivamente, mientras en Occidente se valoraba la libertad subjetiva de la pintura de Asia Oriental - como oposición contestataria a la representación realista imperante - en Oriente se aceptaban formalmente las reglas de la reproducción objetiva de la tradición europea ¿Podemos entender como una contradicción la presencia de elementos del arte de Oriente en el de Occidente y viceversa? Y en el contexto actual ¿podemos seguir hablando de esta binaridad? En cualquier caso, inferimos que sin esta supuesta contradicción no se entendería la relevancia que tuvo para el arte europeo el hecho de que se fuese filtrando la idea del libre subjetivismo de los gestos creativos del pincel $^{102}$. O, por otra parte, el hecho de que en la pintura japonesa o china se fuese inoculando la idea de un espacio pictórico enmarcado, volumétrico y mensurable, adoptando la idea del claroscuro y de la reproducción de un espacio en perspectiva.

Y es que, como ya se ha señalado, las diferencias entre la percepción espacial de Oriente y Occidente nacen del conflicto que se origina para el sujeto entre la representación interior de un espacio y la representación exterior que reproducen las imágenes. A decir de Norman Bryson, el concepto occidental de sujeto se define "en función de un objeto, para el cual su mirada se posiciona y toma posesión". Es decir, una realidad pictórica a la que, según este autor, se le ha quitado "[...] la duración; las posturas de los cuerpos y los gestos están congelados en puntos que la visión normal es incapaz de inmovilizar $[\ldots]^{\prime \prime 103}$.

[...] las pinturas de caballete de Occidente son autóctonas, autocreadas, partenogenética [...] Por un lado, el proceso ha sido eliminado del mundo: todo lo que era rítmico ha sido detenido y todo lo que era móvil ha sido petrificado. [...] espacial y temporalmente, el acto de ver se concibe como la supresión de las dimensiones del espacio tiempo, como la desaparición del cuerpo $[\ldots]^{104}$

Por el contrario, tanto en la pintura china como en la japonesa o la coreana ${ }^{105}$, encontramos el flujo de la afluencia de la tinta sobre el papel o la seda y donde la

\footnotetext{
${ }^{102}$ Aspectos característicos del mundo artístico oriental que se dieron a conocer, principalmente con la llegada a Europa de la pintura japonesa - principalmente estampas del ukiyoe (浮世 絵) - dando lugar a una estética que permitió a Occidente desembarazarse de la imposición académica de la herencia de la perspectiva

${ }^{103}$ Norman Bryson, Visión y Pintura. La lógica de la mirada, Madrid, 1991, p. 106.

${ }^{104}$ Ibídem, p.107.

105 Señalar que esta investigación se focaliza principalmente - en el ámbito de la pintura oriental - en la pintura china y japonesa, tocando tangencialmente la coreana. China fue la fuente inagotable de influencias para Japón y Corea, dando lugar en cada contexto a un arte que interpretó y fusionó estas influencias con sus tradiciones. Como señala Janata "[...] No cabe duda de que el arte coreano tomó de la China gran parte de sus ideas, desde la composición de los colores utilizados en la pintura hasta la ley de la proporción numérica, pero sobre todo rasgos estilísticos. No obstante, los artistas coreanos nunca fueron meros imitadores de modelos extranjeros; sus obras fueron siempre consideradas como la expresión de una actitud típicamente coreana [...]” y añade, “[...] Encerrada entre la nobleza y dignidad del arte chino y el brillo deslumbrante del arte japonés, el arte coreano fue, durante mucho tiempo, eclipsado por sus vecinos [...]'. En Alfred Janata, Pintura coreana, Barcelona, 1960, p. 6. No obstante, la escasa presencia de la pintura coreana en este estudio no atiende a la falta de interés o relevancia de su pintura, sino a las escasas publicaciones y fuentes disponibles sobre su arte.
} 
mirada no está sujeta a una posición o lugar definido, evitando de esta manera un campo de visión limitado. En palabras de Bryson:

[...] Una obra caligráfica de Chu Jan o Sesshu no puede captarse de una vez, tota simul, puesto que ha ido deviniendo durante el proceso de su ejecución; su consistencia es sucesiva, paralela al tiempo somático de su construcción (una traducción más precisa del Primer Canon de Hsieh Ho sugiere la glosa "consonancia del cuerpo con el objeto que el cuerpo tiene que representar" es de la materialidad de la elaboración de donde surge la animación de la representación) ${ }^{106}$.

$\mathrm{Y}$ es que, esa idea tan del gusto occidental de precisar de un objeto como referencia para medir un espacio es un planteamiento totalmente alejado del de la pintura oriental donde, por el contrario, encontramos la idea de un espacio exento de esa mirada posesiva, por lo que podría decirse que el espectador - al carecer de un marco para la mirada - se siente arrastrado por un flujo de fenómenos sensibles ${ }^{107}$. Porque, aunque aparentemente miremos y percibamos todo cuanto nos rodea con los mismos ojos, en esencia, nuestra mirada todavía se diferencia en muchos aspectos, ya que la mirada es la expresión del sujeto, de sus circunstancias y de su entorno cultural. Por eso, la imagen pictórica - su comprensión espacial y todos sus códigos de representación resulta tan útil para comprender aquellos recursos bajo los que opera la percepción, al tiempo que su valor simbólico la relaciona con un momento histórico y un contexto social determinado. Así, volviendo a nuestros ejemplos orientales, dice Gauthier: "la aplicación del sistema de la perspectiva sólo conseguiría hacerles perder toda su fuerza de expresión, y comprendemos que los artistas hayan recurrido a otros sistemas - ellos también a menudo codificados y a menudo intolerantes - que reflejan una organización social diferente y una filosofía diferente" ${ }^{\text {108 }}$.

Por consiguiente, para comprender una imagen necesitamos interpretarla dentro de su contexto social que, así mismo, la significa como transmisora de distintos valores culturales a la vez que esta participa de su construcción transmitiéndolos. Una relación simbiótica que construirá el sistema identitario de una sociedad y que determinará el saber de los propios individuos que la constituyen. Es decir, un análisis de la representación que nos puede ayudar a comprender las particularidades del contexto en el que se ha dado la comunicación y para lo que, en palabras de Gombrich, se precisan tres componentes: "[...] el medio del artista, el equipo mental y el problema de la equivalencia. Al hablar sobre arte, generalmente damos todo eso por sabido: son los ocho novenos del iceberg que permanecen sumergidos y no se nos imponen a la

\footnotetext{
${ }^{106}$ Norman Bryson, Visión y Pintura. La lógica de la mirada, Madrid, 1991, p.106.

107 Es importante señalar que esto no quiere decir que los pintores chinos, japoneses o coreanos no tuviesen interés en representar una tercera dimensión del espacio. No en vano, los pintores chinos distinguían entre Gâoyuân (高遠), Shênyuân (深遠) y Píngyuân (平遠). Normas de representación del paisaje llamadas yuan - distancias, muchas veces mal traducida como perspectiva - que hacen alusión a la distancia física y anímica del espectador y el artista con respecto a la naturaleza representada.

${ }^{108}$ Guy Gauthier, Veinte lecciones sobre la imagen y el sentido, Madrid, 2008, pp. 36-37.
} 
conciencia [...]"109 . Tres componentes implícitos en la composición y percepción del espacio pictórico que distinguen a la cultura occidental y extremo oriental en tanto en cuanto su comprensión difiere en la práctica social de su contemplación.

Efectivamente, en la pintura extremo oriental se ha priorizado una representación más sensible del espacio, prescindiendo de cualquier idea de dimensión tal y como se ha entendido en Occidente. Por eso, como señala Corsi, debemos “[...] definir los términos del problema: existe una distinción entre la 'construcción espacial correspondiente a las proyecciones sobre el plano de las coordenadas lineales' y la composición espacial que tiene como objeto "la representación sensible del espacio""110. Es decir, que hablamos de "construcción espacial" en la pintura europea y de "composición espacial" en la de Asia Oriental: la proyección de unas coordenadas lineales sobre un plano frente una representación más sensible del espacio, haciendo posible, este último, una relación más mental que visual con unas formas esquematizadas que se apoyan sobre unos fondos vacíos. Una discusión entre construcción y percepción sensible que plantea una controversia que ya se había dado en círculos escolásticos - entre los teólogos y los estudiosos de la naturaleza - y que se vio materializado en el ámbito de la pintura europea al introducir en esta el espacio matemático mediante la perspectiva artística ${ }^{111}$. Un asunto, al fin y al cabo, que - a partir de una serie de razones culturales - nos permite argumentar la lógica de la oposición entre la teoría intuitiva de la visión de Oriente y la teoría científica de la imagen de Occidente ${ }^{112}$.

En consecuencia, en la cultura occidental la mirada y la imagen no se conciben separadas por lo que su espacio está, por lo tanto, sujeto siempre al ojo del individuo. Es decir, que el espacio pictórico se comprende conciso y sujeto a la posición de la mirada. Efectivamente, para poder controlar la percepción, la mirada del espacio de la pintura europea - al estar siempre necesitada de certezas - terminó por acuñar un nuevo concepto de espacio. Un espacio métrico: mensurable, siempre sujeto a la percepción de un observador y, por lo tanto, a su posición y punto de vista. Un espacio donde la condición de un horizonte solo permite una vista limitada del mundo. Por eso, la función del denominado "espacio perspectivo" es calcular la medida de un espacio que encuentra en el punto de fuga una dimensión frontal de magnitud matemática. Su proyección espacial se limita al plano del dibujo. Un interesante punto de vista sobre el que Bryson opinaba:

\footnotetext{
${ }^{109}$ E. H. Gombrich, Arte e Ilusión. Estudio sobre la psicología de la representación pictórica, Barcelona, 1979 , p. 317.

${ }^{110}$ Elisabetta Corsi, La fábrica de sueños Los Jesuitas y la difusión de la perspectiva lineal en China, 1698-1766, México D.F, 2004, p. 104.

${ }^{111}$ Durante la Edad Media, el denominado debate escolástico se basaba en el estudio de los textos de la antigüedad. Un estudio al que hoy podríamos denominar como más erudito y que, por entonces, difícilmente se relacionaba con el uso de artilugios o aparatos tecnológicos, a los que se consideraba más propios de un trabajo manual.

${ }^{112}$ Énfasis propio.
} 
[...] El punto de fuga cambió el concepto de la imagen como el cero el álgebra. Al mismo tiempo, fue la "base de un sistema que el espectador materializaba". El punto de fuga es en la perspectiva un cero, un punto de origen desde el que pueden calcularse todos los tamaños y todas las distancias. Por eso, aunque toda la representación esté a él referida, no puede ser representado. Es cierto que encontramos su posición en diagramas, pero la pintura, lo mismo que nuestra vida empírica, sólo puede postular su lugar geométrico ${ }^{113}$.

No obstante, es preciso puntualizar que los modelos de pensamiento antiguo nunca dejaron de imponerse en sendos espacios culturales. De aquí ese ancestral "culto a las imágenes" que, como nos recuerda Belting, paradójicamente evoluciona en unas "imágenes para el culto" de las que terminaron por apropiarse los poderes oficiales ${ }^{114}$. Por eso cuando - ya en la Europa del Renacimiento y de la Época Moderna - las imágenes se aliaron con una mirada más empírica, terminó por reconocerse todo el poder que podía albergar esta mirada personal y por lo tanto más subjetiva. Este fue el principio de un cambio de paradigma donde la pintura de la Edad Moderna europea aunque permaneciese al servicio de los poderes oficiales - ha terminado por emanciparse en gran medida de la religión o del estado, aunque no tanto - como nos demuestra la actualidad - del poder económico de los mercados.

En lo que se refiere a la tradición de la pintura china, japonesa y coreana, se ha conservado una estrecha vinculación con lo sagrado, mediante una relación con el culto que se ha revelado a través de un conocimiento tanto intelectual como sensible. En este sentido, ya durante la dinastía Tang 唐朝 (618-907) Chu Ching-Hsüan sentenciaba que la "[...] pintura es sagrada. Escruta lo que el Cielo y la Tierra no muestran y revela lo que el sol y la luna no ilumina. Mediante un pequeño pincel, el pintor amansa los diez mil seres; y, valiéndose de una "pulgada cuadrada" aprehende el espacio sin límite"115. Generalmente, en estas pinturas los diversos elementos del cuadro carecen de una relación dinámico mimética - corpórea y por lo tanto de cualquier nexo espacial en perspectiva. Así, en estas representaciones los distintos elementos se unen de tal manera que - en el contexto material de la pintura - establecen una alternancia rítmica de claroscuros y colores/formas - vacíos que, en el marco de aquella idea de un equilibrio de tensiones, alcanza una unidad que encuentra su analogía teórica en la concepción de un espacio propio de la filosofía. En este ámbito, en Oriente se ha conservado una ancestral armonía con la naturaleza - para de este modo evocar a los dioses que la penetran - mediante una búsqueda de lo sagrado a través del ritmo creado en la pintura por medio de las tonalidades y las formas. Un concepto de la naturaleza imbuido tanto

\footnotetext{
${ }^{113}$ Norman Bryson, 1983, p 106, en Hans Belting, Florencia Bagdad: Una Historia de la Mirada entre Oriente y Occidente, Madrid, 2012, pp. 201-202.

${ }^{114}$ Hans Belting, Florencia Bagdad: Una Historia de la Mirada entre Oriente y Occidente, Madrid, 2012, p. 31.

115 "Pulgada cuadrada" o el corazón humano, donde residen los sentimientos y el espíritu. Texto de Chu Ching-Hsüan (dinastía Tang). En François Cheng, Aliento-Espíritu. Textos teóricos chinos sobre el arte pictórico, 2017, p. 28.
} 
por la serenidad y equilibrio confucianos como por el taoísmo - que equipara al hombre con el medio - y que se ha enriquecido con el Shintô a su llegada a Japón y con diversos ritos shamánicos en Corea. Efectivamente, al hilo de esta idea - en el marco de un sincretismo religioso que ha sido esencial - Ellisseeff nos indica que "[...] los fundamentos de la estética japonesa descansan sobre el elemento sagrado, sobre el contacto con mundos suprahumanos, sobre la comunión con las esferas sutiles [...] que reflejan con gran lirismo el gozo profundo que provoca la comunión con esa naturaleza" ".16. Mientras, en el caso coreano, Janata destaca que "[...] la fuerza inspiradora del budismo no perduró durante mucho tiempo [...] y en todo caso, nunca fue exclusiva. Aparecía siempre íntimamente entrelazada al shamanismo tradicional y las creencias populares, las ideas confucianas [...]"117. En cualquier caso, hablamos de unas pinturas que con el tiempo se han revelado por su tendencia inconfundible hacia el budismo Chan - Zen en japonés, Son en coreano - donde, añade Ellisseeff” [...] la apariencia exterior de lo pintado tenía una importancia secundaria; lo importante era su significado profundo" "118. Una vinculación con la naturaleza que, en el ámbito del Renacimiento europeo, hizo de la perspectiva una teoría que explicaba la mirada en función del ojo - remitiéndose por lo tanto a cuestiones relacionadas con la naturaleza, en este caso humana - y haciendo de aquella teoría un símbolo cultural de autoafirmación.

Por consiguiente, nos encontramos ante puntos de vista de profundas connotaciones psicológicas; normas específicas de cada cultura que han sido el origen de una manera de mirar muy diferente en Asia Oriental y en Europa, consecuencias de unos paradigmas y tradiciones culturales que nos llevan a contemplar e interpretar una misma obra desde diferentes presupuestos y significados. No obstante, observar estas diferencias no debe hacernos incurrir en ortodoxias comparativas ya que tanto en las culturas occidentales precristianas podemos encontrar la presencia de una conjunción armónica con el entorno natural - aún hoy vigente en el subconsciente popular - como en el contexto de Asia Oriental encontrar religiones populares que plantean una comprensión teísta de esta misma naturaleza. Así, ante el riesgo de ser demasiado generalistas, debemos tener en cuenta lo que señala García Gutiérrez:

Aunque desde el lejano occidente, la actitud china y japonesa ante la naturaleza pueden parecer indistintas, hay diferencias significativas entre ellas dentro de una posición reverente. El Shintoísmo encierra el temor ancestral de los japoneses ante una naturaleza rica e inmortal [...] el mundo era una mezcla de divinidades vivientes - los "kami”- [...] Aunque este primitivo panteísmo, anterior a la aceptación en Japón del Budismo y de la cultura china, no es una religión rica en filosofía y arte, es en ese Shintoísmo, que todavía persiste donde tenemos que descubrir la aceptación de una naturaleza animista ${ }^{119}$.

\footnotetext{
${ }^{116}$ Vadime Ellisseeff, en Jean Riviére, El arte oriental, Barcelona, 1973, pp. 99-100.

${ }^{117}$ Alfred Janata, Pintura coreana, Barcelona, 1960, p. 7.

118 Vadime Ellisseeff, en Jean Riviére, El arte oriental, Barcelona, 1973, p. 12.

${ }^{119}$ Fernando García Gutiérrez, Japón y Occidente. Influencias recíprocas en el Arte, Sevilla, 1990, p. 53.
} 
En suma, como ya se ha señalado Oriente y Occidente comprenden y contemplan cuanto los rodea de forma distinta: Occidente reduce y acota el espacio a una sola panorámica desde una mirada estática focalizada hacia un foco central, mientras Oriente sugiere espacios que se extienden física y temporalmente, que requieren de una mirada dinámica que se desplaza mientras los contempla.

Una síntesis - en lo que se refiere a la relación que se establece entre visión y ojo, sujeto y mundo - de las diferencias en la compresión del espacio y la visión del cosmos de ambas culturas. Una comprensión espacial culturalmente diferente, enmarcada en una cosmovisión impregnada de fuerzas espirituales muy distintas. En este sentido, como elemento anecdótico, resulta significativo comprobar como los números 1, 2 y 3 se representan antagónicamente en el sistema numérico romano y en el chino- japonés. Así, mientras en el primero se representan mediante una, dos o tres líneas verticales, en el segundo estas mismas líneas se escriben horizontales. Es decir que en el sistema numérico romano, y por extensión representativo de Occidente, se escriben en vertical utilizando los trazos I, II, III: una representación que se nos antoja en el marco de una comprensión antropocéntrica del espacio - similar a un sistema vertical de las relaciones, que en el espacio pictórico se traduce en un esquema compositivo que se estructura alrededor de un único foco central. Mientras en Japón y en China estos mismos números devienen en unos trazos horizontales, utilizando para ello los kanji - , 二, 三, (ichi, ni, san en japonés, $y \bar{i}$, èr, sān en chino $)^{120}$ : enmarcados en un sistema horizontal de las relaciones, donde los logros no se comprenden como sucesos aislados e individuales, sino que se conciben como una yuxtaposición del yo, la sociedad, la naturaleza y las divinidades, en una evolución lineal que encuentra su correlato en una preferencia por el desarrollo secuencial y horizontal de numerosas representaciones pictóricas. Por lo tanto, nos encontramos con fórmulas tomadas de dos sistemas numéricos que no pretende demostrar nada, sino que más bien se limitan a ilustrar de manera simplificada las ideas que expondremos en esta tesis. Una ayuda que, aunque habrá quien considere superflua, nos ayudará a aclarar y a acercarnos a la exposición principal que argumenta esta investigación.

En cualquier caso, y retomando el hilo de nuestro estudio, nos encontramos con una comprensión del mito cosmogónico muy diferente en Occidente y en Asia Oriental, que nos aboca a una reflexión sobre la realidad cultural que lo origina. Unos ejemplos que, de manera simbólica, resultan bastante ilustrativos y funcionan como paradigma de las diferencias en la cosmovisión de la tradición europea y de Asia Oriental. Porque, a decir de Corsi "[...] no se puede hablar de una percepción absolutamente subjetiva distinta en cada uno de los seres humanos, ya que en cada uno de nosotros operan ciertas convenciones que son parte de nuestra herencia común y que nos hacen "ver" de una manera distinta [...]"121 dando lugar, con ello, a unos rasgos generales que

\footnotetext{
${ }^{121}$ Elisabetta Corsi, La fábrica de Ilusiones. Los Jesuitas y la difusión de la perspectiva lineal en China, 1698-1766, México D.F, 2004, p.103.
} 
funcionan como particularidades culturales y que ¿pueden encontrar su correlato en la representación del espacio en la pintura?

\section{1.- La Gramática Visual del Arte: Cultura Estética y Valores Culturales en Occidente y en el Extremo Oriente}

Para llegar a comprender las convenciones que subyacen en los diferentes modelos de percepción, necesitamos conocer el origen de sus específicas normas culturales. Porque, entender una determinada cultura implica previamente comprenderla como un fenómeno vivo donde periódicamente, en mayor o menor medida, esta retorna o se mira en su forma primitiva. Es decir, necesitamos contemplarla como una narración que nos ilustra sobre la propia naturaleza de la cultura y, por consiguiente, sobre los orígenes del arte. Sobre la permanencia de unos determinados elementos - esenciales para la mayoría de las manifestaciones culturales - que se basan tanto en premisas filosóficas como en creencias religiosas y supersticiones populares. Por eso, consignar la sensibilidad estética como una facultad humana y el arte como el producto de esta y de una cultura - común a todas las sociedades - es una manera de entender cómo el fruto de esta sensibilidad estética puede tener diferentes usos y valoraciones. Por lo tanto, estos componentes estéticos determinan la imagen e influyen en la sensibilidad de quien la contempla. Porque el arte es una herramienta capaz de mudar el tiempo, provocar situaciones, promover emociones y construir ideas.

Efectivamente, las diferentes representaciones que nos ha dejado el arte lo han abierto a diversas funciones que varían según las culturas. Por eso - como nos indica Fraser en su introducción en La Rama Dorada. Magia y Religión - además de una función antropológica que nos ayuda a conocer y "[...] comprender la mente humana y las conexiones que esta establece de modo habitual [...]" es preciso valorar otros aspectos intrínsecos al medio, como los valores artísticos y estéticos, "[...] elementos constantes a través de distintas culturas y épocas [...] para analizar el proceso de depuración de estos elementos comunes al pensamiento, así como sus diferentes expresiones en distintos lugares y periodos [... "122. Es decir, la raigambre de determinados formas de creación y modos de contemplación - en estrecha relación con una determinada sensibilidad - que vislumbramos en la expresión de un determinado mundo sensible.

Consignar estos preceptos será argumento suficiente para una breve aclaración sobre la distinción entre los denominados valores estéticos y los valores artísticos. Es

${ }^{122}$ Robert Fraser en, J.G, Frazer, La Rama Dorada. Magia y religión, México D.F, 2014, p. 19. 
decir que cuando hablamos de valores artísticos aludimos de manera directa a la obra en cuestión - y por consiguiente, a todo el proceso de creación - y cuando mencionamos los valores estéticos hacemos referencia a la manera en la que un entorno particular y sus individuos pueden percibir esta obra. En el sentido formulado por Lanzaco Salafranca, entender "[...] por "valores estéticos" las características que representan los ideales, cánones y sentimientos de belleza que inspiran la creación [...] en una época determinada. Debemos advertir que la aparición de "nuevos" valores estéticos en determinado periodo histórico no significa la desaparición de los "anteriores valores"123.

Y es que, aunque erróneamente los términos estético y artístico ${ }^{124}$ se han usado para expresar conceptos parecidos - aunque con matices - ambos definen valoraciones que, a nuestro juicio, es necesario distinguir entre sí. Porque, como señala Henckmann, mientras "[...] el concepto de lo estético está fundado en la recepción [...] el concepto de lo artístico está fundado en la obra y en el proceso de creación" ${ }^{125}$. No obstante aunque son solo una parte de la obra de arte - ambos conceptos abarcan la totalidad de la misma, definiendo la comprensión y percepción que de esta tienen sus contemporáneos en el marco de una época determinada. Por eso, aunque no pretendemos realizar un análisis riguroso sobre estos aspectos - puesto que, dada la envergadura de su mismo estudio, precisarían resolverse como otra investigación paralela - hemos querido acercarnos de manera general hasta algunos de aquellos imperativos estéticos que de alguna forma han definido las representaciones artísticas en el Extremo Oriente y en Occidente, ya que señalar su influencia sobre los diferentes códigos de percepción y de representación consignará otras cuestiones relevantes para esta tesis. De aquí, la importancia de recordar algunos valores estéticos y artísticos que conforman tanto la cultura oriental como la occidental y - y a pesar de - la dificultad que entraña esta tarea. A propósito de esta cuestión, George Rowley decía que:

Bien fuese a través de la ciencia - que investiga la mecánica de la representación -, de la estética - que cuestiona la naturaleza de lo bello - o de la psicología que explora las motivaciones de la expresión -, los términos que utilizan los occidentales para definir las notas esenciales de la pintura - así, unidad, equilibrio, escala y empatía -, a la vez que los tipos estéticos de lo bello, lo sublime, etc, son objeto de desdén en los escritos de la crítica china ${ }^{126}$.

Efectivamente, nos encontramos ante dos tradiciones estéticas a las que podemos considerar antagónicas. Una oposición que, en el campo pictórico, podemos comenzar a estudiar a partir de la siguiente diferencia: mientras que en la pintura europea - a partir

\footnotetext{
${ }^{123}$ Federico Lanzaco Salafranca, Los Valores estéticos de la Cultura Clásica Japonesa, Madrid, 2009, p.18.

${ }_{124}$ Énfasis propio

${ }^{125}$ Wolfhart Henckmann, "Sobre la distinción entre Valores Estéticos y Artísticos" / Enrahonar 32/33, 2001, Universitat de Múnic. Philosophie Department Geschwister-scholl Platz, 1. 80539 München, 2001, p. 72. https://ddd.uab.cat/pub/enrahonar/0211402Xn32-33/0211402Xn32-33p67.pdf (última consulta $14 / 06 / 20)$

${ }^{126}$ George Rowley, Principios de la Pintura China. Madrid, 1981, p. 59.
} 
del Renacimiento - el espacio parece existir a través de la contemplación de un mundo ideal - en una realidad que podríamos llamar estática - en la pintura extremo oriental este espacio adquiere su verdadera importancia y razón de ser a través de su proceso creativo; es decir, no en su conclusión sino en el tiempo que precisa su elaboración, tanto mediante el proceso de la creación como de la contemplación. Porque en este tiempo - mediante una íntima conexión con la obra - la figura del espectador que la contempla cobra tanta importancia como la del propio autor. Así, nos encontramos con unas pinturas que, lejos de la inclinación occidental por la fidelidad de la representación - la verosimilitud y la ordenación objetiva del espacio pictórico - recurren a una serie de motivos lineales y planos que, nos recuerda Rowley, carecen de "[...] todas las notas características de la realidad: plasticidad, textura, color natural, escala, espacio y luz"127. Así, continua," [...] En occidente hemos tenido que recurrir a las notas de solidez y peso para reforzar la forma plástica, y la unidad debe mucho a la integración física de lo sólido. Las formas chinas nos producen frecuentemente la impresión de reducirse a una especie de esqueleto ideográfico [...]"128.

Por consiguiente, en Japón, Corea y China, las notas esenciales de la pintura se han caracterizado por recurrir a unos motivos planos dependientes de ritmos lineales y de una serie de relaciones de áreas de carácter aditivo. Unas limitaciones que - en relación con ese equilibrio de tensiones relacionado con el dualismo del Yin (陰) y el Yang (陽) ${ }^{129}$ - buscaban el contraste de dos, tres o raramente cuatro partes. A partir de aquí, en las ocasiones en las que se podía llegar a cinco, estas solían subdividirse a su vez en grupos de dos o tres; un planteamiento que favorecía la sencillez para decir mucho con pocos elementos, concentrando el significado solo en unas cuantas formas [Figura 5] ${ }^{130}$. Esta secuencia rítmica o Qifú (起伏) ${ }^{131}$ se ha conocido como principio del menor número o ley de la proporción numérica; un efecto basado tanto en planos como aislamientos que tiene su origen en el ideal del pensamiento de los primeros pintores chinos, que posteriormente fue transformado por los pensadores del periodo Song 宋朝 como expresión del Tao (道) ${ }^{132}$. De esta manera, como expresión de la presencia del

\footnotetext{
${ }^{127}$ Ibídem, p. 50

${ }^{128}$ Ibídem, p. 64.

${ }^{129}$ Yin 陰 y Yang 陽: Son una noción básica dentro de la cosmovisión china y por extensión de la de Asia Oriental. No se entienden como fuerzas o energías. Son los nombres que reciben las parejas de elementos que están relacionados entre sí por oposición y complementariedad. Es decir, lo Yin existe gracias a lo Yang, y viceversa.

${ }^{130}$ Esta herencia china del Principio del menor número o Ley de la proporción numérica, por ejemplo, la encontramos también en las pinturas coreanas de temática sipjangsaeng, donde las nociones de inmortalidad y longevidad aparecen agrupadas en elementos decorativos, en grupos de dos, tres, cinco incluso diez, una variedad esta última exclusivamente coreana.

${ }^{131}$ Qifú (起伏): Movimiento ondulante en el desarrollo lineal de la pintura.

${ }^{132}$ Podemos decir que el concepto de Tao道 constituye el germen de las notas esenciales de la pintura china: su espíritu creador y la variedad de su temática e interpretaciones. Hablamos de una revisión de la meditación sobre el cosmos, reelaborada por los pintores del periodo Song 宋朝, que la transformaron en aquella realidad viva que ansiaban pintar. De esta manera, la figura del místico y del artista se confundían en su búsqueda por alcanzar una armonía con el universo y, por consiguiente, con la naturaleza. De aquí que esta se erigiese en el leitmotiv de una pintura que participaba del misterio del Tao 道. En el sentido que ha formulado Rowley, nos encontramos ante “[...] una modalidad peculiar de misticismo por virtud
} 
Tao en la naturaleza, utilizaban la voz $Q i$ (氣) - o espíritu - energía compartida con la pintura a través del $L i$ - estructura física de las cosas - que así mismo permitía descubrir el Xing del arte o aspecto del vacío o la naturaleza fundamental. Entendían, por lo tanto, que el Tao se manifestaba en el arte como Qi, motivo por el que se le dio el nombre de Qi-Yun a los que estaban considerados como los tres fundamentos de la experiencia mística: el absoluto, la meditación y la iluminación. Porque, como nos recuerda Rowley, “[...] En China, la belleza formal no se consideraba aisladamente sino en cuanto integrada en el contenido total; por eso los chinos no hablan de belleza o valor estético sino de espíritu o qi [...]"133.

Así pues, los cuatro conceptos básicos que, según el ideal de la antigua China, intervenían en una pintura eran el $Q i$ o aliento vital o lo que permite superar una determinada inclinación por lo realista; el $L i$, principio que define la estructura interna o que permite el conocimiento de las líneas que estructuran todas las cosas; el Yi, la disposición que tiene el artista en el momento de realizar la obra, y por último el Shen o lo que se entiende como esencia divina. En el ejemplo de la figura 1 del apéndice podemos tomar nota de muchas de estas nociones: la soltura del trazo - o Yi acompañada por la idea de vida-movimiento - o Sheng-dong (氣韻生動) - y por una sutileza - o Jing - que viene a ser la quintaesencia del refinamiento ${ }^{134}$. En esta tesitura, el Yijing - o calidad del alma - fue el criterio más importante para juzgar el valor de una obra en China. Porque, al entender que la belleza de una obra residía en su $Y i$ - que es su esencia - la esencia del ser estaba en el Yijing, que viene a significar un estado superior de la mente o aquella resonancia divina también simbolizada por el Shenyong. Dos nociones que designaban el estado hacia el que se inclinaba una obra - que se consideraba verdadero - en el marco de un ámbito que comprendía y contemplaba la pintura dentro del orden de lo natural. En cualquier caso, una pequeña muestra del rico, exquisito y complejo universo de conceptos chinos, que han dado nombre a un conjunto de convenciones y elementos esenciales que, por otra parte, han sido de gran valor e influencia también para el arte japonés.

Efectivamente, en lo que concierne a Japón, la introducción y paulatina asimilación - en la corte del periodo Yamato 大 和 時代 (siglos V-VI) - de la cultura china de las dinastías Sui 隋朝 (581-618) y Tang 唐朝 (618-907) resultó determinante y dejó su impronta en la introducción de la escritura de ideogramas, del Budismos, Confucianismo y Taoísmo, y sus consecuentes repercusiones artísticas. Así, al amparo de este nuevo ámbito, progresivamente se fue desarrollando un arte que, en origen, estuvo profundamente marcado por estas nuevas influencias estéticas - que lo fueron enriqueciendo y definiendo - y que conformaron unos particulares valores estéticos que han ido variando según los diferentes periodos históricos. Para Federico Lanzaco Salafranca la simplicidad, y sugerencia, forman con la irregularidad y la caducidad los

de la cual era más pertinente la expresión a través del arte que a través de la religión [...]".George Rowley, Principios de la Pintura China, Madrid, 1981, p. 27.

133 Ibídem, p. 53.

${ }^{134}$ Véase, Cheng, François, Vacío y Plenitud, Madrid: Ediciones Siruela, 2004. 
cuatro conceptos claves en la expresión artística japonesa, estando los dos primeros muy vinculados entre sí. Así, en su libro Los Valores Estéticos de la Cultura Clásica Japonesa, citando a Umehara Takesi, señala los tres factores que considera determinantes en la evolución de los valores estéticos de Japón:

[... "para estudiar a fondo la cultura japonesa hay que centrarse en estos tres puntos: I) una visión estético-sagrada del mundo, en la que el hombre participa por igual con la Vida del universo, repartida entre todos los seres de la Naturaleza, y en consecuencia, se siente identificado con todos ellos; II) el valor más apreciado de todos es la limpieza (SEIJO) (KIYOSA) (la nettezza en italiano); y III) la percepción emocional prevalece sobre las demás racionales ${ }^{135}$.

$\mathrm{Y}$ es que, tanto en la cultura china como en la japonesa los principios de su creación artística dependen de su sutileza. En el contexto chino, para hablar de una determinada concepción estética debemos remontarnos al periodo Song 宋朝 (Song del Norte 960-1127 y Song del Sur 1127-1279) y sus posteriores aportaciones. Ya en los paisajes Song del Sur de Ma Yuan [Figura 6] o de Xia Gui [Figura 7], aparece uno de los rasgos característicos del arte chino: una consonancia de formas que, de esta manera, se armonizan mediante una semejanza rítmica [Figura 8]. Y aquí, de nuevo, esa idea asociada al Yin (陰) y el Yang (陽) - o la consonancia de un equilibrio de tensiones en lo que atañe al agrupamiento, la escala, el énfasis y la sucesión secuencial - que ha determinado la composición espacial de la pintura japonesa en particular, como podemos comprobar en el caso del emaki (絵巻) de las Grullas de Honami Kôetsu [Figura 9].

Pero además, en el caso concreto de la pintura japonesa, podríamos hablar de la prevalencia de una cierta inclinación metafísica - en tanto en cuanto se recrea una naturaleza purificada de su materialidad - que fue evolucionando hacia la ausencia del color y la eliminación de lo concreto para preservar los valores espirituales. Pero esta afirmación infiere que ¿no era colorida, acabada y exuberante la pintura japonesa? Efectivamente, no es así. Durante el periodo Heian 平安 (794 -1185) la pintura se caracteriza por su profuso cromatismo y, posteriormente, autores como el propio Hasegawa Tôhaku nos han dejado ejemplos de pinturas sobre biombos con pan de oro y gran colorido, ricamente decoradas con figuras y detalles [Figura 10]. No obstante, un gran número de pinturas se han caracterizado por su intento por representar el espacio como un estado del alma, compenetrada con una naturaleza que - como ya se ha señalado anteriormente - juega un importante papel en el arte: la naturaleza del ritmo vital y del movimiento gestual, de los que ya nos hablaba Bryson:

[...] Recordemos la temporalidad del proceso del tiempo real: la caligrafía se despliega en duración y es el producto del gesto. La temporalidad de un Sesshu es una distensión del tiempo normal: destrezas que el cuerpo ha tardado muchos años en adquirir se

\footnotetext{
${ }^{135}$ Federico Lanzaco Salafranca, Los Valores Estéticos de la Cultura Clásica Japonesa, Madrid, 2009, p.
} 19. 
movilizan y explayan en una ejecución que se muestra a sí misma a la vez como impulsiva y como perfectamente deliberada [...] El valor estético del trazo reside precisamente en lo que puede inferirse del cuerpo por el curso del trazo: el pincel ataca el papel in media res, y cuando se levanta de él todavía no ha consumido su energía $[\ldots]^{136}$.

En esta tesitura, el espacio de la pintura extremo oriental en conjunto, solo cobra sentido si se identifica con el tiempo que fluye estableciendo, de esta manera, una relación espacio/tiempo, que podemos expresar con el concepto $M a$ (間), que Javier Vives define como un concepto budista asociado a un intervalo vacío que relaciona diferentes objetos en continuidad ${ }^{137}$. Un término que podríamos traducir como "pausa" o "intervalo", que simultáneamente ofrece la conciencia de la forma/ contraforma de un motivo artístico y que al fragmentar el espacio establece una relación secuencial, yuxtaponiendo los diferentes elementos que intervienen en la pintura. Es decir, un concepto que podría inducir un estado contemplativo en el que fuese posible apreciar la expansión del espacio y del tiempo. En cualquier caso, un recurso para preparar y guiar la mirada a través de un recorrido más o menos explícito, mediante un desarrollo musical que pone el acento sobre los valores espaciales: tanto sobre los formales como sobre los aéreos. Así, en Principios de la pintura china, Rowley nos dice:

[...]El lenguaje pictórico ideográfico era un medio muy desarrollado para expresar un enfoque intuitivo del espíritu esencial de las cosas y siguió siendo la fuente de muchas de las más llamativas características del dibujo chino, a saber: la preferencia por los ritmos lineales, el aislamiento de los motivos, la relación entre las diferentes áreas, la importancia de los vacíos y la composición en función del tiempo $[\ldots]^{138}$.

Una comprensión del espacio - enmarcada en una cosmovisión impregnada de fuerzas espirituales - que buscaba alcanzar una intensa concentración interior para hacer más fácil el contacto con los misterios de la naturaleza. Así, como sucede en el suiboku $g a$ (水墨画) - o pintura de paisaje - al recurrir a los espacios vacíos para delinear un ambiente espiritual, se llegaba a la representación de un espacio cargado de significados que - mediante la sugerencia y expresión del misterio ${ }^{139}$ - cada espectador debe encargarse de interpretar. Por eso, el espacio pictórico se transforma en un espacio más sugerido y espiritual que - al contrario de lo que venido sucediendo en el de la pintura europea - no está sujeto a unos límites espaciales o temporales. Por lo tanto, nos encontramos con una cosmovisión que, en palabras de García Gutiérrez, revela cómo "[...] Tanto el sintoísmo como el Zen hacen propio el sentido cósmico de todo cuanto

\footnotetext{
${ }^{136}$ Norman Bryson, Visión y Pintura. La lógica de la mirada, Madrid, 1991, pp. 126-127.

${ }^{137}$ Véase Javier Vives, El Teatro Japonés y las Artes Plásticas, Gijón, 2010, p. 161.

${ }^{138}$ George Rowley, Principios de la Pintura China, Madrid, 1981, p.50

${ }^{139}$ Hemos recurrido al término "misterio" para definir una impresión poética de lugares "transitados" por el espectador. Es decir, como una retórica sobre el paso del tiempo, del cambio de las estaciones o de referencias a lugares poéticos, en un recorrido que inexorablemente nos lleva hasta la muerte.
} 
nos envuelve [...] La misma figura humana, situada en medio de la naturaleza, puede indicar que es una parte de todo el cosmos universal" ${ }^{\prime 140}$. Una idea que fue adoptada por los estetas japoneses, los cuales - a la manera de los letrados retirados a las montañas del período Tang 唐朝 chino - redefinieron ese ideal estético de soledad y de lejanía tanto física como espiritual. Para ello, como un valor estético y como actitud moral, acuñaron dos conceptos que representan la simplicidad estética y pobreza de medios: wabi y sabi (侘と寂). Conceptos que han encontraron su expresión plástica en la pintura a la tinta, con una temática que- en su búsqueda de lo cotidiano - se adueñó de la apariencia de lo inacabado, destacando de esta manera la asimetría-fukinsei (不均斉) -como principio y rasgo a destacar. El shibui (渋い), una austeridad elegante y discreta característica de la estética zen japonesa ${ }^{141}$.

El concepto japonés de estilo "wabi", que ex presa un sentimiento genuinamente budista de lo bello, reúne lo incompleto, lo imperfecto, lo efímero, lo frágil, lo insignificante. Por eso, los cuencos de té que deben transmitir el sentimiento wabi no pueden tener un aspecto perfecto e impecable. Ates bien, tienen que estar fracturados. Por easo se les incorpora irregularidades y asimetrías intencionadas ${ }^{142}$.

La inspiración para este recurso podemos encontrarla en esa idea tan japonesa de la belleza efímera - temporal y por lo tanto caduca - impregnada de aquella profundidad misteriosa que se encuentra en el principio de la impermanencia y que define y caracteriza el valor estético del yûgen (幽玄) ${ }^{143}$. Término que expresa aquella elegante simplicidad y sutil esteticismo que, por otra parte, recurre a la repetición de una misma historia o motivos agrupados sobre aquellos campos vacíos creados por la ausencia de pinceladas. De esta manera, la obra se impregna de ese sentido de lo inacabado y de ese poder de sugestión que caracteriza gran parte del espacio pictórico de Japón. Ya, en el s. XIII, Kenkô Yoshida 吉田兼好 - como muchos grandes pintores, también monje budista - en su tratado Tsurezuregusa (徒然草) (un ensayo sobre la ociosidad) se refiere de este modo a la sugestión como principio estético:

Si nunca desaparecieran las gotas de rocío en Adashino, se mantuviera siempre inmóvil el humo de la colina de Toribe, y viviésemos eternamente, sin cambiar, ¿nos podría

\footnotetext{
${ }^{140}$ Fernando García Gutiérrez, Japón y Occidente. Influencias recíprocas en el Arte, Sevilla, 1990, p. 106.

${ }^{141}$ El término shibui (渋い) pertenece a la estética japonesa y designa la búsqueda una cierta familiaridad. Es decir, lo vulgar u ordinario en la obra, visibilizado a través de su aspecto inacabado. Esto prueba la riqueza de posibilidades del objeto y, por lo tanto, denota que en él están presentes los kami. Un sentido de lo inacabado que ha resultado de gran atractivo para los artistas japoneses. Véase, Riviére, Jean, Arte Oriental, Barcelona, 1973, pp. 108 y 142.

${ }^{142}$ Han, Byung-Chul, Ausencia. Buenos Aires, 2019, p. 53.

143 “El yûgen (幽玄) es un valor estético medieval japonés. “[...] consta de dos caracteres chinos: $y \hat{u}$ (profundidad, oscuridad), y gen (misterio, sublimidad). [...] El término YÛGEN (en chino you-xuan) comenzó a emplearse para indicar la difícil percepción del Tao de Laozi y Chuangzi [...] en la época de las Seis Dinastías, la secta budista Sanron empleaba términos taoístas para expresar la doctrina budista sobre el "vacío" (sûnyatâ). [...] los seguidores del camino Zen emplearon el término YÛGEN para expresar la profundidad del no-ser $(m u)$ ". En Federico Lanzaco Salafranca. Los valores estéticos de la cultura clásica japonesa, Madrid, 2009, p. 103.
} 
conmover el encanto frágil de las cosas? Las cosas son bellas precisamente porque son frágiles e inconsistentes.

La efímera no llega a ver la noche del día en que nació. ¿No muere la cigarra del estío sin conocer la primavera y el otoño? ¿Qué suerte es poder vivir saboreando despacio y despreocupados sólo un año!

Pero si uno no se siente satisfecho y no se conforma con el paso de las horas, todo el tiempo, aunque viva mil años, le parecerá tan breve como una noche, como un sueño ${ }^{144}$.

En cualquier caso, hemos hecho un recorrido bastante general para orientarnos por la pintura extremo oriental, deteniéndonos en la pintura china y japonesa en particular. Unos valores estéticos y unos elementos esenciales del arte que se nos presentan como requisitos muy diferentes a los que tradicionalmente se han dado en la pintura de la Europa renacentista y de la Edad Moderna. Aquí, encontramos unas teorías estéticas que, nos recuerda Panofsky, a partir de Vasari, se presentaron como "[...] norma, orden, medida, diseño y "manera" (siendo este último una especie de síntesis intuitiva mediante la cual el artista destila de sus experiencias personales un 'tipo' de belleza suyo propio) [...]". Un resumen, en palabras de este autor "[...] sembrado de inconsistencias, por las que Vasari ha sido severamente censurado. Dos de sus 'principios', la 'norma' y el 'orden', parecen haber ido transferidos de la arquitectura a la pintura y escultura" 145 .

No obstante, hagamos de lo dicho una breve síntesis antes de continuar: ${ }^{146}$

1. Mientras en Occidente el espacio pictórico es mensurable, en la pintura extremo oriental está en relación con la distancia emocional y el equilibrio de tensiones espacio - tiempo.

2. Mientras en Europa el cuadro se comprende como una ventana, estableciendo una separación entre el interior y el exterior, la pintura oriental permite una relación más fluida entre ese interior y el exterior.

3. La pintura europea acota el espacio a una sola panorámica desde una mirada estática que se centra en un único foco central, dando lugar a lo que se ha llamado el instante único. La pintura extremo oriental, sin embargo, no tiene un

\footnotetext{
${ }^{144}$ Yoshida Kenkô, Tsurezuregusa, ocurrencias de un ocioso, Madrid, 1986, pp. 24-25.

${ }^{145}$ Erwin Panofsky, Renacimiento y renacimientos en el arte occidental, Madrid, 1975, pp. 70-71.

${ }^{146}$ Cómo síntesis - pero evitando los estereotipos - se reduce a unos rasgos generales que, evidentemente, varían según los diferentes periodos artísticos. En cualquier caso, en el contexto extremo oriental es imprescindible insistir en "[...] la gran influencia cultural de China, cuyos elementos modelaron el arte japonés, pero transformándose siempre en algo nuevo y distinto. Michiaki Kawakita da como ejemplo el traslado de la cultura de Grecia y de Bizancio a Italia y a Francia, donde tomó otro estilo”. Así, según Riviére, "Estos fundamentales conceptos dominan toda la estética de Japón. Esta profunda e inimitable armonía con la Naturaleza, esta evocación de los dioses y de los genios que forman la sustancia de las cosas, esta búsqueda de lo sagrado por el ritmo de las formas y de los colores son los aspectos del sinto de la estética japonesa [...]". Jean Riviére, Arte Oriental, Barcelona: Salvat. Biblioteca Salvat de los Grandes Temas n91, 1973, p. 103.
} 
punto de vista fijo recurriendo a una mirada dinámica que, en el caso la pintura japonesa, parte de una distancia lateral desde el ángulo superior derecho.

4. Lejos de la mímesis y exactitud de la pintura europea, la pintura de Asia Oriental reproduce un mundo de arquetipos a través de unas formas idealizadas.

5. La pintura europea se inclina por una ordenación objetiva mientras que la oriental recurre a un espacio aparentemente irregular - la asimetría fukinsei (不 均斉) como principio estético del budismo zen - mediante la combinación de planos y aislamientos que compone el espacio según la ley de la proporción numérica.

En suma, un conjunto resumido y global de comparaciones que, lejos de querer apuntalar viejos tópicos sobre Oriente y Occidente, señalan concisamente las determinaciones culturales y los rasgos principales de ambas culturas visuales. El conjunto de lo que podríamos denominar como formas pretéritas, que explican en parte el origen de determinados valores y los fundamentos de la versatilidad del arte para, a partir de ellas, dar coherencia a la estructura de este estudio. Unas conclusiones así expresadas en palabras de Rowley:

Oriente y Occidente han enfocado el problema de la disposición de las partes desde perspectivas radicalmente opuestas. En tanto que nosotros hemos aspirado a enlazar las formas, los chinos han resaltado los intervalos existentes entre ellas. Como consecuencia de la orientación más naturalista de nuestra cultura, la relación entre las formas venía determinada en gran medida por la continuidad de la apariencia. Al estar el mundo compuesto de formas sólidas sujetas a un plano geométrico por la gravedad y hallarse éstas entremezcladas en profundidad espacial, hemos apreciado los empujes y contraempujes de las formas plásticas tanto en sentido lateral como en profundidad, y hemos hecho uso de todas las técnicas consistentes en superposiciones, escorzos, posturas y gestos activos para fusionar las formas $[\ldots]^{147}$.

\section{2.- I, II, III: Como Paradigma del Sistema Vertical de la Cosmología Occidental}

De todo lo dicho se desprende que, para entender una cultura se precisa, entre otros aspectos, conocer la tradición de los sistemas de pensamiento de las sociedades

\footnotetext{
${ }^{147}$ George Rowley, Principios de la Pintura China, Madrid, 1981, p. 88.
} 
que la conforman y que, para comprender una forma se necesita, así mismo, interpretarla dentro de ese contexto en el cual, a su vez, adquirirá un significado, como transmisora de una serie de valores culturales que - como ya se ha señalado anteriormente - le dan sentido a la vez que ella los construye y transmite. Una forma que de esta manera terminará por constituirse como un elemento identitario para esa sociedad. Una interrelación que, en cualquier caso, nos ayudará a comprender las implicaciones que se dan entre arte y cultura.

Al hilo de esta idea, nos encontramos con el pensamiento sistémico occidental, caracterizado por una visión monoteísta que ha sido el origen de una tradicional separación entre la naturaleza, la sociedad, la divinidad y el mismo yo. Una cosmovisión que tiene como referente una figura omnipotente paradigmática de occidente, que se relaciona simbólicamente con una jerarquía que - con respecto a la sociedad y la naturaleza - otorga al hombre el estatus más elevado dentro de un sistema vertical de relaciones. Una tradición monoteísta, enmarcada dentro de las grandes religiones de Oriente Medio - el cristianismo, el judaísmo y el islam - que han entendido el origen de la verdad implícito en la revelación divina y para las que la representación en imágenes de los temas sagrados han resultado ser particularmente polémicas. Una discusión, en palabras de Gauthier, que en relación con el problema de la "[...] profundidad nos vuelve a introducir en el corazón de la discusión sobre las imágenes, que todas las religiones han debido resolver a su manera mediante la prohibición (judaísmo), el compromiso (islamismo), la profusión (catolicismo) ${ }^{148}$.

Pero ¿podemos afirmas que en esta jerarquizada tradición se encuentra el origen del desarraigo del yo individualista con respecto al entorno, y del estilo de vida homocéntrico de la cultura occidental? Y, si así fuese ¿encontraría esto su correlato en una cosmovisión cerrada, vertebrada a partir de la idea de un dios único y una verdad única dentro de un sistema único de ideas? Hablamos de un conjunto de valores cristianos - cuyo origen monoteísta se encuentra en el Viejo Testamento - planteados desde un punto de vista antropocéntrico y dentro de un sistema vertical de las relaciones, donde Dios y el individuo ocupan el estatus más elevado. De aquí esa comprensión del yo imbuida por aquella idea de un dios y verdad únicos, pero ¿esta jerarquía podría estar relacionada simbólicamente con la tradición de la pintura moderna europea donde el esquema compositivo gira alrededor de un único foco central? ¿Podría encontrar su correlato en una estructura del cuadro - supeditada a un punto de vista homocéntrico - que ha puesto el acento en la perpendicularidad del espacio compositivo con respecto a una supuesta línea de un horizonte conceptual y físico? Respecto a estas cuestiones, de alguna manera Gauthier puso el acento al señalar que:

[...] La presentación de un objeto en perspectiva es la intersección con la superficie plana que constituye la imagen, rectas que relacionan el punto de vista con todos los puntos del objeto. Este punto de vista, que supone un único ojo y por añadidura la fijeza de la mirada, es perfectamente teórico.

${ }^{148}$ Guy Gauthier, Veinte lecciones sobre la imagen y el sentido, Madrid, 2008, p. 37. 
La línea de la mirada, teóricamente horizontal, se posa sobre un plano horizontal cuya intersección con el plano de proyección, teóricamente vertical, determina la línea de la mirada con la línea del horizonte ${ }^{149}$.

Y es que, en Europa, durante la Edad Media la mirada ya se concebía como una cuestión extramundana que, por lo tanto, estaba dirigida desde arriba a una escala determinada y dentro de una jerarquía donde esa idea de un Dios único se situaba en la parte más elevada. No obstante, cuando el horizonte comenzó a vincularse con la mirada se produjo un cambio transcendental para la cultura visual europea. Fue entonces cuando ese horizonte se convirtió en el límite - tanto de ese espacio como de esa mirada - dando lugar así a un nuevo contexto donde ambos adquirieron una dimensión mensurable a escala humana y, por lo tanto, su percepción comenzó a depender de la mirada de un observador. Por ello Jullien afirma que:

De este poder soberano otorga a la vista, de esta virtu visiva según denominación de Leonardo, distinguimos al menos dos elementos de los que comenzamos a sospechar, a partir de China, que no son evidentes. El primero es que en Occidente hemos concebido la pintura en función de la sola actividad del ojo (conducido por la razón), ese ojo que se volverá concéntrico a fuerza de mirar y de trabajar, cuyo más mínimo defecto, según Cézanne, "echaría todo a perder". [...] El segundo elemento es algo que todos sabemos [...] pero de lo que justamente por ser tan familiar, por ser algo que ha pasado tan comúnmente a nuestra lengua, nos resulta difícil tomar conciencia: que, en el trasfondo de la pintura, el pensamiento europeo no ha dejado de privilegiar la vista como vía de acceso a lo real hasta el punto de que no se conciba otro medio para acceder a él. Al ojo se le considera la ventana del alma (por estar esta última cerrada en la prisión del cuerpo) antes incluso de que la pintura se convirtiera, para Alberti, en la ventana abierta a la perspectiva del cuadro. Soñando siempre con un amanecer claro y con grandes desvelamientos, la razón europea no puede concebir de otra manera más que en función del órgano de la vista tanto el surgimiento de la certeza, que se impone por sí mismo, como el acceso último, inmediato, a la verdad ${ }^{150}$.

A partir de entonces la percepción del espacio pasó a ser corpórea, quedando este determinado no tanto por la medida en sí mismo como por la dimensión que se recogía con esa mirada. Por este motivo, el cálculo del espacio y todo cuánto en él se encuentra empezó a medirse geométricamente con líneas, una particularidad que permite calibrar el lugar que cada cosa ocupa en el campo visual. Así, el espacio comenzó a calcularse a través de las diversas distancias dando lugar, como señala Belting, a lo que en la Europa de la Edad Moderna se ha dado en llamar "medición de la mirada de manera que esta pudiera 'construirse' o 'reconstruirse' en la imagen"151. Es decir, una imagen que, aunque construida de manera geométrica, se comprende como

\footnotetext{
${ }^{149}$ Ibídem, pp. 35-36.

${ }^{150}$ François Jullien, La Gran imagen no tiene forma, Barcelona, 2008, pp. 240-241.

${ }^{151}$ Hans Belting, Florencia Bagdad: Una Historia de la Mirada entre Oriente y Occidente, Madrid, 2012, p.17.
} 
figurativa. Ni más ni menos que el comienzo de un cambio en el que la perspectiva como técnica cultural - transformó totalmente los hábitos visuales de Europa, trocando en imagen la mirada misma. Y así, la pintura comenzó a entenderse como un espejo para aquella metáfora que interpretaba el cuadro como una ventana a través de la cual cada uno se podía asomar al mundo - donde la mirada se hizo dueña de un espacio en perspectiva que, desde entonces, monopolizó y encorsetó la comprensión espacial de la pintura europea. A decir Belting:

[...] En el motivo de la ventana tenemos un eje de la "historia" de la mirada occidental. En la ventana se decide la relación con el mundo. Gilles Deleuze habla, en su libro sobre Leibniz, de aquella scission entre dentro y fuera que en gran medida determinó el pensamiento occidental. Lo interior representó, desde los albores de la Edad Moderna, el lugar simbólico del sujeto (el yo), mientras que el mundo exterior sólo es accesible a través de la mirada. En la visión de lo lejano, concepto que aún resuena en la palabra televisión, se busca el mundo que está fuera de la ventana $[\ldots]^{152}$.

Efectivamente, desde ese momento el espacio pictórico se transformaba en el fragmento de un espacio ${ }^{153}$ donde se enmarcaba una parte concreta de un campo visual, presuponiendo a la vez la subjetividad de un espectador y simbolizando la visibilidad del mundo desde un estricto punto de vista cartesiano. Es decir, un acontecimiento donde la geometría estaba supeditada a la imagen y, por lo tanto, estaba en función de su capacidad para reproducir el mundo. Una geometría que, como una tautología, utilizará como medida un espacio para apoderarse, a su vez, de un espacio tridimensional. O, lo que es lo mismo, un lugar externo susceptible de ser ocupado por un cuerpo que, por su escala, estará determinado dentro de ese espacio en el que hipotéticamente habita. De este modo, la distancia pasa a ser un factor de medida según el cual todo es susceptible de ser representado. Una particular comprensión espacial que, por lo tanto, estará necesitada de la certeza de las cosas. En otras palabras, de la seguridad que le ofrece controlar el lugar que éstas ocupan en el espacio. Por consiguiente, desde ese momento la geometría aplicada a la perspectiva se constituirá en el sistema representativo ${ }^{154}$ del modo de pensar y mirar de toda una cultura. O lo que Panofsky ha dado en llamar forma simbólica ${ }^{155}$, detrás de la cual está el concepto de espacio de Biagio Pelacani - cuyos conocimientos están basadas en la teoría de Vitruvio y en su concepto de proporción - y para quien las matemáticas eran la solución al problema que planteaba la relación entre el conocimiento y la experiencia visual.

Biagio combinaba una matemática, por así decirlo, "concreta" del mundo corpóreo con una teoría del espacio vacío. El espacio podía definirse, según él, solamente mediante la "latitud" (latitudo) y el lugar de los cuerpos en el espacio (distancia). Con

\footnotetext{
${ }^{152}$ Ibídem, p. 205.

153 Énfasis propio.

${ }^{154}$ Énfasis propio.

${ }^{155}$ Véase, Panofsky. E, La Perspectiva como forma simbólica, Barcelona: Tusquets Editores SA. 2003.
} 
la introducción del espacio en la teoría posislámica de la visión, Pelacani puso las bases de la teoría de la imagen que constituía la perspectiva lineal, inventada en Florencia en los últimos años de su vida $[\ldots]^{156}$.

Por lo tanto, durante el Renacimiento y la Época Moderna de la pintura europea encontramos una mirada que Guy Gauthier entiende supeditada a la "racionalidad de la visión y la fijación de un punto de vista" ${ }^{157}$. Una mirada que conlleva implícita una posición y también una disposición y, por consiguiente, la actitud de un espectador. En consecuencia, el sistema de representación en perspectiva - que transformó toda una cultura visual - moldeó la Época Moderna europea tal y como la conocemos hoy en día, trasladando la mirada a la imagen y significando, de esta manera, la presencia de un sujeto que mira, es decir: un sistema de representación que convertía en ley su propio sistema. Así, durante el Renacimiento la perspectiva comenzó a entenderse como una ciencia aplicada - que hizo suya la teoría matemática de la percepción visual desarrollada en un contexto paralelo en el que se entendía que la disciplina artística debía tener competencias teóricas. En definitiva, una teoría árabe que derivará en Europa en una teoría de la imagen para hacer de la mirada - y por lo tanto del hombre el foco principal de la percepción.

\section{3.- - (1), 二(2), 三(3): Los Ideogramas Orientales de los Números 1, 2, 3 y la Comprensión Horizontal de la Cosmología de Asia Oriental}

Vinculada a un universo impregnado de fuerzas espirituales, tradicionalmente la pintura de Asia Oriental ha buscado una intensa concentración interior para, así, poder tomar contacto con los misterios de una naturaleza no antropomorfa. Porque, de esta manera - es decir, purificando esta naturaleza de su materialidad - se alcanzaba una orientación metafísica carente de toda artificiosidad que, a su vez, permitía captar su esencia. Es decir, lo que se podría definir como una experiencia religiosa e intuitiva de armonía con la naturaleza, expresada a través de una dimensión cultural, tal y como lo explica Yoshitsugu:

\footnotetext{
${ }^{156}$ Hans Belting, Florencia Bagdad: Una Historia de la Mirada entre Oriente y Occidente, Madrid, 2012, p. 122.

${ }^{157}$ Guy Gauthier, Veinte lecciones sobre la imagen y el sentido, Madrid, 2008, p. 33.
} 
[...] En las culturas de Asia Oriental, cuyas perspectivas fueron construidas por medio de las influencias mutuas de tales tradiciones religiosas como el pensamiento budista, confuciano y taoísta, se ha expresado de forma concreta una relación armoniosa entre humanos y la naturaleza en el arte, literatura, arquitectura y demás. Las culturas y modos de vida en la Asia Oriental se basan en la creencia de que los seres humanos y la naturaleza están íntimamente relacionados o incluso son idénticos en último término. En las culturas de Asia Oriental, la cercanía de humanos, dioses y naturaleza es característica de estas perspectivas religiosas ${ }^{158}$.

En cualquier caso, todos estos aspectos han constituido un marco para una tradición pictórica que había establecido un estrecho vínculo con los fenómenos naturales y su permanencia. Y es que, tradicionalmente, las sociedades de Asia Oriental han comprendido la naturaleza como un todo unificado donde confluyen la colectividad y el mismo yo. Por este motivo podemos entender de qué manera, en estas sociedades, el ser y sus distintas posibilidades no depende de las diferentes particularidades del individuo, dando así lugar a una idea de destino - o karma - y a su explicación dentro de un marco cosmológico abierto en el cual no se concibe el yo separado del entorno. Así, en su esencia, el mundo no es estático sino que permanece en un cambio perpetuo, en mutación constante. En consecuencia, el mundo de los fenómenos reposa sobre una polaridad de fuerzas; una oposición no excluyente. Es decir, lo positivo y lo negativo, la luz y la sombra, lo creador y lo receptor. Una binaridad de manifestaciones de las fuerzas polares que producen un cambio, una constante mutación ${ }^{159}$.

Al hilo de esta idea, es importante señalar que para la filosofía china - y por extensión e influencia, con sus matices, para Asia Oriental - existe una relación armónica entre el macrocosmos y el microcosmos. Es decir, entre las imágenes que el Cielo envía a la Tierra y las diversas ideas culturales que en su imitación serán interpretadas por los sabios. Así, señala Cheng, en su obra Hua -hsüch hsin-fa wen-ta (Diálogos sobre el espíritu de la pintura) $\mathrm{Pu}$ Yen-t'u, reputado maestro en Historia y Teoría del Arte (s. XVIII, dinastía Qing 清朝) señala:

Sin duda es inmenso el uso de i [idea, deseo, intención, conciencia activa, visión justa], algo que, sentencia, no concierne solamente al arte pictórico. Subyacente en todo aquello que vive y evoluciona en el seno del universo, el i existe antes incluso que el Cielo y la Tierra. En el I-Ching ["Libro de las Mutaciones"] designa ese Casi-nada (o Clic) con el que se inicia toda transformación. En la pintura es él el que suscita el espíritu por el que se encarna toda figura ${ }^{160}$.

\footnotetext{
${ }^{158}$ Yoshitsugu Sawai, Perspectivas de la naturaleza en culturas de Asia Oriental, Universidad de Tenri, Nara, 2008, p.249. < $\quad$ https://ruc.udc.es/dspace/bitstream/handle/2183/12905/CC98_art_13.pdf?sequence $=1 \&$ isAllowed $=y$ [ 23 de mayo 2020]

${ }^{159}$ Todas estas transformaciones giran en torno del gran polo T'ai Ki (T'aiyi 太) - la unidad más allá de toda dualidad. Unas transformaciones cíclicas y progresivas que se producen mediante la vía del cielo que se corresponde en la tierra con la vía del hombre.

${ }^{160}$ François Cheng, Aliento y Espíritu. Textos teóricos chinos sobre el arte pictórico, 2017, p. 45.
} 
Es decir, que el I Ching (易经) trata, paradójicamente, de traducir lo intemporal en términos de tiempo, las leyes del universo en términos de la vida humana ${ }^{161}$. En Vacío y Plenitud, François Cheng nos dice:

La idea fundamental del libro de las mutaciones, como su título indica, es la de la mutación que rige todas las cosas, y que regula ante todo la relación entre las tres entidades que son el cielo, la tierra y el hombre. [...] En esta perspectiva, el cielo y la tierra, por su interacción, representan al mismo tiempo el espacio y el tiempo (más tarde, durante la dinastía Han, encontramos en el Huai-nanzi el término yuzhou, "espacio-tiempo", que designa el universo). El tiempo, esencialmente ligado a la tierra, aparece como espacio vital actualizado; y el espacio, esencialmente ligado al cielo, por el hecho mismo de ser vital, aparece como garante de la calidad justa del tiempo. [...] Como componentes de la vida en mutación, ni uno ni otro son conceptos o marcos abstractos y separados; encarnan la cualidad misma de la vida ${ }^{162}$.

En el contexto de esta cosmovisión, es preciso señalar que las sociedades orientales han desarrollado su propia estructura de valores, enmarcados dentro de un particular sistema epistemológico muy diferente al de la cultura occidental. Así, la cosmovisión de Asia Oriental comprende e integra dentro de un todo a la naturaleza, la sociedad, las divinidades y el yo, relacionándolas por medio de una flexible y fluida secuencia de relaciones horizontales. Una conceptualización de ese yo, naturaleza y sociedad, que se enmarca en unos modelos culturales donde encontramos un cierto paralelismo entre sus estructuras sociales y las diferentes manifestaciones y respuestas culturales.

Una particular ética situacional que ha dado lugar a una comprensión más holística del ser humano - en lo que respecta a la relación social del individuo - y a una visión naturalista del cosmos que, además, explica la coexistencia de múltiples verdades. Nos encontramos en el contexto de un animismo politeísta que ha funcionado como base para una estructura social fundamentada en una idea de colectividad, donde la norma se centra en la idea del grupo y no del individuo ¿Ha favorecido esto una comprensión horizontal en la interpretación del mundo? ${ }^{163}$ Lo cierto es que tradicionalmente en las culturas de Asia Oriental los logros no se comprenden como sucesos aislados e individuales, sino que se conciben como una yuxtaposición del yo, de la sociedad y de la naturaleza; una evolución lineal que ¿podría encontrar su correlato en la preferencia por el desarrollo secuencial y horizontal de numerosas pinturas chinas,

\footnotetext{
${ }^{161}$ La incidencia que ha tenido el I Ching (易经) sobre la estética extremo oriental ha sido fundamental y no puede ser ignorada. En el caso japonés, por ejemplo, en el terreno de la estética - particularmente la literaria - puede decirse que el I Ching tuvo su entrada en Japón en el ámbito del sistema ritual de la corte, ejerciendo desde esta una notable influencia.

${ }^{162}$ François Cheng, Vacío y plenitud, Madrid, 2004, p. 96.

163 “[...] Las danzas orientales no saben de saltos altos ni giros rápidos. La danza coreana de los monjes budistas (sung mu)), que traduce vacío y ausencia en movimiento, describe largas líneas, sobre todo horizontales, con un ritmo extremadamente lento. También el movimiento básico de la danza Nô es el paso deslizante. [...] No hay movimiento vertical. Ninguna antigravedad heroica interrumpe la línea horizontal. [...] Han, Byung - Chul, Ausencia, Buenos Aires, 2019, pp. 71 - 72.
} 
coreanas y japonesas? Lo cierto es que en estas pinturas, gracias a lo que se podría denominar como una experiencia continua - no solo en el tiempo sino también en el espacio - la imagen como concepto ha podido eludir ese carácter estático tan característicamente occidental, mediante la estrecha relación que se establece entre las inflexiones instrumentales del pincel, su visualización y, en palabras de Moulin, el "movimiento del pensar". Una pintura que, como la caligrafía, tiende a la abstracción por su sentido rítmico de los trazos. Se trataba, según este autor, de simplificar y de dar unidad a unas formas tomadas de la realidad, pero también de la espiritualidad.

[...] Así, el concepto y la imagen tuvieron su origen en un mismo hecho normalizador que, por la diversidad de sus inflexiones y de las variaciones instrumentales del pincel, visualizaban el movimiento del pensar. Pintar y escribir constituían la misma operación poética. De aquí, sin duda, ese desdén por la imitación y el parecido ${ }^{164}$.

Para Dǒng Qíchāng (1555-1636) - pintor/calígrafo y crítico de arte durante la dinastía Ming 大明- el hombre culto podía mostrar el conocimiento de los verdaderos principios de la naturaleza por medio de la representación del paisaje. Es decir que lo realmente significativo no era la representación de su apariencia externa, sino aprehender el sentido y orden interno de las cosas. Aquella denominada energía primordial a la que la pincelada daba forma. Hablamos de un juego de relaciones que hunde sus raíces en la iconografía china del paraíso de los inmortales taoístas cuya idea, a su vez, se había basado en los paraísos budistas, que eran aquellos lugares donde el hombre podía alcanzar la armonía con la naturaleza y el Tao (道). En estos se encuentra el origen de los jardines privados e imperiales, de las villas de montaña y de la prosa paisajística o notas de viaje - llamada Youji - que popularmente se han denominado paisajes $^{165}$. En ellos se une el valor plástico de la pintura, el poético y caligráfico del trazo de los caracteres de la escritura, y el del poeta/autor del texto, dándose el caso de que en muchas ocasiones detrás de todos estos valores se encontraba en realidad una sola persona.

Efectivamente, la pintura de Asia Oriental estaba imbuida por una contemplación activa que en gran medida tomaba sus fuentes del culto hacia los fenómenos naturales, traduciéndola en una experiencia continua espacial y temporal mediante un discurrir totalmente alejado de la estática contemplación occidental - que encontró su correlato en la fluidez de la escritura y en la evolución de una serie de soportes para la pintura que favorecieron su característica dimensión espaciotemporal. $\mathrm{Y}$ es que, mientras en la pintura europea el espectador permanece en el exterior de un cuadro $^{166}$ que se extiende hasta y ante un horizonte al que se asoma cuando lo contempla, en la pintura extremo oriental el espectador forma parte activa de la obra,

\footnotetext{
${ }^{164}$ Raoul-Jean Moulin, en Michel Courtois, Pintura china, Madrid, 1969, p.9.

${ }^{165}$ Para más información sobre la cultura del paisaje en la dinastía Song 宋朝 véase, Mezcua López, Antonio José, La experiencia del paisaje en China "shanshui" o cultura del paisaje en la dinastía Song, Madrid: Abada Editores, 2014.

${ }^{166}$ Énfasis propio.
} 
por lo que, podría decirse, cada elemento pintado está visto desde el interior. Hablamos de una particular manera de percibir y contemplar que privilegia la empatía e implica un devenir y una manera de situarse que fusiona de esta manera el yo en el mundo ${ }^{167}$. Un desplazamiento para el que, en vez de certezas - en una idea totalmente alejada de la exactitud del espacio mensurable de Occidente - solo es preciso evocar y sugerir un espacio que se manifiesta precisamente porque rechaza la representación de una acción temporalmente delimitada, buscando proyectarse en el presente del espectador.

Tal vez por esto, y no por casualidad, en las pinturas de Asia Oriental se recurre a formatos que, paradójicamente, expresan la atemporalidad del tiempo y la infinitud del espacio mientras dirigen la mirada en un recorrido sin espacio ni tiempo. Nos encontramos, por lo tanto, con dos rasgos específicos que, a su vez, se tradujeron en la representación de una experiencia y la interpretación de una realidad. Unos rasgos que han depositado su importancia visual en la relación relativa que se establece entre los diferentes elementos espaciales que intervienen en la composición para que, de esta manera, estos puedan ser observados o casi leídos ${ }^{168}$ sucesivamente. En este contexto, para expresar distancias, el vacío crea un diálogo entre los diversos planos de la composición, completando la pincelada y de esta manera también las formas. Un recurso pictórico sobre el que Rowley escribió:

Históricamente, la concepción de las partes vacías evolucionó en todas las civilizaciones desde un fondo neutro ideacional hasta una representación más visual del espacio. En la pintura primitiva la mentalidad ideacional eliminó todo salvo las figuras esenciales, mientras que los lugares vacíos carecían de significado representacional y apenas tenían valor de diseño. Los bajorrelieves Han demuestran la destreza de los artistas primitivos al combinar formas de figuras y áreas de vacío neutro en motivos agradables a la vista, dispuestos en secuencia; las pinturas de las lacas Han y el rollo de Gu Kaichi son buen ejemplo del empleo del vacío neutro en cuanto relieve de las figuras. [...] En los periodos Tang y Song del Norte, los lugares vacíos comenzaron a representar un espacio, que acabaría transformándose en vehículo para transmitir estados de ánimo estacionales y atmosféricos [...] Pero mientras que los artistas Tang y Song del Norte dependían de los sólidos de las montañas para crear el espacio, los vacíos servían sobre todo para aumentar la escala de los sólidos o para sugerir profundidad. Sólo cuando comenzaron a suprimirse los sólidos en la época Song del Sur los vacíos alcanzaron su significado definitivo $[\ldots]^{169}$.

\footnotetext{
167 “[...] la pintura paisajista revela el espíritu del hombre taoísta. En los grandes maestros chinos se ve cómo estos hombres pretendían dar expresión al sentimiento místico inefable de integración con lo percibido: ese gozo que se siente al experimentar intuitivamente la armonía intrínseca de la naturaleza y su armonía con el cuerpo-espíritu humano. Los paisajistas chinos son taoístas expertos en el arte de la meditación y la contemplación, capaces de abrirse totalmente a las percepciones para recibirlas puras. [...] la transformación de emoción en forma, que es la alquimia del arte. Sólo entonces toma el artista los pinceles y pinta el acorde que ha resonado entre la naturaleza y su cuerpo por empatía integradora. [...]". En Luis Racionero, Textos de estética taoísta, Madrid, 2014, p. 19.

168 Énfais propio.

${ }^{169}$ George Rowley, Principios de la Pintura China. Madrid, 1981, p. 106.
} 
En consecuencia, hablamos de una manera de concebir la representación del espacio no encorsetada por los límites de lo preciso, recurriendo al vacío para poder delinear este ambiente espiritual. De este modo, mediante la sugerencia se expresaba el misterio, representando un espacio densamente impregnado de significados culturales que cada espectador debía en primer lugar descubrir para después interpretar. Como sentencia García Gutiérrez:

[...] Se da aquí un paso transcendente en el arte: el hacer un paisaje espiritual y procurar expresar un universo ideal, no atado a los límites de lo concreto. Cuando no es posible delinear ambientes espirituales con elementos materiales, por mucho que se los desmaterialice, el pintor recurrirá al espacio vacío. Entonces el espacio desempeña un papel mucho más importante que los trazos increíbles que lo enmarcan $[\ldots]^{170}$.

Una comprensión del espacio que, precisamente para representarlo, discurre de manera homogénea, prescindiendo de cualquier idea de dimensión tal y como se comprende en Occidente. Así, los diferentes elementos que conforman una pintura carecen de cualquier nexo mimético - corpóreo o espacial - en perspectiva, recurriendo para enriquecer sus posibilidades decorativas a la capacidad de sugestión de la herencia china del principio del menor número. La también llamada ley de la proporción numérica que para captar el Qi (氣) - a partir del sonido y a través de la obra - establece, mediante las ya mencionadas agrupaciones rítmicas, una resonancia musical entre el espectador y el artista. Una manera de comprender el espacio pictórico para la que Los Caquis de Mugi Fuchang, Mu Qi (牧溪) o Mokkei en japonés (牧谿) - monje chan y pintor chino del siglo XIII - puede servirnos como un ejemplo de esa exquisita economía de medios [Figura 11]. Una obra y unos principios que ya expresó Rowley en su libro Principios de la pintura china:

Mu Qi puede pintar seis caquis en un pie cuadrado de seda y hacer que parezcan inagotables las tensiones que se suscitan entre ellos. No sólo cada círculo del fruto se ajusta a los demás gracias al equilibrio entre los intervalos, sino que la medida de dichos intervalos se acentúa como consecuencia de los rabillos ideográficos que, pintados a tinta china y con pincel fuerte, señalan inequívocamente las distancias y el movimiento oscilante de ascenso y descenso dentro del grupo $[\ldots]^{171}$.

Efectivamente, el Qifú (起伏), esa consonancia de elementos armonizados horizontalmente mediante una organización repetitiva y rítmica de formas entendidas como un vehículo para la búsqueda de lo sagrado. Por lo tanto, para captar el $Q i$ (氣) se buscaba una semejanza rítmica que - a la manera del sonido y del ritmo - se traducía en una combinación de intervalos donde se alternan motivos y silencios/vacíos. Una disposición horizontal que ha hecho posible una relación más mental que visual con

\footnotetext{
${ }^{170}$ Fernando García Gutiérrez, El Zen y el arte japonés, Sevilla, 1998, p.38.

${ }^{171}$ George Rowley, Principios de la Pintura China, Madrid, 1981, p.90
} 
unas formas esquemáticas apoyadas sobre fondos vacíos y que ha favorecido la nitidez entre los intervalos grupales haciendo, a su vez, posible la aparición de la distancia lateral. Por lo tanto, si nos atenemos a lo expresado por Rowley:

La pintura china es un arte del tiempo si su unidad depende más de la coherencia que del equilibrio y si los diseños se caracterizan por un movimiento lateral, ¿cómo se controlaban esas notas, de por sí destructivas del marco, de forma que podamos afirmar hoy que los chinos eran superiores en cuanto se refiere a la percepción de las dimensiones del formato? En general, cabe señalar cuatro métodos principales: el compás de las secuencias, la utilización de espacios de parada, la consonancia y la tensión. El compás, al igual que en la partitura musical, era de suma importancia en los rollos de largas dimensiones [...] En los rollos, el momento crucial de ajuste al formato se produce justo al final, y éste se manifiesta de muy diversas maneras, pero sea cual fuere se ciñe al compás de las secuencias $[\ldots]^{172}$.

Entendemos, entonces, que el formato de los rollos horizontales ha definido durante siglos la comprensión del espacio pictórico extremo oriental hasta tal punto que en Japón podemos encontrar un término etimológicamente nuevo, en el que prevalecen unas implicaciones espaciales profundamente arraigadas en la tradición extremo oriental; el fûkeiga shoshiki (風景画 書 式). Un término que alude expresamente al formato horizontal de la escritura, semejante al de la pintura de estilo de paisaje. Un concepto en el que, en el contexto de esta investigación, podemos deducir la implicación de un determinado sistema oculto de ideas. Es decir, que designa expresamente no solo el formato, sino el tema y por lo tanto la distribución de su espacio. Por consiguiente, más que designar un soporte - el emakimono (絵 巻 物) entendemos que nos encontramos con una explícita referencia al espacio en la pintura de paisaje ¿Podría tener algún tipo de relación con un sistema de representación concreto? ¿Podríamos relacionarlo con el Principio de la Narración Gráfica Continua? Un asunto sobre el que, en cualquier caso, volveremos más adelante.

Mientras, retomando el hilo de nuestra investigación, debemos recordar que la capacidad de la pintura extremo oriental para sugerir y crear sitios precisaba de una memoria compartida capaz de evocar y configurar el espacio representado o - lo que es lo mismo - capaz de hacer que la memoria del espectador fluyese en un continuo de fenómenos sensibles a través de un mundo formado por arquetipos. Entonces, solo entonces - lejos de la mímesis que impregnaba la pintura europea - ese espacio pictórico, al encontrar aquella identificación espiritual y estética que le confería su verdadera razón de ser, cobraba verosimilitud. Por lo tanto, hablamos de un espacio pictórico que solo cobraba sentido si se identifica con el tiempo que fluye mientras se contempla. Por este motivo podemos decir que, mientras la pintura europea aspiraba a ser tridimensional, la pintura china y japonesa - aunque, resultase bidimensional - al introducir en su comprensión espacial una combinación de escalas-tiempo aspiraba a ser

${ }^{172}$ Ibídem, p. 102. 
multidimensional. Una idea ya admirablemente expresada para Cheng: "[...] una simbiosis del tiempo y del espacio, y por ende del hombre y del universo. Tomando en cuenta este hecho, cabe hablar de una suerte de quinta dimensión (allende el espacio tiempo) que representa el vacío en su grado supremo $[\ldots]^{\prime, 173}$.

${ }^{173}$ François Cheng, Vacío y plenitud, Madrid, 2004, p. 182. 
“[...] Somos testigos del rito. De forma intermitente somos también celebrantes [...]"174

\section{3.-TEORÍA COGNITIVA DE LA MIRADA}

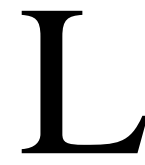

a organización del espacio plano de la imagen se ha constituido, desde siempre, como una preocupación común a todas las culturas. Es decir, cómo resolver el problema que supone trasladar a una superficie bidimensional cuanto vemos y la manera en que lo hacemos. Porque, puesto que las imágenes son una forma de entender y representar el mundo, son también una forma de conocimiento y de comunicación. Es precisamente por esto por lo que una imagen debe solucionar determinadas cuestiones que están al fin y al cabo relacionadas con sus aspectos denotativos y connotativos. Dicho de otra manera: atender tanto a las posibles soluciones técnicas que connota el estilo como a los problemas con los que el artista se enfrenta para poder representar el espacio y el tiempo. Martin Gayford, en ese ameno diálogo que es Una Historia de las imágenes, se lo decía así a Hockney:

[...] una imagen puede compararse con un mapa, que es un tipo de imagen muy especializado. La tarea de un cartógrafo es describir las características de un objeto curvo, la Tierra, sobre otro plano. Hacerlo con total fidelidad, tal y como se demostró hace mucho, es una imposibilidad geométrica. Por tanto, todos los mapas tienen defectos y son parciales, reflejan los intereses y el conocimiento de quien los traza. La situación es análoga con las imágenes. Todas son intentos de resolver esos mismos problemas, cuya solución perfecta es imposible, pero las soluciones imperfectas son infinitas; y cada intento tiene sus virtudes y sus inconvenientes ${ }^{175}$.

\footnotetext{
${ }^{174}$ Frazer, James George. La Rama Dorada. Magia y Religión. México, 2014, p. 32.

${ }^{175}$ Martin Gayford en, Martin Gayford y Hockney, David, Una historia de las imágenes, Madrid, 2018, p. 20.
} 
Efectivamente, podemos decir que en la cartografía de una pintura se refleja, como en un mapa, todos aquellos accidentes que van dando forma a su espacio. El registro de las cicatrices que este y el tiempo dejan en la superficie de las cosas. Es decir, el reflejo de la metamorfosis a la que, inevitablemente, está abocado el espacio que se interpreta y el tiempo a través del cual este se va paulatinamente conformando. En palabras de Bryson, el "[...] tiempo dietico de la pintura como proceso [...]"176. Algo a lo que podríamos denominar el Entre - que más que con la coincidencia de los opuestos está relacionado con la ambigüedad del logos - ya que al ser tanto un arte del espacio como del tiempo, en la pintura ambos no se podrían entender separados.

Pero en Occidente, hasta hace relativamente poco - no mucho más de un siglo el espacio y el tiempo se concebían como entidades separadas. Fue precisamente el contacto con la estética extremo oriental lo que ha permitido que estos dos conceptos hayan dejado de entenderse de manera independiente, pasando a concebirse ambos desde entonces como las dos caras de una misma moneda que son, al fin y al cabo, una sola realidad. Lo que se entiende como la percepción espacial de la pintura que - no sólo en la perspectiva de la Europa renacentista y de la Época Moderna - está siempre supeditada a la dinámica del punto de vista, ya que la imagen se altera en función de las distintas maneras de mirar. Y es que, si el Arte es un emocionado ejercicio de la memoria, podemos asegurar que - ejercitando esos códigos de reconocimiento que conforman el denominado nicho cultural - es precisamente ejercitando esa memoria con lo que solemos mirar. Expresado por Gombrich:

En la pintura, el único individuo capaz de un reconocimiento rememorativo es el pintor [...] los códigos de reconocimiento aquí ocupan el territorio interindividual del signo. El criterio de reconocimiento justo implica siempre a más de un observador: Es esencial que exista acuerdo para que se pueda adjudicar a la imagen un término de reconocimiento $[\ldots]$ convencional y aceptado; únicamente entre individuos torna la mediación del signo $[\ldots]^{177}$.

Por eso, cuando hablamos de una Historia del Arte, inevitablemente también hablamos de una Historia de la Mirada - colectiva o individual - y por lo tanto sujeta a una serie de cambios históricos y culturales. Una historia de la mirada que implica un ejercicio de la memoria en tanto en cuanto hace presentes a aquellos creadores y aquellos para los que las distintas imágenes fueron creadas. Es decir, en tanto en cuanto hace presente determinados códigos perceptivos de un periodo de la historia. Así, como señalábamos en la presentación de esta tesis, en la memoria de la pintura contemporánea encontramos señales de los códigos perceptivos de otras culturas o de otras épocas. En otras palabras, el registro de lo que la contemporaneidad ha hecho con las imágenes, que

\footnotetext{
${ }^{176}$ Norman Bryson, Visión y Pintura. La lógica de la mirada, Madrid, 1991, p. 104.

${ }^{177}$ E.H, Gombrich, Arte e Ilusión. Estudio sobre la psicología de la representación pictórica, Barcelona, 1979, p. 66.
} 
nos desvela factores psicológicos reveladores de la personalidad creadora, del espectador y su contexto.

En esta tesitura, en los apartados anteriores hemos visto como en el espacio pictórico europeo - al final de la Antiguiedad - los diversos elementos del cuadro se yuxtaponen y modifican sobre unos fondos neutros, evolucionando hacia unas formas planas "que se disponen una al lado de otra sin consideración alguna hacia la precedente lógica de composición [...]"178. Lo que Panofsky también define como un "ensamblaje de grupos" - de manera similar a la comprensión espacial de la pintura de Asia Oriental - donde el espacio pictórico se comprende como aquello que rodea a las formas o grupos de estas, por lo que artísticamente, el espacio se representa mediante una superposición y sucesión de figuras más o menos esquematizadas [Figura 12]. Una yuxtaposición que definida por Norman Bryson de esta manera:

“[...] Cuando las imágenes se han expandido en la connotación, el espectador que pasa de una a otra se enfrenta cada vez a una escena distinta, escena que se ha independizado de su secuencia, ha renunciado a su puesto en el ciclo coral, y pide ser contemplada en aislamiento cada vez mayor de su entorno físico y de la langue general. [...] las zonas de pared que quedan entre las escenas están tratadas a la vez como bandas que unifican los espacios separatistas en la coherencia espacial del muro, y al mismo tiempo como intervalos que separan la escena y refuerzan su individualización al transformar la franja de pared en marco $[\ldots]^{179}$.

De este modo, ese espacio construido por una suma de agregados derivará en lo que Bryson denomina un "espacio sistemático" que, en sus orígenes - en el medioevo tardío - adoptó el principio de la Antigüedad de raspa de pez, en cuya cuadrícula en escorzo el tamaño de los cuadros centrales y laterales estaban descompensados [Figura 13]. Nos hallamos por lo tanto ante la comprensión de un espacio pictórico que se conservará en Oriente mediante ese ensamblaje de grupos y se perderá en Occidente con la adopción de la perspectiva como sistema de representación y como símbolo ${ }^{180}$.

Sin embargo sería inapropiado afirmar que en la pintura de Asia Oriental no había interés por una representación de la dimensión del espacio. Es decir, que ese interés es solo patrimonio de Occidente. La diferencia, como ya se ha señalado, está en que la perspectiva europea del Renacimiento tiene un punto de fuga fijo que no existe como tal ni en la pintura japonesa, ni en la china, ni en la coreana. Así, repasemos, mientras en Occidente la pintura adopta un punto de vista fijo que connota una posición inmóvil - que implica que el sujeto se ha detenido - la percepción del espacio pictórico en un rollo de mano es más sutil, adoptando puntos de vista cambiantes que, de este modo, resultan más dinámicos y fluidos. Por lo tanto, ambas maneras de representar el espacio denotan actitudes diferentes para su contemplación: una pintura y una mirada

\footnotetext{
${ }^{178}$ Erwin Panofsky, La Perspectiva como forma simbólica, Barcelona, 2003, p. 3.

${ }^{179}$ Norman Bryson, Visión y Pintura. La lógica de la mirada, Madrid, 1991, p.109.

${ }^{180}$ Véase, Panofsky, Erwin, La Perspectiva como forma simbólica, Tusquets Editores, Barcelona, 2003.
} 
detenida para representar y contemplar una imagen en Occidente y una pintura y una mirada que se desplaza para componer y leer la imagen representada en los rollos de mano de Oriente.

En Europa, desde el Renacimiento, un paisaje era una ventana abierta a un punto particular del mundo. En China era una interpretación del macrocosmos. Este universo representado bajo este aspecto no resulta estático; está animado por un ritmo, esencia misma de la vida cósmica, ritmo que el hombre aprehende contemplando la naturaleza e identificándose con ella. La búsqueda de este ritmo no estaba, pues, centrada en torno a un punto fijo, la ausencia de perspectiva geométrica no era debida a la ignorancia o a la casualidad. El cuadro mismo de una pintura china implica movimiento: rollos que ni a lo largo ni a lo ancho pueden ser aprehendidos en su conjunto de una sola ojeada ${ }^{181}$.

Por lo tanto, llegados a este punto, debemos hacernos una pregunta ¿Podemos decir que el espacio pictórico oriental es más intuitivo y poético que el del Renacimiento y el de la Edad Moderna europea? Es cierto que este último mantiene resonancias cartesianas e introduce el cálculo numérico para la construcción de imágenes. Aun así, y tal vez por eso ¿Debemos entender la pintura europea de entonces sólo como una estructura objetiva, como el esquema métrico al que debía adaptarse el pincel? O, al contrario, esta ventana, esta magnitud espacial ¿podría entenderse como una abstracción de la ambivalencia de lo presente y lo ausente, de la ambivalencia del cuerpo y la mirada? Una idea que - a la luz de lo que había señalado Rotman cuando observa procesos paralelos entre la introducción del cero en las cifras numéricas arábigas y la invención del punto de fuga - conlleva varios significados. Como bien señala Belting citando a Rotman:

[...] El punto de fuga tiene, como el cero, varios significados [...] a su valor cuantitativo - como cifra - se añade su valor como signo con el que se puede organizar de la misma manera infinitas imágenes, igual que con el cero generar infinitos números. El punto de fuga es imprescindible en la perspectiva, cualquiera que sea la imagen representada - o más bien porque - es un punto abstracto en medio de los motivos objetuales.

Rotman descubre una mirada que oscila entre el cuerpo y una imagen, y pone de relieve toda su ambivalencia cuando describe la imagen, a la que el cuerpo no tiene acceso, como lugar de la mirada. [...] La relación indisoluble entre presencia y ausencia vale, según Rotman, también para el cero, que sólo puede ser un número como no-número. $[\ldots]^{182}$.

\footnotetext{
${ }^{181}$ Noticias sobre la exposición "Montagnes et eaux" (Paisajes chinos de los siglos XIV al XVIII) Museo Guimet, París 1957, en Michel Courtois, Pintura China, Madrid, Aguilar, S.A, 1969, pp. 111-112.

${ }^{182}$ Hans Belting, Florencia Bagdad: Una Historia de la Mirada entre Oriente y Occidente, Madrid, 2012, p. 14.
} 
En cualquier caso, para la contemplación de un espacio pictórico - tanto del europeo como del extremo oriental - resulta imprescindible recordar. Es decir, tomar lo que se podría denominar como un dato nuevo, presente, y remitirlo a otro dato pasado $^{183}$, previamente extraído de la memoria, para así poder colocar uno junto al otro. De esta manera, como una sinapsis, los códigos visuales que, como tales, parecen ya olvidados son aceptados como imperativos sensoriales. Es decir, como nichos culturales que se heredan y consideran naturales. Unos códigos sociales de reconocimiento construidos y aceptados culturalmente.

\section{1.- La Representación del Espacio. La Dimensión Mensurable del Espacio Pictórico de la Pintura Moderna Europea}

Hemos visto que en el arte europeo, en la Antigüedad Clásica y en la Edad Media - al igual que sucede en la tradición de la pintura de Asia Oriental ${ }^{184}$ - se recurre a secuencias espaciales y temporales como estrategia para unir varios elementos mediante agrupaciones rítmicas. Una circunstancia que ha favorecido planteamientos espaciales más expresivos e intuitivos que - lejos de plantear el espacio pictórico alrededor de un centro unitario - logran un efecto de unidad mediante una yuxtaposición de espacios, dando así lugar a una sucesión temporal que se perdió en el siglo XV con el desarrollo científico de la perspectiva. A decir de Gauthier, un acontecimiento que supuso una "[...] revolución pictural, que pese a la diversidad de preocupaciones tendía a restablecer la primacía del espacio sobre el lienzo [...]" aunque, continúa, “[...] De momento no olvidemos que la profundidad es uno de los componentes de la estética realista que se ha manifestado en el transcurso de la historia bajo formas muy variadas", 185 .

Efectivamente, ya en los primeros textos sobre pintura los griegos hacían especial mención a la cuestión de la verosimilitud para la que, consideraban, se requería del uso del claroscuro. Por consiguiente, podemos afirmar que el asunto de las sombras

\footnotetext{
${ }^{183}$ Énfasis propio.

184 Esta lectura horizontal de la pintura está relacionada con la escritura. Mientras que los textos occidentales se desarrollan de izquierda a derecha, los chinos y japoneses se desenvuelven de derecha a izquierda, en unos párrafos que antiguamente se escribían de arriba abajo. Esta característica mantiene su vigencia en el mundo editorial del Japón de hoy en día, otorgando - en sus libros - la condición de portada a lo que para los occidentales es la contra portada y, por lo tanto, desplegando su diseño, maquetación y lectura de derecha a izquierda.

${ }^{185}$ Guy Gauthier, Veinte lecciones sobre la imagen y el sentido, Madrid, 2008, pp. 38-39.
} 
- de las que se carece casi absolutamente en el arte japonés y chino - ha sido desde siempre una preocupación para el arte europeo. Así, ya en el s. I d. C, Plinio el Viejo en su Historia Natural - en el relato de la hija de Butades y el retrato que esta hizo de su amante dormido - nos habla de cómo, sin especificar donde, el primer retrato se originó a partir de una sombra: "Los egipcios afirman que su invención surgió de entre ellos, seis mil años antes de que pasara a Grecia; se jactan en vano, resulta obvio. En cuanto los griegos, unos dicen que se inventó en Sición, otros dicen en Corinto; pero todos coinciden en que se originó al trazar unas líneas alrededor de la sombra humana"186.

Según fuentes antiguas, fue Apolodoro, al que apodaron como el esquígrafo pintor de sombras - el primero en aplicar este recurso. Un ateniense que, a decir de Plutarco, fue el primero en graduar la intensificación de la sombra y, según Plinio, quien establece un método para representar apariencias ${ }^{187}$. De aquí el relato sobre la competición entre Zeuxis - y su pintura de unas uvas que, narra Plinio, tal era su realismo que hasta picoteaban los pájaros - y Parrasio de Éfeso - y la ilusionista cortina de lino que parecía cubrir su pintura y que, dado su realismo, hasta pudo confundir a su contrincante -. Es decir: una puesta en escena de la habilidad para disponer sombras que hace posible, de esta manera, que se pueda engañar a la vista ${ }^{188}$. Al hilo de esta idea, Panofsky nos indica:

A juzgar por un conjunto más bien exiguo de pruebas visuales y un corpus mucho mayor de información literaria, en el que se incluyen las célebres invectivas de Platón, un estilo pictórico basado en esta premisa sensualista o ilusionista (ambos calificativos tomados por supuesto, sin implicación condenatoria alguna) había surgido a finales del siglo $\mathrm{V}$ a. C y estaba ya muy avanzado a mediados del IV. Y es cierto que en época helenística y romana conoció un desarrollo pleno. En Roma y la Campania encontramos complicados interiores, paisajes y vistas de ciudades que nos enfrentan, sin lugar a dudas, a "un ámbito aparentemente tridimensional que parece extenderse indefinidamente por detrás de la superficie pintada, objetivamente bidimensional" $[\ldots]^{189}$.

Un trampantojo para el que todo es ilusión y naturalismo, y al que Platón considera como contrario de la verdad, puesto que las imágenes eran consideradas por él tan engañosas como los reflejos en un espejo o como las sombras que los cuerpos

\footnotetext{
${ }^{186}$ Plinio el Viejo, "Historia Natural", (Libro XXXV, 15) en Hockney, David y Gayford, Martin, Una historia de las imágenes, Madrid: Ediciones Siruela, 2018, p. 62.

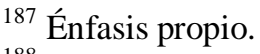

188 "Se cuenta que este último [Parrasio] compitió con Zeuxis: éste presentó unas uvas pintadas con tanto acierto que unos pájaros se habían acercado volando a la escena, y aquél presentó una tela pintada con tanto realismo que Zeuxis, henchido de orgullo por el juicio de los pájaros, se apresuró a quitar al fin la tela para mostrar la pintura, y al darse cuenta de su error, con ingenua vergüenza, concedió la palma a su rival, porque él había engañado a los pájaros, pero Parrasio le había engañado a él, que era artista. ”(Libro 35, 65). Plinio el Viejo, en Ignacio Escobar García-Quirós, Dibutades o el arte de dibujar, Arte, Individuo y Sociedad, 2000, p. 250. file:///C:/Users/Usuario/Downloads/6772Texto\%20del\%20art\%C3\%ADculo-6856-1-10-20110531.PDF (última consulta 13/06/2020).

${ }^{189}$ Erwin Panofsky, Renacimiento y renacimientos en el arte occidental, Madrid, 1975, p. 183.
} 
proyectan sobre una pared ${ }^{190}$. Efectivamente, para Platón, la verdad estaba en los números: para contar o para establecer un sistema mensurable, entendiendo todo ello como una obra de la razón que, como tal, se da y existe en nuestra alma. En palabras de Panofsky "[...] una unidad cuya forma particular encuentra, a su vez, en la concepción del espacio propio de la filosofía de la época un análogo teorético [...] es decir, en la metafísica de la luz del neoplatonismo pagano y cristiano"

El espacio no es otra cosa que la sutilísima luz", escribe Proclo, con lo cual el mundo, igual que el arte, es definido por primera vez como un continuum y queda al mismo tiempo privado de su compacidad y de su racionalidad. El espacio se ha transformado en un fluido homogéneo y, si se nos permite decir, homogeneizador, falto de dimensiones ${ }^{191}$.

Así, en su libro La Perspectiva como forma simbólica, Panofsky estudia cómo, en la pintura de la Antigüedad Clásica y en la Edad Media europea, lejos de simular un espacio en profundidad se prioriza la organización de un espacio plano en la imagen, sin olvidar que, en algunos casos, gracias al recurso del enmascaramiento se establece la relación de unos elementos respecto a otros. Nos encontramos por lo tanto con una superposición de las figuras, de tal manera que la que está en parte enmascarada parece estar - en relación con la mirada del espectador - detrás de la que a ella se superpone. En cualquier caso, unas convenciones que junto con el sistema de representación de sucesión de figuras alineadas - según un canon que privilegiaba una determinada jerarquía - eran las utilizadas en la Europa premoderna [Figura 14]. En suma, el problema de la representación del espacio pictórico europeo, sobre el que Belting nos recuerda que no será hasta el Renacimiento cuando comience la discusión sobre el concepto de escenografía.

[...] sobre el significado del concepto de "escenografía" de Vitruvio, en el cual se quería reconocer la perspectiva. Pero al romano le interesaba el decorado, en el cual podía recrear, sobre superficies pintadas, una apariencia de arquitectura, esto es, producir una ilusión. Textos similares de la Antigüedad tratan de la ilusión de los sentidos [...] La pintura mural pompeyana se tenía en las casas particulares como pintura escénica. Era un medio ilusionista, pero no es ningún ejemplo de la existencia de una perspectiva normada, menos aún si se tiene en cuenta que su procedimiento cambiaba de una generación a otra. Es cierto que también la perspectiva renacentista se utilizó en los escenarios, pero su base matemática era una novedad, al igual que su finalidad científica ${ }^{192}$.

\footnotetext{
${ }^{190}$ La idea del relato de La caverna de Platón que trata sobre las sombras que proyectan los objetos - que otros sujetan desde fuera - en la pared de una caverna al caminar delante de un fuego. Una ilusión o la metáfora de la proyección de la realidad para el que está dentro de la cueva.

${ }^{191}$ Erwin Panofsky, La Perspectiva como forma simbólica, Barcelona, 1983, p. 31.

${ }^{192}$ Hans Belting, Florencia Bagdad: Una Historia de la Mirada entre Oriente y Occidente, Madrid, 2012, p. 20.
} 
Hasta entonces, las pinturas habían conservado la influencia de los principios de representación del arte bizantino, yuxtaponiendo de alguna manera los distintos elementos compositivos para alcanzar una lectura horizontal, mediante una alternancia rítmica de claroscuros sobre fondos vacíos que recreaban un espacio plano e inmaterial. Una influencia que, aunque se mantendrá hasta la Edad Media, desaparecerá con la irrupción - por primera vez en las obras de Giotto, Duccio y Lorenceti - de la simulación de espacios cerrados en los que se recrean interiores arquitectónicos [Figura 15]. Sin duda, unos grandes innovadores, puesto que fueron los encargados de crear lo que se ha dado en llamar el nuevo espacio pictórico ${ }^{193}$ de la pintura europea. Atendiendo a las observaciones de Panofsky:

[...] ese problema era tan nuevo - o mejor dicho, había estado tan absolutamente ausente del panorama europeo occidental durante siglos - que los que por primera vez lo volvieron a suscitar merecen todavía el nombre de "padres de la pintura moderna".

Se puede definir un espacio pictórico como un ámbito aparentemente tridimensional, compuesto de cuerpos (o pseudocuerpos, como las nubes) e intersticios, que parece extenderse indefinidamente, aunque no siempre infinitamente por detrás de la superficie pintada, objetivamente bidimensional; lo cual quiere decir que esta superficie pintada ha perdido esa materialidad que poseía en el arte altomedieval. Ha dejado de ser una superficie de trabajo opaca e impenetrable - dada por una pared, una tabla, un trozo de lienzo, una hoja de pergamino o de papel, o fabricada mediante las técnicas propias del tejedor de tapices o del maestro vidriero - y se ha convertido en la ventana a través de la cual nos asomamos a una sección del mundo visible $[\ldots]^{194}$.

Es decir que, considerados como los fundadores de la concepción del moderno espacio en perspectiva, con sus obras se comienza a superar aquellos principios de la representación que habían estado en vigor hasta la Edad Media, combinando en sus pinturas elementos bizantinos y la proyección espacial del gótico del norte. Se produce así una revolución en la valoración formal de un espacio pictórico que a partir de entonces alcanzará el estatus de un plano a través del cual se puede contemplar un espacio en profundidad. Es decir que, desde ese momento el espacio de la pintura europea sustituye la sucesión por la superposición de figuras sobre un plano cerrado, mayoritariamente rectangular, dando así lugar - sobre todo a partir del siglo XIV - a una nueva categoría para la pintura: la pintura de caballete. Lo que Gauthier define como "[...] el cuadro de forma rectangular. [...] producto de la civilización técnica occidental, sin duda asociado con el empleo generalizado de la perspectiva, la racionalidad geométrica y los imperativos de la manutención [...]"195. Y es que, en Europa, el desarrollo de la perspectiva resultó ser decisivo para la evolución de una serie de representaciones pictóricas que se comprendieron desde entonces sujetas a su férreo corsé matemático. Surgirá así una novedosa comprensión de la pintura que, desde

\footnotetext{
${ }^{193}$ Énfasis propio.

${ }^{194}$ Erwin Panofsky, Renacimiento y renacimientos en el arte occidental, Madrid, 1975, p, 182.

${ }^{195}$ Guy Gauthier, Veinte lecciones sobre la imagen y el sentido, Madrid, 2008, p. 23.
} 
entonces, se entenderá como una ventana a través de la que se puede observar una parte de la realidad, mediante la reconstrucción del espacio en un plano figurativo. A decir de Panofsky:

[...] Hablaremos en sentido pleno de una intuición "perspectiva" del espacio, allí y solo allí donde, no sólo diversos objetos como casa o muebles sean representados "en escorzo", sino donde todo el cuadro - citando la expresión de otro teórico del Renacimiento - se halle transformado, en cierto modo, en una "ventana", a través de la cual nos parezca estar viendo el espacio, esto es donde la superficie material pictórica o en relieve, sobre la que aparecen las formas de las diversas figuras o cosas dibujadas o plásticamente fijadas, es negada como tal y transformada en un mero "plano figurativo" sobre el cual y a través del cual se proyecta un espacio unitario que comprende todas las diversas cosas. Sin importar si esta proyección está determinada por la inmediata impresión sensible o por una construcción geométrica más o menos “correcta” $[\ldots]^{196}$.

En definitiva, un recurso visual al que se denominó perspectiva - que proviene de otro latino, perspicere que viene a significar "ver a través de" - que fue utilizado durante la Edad Media para definir una ciencia de la visión fundamentada en la óptica griega. Reinventada por Filippo Brunelleschi (1377-1446) y Leon Battista Alberti (1404-1472) con el redescubrimiento del arte clásico antiguo y de la geometría euclidiana, se constituyó desde entonces como el principal interés de los artistas renacentistas. A decir de Hans Belting, el término latino "perspectiva" fue un préstamo tomado del título de una teoría árabe de óptica. Una teoría árabe de la visión que ya entonces se conocía en las universidades europeas del siglo XIII, y cuya transformación en una teoría de la imagen no se produciría hasta el siglo XV. Fue entonces cuando pasó a convertirse en enseña del Renacimiento, periodo en el que sus artistas comenzaron a denominarla como prospecttiva. Una "transformación en teoría de la imagen que no tenía [...] ninguna base científica: fue un fenómeno cultural”, a decir de Belting ${ }^{197}$.

Sin embargo, el recorrido de esta nueva comprensión espacial ha tenido una evolución muy diferente en el Norte y en el Sur de Europa. Así, antes de mediados del siglo XIV, en el Norte del continente ya era conocido el eje de fuga y, a finales de este mismo siglo, ya se manejaba en Francia el concepto del punto de fuga ${ }^{198}$. Efectivamente, en el norte de Europa se siguieron los postulados del Trecento italiano que permitieron alcanzar la denominada construcción espacial correcta - siguiendo para ello caminos empíricos alejados de la praxis italiana la cual - apoyada en la teoría matemática - alrededor de 1420 ideó la que se ha denominado construcción legítima, que fue la encargada de corregir erróneos aspectos de la representación espacial. En cualquier caso, se considera que, muy probablemente, fue Brunelleschi el primero en elaborar un plano perspectivo matemáticamente exacto, aunque la descripción de este

\footnotetext{
${ }^{196}$ Erwin Panofsky, La Perspectiva como forma simbólica, Barcelona, 1983, p. 11.

${ }^{197}$ Hans Belting, Florencia Bagdad: Una Historia de la Mirada entre Oriente y Occidente, Madrid, 2012, p. 77.

${ }^{198}$ Énfasis propio.
} 
aparece tiempo después descrita en la De Prospectiva Pingendi de Piero della Francesca ${ }^{199}$. Hablamos de un procedimiento que ya aparece en el fresco de la Trinidad de Masaccio [Figura 16] y que más tarde- a pesar de estar basado en un principio totalmente nuevo - será descrito como un perfeccionamiento del usado en el Trecento. A decir de Panofsky:

Ya los Lorenzetti habían observado la convergencia rigurosamente matemática de las ortogonales, pero todavía les faltaba un método para medir con igual precisión los intervalos en profundidad de las llamadas "transversales" (particularmente la posición de aquella transversal que, delimitando el "cuadrado de base", comienza en los bordes delanteros del cuadro $)^{200}$.

Y es que, por entonces todavía, cada franja de los intervalos transversales que segmentan la base del espacio en una supuesta profundidad, disminuían mecánicamente en un tercio con respecto a la precedente. Fue entonces cuando Alberti sentenció aquello de que "el cuadro es una intersección plana de la pirámide visual". Una definición que ha resultado ser fundamental para la ubicación del punto geométrico y que en Europa terminó por transformar el mundo en una imagen, recurriendo para ello a un sistema determinado de forma matemática [Figura 17]. Por eso podemos afirmar que la influencia de la geometría de la teoría de la visión descrita por el matemático Alhacén $(965-1040)^{201}$ fue el punto de partida para una práctica que permitió pasar del cono imaginario - que tiene su vértice en el centro del ojo - a la pirámide visual en perspectiva cortada por el plano de la imagen ${ }^{202}$. Por consiguiente, nos encontramos con una teoría de la visión que ha derivado en un asunto del arte y que nos revela tanto la dimensión espacial como cultural de este. Es decir, el concepto de la perspectiva que como modelo de percepción adquiere unas acepciones tanto artísticas como filosóficas que no se pueden entender separadas. Un "momento estilístico" en palabras de Panofsky.

Así, atendiendo a esta última definición, nos resultará más sencillo comprender por qué en la cultura de la perspectiva europea encontramos dos metáforas fundamentales: la ventana y el horizonte. Dos metáforas que aunque pertenezcan a distintas categorías están indiscutiblemente ligadas al espacio - y por lo tanto a la mirada - y tan estrechamente vinculadas entre sí como lo están el punto visual y el de fuga. Porque, mientras la metáfora de la ventana - tanto la visual como la metafórica connota una posición del sujeto que implica una mirada al mundo que está fuera, el horizonte simboliza el límite de esa mirada, acotando a su vez el alcance empírico de la misma. Es decir, un mundo visual acotado entre la altura del ojo y el punto de fuga. De

\footnotetext{
199 De Prospectiva pingendi (Sobre la perspectiva de la pintura) escrito entre de 1470 y 1480 - muy posiblemente hacia 1474 - por el maestro italiano Piero della Francesca (1415 - 1492).

${ }^{200}$ Erwin Panofsky, La Perspectiva como forma simbólica, Barcelona, 1983, p. 44.

${ }^{201}$ Kitab al-Manazir (Libro de Óptica) escrito entre 1011 y 1021, compuesta de siete volúmenes.

${ }^{202}$ Para más información sobre este tema véase: Hans Belting, Florencia Bagdad: Una Historia de la Mirada entre Oriente y Occidente, Akal /Estudios Visuales, Madrid, 2012.
} 
este modo, la ventana - como marco - obligará al sujeto a posicionarse en un lugar fijo en el modelo visual occidental. Una noción del formato y del espacio en el sentido que formula Gauthier, cuando alude a una:

[...] forma rectangular y del contorno que lo aísla de su entorno, el cuadro de museo es frecuentemente enmarcado por lo que se llama un marco. Este marco tiende a acentuar la autonomía del cuadro [...] "el marco hace retroceder la superficie del cuadro y ayuda a profundizar la vista; es como el marco de una ventana por la cual se ve un espacio desplegado detrás de un cristal” (M. Schapiro) $[\ldots]^{203}$.

Lo que se ha entendido como el modelo visual de la perspectiva, una característica manera de representar y contemplar un espacio pictórico, condicionado por un concepto de la línea del horizonte que, aunque antiguo, solo alcanza su medición con la técnica de la perspectiva. En esta tesitura, señala Panofsky como fue Pomponio Gauricus quien dijo que "El lugar existe antes que los cuerpos que en él se encuentran por esto es necesario establecerlo gráficamente antes que ellos" ${ }^{\text {204 }}$, expresando con ello una concepción reveladora de un punto de vista moderno en su contexto y que establecerá desde entonces un precedente en la comprensión espacial de la pintura europea.

Por lo tanto, la perspectiva fue una nueva manera de comprender el espacio pictórico - determinante para la mirada de la pintura de la Europa del Renacimiento y de la Edad Moderna - que en su descubrimiento del horizonte desvela la necesidad del sujeto moderno por encontrar un nuevo lugar donde posicionarse en el mundo. Origen de la idea del humanismo como movimiento cultural - del hombre como centro del universo - donde el sujeto se transforma en una referencia para el espacio, tanto en lo que concierne a la escala como en lo que se refiere a la actividad de su mirada. Es decir, un posicionamiento que, como observador, determinará el espacio representado en la pintura.

De aquí, aquella idea de la "forma simbólica" de la que nos habla Panofsky, utilizando el término acuñado por Ernst Cassirer quien, con respecto a la perspectiva nos dice que "[...] debe servir a la historia del arte como una de aquellas "formas simbólicas" mediante las cuales "un particular contenido espiritual se une a un signo sensible concreto y se identifica íntimamente con él [...]"205. Es decir, un proceso intelectual que, como tal, funciona y se expresa dentro de un sistema cultural dado. Una manera de objetivar la realidad - paralela a otros conceptos científicos - donde el arte, los ritos y hasta el propio lenguaje adquieren la categoría de formas de conocimiento que requieren, así mismo, de sus propias formas simbólicas. En este contexto, la particularidad que caracterizará desde entonces a la pintura europea será la de utilizar

\footnotetext{
${ }^{203}$ Guy Gauthier, Veinte lecciones sobre la imagen y el sentido, Madrid, 2008, p.24.

${ }^{204}$ Erwin Panofsky, La Perspectiva como forma simbólica, Barcelona, 1983, pp.40-41.

205 Ibídem, p. 23.
} 
como recurso unas coordenadas que reproducirán el que se ha denominado como espacio sistemático. De este modo, a través de la metáfora de la ventana del espacio pictórico occidental, los objetos aparecen como proyectados sobre un cristal imaginario para intentar provocar, en palabras de Belting, un efecto similar al de "mirar a través de".

"Leonardo entendía la perspectiva simplemente como vista del mundo a través de un cristal "en cuya superficie aparece dibujado todo lo que se halla detrás de él". Durero traducía la nueva palabra latina, conectándola con el verbo antiguo per-spicere y dando a éste el sentido del "percibir", como Durchsehung, que significa el acto de "mirar a través" - a través de la superficie pintada -. Eso tiene su sentido si se piensa en una pantalla a través de la cual se mira. La traducción italiana que los pintores adoptaron prospettiva -guarda aún significado de "vista de"206.

\subsection{2.- PERSPECTIVA: La Teoría Científica de la Visión. Los Dípticos y Trípticos en la Pintura Europea}

La perspectiva ha sido definida por Gottfried Boehm como una "revolución cognitiva" ${ }^{207}$ que da al espectador un lugar preferente frente a la imagen y frente al mundo. Una expresión del pensamiento antropocéntrico renacentista europeo que sustituyó al teocentrismo dominante durante toda la Edad Media. Pero el alcance de la perspectiva ha llegado más allá de los postulados que en el siglo XV concibieron Brunelleschi o Alberti. Efectivamente, mucho más allá de ser un problema artístico, la perspectiva ha resultado ser un problema del espacio que connota, por lo tanto, una imagen. Un problema que, además, se ha revelado como una cuestión cultural - apoyada en unos aspectos estéticos, artísticos y sociales - que define en su conjunto un periodo de la historia. Un recurso visual que, a finales del gótico recuperó la óptica antigua y con ella la teoría del espacio, en una vuelta a la Antigüedad como consecuencia de las exigencias de lo que para aquel momento era considerado como la modernidad. A partir de entonces, la perspectiva pasará a entenderse como un "momento estilístico" que se constituirá en aquella "forma simbólica" - tomada por Panofsky del ensayo Filosofía de las Formas Simbólicas de Ernst Cassirer - a través de la que "un particular contenido espiritual se une a un signo sensible concreto y se identifica íntimamente con

\footnotetext{
${ }^{206}$ Hans Belting, Florencia Bagdad: Una Historia de la Mirada entre Oriente y Occidente, Madrid, 2012, p. 204.

${ }^{207}$ Véase Hans Belting, Florencia Bagdad. Una Historia de la Mirada entre Oriente y Occidente., Madrid: Akal /Estudios Visuales, 2012.
} 
él”208. Es decir, la representación del sistema de valores de Europa: un sistema de representación constituido en el sistema representativo de toda una cultura y que, como tal, ha sido significativo para las diferentes épocas y sus respectivos campos artísticos, no solo en tanto en cuanto tuviesen o no perspectiva, sino en tanto en cuanto al tipo de perspectiva que poseyesen $^{209}$.

En cualquier caso, se han dado diversas teorías que analizan y comprenden este sistema de representación. Una que la comprende como una convención cultural desarrollada en un contexto de prácticas artísticas y culturales - mediante la cual, a partir de los pintores renacentistas, en Europa se representa un espacio tridimensional sobre una superficie bidimensional. Otra que la define como una teoría de la percepción - que recurre a ella como eficaz recurso para plasmar el espacio - cuya vigencia se explica debido a que sigue siendo la estrategia visual que reproduce dicho espacio de la manera más próxima a como el hombre lo percibe; asunto muy discutible por razones obvias. De cualquier manera, hasta nuestros días ha llegado la definición que Durero dio de este concepto, Item perspectiva o "mirar a través de" en el espacio:

[...] esto es donde la superficie material pictórica o en relieve, sobre la que aparecen las formas de las diversas figuras o cosas dibujadas o plásticamente fijadas, es negada como tal y transformada en un mero "plano figurativo", sobre el cual y a través del cual se proyecta un espacio unitario que comprende todas las diversas cosas $[\ldots]^{210}$.

Es decir, aquella que la comprende como una transformación del cuadro como ventana, a través de la que se consigue el efecto de estar viendo un espacio, en una relación directa con el origen latino del término perspectiva: perspicere o "ver a través de". Un término que durante la Edad Media definía una ciencia de la visión fundamentada en la óptica griega. Reinventada, con el redescubrimiento del arte clásico antiguo y de la geometría euclidiana, es en el Renacimiento cuando se supera este VIII Teorema de Euclides o, a decir de Panofsky, se enmienda parcialmente por Filippo Brunelleschi (1377-1446) y L. Battista Alberti (1404-1472), pasando desde entonces a constituirse como el principal interés de los artistas renacentistas ${ }^{211}$. No obstante - más allá del Renacimiento - sus orígenes en la pintura europea se remontan hasta la Edad

\footnotetext{
${ }^{208}$ Ernst Cassirer, en, Erwin Panofsky, La Perspectiva como forma simbólica, Barcelona, 2003, p. 24.

${ }^{209}$ Énfasis propio.

${ }^{210}$ Erwin Panofsky, La Perspectiva como forma simbólica, Barcelona, 2003, p. 11.

211 Según el VIII Teorema de Euclides las diferencias entre dos dimensiones no están determinadas por la distancia sino por la relación de los ángulos visuales correspondientes. "[...] La ciencia árabe comenzó estudiando a Euclides y Ptolomeo. La óptica antigua asociaba la propagación de la luz a la percepción del mundo, y Ptolomeo completó la geometría de Euclides con la teoría de los rayos visuales. Las teorías antiguas de la visión consideraban "la percepción como una imagen reflejada". Esta imagen se formaba en el ojo como en un espejo líquido. En Diógenes de Apolonia se lee que "la mayoría de los pensadores no ve en la percepción otra cosa que la producción de imágenes en el ojo”. Belting, Hans, Florencia Bagdad: Una Historia de la Mirada entre Oriente y Occidente, Madrid, 2012, p.86.
} 
Media cuando en Europa se introduce la ya mencionada teoría árabe de la visión de Alhacén denominada perspectiva, término utilizado por los intérpretes latinos ${ }^{212}$.

Un sistema de representación espacial que, mucho más allá de una ciencia exacta, recogerá la compresión de la estética y de los postulados psicológicos de una cultura y de su época. Así, se pasará de una teoría árabe de la visión que establece las leyes de la óptica a una teoría occidental que mide la mirada a través de la imagen y que, a decir de Corsi "[...] permitía a los pintores dibujar una representación racional del espacio homogéneo, por lo que constituía una de las preocupaciones principales de los artistas del Renacimiento. La perspectiva no se limitaba al mundo de los artistas, pues surgió siendo enseñada como parte de las matemáticas [...]"213. Un sistema que, como tal forma simbólica, hizo que se tambalease el pensamiento altomedieval, ya que otorgó el estatus de real sólo a aquellos estados internos susceptibles de ser conocidos a través de una experiencia psicológica y a aquellas cosas externas conocidas a través de la percepción sensorial. Es decir que, como señala Panofsky, a partir de entonces “[...] Ya no se cree que el pintor deba operar 'a partir de la imagen ideal de su alma', como había afirmado Aristóteles y mantuvieron Tomás de Aquino y el maestro Eckhart, sino a partir de la imagen óptica de su ojo" ${ }^{214}$. Constituirá, pues, una nueva práctica para la producción de imágenes - como condición de la percepción - y un nuevo sistema representativo en el que podemos distinguir dos épocas. Efectivamente, la historia de la perspectiva durante el Renacimiento dio lugar a un vínculo entre el cuerpo y el observador, evolucionando desde una gaze (mirada) detenida y tranquila "vinculada al cuerpo de un observador", a decir de Belting, que en el siglo XVII fue sustituida por la más dinámica y apresurada glance (vistazo), que desvanecía "la presencia de un cuerpo que mira frente a la imagen" y, que, por lo tanto, dio lugar a una crisis del simbolismo de la perspectiva como técnica cultural ${ }^{215}$. De cualquier manera, será a partir de la Edad Moderna cuando las imágenes se someterán al yugo de la mirada, es decir, a la proyección de las coordenadas de los rayos visuales, transformando sus orígenes científicos en una práctica artística. En definitiva, los prolegómenos del llamado espacio en perspectiva de la pintura moderna europea concebido por Giotto y Duccio, dos pintores que - como ya hemos señalado anteriormente - en su obra sintetizaron aspectos del arte gótico y bizantino. De este modo, mientras se fueron dejando atrás los principios medievales de la representación del espacio, la superficie pictórica pasará a

\footnotetext{
${ }^{212}$ Los intérpretes latinos adoptaron el título que ostentaba la edición impresa de la teoría óptica de Alhacén - también denominada teoría de los aspectos (ilm al-manazir) - que estudiaba, por primera vez como ciencia, lo que aparece y no lo que es. Una ciencia árabe que tomaba sus fuentes de las cifras arábigas - que eran a su vez una herencia hindú - y una teoría sustentada principalmente por la obra de Alhacén, inventor también de la camera obscura.

${ }^{213}$ Elizabeta Corsi, La fábrica de ilusiones. Los Jesuitas y la difusión de la perspectiva lineal en China, 1698-1766, México, 2004, p. 90.

${ }^{214}$ Erwin Panofsky, Renacimiento y renacimientos en el arte occidental, Madrid, 1975, p. 183.

${ }^{215}$ Hans Belting, Florencia Bagdad: Una Historia de la Mirada entre Oriente y Occidente, Madrid, 2012, p.13. Véase también, Norman Bryson, Visión y Pintura. La lógica de la mirada, Madrid, 1991, p. 106.
} 
convertirse en "[...] el plano a través del cual nos parece estar viendo un espacio transparente $[\ldots], 216$.

En este contexto, debemos indicar que fue en Florencia, a comienzos del siglo $\mathrm{XV}$, donde surgió la imagen realizada mediante la perspectiva lineal en la que parece que se congela el tiempo. Allí Filippo de Brunelleschi (1377-1446) se hizo famoso por sus innovaciones en la ciencia de la óptica [Figura 18] ${ }^{217}$. En la biografía que sobre él escribió Antonio di Tuccio Manetti, se cuenta que realizó dos famosas demostraciones de la perspectiva: una vista del Baptisterio florentino y otra del Palazzo Vechio desde el otro lado de la plaza. Unas imágenes ya desaparecidas que, en cualquier caso, buscaban ilusiones visuales y no demostraciones matemáticas, cambiando así los fundamentos de la historia de la representación espacial. No obstante, es importante destacar su interés como origen del fructífero encuentro entre óptica y pintura, ya que la imagen del baptisterio era una especie de cosmorama o prototipo de la cámara perforada que ya se conocía en la edad media y que sería incluso tema de debate académico por parte de Roger Bacon ${ }^{218}$.

La primera descripción publicada sobre la perspectiva lineal fue la que hizo León Battista Alberti. En su tratado Della Pittura (1435)- que se ha convertido en una de las obras jamás impresas sobre arte más influyentes - resume aquella teoría óptica tardo medieval donde los rayos de luz se extienden desde los ojos hasta los objetos vistos e hizo algo sin precedentes: formular una definición geométrica de la imagen. Es decir, definir aquel rectángulo - el cuadro - que corta todos esos rayos de luz en un punto determinado. Así, los objetos más lejanos parecerán más pequeños, los cercanos más grandes y los aún más alejados desaparecen. Y es que, Alberti realizó una combinación irrepetible de estética y matemáticas, aportando valor intelectual a una disciplina como la pintura a la que, por otra parte, hasta entonces se había considerado tan solo como una habilidad artesana.

Hasta que Alberti escriba su obra De pictura, los problemas del espacio unificado, la información unificada y su correcta coordinación no tendrán una formulación teórica completa y en un solo término: compositio.

\footnotetext{
${ }^{216}$ Erwin Panofsky, La Perspectiva como forma simbólica, Barcelona, 2003, p. 37.

217 Destaca particularmente su desarrollo del perspectógrafo, un dispositivo -fundamentado en sus estudios sobre perspectiva lineal - que permitía previsualizar construcciones.

${ }^{218}$ Un aspecto que las contextualiza con los conocimientos que había en el siglo XV sobre la linterna mágica que proyectaba una imagen pintada por medio de una luz artificial. De este modo - y como bien señala Belting - las diferentes publicaciones que se sucedieron sobre la perspectiva - en su relación con la invención de determinados artilugios - evolucionaron también hacia una teoría del juego. Posteriormente, en el año 1583 se publica Dos reglas de la perspectiva práctica del matemático Egnatio Danti y más tarde, en 1638, el francés Jean-François Niceron publica La perspective curieuse - reeditada en 1652 junto con l'Optique y Catoptrique por P. Mersenne - un muestrario de los métodos de la perspectiva en el que ya hace mención del anamorfismo
} 
Aunque estamos habituados a pensar en la composición de la pintura como una cuestión de distribución de zonas en el plano pictórico, su significado original es retórico y se aproxima más al término moderno de "sintaxis" $[\ldots]^{219}$

Efectivamente, cuando Alberti describía su método de trabajo, hablaba de cómo dibujaba colocando primero un rectángulo al que imaginaba como "una ventana abierta" a través de la cual se veía todo aquello que se deseaba pintar.

"Cuando se rellenan los espacios circunscritos con colores, ellos [los pintores] sólo deberían buscar presentar las formas de las cosas vistas sobre este plano, como si fuera de vidrio transparente. Así, la pirámide visual podría atravesarlo, colocada a una distancia definida, con luces definidas y una posición definida de centro en el espacio y en un lugar definido respecto al observador" ${ }^{220}$.

De este modo, si con la perspectiva de Alberti el espacio se concreta en un punto matemático, con su ventana este espacio pasará a depender de un punto de vista fijo. Una metáfora - como abertura a un espacio que funcionará como símil y principio de la nueva pintura del Renacimiento -en la que proyectar un espacio imaginario. Por otra parte una metáfora lógica para definir los principios fundamentales de la perspectiva. Es decir: aquella superficie donde se proyecta un espacio imaginado reproducido con una imagen visual. Una comprensión y estudio que, desde tratados de arte como Della Pittura de Alberti o la Perspectiva Pigendi de Piero de la Francesca, buscaba redefinir la perspectiva como un dominio de las artes plásticas, teorizando sobre un sistema de la representación espacial que permite reproducir el espacio físico sobre una superficie bidimensional.

En cualquier caso, este sistema de representación espacial llegó a hacerse tan popular que - buscando una utilidad más práctica- en 1618 Robert Fludd ideó un simplificado principio de la perspectiva, diseñando una pantalla cuadriculada donde se reproducía cuadrado por cuadrado una imagen, reduciendo por lo tanto todo el proceso de la percepción y de la reproducción en perspectiva a un simple mecanismo [Figura 20]. Fue precisamente en este mismo siglo cuando la progresiva conversión matemática de la perspectiva desembocará en diferencias regionales, de manera que la distinción entre la perspectiva aplicada a la pintura y la perspectiva lineal se irá haciendo cada vez más grande. Tan sólo en Italia hasta finales del s XVIII se conservó lo que se podría considerar como una cierta integración - por definirlo de alguna manera - entre la teoría y la práctica artística. Ya, en su Idea del templo de la Pintura (1590), Giovanni P. Lomazzo (1538 - 1600) hacía una distinción entre la llamada perspectiva universal y la específica utilizada para representar la percepción. Y es que, hasta Descartes se interesó

\footnotetext{
${ }^{219}$ Norman Bryason, Visión y Pintura. La lógica de la mirada, Madrid, 1991, p. 113.

${ }^{220}$ Carlos Pérez Infante, trans., Tratado de pintura de León Battista Alberti, México: Universidad Autónoma Metropolitana, 1998, p. 60.
} 
por esta técnica objetando, no obstante, el error de utilizar para la reproducción del espacio pictórico unos rayos visuales rectos que obviaban la forma curva de la retina. Una objeción que establece una separación entre la pintura y el ojo y que ya había sido señalada por Kepler ${ }^{221}$.

De este modo, al alcanzar la modernidad una mirada técnica se transformó la perspectiva en una técnica cultural a través de la que se expresará desde entonces la cultura moderna europea. Así, la pintura se transformó en el plano figurativo de una porción de un espacio, donde el cuadro se define como una manera de mirar a través $d e^{222}$ alcanzando un estatus de símbolo. Una idea denominada perspectiva naturalis, de aplicación artística - que no la perspectiva matemática - que hace referencia a aquella idea de la ventana. Es decir, de un espacio limitado por su encuadre, para el que - como un marco - este no solo funciona como límite conceptual y estético, sino también como medida. Un posible origen de la idea de que el formato de las pinturas no debía sobrepasar el ángulo visual del ojo.

La pintura de caballete, el cuadro trasladable que cuelga de una pared, es un producto exclusivo de Occidente, sin ningún equivalente en otros lugares. Su forma viene determinada por su función social, que es precisamente colgar de una pared. Para apreciar el carácter único de la pintura de caballete, bástenos comparar sus modos de unidad con los de la miniatura persa o la pintura colgante china, ninguna de las cuales la iguala en independencia respecto a las exigencias de la decoración. La pintura de caballete subordina lo decorativo a lo dramático. Excava en la pared que hay detrás de la ilusión de una cavidad en forma de caja y, dentro de esta, como una unidad, organiza apariencias tridimensionales. Cuando el artista achata esa cavidad para obtener mejores efectos decorativos y organiza su contenido en términos de planitud y frontalidad, la esencia de la pintura de caballete - que no debe confundirse con su calidad - se ve comprometida ${ }^{223}$.

Pero debemos recordar que esta idea de cuadro - de la pintura de caballete - ya estaba presente en la Edad Media en Europa, cuando las pinturas comenzaron a independizarse del muro. Una idea que incluso se puso en práctica con los populares dípticos y trípticos que - continuando con los postulados del espacio acotado en la perspectiva - segmentan la obra en compartimentos estancos ${ }^{224}$. En el caso concreto de

\footnotetext{
${ }^{221}$ A principios del siglo XVII, Johannes Kepler (1571- 1630) estudió el ojo humano como instrumento óptico. Unas décadas más tarde, René Descartes (1596-1650) propuso aproximarse al ojo como si fuese un objeto separado del cuerpo, es decir, el ojo objetualizado convertido en materia de estudio que. Así mismo ampliaría la observación estética de la luz. En esta tesitura, se tomará la cámara oscura como analogía para entender la visión humana y también para a explicar la refracción de la luz.

${ }^{222}$ Énfasis propio.

${ }^{223}$ E.H, Greenberg, Arte e Ilusión. Estudio sobre la psicología de la representación pictórica, Barcelona, 1979, p. 177.

${ }^{224}$ Aunque el uso de los polípticos venía ya desde la antigüedad - tanto los dípticos como los trípticos eran ya usados por los romanos - alcanzaron su esplendor durante la Edad Media, cayendo en desuso en los siglos posteriores. Los dípticos, compuestos por un par de paneles unidos y plegables, habían sido usados en el arte europeo desde la antigüedad - como los dípticos consulares de marfil del periodo romano - extendiendo posteriormente su uso a la liturgia cristiana, donde fueron utilizados para inscribir los nombres de aquellos obispos, mártires o benefactores considerados dignos de ser mencionados en las
} 
los trípticos, estos solían recurrir a un elemento o personaje que los vertebraba y que funciona como centro de la composición, ocupando el panel central del conjunto de las tres tablas - como, por ejemplo, en el tríptico de El Jardín de las Delicias de el Bosco (1450-1516) [Figura 21] - y donde las hojas laterales, de un tamaño menor, pueden cerrase sobre la tabla central. Es decir, una idea de ensamblaje de cuadros $^{225}$ con una misma temática o relacionada, pero que casi siempre funcionan como entidades separadas. En cualquier caso, en ellos se perpetúa esa idea de la denominada "perspectiva central" que hace alusión al homocentrismo de un observador donde, nos recuerda Belting, su mirada se "constituye como "vértice de la pirámide visual" y donde el mundo es un espacio mensurable, calculado en su condición de "mundo visto"226. Una teoría que presupone que miramos con un único ojo móvil y que encontrará su correlato en el formato acotado del cuadro occidental, desterrando paulatinamente el uso de otros soportes.

Por lo tanto y resumiendo, la perspectiva - como concepto metafórico - adquirió acepciones filosóficas que como tal hacen alusión a su propio dogmatismo. Un punto de vista fijo defendido por la perspectiva - o monoperspectivismo - que argumenta su posicionamiento como una única verdad. Una aportación revolucionaria tanto en el terreno artístico como en el cultural, que hizo que Europa olvidase la idea del strip cartoon, es decir, que olvidase la condición narrativa implícita en los orígenes de la pintura. De este modo, con la perspectiva la mirada se convirtió en el indicador de una presencia - la de un espectador - transformando el mundo en una imagen - en una escena - y desplazando el protagonismo a la mirada. Es decir, pasando de la narración a lo anecdótico y del tema al acontecimiento - o, lo que es lo mismo, del asunto del cuadro a acto de mirar - haciendo de esta manera que la sugestión de la pintura moderna hiciese parecer real aquello que en realidad solo era imagen y, como nos recuerda Belting, permitiendo que el hombre dejase de mirar iconos para paradójicamente alcanzar una "mirada icónica" 227 que transformará en imagen la propia mirada.

\footnotetext{
misas y oraciones. Los trípticos de grandes dimensiones evolucionaron a partir de una tableta de escritura romana y llegaron a hacerse habituales en los templos cristianos entre los siglos XIV y XV. Constituidos por tres paneles, como su nombre indica, su particularidad radicaba en que las dos tablas laterales se podían cerrar sobre la central. Fueron un soporte utilizado sobre todo para pinturas de carácter religioso, donde habitualmente el tema o motivo representado ocupaba la tabla central y principal, mientras las laterales se utilizaban para pinturas temáticamente relacionadas.

${ }^{225}$ Énfasis propio.

${ }^{226}$ Hans Belting, Florencia Bagdad: Una Historia de la Mirada entre Oriente y Occidente, Madrid, 2012, pp. 32-33.

${ }^{227}$ Véase, Hans Belting, Florencia Bagdad: Una Historia de la Mirada entre Oriente y Occidente, Madrid: Akal /Estudios Visuales, 2012.
} 


\section{2.- La Dimensión Temporal del Espacio Pictórico Oriental}

En la tradición extremo oriental en general - en ese paralelismo que se da entre lo divino, lo humano y el medio natural - se comprendían e integraban como un todo unificado, la naturaleza, la sociedad y el yo, redefiniendo así la interpretación de un espacio que comprendía a unas divinidades que estaban relacionadas con los fenómenos y con las fuerzas de la naturaleza. En el contexto japonés, por ejemplo, estas divinidades - que son una representación de todo cuanto hay como sagrado, a las que el sintoísmo denomina kami (神) y el budismo hotoke (仏), y según la misma categoría semiótica para espíritus, shen (神) para del daoísmo - están comprendidas dentro de una visión cosmogónica, a la que podemos considerar panteísta o animista, caracterizada por una armonía no dualista donde el hombre y el medio natural conformaban una unidad. Porque, como observa Alfonso Falero, "un kami no es tanto un plano superior cuanto la prolongación de todo espacio de vida a su mismo origen" 228 .

Una visión politeísta del mundo que tiene a su vez un cierto paralelismo con las creencias populares chinas donde muchas divinidades son representaciones de fenómenos naturales. En esta tesitura, el Shintô (神道) - religión autóctona de Japón cree en la existencia de múltiples fuerzas invisibles a las que se ha dado en llamar kami (神) - término utilizado fundamentalmente como tratamiento honorífico para referirse a los espíritus nobles y sagrados - a los que entendemos como un factor imprescindible para esta investigación sobre la comprensión del espacio pictórico extremo oriental y en este caso concreto para el de la pintura japonesa en particular ${ }^{229}$. Es decir, la rica y variada representación de un mundo fenoménico al que el budismo - al coexistir con el Shintô, en el caso concreto de Japón - aportó el elemento místico de los monjes artistas del periodo Song 宋朝 chino $^{230}$. Efectivamente, esta particular cosmovisión sintoísta se enriquecerá en los siglos VI y VII cuando llegue a Japón el orden social del

\footnotetext{
${ }_{228}$ Alfonso Falero, Aproximación a la cultura japonesa, Salamanca, 2006, p.67.

${ }^{229}$ Entre los fenómenos y objetos designados como kami (神) desde tiempos inmemoriales, están las cualidades del crecimiento, la fertilidad, los fenómenos atmosféricos como el viento o el trueno, los elementos de la naturaleza como el sol, las montañas, los ríos, rocas, árboles, los espíritus protectores de la tierra, de las profesiones, los espíritus de los héroes.... A diferencia de lo que sucede con el resto de las religiones monoteístas, en el sintoísmo no existe una deidad absoluta creadora que gobierna sobre todas las cosas. La función creadora se realiza a través de la cooperación armónica de los kami. Una idea de la que los japoneses son conscientes de manera intuitiva. Es decir, comprender como explícito algo que por su naturaleza resulta vago e impreciso. Los kami no se comprenden ni individualizados ni personalizados, sino que se entienden como espíritus protectores o destructores, “[...] fuerzas vivas que se presentan bajo la apariencia insensible, rígida y dura de la materia" (Jean Riviére, Arte Oriental, Barcelona, 1973, p. 101).

${ }^{230}$ Véase, Alfonso Falero, Aproximación al shintoísmo, Salamanca, 2007.
} 
confucianismo y la armonía natural del taoísmo, que junto con el budismo aportaron al Shintô la novedad que supuso el elemento contemplativo y místico ${ }^{231}$.

En este contexto, para poder explicar los fenómenos naturales, el sintoísmo ideó unos modelos visuales donde el espacio y el tiempo no se podían entender separados, dando lugar así a la comprensión de un ámbito que solo mutaba en espacio cuando lo penetraba un kami. De este modo, explica Ruiz de la Puerta "[...] El arte de esperar la llegada del kami generó la unión del espacio y el tiempo, ya que lo esencial no fue la sustancialidad del espacio, sino el fenómeno que en él ocurrían, la llegada de la divinidad [... $]^{\eta 232}$. Así, el fenómeno - donde se conjugaban los diferentes aspectos del suceso - daba pleno sentido al concepto de espacio que - al estar siempre ligado al tiempo en el que se daba este suceso - estaba por lo tanto sujeto a la percepción del individuo. Por eso, en Japón la cuestión del espacio se plantea siempre en una relación directa con el tiempo, dando lugar a una combinación que conforma una unidad indisoluble. Unas impresiones que, por otra parte, no parecen ajenas al término yuzhou ( 宇宙) que ya en la dinastía Han 漢 (206 a. C. hasta el 220 d. C.) designaba el concepto de espacio-tiempo. En cualquier caso, nos encontramos con una manera de percibir el espacio que ha favorecido una relación más holística entre interior/exterior, un binomio que podemos extrapolar a la relación no excluyente que en la pintura de Asia Oriental se establece entre el mundo del arte y el mundo natural para, así mismo, poder identificar el yo y el mundo ${ }^{233}$.

\footnotetext{
${ }^{231}$ Un encuentro que, por otra parte, provocará en sus comienzos algunos enfrentamientos entre esta última religión autóctona y el budismo. De este modo, hasta el siglo VIII no se alcanzará un compromiso entre ambos credos, resolviéndose entonces que los kami se sentían complacidos de recibir los Sutra budistas como ofrendas y de escuchar sus versos en el culto, y ya por el siglo IX muchos de los kami venerados en los santuarios se habían transformado en guardianes de los templos budistas. Será así como en Japón el budismo comience a predicar una fe sincrética, considerando a los budas como la esencia primera y a los kami como sus manifestaciones japonesas Para más información sobre esta cuestión véase, Sokyo Ono, El sintoísmo. El camino de los kami. Gijón, 2009 y Alfonso Falero, Aproximación al shintoísmo, Salamanca, 2007.

${ }^{232}$ Felix Ruiz de la Puerta, Lo sagrado y lo profano en Tadao Ando, Madrid, 1995, p. 87.

${ }^{233}$ Para entender esta cuestión filosófica, es preciso conocer algunos aspectos sobre el origen de algunos términos, en el contexto cultural de Japón y China. Es muy significativo descubrir cómo el concepto de "Naturaleza" tiene el origen de su significado en el término自然 en chino tzujan o e shizen japonés. En el Japón previo al periodo Tokugawa 徳川 (1600-1868) la comprensión del medio natural no se entendía separada de los seres humanos. Antes de esta época, la palabra shizen 自然 significaba "quizás" y en la tradición budista este carácter venía a significar "naturalmente" (onozukara 自ずから). En el capítulo XXV de Lao-tse 老子 (Tao Te Ching) el término tzujan significa "espontaneidad", correspondiéndose en los Sutras budistas con la palabra sánscrita svabhava, que significa "naturaleza esencial".

Por otra parte, el término "paisaje" no se comprende como una panorámica de un espacio natural, sino como un punto de vista sobre el entorno en el que, desde la mirada de la filosofía budista, una flor, un insecto o una hierba simbolizan la interdependencia dinámica que relaciona todas las cosas del mundo. Todo ello entendido en el contexto de unos planteamientos culturales que, además, expresan otras dimensiones, como las religiosas, filosóficas y artísticas, a través de una lectura simbólica.

En La Experiencia del Paisaje en China. "Shanshui" o cultura del paisaje en la dinastía Song, A.J Menzúa indaga sobre el origen de la idea del paisaje en China, que se encuentra en la iconografía de los inmortales. Estos se basan en los paraísos budistas donde el hombre podía alcanzar la armonía con la naturaleza y el Tao. Fueron, a su vez, la inspiración de los jardines privados e imperiales, las villas de montaña y la prosa paisajística llamada Youji - o notas de viaje, también conocidas como "paisajes"- que gozaron de gran popularidad. Es aquí donde encontramos el uso de dos términos para referirse a paisaje:
} 
La vida y, por consiguiente, el arte japonés, ha estado de siempre en una íntima conexión con la naturaleza. El hombre nunca ha sido un agente dominador al margen, sino que se ha entendido y vivido como un elemento de aquella. El conocimiento profundo de la naturaleza circundante es lo que ha sido absolutamente decisivo a la hora, por ejemplo, de acuñar términos que de algún modo nos comuniquen toda una apabullante constelación de sensaciones de gran riqueza de matiz.

Este universo es sensorial, intuitivo y profundamente anti intelectual, quiere esto decir que su significado último no es posible aprehenderlo mediante rigurosos análisis: es un mundo para ser sentido y vivido directamente, sin filtros que puedan desvirtuar la identificación plena entre sujeto y objeto ${ }^{234}$.

Por lo tanto, en esta relación espacial, el mundo natural es aquel espacio del yo mientras que este mismo yo se transforma en un reflejo del mundo. De aquí esa idea que lo entiende como un ejercicio espiritual del arte y que, como ejemplo, podemos encontrar en las pinturas a la tinta de Sesshû Tôyô 雪 舟 (1420-1506) ${ }^{235}$. En ellas, en el sentido expresado por Bryson, encontramos la temporalidad como una "distensión del tiempo normal: destrezas que el cuerpo ha tardado muchos años en adquirir se movilizan y explayan en una ejecución que se muestra a sí misma a la vez como impulsiva y como perfectamente deliberada $[. . .]^{p, 236}$. Lo que entendemos como el valor estético del trazo, implícito en la pintura de paisajes - sansuiga 山水画 - que permite secuenciar el paso del tiempo, expresando a la vez una particular comprensión del $\operatorname{cosmos}^{237}$. Así, como oposición al espacio geométrico de Occidente encontramos lo que Ruiz de la Puerta denomina "espacio en movimiento" en el cual "[...] no tiene sentido introducir un sistema de coordenadas cartesianas o polares, ya que la posición de los elementos en el espacio no es importante; lo que prima son las posiciones relativas de

Shanshui 山水 “montaña -agua” que fue usado para la pintura de paisaje y para los paisajes, todos con las mismas fuentes filosóficas y estéticas, y el Fengjing "viento-atmósfera" o "espectáculo-aspecto, que encontramos en numerosas manifestaciones artísticas.

${ }^{234}$ Manuel Luca de Tena, La Presencia de lo Ausente. El concepto y la expresión del vacío en los textos de los pintores contemporáneos occidentales a la luz del pensamiento extremo-oriental (Tesis doctoral, Universidad de Salamanca, 2008) p. 62.

${ }^{235}$ En un principio, los denominados monjes artistas de los cinco grandes monasterios zen de Japón, imitaron el estilo de las pinturas chinas. Sesshû Tôyô 雪舟 等楊 (1420 -1506) había estudiado estas aguadas monocromas en un viaje realizado a China para, posteriormente, a su regreso a Japón establecerse en Yamaguchi 山口県. Monje zen y uno de los pintores más representativos del periodo Muromachi 室町 (1392-1573), su pintura se caracterizó por utilizar la tina china como principal medio de expresión, prescindiendo del color y simplificando las formas, todo ello con el fin de provocar la iluminación interior.

${ }^{236}$ Norman Bryson, Visión y Pintura. La lógica de la mirada, Madrid, 1991, p. 126.

237 Sansuiga 山水画: Pintura de montaña y agua característica de Asia Oriental, donde se representa una naturaleza idealizada. Aunque su traducción habitual es la de pintura de paisajes, podría decirse que el términofuukeiga 風景画 está más cerca del concepto de paisaje de la pintura occidental. El término sansuiga se aplica a la pintura china, coreana y japonesa, que representa imágenes idealizadas de la naturaleza, mediante la representación de montañas, nubes, ríos y otros elementos naturales como rocas y árboles. 
unos elementos con respecto a otros, lo cual va a obligar a que los componentes espaciales sean observados sucesivamente" ${ }^{, 38}$.

¿Podemos elucidar que esta particular percepción está relacionada con la comprensión de un universo más sensorial e intuitivo? ¿Podría estar relacionado con el camino de la naturaleza - o el Tao 道- que ha permitido desarrollar en Japón un sentido más intuitivo para conservar así una animista percepción del mundo? De cualquier manera, hablamos de un universo caracterizado por una sacralización estética que, como aportación del shintô, permite una identificación entre el yo y los elementos que integran el paisaje y que - en el terreno del arte - mediante la confluencia de fondo y forma crea un espacio personal - independiente del espacio colectivo - basado en una filosofía de la naturaleza no antropomórfica. De este modo, la naturaleza y el paisaje pasarán a convertirse en el leitmotiv de una pintura que interpreta unas formas idealizadas para constituirla como principio y como fin. Una interpretación del ser y noser que, para poder expresar artísticamente esta misma naturaleza, ha buscado una fusión con su ritmo y su devenir - vinculando un conjunto de concepciones cosmogónicas, religiosas y místicas - mediante una síntesis del confucianismo, taoísmo, budismo y sintoísmo. Un sincretismo religioso que ha encontrado su correlato en la multivocidad expresiva de la coexistencia de planos, que han permitido la articulación de lo múltiple a través de la experiencia artística ¿Una resistencia a la unidad como reflejo de la cosmología budista que, así mismo, entendía el universo como un continuo sin principio ni fin? y ¿con la armonía que se da en la relación con una naturaleza que se entendía, percibía e interpretaba a un mismo nivel? ¿Podemos encontrar alguna conexión entre esta articulación de lo múltiple y la armonía de los opuestos complementarios? ¿Podemos establecer alguna vinculación entre este aspecto con el gusto secuencial de las composiciones pictóricas?

En el Extremo Oriente, nos dice Elisseeff, la práctica de la pintura se entendía como un culto que exigía un doble conocimiento, el de la "vía sensible y de la vía intelectual, en la que un individuo debe ser al mismo tiempo un calígrafo, un poeta y un pintor" ${ }^{, 39}$. Es decir, un erudito y a la vez un artesano. Una tradición que había llegado desde China - junto con el budismo y otras influencias - y que transformará profundamente la cultura japonesa aunque sin cambiar los postulados de la estética sintoísta los cuales, por el contrario, se acentuarán al impregnarse del refinamiento cultural chino. Un desenfoque en el origen del uso de símbolos y elementos compositivos de cada sistema que, por ejemplo, en el caso de Corea se originó tras la mezcla del budismo, neoconfucianismo, taoísmo y chamanismo ${ }^{240}$. Según Zo Za-yong:

\footnotetext{
${ }^{238}$ Felix Ruiz de la Puerta, Lo sagrado y lo profano en Tadao Ando, Madrid, 1995, p.82.

${ }^{239}$ Vadime Elisseeff, en Jean Riviére, El arte oriental, Barcelona, 1973, pp. 14 -15.

240 Como ejemplo de esto encontramos una serie de temas comunes al taoísmo, chamanismo y al sintoísmo: temas para invitar a la buena fortuna o para repeler a los espíritus malignos. En el caso de Corea, el espíritu de la montaña del chaman Sanshin se representa de varias maneras: como un inmortal taoísta, un sabio confuciano o un bodhisattva. Véase Bailey, Penny, "La iconografía de Sipjangsaeng de Corea: la búsqueda de la longevidad y la inmortalidad en las artes visuales de la dinastía Joseon", The Asia-Pacific Journal: Japan Focus 18 (8): 1-18 · abril de 2020 (última consulta 14/06/20)
} 
[...] no tardamos en tropezar con un fenómeno extraño: todos estos motivos religiosos se hallan tan complejamente entretejidos unos con otros que nos perdemos al tratar de precisar a qué religión específica pertenece cada uno de ellos. Acabamos teniendo la impresión de que, en Corea, hay un budismo taoísta, un chamanismo budista y un taoísmo chamanista, y de qué el pensamiento inspirador de cada una de las pinturas religiosas rituales es, en realidad, más que su lado académico, el lado popular y chamanístico de cada religión

Ahora bien, si analizamos las pinturas coreanas domésticas y los distintos símbolos que en ellas parecen, nos encontramos con que poseen un denominador común que crea una trabazón muy estrecha entre las diferentes concepciones religiosas. Se trata de la aspiración innata a una vida larga y feliz y a la protección contra los espíritus malignos $[\ldots]^{241}$.

En este contexto se desarrollará una sensibilidad estética que en China tendrá como máximo exponente a las pinturas chan (禪) de los Sung que, posteriormente, ejercerán una clara influencia sobre las pinturas de los monjes del Zen (禪) de Japón. En estas encontramos un espacio sin contornos donde los objetos pierden su silueta definida, al que el taoísmo ha denominado $x u$ y el budismo shûnyattâ. Este último, expresado en palabras de Luca de Tena, es un "[...] término sánscrito que significa Vacuidad, que nos llega como el producto más valioso y característico de la metafísica tradicional de Oriente. Sûnyattâ es vacío de designación, de clasificación y calificación subjetiva; trasciende todas las discriminaciones de orden intelectual superando la barrera Maya, o ilusión. Las categorías fijas de pensamiento se nos presentan 'vacías' al experimentarse la relatividad de todas las clasificaciones, divisiones y polarizaciones del intelecto [...]"242. El denominado $K \hat{u}$ (空) del budismo zen japonés: una idea del vacío como generador de vida, donde el mundo fenoménico es una sombra, la ilusión del auténtico mundo que es el espiritual. De aquí la categoría de yohaku (余白) o blanco que resta, que define aquel espacio vacío gracias al cual el trazo del pincel adquiere su verdadera razón de ser. Un asunto sobre el que, en Los valores estéticos en la cultura clásica japonesa, Lanzaco Salafranca nos dice:

El valor YOHAKU apunta a aquellos "espacios vacíos", tan característicos en la pintura a la tinta china suibokuga de profunda inspiración Zen. Este valor estético testimonia la

\footnotetext{
241 “[...] Un rasgo típico de esta pintura es la estilización, muy pronunciada, que lleva hacia el arte abstracto, en la expresión de los sueños, de la imaginación, del simbolismo, del amor, del humor, de la sátira y del sentido de la fantasía humanos. No hay aquí ningún parentesco con la representación realista de un asunto cualquiera; lo que domina es el empeño en ocupar el espacio, frente a la estética de los espacios despejados, típica de la pintura clásica de Oriente.

El segundo rasgo característico es el animismo, positivamente expresado en toda clase de representaciones de animales, rocas o árboles y que es un auténtico reflejo del animismo chamanista". Zo Za-yong, "Los pintores anónimos del alma popular". En El correo de la Unesco, Corea "país de la mañana serena", 1978, p. 42.

${ }^{242}$ Manuel Luca de Tena, La Presencia de lo Ausente. El concepto y la expresión del vacío en los textos de los pintores contemporáneos occidentales a la luz del pensamiento extremo-oriental (Tesis doctoral, Universidad de Salamanca, 2008), p. 21.
} 
"belleza del espacio vacío". Y a menudo se descubre como la apertura hacia la tercera dimensión absoluta.

Sugiere la expresión indefinida de la nada que lo es todo. En efecto, el espacio en blanco, vacío, que evoca al contemplar la obra de arte una ilimitación infinita de belleza absoluta que comunica y recrea. Son espacios del mundo en silencio, pero pletóricos de vida sugestiva ${ }^{243}$.

De este modo, en el caso concreto del budismo zen, la representación pictórica del mundo espiritual debe eludir el color y la forma, motivo por el que en sus pinturas se alternan líneas y manchas monocromas con grandes espacios vacíos. Pero, sea como fuere, en estas pinturas encontramos la comprensión de un espacio irregular y asimétrico - fukinsei (不均斉)- totalmente alejado de ese otro simétrico y ordenado característico de la pintura occidental, donde esa idea del vacío como concepto filosófico, alcanzará en las pinturas de paisaje su máxima expresión plástica. Efectivamente, en estas el vacío adquiere un valor compositivo que - como el rito dotará a la pintura de una fuerte carga poética, convirtiendo así al artista en el intérprete de una obra que buscaba más sugerir que demostrar y que - como medio - alcanzará su plena significación al ser contemplada por un espectador. Nos encontramos, por lo tanto, de nuevo en el ámbito de un equilibrio de tensiones - asociado al sentido taoísta del Yin (陰) y el Yang (陽) - que expresaba ese vacío mediante los binomios composición - contenido y método - forma, y que resultó determinante para la obra de los pintores de Japón y China ${ }^{244}$. De este modo, nos dice Courtois," en su pintura [...] no solo se manifiesta una cierta sutilidad en las pinceladas y en la riqueza de modulaciones del color de tonos ligeros, sino sobre todo también un sentido de equilibrio entre los llenos y los vacíos y entre los estáticos y lo dinámico, expresados sin recurrir a artificios que den ilusión de profundidad o de un escalonamiento de los planos y del relieve, normales en el arte europeo" $" 245$.

Nos encontramos así ante un espacio pictórico que recurre a un movimiento discontinuo que, contradictoriamente - en lo que atañe a la escala, agrupación, y la sucesión - busca dar continuidad a la pintura mediante un conjunto de fragmentos aparentemente inconexos que, en su pluralidad, se nos aparecen como una totalidad gracias a la aplicación del concepto budista $M a$ 間 - asociado a un intervalo vacío que

\footnotetext{
${ }^{243}$ Federico Lanzaco Salafranca, Los Valores Estéticos de la Cultura Clásica Japonesa. Madrid, 2009, p. 100.

${ }^{244}$ El Shintô y el zen dieron forma a la sensibilidad y expresión japonesa. En el aspecto estético, los pintores retomaron la pintura china a la tinta del periodo Sung: la técnica llamada en Japón sumi e 墨絵. En un principio, las propuestas estéticas de los denominados monjes artistas de los cinco grandes monasterios zen de Japón se inspiraron en los modelos chinos, pero incorporando aspectos locales que terminó por hacerlas absolutamente originales. En este sentido, podemos considerar que el rechazo de la sensibilidad japonesa hacia una obra "acabada" es una aportación absolutamente personal y autóctona.

${ }^{245}$ Michel Courtois, Pintura China, Madrid, 1969, p. 27.
} 
define la distancia dada entre dos o más cosas que se relacionan en continuidad - que funciona como intervalo entre los objetos ${ }^{246}$.

Lo que importa más que nada es precisamente este espacio vacío, la parte no pintada de la obra, puesto que este mundo invisible es considerado como el mundo originario y espiritual que cada pintor quiere expresar sacrificando otra parte del espacio, pintando frugalmente algún motivo que no tiene otro fin que sugerir y destacar la riqueza inagotable de este mundo no manifiesto ${ }^{247}$.

He aquí, pues, una idea de movimiento relacionada tanto con el budismo como en el caso japonés - con la intuición y la percepción del sintoísmo, donde forma y vacío establecen una relación recíproca, de manera que - dentro de ese constante equilibrio de tensiones - ambas se perciben en su mutua necesidad. Porque en la pintura extremo oriental, al depender del tiempo el espacio devino en secuencial, en un flujo temporal al que - como un travelling o experiencia espacial - los japoneses denominaron michiyuki (道行き): la percepción de un recorrido que dota de un particular misterio al espacio transformándolo en un tiempo que se expresa como un instante que fluye.

[...] la experiencia espacial que los japoneses denominan michiyuki, que literalmente significa "andando a lo largo del camino". Este término también se utiliza para una de las categorías de escena en el teatro kabuki, en la cual aparecen personajes viajando juntos de un lugar a otro. En la actualidad la escena michiyuki es muy reducida, y la distancia es concebida como un flujo de tiempo que se percibe a través de las experiencias de los personajes.

[...] lo que se pone de manifiesto en este recorrido es que el espacio es secuencial y depende del tiempo, es decir, es un espacio de movimiento $[\ldots]^{248}$.

En lo que respecta al plano pictórico - que al fin y al cabo es el ámbito en el que se desarrolla nuestra investigación - se repiten una serie de motivos depurados y fáciles de asimilar, estructurando con ellos un espacio que mantiene su unidad a través del ritmo que establecen los intervalos grupales ${ }^{249}$. Con este fin, se repite un motivo o se crea un ritmo con diferentes objetos, algo que podemos apreciar, por ejemplo, en el biombo Pinos en la Niebla [Figura 22] de Hasegawa Tôhaku 長谷川等伯 (1539 - 1610) quien, sabemos, estudió y se inspiró en la obra de Sesshû Tôyô雪舟等楊. En esta pintura el espacio se entiende como una interpretación de la realidad - lejos de las coordenadas

\footnotetext{
${ }^{246} \mathrm{El}$ término $M a$ se utiliza en el budismo japonés para expresar el concepto del espacio vacío. En esta idea, el vacío no es la oposición al no ser. "El vacío es lo no existente en que está lo que existe" (Felix Ruiz de la Puerta, 1995, p. 93). Esta manera de comprender el vacío llega mucho más allá de ser solo un concepto estético - filosófico. Es una idea que se encuentra en la contemplación y en la meditación.

${ }^{247}$ Kitaura Yasunari, "Yohaku o concepto del espacio en la pintura medieval". En La Plenitud del Vacío. Ensayos sobre el Aikido y Otros Aspectos de la Cultura Japonesa, Madrid, 1999, p.87.

${ }^{248}$ Felix Ruiz de la Puerta, Lo sagrado y lo profano en Tadao Ando, Madrid, 1995, p.83.

${ }^{249}$ Este efecto basado en planos y aislamientos tiene su origen en el ideal del pensamiento de los primeros pintores chinos que, con posterioridad, fue transformado por los pensadores del periodo Song 宋朝 como expresión del Tao. Así, buscando el $L i$ o estructura física de las cosas encontraban el Xing del arte, que venía a ser el aspecto del vacío o la naturaleza fundamental.
} 
cartesianas que definen el concepto del espacio pictórico europeo - cuya importancia radica en la relación relativa que se estable entre los diferentes elementos espaciales que intervienen en la representación para que, de esta manera, estos puedan ser observados o casi leídos sucesivamente. Por lo tanto, nos encontramos con un desarrollo lineal y temporal del espacio pictórico donde, en el sentido formulado por Cheng, "[...] el vacío introduce la discontinuidad interna, y con el vuelco de las relaciones interior-exterior, lejano-cercano, manifiesto-virtual, inaugura el proceso reversible del regreso, el cual significa "volver a echar mano" de toda la vida rememorada o soñada, que brota sin

cesar $[\ldots]^{p 250}$. Una simbiosis del tiempo y del espacio que se ha comprendido como "una suerte de quinta dimensión (allende el espacio-tiempo) que representa el vacío en su grado supremo" ${ }^{251}$. En este contexto, el vacío - como recurso pictórico - para expresar distancias establece un diálogo entre los diversos elementos de la composición, completando la pincelada y de esta manera también las formas.

\subsection{1.- NARRACIÓN GRÁFICA CONTINUA: La Teoría Intuitiva de la Mirada. Del emakimono (絵巻物) a los byôbu (屏風)}

Consignar las diferencias que hemos visto hasta ahora entre el espacio extremo oriental y europeo, nos obliga a plantearnos una cuestión relevante: al igual que consideramos la perspectiva como la expresión y representación de un espacio que - por su peculiar concepción del mundo - define el pensamiento de la Edad Moderna europea ¿podemos considerar el recurso de la narración gráfica continua como aquella composición espacial más intuitiva que define la cosmovisión extremo oriental? Como bien dice Courtois:

En Europa, desde el Renacimiento, un paisaje era una ventana abierta a un punto particular del mundo. En China era una interpretación del macrocosmos. Este universo representado bajo este aspecto no resulta estático; está animado por un ritmo, esencia misma de la vida cósmica, ritmo que el hombre aprehende contemplando la naturaleza e identificándose con ella. La búsqueda de este ritmo no estaba, pues, centrada en torno a un punto fijo, la ausencia de perspectiva geométrica no era debida a la ignorancia o a la

\footnotetext{
${ }^{250}$ François Cheng, Vacío y plenitud, Madrid, 2004, p. 185.

${ }^{251}$ Ibídem, p. 182.
} 
casualidad. El cuadro mismo de una pintura china implica movimiento: rollos que ni a lo largo ni a lo ancho pueden ser aprehendidos en su conjunto de una sola ojeada"252.

Por lo tanto, nos encontramos con dos sistemas de representación y dos sistemas de pensamiento. Pero, vayamos por partes. En el marco geográfico de Asia Oriental, el origen de esta manera de componer el espacio - también denominado método continuo, foco móvil o narración gráfica continua - se da en la China del periodo Tang 唐 (618907), donde nace como una solución a los problemas de la representación del espacio en la pintura [Figura 23]. Un recurso visual que se encuentra tras gran parte de la identidad de la pintura y del pensamiento de China, Japón y Corea ${ }^{253}$. Hablamos de una comprensión diferente del llamado espacio narrativo, que al transcender el espacio pictórico ha podido prolongar la narración más allá de los límites de la obra y sobre el cual Belting nos dice: "Lo conocemos como principio de la narración gráfica continua, que no necesita atenerse a la moderna unidad del espacio y el tiempo subyacente en la perspectiva" ${ }^{254}$. No obstante, recordemos, esta solución a los problemas de la representación del espacio también está presente al final de la época antigua en Europa, en unas pinturas que se caracterizan por la yuxtaposición de sus distintos elementos. Una peculiaridad que - como sucede con la tradición de la pintura de Asia Oriental favorece la lectura de unos motivos, como si fuesen pictogramas, y otorgan al espacio una comprensión horizontal que en el caso de la pintura oriental estaba determinada por los diferentes usos que se daban a la obra. Efectivamente, a diferencia de lo que sucede en la tradición europea, en países como China, Corea y Japón las pinturas solo se mostraban ocasionalmente, permaneciendo el resto del tiempo recogidas ${ }^{255}$. Una particularidad que requería de unos soportes ligeros - fáciles de almacenar y transportar - y que encontró como medio más apropiado el formato horizontal de unos rollos de mano donde se representan progresivamente imágenes y textos. Por ejemplo, en el Rollo Largo del Paisaje de las Cuatro Estaciones de Sesshû [Figura 24] se muestra paulatinamente la transformación del paisaje a lo largo de las diferentes épocas del año, haciendo uso de unos gestos y de un trazo pictóricamente caligráfico que en su discurrir sobre el soporte, y por medio del vacío, representan unas imágenes que, a su vez, solo se expresan en este mismo vacío y para las que el formato horizontal del rollo resulta determinante. Es decir, un encuentro con lo numinoso a través del desarrollo temporal del espacio pintado.

\footnotetext{
${ }^{252}$ Noticias sobre la exposición "Montagnes et eaux" (Paisajes chinos de los siglos XIV al XVIII) Museo Guimet, París, 1957, en Michel Courtois, Pintura China, Madrid: Aguilar, S.A, 1969, pp. 111-112.

${ }^{253}$ En la tradición pictórica de China, Japón y Corea, se han utilizado los mismos patrones compositivos y decorativos, como un medio simbólico que permitiese avanzar en su significado filosófico, social e ideológico.

${ }^{254}$ Hans Belting, Florencia Bagdad: Una Historia de la Mirada entre Oriente y Occidente, Madrid, 2012, p. 70

${ }^{255}$ Estas obras se pueden enrollar, plegar y guardar, para ser mostradas nada más que en momentos determinados, eventos conmemorativos o celebraciones: cuando se recibe a un amigo capaz de apreciarlas o exhibirlas solo durante unos días según la estación o el acontecimiento para el cual lo crea apropiado su dueño de la obra.
} 
A los tiempos T’ang corresponde, sin embargo, la adopción del cuadro de rollo. El Kakemono Japonés se instituye como formato usual de la pintura; pero el cuadro de rollo no aparece hasta el s VII, si acaso, y el rollo pictórico (el antiguo en forma de libro) sobrevive aún, si bien se destina frecuentemente a otros tipos de pintura. A medida que se va desenvolviendo el rollo pictórico, el ojo sigue el paisaje como se ve, por ejemplo desde la ventanilla de un tren. La composición no tiene punto fijo ${ }^{256}$.

Efectivamente, en el espacio de muchas de las pinturas de los rollos de mano aparecen representadas vistas que fluyen y mutan en un constante movimiento. Unas imágenes pintadas en las que, al carecer de un foco fijo, la mirada se desliza de un lugar a otro sin tener un punto obligado hacia el que dirigirse. A decir de François Jullien:

Guo Ruoxu, entre otros, inaugura así su importante tratado: cada vez que me siento en la habitación vacía y silenciosa, suspendo bien alto contra el muro blanco un rollo y, todos los días, "permanezco frente a él", "respondiendo", "recogido": colmado, ya no soy consciente de la grandeza del cielo y de la tierra ni de todas las implicaciones de las cosas; menos aún soy perturbado por las eventualidades favorables o desgraciadas del mundo del poder y del beneficio, o especulo sobre mis posibilidades de éxito, sobre los peligros del fracaso, en la esfera de la "urgencia".... Es preciso señalar dos elementos de este exordio: primero, que la pintura letrada no está destinada a una exposición continua, como lo están nuestros cuadros, sino que es escogida y desenrollada en función de la ocasión, según el momento (y contribuyendo a la calidad del momento), por uno mismo o por las amistades. Por otro lado, no hay ninguna diferencia al ojo, menos aún una reivindicación de la actividad perceptiva, sino, dado que la pintura no "describe" (objetos), es por medio de la coherencia interna que el paisaje (pintado) despliega un dispositivo energético en cuyo interior el espíritu, afinándosedecantándose, se deja absorber ${ }^{257}$.

Esta manera de narrar en el tiempo tuvo sus primeras manifestaciones en China con los rollos de mano a lo que se llamó chüan (手捲); término que designa un formato horizontal de rollos de papel que solían tener una altura de 40 centímetros y una longitud que oscilaba entre los 8 y los 12 metros de largo. Llamados en Japón emakimono (絵巻物) - a donde llegaron desde China junto con la escritura de ideogramas y el budismo, en los siglos VI y VII - fueron ampliamente difundidos para distintos usos, destacando sobre todo como una variedad de novelas ilustradas que proporcionaban entretenimiento e informaban al lector, y a las que en el archipiélago japonés se ha denominado como monogatariemaki (物語絵巻) ${ }^{258}$. Una versatilidad sobre

\footnotetext{
${ }^{256}$ Alan Houghton Brodrick, La Pintura China, México, 1954, p. 30.

${ }^{257}$ François Jullien, La gran imagen no tiene forma o del no Objeto por la Pintura, Barcelona, 2008, p. 263-264.

${ }^{258}$ El primer emakimono realizado en Japón fue una vida ilustrada de Buda que, a su vez, estaba basada en la Sutra kako genzai inga kyô emaki (過去現在因果経絵巻断簡), de finales del s XIII. Dos ejemplos relevantes de estas obras decoradas con unas pinturas, que como ilustraciones decoraban los largos rollos de papel, los encontramos en narraciones como Heiji monogatari (平治物語) y Genji monogatari (源氏
} 
la que van Gulik decía: "En China, los rollos de mano también se denominan chüan-tzû, hêng-chüan, chüan-chou o simplemente chüan. Las pinturas de los rollos de mano abarcan un amplio registro de temas. Los paisajes son tal vez más adecuados para su presentación como una pintura continua en un largo y estrecho rollo" ${ }^{259}$. Efectivamente, para contemplarlos era preciso desenrollarlos lentamente, en un proceso que comenzaba con la lectura de un texto y continuaba con una recreación de este en unas imágenes que se acompasaban con su lectura y con el despliegue de derecha a izquierda del rollo de mano [Figura 25]. Es decir, un proceso en cierto modo ceremonioso que Cheng nos describe de la siguiente manera:

[...] Desenrollarlo es crear cada vez (para el espectador que participa) el milagro de desanudar el tiempo, de revivir su ritmo vivido y dominado (recordemos que, en China, desenrollar y contemplar durante horas una obra maestra constituye un rito casi sagrado). A medida que se desenrolla el cuadro, ese tiempo vivido se espacializa, no en un marco abstracto, sino en un espacio cualitativo e inconmensurable. El artista [...] busca ante todo traducir el tiempo vivido en espacio viviente $[\ldots]$ ¿A caso es menester insistir, una vez más, en que esta mutación del tiempo-espacio sólo es posible gracias al vacío? En el desarrollo lineal y temporal del cuadro, el vacío introduce la discontinuidad interna, y con el vuelco de las relaciones interior-exterior, inaugura el proceso reversible del regreso $[\ldots]^{260}$.

Con el paso del tiempo estos rollos se fueron plegando y evolucionaron, poco a poco, hacia los denominados en chino ts'e o ts'e yeh (冊) - gachô (画 帳) en japonés [Figura 26] - unos exquisitos álbumes plegados en forma de acordeón, cuya estructura hace necesaria una lectura horizontal de la secuencia de imágenes que se representan ${ }^{261}$. Unos álbumes que, curiosamente, con el tiempo terminaron por ser cortados por cada uno de sus pliegues dando lugar, así, a unas páginas individuales que, tras ser cosidas, han terminado por transformarse en nuestros familiares libros. Así, con el transcurso del tiempo, para representar el espacio pictórico mediante el recurso del Foco Móvil o Narración Gráfica Continua, en Asia Oriental los soportes fueron evolucionando desde los rollos de mano a los álbumes plegados para, posteriormente, derivar en nuestros actuales libros. En todo caso, hablamos de una comprensión espacial que - una vez

物語), que combinan imágenes y texto. Los emakimono se clasificaban principalmente en dos grupos, dependiendo de las características de sus imágenes: por una parte estaban los hakubyoemakimono (白描 絵巻物), que se caracterizaban porque en ellos la tinta negra era casi el único material empleado, y por otra los tsukuriemakimono (作り絵巻物), que estaban pintados con una variedad más amplia de colores.

${ }^{259}$ Las citas han sido traducidas del texto original para la redacción de este resumen. Robert H. van Gulik, Chinese Pictorial Art. As viewed by the Connoisseur, Notes on the Means and Methods of Traditional Chinese Connoisseurship of Pictorial Art .New York, 1981, p. 38.

${ }^{260}$ François Cheng, Vacío y plenitud, Madrid, 2004, p. 184- 185.

${ }^{261}$ En el siglo IX d.C. aparece un nuevo tipo de encuadernación en forma de acordeón, denominada también sutra. En este tipo de formatos se utiliza un papel más fuerte para que en lugar de ser enrollado sea plegado en forma de acordeón. Además, la primera y última página de estos álbumes se realizaban con un papel más fuerte para proteger así al que podríamos denominar libro. En cualquier caso, un diseño que estaba supeditado a una cierta comodidad ya que se trataba de una encuadernación que permitía encontrar el texto con más facilidad que en el rollo de mano. 
plegados los rollos - también encontró un medio apropiado en los abanicos de tijera [Figura 27] denominados zhê san (折扇) en chino o sensu (扇子) en japonés y que, como señala van Gulik en Chinese Pictorial Art. As viewed by the Connoisseur, fueron “[...] introducidos en la dinastía Ming desde Japón, probablemente a través de Corea, llamados en japonés sen-su u ôgi" ${ }^{262}$. Un interesante estudio sobre la evolución y expansión de los soportes para la pintura en el Extremo Oriente, donde también podemos observar cómo, una vez que los rollos se compartimentaron, fueron el origen de los biombos, llamados byôbu (屏風) en japonés, pingfeng (屏風) en chino [Figura 24]. Una aportación china - su origen data de la dinastía Tang 唐朝 (618-907) - que llegará a través de Corea al archipiélago japonés donde alcanzará una gran popularidad a partir del periodo Heian 平安 (794-1185). Unos soportes que a decir de van Gulik, aunque en un principio se concibieron como un solo panel rígido, poco a poco fueron evolucionando hasta llegar a los sofisticados desplazamientos de planos sobre múltiples paneles de la época Qing 清朝 (1644- 1911).

\begin{abstract}
Antiguamente tanto las muestras de pintura como de caligrafía estaban a menudo montadas en forma del panel único de tales pantallas. El fino papel o seda del original era tensado en el marco apropiado a lo largo de una madera negra o palisandro, profusamente trabajado. Los paneles plegables, consistentes en tres, cuatro o más paneles eran usados para el montaje de rollos de pinturas y caligrafías conforme a las mismas técnicas aplicadas en el caso de los paneles de tableros individuales ${ }^{263}$.
\end{abstract}

Tradicionalmente el montaje de los rollos pintados solía formar parte de la decoración de los interiores de las viviendas. Van Gulick nos habla de cómo en las casas chinas había la antigua tradición - que con posterioridad llegaría a Japón - de disponer un sencillo panel para poder contemplar las pinturas de los rollos, al que se denominará yen-chang o chang- $t z \hat{u}^{264}$. Unos paneles que, en su origen, estaban muchas veces fragmentados temporalmente sobre varias secciones del vestíbulo principal de la vivienda. Unos sencillos montajes que evolucionarán desde esta primera estructura de un solo panel hasta otras más sofisticadas compuestas por varios paneles plegables en los que se representaba una pintura ininterrumpida. He aquí pues, el origen de los paneles móviles individuales - llamados tsuitate (衝立)- de los biombos o paneles plegables - llamados en Japón byôbu (屏風） y en China pingfeng（屏風） - y de los

\footnotetext{
${ }^{262}$ Las citas han sido traducidas del texto original para la redacción de este resumen. Robert H. van Gulik, Chinese Pictorial Art. As viewed by the Connoisseur. Notes on the Means and Methods of Traditional Chinese Connoisseurship of Pictorial Art, based upon a Study of the Art of Mounting Scrolls in China and Japan, New York, 1981, p. 39.

${ }^{263}$ Ibídem, p. 34

${ }^{264}$ En China, estos montajes con caracteres escritos en horizontal se llaman ê, bêng-ê o pien-ê. En Japón, al formato horizontal de estas tablas, que frecuentemente estaba situado sobre la entrada principal de la vivienda, se denomina gaku (額).Para más información sobre este tema véase, Van Gulik, Robert H. 1981. Chinese Pictorial Art. As Viewed by the Connoisseur. Notes on the Means and Methods of Traditional Chinese Connoisseurship of Pictorial Art, based upon a Study of the Art of Mounting Scrolls in China and Japan. New York. Hacker Art Books.
} 
fusumae (襖絵) - pinturas de las puertas deslizantes de las casas japonesas - que decoran con sus imágenes los interiores tradicionales de Japón, China y Corea [Figura $28]^{265}$. Por consiguiente, la estructura de los biombos evolucionará desde aquel único panel a los juegos de pantallas plegadas por pares; una particularidad que ha favorecido el uso de secuencias móviles donde se combinan sutiles juegos de planos, armonizados con ese particular sentido del ritmo que el vacío enfatiza, al tiempo que articula la relación entre los grupos de figuras pintadas ${ }^{266}$. Una serie de estrategias artísticas y recursos visuales que, además, también podemos encontrar en los fusumae (襖絵), o pinturas de las puertas deslizantes, que compartimentaban los interiores de las casas tradicionales japonesas [Figura 29]. Hablamos, en suma, de las peculiaridades de unos soportes que - con su formato y la disposición de las imágenes y textos - han favorecido el carácter narrativo de la pintura extremo oriental o, al contrario, tal vez este carácter narrativo haya sido el epítome de los formatos horizontales de la pintura, permitiendo que de alguna manera estas pudiesen casi ser "leídas".

Así, en su libro Principios de la Pintura China (1981), G. Rowley nos habla de cómo la mirada percibe la escena representada en un rollo de papel, captando un tiempo que se desarrolla en un movimiento lateral de derecha a izquierda, y no en profundidad como sucede en el arte de la Edad Moderna europea ${ }^{267}$. Ni más ni menos que un formalismo relacionado con la escritura y con la dirección de su lectura - de derecha a izquierda - que hizo posible que se estableciese un estándar cultural de la percepción que además de determinar la lectura de los textos escritos, determinaba la manera de contemplar las imágenes que los ilustraban ${ }^{268}$. De aquí esa factura horizontal de los

\footnotetext{
${ }^{265}$ Los biombos se hicieron muy populares en Japón donde su uso guarda una relación directa con los interiores arquitectónicos japoneses, donde esta idea de los paneles se trasladó a los denominados fusuma 襖, puertas correderas y portátiles que estructuraban los interiores y exteriores arquitectónicos.

En Corea, durante la dinastía Joseon (1392 - 1897) gozaron de gran popularidad los biombos con la iconografía de los paisajes sipjangsaeng - representación que recuerda a los Paraísos de los Inmortales taoístas - usados para grandes eventos reales, en ceremonias judiciales, bodas, sexagésimos cumpleaños o investiduras. Para más información, ver: Park, B. (2002). Kungnip Chung'ang Pangmulgwan sojang shipjangsaengdo (Los diez símbolos de la longevidad en la Colección del Museo Nacional de Corea). Misulsa nonjip, 15, 385-400.

${ }^{266}$ De origen chino, el biombo se concibió como un solo panel que evolucionó progresivamente hacia modelos de pantalla fija o plegable, con un esquema compositivo que evolucionará desde las amplias áreas de vacío para llegar hasta llegar a los exquisitos desplazamientos de planos de la época Qing 清朝 (1644- 1911). Fue en Japón donde se popularizó el uso de los biombos - como pantallas plegables en parejas de seis u ocho paneles - cuyo uso guarda una relación directa con los interiores arquitectónicos japoneses, donde la idea de estos paneles también fue utilizada en los fusuma (襖) (puertas correderas que compartimentan el interior de las casas tradicionales de Japón). Estos byô bu (屏風) compuestos por tres, cuatro o más paneles -casi siempre organizados por pares - no solían sobrepasar los dos metros de alto, pudiendo alcanzar más de siete de anchura, y teniendo en común con las puertas correderas o fusuma (襖) el hecho de que el conjunto de sus paneles conforman una unidad claramente apaisada.

${ }^{267}$ George Rowley, Principios de la Pintura China, Madrid, 1981, p.10.

${ }^{268}$ Este formalismo estaba relacionado con la escritura y, por consiguiente, con la dirección de su lectura - de derecha a izquierda - ha sido el origen de un particular estándar de percepción, que también ha determinado la manera de ilustrar los libros y, en general, representar la pintura. Esta lectura horizontal de derecha a izquierda, tanto de las imágenes como de los textos que las acompañan, mantiene su vigencia en el mundo editorial del Japón de hoy en día. Los libros nipones continúan editándose con un particular formato en el que su portada se corresponde con lo que para los occidentales es la contraportada de la
} 
álbumes ilustrados - plegados como un acordeón - que requerían ser desplegados para poder ser leídos y contemplados, recurriendo a una estrategia compositiva común a todo el ámbito extremo oriental. En palabras de Rowley:

[...] Al tratar de describir semejante experiencia en el tiempo eludimos instintivamente los términos propios del diseño espacial y recurrimos a voces procedentes del campo de la música. Así, hablamos de los temas y de su expansión, contracción e inversión, de las líneas melódicas y de su contrapunto, de los acelerandos y ritardandos, y hasta de los crescendos y diminuendos [...] El momento oportuno de estas notas depende más del movimiento lateral que del movimiento en profundidad, no siendo las líneas de movimiento meras líneas directrices sino melodías lineales que constituyen la esencia misma del diseño. Aunque estos principios temporales son patentes en el rollo, pocos observadores occidentales han advertido que estos mismos principios se empleaban en las pinturas que se cuelgan y en las que se pegan en álbumes. Con independencia de la escasez de motivos o de su sencillez, debemos ver el diseño paso a paso si queremos captar todos los sutiles matices que encierra, porque el diseño en el tiempo no derivaba de la configuración del formato sino de una singular actitud frente al espacio $[\ldots]^{269}$.

Efectivamente, este principio de la narración continua prolonga la narración en varias etapas que se extienden más allá de los límites físicos de la pintura ${ }^{270}$. Y es que, el que podríamos considerar espacio narrativo no es un espacio arquitectónico o natural, sino que es un espacio condicionado por una lectura que se proyecta de derecha a izquierda y de arriba abajo - en un movimiento diagonal que evoluciona desde el ángulo superior derecho hasta el inferior izquierdo - provocando, en palabras de Moulin, una "zambullida panorámica que invierte la perspectiva" ${ }^{271}$ pero que, contrariamente a esta, hace que la línea del horizonte se aleje tras nosotros. Es decir, una particularidad que modifica la percepción del tema - el cual precisa de una comprensión donde la temática predispone la mirada a medida que se despliega el rollo de mano - y donde las diagonales cruzan la escena, multiplicando los puntos de vista e introduciéndonos en el contexto físico de la obra ${ }^{272}$. En palabras de Courtois:

En la pintura europea, el observador queda al exterior del cuadro. Lo que mira, lo siente como una cosa situada ante él y que partiendo de él, partiendo de sus ojos, se despliega en toda su extensión hasta el horizonte. [...] Por el contrario, en las pinturas chinas y japonesas, la mirada no procede del exterior, sino que cada detalle representado en el

publicación. Además, la escritura y la lectura se realizan de derecha a izquierda, en unos párrafos que unas veces discurren de arriba abajo, mientras que en otras se desarrollan en horizontal.

${ }^{269}$ George Rowley, Principios de la Pintura China, Madrid, 1981, p. 93-94.

${ }^{270}$ Énfasis propio.

${ }^{271}$ Raoul -Jean Moulin, en Michel Courtois, Pintura china, Madrid, 1969, pp. 8-9.

${ }^{272}$ La empatía es un aspecto psicológico fomentado mediante la relación establecida con las imágenes que acompañan a los textos de muchas de estas novelas ilustradas denominadas monogatariemaki (物語絵). Los personajes que las protagonizan están sutilmente esbozados, no por una limitación técnica, sino con el propósito de que al lector le resulte más fácil imaginarse y ponerse en su lugar, y vivir de esta manera con más intensidad los sucesos que se narraban. 
cuadro está visto desde el interior, aunque el observador deba, para hacerle justicia, tomar parte activa en él y vivirlo personalmente ${ }^{273}$.

Por lo tanto, nos encontramos ante un posicionamiento del espectador que se nos muestra como una particularidad reveladora, no solo de las condiciones del formato, sino también de unas actitudes muy diferentes en cuanto a la comprensión del espacio y sus mutuas influencias. Pero, además, es un factor que nos revela unas peculiares formas de habitar que han condicionado el concepto del sujeto de una manera muy diferente a la occidental. Unas formas de habitar que, concretamente en el contexto de la cultura japonesa, han establecido una relación más fluida entre dentrolfuera, y que se encuentran en el origen - o son una consecuencia - de la característica arquitectura tradicional de Japón, estructurada de manera flexible por medio de paredes y puertas desmontables y correderas ${ }^{274}$. Efectivamente, en Japón la relación entre el interior y el exterior se ha visto reforzada por la configuración de los interiores arquitectónicos tradicionales, donde sus paredes y puertas correderas - shôji (障子) y fusuma (襖) hacen más versátil la distribución espacial de las viviendas y, además, ofrecen una conexión más fluida con el espacio que las rodea. Algo que podríamos definir como un rítmico abrir y cerrar, en el sentido formulado por Kitaura que lo define como si fuese un inspirar y expirar, y que establece un flujo continuo entre el interior y el exterior.

[...] la estructura del espacio interior de la arquitectura japonesa es tan plástica y dúctil que su perspectiva cambia con una gran libertad y en el abrir y el cerrar de fusuma o shôji existe una sensación semejante a la respiración: la condensación y la expansión alternativas del espacio creando de este modo un dinamismo aéreo y visual en el ambiente $[\ldots]^{275}$.

Un contexto que ha dado lugar a la idea de un espacio pictórico diferente - donde la línea divisoria entre dentro y fuera se ha ido difuminando - fusionando arquitectura y pintura en general con el sujeto y la naturaleza. Con el entorno, recurriendo para ello a un espacio pictórico que, como un inspirar y expirar, se integra y forma parte del espacio arquitectónico [Figura 30]. Y aquí, de nuevo, una combinación de pares de opuestos complementarios. Es decir, de contrarios pero no contradictorios - que se corresponden con ciertas categorías del espíritu - dentro de una idea directamente relacionada con la filosofía taoísta que entiende el mundo como un equilibrio de fuerzas opuestas.

Así, en este ámbito pictórico, nos encontramos con unos paneles exquisitamente decorados con unas pinturas que evocan de manera intuitiva una rica y vivida

\footnotetext{
${ }^{273}$ Michel Courtois, Pintura china, Madrid, 1969, p.103.

${ }^{274}$ Esta sucesión de espacios - irregular y carente de esa idea de orden simétrico tan del gusto occidental está estrechamente relacionada con las peculiares formas de habitar del espacio japonés.

${ }^{275}$ Yasunari Kitaura, La Plenitud del Vacío. Ensayos sobre el Aikido y Otros Aspectos de la Cultura Japonesa, Madrid, 1999, p. 83.
} 
naturaleza. Un mundo sensorial que logra hacer que el exterior penetre en el interior de la vivienda algo, por otra parte, totalmente alejado de ese concepto de ventana que caracteriza desde el Renacimiento a la pintura europea y que separa el interior de ese exterior soñado al que el espectador se asoma. Es decir, una percepción de la dimensión más emocional que física del espacio pictórico que se muestra totalmente alejada de esa necesidad tan occidental de acotarlo. Es decir, de esa necesidad de una escala métrica que ha terminado por individualizar la mirada europea y que ha entendido la mímesis como la única manera de proporcionar al espectador ese espacio concreto que la mirada occidental anhelaba. Y es que, el modelo de cuadro europeo - como ventana delimitada por un marco - y cuanto condiciona todo esto a su contemplación, no se aceptará en Japón hasta el siglo XIX, cuando su uso se afianzará como una moda en este país. Efectivamente, fue entonces cuando Shiba Kôkan 司馬江漢 (1747-1818) ${ }^{276}$ afirmó:

[...] que no había más que una única "manera correcta de mirar, y por eso se enmarcan y cuelgan las pinturas occidentales. Quien las contempla, aunque solo sea brevemente, debe colocarse frontalmente ante ellas". Hay que recordar, proseguía, que el horizonte, "que separa el cielo de la tierra", esté exactamente a la altura de los ojos y esforzarse por mirar una imagen a la distancia correcta. "Si se respetan estas reglas, la imagen no se diferencia en nada de la realidad ${ }^{277}$.

En definitiva, y retomando esa idea del tiempo y del espacio de la pintura extremo oriental, nos encontramos con unas particularidades que han propiciado la evolución progresiva de un espacio capaz de captar el paso del tiempo al desenrollar o desplegar estas pinturas. De este modo - mediante un acuerdo tácito que implicaba una participación activa del espectador - contemplarlas será en una suerte de ritual para recorrer con la mirada un espacio que invita a la intimidad de un paseo de plurales y complementarios recorridos. Es decir, una participación activa - que requiere de un conocimiento profundo de los códigos perceptivos - mediante un desarrollo musical que ofrece tantas y variadas posibilidades de lectura como todo lo variado pueda ser el espacio representado. Así, la pintura alcanzará un valor compositivo implícito en una particular comprensión del rito, que dotará a la pintura de una fuerte carga poética, convirtiendo al artista en el intérprete de una obra que buscaba más sugerir que demostrar y que - como medio - alcanzará su plena significación al ser contemplada. Entonces, sólo en ese momento, era cuando la pintura lograba el estatus de imagen poética que, al igual que un texto, se iba leyendo conforme era desenrollada o desplegada.

\footnotetext{
${ }^{276}$ Seudónimo artístico con el que artístico con el que firmaba Suzuki Harushige (鈴木春重? ${ }^{2}$ ) (1747-1818 pintor y grabador japonés del período $E d o$ 江 戸. Artista que se hizo particularmente famoso por sus pinturas de estilo occidental, en las que imitaba los métodos, estilo y temas de las pinturas holandesas realizadas con la técnica del óleo.

${ }^{277}$ Hans Belting, Florencia Bagdad: Una Historia de la Mirada entre Oriente y Occidente, Madrid, 2012, pp. 41-42.
} 
Nos encontramos, por lo tanto, con una capacidad para sugerir y crear sitios que, no obstante, precisará de una evocadora memoria compartida capaz de configurar el espacio representado o - lo que es lo mismo - capaz de hacer que la memoria del espectador fluyese en un continuo de fenómenos sensibles a través de un mundo de arquetipos. Entonces, solo entonces - lejos de la mímesis que impregnaba la pintura europea - ese espacio pictórico, al encontrar aquella identificación espiritual y estética que le confería su verdadera razón de ser, cobraba verosimilitud. Una pintura que, en palabras de Moulin, al estar "[...] impregnada por la contemplación activa de los fenómenos naturales y de su permanencia, escapó a la petrificación, gracias a una experiencia continua en el tiempo y en el espacio, ya virtualmente ostensible en la fluidez y en la vivacidad de la escritura de las aguadas monocromas, y que se concretó en el desarrollo de los rollos pintados, en ese avance real, a través de una nueva dimensión visual y temporal" ${ }^{278}$.

En cualquier caso, entendemos que estas particulares condiciones de los soportes han logrado establecer un predominio de la horizontalidad en la pintura, adaptando el punto de vista y el todo compositivo a las particularidades del tema representado. Es decir, que al desarrollar la imagen en los rollos horizontales - o en cualquier otro de los soportes que hemos mencionado - se logra un desplazamiento del espacio a través del tiempo y, puesto que nunca se llega a abarcar de una sola vez todo ese espacio, este se percibe como una mutación ${ }^{279}$. Es decir - tal y como nos recuerda el I Ching - como una fase en el cambio constante de las cosas. En palabras de François Cheng:

[...] Resulta de ello que un cuadro de paisaje está marcado a menudo por un movimiento vivaz de expansión y de circularidad, lo que corresponde precisamente a la concepción espacio-temporal de la cosmología china, la cual, recordémoslo aun a riesgo de repetición, no contempla en absoluto un espacio estático o congelado ni un tiempo en línea recta [...] Para conseguir este resultado el artista se sirve precisamente de todo el juego del Yin y el Yang, de los vacíos y los llenos para componer, en el seno de un espacio constituido, elementos en secreta mutación, a todos los niveles, desde un punto, la ejecución de un trazo, un matiz de tinta, hasta la organización del cuadro en su totalidad ${ }^{280}$.

Así, entendemos, se favorecieron unas condiciones específicas que pudieron condicionar la manera de representar el espacio y los códigos que regían su sistema codificado de percepción. El llamado principio de la representación gráfica continua del que no hemos encontrado un término equivalente en el Extremo Oriente, a excepción del ya mencionado fûkeigashoshiki (風景画 書 式) que podríamos traducir como «formato de escritura horizontal a la manera de pintura de paisaje». Efectivamente, aunque etimológicamente se trata de un término relativamente nuevo,

\footnotetext{
${ }^{278}$ Raoul -Jean Moulin, en Courtois, Michel, Pintura china, Madrid, 1969, p. 9.

${ }^{279}$ Énfasis propio.

${ }^{280}$ François Cheng, Aliento y Espíritu. Textos teóricos chinos sobre el arte pictórico. Valencia, 2017. p. 169
} 
encontramos en él unas implicaciones espaciales profundamente arraigadas en la tradición extremo oriental. En cualquier caso, no podemos aplicarlo a una definición de este supuesto sistema de representación, ni este ni ninguno de los otros términos utilizaos para expresar las distancias en la pintura tradicional china.

En consecuencia inferimos, por comparación, que desde el Extremo Oriente este Principio de la Narración Gráfica Continua no se ha comprendido como un sistema espacial y, como tal, como sistema de pensamiento. Su representación se perpetúa en la intuición de una horizontalidad dilatada que no precisa de un dogma. Dicho con otras palabras, se perpetúa en la tradición de una dimensión natural exenta de la oposición entre logos y natura, y por consiguiente está alejada de cualquier noción que se aproxime a la idea de un proceso intelectual que, por lo tanto, funcionaría dentro de un sistema dictado por una cultura. Sería, en ese caso, un proceso contranatura. 
APÉNDICE DE IMÁGENES 


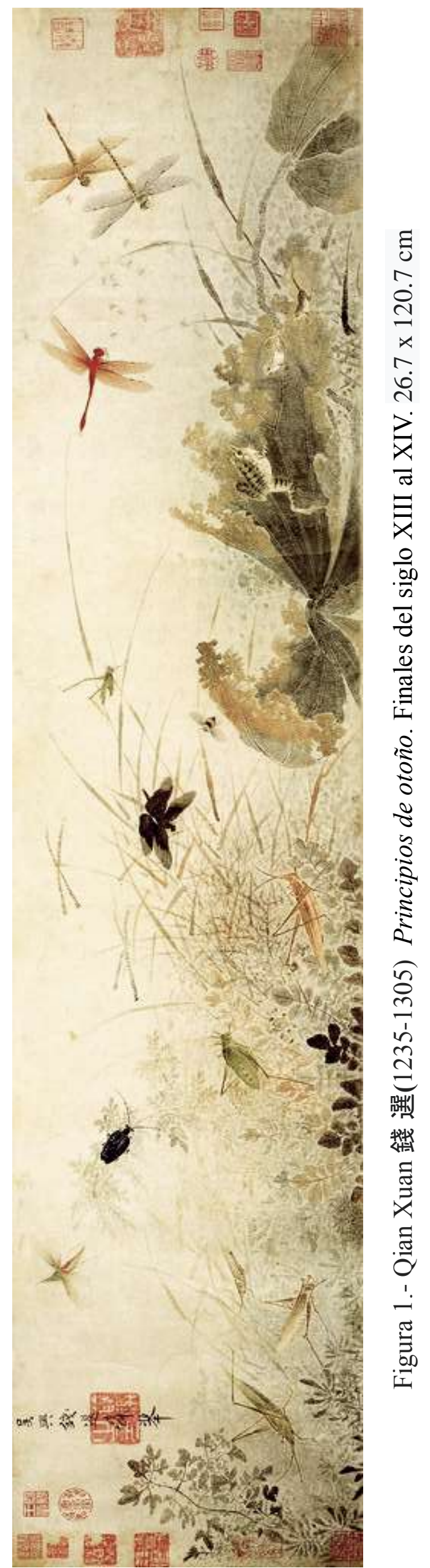




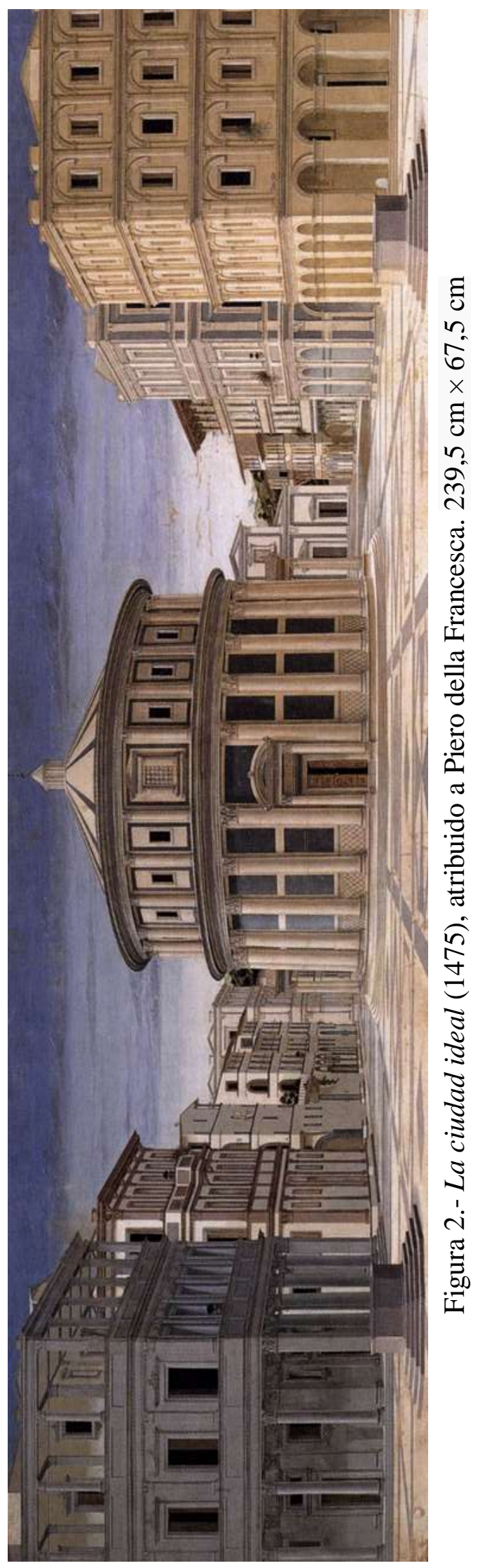




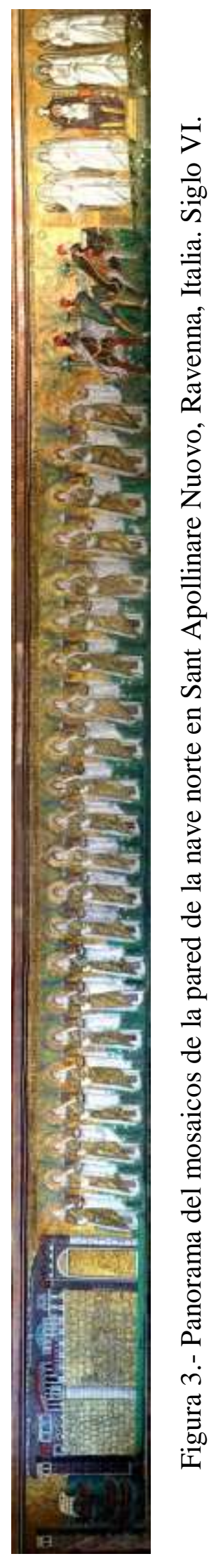




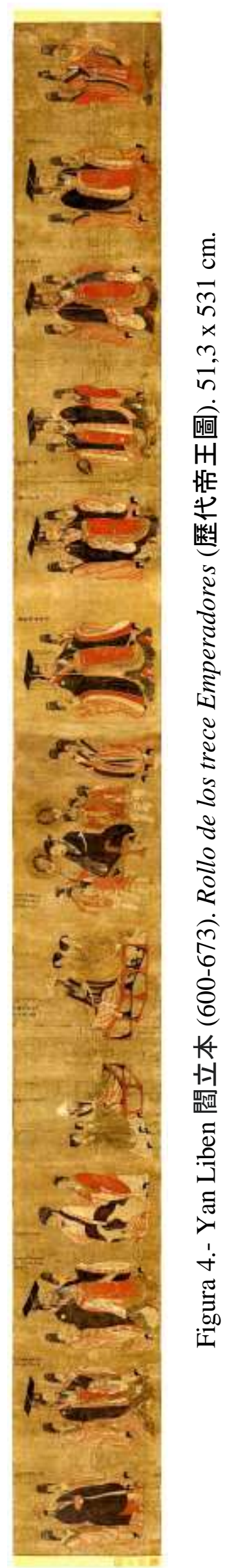




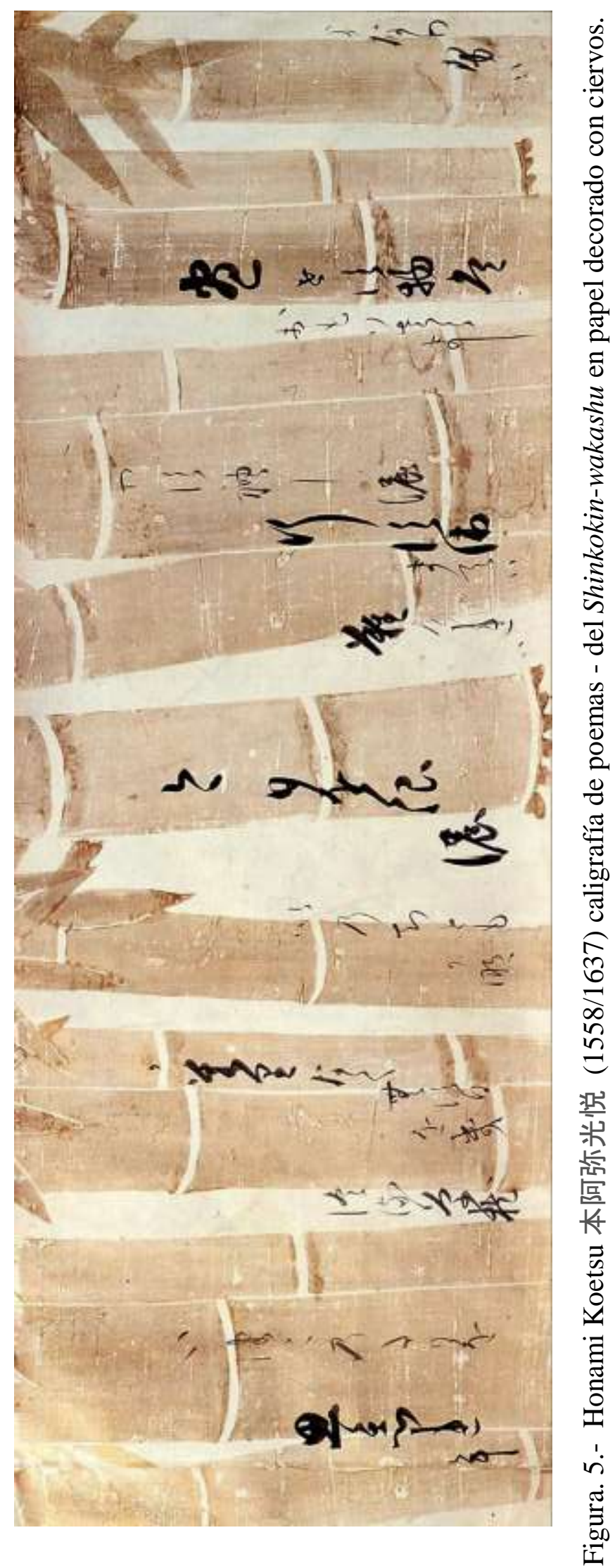




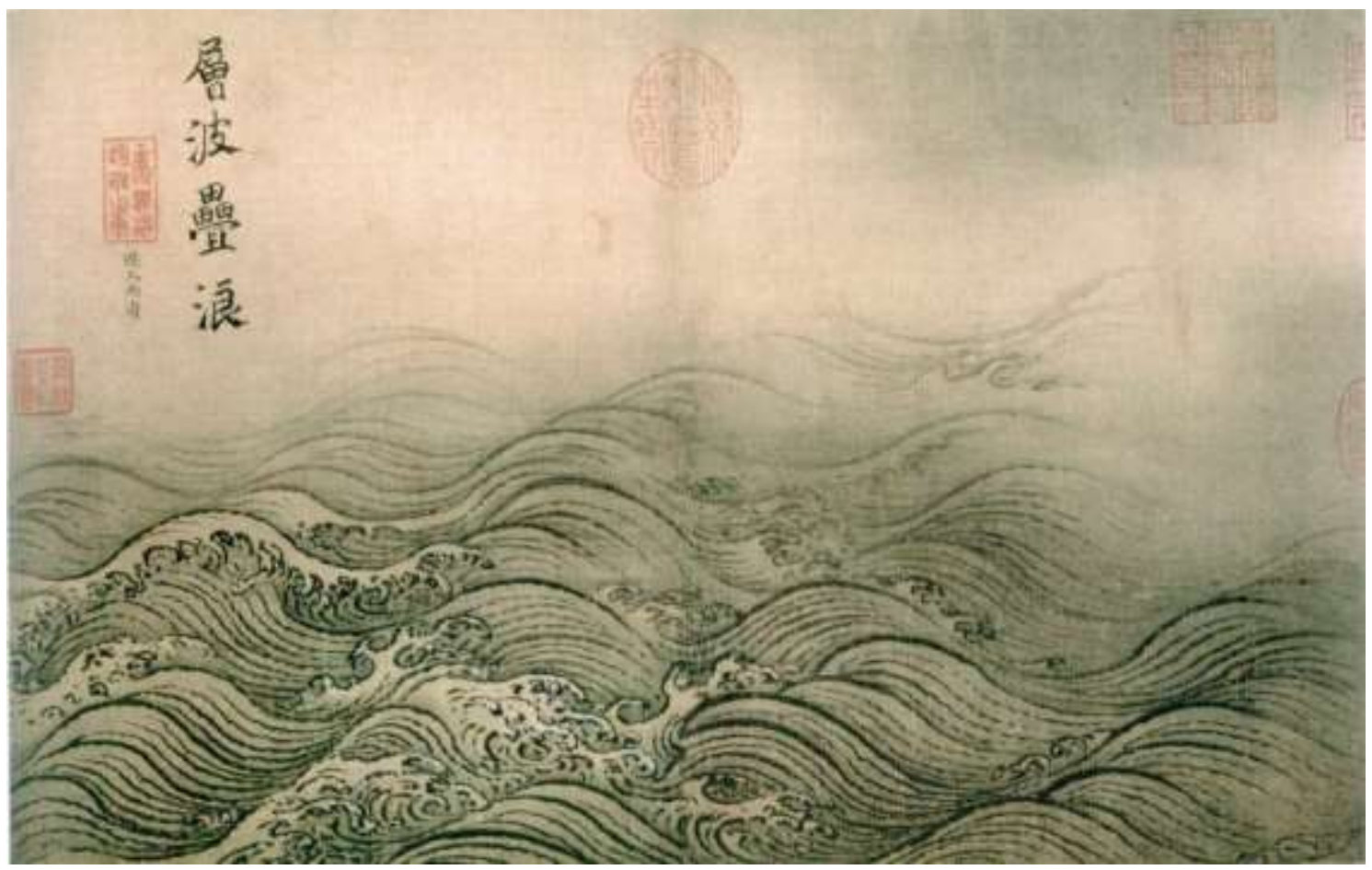

Figura 6.- Ma Yuan (馬遠/马远, 1160-1225) Dinastía Song.

Capas de olas sobre olas, perteneciente a Doce estudios del agua (二十水圖)

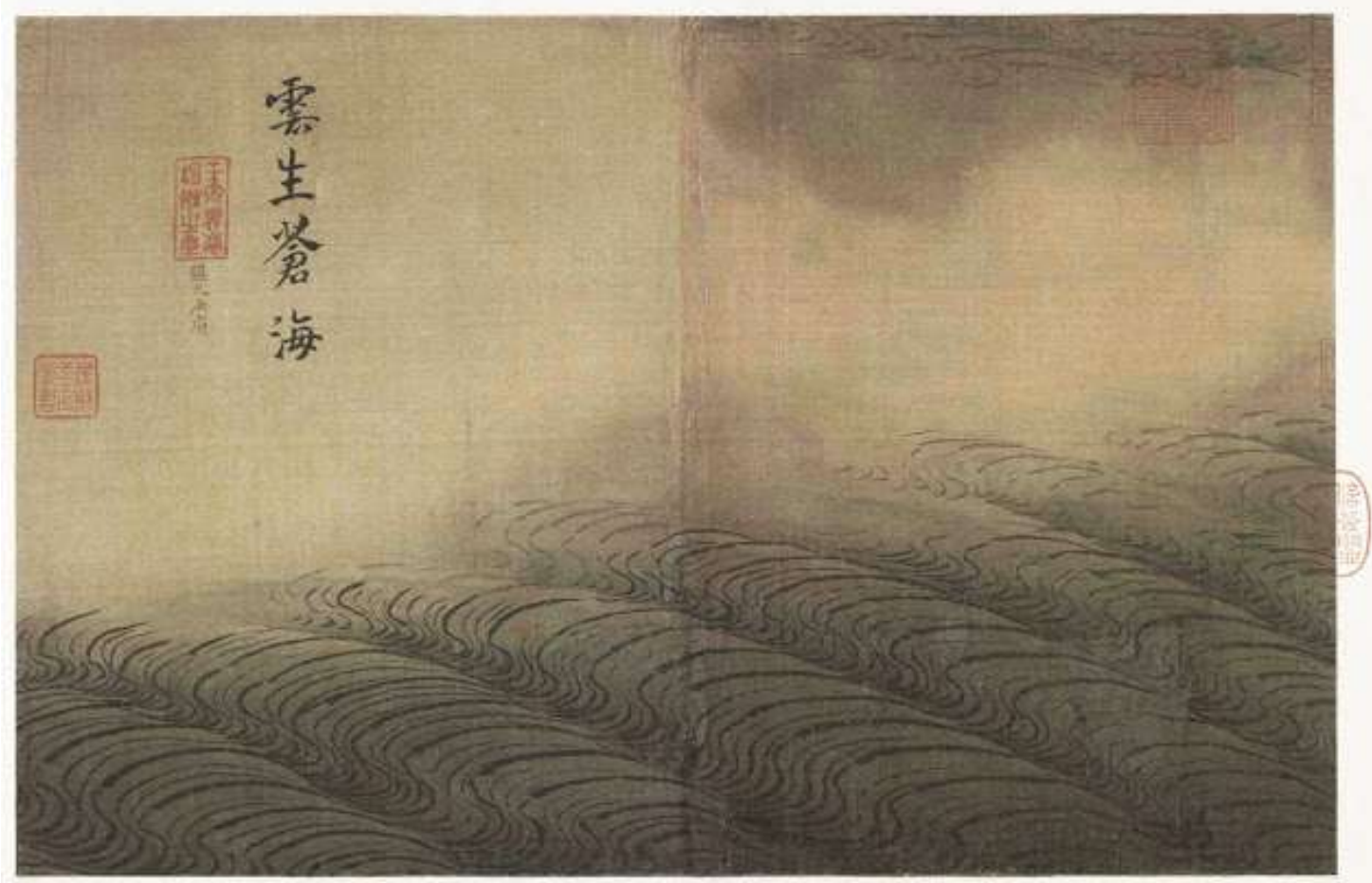

Ma Yuan. Tinta sobre seda. 1160-1225

Clouds Rising from the Green Sea, perteneciente a Doce estudios del agua (二十水圖) 


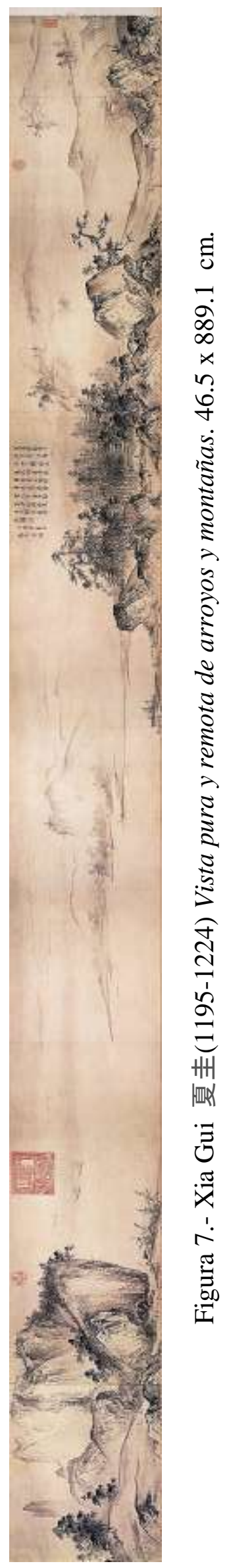




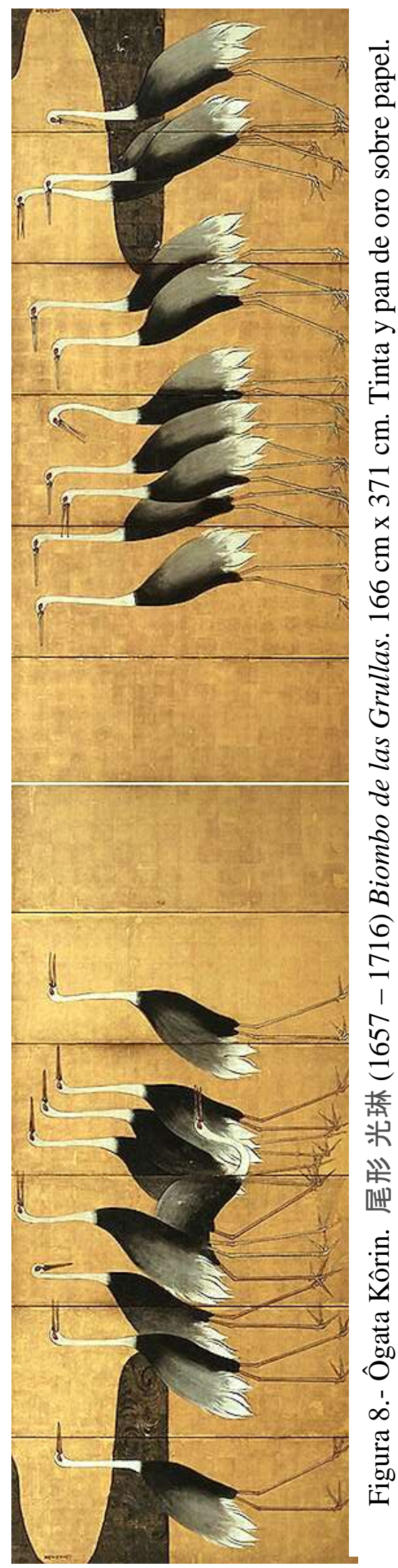




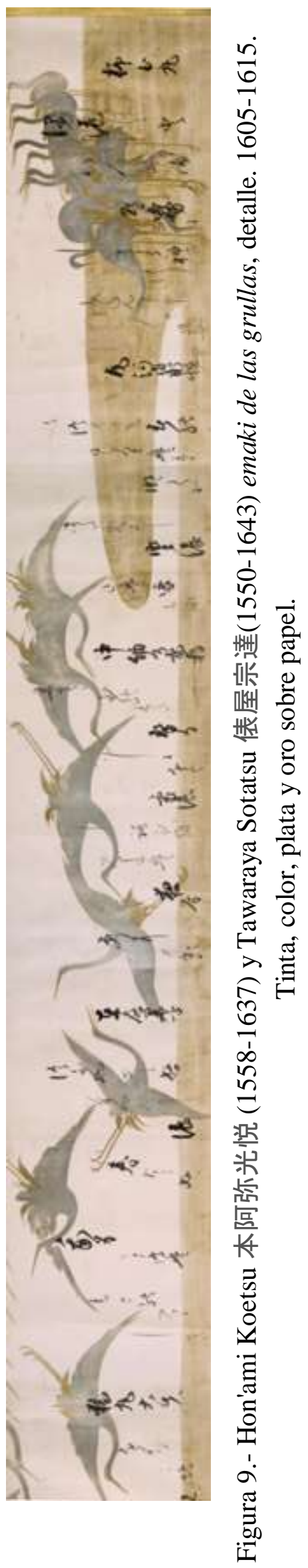




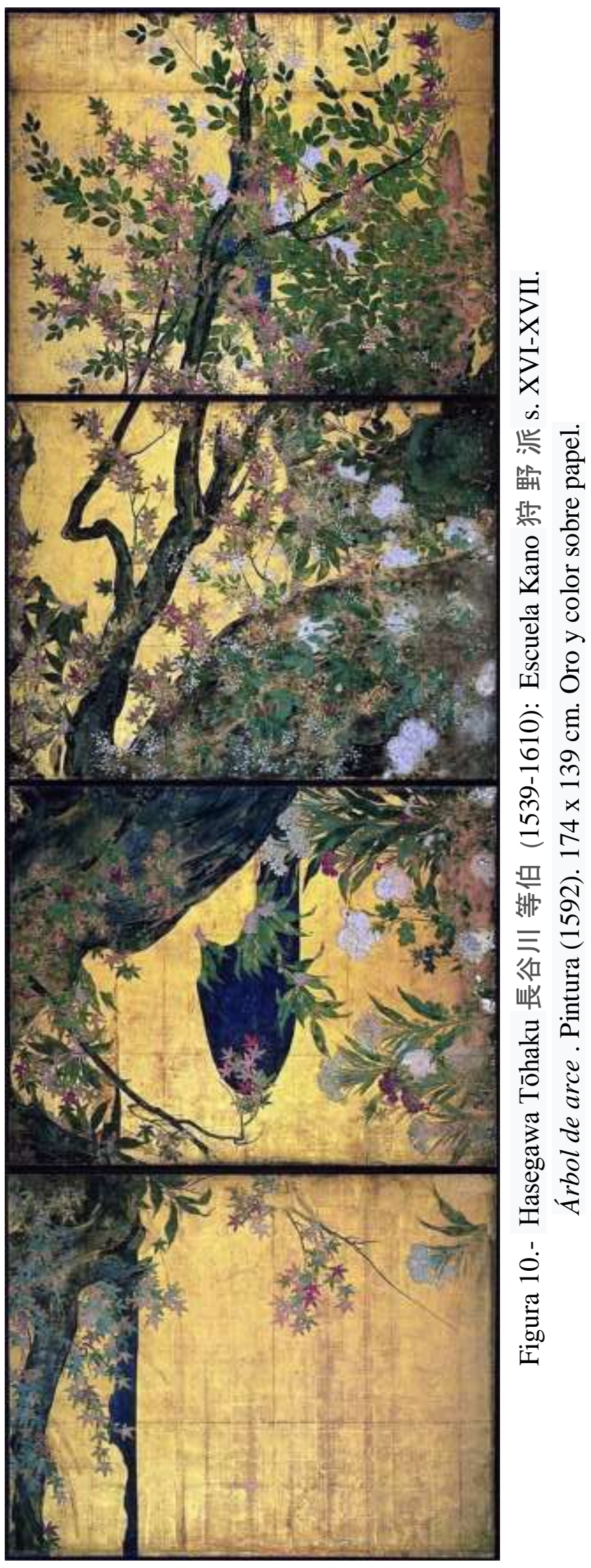




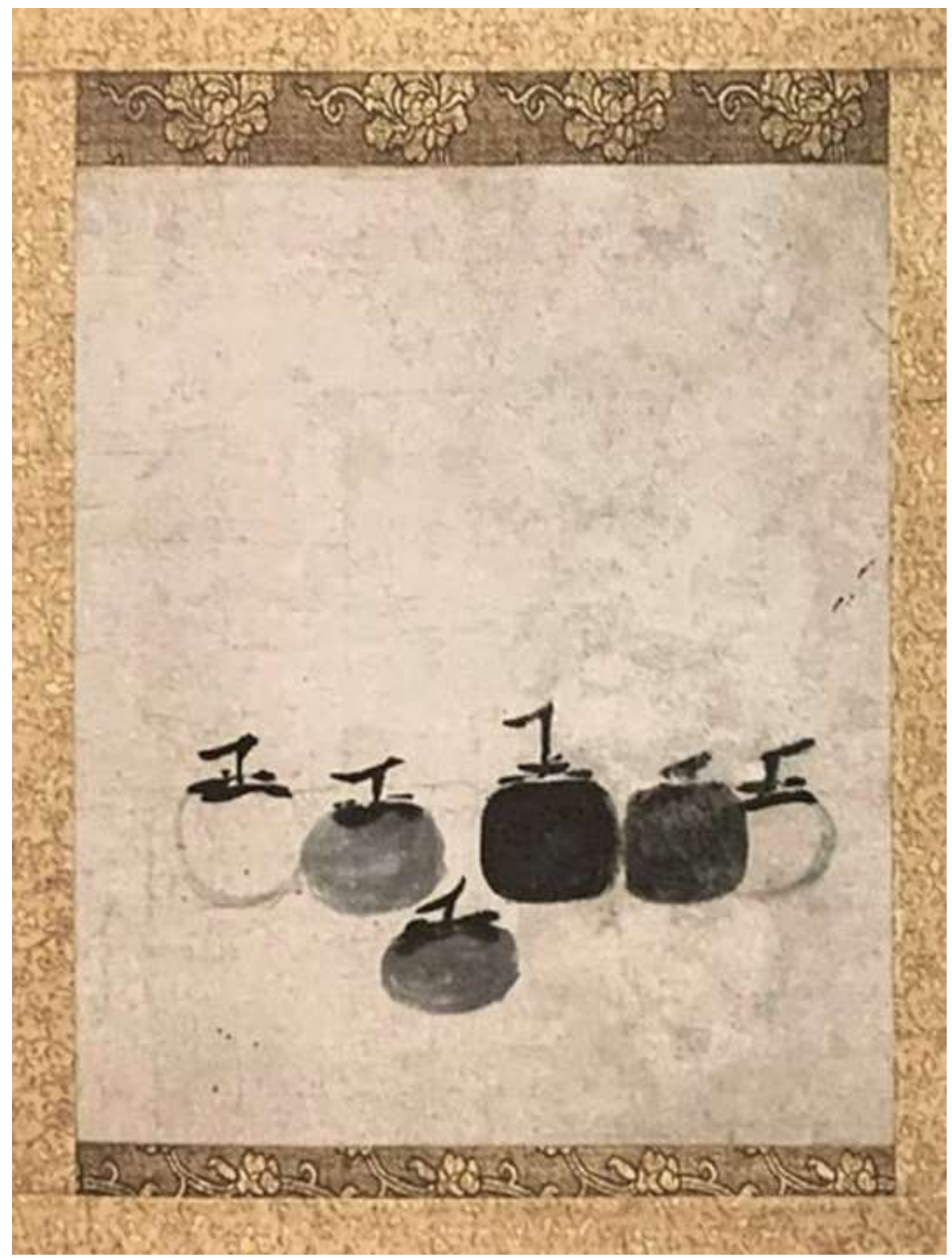

Figura 11.- Mu Qi Fachang (Mokkei)

Seis caquis, siglo XIII, Daitoku-ji, Kioto. Pintura a tinta. 


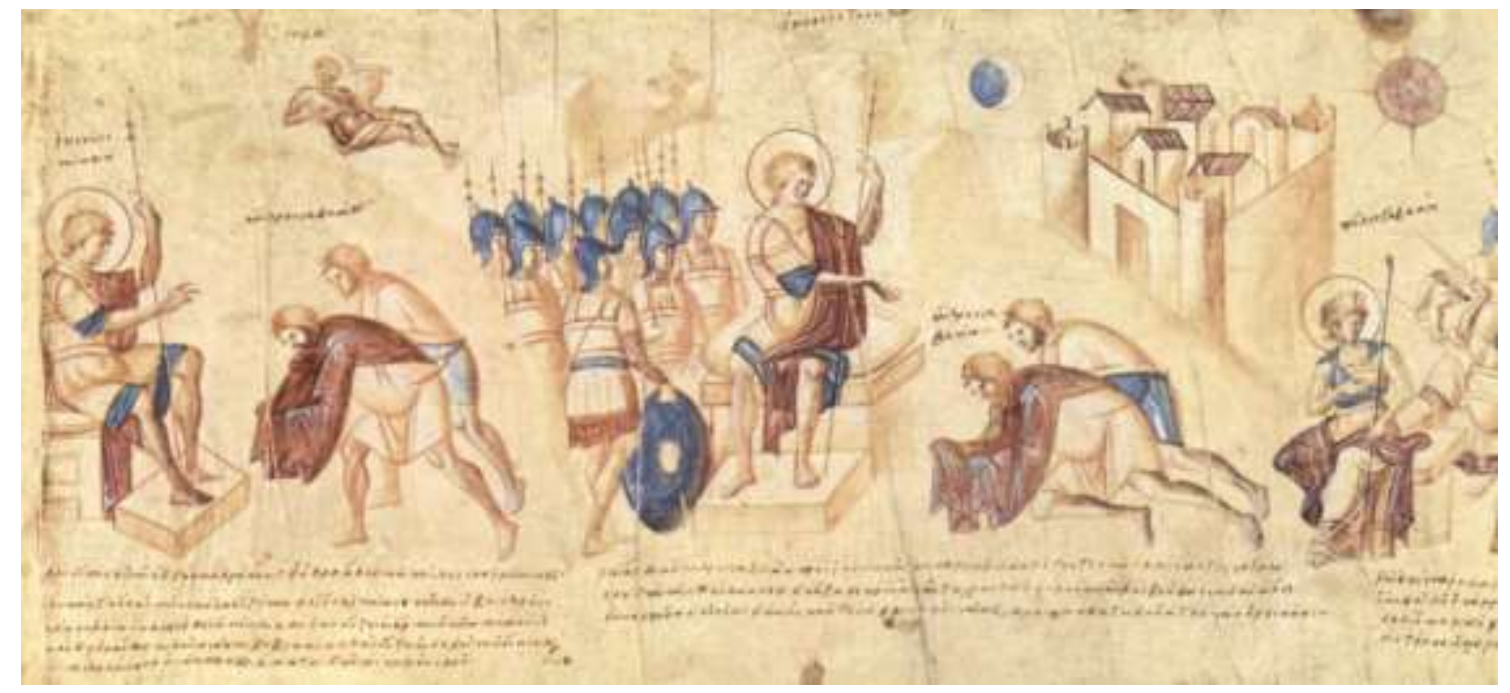

Figura 12.- Rollo de Josué (fragmento) s. X, Biblioteca del Vaticano.

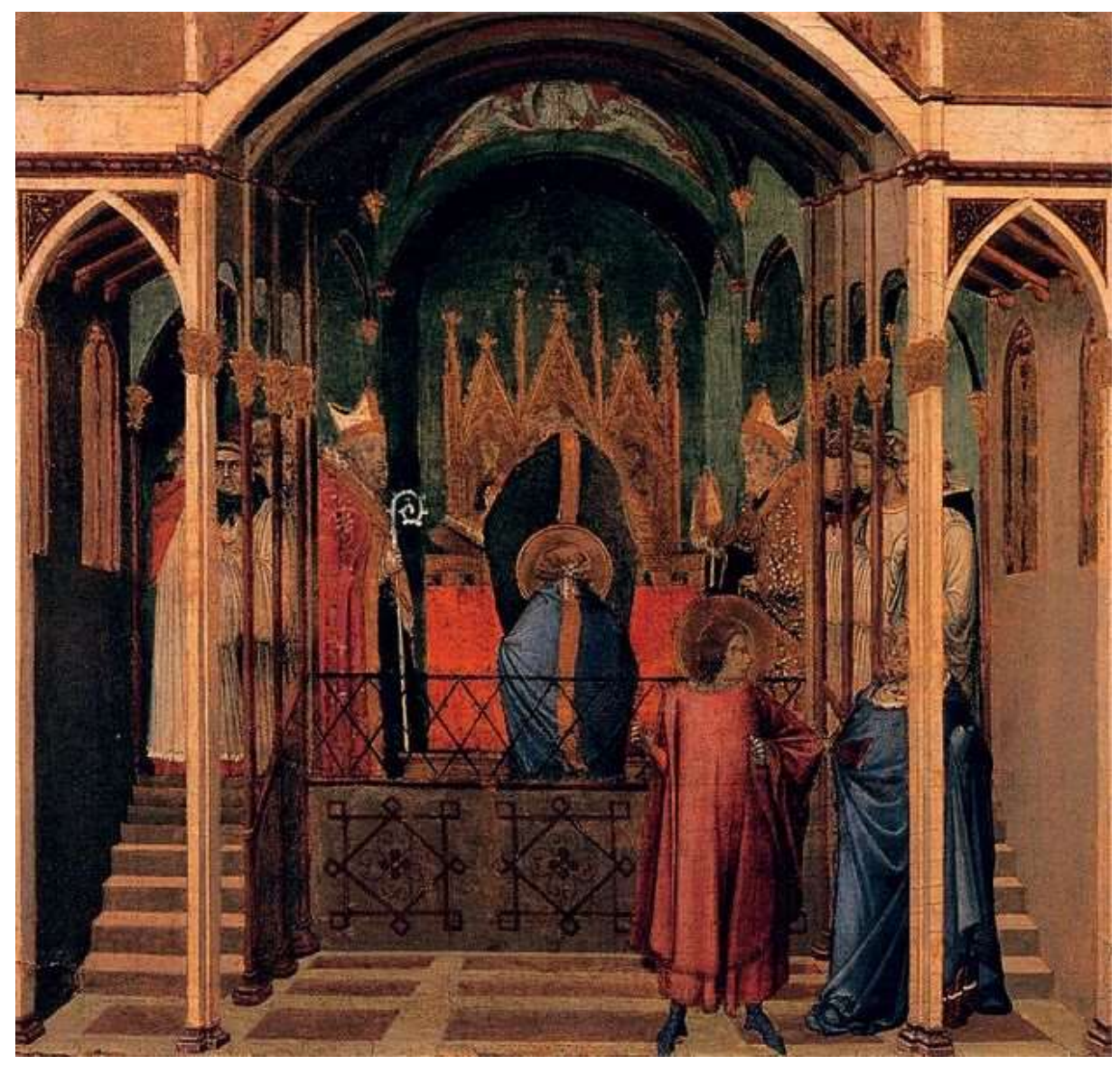

Figura 13.- Lorenzetti, Ambrogio (1290 - 1348)

Escenas de la vida de San Nicolás (1332) Pintura al temple sobre madera. 96 x $53 \mathrm{~cm}$. 


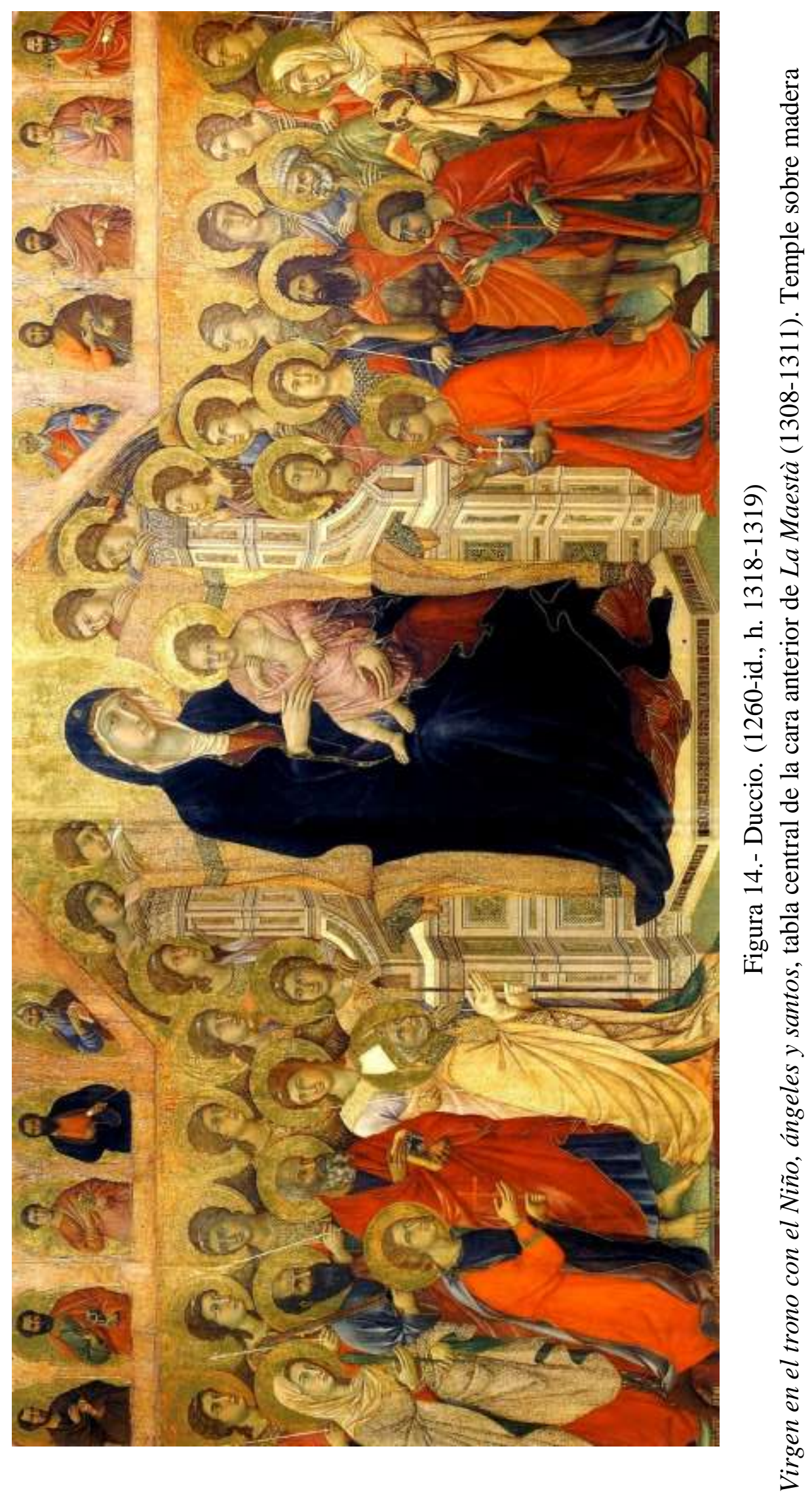




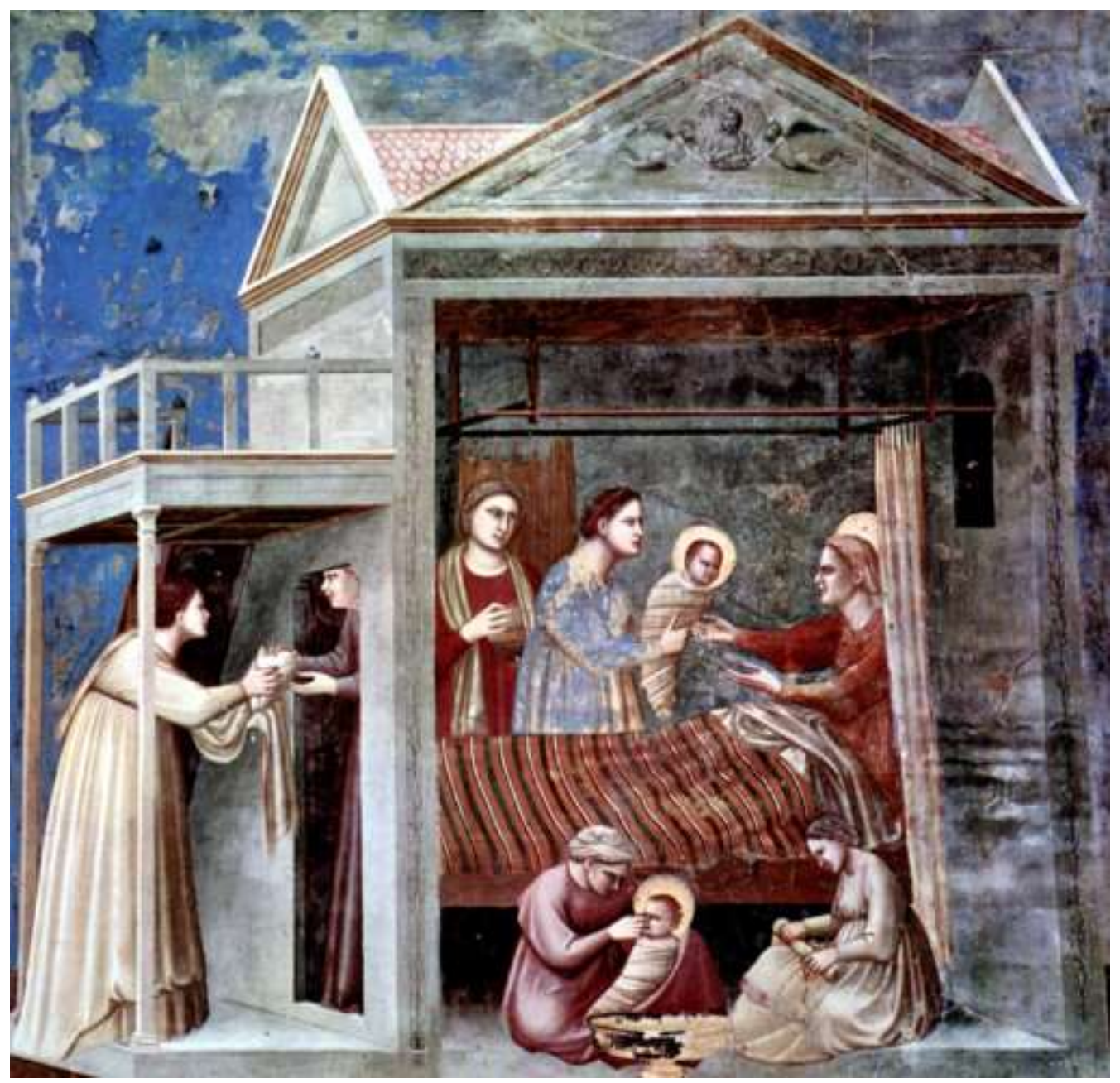

Figura 15.- Giotto di Bondonde (1267- 1337)

Escenas de la vida de María: 7. Natividad de los Theotokos. Fresco, entre 1304 y 1306. 


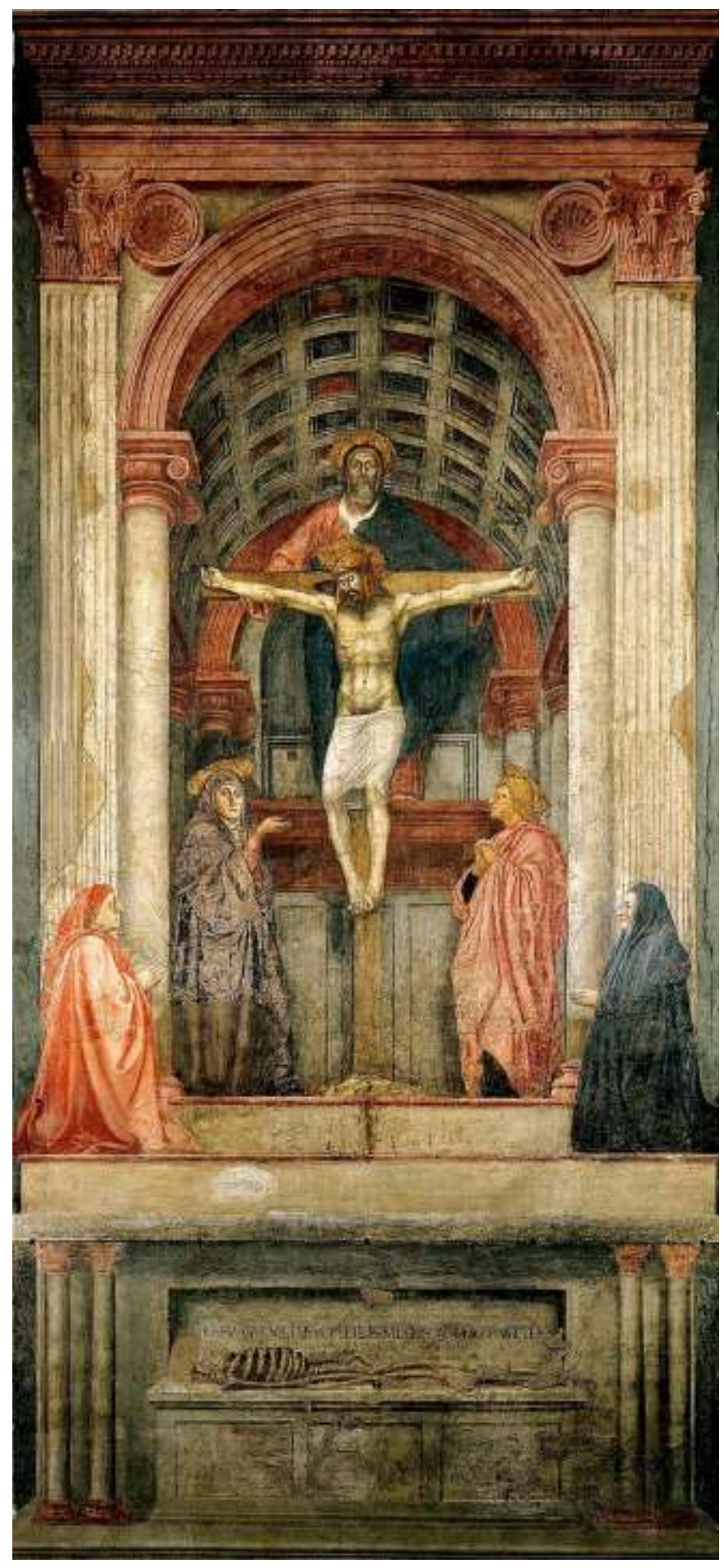

Figura 16.- Masaccio (1401 - 1428)

Santísima Trinidad. (1426 - 1428). Basílica de Santa María Novella. Pintura al fresco. $680 \times 475 \mathrm{~cm}$. 


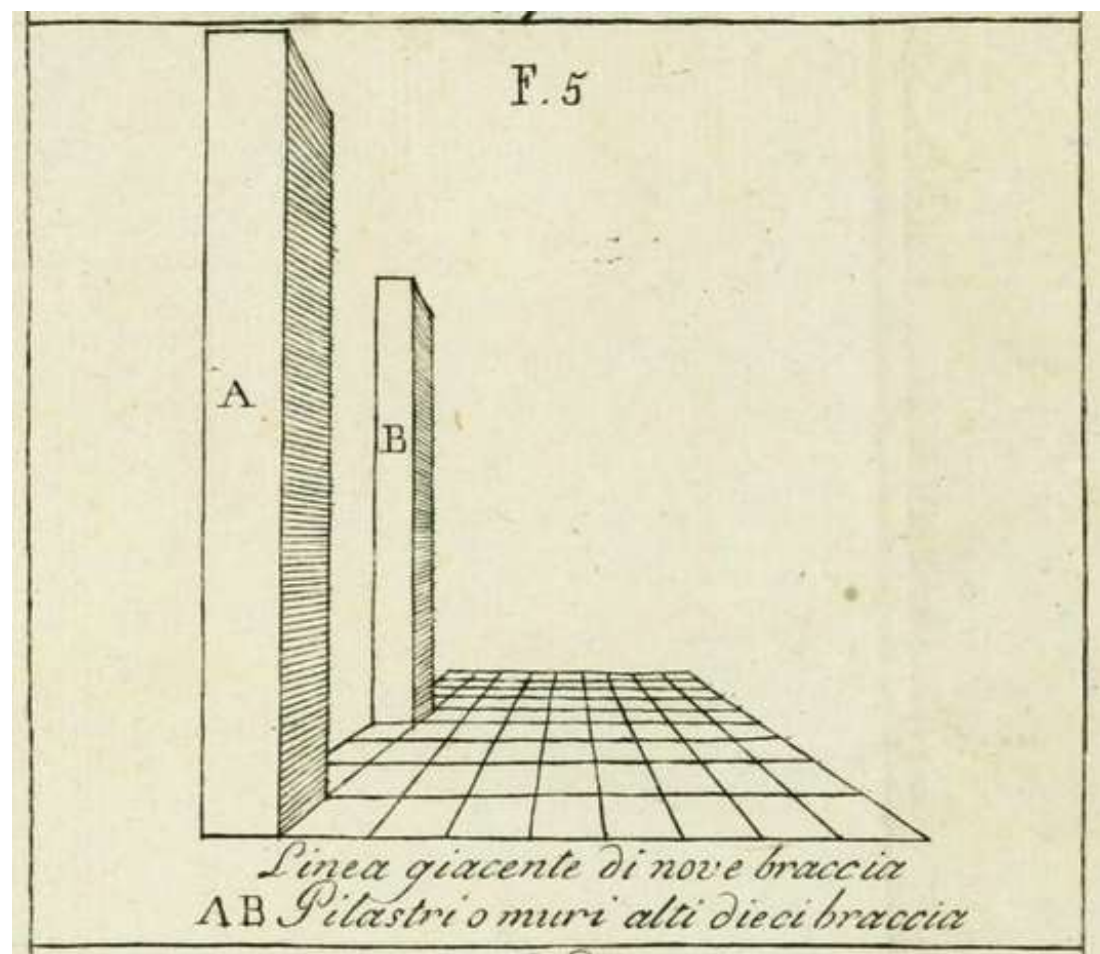

Fifura 17.- Leon Battista Alberti (Génova 1404-- 1472)

Diagrama de pilares en perspectiva sobre una cuadrícula en Della Pittura

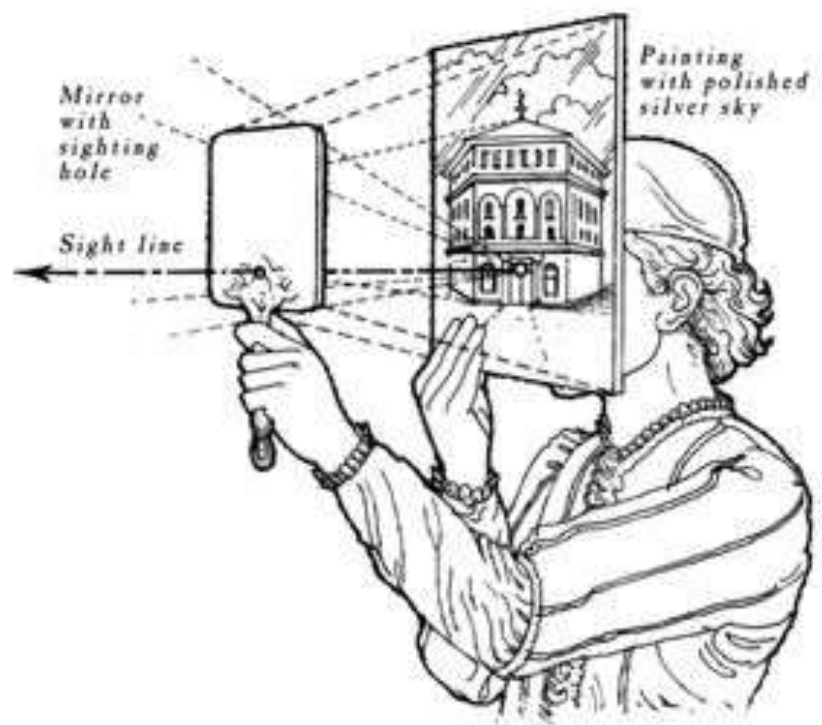

Figura 18.- Instrumento óptico de Brunelleschi 


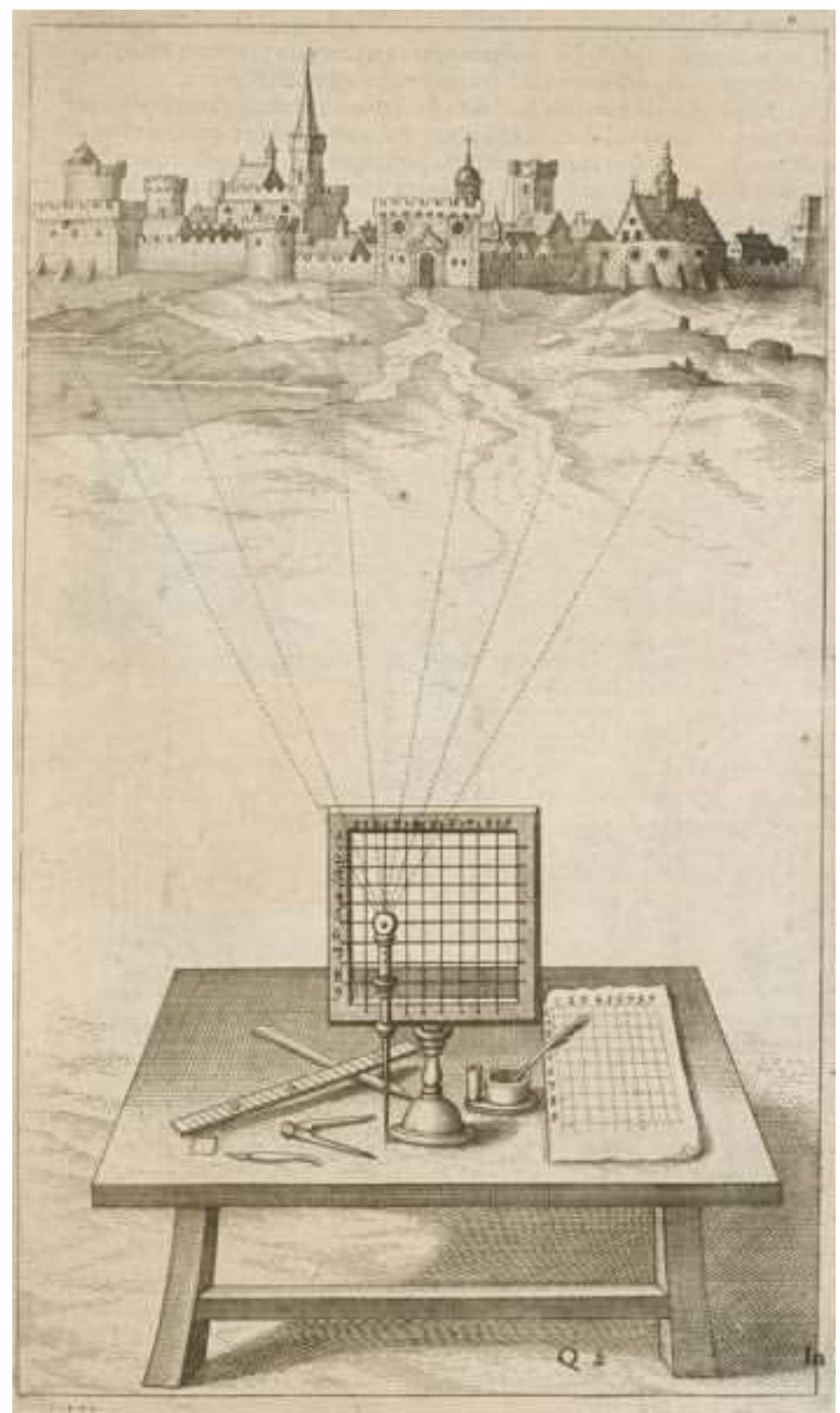

Figura 19. Robert Fludd (1574-1637),

Utriusque cosmic maioris scilicet et minoris metaphysic (Oppenhemii: Ere JohanTheodori de Bry, typis Hieronymi Galleri, 1617-21). 


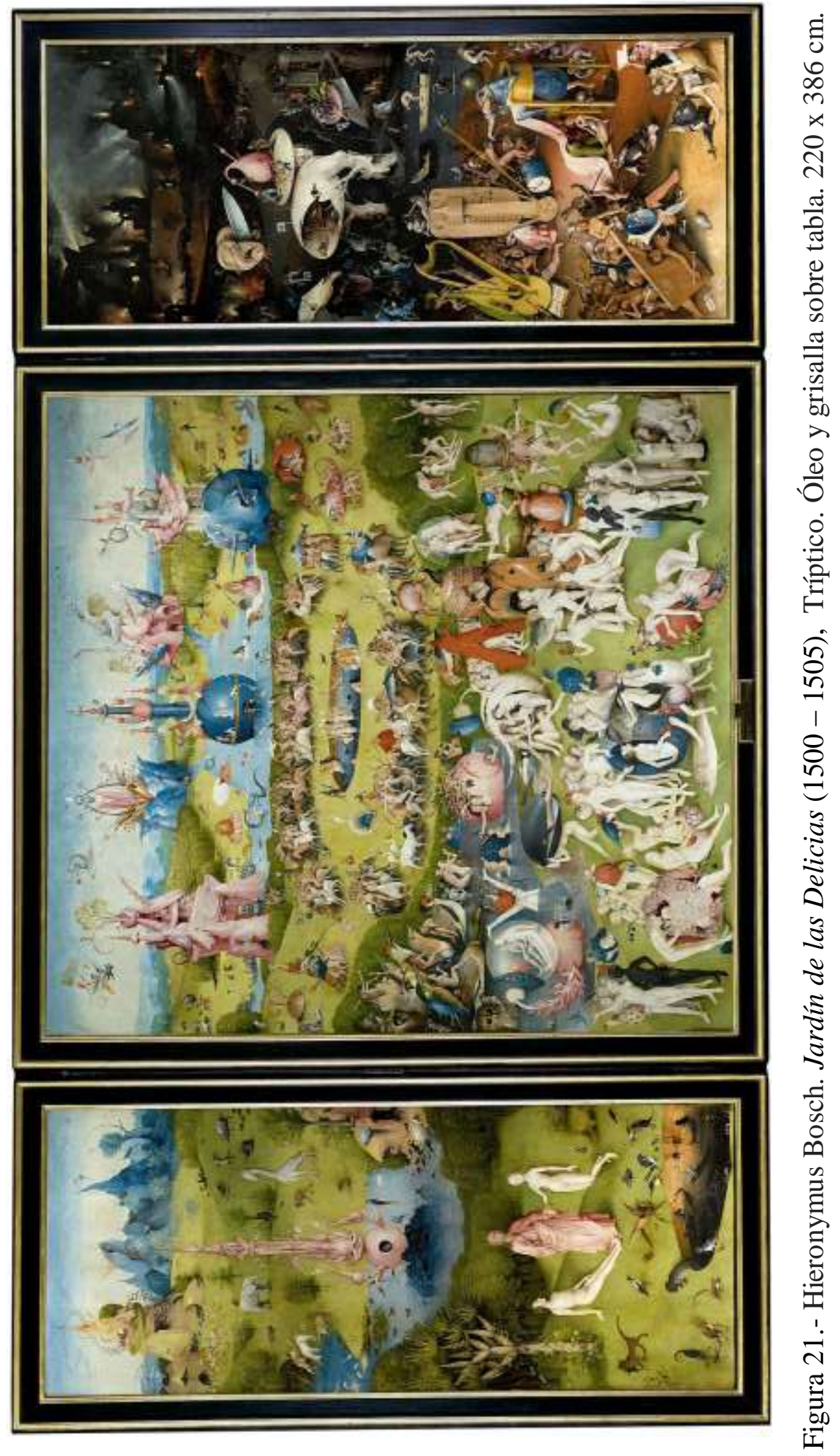




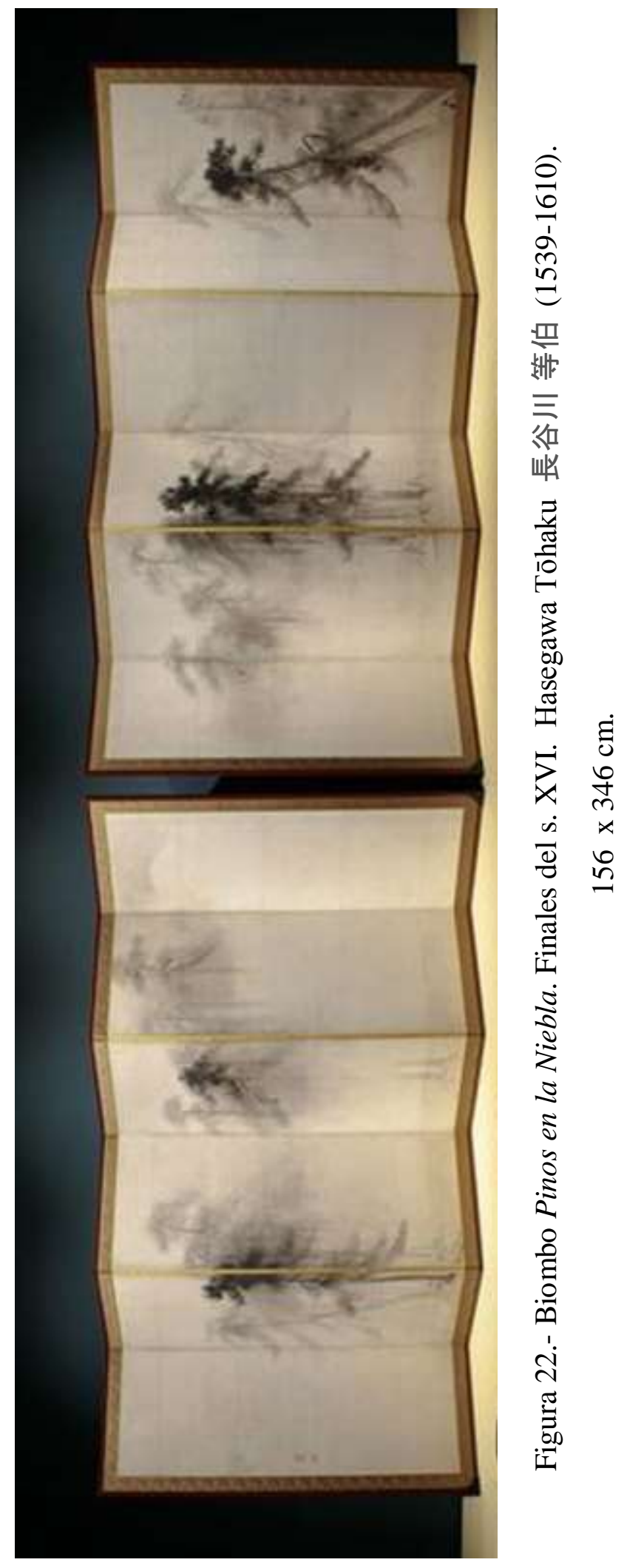




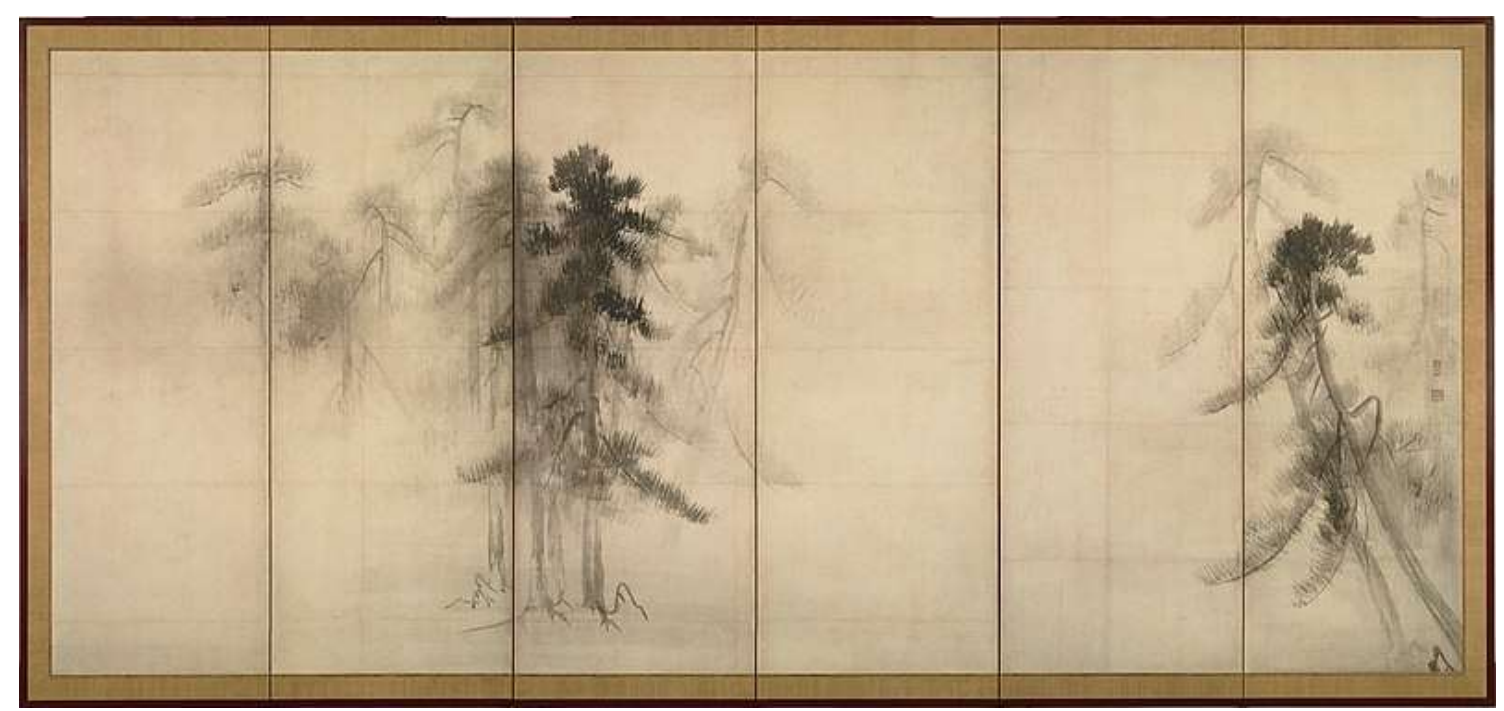

Biombo Pinos en la Niebla (panel derecho)

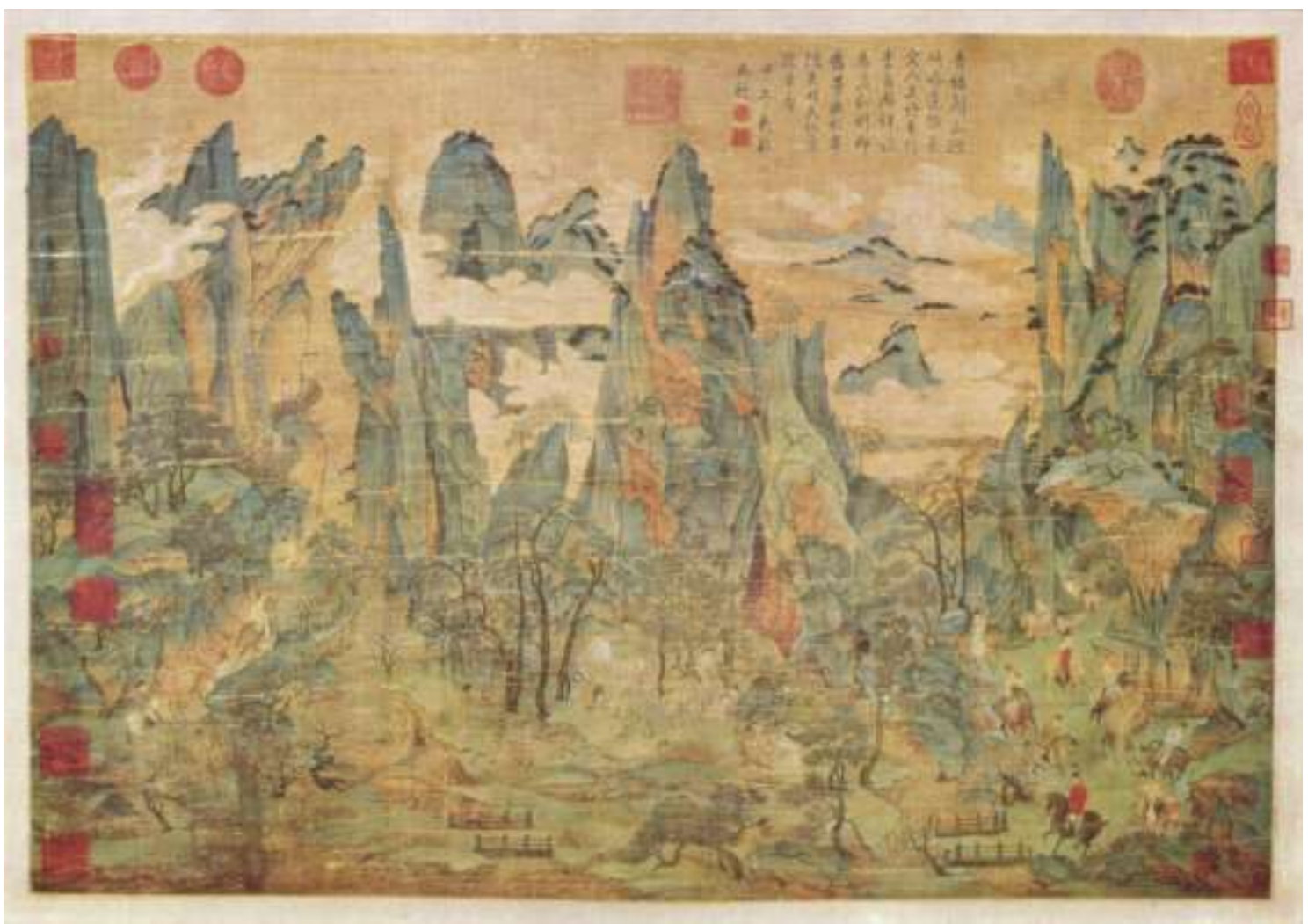

Figura 23.- Viaje de Minghuang a Shu, tinta y color en pergamino colgante de seda, atribuido a Li Zhaodao, estilo de la dinastía Tang, posiblemente una copia de un original del siglo X-XI. 

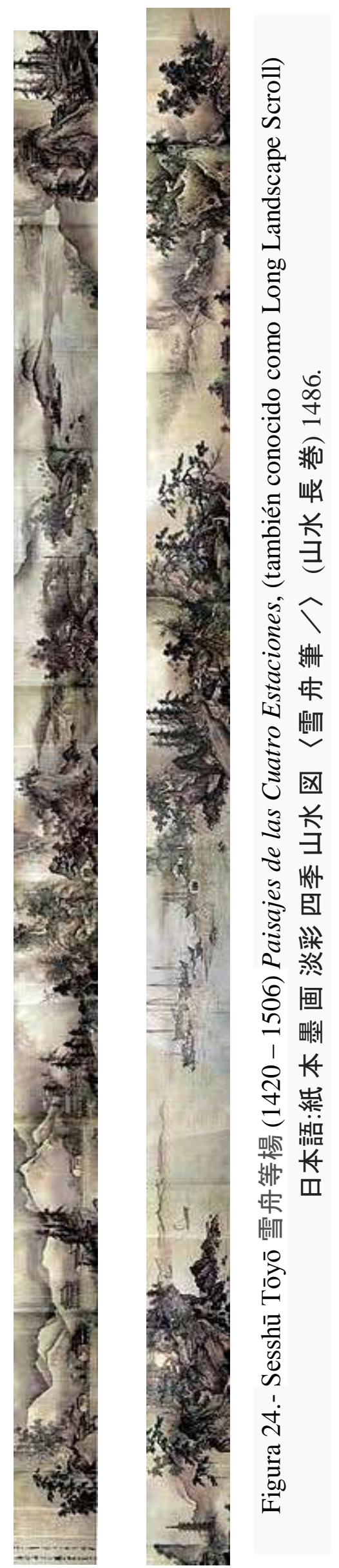


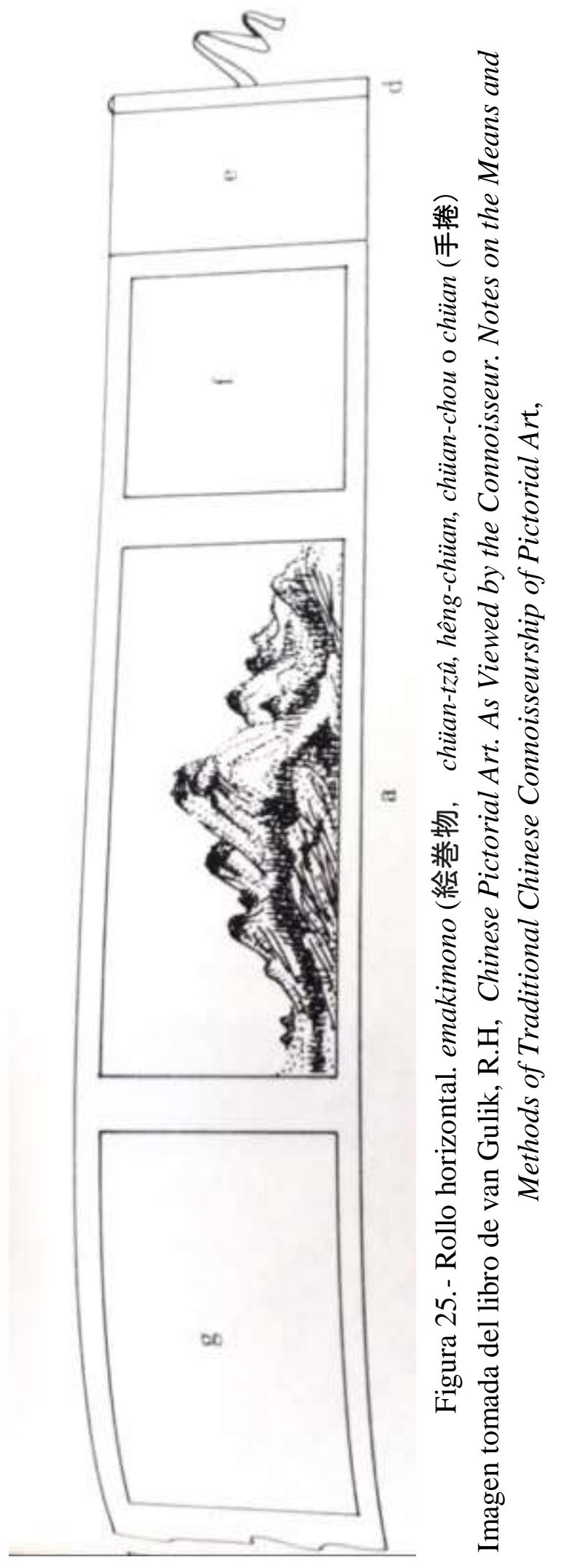



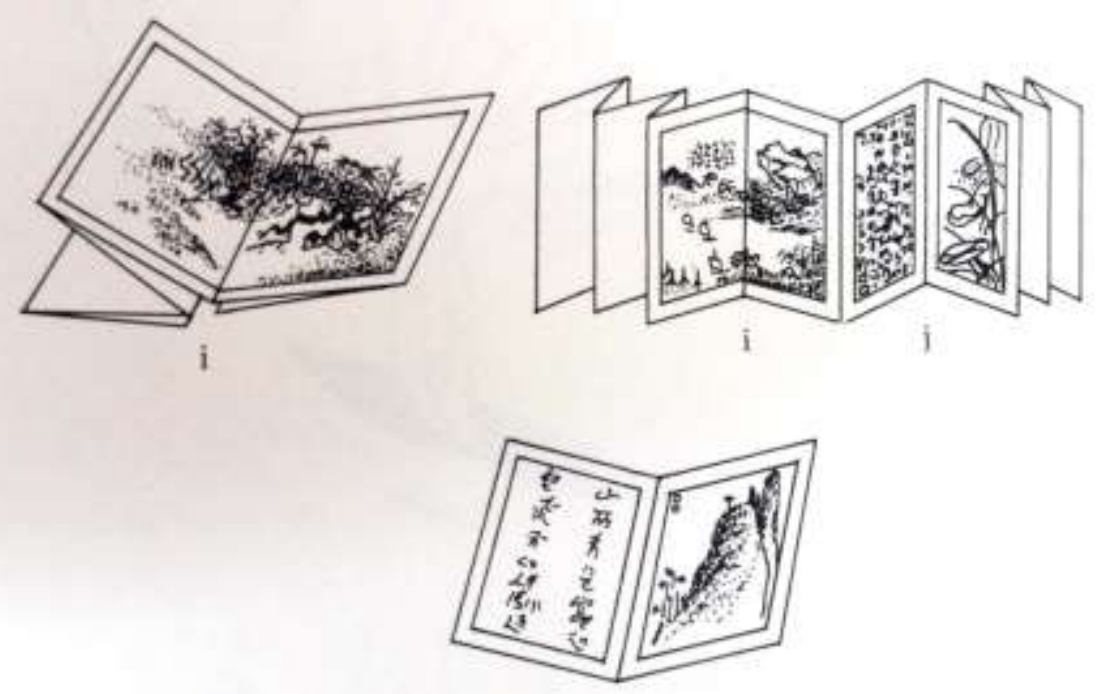

Figura 26.- Álbum plegable. Gachô (画帳), ( $t s^{\prime} e$ yeh o $t s^{\prime} e$ 冊) Imagen tomada del libro de van Gulik, R.H, Chinese Pictorial Art. As Viewed by the Connoisseur. Notes on the Means and Methods of Traditional Chinese Connoisseurship of Pictorial Art.

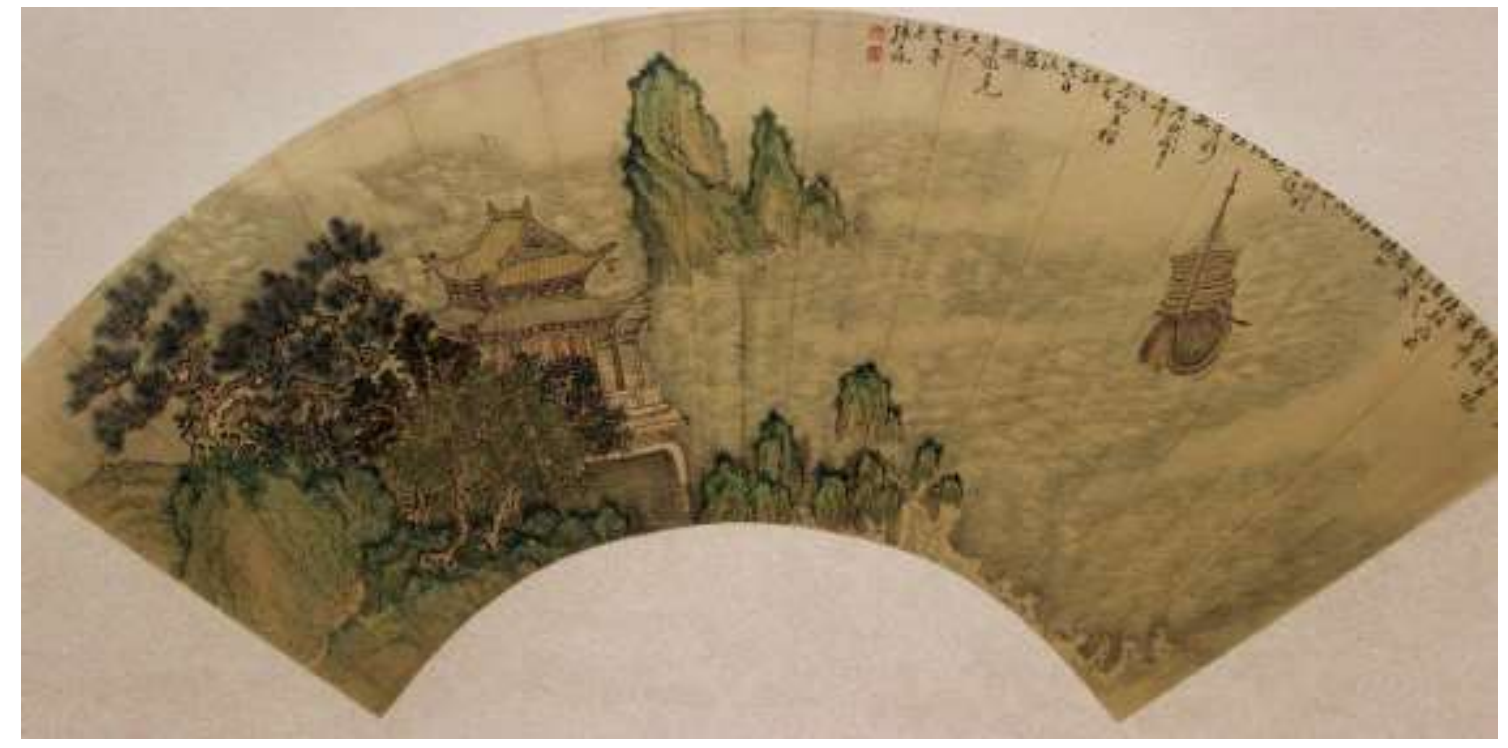

Figura 27.- Zhang Wenlin (Dinastía Qing). Abanico pintado. zhê san (折扇), (sensu 扇子). 


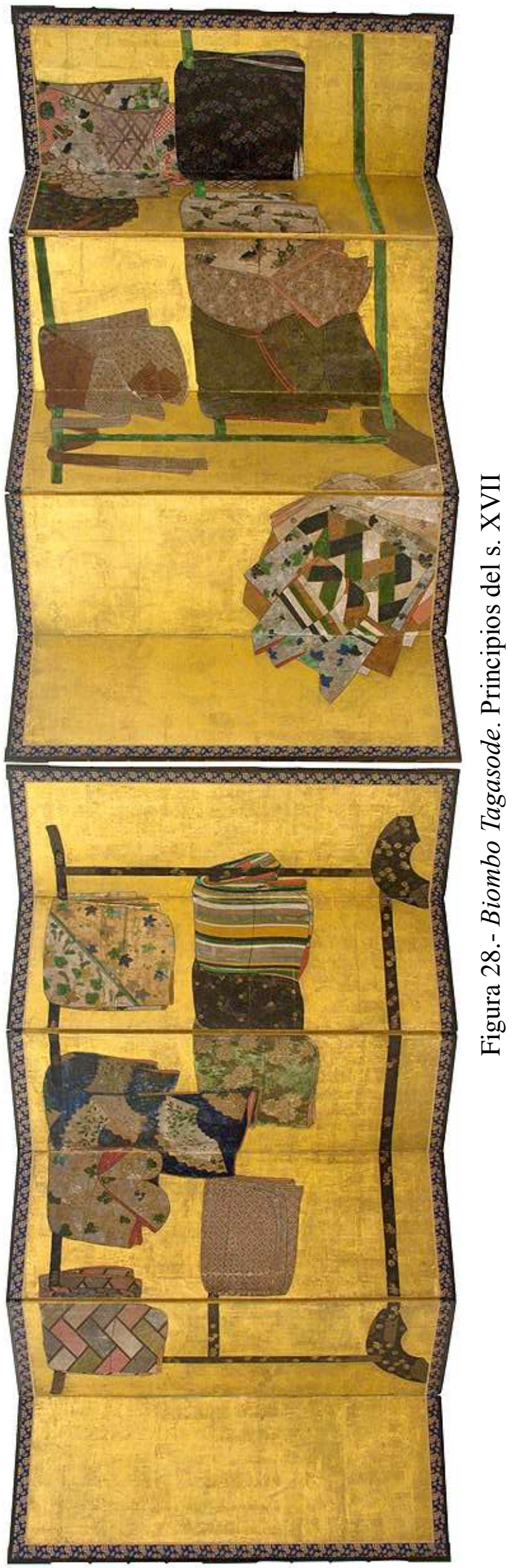




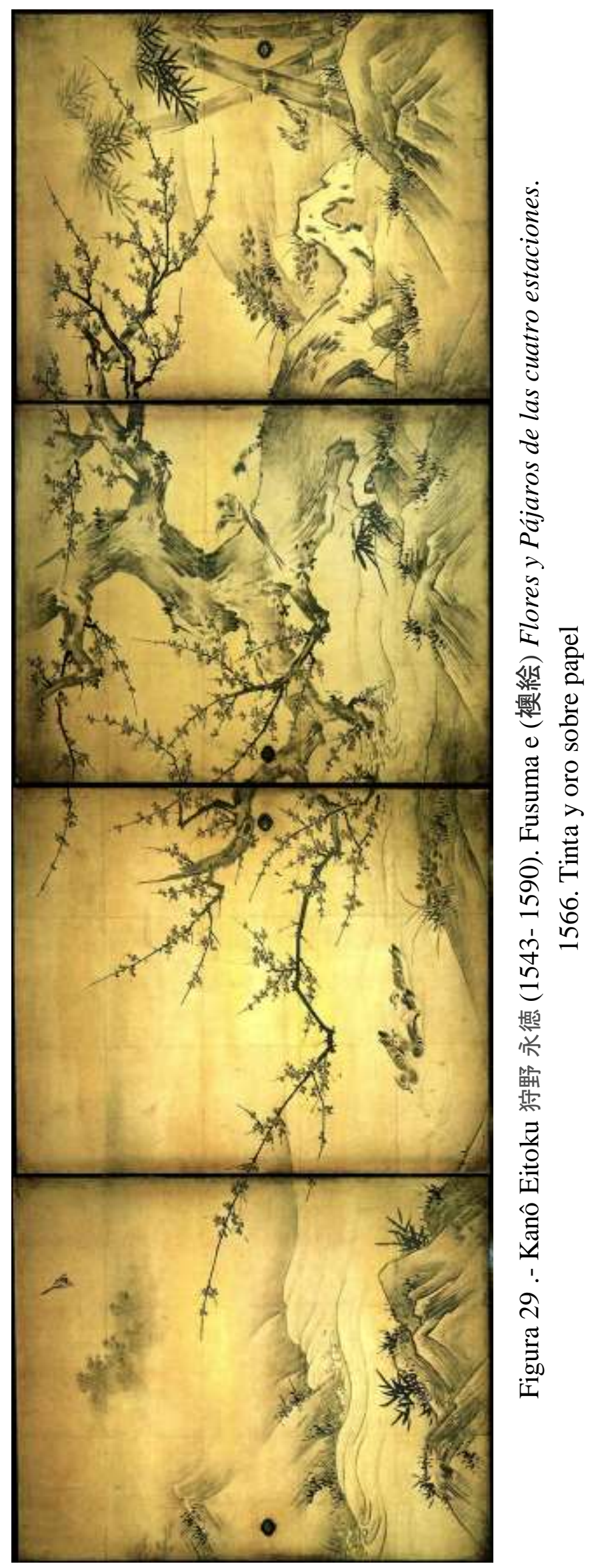




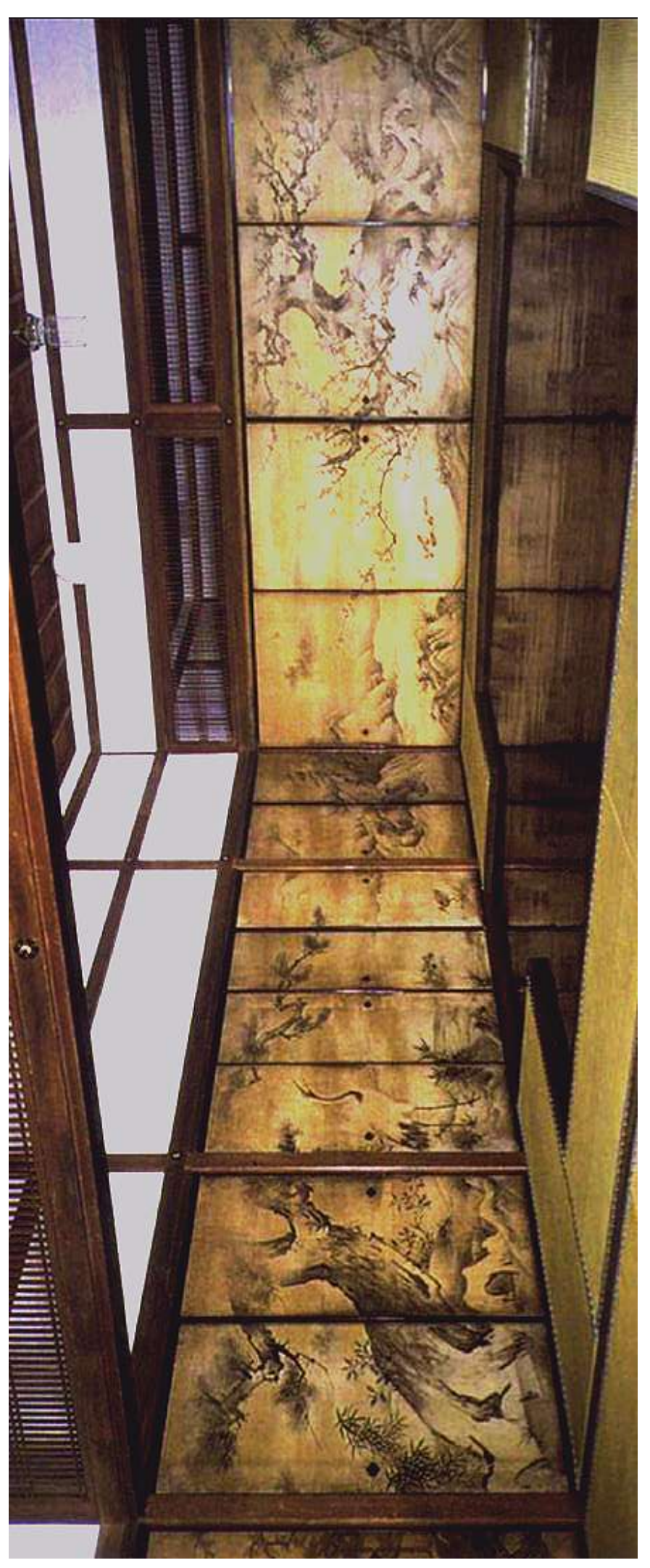

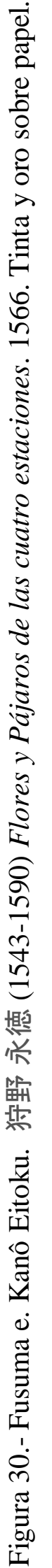


La Horizontalidad de la mirada de Oriente en Occidente 
SEGUNDA PARTE 
"Pintar consiste en dibujar fronteras" 281

\section{LA IMAGEN Y SU SINTAXIS}

$\mathrm{P}$ uesto que las culturas han ido creando imágenes, asumimos que prácticamente desde el primer momento éstas han estado sujetas a unos códigos sociales específicos dependientes de su contexto, por lo que podemos hablar, en cada caso, de una sintaxis en el orden interno de la concepción de su espacio. Porque, añade Ernst H. Gombrich "[...] El artista, no menos que el escritor, necesita un vocabulario antes de poder aventurarse a una 'copia' de la realidad. [...] Todo apunta a la conclusión de que la locución 'el lenguaje del arte' es más un bien desarrollado sistema de esquemas. [...]"282. Por lo que, en palabras de este autor, "[...] la forma de una representación no puede separarse de su finalidad, ni de las demandas de la sociedad en la que gana adeptos su determinado lenguaje visual" ${ }^{, 283}$. En esta tesitura, el objetivo de los anteriores capítulos de esta tesis ha sido estudiar las limitaciones que el contexto cultural ha impuesto a la percepción visual europea y a la extremo oriental. Es decir, conocer la estructura de los distintos códigos sociales de reconocimiento, de los cuales se podemos deducir determinadas elecciones artísticas limitadas por el contexto y, como consecuencia, las posibles restricciones de su vocabulario. Y es que a decir de este historiador "[...] Aunque estamos habituados a pensar en la composición de la pintura como una cuestión de distribución de zonas en el plano pictórico, su significado original es retórico y se aproxima más al término moderno de 'sintaxis" "284, dando lugar a lo que podríamos entender como imagen anecdótica que precisa de unos elementos narrativos inducidos; una problemática que cada cultura y cada momento de la historia

\footnotetext{
${ }^{281}$ Chou Wen Houa, en Guy Gauthier, Veinte lecciones sobre la imagen y el sentido, Madrid, 2008, p. 176.

${ }^{282}$ Ernst. H, Gombrich, Arte e Ilusión. Estudio sobre la psicología de la representación pictórica. Barcelona, 1979, p. 15.

${ }^{283}$ Ibídem, p. 18.

${ }^{284}$ Ibídem, p. 113.
} 
ha querido solucionar de alguna manera. Explicado en los términos formulados por Norman, Bryson:

[...] La lingüística reserva una categoría para las oraciones que contienen información sobre su propia situación relativa, y les da el nombre de deíticas (de deikonei, mostrar) [...] La pintura europea está basada en la negación de la referencia deítica, en la desaparición del cuerpo como sitio de la imagen; y eso por partida doble; por parte del pintor y por parte del espectador. [...] Para encontrar un equivalente en la pintura a esta temporalidad del proceso debemos mirar fuera de Europa, y sobre todo al lejano Oriente. [...] La pintura china está basada en el reconocimiento y de hecho en el cultivo de las señales deíticas: al menos ya desde los Seis Cánones de Hsieh Ho, el mayor imperativo para la pintura, después de "la animación por el espíritu de consonancia", se dice que es "la construcción de la estructura mediante la pincelada" [...] el paisaje es sin duda el tema, pero también lo es el trabajo del pincel en "tiempo real" y como extensión del propio cuerpo del pintor $[\ldots]^{285}$.

A partir de estas reflexiones, podemos inferir que miramos psicológicamente, puesto que las imágenes están creadas para ser vistas y, en muchos casos, para intentar ser comprendidas. Consignados estos preceptos, cuando vemos una imagen ¿Presuponemos en ella siempre un significado? Lo cierto es que el ser humano, como individuo, parece estar siempre buscando respuesta. Entonces ¿podemos organizar la sintaxis de una imagen desde un estricto punto de vista particular? Podríamos decir que en la mayoría de los casos sí aunque, como ya hemos visto, no podemos obviar la influencia del medio cultural. Así, como bien señala Gombrich

[...] el lenguaje no pone nombre a cosas o conceptos preexistentes, sino que sirve más bien para articular el mundo de nuestra experiencia. Las imágenes del arte, cabe sospechar, hacen lo mismo. Pero estas diferencias entre estilos o lenguas no tienen por qué ser obstáculo para la obtención de respuestas y descripciones verídicas. Puede encararse el mundo desde diferentes puntos de vista, y sin embargo la información obtenida puede ser la misma ${ }^{286}$.

En cualquier caso, a la manera de un enunciado que mantiene ciertas equivalencias lingüísticas, la imagen está estructurada como un todo, como un conjunto que se percibe según un espacio bidimensional y autónomo. Un asunto que, a decir de Gauthier, nos sitúa de nuevo "[...] en el ámbito de la percepción visual [...] pero que además, por su [...] motivación nos invita a explorar presupuestos - pulsiones, rasgos de cultura interiorizados - que guían, generalmente sin él saberlo, al sujeto enunciador [...]"287. Es decir, todo un conjunto de creencias, normas y sentimientos que conforman

\footnotetext{
${ }^{285}$ Norman Bryson, Visión y Pintura. La lógica de la mirada, Madrid, 1991, pp. 100-101.

${ }^{286}$ Ernst H. Gombrich, Arte e Ilusión. Estudio sobre la psicología de la representación pictórica. Barcelona, 1979, p. 17.

${ }^{287}$ Guy Gauthier, Veinte lecciones sobre la imagen y el sentido, Madrid, 2008, p. 14.
} 
un nicho cultural o el denominado por J. Antonio Marina "sistema ideológico oculto" ${ }^{288}$.

Por lo tanto, dadas estas circunstancias ¿podríamos decir que todo esto incide en el factor influyente que la imagen ejerce sobre la sociedad? Efectivamente, es algo incuestionable el poder que las imágenes ejercen sobre nosotros. El acto de mirar es, en sí mismo, mucho más que una experiencia; es un proceso que no solo descubre sino que, además, testifica y documenta. Y es que, el interés que el mundo de las imágenes refleja en el espectador radica en un significado que reúne en sí mismo - además de diferentes tiempos - diferentes espacios de valoraciones y experiencias heterogéneas: la constatación de la relación que existe entre toda experiencia estética y el contexto social e histórico en el que se localiza. Porque se puede decir que las imágenes de alguna manera nos permiten ver el mundo; nos ayudan a ver y nos ayudan a expresarnos. Forman parte de nuestro imaginario y conforman - y además se conforman - con nuestra memoria. Por eso la imagen pictórica, como lenguaje, requiere de su particular comprensión del espacio y, como ya hemos visto, se dan tantos tipos de espacio como de imágenes y, por lo tanto, de contextos.

Así, recapitulemos, hemos visto como en Europa la comprensión de un espacio pictórico unificado alcanzará su correlato teórico en la perspectiva: un sistema de representación que se convertirá en el sistema representativo de Occidente. Mientras, en el Extremo Oriente durante siglos se ha perpetuado una combinación espacio/tiempo como pares de complementarios: es decir, se recurrirá a la espera; a la temporalidad de una serie consecutiva de secuencias mediante el principio de la narración gráfica continua. Resumiendo, la representación de un campo de visión - de un punto fijo del espacio sin extensión - frente a la esquematización repetitiva de un espacio con múltiples puntos de vista. Dos sistemas culturales de organización de símbolos que nuestra cultura actual cada vez asocia más estrechamente.

En los próximos capítulos nuestro objetivo será argumentar como las supuestas limitaciones del esquema de la tradición sobre la sintaxis de la imagen, lejos de debilitarla, han dado lugar a estilos estructurados de expresión y de innovación al enriquecerse con lenguajes pictóricos pertenecientes a tradiciones distintas. Partiendo de estos presupuestos, intentaremos, parafraseando a Gombrich "[...] establecer una conexión entre los experimentos de los artistas del s XX y los problemas que planteó el triunfo de la habilidad representativa en los descubrimientos visuales de los impresionistas [...]". Una progresión pictórica que, según nos recuerda el autor, desde "[...] los egipcios y su método de representar todo lo que sabían y no lo que veían [...] hasta el arte griego y romano que [...] insufló vida aquellas formas esquemáticas [...]" el de la Edad Media que "[...] las usó a su vez para narrar la historia sagrada [...] o [...] el arte chino para la contemplación [...]"289 nos reafirman en que, lo que hoy

\footnotetext{
${ }^{288}$ Véase, Marina, José Antonio, Las arquitecturas del deseo. Una investigación sobre los placeres del espíritu, Barcelona: Editorial Anagrama, 2007.

${ }^{289}$ Gombrich, Ernst. H, Arte e Ilusión. Estudio sobre la psicología de la representación pictórica. Barcelona, 1979, p. 334.
} 
consideramos como pintura moderna es el producto de la búsqueda de nuevas formas de representar el espacio. En otras palabras, el resultante de transgredir la perspectiva lineal, impuesta por Occidente, de manera que - como recuerda Serraller - "[...] frente a la concepción clásica del arte basado en normas intemporales, el necesariamente inestable de nuestra época se rige por el tiempo, cuya única cualidad es el cambio [...] 290. Una explicación para la recuperación y asimilación tanto de la pintura medieval como de la oriental para la pintura contemporánea, sin olvidarnos de cualquier otra que se haya realizado en lugares situados fuera del continente europeo.

Hablamos de un cambio que dio sus primeras señales a mediados del siglo XVIII y que supondrá progresivamente una transgresión del arte tradicional de Occidente. De este modo, a decir de Serraller, a partir del siglo XX la pintura como tal "[...] prescinde de los elementos de ordenación matemática mensurable que habían caracterizado su historia anterior como la perspectiva, la proporción, la simetría o la armonía [...]"291, para reafirmarse en el uso de formas planas - intentando huir de aquella falsa ilusión de volumen y de profundidad - como negación de lo que hasta entonces se había legitimado como único canon para la representación del espacio pictórico ${ }^{292}$. Esto explica, a decir de Gauthier, por qué “[...] es en gran parte bajo la influencia de la estampa japonesa como ha sido conducida la revolución pictural que nos lleva del final del Impresionismo a los inicios del Cubismo y de la Abstracción [...]"293. Es decir, nos explica el principio de un cambio que, en consecuencia, provocará una vuelta hacia el denominado arte primitivo o lo que pasó a llamarse primitivismo en el arte de principios del pasado siglo XX.

Cézanne reprochaba a Gauguin su forma de trabajar los colores planos rodeando los contornos [...] Al reproche de Cézanne no le faltaba, pues, coherencia, ya que Gauguin fue influido si no por la pintura china, al menos por obras venidas del Extremo Oriente (Japón, Java). Añadamos que Gauguin, influido igualmente por la vidriera y la imaginería popular, en busca de fuentes tan distintas como Bretaña, las Antillas y Polinesia, es probablemente el pintor del siglo XIX que ha roto de la forma más deliberada con el modelado como técnica de representación del mundo sensible ${ }^{294}$.

\footnotetext{
${ }^{290}$ Aplicamos el término "moderno" según el sentido etimológico de palabra latina: "lo hecho al modo de hoy o actual, $[\ldots]$ con lo que lo genuinamente moderno en el arte contemporáneo es que basa su fundamento en el cambio, la inapelable sucesión de novedades o modas". Calvo Serraller, Francisco, El Arte contemporáneo, Madrid, 2001, p. 11.

${ }^{291}$ Ibídem, p. 9.

${ }^{292}$ Muchos, como Wener Hofmann - considerado como uno de los más distinguidos eruditos europeos sobre arte moderno - establecieron diversas afinidades entre la mirada del arte moderno y la del medievo antes de la perspectiva. Para este, la perspectiva supuso solo un intervalo en la evolución artística occidental, que lo encorsetó entre el Arte de la Edad Media y el Arte moderno. Véase Hofmann, Werner, Los fundamentos del arte moderno. Una introducción a sus formas simbólicas, Barcelona: Ediciones Península, 1995.

${ }^{293}$ Guy Gauthier, Veinte lecciones sobre la imagen y el sentido, Madrid, 2008, p. 33.

${ }^{294}$ Ibídem, pp. 175 - 177.
} 
En cualquier caso, una observación que - aunque a nuestro juicio cabe ser entendida con algunos matices - nos habla de un fenómeno que allanará el camino al Cubismo, movimiento deseoso de liberase de la imposición de la perspectiva. Un recurso comprendido como base para la estructura de un sistema entendido como la dictadura de unas convenciones académicas que - paradójicamente y en la misma época - se estaban introduciendo en otras partes del globo como una auténtica revolución visual. Es decir, lo que por entonces se entendía, al margen de la cultura occidental, como el paradigma de la modernidad. Una innovación, entendida esta por Panofsky como una "alteración de lo establecido" que "[...] presupone necesariamente la existencia de algo establecido (tanto da que lo llamemos tradición, convencionalismo, estilo o modo de pensar) como constante respecto la cual la innovación aparece como variable $[\ldots]^{, 295}$.

Así, a tenor de lo formulado por Surela, "[...] La pintura del s XX [...] Se ha ido inclinando más hacia la ruptura con el pasado que hacia la continuidad renovada de lo exclusivamente formal e incluso temático. Los momentos de 'riesgo' han sido espejismos vitoreados, eso sí, por aquellos que no querían aceptar que el sistema de valores plásticos establecido por el humanismo renacentista se estuviese agotando en un devenir histórico que, a su vez, seguramente también llegaba a su fin" ${ }^{296}$. Por eso, a nuestro juicio, cuando Claude Monet pone el foco de atención en el tema de los reflejos del agua de su estanque japonés, modificará y revolucionará - consciente o inconscientemente - los pilares sobre los que hasta entonces se había sostenido la pintura europea. Efectivamente, al hacer desaparecer la línea del horizonte el pintor recurrirá a otra manera de representar el espacio en sus pinturas ¿Adopta con esta idea el recurso del foco móvil o narración gráfica continua de Asia Oriental? Efectivamente, hay muchos factores que nos hacen pensar que sí. Para empezar, en la serie de los Nenúfares, Monet recurrirá al formato horizontal de unos lienzos que se yuxtaponen para ser contemplados, mediante la instalación ${ }^{297}$ de unas pinturas que se desplazan y extienden su espacio a través de ellos, y donde el espectador debe adoptar una posición activa para poder contemplarlos ${ }^{298}$ [Figura 1]. Al hilo de esta idea, ¿podríamos considerar que este planteamiento bidimensional y secuencial de la pintura ha permitido la creación de espacios multidimensionales, origen de la instalación como género dentro del arte? En cualquier caso, al margen del posible acierto o desacierto de esta pregunta, este cambio supondrá la adopción de una nueva comprensión del espacio para la pintura

\footnotetext{
${ }^{295}$ [...] Para dilucidar si la innovación es o no "influyente", tenemos que tratar de averiguar si la dirección de la constante ha cambiado o no por efecto de la variable. Y la dificultad reside en que tanto la dirección original de la constante como su ulterior desvío por una innovación [...] pueden desenvolverse dentro de un ámbito cronológico únicamente limitado por la perceptibilidad de la interacción cultural. [...]. Erwin Panofsky, Renacimiento y renacimientos en el arte occidental, Madrid, 1975, p. 32.

${ }^{296}$ Joan Surela, en Anna María Guasch et al, Summa Pictórica, de las Vanguardias a la Postmodernidad. Tomo X, Editorial Planeta, 2001, p. 9

${ }^{297}$ Énfasis propio.

${ }^{298}$ Una idea cercana a la pintura extremo oriental que precisa de un espectador que, en una ceremonia que parece casi un ritual, despliega y contempla la obra. Es decir, una intervención sobre el concepto del espacio que por otra parte, al abstraerlo, pone el énfasis en el color y en una mancha más expresiva, casi caligráfica.
} 
europea. Una comprensión que, desde ese momento, incorporará para el espacio el factor del tiempo. Un acoplamiento que a partir de entonces permitirá a la pintura jugar con las dos dimensiones ficticias del tema representado - la que se ve y la que no se ve que son a su vez causa y origen del motivo del cuadro ${ }^{299}$. En otras palabras: que desde ese momento en Occidente el plano pictórico - del que se representa un fragmento abstrae el espacio real en una imagen visual que se desplaza al tiempo que el ojo del espectador la recorre, dando lugar a unas obras que - a la manera de la pintura china y japonesa - recrean la belleza efímera del reflejo de una naturaleza que está representada en sus más modestos elementos [Figura 2].

Por consiguiente, para comprender las relaciones actuales entre el hombre y el arte, será preciso relacionar estas con las variadas experiencias que se han establecido entre diversas culturas. Descubrir y reconocer las relaciones con otros ámbitos visuales más allá de la perspectiva renacentista: es decir, más allá de un espacio sistematizado en la medida en que se ha convertido en un sistema de representación espacial y, por lo tanto, en un sistema ideológico y cultural. Un espacio reconstruido donde, de alguna manera, la perspectiva reproduce el mundo a la medida de esa mirada simbólica. Lo que podríamos definir como un pragmatismo visual que como medio ha sido empleado para difundir la cultura occidental a la vez que esta lo inculca ${ }^{300}$.

Por eso, más allá de la cultura visual occidental, los actuales códigos visuales del mundo contemporáneo se basan en un sincretismo visual fruto de la influencia recíproca de Europa y Oriente, sin olvidarnos por supuesto de la diversas influencias de otras latitudes. Entonces ¿podemos inferir que en la actualidad - donde los medios de comunicación se nutren de la necesidad ilusoria del llamado público global - la imagen se ha liberado del encorsetamiento de la perspectiva? No nos engañemos, los medios de comunicación de masas recurren a unas nuevas tecnologías que, no obstante, no han dejado de estar adaptadas a las viejas convenciones de Occidente; nuevos recursos que, paradójicamente, perpetúan viejas estrategias. Porque, como Francastel nos recuerda, aunque el cuadro rectangular no es universal, este mundo globalizado posa su mirada en la sintética horizontal del "formato cuadrado" de un monitor ${ }^{301}$.

No obstante, es indiscutible que han cambiado muchas cosas en los espacios del arte donde poco a poco se han ido introduciendo y han ido asomando nuevas estrategias, dando lugar con ello a la hibridación del espacio pictórico. A decir de Francastel, actualmente "[...] La masa está perfectamente capacitada para entrar en un juego de representaciones abstractas. Viene complaciéndose en ello desde siempre. Los misterios siempre han fascinado a los hombres. Ya se trate de ritos o de fábulas el hombre de la calle ha sido siempre sensible al símbolo [... $]^{, 302}$. Un embrollo, en cualquier caso, donde - para orientarnos en la madeja de su percepción - debemos tener en cuenta otros aspectos que inciden sobre las leyes que gobiernan la visión, aspectos al margen de toda

\footnotetext{
${ }^{299}$ Énfasis propio.

${ }^{300}$ Ibídem.

${ }^{301}$ Énfasis propio.

${ }^{302}$ Pierre Francastel, Sociología del arte, 1984, p. 201.
} 
norma semántica que, partiendo del reconocimiento de la forma, nos permitirán llegar hasta la organización del sistema. Por lo tanto, como indica Gauthier, el "problema inicial es, pues, localizar las grandes configuraciones con valor emblemático, [...] Avanzando más allá, volveremos a encontrar, quizás, fantasmas ampliamente compartidos, o las particularidades culturales que ordenan la elaboración del mito",303.

${ }^{303}$ Guy Gauthier, Veinte lecciones sobre la imagen y el sentido, Madrid, 2008, p. 120. 
"Recordemos aquello de los extremo-orientales, que en virtud de su concepto de "fragmentación", pintan un vegetal incompleto precisamente para que el espectador lo complete con la imaginación y así se dé cuenta de la fuerza germinativa de la planta. Sin espectador activo no hay arte, como sin ojos no hay luz" ${ }^{304}$.

\section{4.- LA FORMA Y EL CONTEXTO}

$\mathrm{U}$

n espacio es aquello que no une o nos separa. Un espacio y un momento que, en un contexto que nos define y nos sitúa, determinará aquellos rasgos que nos caracterizan. Hablamos de un espacio físico o imaginado que, en el terreno pictórico, para su representación estará sometido a un conjunto de normas fijas. Un facto necesario para la explicación de lo que se entiende por arte, al ser este definido como aquel espacio donde se articula una experiencia interior con la respuesta al mundo que nos rodea y que, en definitiva, nos define y determina. Porque, como señala Luca de Tena “[...] El mundo no se interpreta, se crea, y, por tanto, toda ficción es una construcción, no una traducción. De modo que quienes al notar el paulatino deterioro de una ficción, sienten que a la vez se están destruyendo la esencia de su propio mundo no se equivocan, como tampoco parecen que se equivoquen los que dicen sentirse caer en el vacío [... $]^{305}$. Po consiguiente, hablamos de la realidad de un espacio que entendemos a la medida de quien lo ocupa o lo contempla o, en otras palabras, a la medida del poder del entorno, de un ámbito que en mayor o menor medida nos permite considerar los distintos sistemas de representación pictóricos como sistemas representativos organizados a la manera de formas simbólicas ${ }^{306}$. A decir de Francastel, está "el espacio de la tela y el espacio exterior que se trata de representar". Los que a decir de este autor podríamos considerar como "[...] el espacio sensible y el espacio representativo; el espacio-superficie y el espacio-profundidad. Porque [...] el espacio

\footnotetext{
${ }^{304}$ Tapies, A, El Arte contra la Estética, 1986, Editorial Planeta-De Agostini, p. 212.

${ }^{305}$ Manuel Luca de Tena, La Presencia de lo Ausente. El concepto y la expresión del vacío en los textos de los pintores contemporáneos occidentales a la luz del pensamiento extremo-oriental, (Tesis Doctoral, Universidad de Salamanca, 2008), p. 20.

${ }^{306}$ Énfasis propio.
} 
no es un dato simple, común a todos los espíritus. Responde a nociones complejas que cambian de acuerdo con cada medio y con cada grado de civilización [...]"307. En definitiva, lo que entendemos como una selección cultural que termina por imponerse tarde o temprano ${ }^{308}$. Ante la constatación de este hecho, hay quien se acomoda a ese espacio, quien huye de él o quien alberga la voluntad de cambiarlo. Y en el mundo del arte, cambiar la percepción, representación y contemplación del espacio pictórico nos revela, al fin y al cabo, la necesidad de realizar un cambio en el implícito sistema ideológico de la cultura donde se ha dado. Nos encontramos entonces con lo que, según Francastel, sería más ajustado entender como la "sustitución del antiguo sistema espacial por uno nuevo, ya que, [...] una sociedad no abandona un espacio imaginario y un espacio representativo, lo mismo que un espacio geográfico, mecánico o técnico dados, sino para instalarse en otro [... $]^{309}$. En otras palabras, lo que podemos entender como aquellas astucias que utiliza indirectamente la razón para transformar una cultura y su creatividad mediante "[...] una secuencia de elecciones libres y no condicionadas, a través de las cuales poder redimirse de su alienación en una sociedad y una tradición estética dada [...] una forma de autodefensa" ${ }^{310}$. Inferimos entonces que, cuando todo esto sucede, como una catarsis el arte toca fondo y se renueva. Es decir, se modifica aquella lectura condicionada por la información que se haya podido acumular en el tiempo - tanto por los distintos referentes culturales como por la individualidad de nuestros sentidos - descodificando los datos que se obtengan en busca de una nueva lectura. Entonces, si como afirma Levi- Strauss ${ }^{311}$, son las nuevas experiencias las que hacen posible el despliegue de nuevos paradigmas ¿qué sucede cuando nos encontramos ante una experiencia visual para la que todavía nos faltan referencias? ¿Acaso, nuestra respuesta ante el desafío que supone una novedad explica nuestra manera de concebir el mundo? Francastel apunta que "[...] En su esencia, la obra no expresa lo real, sino que ofrece un modelo selectivo de ordenación de las sensaciones visuales". Un hecho que explica nuestra capacidad natural para "[...] entrar en comunicación directa con obras de arte creadas en civilizaciones alejadas de nosotros tanto en el tiempo como en el espacio [...]" adoptadas y adaptadas "[...] mediante un juego de alteraciones, de imitaciones, de transferencias, sobre las cuales todo está por aprender,312.

Ahora bien, aunque actualmente los asuntos locales son también problemas globales, crisis que no diferencian entre distancias culturales o geográficas - y nuestras actuales circunstancias históricas son un claro ejemplo de todo esto - todavía somos portadores de códigos que han consignado creencias que, a su vez, han perpetuado prácticas en el contexto donde han prosperado. Un contexto que en el terreno del arte ha derivado hacia la búsqueda de nuevos caminos que han permitido en parte sortear aquellas crisis. Esto explica como los modelos perceptivos paulatinamente se han ido enriqueciendo porque paradójicamente, entre otras cosas, los procesos artísticos hunden

\footnotetext{
${ }^{307}$ Pierre Francastel, Sociología del arte, 1984, p. 193.

${ }^{308}$ Énfasis propio.

${ }^{309}$ Pierre Francastel, Sociología del arte, 1984, p. 178.

${ }^{310}$ Anthony Everitt, El Expresionismo Abstracto, 1975, p. 7.

${ }^{311}$ Véase Lévi-Strauss, Claude, Mito y significado, Madrid: Alianza Editorial, 1990.

312 Pierre Francastel, Sociología del arte, 1984, p. 34.
} 
sus raíces en dogmas culturales de sociedades que, en muchos casos, se han sentido profundamente desencantadas. En consecuencia, a nuestro juicio las crisis demuestran ser extraordinariamente fecundas y las diferencias se muestran como una oportunidad para subsanar cualquier inclinación reduccionista.

En este contexto, señala Leví-Strauss que “[...] Cuánto más homogénea se torna una sociedad, tanto más visible serán las líneas internas de separación, y lo que se ganó en un nivel se perderá, inmediatamente, en el otro [... ${ }^{3313}$. En esta tesitura, en lo que concierne a este estudio, en la actualidad, por un lado se han dado unos procesos de asimilación del arte occidental en China y en Japón - iniciados en los siglos XVII Y XVIII de la mano de las órdenes religiosas y de la política colonialista - y, por otro, se han producido unos intercambios comerciales y culturales - con posteriores corrientes estilísticas ampliamente difundidas por los medios de comunicación - que han acercado el arte chino y japonés a los gustos de Occidente. Por lo tanto, llegados a este punto, actualmente podemos decir que las diferencias estéticas entre las obras de estilo occidental y extremo oriental se han ido difuminando; es decir, que las categorías de pintura oriental o europea, en gran medida, se han desdibujado. No obstante, los distintos códigos culturales todavía permanecen implícitos en los lenguajes del arte. Es decir, hablamos de elementos inducidos que serán traducidos en pulsiones visuales. Entonces ¿podemos afirmar que todavía permanecen las diferencias entre el arte de Oriente y de Occidente o, por el contrario, se han asimilado culturalmente estos distintos modelos estéticos en ambas latitudes? Es indudable que la actualidad del arte se significa por una hibridación cultural, aunque tanto en Oriente - particularmente Japón - como en Occidente las influencias foráneas se adaptaron a su propia tradición ${ }^{314}$. Una observación que resulta interesante - y cuya importancia ya había señalado Francastel - "[...] porque nos permite demostrar cómo una época no utiliza, del conjunto de nuevas posibilidades que se le presentan, sino aquello que concuerda con sus preocupaciones [...]"315. En cualquier caso, aunque haya sido determinante el descubrimiento del arte japonés allá por 1870, debemos recordar que para los artistas occidentales ha resultado particularmente difícil penetrar en la tradición estética china y japonesa. Hablamos de contextos culturales complejos y a menudo impermeables - ante los que se han encontrado unas dificultades que aún permanecen en gran medida - que precisan desarrollar la empatía como medio para poder penetrar en los secretos más íntimos de su estética.

Así, hasta, finales de la primera guerra mundial, Europa no entendió el arte de Asia Oriental como lo que ha resultado ser: una fuente estética inagotable y un paliativo

\footnotetext{
${ }^{313}$ Claude Lévi-Strauss, Mito y significado, Madrid, 1990, p. 45.

314 El imaginario japonés se ha caracterizado por su extraordinaria capacidad para asimilar aspectos importados de otras culturas, remodelarlos según sus propios códigos y alcanzar resultados de una originalidad indiscutible. En este sentido, podemos afirmar que, como resultado, su nueva estética se ha revelado como una corriente muy influyente y extraordinariamente popular. El caso chino ha tenido un recorrido diferente debido principalmente a los abruptos cambios políticos y sociales del hoy conocido como Gigante Asiático. El advenimiento del Partido Comunista al poder, la figura de Mao y la Revolución Cultural pretendieron acabar, en el caso concreto del arte, con una tradición secular.

315 Ibídem, pp. 168-169.
} 
para el profundo sentimiento de fraude que por entonces se percibía en cuanto a la propia tradición. Efectivamente, si durante los siglos XIX y XX la combinación de industrialización, colonialismo y revoluciones - con la consecuente serie de cambios políticos y culturales, innovación tecnológica y comunicación global - marcaron irremediablemente la trayectoria cultural de la llamada modernidad europea, las sucesivas catástrofes que supusieron las dos grandes guerras mundiales ocasionaron entre otras unas condiciones específicas, determinantes para el arte que se estaba realizando en aquellos momentos.

[...] La modernidad hundía sus raíces en el mito del progreso, principalmente, y en los años cincuenta y sesenta el mito de que la cultura europea guiaba al resto del mundo había sufrido un revés doloroso e irónico. Las dos guerras mundiales, el Holocausto, el desarrollo del armamento nuclear (y su utilización contra una cultura no blanca), la mareante proliferación de desastres ecológicos y otros factores habían revelado el lado oscuro del mito hegeliano $[\ldots]^{316}$.

En consecuencia, a mediados del s. XX el racionalismo - considerado hasta entonces como la esperanza de la sociedad moderna - terminará por perder todo crédito, una circunstancia que afectará a los jóvenes pintores europeos y norteamericanos para quienes las premisas del cubismo y posteriores movimientos artísticos del periodo de entreguerras ya no tenían el mismo sentido. Así, buscarán un enfoque nuevo que dé alguna respuesta a lo que Anthony Everitt ha definido como "una crisis de temática" que, según su criterio, pone el acento en el gesto, en el "acto de pintar" y que, entiende, "[...] no fue consecuencia de una simple revolución de la tradición occidental contemporánea. Los artistas encontraron muchos aportes en el arte oriental, sobre todo en la caligrafía china, aportes que esclarecieron la crisis de temática que padecían. En la caligrafía china, la pincelada tiene una suprema importancia”. A partir de entonces, a decir de Everitt "El pintor/escribiente eleva la contradicción entre sujeto y objeto [...]"317 en un proceso que, al centrarse en la elaboración del signo, elevará su creatividad a través de una consecución de elecciones que en el contexto occidental se estaban liberando de una tradición estética dada [Figura 2] ${ }^{318}$.

Efectivamente, la crudeza de las dos grandes guerras mundiales del pasado siglo XX provocará, entre otras, sendas crisis de valores que terminarán por modificar drásticamente algunos de los principios estéticos y artísticos del arte occidental - entre

\footnotetext{
${ }^{316}$ Tomas Mcevilley, "Del Estilo Internacional a la Aldea Global: La Transformación Postmoderna de la Pintura", en Guasch, Anna María et al, Summa Pictórica, de las Vanguardias a la Postmodernidad. Tomo X, Editorial Planeta, 2001, p. 20.

317 Anthony Everitt, Expresionismo Abstracto, Barcelona, 1984, p. 7.

${ }^{318}$ Durante siglos, la pintura europea - bajo el estricto dogma de la perspectiva - había mantenido inamovible una concepción homocéntrica de esa idea de la ventana abierta a un espacio en profundidad, recurriendo a la valoración del claro oscuro para lograr una percepción volumétrica. Un sistema cifrado en el que "[...] desde la época de Alberti y Piero, una generación después de Brunelleschi, comprobamos un estrechamiento de horizontes. De ahora en adelante los artistas se contentarán con especular sobre un espacio estrictamente limitado: el espacio cúbico [...]". Pierre Francastel, Sociología del arte, 1984, p. 155.
} 
ellos, sus distintas normas y convenciones académicas - algunos de los cuales hasta entonces nunca se habían puesto en entredicho. Así, en Occidente - y tal vez como respuesta - surgirá una sensibilidad artística nueva que cuestiona y cambia la manera de comprender el espacio pictórico, y con ello también el paradigma de forma simbólica que ostentaba el cuadro desde el humanismo renacentista. Desde este punto de vista, se irán introduciendo cambios en los códigos perceptivos de manera que, a medida que surgen las nuevas corrientes informalistas, la mirada vaya poco a poco habituando a la abstracción.

En este nuevo contexto, serán los jóvenes pintores norteamericanos de posguerra los que recuperen con admiración la obra tardía de Monet, la cual había sido desdeñada hasta ese momento por considerársela como el producto de la decadencia artística de un pintor. Efectivamente, hasta nuestros días, estas obras han llegado con el aura de una revelación ${ }^{319}$ para esta nueva generación de pintores que, desde ese momento, percibirán al viejo maestro como al padre del arte moderno. No obstante, debemos señalar que esta idea no reunió el consenso de todos los miembros de aquella generación y que - con el fin de apuntalar la categoría de arte norteamericano ${ }^{320}$ después de la victoria en la II Guerra Mundial - fue en gran parte alimentada y ampliamente difundida por críticos como Greenberg y Steinberg [Figura 3].

Bien mirado, a nuestro juicio, se puede encontrar una cierta coherencia entre las circunstancias en las que se realizaron las obras tardías de Monet durante la Gran Guerra y las propias experiencias vividas durante la II Guerra Mundial por esta nueva generación de pintores. En cualquier caso, hablamos de experiencias que podemos entender como un referente para un cambio de paradigma. De este modo, a decir Gauthier" [...] la pregunta queda entera ¿por qué una época segrega formas dominantes qué la época siguiente pondrá en entredicho, pondrá en duda, abolirá? [...] Su sello propio no ha podido manifestarse más que en el interior de un sistema de características apremiantes. En la Historia del Arte (con A mayúscula) los creadores han podido tomar sus distancias frente a este sistema, hasta el punto de separarse resueltamente de su tiempo [... $]^{321}$. Un distanciamiento al que Monet recurrirá en pleno horror de las trincheras de la I Guerra Mundial, emprendiendo un ambicioso proyecto decorativo inspirado en el estanque de aquel jardín japonés que él mismo había estado construyendo pacientemente durante los años anteriores [Figura 4] ${ }^{322}$. Unas circunstancias históricas que se unieron a unos condicionantes físicos, cuando la vista del pintor - cada vez más limitada por su problema de cataratas - precise de una percepción más intuitiva para representar un espacio no tan fiel a aquel instante en la naturaleza que, durante años, se había empeñado en captar como buen pintor

\footnotetext{
${ }^{319}$ Énfasis propio.

${ }^{320}$ Énfasis propio.

${ }^{321}$ Guy Gauthier, Veinte lecciones sobre la imagen y el sentido, Madrid, 2008, p. 183.

${ }^{322}$ Para ello, había comprado un estudio más amplio y había encargado cincuenta lienzos de unas dimensiones mucho más grandes de lo que en él era habitual. Debemos recordar que Monet, y el resto de los pintores impresionistas, habían recurrido a un tamaño más reducido y ligero de los lienzos, para poder desplazarse con ellos y poder pintar directamente en la naturaleza.
} 
impresionista $^{323}$. Pero paradójicamente, gracias a esta nueva intuición del espacio la representación pictórica - como si estuviese suspendida - terminará por desprenderse de cualquier tipo de referencia espacial en perspectiva [Figura 5]. A decir de Steinberg, en estas obras Monet había encontrado la fórmula de la mirada del siglo XX, cultivando el idioma del XIX, o "[...] en sus propias palabras "producir la ilusión de un todo interminable, una ondulación sin horizonte, sin orilla"324.

Efectivamente, bajo esas circunstancias su pintura alcanzará texturas de colores que permiten desarrollar los cuadros solo desde un primer plano, realizando radicales combinaciones cromáticas que han pasado a considerarse por Greenberg como "la primera semilla de la modernidad, plantada por los impresionistas" demostrando ser la suya "la más radical de todas" "325. En estas pinturas, la ilusión del espacio se experimenta como una progresión "[...] en la que cada elemento se desvela en el preciso momento en el que interviene en el proceso demostrativo [...]" sucediéndose, a decir de Gauthier, la "lectura" de los diferentes elementos representados y, a pesar de que existen en el espacio del cuadro - dada su simultánea aparición en el campo de visión del espectador - "[...] nuestros hábitos de lectura los introducen en la única dimensión temporal [...]"326. Algo que, como bien señalaba Greenberg, será un cambio revolucionario para la pintura y que - premeditadamente o no - provocará un quiebro en la carrera de Claude Monet, abocando su trabajo durante un tiempo a la más absoluta incomprensión. Por lo tanto, hubo que esperar unos cuantos años más para que aquel grupo de jóvenes pintores norteamericanos lo redescubriesen, comprendiesen y revalorizasen.

[...] ya estaban aprendiendo de Monet, y de Matisse, que se necesita una gran cantidad de espacio físico para el desarrollo de una idea pictórica fuerte que no implicara meramente una ilusión de profundidad [...] en primer lugar y ante todo color, color en campos y zonas, más que en formas; y que ese color había de ser inducido desde la superficie así como aplicado a ella. Bajo la tutela del último arte de Monet, esos mismos americanos

\footnotetext{
${ }^{323}$ La idea del transcurrir del tiempo, que con la aparición de la fotografía - con la primera imagen positiva fijada, en 1839 por Jacques Daguerre - había hecho que los pintores se cuestionasen el aparente conformismo subyacente en la pintura académica, interesada en captar la apariencia de las cosas. En muchos aspectos más cercana a la estética de la pintura japonesa, la pintura impresionista modificó sus encuadres y - en su búsqueda del instante - se empeñó en captar la esencia de las cosas, en una comprensión más espiritual de la pintura." [...] esta sensación supone, sobre todo, la fusión arbitraria de puntos de vista que no pueden, en ningún caso, ser tomados desde un mismo lugar de observación. En Degas se renuncia a la posición clásica del observador según Alberti, inmóvil y reduciéndolo todo a una visión monocular instantánea, y en su lugar se asocian fragmentos de visión sucesiva; en Van Gogh se armonizan, en función del arabesco decorativo dado por la tela y por la composición plástica, varios fragmentos de visión absolutamente heterogéneos [...]" (Pierre Francastel, Sociología del arte, Madrid, 1984 p. 184). En cualquier caso [...] con los impresionistas primero, luego con la generación siguiente, la de los hombres de 1880-1890, el problema de la representación plástica de las cosas en el espacio fue completamente replanteado, en la misma medida en que cambiaron las concepciones generales de la vida [...]. Ibídem, p. 195.

${ }^{324}$ Leo Steinberg, "Monet's Water Lilies", en Steinberg, Leo et al, Other Criteria. Confrontations with Twentieth-Century Art, Chicago, The University of Chicago Press, 2007, p. 239.

${ }^{325}$ Clement Greenberg, "El último Monet", en Greenberg, Clement et al, Arte y Cultura, Barcelona, Paidós Estética, 2016, p.56 (traducción del autor)

${ }^{326}$ Gauthier, Guy, Veinte lecciones sobre la imagen y el sentido, Madrid, 2008, p. 137.
} 
jóvenes empezaron a rechazar el dibujo escultórico - el dibujo-dibujo - por melindroso y trivial, y se volvieron hacia el dibujo "de área", al dibujo "antidibujo"327.

Nos encontramos, por lo tanto, con un espacio en reconstrucción continua que en contextos similares se desarrollará en la mente del pintor. Al hilo de esta idea, podemos establecer un paralelismo: si cuando este grupo de pintores norteamericanos encuentra la obra de Monet el mundo - tras la catarsis que supuso la debacle de la II Guerra Mundial - intentaba comenzar una etapa nueva, cuando Monet emprendió su nueva deriva creativa, el mundo - tal y como se había conocido hasta la fecha - se había quebrado y los viejos paradigmas desaparecían. En este sentido, según lo formulado por Gombrich, "[...] si un espacio plástico traduce las conductas generales y las concepciones matemáticas, físicas, geográficas de una sociedad, es necesario que ese espacio cambie cuando la propia sociedad se transforma lo suficiente como para que todas las evidencias intelectuales y morales que han hecho transparente durante un cierto tiempo una representación del espacio, ya no tengan vigencia $[\ldots]^{\prime 328}$. En cualquier caso debemos señalar que no se trata de realizar una similitud global, más bien indicar como, al inventar formas específicamente pictóricas, será la propia obra quien redescubra estructuras que ya estaban en la pintura.

En definitiva nos encontramos, por lo tanto, con un antiguo sistema de valores necesitado de un reemplazo y con una crisis de identidad que avocará a los artistas a buscar y mirar hacia otros lugares en busca de una nueva sensibilidad para el arte. Es decir, como nos indica Gombrich, a la búsqueda de una forma de representar y percibir distinta, "[...] una conclusión tentadora, y atractiva para quien enseña a apreciar el arte, ya que obliga al lego a reconocer hasta qué punto lo que llamamos "ver" está condicionado por los hábitos y las expectativas. Tanto más importante resulta, entonces, especificar hasta dónde llevaría este relativismo [...]"329.

\section{1.- Nuevos Sistemas de Representación}

En la actualidad, el sistema de representación de la perspectiva está ampliamente difundido por medios de comunicación de masas tales como los audiovisuales y la

\footnotetext{
${ }^{327}$ Ibídem, p.57.

${ }^{328}$ Pierre Francastel, Sociología del arte, 1984, p. 155.

${ }^{329}$ Ernst. H Gombrich, Arte e Ilusión. Estudio sobre la psicología de la representación pictórica. Barcelona, 1979, p. 17.
} 
prensa escrita. Pero su relevancia se revela mucho más allá de la eficacia de un procedimiento técnico capaz de lograr efectos tridimensionales sobre una superficie bidimensional. Efectivamente, como nos recuerda Corsi, es preciso reconocer que su transcendencia reside en el logro que ha supuesto realizar una "[...] representación experimental del mundo humano y perceptible, distinto en su definición moral respecto de cómo había sido interpretado en la Edad Media [...]". Por lo tanto, reconocer su papel como un medio que en un momento dado acuñará a una nueva estética. Es decir, en palabras de la autora, como un catalizador para "[...] la necesidad de escudriñar y definir el mundo de los sentidos modificando su espacio - que es la llave de todos los demás problemas - y representando plásticamente el universo, de acuerdo con las reglas establecidas y con base en los elementos obtenidos de los sentidos - y no conforme a normas proporcionadas por el espíritu - [... "330. Así, de este modo nos resultará más fácil comprender la envergadura del calado que la perspectiva ha tenido sobre los códigos visuales de otras culturas.

Al hilo de esta idea, cabe pensar que de alguna manera, en nuestro actual mundo globalizado, la influencia de la perspectiva permite todavía perpetuar el legado de la dominación colonial; un hecho que parece haberse acrecentado con la influencia de los medios de comunicación de masas. Es decir, que hoy en día, la perspectiva - a pesar de haber perdido sus fundamentos científicos - ha llegado hasta nosotros convertida en la norma visual - característica de nuestra consumista cultura de imágenes - de nuestra contemporánea globalización cultural. Un asunto que, en determinados contextos, ha supuesto el ajuste de alguna tradición del vocabulario del arte, que en palabras de Gombrich:

[...] opera como una pantalla selectiva que solo admite los rasgos para los que dispone de esquemas. El artista será atraído por motivos que pueden verterse a su idioma. [...] El estilo, como el medio, crea una "disposición mental" por la cual el artista busca, en el escenario que le rodea, ciertos aspectos que sabe traducir. La pintura es una actividad, y por consiguiente el artista tenderá a ver lo que pinta más que a pintar lo que ve $[\ldots]^{331}$.

Pero, en el contexto del desarrollo de este estudio, hasta este momento nos encontramos en el ámbito cultural de la Europa de la época moderna donde, la por entonces considerada nueva norma visual - transformada ya en una forma simbólica implementará la representación dramática del cuadro y de la escenografía del decorado teatral [Figura 6$]^{332}$.

La imagen representativa - llamada alguna vez "cuadro" - tendría pues, mayoritariamente al menos para el oeste de Europa, América del Norte y en algunas zonas sometidas a su influencia, valor de simulacro. Lo que simula es, con algunos

\footnotetext{
${ }^{330}$ Elisabetta Corsi, La fábrica de Ilusiones. Los Jesuitas y la difusión de la perspectiva lineal en China, 1698-1766, México D.F, 2004, p.104.

${ }^{331}$ Ernst. H, Gombrich, Arte e Ilusión. Estudio sobre la psicología de la representación pictórica. Barcelona, 1979, p. 13 -14.

${ }^{332}$ Énfasis propio.
} 
arreglos de circunstancia, la visión que un observador inmóvil podría tener del espacio exterior a través de una ventana rectangular $[\ldots]^{333}$.

Lo cierto es que, hasta hace relativamente poco tiempo, el cuadro - tal y como se conoce en Occidente - era un elemento desconocido en otras latitudes, donde solo se introdujo por medio de la en ocasiones intransigente influencia ejercida por el sistema colonial y las órdenes religiosas. Un adoctrinamiento para el que se recurrió a la enseñanza de la perspectiva, con el ánimo de cambiar los usos y maneras de percibir el entorno de otras culturas ajenas a la europea y, por lo tanto, con el ánimo de influir en su cosmovisión y su psicología. Efectivamente, hasta finales del s. XVIII, el concepto europeo del cuadro y su formato como ventana era algo prácticamente desconocido en Oriente. En el contexto de los soportes pictóricos de Asia Oriental, el rollo horizontal u otros soportes como biombos o álbumes - tanto en su formato como disposición de imágenes " [...] no guarda ninguna relación con la vista a través de una ventana, la cual presupone una posición frente a la pared", aunque Belting encuentre una similitud entre el cuadro y "[...] el caso del biombo pintado, pues este se desplegaba y colocaba en cualquier lugar de la vivienda $[\ldots]^{3334}$. Una semejanza que en cualquier caso no compartimos, puesto que mediante las pinturas sobre biombos - en vez de asomarse por una ventana desde dentro a un mundo que está fuera - en cierto modo lo que se buscaba era introducir ese exterior en el espacio interior de la vivienda. Dos maneras de interactuar con el medio que no parecen operar bajo los mismos preceptos

De cualquier modo, podemos afirmar que la idea de aquella forma rectangular aislada del entorno - a la que se ha dado en llamar cuadro - basará gran parte de su difusión e influencia en la política colonialista y en las campañas de reeducación llevadas a cabo por las misiones cristianas. Unas circunstancias que, como ya se ha mencionado, pretendían que la enseñanza de la técnica de la perspectiva se impusiese sobre la tradición y los hábitos visuales de otras culturas, siendo utilizada como instrumento de colonización y, como nos recuerda Belting, con un mensaje implícito: la perspectiva "[...] se consideraba la norma de la "visión natural" y su realismo podía evidenciar el progreso que traerían, también en las colonias, los frutos de la modernidad" 335 .

Efectivamente, como nos recuerda este autor, es bien sabido que - como parte de esa mencionada reeducación colonial - en la India y también en otros territorios de ultramar terminará por imponerse la enseñanza del dibujo en perspectiva.

[...] Lockwood Kipling, padre del escritor Rudyard Kipling, trabajó desde 1865 en la School of Art and Industry de Bombay, en cuyo nombre resuena el nuevo interés de Inglaterra por la formación en diseño. Mientas en Londres se estableció la School of

\footnotetext{
${ }^{333}$ Guy Gauthier, Veinte lecciones sobre la imagen y el sentido, Madrid, 2008, p. 29.

${ }^{334}$ Hans Belting, Florencia Bagdad: Una Historia de la Mirada entre Oriente y Occidente, Madrid, Akal /Estudios Visuales, 2012, p. 204 y 205-

${ }^{335}$ Ibídem, p. 43.
} 
Ornamental Art junto a la Academia de las Artes, en Bombay se enseñaba arte figurativo con empleo de la perspectiva. Kipling consideraba a los hindúes incapaces de producir arte en el sentido occidental, pero Sir Richard Temple impuso una estricta educación artística occidental. Los hindúes debían "aprender algo que jamás habían aprendido en los siglos precedentes, y es a dibujar correctamente las cosas. Así se desharían de las carencias mentales (mental faults) innatas y podrían estimar esas glories of nature que después de todo tanto aman. ${ }^{336}$.

Por consiguiente, sin hacer juicios de valor podemos suponer que desde el primer momento en el que los jesuitas llegaron a China este fue un hecho absolutamente premeditado $^{337}$. Un terreno abonado, por otra parte, debido a la curiosidad que por entonces inspiraban en la población oriental el realismo de las imágenes de los libros occidentales; unos grabados en los que destacaba una, para Oriente, exótica valoración de claroscuros, que a menudo eran confundidos con pequeñas esculturas. En cualquier caso, como nos indica Corsi, ya en el año 1601 la Orden Jesuita había fundado en su misión de Bei Tang, en Béijing, la primera biblioteca donde, desde poco tiempo después de su inauguración, ya se habían registrado 18 libros sobre perspectiva, "incluyendo algunos de los textos más importantes sobre el tema producidos en Europa entre los siglos XVI y XVII [...]" "338. Un adoctrinamiento que en Oriente favorecerá la difusión y el interés por un novedoso sistema de representación que se consagró cuando el padre Giovanni Nicolao fundó los primeros talleres para su enseñanza en Japón ${ }^{339}$. Pero, en ningún caso esta afirmación debe darnos a entender que aquí este sistema tuviese un

\footnotetext{
336 Andrew Lycett, "Rudyard Kipling”, Londres, 1999, p. 36, en Belting, Hans, Florencia Bagdad: Una Historia de la Mirada entre Oriente y Occidente, Madrid, 2012, p. 42.

${ }^{337}$ El jesuita Mateo Ricci llegó a China en 1583 y, en su labor evangelizadora, incluyó en las campañas religiosas la difusión de la ciencia y de la técnica, además de la Propaganda Fidei y, como no, la enseñanza del dibujo en perspectiva. Siguiendo esta dinámica, un superior de Mateo Ricci - el padre Alesandro Valignano - además de apoyar activamente la enseñanza de la perspectiva lineal entre los artistas chinos extendió también su enseñanza a los japoneses y coreanos. "La ola de actividades misioneras cristianas comenzó a penetrar en Corea ya en el siglo XVII, cuando la misión tributaria anual enviada a Pekín para intercambiar presentes con el Emperador chino volvió de allí con ejemplares de las obras en chino del misionero católico Matteo Ricci". Chang Byung-kil, "Corrientes espirituales en la Corea tradicional” en Corea "país de la mañana serena”. El correo de la Unesco, 1978, p. 9.

338 [...] tales como Practica della Prospectiva de Daniele Barbato (impreso en Venecia en 1568), Perspectivae Libri Sex, de Guidobaldo del Monte (Pesaro 1600). La colección albergaba más de 30 libros de arquitectura, entre los cuales había varios tratados importantes, como la edición de Barbaro de Vitruvius de I dieci libri dell'arquitettura (Venecia 1567), Arquitectura Liber Septimus de Sebastiano Serlio (Frankfurt, 1575), Los Quattro libri dell'arquitettura de Andrea Palladio (Venecia 1601) [...] En Elisabetta Corsi, La fábrica de Ilusiones. Los Jesuitas y la difusión de la perspectiva lineal en China, 1698-1766, México D. F, 2004, p. 85.

${ }^{339}$ Según consta en documentos de la Compañía de Jesús en Japón, Giovanni Nicolao fue maestro de pintura en el seminario de Nagasaki en el periodo que va desde 1613 hasta 1614. Las imágenes representadas en perspectiva recibieron en Japón el nombre de ukie (浮き絵) (imágenes fluidas) $\mathrm{o}$ kubomie (窪み絵) (imágenes inmersas). Por entonces, la población japonesa tenía la impresión de que la mirada fluía hacia el espacio que se representaba en las pinturas occidentales, realizando una inmersión que penetraba en aquel espacio ficticio. En todo caso, mucho más allá de las cuestiones artísticas, la perspectiva terminó por imponerse a través del pragmatismo que implicaban la enseñanza de una técnica aplicada a la arquitectura y las estrategias bélicas, transformándose en este último caso en una herramienta fundamental para las academias militares.
} 
terreno abonado ya que, aunque indudablemente su aceptación connotaba unos nuevos hábitos visuales, en el archipiélago japonés la perspectiva no se implantaría realmente hasta el s XVIII, favorecida por la difusión del arte occidental que, entre otras, realizaría la Oficina Comercial Holandesa de Nagasaki. Hablamos de un contexto histórico en el que ya se había popularizado el denominado arte Nanban 南蛮美術 (XVI y XVII), término con el que se designaban tanto las obras producidas en Japón bajo influencia occidental en el Siglo Cristiano como aquellas obras llevadas a Japón desde Europa y que, por consiguiente, influyeron en los artistas japoneses de aquel momento. Es decir, lo que podríamos considerar las primeras manifestaciones de un encuentro entre dos expresiones artísticas que hasta entonces se desconocían [Figura 7] ${ }^{340}$.

Fue por entonces cuando Shiba Kôkan (1747 - 1818) sentenció que sólo existía una única "[...] manera correcta de mirar, y por eso se enmarcan y cuelgan las pinturas occidentales. Quien las contempla, aunque solo sea brevemente, debe colocarse frontalmente ante ellas [...]" y, añadía además, era necesario que el horizonte estuviese a la altura exacta de los ojos y mirar también desde la distancia correcta. Entonces, afirmaba, si "[...] se respetan estas reglas, la imagen no se diferencia en nada de la realidad $[\ldots]^{\prime 341}$. Una muestra de la aceptación de lo que por entonces se entendió como un novedoso planteamiento y de cómo en ello influyó la curiosidad popular que despertaban las representaciones en perspectiva por aquellas latitudes [Figura 8].

Por lo tanto, al margen de todo esto, debemos insistir sobre como en los orígenes religiosos de la difusión de la perspectiva en el Extremo Oriente jugó un papel fundamental la Compañía de Jesús, para la cual la pintura en perspectiva poseía profundas implicaciones teológicas. Efectivamente, este sistema de representación fue utilizado como una potente herramienta evangelizadora, a la que la orden religiosa recurrirá para compensar así la falta de iconos que había dejado la reforma protestante. Al hilo de esta idea, una interesante observación de Francastel nos recuerda que "[...] No se veían más que las representaciones en gran escala o los retablos"

[...] Estas composiciones ligaban con las representaciones dramáticas, que desempeñaban en la vida de los hombres de esa época un importantísimo papel: Sacra rapresentazione, Misterios. Además todos los temas eran extraídos de la religión [...] Tanto por los sentidos como por el espíritu, las imágenes remitían no al espectáculo fluyente del mundo exterior, sino a conocimientos elaborados a nivel de civilizaciones [...] se las asimilaba lentamente, en función de una lenta maduración, y el tiempo no las

\footnotetext{
${ }^{340}$ Una observación reveladora de un cambio que nos explica por qué, sucesivamente, otros pintores japoneses adoptaron las particularidades del arte europeo para convertirlas en parte de su lenguaje pictórico, abandonando las líneas de los contornos para sustituirlas por grandes empastes de pintura, adoptando las valoraciones de claroscuros e introduciendo la técnica de la perspectiva. Dentro de esta nueva tendencia destacan Yokoyama Taikan 横山 大観 (1868-1958), además de Kuroda Seiki 黒田 清輝 (1866-1924), Fujishima Takeji 藤島 武二 (1867 - 1943) y Aoki Shigeru 青木 繁 (1882- 1911).

${ }^{341}$ Belting, Hans, Florencia Bagdad: Una Historia de la Mirada entre Oriente y Occidente, Madrid, 2012, pp. $41-42$.
} 
impregnaba sólo porque constituían una especie de largo adoctrinamiento visual, sino porque eran el depósito de una antigua sabiduría $[\ldots]^{342}$.

En cualquier caso, en el Extremo Oriente las representaciones pictóricas con fines evangelizadores fueron mucho más modestas y en el caso de Japón la difusión de esta nueva forma de representación se mantendrá solo mientras funcionen las escuelas de dibujo. Efectivamente, en el año 1614 se promulgará la expulsión de la orden Jesuita, lo que no impidió que ya se hubiesen adquirido una serie de conocimientos teóricos y prácticos que, aunque en muchos casos estaban relacionados con la arquitectura y la práctica militar, terminarán por abrir el camino a una nueva percepción del espacio pictórico $^{343}$.

A partir de este hecho ¿Podemos pensar que la perspectiva fue valorada más como un recurso ajeno a la práctica del arte? ¿Podemos inferir que, por entonces, este sistema de representación fue entendido en Asia Oriental como el paradigma del desarrollo occidental, es decir, de la modernidad? En lo que respecta a este último aspecto, hoy sabemos que ante la innovación cultural que por allí supuso esta influencia, algunos pintores japoneses - a pesar de continuar dentro de su propia tradición pictórica - aceptaron esta novedad y terminaron por introducirla en sus cuadros. En cualquier caso, las imágenes de Occidente - que con el tiempo se asociaron a las imágenes impresas de los reportajes occidentales - eran valoradas como un arte de calidad inferior y por lo tanto resultaban más asequibles para las masas populares, mientras la tradición pictórica japonesa se perpetuará en unas obras destinadas a un consumo más refinado y elitista. Es decir, que al principio las imágenes en perspectiva despertarán poco más que una simple curiosidad popular. Un interés alimentado por el uso de artilugios tales como el zograscope [Figura 9] - un visor de transparencias o vues d'optique - que, como tal artilugio, era un signo por entonces relacionado con la llegada de nuevas técnicas ${ }^{344}$. En cualquier caso, un estilo que en Japón se relacionaba con los ukie (浮絵) - traducido literalmente como "mundo flotante" - un género menor de xilografías en perspectiva que se constituyeron como una de las primeras representaciones de un fenómeno que resultará ser una verdadera revolución, alterando el hasta entonces el marco estable de la representación del espacio en la pintura de Asia Oriental [Figura 10].

Pero, en este contexto de inculturación se dará una paradoja: mientras los europeos obligaban a que Japón se abriese a la cultura occidental, las primeras muestras del arte japonés se conocían en Europa generando un interés inusual. Ni más ni menos que el encuentro entre dos tradiciones visualmente distintas que originará un fructífero

\footnotetext{
${ }^{342}$ Pierre Francastel, Sociología del arte, 1984, p. 47.

343 El jesuita Alessandro Valignano creó la primera escuela de pintura en Asia Oriental, que dirigía Giovanni Niccoló (1563-1626). Cosme de Torres (1510-1570) fue el primero en introducir las primeras representaciones occidentales con intenciones inculturadoras. Unas obras que reproducían pinturas y grabados de imágenes renacentistas, mediante la perspectiva y el claroscuro, y técnicas al agua o el aceite en cobre o madera, sobre lienzo o papel.

${ }^{344}$ Vues d'optique fue un género de aguafuertes que gozó de gran popularidad entre los s. XVIII y XIX. Estas imágenes estaban creadas especialmente para ser contempladas a través de una máquina diagonal óptica - zograscope - que aumentaba la impresión de profundidad de unas imágenes que principalmente recreaban arquitecturas urbanas con una marcada perspectiva lineal.
} 
diálogo bidireccional y que hoy entendemos como un contrasentido. Así, mientras en Asia Oriental penetraba el realismo de la pintura europea, en Occidente el mundo artístico se rendía ante la fascinación producida por la libertad subjetiva y gestual que, sobre todo, encontraban en la estampa japonesa. Efectivamente, como nos recuerda García Gutiérrez, estas imágenes con una diferente expresividad y comprensión espacial - con un punto de vista en diagonal desde el ángulo superior derecho - revolucionaron la estética occidental donde "[...] el arte realista de Francia y de otras escuelas europeas empezaba a buscar nuevos derroteros que seguir por haber alcanzado ya un grado de saturación" [Figura 11] ${ }^{345}$. En definitiva, un intercambio no exento de una cierta contradicción: mientras en Europa se abrazaba la autonomía que ofrecía la pintura de Asia Oriental y rechazaba el encorsetamiento del espacio pictórico académico, en Japón - y también en China - se entendía el realismo de la pintura europea como la manifestación de un arte más avanzado.

No obstante, consignar esta confluencia nos obliga a retomar sus orígenes. Así, repasemos, la técnica de la perspectiva, como tal - vinculada con la geometría euclidiana - tenía profundas implicaciones teológicas. Mediante esta, se entendía que el orden lógico de la creación se manifestaba a través de unas formas susceptibles de ser medidas y conceptualizadas en la regularidad de unas formas geométricas que se consideraban reveladoras de un acto divino. Como tal, ya hemos visto, la perspectiva fue adoptada y ampliamente difundida por la Compañía de Jesús. Un enfoque novedoso que supieron ver figuras como A. Michele Colona (1600-1687) - maestro de Giovanni Gherardini - y Agostino Mitelli (1609 -1660) $)^{346}$. Dos grandes innovadores que exploraron las posibilidades que ofrecían los temas religiosos realizados a gran escala en la pintura en perspectiva, inaugurando una tradición pictórica conocida como Quadratura, ampliamente difundida en Europa entre los siglos XVII y XVIII [Figura $12]^{347}$. Una característica panorámica ofrecida en el s. XVII sobre el desarrollo de la

\footnotetext{
${ }^{345}$ Fernando García Gutiérrez, Influencias mutuas entre España y Japón, Sevilla, 1998, p.124.

${ }^{346}$ Jesuitas que escribieron sobre la importancia de las imágenes espirituales, imágenes simbólicas "que hablan a la mente": Daniello Bartoli (1608- 1685), Theóphile Raynand (1587 - 1663), Claude -François Menestrier (1631 -1705).

Jesuitas que han escrito sobre la perspectiva lineal: Jean Dubrevil (1602 - 1670) "La perspective pratique, necessaire à tous peintres, graveurs, sculpteurs, architects, orfebres, brodeurs, tapissiers et autres, servaus du Desseim" (Paris, 1642).

François de Aguilon (1567 - 1617) "Opticorum libri sex philosophis juxta as mathematicis utile" (Auversa 1613)

Mario Bettini (1582-1657) "Apiaria universae philosophiae mathematicae: in quibus paradoxa, et nova pleraque machinamenta ad usus eximios traducta, et facilimis demonstrationibus confirmata" (Bolonia, 1642)

Athanasius Kircher (1602 - 1680) “Ars Magna Lucis el Umbrae” (Roma 1646)

Dubreuil "Perspectiva lineal como disciplina autónoma"

Guilón Bettini y Kircher "Perspectiva como parte de la óptica medieval o perspectiva que atribuye un significado místico y gnoseológico a la luz"

Véase: Corsi, Elisabetta, La fábrica de Ilusiones. Los Jesuitas y la difusión de la perspectiva lineal en China, 1698-1766, El Colegio de México Centro de Estudios de Asia y México, México D. F, 2004.

347 De este modo, se creaba una ilusión óptica que, como enormes decorados, ilustraban los techos pintados, fusionando la arquitectura del templo con unos frescos que recreaban celestiales estructuras arquitectónicas. Un conjunto de conceptos que recoge Andrea Pozzo en su Perspectiva Pictorum et Architectorum, y que se enmarcan en la literatura jesuita sobre la perspectiva lineal, donde se aúnan dos
} 
perspectiva como una ciencia empírica, al tiempo que se recuperaban los estudios aristotélicos, los de óptica del medioevo y el planteamiento de una relación entre el sentido y el intelecto. En consecuencia, no podemos tener ninguna duda sobre las implicaciones morales que la experiencia visual tenía para la Orden Jesuita. Efectivamente, para Andrea Pozzo la perspectiva monofocal era transmisora de verdades espirituales o, lo que es lo mismo, era la representación de la unicidad de la virtud, donde la transcendencia divina se revelaba como el verdadero punto de vista. El paradigma del sistema de un representación que como tal, señala Francastel, "[...] ha terminado por transformarse, través de alguna de sus formas, en uno de los instrumentos de propaganda más eficaces y que ha formado ampliamente la conducta de las multitudes durante siglos [... "348. En consecuencia, la perspectiva supondrá una renovación cultural que entre otros fue aprovechada por los jesuitas que, en su función de asesores, profesores o artistas, la introdujeron en Asia Oriental.

Ahora bien, el punto de partida de esta confluencia cultural $^{349}$ lo encontramos en China con Giuseppe Castiglione (1688 - 1766), un italiano miembro también de la Compañía de Jesús y discípulo de Andrea Pozzo. Efectivamente, podemos decir que Lang Shi Ning 郎世寧 ${ }^{350}$ (Paz del Mundo) ha sido el precursor de una verdadera hibridación entre el arte extremo oriental y europeo [Figura 14]. Es decir, el primer pintor que ha fusionado aspectos de las tradiciones pictóricas de Occidente y Oriente. Porque, por primera vez Castiglione introduce en China los principios occidentales del claroscuro y - en combinación con el sistema de la narración continua - también los de la perspectiva, asimilando soportes, materiales y técnicas chinas - mediante trazos que aluden a la soltura de la mano y a la aplicación caligráfica del pincel - sin olvidarse de aplicar los principios básicos del espacio pictórico en perspectiva. En otras palabras, al mismo tiempo que para la difusión de la fe católica adopta el simbolismo de las escenas bucólicas y rituales sobre los formatos y soportes de la pintura china, no abandona los conceptos occidentales de geometría, matemáticas y óptica, dando lugar así a unas obras de extraordinaria originalidad [Figura 15]. Observando este proceso podemos inferir que su trabajo ha sido todo un acontecimiento - teniendo en cuenta tanto su repercusión teológica como artística - ya que la pintura de Castiglione se nutre tanto de los

interpretaciones sobre la misma: la científica y la teológica. Es decir, los principios técnicos de la perspectiva y la enorme carga simbólica de esta técnica.

Acorde con el espíritu barroco, su característico ilusionismo perseguía, a través de la perspectiva, crear una ilusión más real de la realidad. De esta manera, las obras resultantes de esta teoría fueron denominadas "arquitectura al revés" por Francesco Milizia, quien recriminaba el "confuso delirio de la fantasía barroca". Un compendio de conceptos que definen a la perspectiva barroca y que se recogen en Perspectiva Pictorum et Architectorum de Andrea Pozzo [Figura 13]. Para más información, véase: Corsi, Elisabetta, La fábrica de Ilusiones. Los Jesuitas y la difusión de la perspectiva lineal en China, 1698-1766, México D. F, El Colegio de México Centro de Estudios de Asia y México, 2004.

${ }^{348}$ Pierre Francastel, Sociología del arte, Madrid, 1984, p.33.

349 Énfasis propio

${ }^{350}$ Nombre con el que Giuseppe Castiglione era conocido en la corte del Celeste Imperio, donde había logrado ser pintor durante 51 años. El jesuita Giuseppe Castiglione - nacido en Milán en1688 - había ingresado en la Orden Jesuita en Génova en el año 1707, llegando en 1715 a Beijing donde trabajó como pintor en la corte Qing hasta su muerte, en el año 1766. Allí despertó el interés chinos por la perspectiva de la pintura europea entre los artistas y eruditos. Trabajó para los emperadores Kangxi (1654-1722), Yongzheng (1678-1739) y Qianlong (1711-1799). 
elementos básicos de la perspectiva lineal como de los de la tradición de la pintura china, instaurando un precedente y transmitiendo los conocimientos sobre la técnica occidental a otros alumnos de la corte imperial [Figura 16].

Por lo tanto, hablamos de un acontecimiento estilístico de tal envergadura que dará lugar a una autóctona versión china de la perspectiva lineal a la que se ha denominado método Xianfa (線法) - método de las líneas para la perspectiva china -. Así, tanto el método Xianfa como la técnica aotufa (凹凸法) - método de llenos y vacíos - y la técnica gougufa (句股法) - método de triángulos y rectángulos - son nuevos sistemas de representación resultantes de la hibridación visual del Extremo Oriente y Europa [Figura 17] ${ }^{351}$. Como nos recuerda Corsi:

[...] la perspectiva lineal del Quattrocento, así como todos los demás métodos de representación del espacio plástico tienen un carácter histórico relativo. En realidad no es tan sólo la representación del espacio plástico la que estaría dotada de un valor diacrónico y no absoluto o universal, sino el contenido mismo de la noción de espacio. [...] De lo que se trata más bien es de definir los términos del problema: existe una distinción entre la "construcción espacial correspondiente a las proyecciones sobre el plano de las coordenadas lineales" y la composición espacial que tiene como objetivo "la representación sensible del espacio" 352 .

¿Podemos considerar el trabajo de Castiglione como precursor de nuestra actual globalidad cultural? ¿Podemos afirmar que sus conceptos artísticos coinciden con aquellos que han inspirado a la modernidad? Paradójicamente, debemos advertir, su labor buscaba perpetuar un sistema figurativo que servirá para que Occidente imponga durante cinco siglos en todo el planeta su manera de vivir y pensar. Siguiendo este principio, como nos recuerda Manuel V. Castilla, no tenemos ninguna duda de que Castiglione "[...] estaba convencido de que su pasión evangelizadora era el camino perfecto para la hibridación artística entre China y Europa. Sin conocer el papel de precursor de una posible mundialización artística, Castiglione siempre tuvo claro que el acercamiento a China era ante todo una misión evangélica, basada en el intercambio de las ciencias y las artes $[\ldots]$ "

[...] Su trinomio inculturador, ciencia-arte-religión, siempre estuvo fundamentado en una base científica, un propósito artístico y una finalidad evangelizadora. Esta convergencia de intereses no es ajena al principal objetivo del jesuita misionero: conectar su obra con la presencia de Dios como fuente de realidad geométrica a través de sus pinturas y proyectos arquitectónicos. La evangelización como consecuencia del

${ }^{351}$ En 1729 Nian Xiyao (年希堯) publica el Shi Xue, publicado en 1729 con el título Esencia de la ciencia de la visión (Shixue jingyung 視學精蘊) al que sigue una segunda edición en 1735 aumentada con más tablas y una traducción de la obra de Pozzo que se había adaptado a la tradición china. Una obra que fue muy utilizada por los eruditos de la corte china y que además de difundió tanto la enseñanza de la perspectiva lineal como de la pintura al óleo. No cabe ninguna duda de que Giuseppe Castiglione ayudó a Nian con este trabajo, quien además era su discípulo.

${ }^{352}$ Elisabetta Corsi, La fábrica de Ilusiones. Los Jesuitas y la difusión de la perspectiva lineal en China, 1698-1766, México, 2004, p. 104. 
Concilio de Trento (1545-1563) y su pasión por las artes fueron sus puntos de partida, defendidos incluso por encima de los decretos imperiales contra la religión católica $[\ldots]^{353}$.

En cualquier caso, en su obra se encuentran los primeros pasos dados por la nueva pareja espacio-tiempo en el campo de las futuras artes figurativas, donde, parafraseando a Francastel, el hombre "ya no está enfrentado a los problemas de la evolución, sino a los de la mutación”,354. En suma, un encuentro que aportará aires nuevos a los artistas de la corte de la China Qing 清朝 (1644 - 1912) y que, además, supondrá el preludio de lo que con el tiempo se ha entendido como un mestizaje cultural que, señalemos, tuvo una fuerte influencia sobre las chinoiseries que a partir de entonces serán extraordinariamente apreciadas en Europa [Figura 18]. Una occidentalización que - y por extensión - llegará más tarde a Japón - no olvidemos el arte Nanban (南蛮美術) y los ukie (浮絵) - y que paradójicamente coincidirá con el fenómeno del Japonismo occidental. A decir de Almazán "La occidentalización del Japón desde la segunda mitad del siglo XIX coincidió en Occidente con el fenómeno del Japonismo, que en voces entusiastas de la época se equiparaba a la influencia de griegos y romanos en el Renacimiento" [Figura 19] ${ }^{355}$.

\section{2.- Claude Monet y las Nymphéas}

Hasta ahora hemos visto como el asunto de la imagen y, por extensión el de su espacio, se ha ido hibridando progresivamente mediante la imposición de la perspectiva y la asimilación de la pintura extremo oriental. En el sentido comparado, formulado en el apartado anterior, entre los espacios pictóricos de Oriente y Occidente, la diferencia más significativa tal vez tenga que ver con la manera en la que se han ido introduciendo estos cambios en ambos espacios culturales. Consignar estas diferencia resulta imprescindible puesto que, como ya hemos señalado, si en Asia Oriental se inoculó el paradigma espacial de la pintura europea - mediante la enseñanza de la perspectiva

\footnotetext{
${ }^{353}$ Manuel V. Castilla, "Giuseppe Castiglione (Lang Shining), precursor de la primera mundialización pictórica -arquitectónica", Estudios de Asia y África, Vol. 51 Núm 3, 2016, p. 628. https://estudiosdeasiayafrica.colmex.mx/index.php/eaa/article/view/2245 (última consulta $18 / 06 / 20)$

${ }^{354}$ Pierre Francastel, Sociología del arte, Madrid, 1984, p.44.

${ }^{355}$ David Almazán Tomás, "La seducción de Oriente: de la Chinoiserie al Japonismo", Artigrama, № 18 , 2003, p. 84.
} 
como disciplina evangelizadora y como dogma cultural - en Europa los aspectos estéticos más característicos de la pintura oriental fueron recibidos con auténtica expectación, desde la admiración y curiosidad que despertaba lo que por entonces era considerado como un arte exótico ${ }^{356}$. Es decir, una intención inculturadora o aculturadora frente a una necesidad de renovación o, lo que es lo mismo, la voluntad de cambiar los códigos visuales de otra cultura, frente a la necesidad de enriquecer y ampliar los de la propia ¿Es relevante esta diferencia en nuestra comparación cultural? ¿Puede tener alguna transcendencia en las condiciones de los lenguajes de la pintura contemporánea?

Lo cierto es que, como ya dijo Gauthier, hasta hace relativamente no mucho, en "la esfera occidental moderna, a cuyo lugar real atribuimos una importancia desproporcionada [...] el concepto europeo de imagen ha sido considerado como el centro del mundo". Es decir, que se ha entendido nuestra idea de lo visible como algo común en todas las civilizaciones. Un punto de vista que ha ido cambiando, puesto que, a decir de este mismo autor, el" [...] arte del siglo XX ha renovado por completo, desde hace tiempo, su relación con lo visible, inspirándose, según los autores o según las corrientes, de la pintura china, de la estampa japonesa, del arte negro o de composiciones de la prehistoria [...]"357.

Evidentemente, en algunos aspectos Gauthier plantea un entroncamiento que actualmente puede parecernos excesivamente reduccionista. No obstante, es incuestionable que ya desde la antigüedad las artes decorativas europeas venían nutriéndose del lenguaje plástico extremo oriental. Así, desde el s. XIII - tras la conquista del mundo árabe por los mongoles - en Europa había calado la influencia de los temas y decoraciones que provenían del mundo chino; aunque estas siempre habían llegado filtradas por las geometrías a las que fueron sometidas tras la mediación de la cultura árabe. De este modo - mediante la mixtura producida entre los motivos originados en el Extremo Oriente y su posterior conversión geométrica en Oriente Medio - surgirán los reconocidos arabescos que llegaron a hacerse muy populares durante el Renacimiento europeo [Figura 20]. Un mundo ricamente poblado de motivos vegetales y roleos que tras recalar en Europa se someterá a una nueva transformación, llegando a consolidarse con el tiempo en los parámetros visuales de la Época Moderna europea. Se trata por lo tanto de un tránsito que desde el Extremo Oriente llegará hasta Oriente Medio, cosechando sus frutos en Occidente donde, a pesar de todo, el sistema visual se mantuvo inalterable. Será necesario esperar hasta finales del s XVIII para que se empiecen a notar los primeros cambios en los cimientos de la pintura europea ${ }^{358}$.

A tenor de este flujo de influencias, las Chinoiseries y el Japonismo fueron las posteriores e inevitables consecuencias de la acrecentada fascinación ejercida en Europa por el arte extremo oriental. Efectivamente, la producción de objetos con motivos y

\footnotetext{
${ }^{356}$ Énfasis propio.

${ }^{357}$ Guy Gauthier, Veinte lecciones sobre la imagen y el sentido, Madrid, 2008, p. 58.

${ }^{358}$ Énfasis propio.
} 
técnicas del arte chino - conocidos con el nombre de chinoiseries o chinerías - fue el resultado de la extraordinaria demanda europea de productos artísticos manufacturados en China, los cuales - debido, entre otras, a la labor mercantil de las compañías comerciales - ejercieron un gran atractivo sobre los coleccionistas europeos, dando lugar a lo que Barlés define como el "fenómeno del coleccionismo, del que fueron partícipes reyes y príncipes europeos de finales del s. XVI, y de los s. XVII y s. XVIII' ${ }^{359}$. En términos globales podemos afirmar que en Occidente el éxito de estas manufacturas - que eran tanto auténticas piezas chinas como de imitación - se dará en un momento caracterizado por la fascinación generada por el ideario cultural del Imperio Chino. Es decir, un ámbito marcado tanto por la admiración occidental hacia el arte chino como hacia la imagen exterior que por entonces se tenía del "Celeste Imperio" (神州) - Shénzhōu - y que posteriormente comenzaría su declive merced a la combinación de dos factores claves: los intereses económicos y estratégicos de las políticas occidentales sobre China y el declive militar de su secular imperio ${ }^{360}$.

Pero, en cualquier caso, será la pintura japonesa la que calará sobre todo en el ideario del arte europeo. Efectivamente, tras una serie de acontecimientos, Japón será obligado a abrirse al mundo permitiendo de esta manera la difusión de su gran riqueza cultural y surgiendo entonces en Europa el fenómeno denominado Japonismo; es decir, la captación y asimilación de todo lo japonés por parte de la cultura occidental ${ }^{361}$. Por consiguiente, los elementos más característicos de la cultura japonesa serán interpretados y aceptados en una Europa que tendrá como focos centrales de este movimiento a París, Londres y Viena. Y es que, como señalábamos anteriormente, en su búsqueda de nuevos caminos para su expresión creativa los pintores europeos cayeron fascinados por lo que entonces fueron consideraros nuevos conceptos de belleza, a través de una serie de obras pertenecientes a diferentes escuelas japonesas especialmente la del Ukiyoe (浮世絵) y sus estampas del mundo flotante - que contaban como principales artistas con Utamaro 喜多川歌麿 [Figura 21], Hokusai 北斎 [Figura 22] y Utagawa Hiroshige 歌川広重 [Figura 23] ${ }^{362}$.

\footnotetext{
${ }^{359}$ Elena Barlés Báguena, 1997, Lo mejor del Arte del Extremo Oriente, Madrid, p. 28.

${ }^{360}$ Un punto de inflexión de la imagen que se tenía en Occidente sobre China y que quedará definitivamente distorsionada y señalada a partir de la I y II Guerra del Opio (1839 - 1942 y 1856 1860) y el levantamiento de los bóxers (1900).

${ }^{361}$ Un fenómeno que se extiende desde mediados del s XIX hasta los años treinta del pasado s XX. Tuvo lugar a partir de la era Meiji 明治時代 - desde 1868 cuando - cuando tras siglos de aislamiento, Japón fue obligado a abrirse al mundo. Efectivamente, cuando el régimen del shogunado cae, el emperador Mutsuhito - Meiji Tennō 明治天皇 - toma las riendas de un nuevo gobierno e inaugura una nueva era Meiji - que se prolongará hasta 1912.

${ }^{362}$ En el arte hanga (版画) - xilografía o grabados en madera - se representaban los temas predilectos de los chonin (町人) - habitantes de la ciudad en el periodo Edo 江戸時代 - una burguesía de comerciantes, artesanos y demás miembros de clases sociales bajas, cuya cómoda situación social permitió que gozasen de una vida de goces y placeres, dando lugar a una cultura muy viva y rica. De este modo, la existencia girará alrededor del goce y crecerán los denominados barrios de placer donde las cortesanas llegarán a ostentar un estatus privilegiado. Todo esto se refleja en la demanda de los Ukiyoe, las llamadas pinturas del mundo flotante. Unas obras de carácter efímero y ligero, que reproducen imágenes de género y que ponen especial énfasis en lo sensual, erótico y mundano.
} 
Así, los lenguajes pictóricos extremo orientales - que en esencia recoge el Japonismo - a través del filtro de la pintura japonesa ejercerán gran influencia sobre el arte europeo. En palabras de Brodrik, “[...] los hombres del Nipón tomaron para sí las mejores galas de la civilización de la china de Tang".

Lo tomaron todo: escritura, lenguaje, (pues el chino fue, durante muchos años, la lengua cortesana del Japón), modales, religión, vestiduras, costumbres y arte. A medida que vayamos siguiendo el desenvolvimiento de la pintura china veremos cuán frecuentemente fue imitada en el Japón, si bien en lo pictórico, como en las artes, los japoneses dieron pruebas de gran originalidad y fuerza creadora, dando en conjunto a su pintura rasgos característicos que la diferencian de cualquier otra ${ }^{363}$.

En cualquier caso, la verdadera importancia del Japonismo ha sido la transcendencia de su legado estético sobre los pintores occidentales. Es decir, la aceptación por parte de los artistas europeos de lo que podemos considerar aspectos y técnicas visualmente novedosos aunque, en esencia, no llegaron a modificar la comprensión del espacio plástico occidental. Efectivamente, los artistas occidentales imitaron aquellos aspectos más pintorescos de las obras que por entonces llegaban desde Oriente a Europa, incorporando para sus pinturas composiciones asimétricas, colores planos y fondos neutros; aspectos con los que sin duda lograron innovaciones revolucionarias, pero siempre "conservando cuidadosamente el encuadre, los planos, el desglose, inclusive, los esquemas de composición" ${ }^{364}$ a decir de Francastel. Una

El barrio más famoso de Edo fue el de Yoshiwara 吉原 siendo la vida de sus personajes uno de los temas preferidos del arte del ukiyoe (浮世絵): Una denominación de connotaciones negativas - que en origen estaba vinculada al budismo - y que cambió su significado adquiriendo un tono positivo: disfrutar de lo efímero precisamente por su brevedad. Aunque de manera más esporádica la tradición de representar la vida cotidiana y los placeres populares mediante xilografías ya se puede encontrar en Japón desde el s XII y XIII, el auge de esta técnica se dará en los s. XVI y s. XVII, cuando surgen los pintores de ciudad que aunque anónimos - sus similitudes estilísticas nos permiten pensar en un cierto estilo de determinadas escuelas. En su composición incorporan la manera de mirar el objeto desde arriba, representando el espacio en una dirección diagonal e imprimiendo al objeto representado un sentido de movimiento. Por otra parte, surge una importante novedad: la representación de personajes de cierto tamaño e imágenes que focalizan escenas de gran vivacidad, un aspecto que contrasta con planteamientos anteriores en los que se recreaban escenas de grandes panorámicas donde los personajes representados se caracterizaban por su diminuto tamaño.

Efectivamente, finales del s XVII en Japón se comienza a usar un formato pequeño, reduciéndose el número de personajes que recreaban unas escenas afines a las clases populares y a las cortesanas. Estas imágenes eran ampliamente demandadas, por lo cual se reproducían de manera numerosa a través del grabado. En este contexto, la escuela del Ukiyoe 浮世絵 estructurará sus temas en diferentes géneros: bijinga (美人画) - imágenes de mujeres hermosas y prostitutas - shunga (春画) - imágenes eróticas yakushae (役者絵) - imágenes de actores - sumoe (相撲絵) - imágenes de luchadores de sumo que proliferan sobre todo en el s XVIII - kash ga (箇所画) - estudios de la naturaleza, generalmente aves y peces, vinculadas a un estilo de poemas denominados paisajes - fûkeiga (風景画) - retratos paisajísticos - escenas de guerra con héroes y guerreros famosos; imágenes de fantasmas y espectros - que surgen en el s XIX - y por último los temas imaginativos que se acercan mucho al surrealismo.

${ }^{363}$ A. Houghton Brodrik, Pintura China, México, 1954, p, 20.

${ }^{364}$ Así se adoptó el uso de la línea para contornear las formas, la temática japonesa - especialmente los temas florales y animales - la aplicación del color plano prescindiendo de las sombras, los encuadres cortados que introducen la diagonal en un formato que sigue al kakemono( 掛け物) y emakimono (絵巻物 ) de Japón. Véase, Pierre Francastel, Sociología del Arte, Madrid, 1984, p.158. 
revelación que se produce en un periodo de la Historia del Arte en el que, concretamente en Europa, el Impresionismo estaba en plena ebullición. Una corriente artística que no debemos minusvalorar aunque, como nos recuerda este autor, permaneciese "[...] fiel a ciertas concepciones tan profundamente arraigadas en la imaginación de los hombres, a un cierto nivel mental y social de su historia, del que aún no estamos totalmente liberados [...]". Por el contrario, a decir de Francastel, es indudable el valor que estos artistas demostraron, ya que "[...] en su intento de modificar la triangulación del espacio, se apoyaron en el estudio de otra civilización que hablaba otro lenguaje, y aquí si hay una innovación"365.

Pero ¿podemos fundamentar una renovación pictórica sólo en la adopción de determinados aspectos estilísticos del arte de otras culturas? ¿Es, así mismo, aplicable este principio de renovación a un retorno a las antiguas leyes artísticas autóctonas? Hoy no tenemos ninguna duda de que el reconocimiento del arte de otras culturas particularmente el de la japonesa - permitió que los pintores occidentales cuestionasen la concepción escenográfica de la pintura que dominaba Europa desde hacía más de cuatrocientos años. Por lo tanto, hablamos de unos aspectos visuales que han sido adoptados por los artistas occidentales pero sin abandonar por ello los, por entonces, aún vigentes códigos perceptivos occidentales. Por consiguiente podemos afirmar, como ha expresado Pierre Francastel, que aunque pudo cambiarse lo anecdótico no lo hizo "el sistema, el cifrado, uno de cuyos elementos fundamentales es el espacio". Y es que, "la renovación del espacio plástico, renovación que se había hecho necesaria por la transformación radical del lugar ocupado por el hombre sobre la tierra, no podía hacerse únicamente mediante la renovación del tema anecdótico [...]"366. En todo caso, hoy podemos considerar atrevidas muchas de las obras de algunos artistas de finales del siglo XIX. Es decir, que en ellas encontramos audacias donde vislumbrar, como advierte Francastel, "el origen de algunas fórmulas cuyo éxito ha sido determinante en el desarrollo ulterior del arte contemporáneo"367. Por lo tanto, atendiendo a este enfoque, los pintores europeos no solo adoptaron las técnicas y recursos artísticos del arte extremo oriental, sino que encontraron en este un enriquecimiento y una inspiración que ha hecho posible la renovación del arte del momento. Como nos recuerda Gauthier:

[...] Para finales del siglo XIX en particular, conocemos mejor cual ha sido la influencia del arte del Extremo Oriente, situado al límite de la imaginería popular [...] El artista del siglo XIX, creador genial e inspirado, podía descubrir alguna escuela desconocida y de preferencia exótica; en cambio, hubiera sido como una decadencia el parecer deberle a géneros subalternos. Habrá que esperar a los años XX para que el movimiento se invierta no sin ambigüedad ${ }^{368}$.

\footnotetext{
${ }^{365}$ Pierre Francastel, Sociología del arte, Madrid, 1984, pp. 167- 168.

${ }^{366}$ Ibídem, pp. 162 - 163.

${ }^{367}$ Ibídem, p. 193.

${ }^{368}$ Guy Gauthier, Veinte lecciones sobre la imagen y el sentido, Madrid, 2008, p. 81.
} 
Efectivamente, al incorporar para la pintura europea diversos medios de expresión pertenecientes al arte japonés, hoy consideramos precursores a pintores como Degas (1834 - 1917) [Figura 24], Van Gogh (1853- 1890) [Figura 25] o Klimt (1862 1918) [Figura 26]. Pero también a movimientos artísticos como el gráficamente denominado Art Nouveau (1893 - 1905) [Figura 27] - y sus diferentes prácticas decorativas - que tomaron como fuente de inspiración los grabados japoneses de ukiyoe (浮世絵) y la escuela decorativa Rinpa (琳派), fieles al estilo yamatoe (大和絵) de la pintura japonesa[Figura 28] $]^{369}$.

Lo interesante es que, en este contexto de nuevas influencias, destacarán principalmente dos aspectos fundamentales: la incorporación de una temática novedosa donde recrear interiores con escenas cotidianas y el uso de unos fondos neutros sobre los que destacar las figuras. Por consiguiente, surgirán unos temas que en su ejecución, como novedad, recurrirán a la sutileza del dibujo enfatizada por la delicadeza de las formas, la expresión del movimiento y una nueva visión de la composición mediante encuadres asimétricos - recordemos la asimetría o fukinsei (不均斉) - a través de unas líneas oblicuas - en una diferente comprensión del espacio y de la profundidad de este sin recurrir a la perspectiva matemática. Es decir, una nueva concepción del espacio pictórico que se compone evitando cualquier escala o intención mimética y recurriendo a un cierto equilibrio musical mediante la rica gradación de colores

$\mathrm{Y}$ es precisamente en este contexto cuando Monet introduce en su pintura una estructura compositiva alargada y horizontal - y la manera de comprender en ella el espacio - aportando con ello uno de los rasgos más novedosos de la Historia del Arte europeo, sobre el que, por otra parte, menos se ha estudiado y se es consciente. Por consiguiente, nos encontramos con una idea que en Europa - por primera vez desde la antigüedad - buscaba componer - siguiendo algunos de los principios de la pintura china y japonesa - y no construir o, por qué no, deconstruir el espacio - y que supuso un cambio de paradigma para la mirada del arte moderno europeo ${ }^{370}$. Por tanto, una propuesta que ha hecho posible que el secular oculocentrismo europeo comenzase a reconocer otros modos de mirar, encontrando en el arte de otras culturas particularmente en las del Extremo Oriente - una fuente de inspiración revolucionaria ¿Una búsqueda premeditada tras la que se escondía un anhelo de cambio en Europa?

\footnotetext{
${ }^{369}$ El estilo yamatoe (大和絵) -literalmente, pintura japonesa- es un estilo clásico de la pintura japonesa que se desarrolló a finales del periodo Heian 平安時代 inspirándose en las obras de la dinastía china Tang 唐朝. A partir del periodo Muromachi 室町時代 el término será utilizado para distinguir la pintura japonesa, en oposición a las realizadas bajo el influjo chino, llamadas Karae (唐 絵) que originalmente hacía referencia a pinturas grandes, como pantallas plegables o deslizantes. Sus principales características fueron su diáfana luminosidad, colores brillantes y una decoración geométrica de líneas simples.

Dentro de las escuelas decorativas de Japón, destaca la escuela Rimpa (琳派) (s XVII), iniciada por Honami Kōetsu 本阿弥光悦, (1558-1637) y Tawaraya Sōtatsu 俵屋宗達 (d. c.1643), y consolidada por Ōgata Kōrin 尾形 光琳, (1658-1716) [Figura 29].

${ }^{370}$ La idea de deconstruir se aplica en este caso en alusión al concepto de deconstrucción, empleado en el terreno de la filosofía y también de la teoría literaria, en tanto en cuanto hace referencia al acto y el resultado de deconstruir: verbo, que procede del vocablo francés déconstruire y que hace alusión a la idea de desmontar cierta estructura conceptual a través del análisis intelectual.
} 
Efectivamente, no hay ninguna duda de que el interés por el entonces llamado Arte Exótico no fue resultado de una elección arbitraria; fue la expresión de una profunda transformación en el seno de lo que hasta entonces se había entendido como el único arte verdadero ${ }^{371}$ y un reflejo, así mismo, de una transformación social que, como consecuencia, producirá un cambio en los códigos perceptivos occidentales. Y es precisamente en este contexto social y artístico donde Monet comenzará a fraguar un proyecto pictórico en el que, a decir de Rosenberg, lo que se "[...] iba a producir en el lienzo ya no era una imagen, sino un acontecimiento [...]"372 que ha resultado ser crucial para la posterior Historia del Arte. Hablamos de un contexto social y artístico que en lo personal coincidirá además con el interés de Monet por la jardinería japonesa $^{373}$. Un aspecto puramente anecdótico, que no pretende demostrar nada, pero que, en cualquier caso, nos permite ilustrar la vinculación entre la estética japonesa y la obra de Monet. Una relación que, por otra parte, ya había destacado Louis Gillet en Trois variations sur Claude Monet, donde por primera vez se establece un vínculo entre la gran obra del maestro francés y la influencia de la estética extremo oriental. Una tesis muy significativa - aunque posteriormente fuese rebatida por Clemenceau en su libro Claude Monet, les Nymphéas - que al establecer la influencia de la estética japonesa sobre Monet, a nuestro juicio, conscientemente plantea por primera vez la posible conexión entre los códigos perceptivos del espacio pictórico de Oriente y de Occidente.

De este modo, siguiendo idea podemos comenzar a establecer una estrecha conexión entre la horizontalidad del desarrollo espaciotemporal de la pintura japonesa y la serie de pinturas de las Nymphéas de Monet [Figura 30] ${ }^{374}$. Es decir, entre la tradición del fûkeiga shoshiki - 風景画 書 式- (formato de horizontal de escritura al estilo de la pintura de paisaje) y el formato horizontal de los lienzos de los Nenúfares [Figura 31]. Reconocer este vínculo también nos permite establecer una interrelación particularmente interesante para esta investigación: el paralelismo espacio/tiempo y flores/agua que se establece en el mismo seno del jardín de Giverny. Dos tensiones complementarias - como el Yin-Yang - que, como formulará Arséne Alexadre, se pueden corresponder a su vez con dos ámbitos: "[...] el mundo de los colores y el mundo de los matices $[\ldots]$ "

Aquí no hay más que bajar la mirada para asistir a la extraña simbiosis de las imágenes celestes y los espejismos del agua; una unión tan perfecta que a uno le da la impresión de sumergirse en lo más profundo de las nubes y de las infinitas capas de aire. Entre estas dos profundidades, la que se ve y la que se refleja, las plantas acuáticas parecen nadar en el espacio más que flotar en la superficie líquida. [...] la realidad de la materia

\footnotetext{
${ }^{371}$ Énfasis propio.

372 Harold Rosenberg, "Los Pintores de Acción Americanos", en Alarcó. P, et al, Monet y la Abstracción, catálogo de la exposición, Madrid, 2010, p. 156.

${ }^{373}$ Fue en 1891 cuando Monet comenzó las obras para la construcción y posterior ampliación de su jardín en Giverni, para lo cual - y debido a su interés por el arte de la jardinería japonesa - buscará el asesoramiento de un maestro del jardín japonés. Pero no será hasta 1897 cuando - acompañando a Maurice Guillemot de Le Figaro - Monet hablase por primera vez de su idea de crear un espacio circular en el que las paredes estuviesen decoradas enteramente por grandes cuadros representando su jardín acuático.

${ }^{374}$ Énfasis propio.
} 
sólida y líquida [...] el juego de estos dos elementos que intercambian sus efectos de irrealidad - ya que el agua que se ve es el cielo y el cielo que no se ve adquiere apariencia acuática - ha podido atraer irresistiblemente, acaparando su atención, a ese pintor que siempre había estudiado con pasión el interminable dueto que cielo y agua mantienen, interrumpen y retoman $[\ldots]^{375}$.

En cualquier caso, una relación espacio/tiempo para la que, recordemos, ya se había acuñado el término yuzhou (余白) en la dinastía Han 漢. Sobre este particular, no está de más advertir que incluso Marcel Proust en la última parte de En busca del tiempo perdido, pareció apercibir una relación que, además, terminará por influir en la posterior recuperación de la obra de Monet por parte de los artistas franceses y norteamericanos de la segunda mitad del s. XX. De cualquier modo, un prefacio de lo que llegará más tarde y que visionarios como Kandinsky supieron intuir al contemplar uno de los Almiares de Claude Monet que estaban expuestos en Moscú. Es decir, las posibilidades autónomas de la pintura como punto de partida para la abstracción.

Así, a partir de 1880, Monet se irá distanciando del grupo de los impresionistas y, tras los primeros cuadros de la serie de los Nenúfares realizados en 1898, comenzará a trabajar en una serie de pinturas en las que se obvia cualquier alusión al motivo ${ }^{376}$. Hablamos de unas obras inspiradas en su jardín acuático donde se da una profunda comunión entre naturaleza y arte. Una binaridad que, desde esta perspectiva, no parece descabellado vincular con la ya mencionada relación armoniosa del hombre, la naturaleza y el arte - que ha caracterizado la cosmovisión extremo oriental - en relación con lo formulado por Seitz que así lo expresaba: “[...] Visto como un objeto, el hombre es una parte de la naturaleza. Entonces es cuando el yo se vuelve hacia dentro cuando se produce una ruptura. Monet no permitió que esa ruptura se produjera en su arte [...]"377. Un asunto que, a su vez, nos remite hasta aquel equilibrio de tensiones característico de la pintura china, coreana y japonesa, y a la interrelación hombre/naturaleza y espacio/tiempo. No obstante, constatar esta premisa nos obliga a platearnos otra pregunta ¿Al igual que sucede con la pintura de Asia Oriental, podemos considerar estas obras como un ejercicio espiritual del arte que, como tal, supondrá el anteproyecto de un cambio de paradigma en los códigos perceptivos occidentales?

\footnotetext{
375 Arséne Alexandre, en Monet y la Abstracción, catálogo de la exposición, Madrid, 2010, p. 200.

${ }^{376}$ Entre 1914 y 1926 realizará este último y gran proyecto pictórico que dará un impulso vital a los últimos años de su vida. La recreación de un espacio físico y temporal que será en lo duros años de la Gran Guerra, además de una proyección artística del propio jardín de Monet, un refugio físico y espiritual para el pintor. Años después, con la celebración del armisticio - el 11 de noviembre de 1918 algunas obras de esta serie serían donadas al estado para crear con ellas un monumento conmemorativo a la paz. No obstante, aun así habrá que esperar hasta 1927 - pocos meses después de la muerte del pintor para que se realice en París - en la Orangerie - una exposición sobre las Grandes Décorations Una gran muestra que estaba integrada por veintidós paneles y cuya inauguración correrá a cargo de Michel Monet y Clemenceau. Curiosamente, en este mismo año sale a la luz Trois Variations sur Claude Monet, que había sido publicado por Louis Gillet.

${ }^{377}$ William C. Seitz, "Monet y la Pintura Abstracta", en Alarcó, et al, Monet y la Abstracción, catálogo de la exposición, Madrid, 2010, p. 150.
} 
Efectivamente, retomando el hilo de nuestra investigación, la vinculación de Monet con Japón se evidencia mucho más allá de la presencia, en algunas de sus obras, de un puente arqueado que inevitablemente nos hace recordar aquellos que aparecen en los paisajes de Utagawa Hiroshige (歌川広重) [Figura 32]. Es decir, mucho más allá de algunos tópicos temáticos o estilísticos. En sí, el conjunto de Los Nenúfares es una instalación ${ }^{378}$ proyectada para lograr la empatía del espectador con un espacio que se recrea, recurriendo a unas pinturas que, más que construir, componen rítmicamente un espacio con colores y manchas. En consecuencia, la figura del estanque no será utiliza como modelo sino como guía. Así, nos recuerda Michel Butor:

[...]"abordaba el tema con grandes masas de color. Este fue el punto de partida de nuevas composiciones. [...] una especie de "síntesis" donde resumiera, en uno o dos cuadros, las impresiones y sensaciones de antaño." [...] Al no poder fiarse lo suficiente del color, Monet distinguirá sus elementos sobre todo por la pincelada. En este sentido, los Nenúfares constituyen la recapitulación de toda su obra. [...] todos aquellos detalles que se le escapan han de producir "efectos fugitivos" subordinados a la composición $[\ldots]^{379}$.

Por lo tanto, Monet buscaba configurar un espacio que le permitiese recrear la sugestión de una atmósfera de agua y flores acuáticas, sustituyendo el sistema de representación de la perspectiva por un recurso muy similar al de la narración gráfica continua característica de la pintura extremo oriental [Figura 33]. Una idea inspirada en los populares Panoramas y Cicloramas - tremendamente populares en aquel momento que permitían al espectador zambullirse en la visión de $360^{\circ}$ de una imagen panorámica y que, a su vez, estaban inspirados en la percepción espacial de las representaciones de la pintura china de paisajes de la dinastía Song 宋朝. Un aspecto interesante que, de nuevo, nos permite establecer una vinculación con el espacio de la pintura extremo oriental. En cualquier caso, se trata de una tendencia de gran aceptación en la época: decorar una estancia mediante el recorrido visual que ofrece la yuxtaposición de unas pinturas que, en el caso de la Orangerie, precisarían del proyecto de una instalación, instaurando de este modo una novedoso planteamiento del espacio pictórico [Figura $34]^{380}$. Pero, si otorgamos a estas obras la categoría de instalación, debemos arriesgarnos y hacer la siguiente pregunta ial igual que los panoramas y los cicloramas para el proyecto de la Orangerie, podemos suponer que éste ha podido suponer una suerte de prototipo para el arte de nuestras modernas instalaciones? En cualquier caso,

\footnotetext{
${ }^{378}$ Énfasis propio.

${ }^{379}$ Michel Butor en Monet y la Abstracción, catálogo de la exposición, Madrid, 2010, p 116.

${ }^{380}$ Los Panoramas y los Cicloramas se hicieron muy populares en el siglo XIX. El primer Ciclorama se abrió en Edimburgo en 1787 por Robert Burker. Por otra parte, la idea de proyectar un conjunto de pinturas destinadas a envolver al espectador - cubriendo las paredes de un espacio arquitectónico - la podemos encontrar también en espacios como el que Sorolla ideó para su Mirada de España en la sede de la Hispanic Society of America de Nueva York - encargo que había recibido en 1911 de su fundador, Archer Milton Huntington - o la Rotonda del Círculo del Liceu proyectado por Ramón Casas entre 1901 y 1902.
} 
una tesis francamente interesante que abre una futura vía de investigación. Como se recoge en el catálogo del MoMa del año 1960:

Revisando de la exposición de 1909 en la Gazette des Beaux-Arts, el crítico Claude Roger-Marx incluyó una conversación "imaginaria" en la que Monet habló así: "He tenido la tentación de emplear este tema de Nympheas en la decoración de un salón: llevado a lo largo de las paredes, su unidad, desplegando todos los paneles, habría dado la ilusión de un todo sin fin, de agua sin horizonte o banco; la tensión nerviosa del trabajo se relajaría allí [...] y él que vivía allí, esa habitación habría ofrecido el refugio de una meditación pacífica en el centro de un acuario con flores ${ }^{381}$.

Efectivamente, en lo que compete a la vinculación de la horizontalidad de estas obras de Monet con el arte extremo oriental, a nuestro juicio los Nenúfares son una suerte de poemas musicales de un instante que fluye - en una relación afín al gusto extremo oriental de la unión entre la composición pictórica, poética y los ritmos musicales - recurriendo a la repetición horizontal de una serie de elementos que se agrupan y conjugan sobre unos campos vacíos creados por la ausencia de pinceladas. En este sentido la obra de Monet se acerca a una suerte de impermanencia - tan del gusto de la estética japonesa - aceptando lo efímero como una particular manera de contemplar, sentir y amar la naturaleza. Así, al aceptar el paso del tiempo el pintor recrea la naturaleza desde una cierta actitud contemplativa. El ensueño de un lugar utópico donde mediante una simbiosis de relaciones recogidas a través de composiciones de acordes, surge de manera natural la creación. Seitz lo explicaba de la siguiente manera:

En 1890 estaba tratando de representar cosas que, como él mismo afirmó, eran "admirables de ver" pero "imposibles de hacer: el agua con plantas que se mueven ondulantes en su fondo". Los reflejos de los sauces, las nubes y el cielo se mezclan, tanto en la superficie del agua como bajo ella, con las formas de las plantas. En 1905, en cambio, cuando la mirada del pintor se acerca más al motivo, los árboles, el puente, la orilla - los puntos de referencia tangibles que distinguen la masa física de su imagen reflejada como un espejo - quedan eliminados. Los reflejos que se funden entre sí forman un único y trémulo segmento de un mundo despojado de objetos sólidos. En sus Nenúfares o Paisajes acuáticos, el espíritu de Monet, impulsado hacia apariencias que son misteriosas y envolventes, se acerca al de la poesía de Mallarmé o la música de Debussy ${ }^{382}$.

Efectivamente, esa capacidad de síntesis será la gran aportación de la naturaleza que se representa en estas pinturas de la última etapa de Monet. Todo el jardín será la encarnación de poemas o piezas musicales, expresados mediante una yuxtaposición de armonías basadas en matices de colores dominantes. En consecuencia, podemos inferir

\footnotetext{
${ }^{381}$ Claude Roger-Marx, "Les Nympheas de M. Claude Monet", Gazette des beaux-arts, Series IV, Vol. 1, June 1909, p. 529 , et al Claude Monet: seasons and moments. Catálogo del MoMA, 1960 pp 45 -46. Las citas han sido traducidas del texto original para la redacción de esta tesis.

${ }^{382}$ William C. Seitz, "Monet y la Pintura Abstracta", en Alarcó, et al, Monet y la Abstracción, catálogo de la exposición, Madrid, 2010, p. 150.
} 
que la gran aportación de Monet para la pintura contemporánea será abstraer un fragmento de un espacio o, en otras palabras, una parte de un todo para así poder recrear un todo espacial. Se trata de un posicionamiento consciente que implica la fusión de horizontes a través de la secuencia horizontal de un ensamblaje de grupos. Una idea que enlaza con aquella experiencia religiosa e intuitiva de armonía con la naturaleza y la disolución del yo en el mundo característica de la pintura extremo oriental. En palabras de Seitz:

[...] El primer impacto de estas obras es de una profusión casi tropical de árboles, arbustos, festones de sauce llorón, y lechos de iris; su abundancia exótica, dramatizada por acentos floridos, es similar a las extravagantes descripciones literarias del amigo de Monet, Octave Mirbeau, o la música atonal de Debussy y Stravinsky. Sobre los verdes saturados, azules, sienas y ocres del estanque y sus reflejos vacilantes, las almohadas de lirios y las flores, vistas en recesión, se encuentran como una alfombra rica pero andrajosa trabajada con hilos de rosa y blanco $[\ldots]^{383}$.

En este contexto, al igual que sucede con la pintura de Asia Oriental, en los Nenúfares de Monet el espacio ya no se representa sino que se expresa. Porque lo que Monet busca no es representar sus cualidades físicas sino captar toda la dimensión del proceso que, como desarrollo temporal, connotaba el espacio. Pero además, al carecer de demarcación formal, el espacio selecciona el asunto del cuadro controlando las diagonales de la perspectiva - y en consecuencia restringiendo la ilusión de un espacio volumétrico y en profundidad - de tal manera que la dimensión del cuadro se organiza en un sentido lateral, dando a la composición una inusitada riqueza de ritmos. Así, como sentencia Masson, mediante "[...] Una pincelada de múltiples matices: entrecruzada, desordenada, oscilante. [...] Algunos rasgos - o acentos - sintéticos acompañan a veces a las masas coloreadas y las hacen "significar". Nunca estará Monet tan cerca de esas estampas japonesas que tanto admiraba como en algunos cuadros de Holanda. Esta factura de amplias superficies casi plana aparece ya en algunos cuadros de juventud. $[\ldots]$

[...] los Nenúfares. A pesar de su monumental tamaño, no presentan en absoluto las características de la gran decoración flamenca o veneciana. Su disposición mental me parece la de un pintor "de caballete" que decide dar a su visión un campo lo suficientemente amplio como para abarcar el mundo $[\ldots]^{384}$.

En todo caso, en estas obras encontramos una fragmentación de la superficie pintada que posibilita una noción de multidivocidad de espacios, permitiéndonos pasar de la dimensión de lo físico a la del espacio evocado. Es decir, permitiéndonos transitar

\footnotetext{
${ }^{383}$ William C. Seitz, Claude Monet: seasons and moments. Catálogo del MoMA, Nueva York, 1960, p. 40. Las citas han sido traducidas del texto original para la redacción de esta tesis.

${ }^{384}$ André Masson en Monet y la abstracción, Catálogo de la exposición, Madrid, 2010, pp 122 y 124.
} 
desde una realidad física hasta otra dimensión subjetiva involucrada en la percepción. Por lo tanto, a nuestro juicio, consideramos que la representación se encuentra en una tensión dinámica: entre la representación de una experiencia y la interpretación de una realidad. Una idea que se aleja de aquella estructura formada por las coordenadas cartesianas que habían definido hasta entonces el concepto del espacio pictórico europeo. Parafraseando a Seitz: "al seleccionar el asunto del cuadro se evitaban, o al menos se controlaban estrictamente, las diagonales de la perspectiva lineal y el espacio volumétrico que de ellas se deriva" ${ }^{, 385}$.

Por consiguiente, nos encontramos ante la novedad de un proyecto que buscando crear un clima envolvente para el espectador recurre al formato de unos cuadros de dimensiones muy superiores a las que hasta entonces el propio Monet había utilizado ${ }^{386}$. Hablamos, sin embargo, de una fructífera etapa tardía que no será comprendida hasta mucho tiempo después ${ }^{387}$. Un legado que hoy se reconoce como inigualable para la historia de la pintura y en el que Monet logró la abstracción de un espacio pictórico donde, observaba William Seitz, "por mucho que se hiciera retroceder el fondo, el cuadro quedaba comprimido en un espacio de escasa profundidad que estaba organizado en sentido lateral" 388 . En definitiva, unas pinturas que más que verlas es preciso leerlas, pues su concepción es absolutamente horizontal. Así, conforman un libro con su propio código de signos para interpretarlo, siguiendo una lógica naturalista del espacio pictórico en un plano secuencia que, como un travelling, se desenvuelve en un discurrir espaciotemporal. Es decir, modificando el sistema dominante de la representación vigente hasta entonces, en el marco del arte europeo. Como señala el pasaje de Rubin:

En sus grandes obras tardías, Monet desarrolló otra solución que comportaba un retorno a la pincelada all-over, pero ahora mucho más ancha de lo que había sido originalmente (lo

${ }^{385}$ William C. Seitz, "Monet y la Pintura Abstracta", en Alarcó, et al, Monet y la Abstracción, Madrid, p. 150.

${ }^{386}$ Debemos recordar que los estudios preliminares que Monet había realizado para el proyecto de los Nenúfares fueron abandonados debido a la inactividad en la que se sumió tras determinados sucesos: la muerte de Alice Monet en 1911, la catarata que se le diagnostico en 1912 y la enfermedad y muerte en 1914 de su hijo Jean. Hubo que esperar hasta 1915 para que el pintor retomase este proyecto.

${ }^{387}$ En 1931 se celebra en Francia la única exposición retrospectiva sobre la obra de Claude Monet del periodo de entreguerras. Celebrada en la Orangerie, el prólogo del catálogo de la exposición fue escrito por el conservador del Louvre, Paul Jamot. En este, las obras que integran la última etapa del trabajo de Monet casi no se mencionan ni se hace referencia a las Grandes Decorations. Antes de los años 50, algunas de estas obras estaban consideradas como material sobrante, como esbozos del proyecto pictórico de la Orangerie. De hecho, la gran mayoría de estas obras estaban sin fechar y sin firmar, y se encontraban almacenadas en el estudio del artista.

Por otra parte, la escasa crítica que siguió en aquel momento el evento, definió a estas grandes obras como gran error y catástrofe (véase "Retrospective" de Albert Flament, publicada en La Revue de Paris). Efectivamente, para los críticos de la época - y también para los anteriores - lo más importante de la obra de Monet estaba en la primera fase porque, a pesar de que se relajaba la estructura de la pintura, la mirada podía reconocer aún unas formas que no corrían peligro de desaparecer. De esta manera, al considerar que el pintor había incurrido en el craso error de eliminar la forma, se desdeñaba su obra tardía. Sin embargo, una nueva valoración crítica puso el énfasis en estas obras. Pero, aún más, consideró que dentro de esta última etapa pictórica, las obras finales eran las que reunían una complejidad que las hacía más interesantes. Así se entendió que las obras realizadas entre 1914 y 1926, periodo en que realizó las pinturas más "abstractas" sobre el tema de los Nenúfares, eran el culmen de su carrera.

${ }^{388}$ William C. Seitz, "Monet y la Pintura Abstracta", en Alarcó, et al, Monet y la Abstracción, catálogo de la exposición, Madrid, p. 150. 
cual le venía impuesto en parte, pues ya le fallaba la vista). La unidad compositiva de estos cuadros depende generalmente de una simetría especular entre la parte superior del lienzo y la inferior (equiparación óptica de las sensaciones que producen las formas del paisaje y su reflejo en el agua) y, en los casos en que el cuadro es muy ancho, de colocación de unos árboles o unas ramas colgantes en los límites laterales que actúan como mecanismos de cierre (es el caso de los más grandes de la Orangerie). Esos "paréntesis" compositivos, que no están en los mejores Nenúfares, reflejan el temor de Monet a que la enorme anchura del cuadro (en relación con su altura) le hiciera perder cohesión $[\ldots]$

Una semiótica, o resolver la dificultad de esos formatos tan horizontales sin tener que recurrir a mecanismos de cierre de ese tipo. [...] Los cuadros de gran formato de Monet anunciaban una concepción totalmente nueva del tamaño de la pintura "de caballete", no mural $[\ldots]^{389}$.

En definitiva, un proceso que ha resultado ser la antesala del Expresionismo Abstracto; el abstracto sublime que será la culminación del hilo conductor del arte occidental durante el s. XX y que visualmente tendría sus primeras raíces no sólo en la tradición de pictórica de mediados del s. XIX con Turner, si no especialmente en la obra tardía de la primera parte del s. XX con Claude Monet y su más que hipotética influencia compositiva extremo oriental.

\section{3.- Las Neovanguardias Americanas}

Hemos visto como en su obsesión por captar los diferentes efectos atmosféricos - con sus cambios de luz y de color - aquella naturaleza que tanto había interesado a Monet llegará a convertirse en el verdadero leitmotiv de su última etapa pictórica. Es decir que, como tema - al poner el énfasis en aquella mirada sobre la naturaleza - su empoderamiento hará posible la transformación en una abstracción subjetiva de su propia representación y de la comprensión de su ámbito espacial ${ }^{390}$. Porque Monet, a la manera de los sabios daoístas, había entendido que su jardín contenía en sí mismo todo el universo. Una idea de jardín como nos recuerda Alfonso Falero:

\footnotetext{
${ }^{389}$ William Rubin, "Monet y la Pintura Abstracta", en Alarcó, et al, Monet y la Abstracción, catálogo de la exposición, Madrid, p. 160

${ }^{390}$ Énfasis propio.
} 
En este planteamiento el jardín juega un papel esencial, porque es el locus donde todo ello acontece. El jardín resulta ser un microcosmos, un mundo completo en sí mismo donde el entorno natural, el fluir de la corriente de la vida y la percepción estética que lo registra y lo disfruta confluyen y se sintetizan armoniosamente. Es por tanto el espacio de la felicidad, y en esto coincide con aquellas mitologías y el folclore universal que han concebido la idea del paraíso como un jardín. El sabio daoísta entendió que en un solo jardín estaba contenido el universo entero. Así se transmitió y así se vivió en la historia estética japonesa. El jardín daoísta tiene en su origen un componente de pensamiento mágico, es un enclave cerrado y poseedor de una fuerza misteriosa. Nos recuerda a un círculo mágico. En su interior anida la fuerza de la vida ${ }^{391}$.

Así, entendemos que - como el puente japonés del jardín de Giverny - estas obras tardías del maestro francés articulan y relacionan como una bisagra dos maneras distintas de comprender el espacio pictórico: el extremo oriental y el europeo, y también el moderno y contemporáneo. En este sentido, Meyer Schapiro considera que "[...] los Nenúfares con sus increíbles formas espaciales, en cierto modo relacionadas con el arte abstracto contemporáneo, pertenecen ya al s XX [...]"

Notas como la improvisación críptica, la intimidad microscópica de las texturas, puntos y líneas, las formas impulsivamente garabateadas, la precisión mecánica en la construcción de ámbitos irreductibles e inconmensurables, las mil y una ingeniosas técnicas formales de disolución, penetración, inmaterialidad e inconclusión que afirman la soberanía activa del artista abstracto sobre los objetos, son algunas entre las muchas facetas del arte moderno que descubren experimentalmente los pintores que buscan la libertad al margen de la naturaleza y la sociedad, a la vez que niegan conscientemente los aspectos formales de la percepción - como la asociación existente entre la forma y el color o la discontinuidad entre el objeto y su entorno - que entran en las relaciones prácticas del hombre en la naturaleza ${ }^{392}$.

¿Podemos entonces inferir que los Nenúfares de Claude Monet son el eje que vertebra el tránsito entre la tradición de la pintura europea del s. XIX y las obras de la abstracción contemporánea? Pero, dado este supuesto, al estudiar tal y como estamos haciendo en esta investigación las evidentes relaciones y similitudes de la obra tardía de Monet con el espacio pictórico extremo oriental, nos vemos obligados a plantear las posibles relaciones de este último con las neo vanguardias americanas. Entonces, en este caso cabe preguntarse sobre ¿cuánto debe el espacio pictórico de estas pinturas norteamericanas al de la pintura extremo oriental? y, tal y como proponemos en esta tesis ¿cuánto ha influido ésta última en la recuperación de los dípticos y trípticos para aquellas pinturas $?^{393}$. En alusión a esto último, en capítulos anteriores hemos visto

\footnotetext{
391 Alfonso Falero, "El Fūryū como categoría estética", en Menene Gras Balaguer (ed. 2015) El jardín japonés: Qué es y no es entre la espacialidad y la temporalidad del paisaje, Madrid: Tecnos, 137-154.

${ }^{392}$ Meyer Schapiro, Monet y la Abstracción. Catálogo de la exposición, Madrid, 2010, p 132

${ }^{393} \mathrm{La}$ posible influencia del arte extremo oriental sobre las vanguardias norteamericanas ya había sido planteada, entre otros, por Greenberg: “Gorky ensayó ya el cuadro grande en los primeros años cuarenta
} 
cómo la pintura china, japonesa y coreana acopla el desarrollo del tema a una yuxtaposición de sucesivos soportes - mediante paneles y papel o tela plegados mientras que, de manera similar, una de las aportaciones pictóricas de las neovanguardias ha sido la recuperación de los polípticos como una suma de soportes, donde el asunto del cuadro se extiende todo a lo largo. En cualquier caso - mucho más allá de la idea del vacío, del gesto caligráfico o de su carácter bidimensional - lo que denota la posible influencia oriental en muchas de las pinturas norteamericanas de la segunda mitad del s. XX - lo que realmente ha sido determinante para el arte occidental - ha sido una configuración espacial y temporal que, rompiendo con una tradición dada, ha posibilitado la composición del espacio mediante el principio de la narración gráfica continua $^{394}$. Es decir, suprimiendo la perspectiva y articulando el espacio mediante la disposición horizontal de sus estructuras [Figura 35].

En este sentido, Steinberg nos india que la gran aportación para la pintura de las Grandes Decoraciones de Monet ha sido prescindir por primera vez de la línea del horizonte, con el consiguiente desconcierto que, en su momento, este hecho llegará a provocar en el posicionamiento del espectador. En su opinión " [...] Había presentado la fórmula de la mirada del s XX, cultivando el idioma del XIX [...] para, parafraseando al maestro francés [...] "producir una ilusión de un todo interminable, una ondulación sin horizonte, sin orilla" [...]. Así, cuando Steinberg imagina que el espacio pictórico recreado por Monet permitía "inclinar algunas partes en planos horizontales, para luego dejar que se cerraran de nuevo en una lámina vertical [...]"395, estaba teorizando sobre una nueva manera de percibir que se desarrollará plenamente en su concepto de "plano pictórico horizontal", donde la superficie y el espacio del lienzo ya no se perciben orientados en el sentido de una ventana, en un eje vertical, sino como un plano horizontal que se desenvuelve sin un aparente principio ni fin. Sobre este particular, Seitz opinaba que algunos de los cuadros de Monet "[...] tiemblan en el filo de la

[...] la crecente superficialidad de su ilusión de profundidad le empujaba a buscar sitio en la superficie literal del lienzo para lograr un equivalente de las transacciones pictóricas que solía producir en el imaginado espacio tridimensional de detrás. Al mismo tiempo, comenzó a sentir la necesidad de "escapar" del marco - del rectángulo que encierra el lienzo - que Cézanne y los cubistas habían establecido como un coordinado de diseño y dibujo que todo lo controlaba. [...] hasta la segunda mitad de los años cuarenta, y en Nueva York, no se descubrió el modo de situarse en una superficie tan extensa que sus confines quedaban fuera (o eran meramente periféricos) del campo de visión del artista mientras este trabajaba. De esta manera el pintor fue capaz de llegar al marco como resultado, en lugar de someterse a él como algo dado de ante mano. [...] En 1945, o quizás antes aún, Gorky pintó óleos en blanco y negro que fueron algo más que un tour de force. De Kooning le imitó un año o dos después. Pollock, que había pintado cuadros aislados en blanco y negro desde 1947, hizo una exposición entera con ellos en 1951. Pero fue Franz Kline, un recién llegado, el que se limitó sistemáticamente al blanco y negro, en grandes lienzos que eran como dibujos lineales monumentales. Las aparentes alusiones de Kline a la caligrafía china o japonesa estimularon los cánticos, ya iniciados ante el caso Tobey, a cerca de una influencia oriental general sobre el "expresionismo abstracto". [...] En realidad, ni uno de los "expresionistas abstractos" de comienzos -y mucho menos Kline - han sentido por el arte oriental algo más que un interés episódico. [...]“. Clement Greenberg, Arte y Cultura, Barcelona, 2016, pp. 246-247.

${ }^{394}$ Énfasis propio.

${ }^{395}$ Leo Steinberg, "Lilas de Agua de Monet" en Steinberg, Leo, et al, Other Criteria. Confrontations with twentieth-century Art, Chicago, 2007, p. 235. Las citas han sido traducidas del texto original para la redacción de esta tesis. 
navaja, allí donde la visión media entre el mundo exterior y la experiencia interior de la mente, las sensibilidades y las emociones"

Como poeta de la naturaleza que era, el estado psíquico de Monet se veía más determinado por las condiciones atmosféricas que por ninguna otra influencia”. Esa relación dinámica entre naturaleza y psique que observaba Seitz en la pintura de Monet era otro importante nexo de unión con el expresionismo abstracto ${ }^{396}$.

Así, mucho más allá de aquella categoría de poeta de la naturaleza, Seitz hace hincapié sobre la serena extensión del espacio de las obras tardías de Monet. No en balde, esta era una particularidad que, desde su punto de vista, ya había sido recogida sobre todo en las obras de la Escuela de Nueva York, integrando así la obra del francés en la historia de la abstracción y reconociendo ya - por primera vez - la influencia de éste sobre el carácter abstracto y musical de las pinturas de Kandinsky y Mondrian. Efectivamente, a partir de las últimas obras de Monet - y por extensión, desde las de las últimas Vanguardias - la pintura comenzará a desarrollar texturas de colores que han permitido concebir los cuadros solo desde un primer plano, realizando radicales combinaciones cromáticas que - como señala Greenberg - han terminado por ser consideradas con posterioridad como la semilla de la modernidad, desplegando su espacio pictórico como un "continuo ininterrumpido que conecta las cosas en lugar de separarlas". Es decir, un nuevo concepto de espacio "[...] como continuo que los objetos modulan pero no interrumpen, y una idea de los objetos como algo constituido, a su vez, por la modulación del espacio [... $]^{397}$. De este modo el viejo concepto de pintura de cámara - pensada sólo para ocupar un espacio fijo en la pared - será sustituido por una especie de pintura que "[...] sin identificarse realmente con la pared, como el mural, se extiende sobre ella [...]"398. Una disposición pictórica que, a nuestro juicio, no parece descabellado relacionar con aquella moda ya mencionada de los panoramas y cicloramas que - como habíamos considerado - pudieron también influir en el proyecto de las obras de la Orangerie.

Greenberg aseguraba que "[...] Cézanne, Van Gogh, Gauguin, Bonnard y Matisse siguieron reduciendo la profundidad ficticia de la pintura, pero ninguno de ellos, ni siquiera Bonnard, intentó algo tan radical en su violación de los principios tradicionales de la composición como hizo Monet en las etapas intermedias y últimas de su carrera"

Y es que el cuadro, por mucho que disminuya su profundidad, seguirá siendo pintura de caballete mientras sus formas resulten suficientemente diferenciadas en términos de

\footnotetext{
${ }^{396}$ William Seitz, "Monet y la Pintura Abstracta", en Alarcó, et al, Monet y la Abstracción, Catálogo de la exposición, Madrid, 2010, p. 56.

En Nueva York, a finales del año 1950 se extendió el interés por la obra de Monet, un interés que había cruzado el Atlántico y llegaría posteriormente a los Ángeles. En la retrospectiva sobre el pintor francés que se hizo en Nueva York, comisariada por William Seitz, se reafirmó la relación entre Monet y la Escuela de Nueva York.

${ }^{397}$ Clement Greenberg, Arte y Cultura. Barcelona, 2016, p. 197.

${ }^{398}$ Clement Greenberg, en Anthony Everitt. Expresionismo Abstracto, Barcelona, 1975, p. 28.
} 
claroscuro y se mantengan en un desequilibrio dramático. Y fue precisamente en estos puntos donde la práctica posterior de Monet amenazó los convencionalismos de la pintura de caballete. Y hoy, a los veinte años de su muerte, su práctica se ha convertido en el punto de partida de una nueva tendencia de la pintura.

Esta tendencia aparece en el cuadro "polifónico", "descentralizado", repetitivo all-over, que se basa en una superficie estructurada a base de elementos idénticos o muy parecidos que se repiten sin variación apreciable desde un extremo al otro. Es una clase de cuadros que aparentemente renuncia a tener un comienzo, una mitad y un final. Aunque el cuadro all-over cuelgue espectacularmente de una pared, si tiene éxito, se aproxima mucho a la decoración; al tipo de decoración que vemos en los empapelados domésticos, que se repiten indefinidamente $[\ldots]^{399}$.

¿Podemos establecer algún tipo de paralelismo entre esa repetición de elementos sin variación apreciable y la ley de la proporción numérica de la tradición extremo oriental? En cualquier caso, nos encontramos ante unas estructuras horizontales que se expresan siguiendo un patrón muy parecido al del principio del Qifú (起伏); es decir, mediante una sucesión rítmica de formas que se repiten y que pueden ser leídas como una secuencia seriada. Una semejanza, por otra parte, no exenta de diferencias importantes: mientras el Qifú adquiere sentido a través de la tradición secular de unas normas colectivas de representación, el desarrollo horizontal de la pintura norteamericana busca romper con cualquier tipo de canon o tradición dada ${ }^{400}$.

De cualquier modo, cuando en su libro Expresionismo Abstracto Anthony Everitt habla de la escala de los lienzos como factor fundamental y definitivo para las obras de la Neovanguardia, sin demasiado esfuerzo relacionamos este aspecto con el tamaño y formato de las obras tardías de Monet ${ }^{401}$. No obstante, no podemos olvidar la decisiva influencia que había ejercido la pintura de los muralistas mexicanos sobre la envergadura de los cuadros de los norteamericanos - con sus correspondientes implicaciones ideológicas y políticas - dando como resultado unas obras polémicas y radicales en las que destaca "[...] un realismo dinámico que debía mucho a los pintores revolucionarios mexicanos José Clemente Orozco, David Alfaro Siqueiros y Diego

\footnotetext{
${ }^{399}$ Clement Greenberg, Arte y Cultura. Barcelona. 2016, p.178.

${ }^{400}$ Debemos recordar que tanto la europea como la extremo oriental son culturas escópicas y que, como tal, han recurrido a sistemas de representación codificados; es decir, que se han organizado según estrictas normas colectivas para la mirada que han sido explicadas teóricamente según una suerte de academicismo contra el que, como principio, se habían posicionado los jóvenes artistas surgidos tras el final de la Segunda Guerra Mundial.

${ }^{401}$ Así, la Escuela de Nueva York jugó un papel fundamental en ese capítulo de la Historia del Arte que se ha dado en llamar modernidad tardía. Un periodo comprendido desde el año 1945 hasta 1965 o 1970 y que coincide, casi exactamente, con los años del Expresionismo Abstracto de la ya citada escuela neoyorquina. El expresionismo abstracto, que culminó la abstracción sublime del s. XX - que hundía sus raíces en la obra de Turner - concretará en 1915 con el Cuadrado Negro de Malevich y continuará con el Suprematismo, el Neoplasticismo y la Metafísica Monocroma de mediados del s XX, alcanzando su cumbre con las obras de Barnett Newman, Jackson Pollock, Willem de Kooning, Mark Rothko, Franz Kline o Adolph Gottlieb. Una corriente artística que, pocos años después, dará lugar a una segunda generación de pintores - los llamados impresionistas abstractos - que evocarán en sus obras la tradición del paisaje y recuperarán una cierta conexión con las formas naturales.
} 
Ribera [...] [Figura 36]"402. Así, afirma Everitt, los artistas recurrieron a unas telas de tamaño más grande que "[...] alteraron la relación entre el espectador y la obra: ya no le era posible 'captarla' o enmarcarla de una sola mirada [...]". Efectivamente, el espectador " [...] a veces se sentía abrumado por la extensión del color que superaba su capacidad de visión [...]"

Rothko argumentaba en 1951 que "pintar un cuadro pequeño es ubicarte fuera de tu experiencia, es contemplar una experiencia con una visión estereotipada o con una lente reductora. Siempre que pintas un cuadro grande, estás dentro de él. No es algo que tú gobiernes". Ya no era un objeto en un medio ambiente, sino un medio ambiente en sí mismo $^{403}$.

Una suerte de cosmogénesis, en el sentido formulado por Cheng quien, atendiendo a la integración del tiempo en la representación espacial de la pintura china clásica, entiende que "la intención de su práctica no era tanto fijar cualquier paraje (o escena) privilegiado como la de crear un microcosmos orgánico correspondiente al macrocosmos del Tao"404. Una comprensión del espacio pictórico similar al del fûkeiga shoshiki 風景画 書 式, aquella caligrafía en el formato horizontal de la pintura de paisaje, pero pasado por el filtro monumental de las pinturas de la Orangerie. Y es que, mediante su desarrollo horizontal, estas pinturas alcanzarán algo similar a aquel mencionado equilibrio de tensiones de la pintura extremo oriental, a través de la organización de la superficie plana de sus diseños y eliminando cualquier intención de profundidad o atisbo tridimensional en la composición de un espacio organizado mediante una disposición que se repite horizontal e indefinidamente, más allá de los límites físicos de la obra ${ }^{405}$.

Así, nos encontramos con un espacio pictórico transformado en una entidad que ha perdido aquella tradicional separación occidental ente interior y exterior, y donde el espectador ya no puede escapar de su espacio real para asomarse a su otrora espacio imaginado. Discutiblemente, a decir de Greenberg, ahora "[...] los medios son más ópticos que pictóricos: relaciones de color y forma muy divorciadas de las connotaciones descriptivas y, a menudo, manipulaciones en las que arriba y abajo, primer plano y fondo, son intercambiables". En cualquier caso, en estas obras la mirada se ve impulsada a tratar toda la superficie como un solo indeferenciable. Es decir, como un único campo de interés que, en términos de unidad, nos permite percibir el cuadro en su conjunto de manera inmediata. "[...] Y no es sólo que el cuadro abstracto parezca ofrecer un tipo de experiencia más estrecha, más física y menos imaginativa que el

\footnotetext{
${ }^{402}$ Efectivamente, durante el periodo de guerra y posguerra, en Nueva York muchos artistas de diversas tendencias estéticas se sintieron atraídos por el partido comunista. Para más información ver: David Anfam, Expresionismo Abstracto. Catálogo de la exposición, Bilbao. 2017, p. 11.

${ }^{403}$ Anthony Everitt, Expresionismo Abstracto, Barcelona, 1975, p. 28.

${ }^{404}$ François Cheng, Aliento y Espíritu. Textos teóricos chinos sobre el arte pictórico, Valencia, 2017, p. 167.

${ }^{405}$ Ënfasis propio.
} 
cuadro ilusionista, sino que parece hacerlo sin los nombres y los verbos transitivos, por decirlo así, del lenguaje de la pintura [...]"406.

Al amparo de esta idea, no por casualidad, Henri Michaux considera la pintura como una extensión "no verbal de la escritura: Una elaboración de la poesía con otros medios. Al igual que Hartung y Mathieu, estuvo influenciado por la caligrafía oriental y habla de 'estar poseído por los movimientos, completamente tenso, por esas formas que vienen a mí a toda velocidad, en una sucesión rítmica" " [Figura 37] ${ }^{407}$. Efectivamente, como las palabras, los elementos compositivos de estas pinturas son en sí mismos realidades físicas que para ser usadas requieren de una cartografía mental; es decir, de unos nichos culturales de asimilación y de unos códigos culturales de reconocimiento. Pero, en el contexto posbélico de las Neovanguardias del s. XX las funciones connotativas de la cultura dominante se habían replegado desde subespacios culturales para alcanzar, como nos indica Bryson, nuevos valores "[...] como medio para expresar visualmente su propia existencia ante sí misma [...] que es lo mismo que decir que el éxito de una imagen en su naturalización de las creencias visuales de una determinada comunidad depende del grado en que guarde su incógnito como entidad independiente" ${ }^{\text {408 }}$. Es decir, que los aspectos técnicos de la pintura establecieron relaciones con los nuevos dominios ideológicos surgidos, así mismo, de un nuevo orden mundial $^{409}$. Entonces en este caso, como ya hemos observado en capítulos anteriores ¿la pintura recurre al arte de otras culturas o al anterior o más antiguo de la propia?

Sobre este parecer, es interesante recordar el interés que despertaba entre algunos de aquellos pintores norteamericanos - como es el caso de Pollock y Rothko - el denominado arte primitivo. Así, Rothko llegará a afirmar que "el arte arcaico y la mitología contienen símbolos eternos" por lo que, entonces, nos resultará más fácil comprender por qué - ante el descrédito de todo el arte previo a la guerra - las características artísticas de las tribus indígenas de Norteamérica llegarán a cobrar gran relevancia para algunos de estos pintores ${ }^{410}$. En el caso concreto de Pollock, este había mostrado un claro interés por la figura del chamán, a través de una estrecha vinculación

\footnotetext{
${ }^{406}$ Clement Greenberg, Arte y Cultura. Barcelona. 2016, p.159.

${ }^{407}$ Anthony Everitt, Expresionismo Abstracto, Barcelona, 1975, p. 56.

${ }^{408}$ Norman Bryson, Visión y Pintura. La lógica de la mirada, Madrid, 1991, p. 32.

${ }^{409}$ Esta nueva generación de pintores había tomado una nueva deriva respecto a la generación anterior de expresionistas abstractos. La primera estaba más preocupada por expresar conceptos y sentimientos, como reflejo de un anhelo que aspiraba a subrayar la experiencia visual del mundo como tema de la pintura. Así, la vehemencia emocional, la psicología, la experiencia interior o los recursos que precisaba la creación artística fueron el cauce requerido para su creación. Mientras, la segunda generación de expresionistas abstractos se definió y diferenció de la primera. Así, su producción se caracterizó por unas obras donde el campo pictórico estaba fragmentado mediante un conjunto de pinceladas más pequeñas y de alguna manera ordenadas, que de alguna manera sugería algún tipo de referencia conceptual o figurativa, recurriendo a elementos paisajísticos.

${ }^{410}$ Efectivamente, el arte de África o de Oceanía habían dejado de ser “[...] el centro de interés, como lo había sido para los cubistas y los expresionistas alemanes [...] su lugar lo ocupara ahora el arte de los nativos americanos, era una prueba de que los jóvenes pintores estadounidenses buscaban una genealogía autóctona y no europea, para construir así una identidad propia [...]”. En: David Anfam, Expresionismo Abstracto, Catálogo de la exposición, Bilbao, 2017, pp. 18-19.
} 
del arte con los fenómenos suprahumanos [Figura 38] ${ }^{411}$. Es decir, lo que podríamos entender como la recuperación de una estrecha relación entre el arte y el ritual; de una suerte de cosmovisión animista donde se retoma la relación entre el hombre y el medio natural a través, en palabras de Rothko, de "un panteísmo en el cual el hombre, los pájaros, las bestias y los árboles - tanto conocidos como desconocidos - se funden en una única idea trágica" ${ }^{, 412}$.

Por lo tanto, no cabe sorprenderse ante la curiosidad que la mayoría de estos pintores norteamericanos habían mostrado hacia ciertos aspectos del arte extremo oriental - especialmente hacia su pintura y su caligrafía - aspecto que se vio reflejado por ejemplo, en el caso de Mark Tobey - además del interés ya mencionado por el arte de los indios americanos - en su interés por las xilografías japonesas. Nos encontramos entonces con una gran deuda con el arte extremo oriental que - en lo que atañe a la comprensión del espacio - se verá materializada en el formato alargado de unos cuadros que, más que ilustrar un ámbito, son la expresión de una sensibilidad. Es decir, que la obra dejará de ser una mera representación para transformarse en el catalizador de la expresión directa de una emoción. En suma, como nos recuerda Paloma Alarcó:

Seitz presentaba a Monet como un artista que "forzó el naturalismo hasta hacerlo reventar", que en su último periodo "re-formó la naturaleza conforme a su angustia interior y a la visión distorsionada que le acuciaba, para realizar sus únicas obras auténticamente expresionistas". Monet fue a su juicio un puente decisivo en la historia del arte moderno, un puente entre Coubert y Kandinsky, entre el materialismo y el espiritualismo, entre el naturalismo y la abstracción. Además, la espiritualidad que había en la comunión de Monet con la naturaleza miraba ciertamente tanto al pasado, a los texto de Ralph Waldo Emerson y Henry David Thoreau, como al futuro de Pollock y Newman. Por eso sus formas le resultaban familiares al público estadounidense. Aún más, el Monet de Seitz sintonizaba mejor con los intereses espirituales y psicológicos de los expresionistas abstractos - mejor que el Monet de Greemberg - y era una buena respuesta a la crítica del "monismo" de los impresionistas que había hecho Newman ${ }^{413}$.

Hablamos de obras monumentales que, como Los Nenúfares, precisan de una cierta distancia para poder ser contempladas. A decir de Leonhard Enimerling “[...] Monet, al igual que sus sucesores los puntillistas y los divisionistas, necesita una distancia que permita que la pincelada y los trazos de color se fundan en el ojo para

\footnotetext{
${ }^{411} \mathrm{~A}$ diferencia de los otros que se inspiraban en el arte de las tribus indígenas, los pintores integrantes de la escuela del expresionismo abstracto norteamericano recurrieron a la combinación de la espiritualidad de los signos nativos con una introspección más cercana al surrealismo. "“...] Las relaciones ser humano - animal de sus primeras obras, el concepto de tótem mismo; la unión de contrarios; el recurso del arte llamado primitivo o prehistórico 'precultural'; el rechazo a una civilización responsable del infierno de la Segunda Guerra Mundial; la transformación del pintor en un chamán, en una especie de médium para que el arte fluya desde su inconsciente sin ningún control de la razón [...]”. En David Anfam, Expresionismo Abstracto, Catálogo de la exposición, Bilbao, 2017, p. 48.

${ }^{412}$ Mark Rothko, et al David Anfam, Expresionismo Abstracto, Catálogo de la exposición, Bilbao, 2017, p.31.

${ }^{413}$ Paloma Alarcó, Monet y la Abstracción, Catálogo de la exposición, Madrid, 2010, p. 55.
} 
poder alcanzar una unidad pictórica [... $]^{, 414}$. Un planteamiento correcto con el que, aun así, no acabamos de estar del todo de acuerdo ya que, a nuestro juicio - lejos de Signac o Seurat - el tamaño de las Grandes Décorations de Monet más que buscar un cierto efecto óptico desde un analítico punto de vista cartesiano, buscan una dimensión más psicológica del espacio. Es decir, expresar una impresión a través de una secuencia de emociones libres, por medio de algo similar a un ejercicio espiritual del arte ${ }^{415}$. Desde ese momento, sentencia Anfam, en la pintura [...] los factores de espacio y tiempo cobran una importancia fundamental, y se traducen en el significado que logran los formatos de sus cuadros y su técnica de la "action painting" 416 . Entendemos, por lo tanto, que el artista retomará y trabajará con lo que entiende que es un concepto nuevo que, sin embargo, como ya hemos visto ya estaba definido desde la antigüedad; desde la antigua dinastía Han 漢: el denominado yuzhou (宇宙) o la idea extremo oriental del espacio - tiempo. En cualquier caso, hablamos de las obras de algunos pintores expresionistas abstractos - tales como Jackson Pollock, Clyford Still, Willem de Kooning o Mark Rothko ${ }^{417}$ - que con su forma de mirar facilitarán el reconocimiento de los logros del maestro francés. De este modo, entre Los Nenúfares y algunas obras de la escuela de Nueva York se plantearán algunos paralelismos cuyo alcance llegará mucho más allá del plano pictórico ${ }^{418}$.

Cuando el grupo de jóvenes pintores norteamericanos recuperó la obra de Monet, el mundo - tras la catarsis que supuso la debacle de la Segunda Guerra Mundial - intentaba recuperarse y comenzar una etapa nueva. De la misma manera, cuando Monet inició su nueva deriva creativa, el mundo - tal y como se había conocido hasta la fecha - se quebraba y desaparecía. En ambos casos, el antiguo sistema de valores necesitaba de un reemplazo, mientras una crisis de identidad obligaba a los artistas a buscar y mirar hacia otros lugares, en busca de una nueva sensibilidad en el seno del arte. Una forma de representar y percibir distinta ${ }^{419}$.

\footnotetext{
${ }^{414}$ Leonhard Enimerling. Expresionismo Abstracto. Catálogo de la exposición, Bilbao, 2017, p. 8.

415 Énfasis propio.

${ }^{416}$ David Anfam, Expresionismo Abstracto, Catálogo de la exposición, Bilbao, 2017, pp. 22 - 23.

${ }^{417}$ Debemos recordar que su influencia sobre aquellos pintores norteamericanos fue tal que su obra tardía ha estado presente en los análisis formales del expresionismo abstracto. "[...] el mérito de haber iniciado la recuperación de Monet no se les reconoció a aquellos sagaces y atrevidos compradores. El mérito era de los artistas. [...] el surrealista francés André Masson, quien en 1952 había escrito en la revista francesa Verve que la Orangerie era la "Capilla Sixtina del impresionismo", Masson decía que las Grandes Décorations eran la obra suprema del pintor, y expresaba su confianza en que los jóvenes artistas franceses la descubrieran y reconocieran los nuevos caminos que abría su pintura. En Estados Unidos, los críticos y periodistas coincidieron en general [...] Y no cambia nada que él no pudiera reconocer de manera consciente o aceptar "lo abstracto" - las cualidades del medio por sí solas - como un principio de coherencia: eso está ahí diáfano, en los cuadros que pintó en su vejez [...]”. En Paloma Alarcó, Monet y la Abstracción, Catálogo de la exposición, Madrid, 2010, p 49.

${ }^{418}$ Ya entre 1952 y 1955 - antes de que Greenberg, Seitz y otros comenzaran a articular conexiones entre Monet y el expresionismo abstracto - la referencia del impresionismo se estaba convirtiendo en uno de los rasgos distintivo de los nuevos valores de la pintura neoyorquina, al introducir variaciones formales en la pintura del movimiento y, por lo tanto, al cambiar la comprensión del espacio pictórico.

${ }_{419} \mathrm{M}^{\mathrm{a}}$ del Mar Sueiras, "El espacio en la pintura contemporánea", en ASRI - Arte y Sociedad, Revista de investigación, $\mathrm{N}^{\mathrm{o}} 12,2017$, p. 4.
} 
Ya en 1957, la revista LIFE publicaba Old Master's modern heirs [Figura 39] un artículo sobre los herederos modernos de Monet, donde describe para los lectores cómo "[...] la despreciada obra de Monet de sus últimos años inspira hoy a una generación de pintores [...] que están creando a su estilo una pintura de pincelada explosiva y cromatismo vibrante $[\ldots]^{, 420}$.

[...] El retraso que apreciaba el trabajo tardío de Monet fue causado principalmente por el advenimiento del cubismo. En el mismo momento en que Monet estaba tratando de capturar los efectos efímeros de la naturaleza, de la luz, el aire y el agua, pintores como Picasso estaban tratando de transmitir las formas permanentes de la naturaleza, formas fundamentales no afectadas por los accidentes de la atmósfera. Sus desarrollos dominaron el mundo del arte hasta finales de la década de 1940, cuando artistas estadounidenses como Jackson Pollock abandonaron estilos cubistas para crear un arte espontáneo de colores sensibles y superficies tempestuosas. Estas innovaciones abrieron los ojos del mundo del arte a las innovaciones similares de Monet. Ahora una nueva generación de pintores, algunos de los cuales se muestran aquí con sus obras, está derivando nueva inspiración del pintor francés que "llegó demasiado pronto" $"$ "21

Curiosamente, en este artículo se habla de los herederos de Monet y la vuelta a la naturaleza de unas obras que parecen querer recuperar el mundo natural y que algunas voces consideran como precursoras de una cierta conciencia ecológica en el marco del arte, en un contexto de alarma general sobre los efectos de la exposición a la radioactividad y de los vertidos contaminantes ${ }^{422}$. Pero, esta recuperación del mundo natural ¿pudo estar también relacionada con una respuesta a la suburbanización del expresionismo abstracto que se originó en un momento de gran crecimiento demográfico tras la hecatombe de la Segunda Guerra Mundial? y, atendiendo a una cuestión pertinente para esta investigación, este interés por el mundo natural ¿puede haber estado influenciado por el paralelismo que se establece entre arte y naturaleza en la pintura extremo oriental? Un paralelismo entre el espacio natural y el espacio pintado que nos obliga a retomar el que, a nuestro juicio, también se establece entre la pintura extremo oriental, las obras tardías de Monet y muchos de estos pintores norteamericanos. Al amparo de esta idea - del registro de algunos valores de la cultura china y japonesa sobre la pintura occidental - con motivo de la histórica exposición del MoMA sobre Monet, nos encontramos con la insistencia de Seitz sobre el papel decisivo que la espiritualidad y la naturaleza misteriosa habían desempeñado en las

\footnotetext{
${ }^{420}$ En Paloma Alarcó, Monet y la Abstracción. Catálogo de la exposición, Madrid, 2010, p. 61.

${ }^{421}$ Revista LIFE, 2 de Diciembre 1957. Old Master's Modern Heirs. The scorned work of Monet's later years inspires a present generation of painters, p. 94. Las citas han sido traducidas del texto original para la redacción de esta tesis.

${ }^{422}$ La influencia de Monet en el discurso de la obra de los pintores de aquel momento comenzaba a ser reivindicada. En 1953 Barnett Newman enviaba una carta al presidente del MoMA, en la que ponía en tela de juicio la política que hasta entonces había llevado el museo, obviando la influencia sobre la pintura contemporánea de Monet y los impresionistas. Por entonces, André Masson publicaba Monet le fondateur, donde reivindica el peso de Monet sobre la pintura de la segunda mitad del s Xx. Pero lo más destacable de este escrito es que pone el énfasis sobre las Grandes Decorations de la Orangerie, invitando a los jóvenes pintores a seguir el nuevo camino que estas obras habían inaugurado.
} 
pinturas del maestro francés ${ }^{423}$. Por consiguiente, no nos parece descabellada su consideración como un "panteísta instintivo", al señalar como su fe en una realidad inmaterial había propiciado el inicio de una nueva fase esencial en la Historia del Arte del s XX.

Efectivamente, la evolución de la obra del pintor francés hacia un naturalismo más metafísico parece, a nuestro juicio, haber influido sobre la abstracción de la comprensión del espacio natural, interpretado por Monet como una abstracción del espacio pictórico, y decisiva en la interpretación sinestésica de los colores de la pintura de Kandisnky. Una sinestesia musical que compone el espacio mediante una combinación rítmica de colores y que, de algún modo ¿puede tener relación con los principios compositivos de los artistas del pincel? Pero si otorgamos tanto a estas como a aquellas pinturas la categoría de sinestésicas, tenemos que aceptar que sus principios "compositivos" han recaído sobre otros valores, a decir de Greenberg, menos evidentes y mensurables.

[...] Acabó por encontrar lo que buscaba, que no era tanto un principio nuevo como un principio que englobaba además otras cosas, y que no se basaba en la naturaleza, sino en la esencia del arte mismo, en "lo abstracto" del arte. [...] esos enormes primeros planos que son sus últimos Nenúfares dicen - a los expresionistas abstractos radicales y junto con ellos - que se necesita mucho espacio físico para desarrollar suficientemente una idea pictórica potente que excluya la ilusión de profundidad espacial. Las amplias manchas garabateadas con que están pintados los Nenúfares dicen que la superficie del cuadro ha de respirar. [...] los Nenúfares nos dicen, una vez más, que todos los cánones de excelencia son provisionales $[\ldots]^{424}$.

En cualquier caso, a partir de entonces la pintura alcanzará nuevas formas, recurriendo en principio a la limpia y armoniosa composición de un espacio que, se nos antoja, parece evocar "[...] aquellas suaves atmósferas de los conciertos de instrumentos de cuerda, tan valorados por el emperador Ming Huang, y que constituían uno de los temas pretéritos de los pintores del estilo T’ang [... ${ }^{\prime 425}$. De hecho, la supresión de los contrastes de valor llegará a provocar la ruptura con aquella tradición pictórica occidental que aspiraba a ser tridimensional mediante el recurso de la luz y la sombra. Es decir, que en vez de bucear en su profundidad, la pintura comenzará a

\footnotetext{
${ }^{423}$ Así, por primera vez en treinta años, comenzaron a organizarse exposiciones dedicadas a Monet por Estados Unidos. La prensa especializada y las revistas más populares de gran tirada comenzaron a hacer hincapié en la obra del pintor. Un eco de gran magnitud para asombro de los críticos que habían comenzado aquel movimiento. Un redescubrimiento iniciado sobre 1955, como producto de la colaboración iniciada entre críticos, conservadores de museos, coleccionistas y hasta los propios artistas. Las tres exposiciones de Monet que se organizaron en 1957 en San Luis/Mineápolis, Chicago y Boston fueron las primeras que organizaban museos estadounidenses desde 1927, año en el que se le había dedicado una conmemorativa en Boston al maestro francés. En los tres decenios que mediaron entre estas fechas hubo tres destacadas exposiciones de Monet en galerías de Nueva York. Durand-Ruel en 1940, Wildenstein en 1945 y Knoedler en 1956.

${ }^{424}$ Clement Greenberg, en Alarcó, Monet y la Abstracción. Catálogo de la exposición, Madrid, 2010, p. 138.

${ }^{425}$ Michel Courtois, 1969. Pintura China, Madrid, 1969, p. 271.
} 
recorrer su horizontalidad para que de esta manera el cuadro, como un texto, pueda ser casi escrito y leído. Así, como respuesta al academicismo geometrizante de la primera pintura abstracta, surgirá una abstracción más lírica, bajo cuya expresión plástica se amparará un arte multidimensional, poético y cuasi musical ${ }^{426}$. Pero lo que tal vez Greenberg y otros críticos no han parecido apreciar ha sido el cambio o, mejor dicho, la sustitución del paradigma espacial. En otras palabras, la modificación del sistema de representación del espacio pictórico que connota a su vez otro cambio en el secular sistema de pensamiento, caduco y dominante, de la cultura occidental.

Nos encontramos pues con un nuevo aspecto, más filosófico y por lo tanto estético, que enlaza la pintura de Occidente con la del Extremo Oriente. Un "momento estilístico" a partir del cual los jóvenes pintores comenzarán a componer el espacio de sus pinturas, mediante la alternancia de fragmentos - brochazos y colores - sobre inconmensurables fondos neutros que, en su vacuidad, enfatizan los grupos o fragmentos pintados. He aquí, por lo tanto, un aspecto fundamental ya que al imprimir a la obra un peculiar acento secuencial se comenzará a recurrir a formatos horizontales ¿Pudo haber sido este el comienzo de la recuperación para la pintura de los dípticos, trípticos y polípticos de más tres paneles? Un recurso plástico característico del arte europeo, caído en desuso y que, a nuestro parecer, se ha recuperado poniendo en práctica aquella herencia china del Qifú (起伏) y de la proporción numérica, mediante el desarrollo horizontal de unas pinturas que - como un biombo - se extienden de un extremo a otro del conjunto de paneles pintados:

[...] Sin embargo -en particular en el impresionante tríptico del Museo de Arte Modernoel equilibrio se mantiene mediante una horizontal indeterminada; un cuadro sombrío ante el cual el globo circundante del cielo, visto en las nubes iridiscentes que se curvan hacia abajo en una imagen invertida, se convierte en uno con el agua para formar una atmósfera común. La superficie del estanque apenas es adumbrada por las constelaciones inacabadas de lechos de lirios que, al igual que los vuelos de aves, marcan el espacio en expansión. [...] Para Monet estos paisajes finales de agua, como los de las playas normandas, el Sena, o el mar abierto, eran registros de la realidad percibida, ni abstracta ni simbólica; pero para él, desde el principio, la naturaleza siempre había parecido

\footnotetext{
${ }^{426}$ Algunos pintores norteamericanos comienzan a trabajar de una manera particular, haciendo en algunos casos "escuela". De aquí el origen de la "escuela del Pacífico", que se desarrolló sin ninguna comunicación con Europa ni casi con Nueva York, como por ejemplo pintores como Mark Tobey y su grupo de Seattle. Al mismo tiempo, en el contexto norteamericano parecidas investigaciones dieron lugar a la aparición de obras como las de Pollock, De Kooning, Rothko, Still y de esa Escuela del Pacífico.

Fue a finales de 1946, cuando Wols, Hartung, Mathieu, Bryen y algunos pintores más se ponen de acuerdo y se unen a favor del abstraccionismo lírico. En 1947, en la exposición L'Imaginaire, y en 1948 en HWPSMTBb y White and Black, presentadas por Jean-José Marchand, Éduard Jaguer y Michel Tapié, abogarán, entre otras cosas, por la explosión lírica, la anarquía estructural y por la exploración de la materia prima, es decir, lo informal. Por otra parte, numerosos pintores estadounidenses se instalan en París. Así, Joan Mitchell, Philip Guston, Jean.Paul Riopelle o Sam Francis se convierten en los primeros artistas norteamericanos en visitar la Orangerie. Para ellos, que entonces comenzaban su andadura pictórica por la abstracción, el descubrimiento de la obra de Monet fue toda una revelación para su carrera. Así, pintores como Joan Mitchell, Sam Francis, Philip Guston, Nell Blaine, Miriam Schapiro, Wolf Kahn y otros, comenzaron a dirigir la pintura gestual hacia un terreno artístico marcado por la evocación de unas formas naturales que se organizarían mediante pinceladas más estructuradas y un espíritu más sereno y meditativo.
} 
misteriosa, infinita e impredecible, así como visible y lícita. Estaba preocupado por las realidades "desconocidas", así como las aparentes. "Su error", le dijo una vez a Clemenceau, "es desear reducir el mundo a su medida, mientras que, ampliando su conocimiento de las cosas, usted encontrará su conocimiento de la auto-ampliación" ${ }^{\text {"427. }}$.

En esta tesitura, en esta nueva pintura se perpetuará un nuevo tipo de planitud, conformada a partir de contrastes amortiguados, mediante un equilibrio de tensiones que, en alusión a la obra de Monet y en palabras de Steinberg "[...] cortan el lienzo, partes de ellos 'reales' y el resto en reflexión, mientras que un solo horizontal [...]

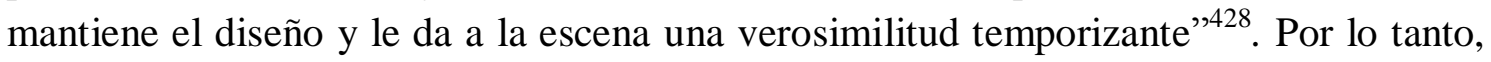
nos encontramos ante unas líneas compositivas que paradójicamente delimitan pero no limitan la obra. En consecuencia, el espacio pictórico dejará de entenderse como un objeto aislado y codificado, y de esta manera, en pinturas como las de Newman - quien había estudiado el impresionismo tardío - se llegará a formas más radicales, comenzando entonces a aplicarse la categoría de campos de color [Figura 40]. A decir de Greenberg ${ }^{429}$ :

Pese a ello, muchos cuadros all-over parecen triunfar justamente en virtud de su uniformidad, de su pura monotonía. La disolución de lo pictórico en la mera textura, en una aparente sensación cruda, en una acumulación de repeticiones, parece hablar en nombre de algo muy profundo en la sensibilidad contemporánea, y responde a ello.[...] all-over, lo repetitivo, tal vez responda a la idea de que todas las distinciones jerárquicas han quedado literalmente exhaustas e invalidadas; de que ningún área u orden de experiencia es intrínsecamente superior, en cualquier escala de valores definitiva, a cualquier otro campo u orden de experiencia $[\ldots]^{430}$.

Por lo tanto, será a partir de Monet cuando la pintura ponga el acento en la intensidad de unos tonos que recrean campos pictóricos que se desarrollan en sentido lateral, renunciando a esa ilusión mensurable entre la superficie pintada y la ficticia de

\footnotetext{
${ }^{427}$ William Seitz. Claude Monet: seasons and moments. Catálogo Exposición del Museum of Modern Art. New York: 1960. Catálogo del MoMA p. 52. Clemenceau, op. cit., pp. 154-155. Las citas han sido traducidas del texto original para la redacción de esta tesis.

${ }^{428}$ Leo Steinberg, et al "Monet's water Lilies" en Steinberg. Leo, Other Criteria. Confrontations with Twentieth-Century Art, Chicago, 2007, p. 235. Las citas han sido traducidas del texto original para la redacción de esta tesis.

${ }^{429}$ Pero debemos recordar que los artistas que integraban el expresionismo abstracto no se entendían ellos mismos relacionados con la obra de Monet. La aproximación a su manera de comprender el espacio fue tal vez una respuesta inconsciente, un impulso revelador de una ruptura con el estatus del arte hasta entonces reconocido. Tal vez, por la fuerza de la herencia o por la necesidad de ser aceptados, se declararon herederos de diversos pintores abstractos, cubistas y surrealistas ya que, por otra parte, la teoría y su herencia se puede encontrar en sus obras. Pero un aspecto tan esencial como es la comprensión del espacio - y su relación con la percepción del individuo en un contexto cultural - no fue un asunto de interés explícito dentro de los recursos del arte. Más bien, se ha entendido como un recurso visual de lenta asimilación.

${ }^{430}$ Clement Greenberg, Arte y Cultura, Barcelona, Paidós Estética, 2016, p. 180.
} 
la profundidad representada ${ }^{431}$. De este modo, las consideraciones formales se convirtieron en el verdadero valor pictórico, a través de una nueva estructura para una pintura que desde entonces - en palabras del mismo Monet - se definirá como "cromática y sinfónica" ${ }^{432}$. Es decir, que el cambio de paradigma del espacio pictórico se dará a través de una mirada renovada de la pintura, que pasará entonces a ser tan musical como pictórica, en el sentido formulado por Cheng cuando, en alusión al Libro de la Música ${ }^{433}$, menciona que la "vía del rito y de la música es la vía misma del cielo y de la tierra. Esta música visual, por su doble aspecto melódico y armónico, se une al aliento primordial del que proviene el ritmo irresistible del universo" ${ }^{~}{ }^{434}$. Unas palabras que ilustran como desde ese momento - al igual que en la estructura de una pieza musical oriental tradicional - en la pintura se repite una melodía con diferente ejecución, recurriendo a la sucesión de acordes distintos que se alternan a través de diferentes voces pero con un idéntico desarrollo. Por consiguiente, nos encontramos con una visión que, más allá de un ámbito definido por unas formas finitas, nos permite obtener de un solo vistazo infinitas extensiones. Es decir, unas pinturas donde no hay límites, donde no están determinados los lindes para su autopropagación, alcanzando entonces un efecto infinito:

"Ciertos procedimientos y soluciones comunes subyacen a las obras de este período, aunque están tanto en el motivo como en su interpretación. Como antes, las composiciones son "descubiertas" bloqueando una parte de una escena sin reorganizar sus elementos, pero ahora se hace con mucha menos consideración por la tradición paisajística occidental. El recorte radical llama a la mente impresiones japonesas, de las cuales Monet se convirtió en un ávido col-lector. Al igual que en Fisherman s Cottage onthe Cliffs at Varengeville (uno de un grupo grande), la superficie a menudo se divide en muy pocas áreas grandes. Las recesiones horizontales se evitan o se coaccionan suavemente hacia la vertical. Dentro de las formas cuidadosamente contorneadas, un amplio vocabulario de caligrafía colorista se traduce simultáneamente en pigmento tanto la vibración de la luz como los ritmos y texturas de las hierbas, la tierra, las nubes, el follaje, las superficies de roca y las olas (Uno sospecha que los pintores y calígrafos de China que originaron los modos tradicionales deben haber hecho traducciones similares a partir de percepciones de primera mano.) ${ }^{435}$.

En suma, hablamos de una nueva pintura que será una consecuencia de la rehabilitación de la figura de Monet en general - y en particular de su obra tardía - y en

\footnotetext{
${ }^{431}$ Efectivamente, como bien señaló Greenberg, a partir de los Nenúfares de Monet, la pintura abandonará su carácter ilusionista y - al plantearse esta consideración - las imágenes mejoraron sus cualidades formales, es decir, su carácter propiamente pictórico.

${ }^{432}$ Debemos recordar que en la tradición de las culturas extremo orientales no se da la radical separación occidental entre música, literatura y artes visuales.

${ }^{433}$ Yuejing 樂經 (Libro de la música): Uno de los seis textos fundamentales del pensamiento chino, de origen confuciano. Trata sobre la relajación de la mente, para que el sabio muestre su armonía interior.

${ }^{434}$ François Cheng, Vacío y plenitud, Madrid, 2004, p. 185.

${ }^{435}$ William Seitz. Claude Monet: seasons and moments. Catálogo Exposición del Museum of Modern Art. New York: 1960.Catálogo del MoMA pp. 16-19. Las citas han sido traducidas del texto original para la redacción de esta tesis.
} 
la que jugarán un papel determinante algunos críticos de arte y artistas emergentes, defensores de la nueva abstracción ${ }^{436}$. Pero, sobre todo, unas obras que supondrán una verdadera revolución para la manera de comprender el espacio en la pintura que, en consecuencia, modificará la actitud del espectador, haciendo que esta se vuelva más activa e incorporando para el arte el concepto de empatía. A partir de este momento, quien contempla la obra se sumergirá en ella - a través del uso de una escala monumental - en una atmósfera envolvente donde la mirada del espectador se desplaza a medida que se desarrolla la obra. Así, a falta de una estructura geométrica, se acentúan y modula las áreas del espacio pintado mediante el color y el valor, a través de la composición del espacio ¿Un nuevo lenguaje artístico conformado a partir de nuevos códigos visuales? ¿Un lenguaje artístico con nuevas estructuras que, por lo tanto, educarán en nuevos códigos perceptivos? O ¿hablamos de un lenguaje artístico conformado con un préstamo de otros códigos culturales?

\footnotetext{
${ }^{436}$ Había un gran interés por relacionar las obras de artistas norteamericanos con el prestigio que se daba a los pintores europeos. La conclusión radical de la doctrina del aislamiento de las facultades fue la que siguió Greenberg. Para este la facultad estética estaba separada de la cognitiva y de la moral, por lo que la obra de arte debía excluir toda referencia a ellas, siendo la pintura pintura pura mediante el uso abstracto del color y la línea. Una versión de la teoría kantiana dio lugar al formalismo ha resultado obsoleta en el discurso del arte moderno
} 
"[...] Bella no es la duración de un estado, sino la fugacidad de una transición. Bella no es la presencia total, sino un aquí que está recubierto de una ausencia, que por el vacío es menor o más ligero. Bello no es lo claro o lo transparente, sino lo que no está delimitado nítidamente $[\ldots]^{, 437}$

\section{5.- LOS DÍPTICOS, TRÍPTICOS Y POLÍPTICOS EN LA PINTURA}

$\mathrm{P}$ ara realizar el análisis de una obra pictórica necesitamos comprender tanto los aspectos formales como los estéticos. Es decir, comprender la relación íntima que se da entre forma y pensamiento que, como proceso conceptual, mantiene un cierto paralelismo con la metáfora. En otras palabras, valorar tanto la estructura, organización interna de la obra y la técnica general o, lo que es lo mismo, todas aquellas características formales que nos permitan incluir dicha obra dentro de una corriente estilística determinada. Porque, al traducir a una forma gráfica una idea, una emoción o un sentimiento, se conforma un ideograma al que solemos atribuir una capacidad de circulación casi universal y su estudio - sea una hipótesis planteada como verdadera o como falsa - no puede limitarse a una mera interpretación de la imagen que la analice solamente como una lectura de un espacio; será necesario plantearlo desde su simbolización y codificación cultural.

En esta tesitura, en el espacio temporal que transita de la modernidad/colonialismo a la postmodernidad/postcolonialismo, nos encontramos ante el final de una etapa inevitablemente avocada a un importante cambio sobre la idea de la jerarquización de las culturas. Así, finalizado el periodo histórico marcado por el colonialismo, las culturas dominadas comenzarán a expresarse a través de su propia voz, utilizando un lenguaje visual que definirá y reivindicará su identidad. De este modo surge una nueva conciencia cultural que, a través de la actividad artística, contribuirá y mediará en las relaciones interculturales, exportando una cultura visual cuya aceptación

${ }^{437}$ Byung-Chul Han, Ausencia, Buenos Aires, 2019, p. 53. 
como préstamo flexibilizará la comunicación transcultural y enriquecerá la capacidad de expresión de los lenguajes del arte. Porque al final, como bien señala Serraller “[...] materia y signo son los accidentes de las huellas del tiempo, y el arte la evocación elegíaca de este. [...] un arte que innova excavando la superficie de lo recóndito del pasado, al que 'araña' o 'rasca', porque no en balde, tras su afición por el palimpsesto, es fiel al sentido etimológico del término: 'rascar de nuevo' [...]"438.

Pero los valores culturales son una norma no escrita difícil de modificar. Así, para la gran mayoría de los pintores no occidentales, la idea de la pintura de caballete posee unas connotaciones que difícilmente la desvinculan de Occidente - y por consiguiente, de estar conceptualmente vinculada a la política colonialista e imperialista - abarcando un vasto periodo que va desde el Renacimiento hasta el final de la modernidad. Por ejemplo, todavía durante los años 50 y 60 del pasado s. XX el internacionalismo $^{439}$ de la modernidad consideraba tan universal la abstracción como las ideas de Platón. Mientras, por el contrario, en la siguiente posmodernidad globalizada el artista buscará mostrar elementos reconocibles de su cultura e identidad, combinándolos de alguna manera como medio de acercamiento cultural. Por consiguiente, se dará una deconstrucción de la propia tradición que, en el caso de Occidente, a partir de los años 80 aprovechará la avalancha de propuestas de otras culturas. Hablamos por lo tanto de una postmodernidad híbrida que fusiona lo global con lo local, pero evitando incurrir en una práctica apropiacionista para combinar elementos de diferentes culturas. Es decir, que estos nuevos lenguajes culturales resultado de una paulatina hibridación cultural - no son ni exclusivos ni característicos de una sola cultura, ni tampoco el resultado de elementos de diferentes culturas reunidos de forma gratuita. Por el contrario, nos referimos a una lenta y sólida asimilación de elementos estéticos - y, por lo tanto, filosóficos y culturales - donde los factores de espacio y tiempo tienen un valor insoslayable.

Efectivamente, hemos visto como en nuestra reciente Historia del Arte los creadores han querido - y en ocasiones también necesitado - tomar sus distancias frente a los pretendidos sistemas dominantes. En consecuencia Serraller observa que "[...] al arte de nuestra época le ocurre lo mismo que al resto de los valores coetáneos: que han perdido toda consistencia dogmática, porque ya no se cree que existan valores absolutos e intemporales fuera de los cambiantes avatares del tiempo" "440. Así, desde Oriente hasta Occidente la pintura evolucionará hacia un espacio nuevo y necesariamente plano, que sólo mantiene algún vínculo con la concepción del espacio métrico europeo por convenciones culturales. Porque, lo que es conocido compete a la memoria y atestigua los efectos del tiempo y del espacio en la subconsciente emocional. De este modo, observa Greenberg:

[...] Los viejos maestros perseguían efectos escultóricos no sólo porque la escultura aún les enseñaba lecciones sobre el realismo, sino también porque la visión posmedieval del

\footnotetext{
${ }^{438}$ Francisco Calvo Serraller, El Arte Contemporáneo, Madrid, 2001, p. 29.

${ }^{439}$ Énfasis propio.

${ }^{440}$ Francisco Calvo Serraller, El Arte Contemporáneo, Madrid, 2001, p. 11.
} 
mundo ratificaba las ideas de sentido común sobre el espacio como algo libre y abierto, y sobre los objetos como islas en ese espacio libre y abierto. En el arte moderno se ha insinuado un concepto opuesto de espacio como continuo que los objetos modulan pero no interrumpen, y una idea de los objetos como algo constituido, a su vez, por la modulación del espacio. El espacio, como continuo ininterumpido que conecta las cosas en lugar de separarlas $[\ldots]^{441}$.

Nos encontramos por lo tanto ante un collage en el que, paradójicamente, al tiempo que se fusiona una nueva manera de comprender el espacio pictórico - como un rechazo a las europeas perspectiva y pintura de caballete - se recupera la tradición de los dípticos y trípticos de la pintura europea. Al hilo de esta idea cabe hacerse entonces algún interrogante: ¿Podemos entender la figura del artista como una especie de antena que percibe y anticipa los cambios de dirección que subyacen en la base de su sociedad? Y, en este caso ¿Hablamos de una sincera transformación cultural o solo de un juego de imágenes que no tiene nada que ver con la realidad? De cualquier modo, entendemos que cada época y estilo pictórico tienen su propia relación con los asuntos históricos, tanto en el marco oriental como en el occidental. En el caso de este último comprobamos como, mediante el uso de formas abstractas, el arte de lo sublime abstracto continuó recurriendo a gran parte de los depósitos de su implícito nicho cultural. Es decir, que hizo gala del énfasis histórico de Occidente, mediante un conjunto de formas abstractas de pensamiento - similares a las matemáticas, la lógica, la sociología o la metafísica - en el contexto de una cosmovisión hecha de estrictas divisiones binarias: el bien y el mal, la verdad o la mentira, el allí y el aquí, lo espiritual y lo filosófico, el tiempo y el espacio, etc. Y así, con este último ejemplo, hacemos alusión al concepto espacio/tiempo que, como ya hemos visto, en el plano pictórico se ha definido a través de la fragmentación del espacio pintado. En esta tesitura, desde la tradición del pensamiento extremo oriental se ha entendido que intervenir en el espacio implica también hacerlo en el tiempo - tanto en el real como en el imaginado - en un ámbito donde se recrea el espacio figurado. Por consiguiente, se trata de un ámbito donde se da una binaridad de fuerzas no excluyentes que son el paradigma de la cosmovisión extremo oriental. Porque, lejos de la crítica Kantiana, todo es relevante y difícilmente podemos entenderlo separado. Por lo que, ni la actividad ni los sentidos ocupan parcelas independientes.

Así, de alguna manera la imagen contemporánea, como lenguaje, permite establecer un diálogo con los otros y - al igual que sucede en la tradición extremo oriental - establece una comunicación entre el espectador y la obra. Una relación donde la pintura, en el contexto de la postmodernidad, recurre a formatos de gran tamaño o composiciones realizadas con múltiples y consecutivos soportes, donde la imagen se desarrolla en continuidad. Un planteamiento similar al despliegue de los biombos que ha permitido el recurso de la narración gráfica continua y que ¿puede tener alguna

${ }^{441}$ Clement Greenberg, Arte y Cultura, Barcelona, Paidós Estética, 2016, p. 197. 
relación con la reincorporación de los dípticos y trípticos para la pintura contemporánea? Porque, aunque en el arte europeo el uso de estos polípticos venía desde la antigüedad, su concepto y composición son totalmente distintos de los de la pintura contemporánea ${ }^{442}$. En ese sentido, cabe preguntarse cómo y cuánto ha podido influir la reintroducción de este recurso pictórico en la percepción y uso del color en la pintura y el cambio que se produjo en la percepción de estos. Es decir, del uso del color en función de la construcción del espacio pictórico y su desplazamiento como elemento sensorial de la composición. Hablamos por lo tanto de una libertad de color y de ritmo que los pintores europeos habían encontrado en la pintura japonesa y que también podemos encontrar en las pinturas de la etapa tardía de Monet, posteriormente emuladas por los jóvenes pintores norteamericanos de la primera mitad del s XX. En palabras de Roland Barthes:

Un yo y un ello vibrantes, únicos y complejos en paisajes, espacios y sucesos siempre prolongados $[\ldots]$ De esta concepción más compleja y más natural de la línea se deriva un comportamiento también más diferenciado con respecto al campo de la imagen y por tanto a su espacio y a su terreno [...] [...] cualidades inherentes al espacio, al tacto, suscitadoras de asociaciones y estimulantes del continuo espacial [...] Los frutos de esta actividad son aquellos que significan las nuevas libertades frente a los códigos tradicionales y se convierten en nueva realidad. Punto, línea y superficie quedan pulverizados, desmembrados y con un nuevo fluir $[\ldots]^{443}$.

Efectivamente, actualmente la sintaxis del lenguaje pictórico ya no se restringe a códigos culturales limitados en el tiempo y en el espacio. Por el contrario, se ha convertido en un conjunto de signos que de alguna manera se han desentendido de la idea de sistema. Su lenguaje artístico se conforma con imágenes, colores y significados, donde la pintura asume sus propios códigos a través de los que se significa y se expresa. Pero, en cualquier caso, la preocupación por la representación del espacio pictórico no ha dejado de estar siempre presente. No obstante, la confluencia de gran parte de todos estos planteamientos - sobre todo a partir de los artistas del action painting - ha favorecido una nueva dimensión del espacio, prescindiendo de los elementos de ordenación matemática mensurable característicos hasta entonces; es decir, la perspectiva, la proporción, la simetría o la armonía. ¿Podemos decir que desde entonces el pintor entiende que su individualidad no se puede reducir solamente a un código

\footnotetext{
${ }^{442}$ Estos polípticos alcanzaron su esplendor durante la Edad Media. Cayendo en desuso en los siglos posteriores, no será hasta finales del s XIX cuando este recurso artístico volverá a aparecer en la pintura europea.

Los dípticos - compuestos por un par de paneles unidos y plegables - han sido usados en el arte europeo desde la antigüedad como, por ejemplo, los dípticos consulares de marfil del periodo romano. Su uso se extendió, posteriormente, a la liturgia cristiana que los utilizaba para inscribir en ellos nombres de obispos, mártires o benefactores, dignos de ser mencionados en las misas y oraciones.

En los siglos XIV y XV los trípticos de grandes dimensiones se popularizaron en los templos cristianos. Estaban constituidos por tres paneles, y su particularidad estaba en que, las dos tablas laterales se podían cerrar sobre la central que funcionaba como eje vertebrador de la escena representada.

${ }^{443}$ Roland Barthes, "La sabiduría del arte" et al en Verlag, Merve Prólogo del Catálogo de la Exposición de Cy Twombly en el Whitney Museum of Ameican Art. Nueva York. 1979, p.10
} 
social? O, por el contrario ¿Ha intentado romper las normas establecidas adoptando los discursos que le han llegado desde otras culturas, liberándose del sistema e incurriendo en controversia con el código de comunicación establecido?

En este contexto, de manera similar a la tradición de la pintura china, para la pintura contemporánea cuenta tanto la obra terminada como el tiempo y el proceso de su realización, lo que a decir de Cheng ${ }^{444}$ nos ofrece una visión de la pintura como una performance que sería más musical que pictórica y que, por su doble aspecto melódico y armónico, como afirma el Libro de la música, se une al aliento primordial del que proviene el ritmo del universo. Una afirmación que en cualquier caso no deja de ser discutible si cuestionamos los conceptos de armonía o simetría, como valores estrictamente incluidos en la actual cultura visual de Occidente. No obstante, entendemos que cuando la pintura de Occidente descubre otras maneras de concebir el espacio, en mayor o menor medida también modifica sus valores culturales, adoptando otros criterios compositivos más cercanos o afines a los de las culturas extremo orientales. Es decir, que el abandono de la perspectiva ha supuesto el abandono de otros criterios espaciales y la adopción de principios como el de la proporción numérica que para componer el espacio utiliza recursos muy semejantes a una partitura musical ${ }^{445}$. Efectivamente, en numerosas pinturas, al igual que en la estructura de una pieza musical tradicional de Oriente, se repite una melodía con diferente ejecución, mediante la sucesión/yuxtaposición de diferentes acordes donde se alternan distintos elementos mediante un idéntico desarrollo. Expresado en palabras de Antonio Colinas:

El qi también llega incluso - según los seis cánones de la pintura china - a dar valía y autenticidad a la obra pictórica. El gran pintor sería el que sabe desplazar - por medio de su pincel -el qi del mundo hasta la tela. Así se lograría apresar el alma del mundo. Por la misma razón, el músico sería el que fija el qi por medio de sonidos y el poeta por medio de palabras. Apresar el alma del mundo gracias al qi podría ser, en definitiva, el fin del verdadero Arte ${ }^{446}$.

Una sacralización del arte que, como nos recuerda Colinas, nos relaciona con una de las formas del Tao: el $Q i$ (氣) en China o energía invisible que deviene en el $K i$ ( 氣) japonés y que mantiene un paralelismo con determinadas nociones de energía cósmica a la que los hebreos han denominado ruach. "[...] el num de los nómadas del desierto, el relung de los tibetanos y el prana de los hindúes 'energía cósmica', 'hálito de Dios', 'soplo vital' " 447 . Unas nociones, como vemos, que han estado presentes desde siempre en todas las culturas y que nos permiten establecer un vínculo con esa idea de la que ya hemos hablado anteriormente: la del ejercicio espiritual del arte que se aleja en parte de la noción del Abstracto sublime de pintura pura ${ }^{448}$.

\footnotetext{
${ }^{444}$ Véase: François Cheng, Vacío y plenitud, Madrid: Siruela, 2004

${ }^{445}$ Énfasis propio.

${ }^{446}$ Antonio Colinas, La simiente Enterrada. Un viaje a China, Madrid, 2005, p. 118.

${ }^{447}$ Véase: Antonio Colinas, La simiente Enterrada. Un viaje a China, Madrid: Siruela, 2005, p. 118.

${ }^{448}$ Énfasis propio.
} 
En cualquier caso, al hilo de esa idea del $Q i$ (氣) - y en relación con las palabras de Cheng - Adorno establece un paralelismo entre la música y la pintura contemporánea. Es decir, la renuncia de la pintura a parecerse al objeto que le sirve de base y la renuncia de la música al orden tonal. Por consiguiente, entiende que disuelto este vínculo entre objeto y arte se incurre en una desobediencia ante la realidad preexistente. Nos encontramos entonces con una libre atonalidad tanto en la pintura como en la música que, al igual que una transición de un intervalo a otro, compone el espacio abstracto pictórico o sonoro, dando lugar a la sutil percepción de la belleza que podemos encontrar en la coherencia de los diferentes elementos que componen la obra $^{449}$. En este sentido, pintores como Manuel Luca de Tena introducen en sus pinturas variantes tan sutiles que percibimos, aunque solo a primera vista, en el resultado final [Figura 41]. En estas obras encontramos una casi total ausencia de elementos figurativos - aunque sería más correcto hablar de una decodificación de los mismos - que, no obstante, no evita que estas sean sensibles a la continuidad de un espacio que se despliega mediante un sentido exquisito del color - o del no-color - y a una espontaneidad profundamente anclada en la estructura. Hablamos de un espacio y un tiempo, paradójicamente sin tiempo ni espacio, en muchos casos conformado por una continua uniformidad de paneles que permiten intensificar la evocación de un ámbito. Así, las consecutivas superficies plásticas ya no interactúan entre ellas de acuerdo con las leyes occidentales de la mímesis o del contraste de valores. Aunque, a pesar de esto, será sobre esta aparente ausencia de contraste de valores cromáticos - más que sobre la perspectiva - donde se apoyará su pintura para así alcanzar una impresión de multivocidad. Es decir, la proyección de una multidimensionalidad, de un macrocosmos como un microcosmos, como un multiverso anímico e íntimo que, mediante el tacto leve de su mano, transforma la tenue materia de manchas y trazos. Por consiguiente, nos encontramos ante una realidad fragmentada y compuesta según sueños, impresiones, anhelos o recuerdos [Figura 42]. Una realidad latente, inmanente en el lenguaje secuencial de sus pinturas, donde - como una pieza musical - cada sonido/elemento de la composición tiene la misma equivalencia en el énfasis. Una suerte de equilibrio de tensiones entre lo oriental y lo europeo, donde la pintura recurre a nociones sintéticas para conformar un clima de conjunto parecido a un universo poético. Se trata del color, del matiz y de su intensidad; se trata del gesto y de la mano; se trata del espacio y del tiempo, se trata de su horizontalidad.

Efectivamente, se trata de una peculiar manera de escribir y de narrar en el tiempo mediante un ritmo fluctuante, secuencial. Unas superficies múltiples que aumentan en número y que se comunican. Así, sobre esta cuestión de los formatos, Rubin observa como:

[...] las obras de gran formato que pintó Monet en sus últimos años son el único precedente auténtico, dentro de la tradición moderna, de los cuadros de tamaño de mural que a partir de 1950 empezaron a pintar Pollock, Rothko, Newman y Still. Estas obras panorámicas, a menudo de más de 6 metros de ancho y a veces hasta de 12, fueron

${ }^{449}$ Énfasis propio. 
concebidas por Monet no como una "ventana" al mundo, que es la idea del cuadro de caballete tradicional, sino como un mundo en sí mismas (y así se percibirían en la Orangerie). Aunque son las obras de mayor tamaño de la tradición moderna (excluyendo, claro está, algunos murales institucionales), se pintaron con independencia de la arquitectura, la cual, como los lienzos más grandes de los pintores estadounidenses, se veía idealmente desplazada por ellas en vez de decorada ${ }^{450}$.

No obstante, a diferencia del arte europeo - donde el uso de estos polípticos venía desde la antigüedad - la reincorporación de esta estrategia artística introduce como novedad un enfoque que adopta en su concepto y composición el recurso la narración gráfica continua de Asia Oriental ${ }^{451}$. Una estrategia artística que, a nuestro juicio, había servido de inspiración para las Grandes Décorations de Claude Monet y que se verá reflejada en la renovación de sus composiciones, en el abandono de la perspectiva y en la adopción de una inmediatez captada tanto en esa primera impresión como en sus diseños sencillos de colores puros. No obstante, aunque pintores contemporáneos, como por ejemplo Francis Bacon, han utilizado de manera recurrente los dípticos y trípticos como soporte - mediante un juego en el que los dos o tres paneles se unen conceptualmente - en ellos no aparece ese foco móvil o secuencialidad del motivo representado. Mientras, por el contrario, pintores como Marden, Mitchell, Tàpies o Twombly adoptarán el uso oriental de los dípticos y trípticos, y - sobre todo, en el caso de Cy Twombly - la yuxtaposición de una mayor configuración de paneles que permiten que la obra fluya libremente, en un discurrir que debe mucho a la estructura formal y conceptual de las pinturas de los biombos chinos y japoneses. Así, en estas obras, la mirada se desplaza consecutivamente y, los elementos o los trazos, aunque parecen aparentemente aislados, están unidos por una sintaxis que los estructura mediante un exquisito concepto del ritmo y un sutil equilibrio - en una comprensión de la pintura que incorpora el tiempo como condición y concepto.

Al hilo de esta idea, observamos como en algunas de sus pinturas, Twombly dejará la obra abierta en su desarrollo para ser completada por la mirada del espectador. Mientras, Marden recurre a esta comprensión del espacio en la serie Grove Group de 1970, dividiendo la superficie en dos o tres lienzos verticales u horizontales y donde encontramos una directa alusión a los shôheiga 障屏画 o pinturas de los biombos o los fusumae 襖絵. Una explícita alusión al concepto de espacio/tiempo yuzhou (宇宙) que en su pintura las Estaciones encontramos no solo en los aspectos formales de la obra, sino también en el propio título de la misma [Figura 43]. En cualquier caso, en la

\footnotetext{
${ }^{450}$ William Rubin en Paloma Alarcó, Monet y la Abstracción, Madrid, Catálogo Museo Thyssen Bornemisza, Febrero-Mayo 2010, p. 160.

${ }^{451}$ Utilizados sobre todo para las pinturas de carácter religioso, el tema o motivo representado se adaptaba a la particular estructura del políptico. En el caso concreto de los trípticos, solía recurrirse a un elemento o personaje que vertebraba y funcionaba como centro de la composición, ocupando el panel central del conjunto de las tres tablas.

Sin embargo, en la pintura china y japonesa, los polípticos se distribuían por pares de paneles, planteándose su número y su composición según las necesidades espaciales del tema.
} 
confluencia de todos ellos, nos indica Gauthier, la pintura - como la viñeta de un comic - compone “[...] una imagen fija provista de un 'antes' y un 'después', por el juego de la disposición secuencial [...] organizando el espacio en función del tiempo del relato" 452 . En suma, en palabras de Greenberg:

[...] La pintura de Mark Rothko [...] Las tres o cuatro franjas, sólidas horizontales, de colores planos, que componen sus típicas pinturas permiten al espectador pensar en un paisaje; algo que quizás sucede porque su simplicidad decorativa parece encontrar menos resistencia. [...] La supresión de los contrastes de valor y la apuesta por los tonos cálidos de Still, Newman y Rothko lleva emparejada la ausencia de profundidad enfática en sus pinturas. El color, al no verse fragmentado por cambios de valor súbitos o por incidentes provocados por el dibujo o la composición, respira desde el lienzo con un efecto envolvente, que el mismo tamaño del cuadro intensifica. El espectador tiende a comportarse ante esta situación de una manera más próxima a como lo haría ante un decorado o un entorno espacial en vez de ante una pintura colgada de una pared. Por ello, la cuestión principal que plantea la obra de estos tres artistas es donde cesa lo pictórico y empieza lo ornamental. Su arte, en efecto, contiene elementos decorativos e ideas en un contexto pictórico $[\ldots]^{453}$.

\section{1.- La Tradición: Francis Bacon y Hiroshi Senju}

A lo largo de este estudio, hemos visto dos diferentes modelos de representación del espacio pictórico: véase, la narración gráfica continua extremo oriental y la perspectiva europea, desarrolladas en dos distintos ámbitos culturales. En este contexto, hemos analizado como, a diferencia de Oriente, Occidente ha erigido en norma su propio sistema, traduciendo la visión en estrictos códigos de reconocimiento y organizando el espacio plano de la imagen según la construcción que impone su espíritu y no según una percepción inmediata. No obstante, tanto la pintura europea como la china, japonesa o coreana han sido, todas ellas, objeto de una verdadera doctrina. Es decir, han sido objeto de unos estrictos códigos perceptivos en consonancia con una estrecha relación con todo un trasfondo ideológico. Un universo figurativo de tradición multisecular donde - dependiendo de cada uno de estos ámbitos culturales - la pintura construye o compone el espacio según principios diferentes. Así, Oriente y Occidente han enfocado el problema de la disposición de las partes del espacio desde puntos de

\footnotetext{
452 Gauthier, Guy, Veinte lecciones sobre la imagen y el sentido, Madrid, 1996, p. 63.

453 Clement Greenberg en Paloma Alarcó, Monet y la Abstracción, Madrid, Catálogo Museo Thyssen Bornemisza, Febrero-Mayo 2010, p 144.
} 
vista radicalmente distintos. Una cuestión que, a pesar de su complejidad, podemos sintetizar diciendo que la imagen en la pintura occidental comprendida en el interior de un cuadro - al abandonar su carácter narrativo - solo cobra sentido en relación con el fuera de campo. Es decir, como señala Gauthier, “[...] no cobra sentido más que en relación con un 'fuera de tiempo' que debe ser significado sin estar presente [...]”,454.

Pero hoy, tal vez, nuestra actualidad pueda caracterizarse por la búsqueda de un universal estético. En el contexto de la pintura europea, esta ha ido evolucionando desde la otrora necesidad del relato hasta un marco cerrado que, paradójicamente, de nuevo ha regresado a ese relato culturalmente estructurado. Es decir, cómo desde una unidad más pequeña se ha retomado un cierto ritmo narrativo según los propios códigos perceptivos. Un reflejo de cómo estos han mutado y, aunque los actuales modelos culturales no parecen reclamar sistemas, desde el mismo momento en el que se han convertido en formas de conocimiento se han visto necesitados de procesos culturales. En otras palabras, retomando los contemporáneos nichos culturales que ofrecen al pintor un elemento de autoafirmación. Porque, la semiótica del mensaje visual se concibe solo en el interior de un sistema cultural regulado con sus propios códigos perceptivos.

Así, a partir del pasado s. XX la idea de un '[...] 'territorio' como ambiente cultural específico más que como área geográfica definible en términos de latitud y longitud [...]"455 - en palabras de Panofsky - modificará aquellos parámetros espaciales, temporales y culturales. De este modo, la imagen pictórica nos remitirá a un espacio, real o imaginado/el suyo propio o el que representa, que a su vez nos remite al equilibrio de tensiones de las relaciones espacio/tiempo que, a todas luces, en esta tesis ha servido como paradigma de la imagen en secuencias. Sin embargo, en la obra de algunos pintores se han perpetuado unos modelos perceptivos paradigmáticos de un determinado nicho cultural. Porque, pensar que cada autor crea sus reglas al margen de un sistema de significantes es una falacia.

En este contexto, en las páginas que siguen, podremos comprobar como en las obras de Francis Bacon y Hiroshi Senju encontramos un despliegue de medios donde podría decirse que los materiales y los gestos ocupan un lugar secundario. En su lenguaje artístico se dan signos, imágenes, colores estructurados mediante códigos de significados multiseculares. Pero aun así, a nuestro juicio, en sus pinturas el color, el dibujo y la composición - la imagen - no dejan de ser nada más y nada menos que elementos auxiliares que, prescindibles o no, ocupan un lugar secundario ante la distribución del espacio pintado. De este modo, observaremos como recurren a formatos reconocibles en cada una de sus propias tradiciones culturales. Es decir, a una sucesión o combinación de soportes que, en cada caso, nos remiten a la tradición europea o extremo oriental.

\footnotetext{
${ }^{454}$ Guy Gauthier, Veinte lecciones sobre la imagen y el sentido, Madrid, 1996, p. 72.

${ }^{455}$ Erwin Panofsky. Renacimiento y renacimientos en el arte occidental, Madrid, 1975, p. 34.
} 
La Horizontalidad de la mirada de Oriente en Occidente 
FRANCIS BACON/ HIROSHI SENJU 


\section{FRANCIS BACON}

$\mathrm{E}$

L uso recurrente de dípticos y trípticos como soporte para la pintura puede ser considerado como uno de los aspectos más característicos de la obra de Bacon. Una elección sobre la que tal vez haya podido influir la conocida predilección de este artista por la fotografía; como así atestigua la especial atracción del pintor por las secuencias fotográficas de Eadweard Muybridge ${ }^{456}$. Una influencia incuestionable que podemos constatar en los retratos realizados por el pintor y que, a decir de Dennis Farr, son el resultado "[...] de las secuencias de imágenes que él recordaba de memoria de la persona en cuestión [...]". Así, continua, frecuentemente "Bacon hablaba de destruir una imagen para transformarla y recrearla, y en sus retratos acabados, normalmente trípticos, con los perfiles derecho e izquierdo y una vista frontal, capta de forma magistral los distintos aspectos de la personalidad del retratado" ${ }^{457}$.

Pero además, como nos recuerda este autor en alusión a Michel Peppiatt, el cine se ha revelado como otra influencia importante en la comprensión del espacio pictórico de la obra de Francis Bacon. Efectivamente, Farr nos habla sobre como la experiencia de la proyección simultánea en tres pantallas de la película Napoleón, de Abel Gance pudo influir sobre Bacon en la elección de los trípticos como formato para su pintura. Una influencia que, a decir de este autor, pudo tener incluso más peso que los propios

\footnotetext{
${ }^{456}$ Eadweard Muybridge (1830-1904) fue un fotógrafo inglés pionero en los estudios fotográficos de movimiento y sus primeras proyecciones en películas. Entre los años 1884 y 1887, realizó para Universidad de Pensilvania sus estudios fotográficos más importantes sobre el movimiento. Unas fotografías sobre figuras humanas realizando diversas actividades, con las que formará un compendio visual de movimientos humanos para el uso de artistas y científicos. Posteriormente, en 1987, muchas de estas fotografías serán publicadas en Animal Locomotion: An Electro-Photographic Research of Conse consecutive of Animal Movements.

${ }^{457}$ Dennis Farr, "Francis Bacon" et all Guasch, Anna María et al, Summa Pictórica, de las Vanguardias a la Postmodernidad, Tomo X, España: Editorial Planeta, 2001, pp. 306-307
} 
trípticos pictóricos de la pintura del Barroco europeo ${ }^{458}$. En cualquier caso, una conclusión con la que no acabamos de estar del todo de acuerdo.

El interés que Francis Bacon había manifestado siempre por la cultura moderna europea, y en particular por la pintura del Barroco, ha resultado ser a todas luces un factor decisivo que a todas luces jugará un papel fundamental en su predilección por el uso de los dípticos y sobre todo de los trípticos. Efectivamente, Bacon siempre recurre a un panel central acompañado de otros dos laterales que centralizan, acompañan y complementan la composición. Una inclinación por esta variedad de soportes característicos de la pintura barroca que Bacon acompañará con otro elemento decididamente europeo, el marco del cuadro. Así “[...] Bacon insistía en que sus cuadros tuvieran marcos dorados, como se hacía con los maestros clásicos [...]", y como nos recuerda Farr "también quería que cada parte del tríptico estuviera separada, pero no a gran distancia, lo que evitaría ver el tema de cada cuadro relacionado con el anterior de una forma lineal" ${ }^{\text {" } 59}$. En cualquier caso, independientemente del tema, el uso de los trípticos formará parte siempre del imaginario colectivo que sobre Bacon existe en la actualidad.

\footnotetext{
${ }^{458}[\ldots]$ También sentía especial atracción por los libros de secuencias fotográficas de finales del s. XIX, que con una técnica fotográfica adecuada reflejaban el movimiento". Véase, Dennis Farr, Summa Pictórica, "Francis Bacon" et all Guasch, Anna María et al, Summa Pictórica, de las Vanguardias a la Postmodernidad, Tomo X, España: Editorial Planeta, 2001, p. 299

${ }^{459}$ Ibídem, p. 311.
} 


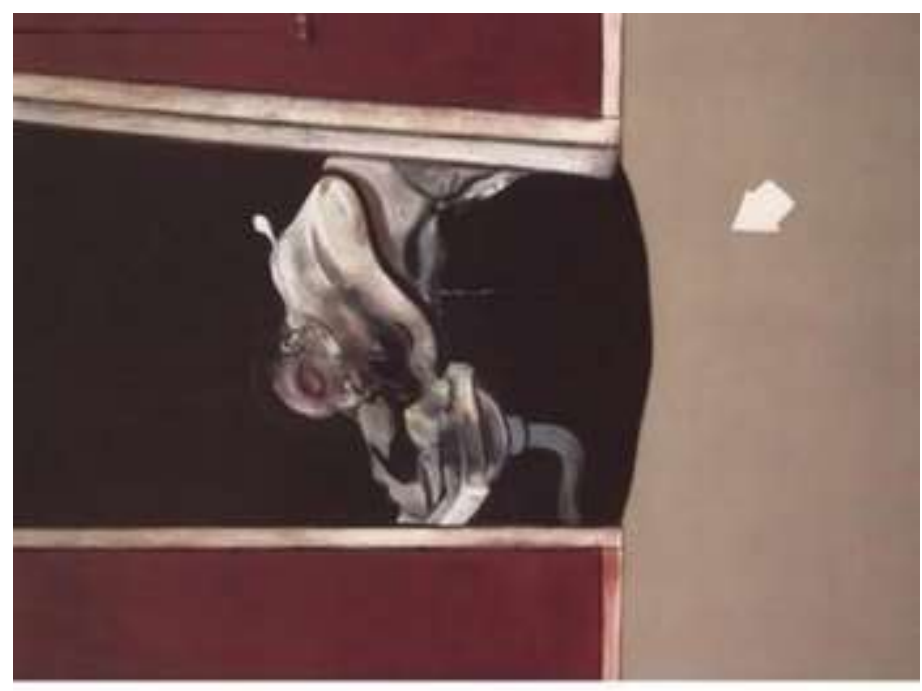

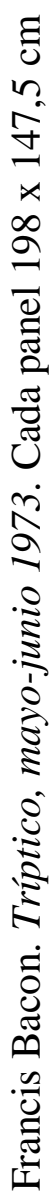
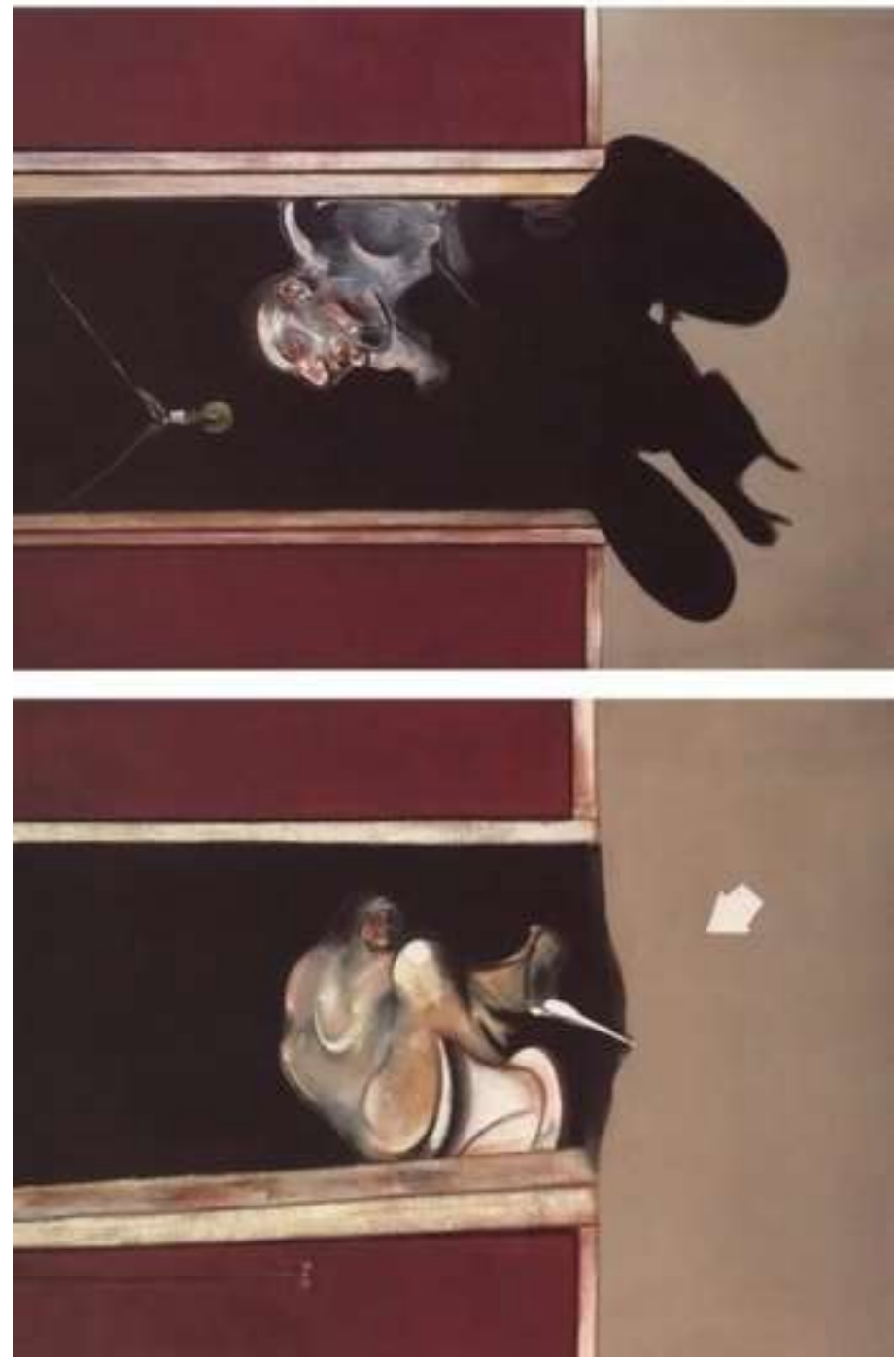


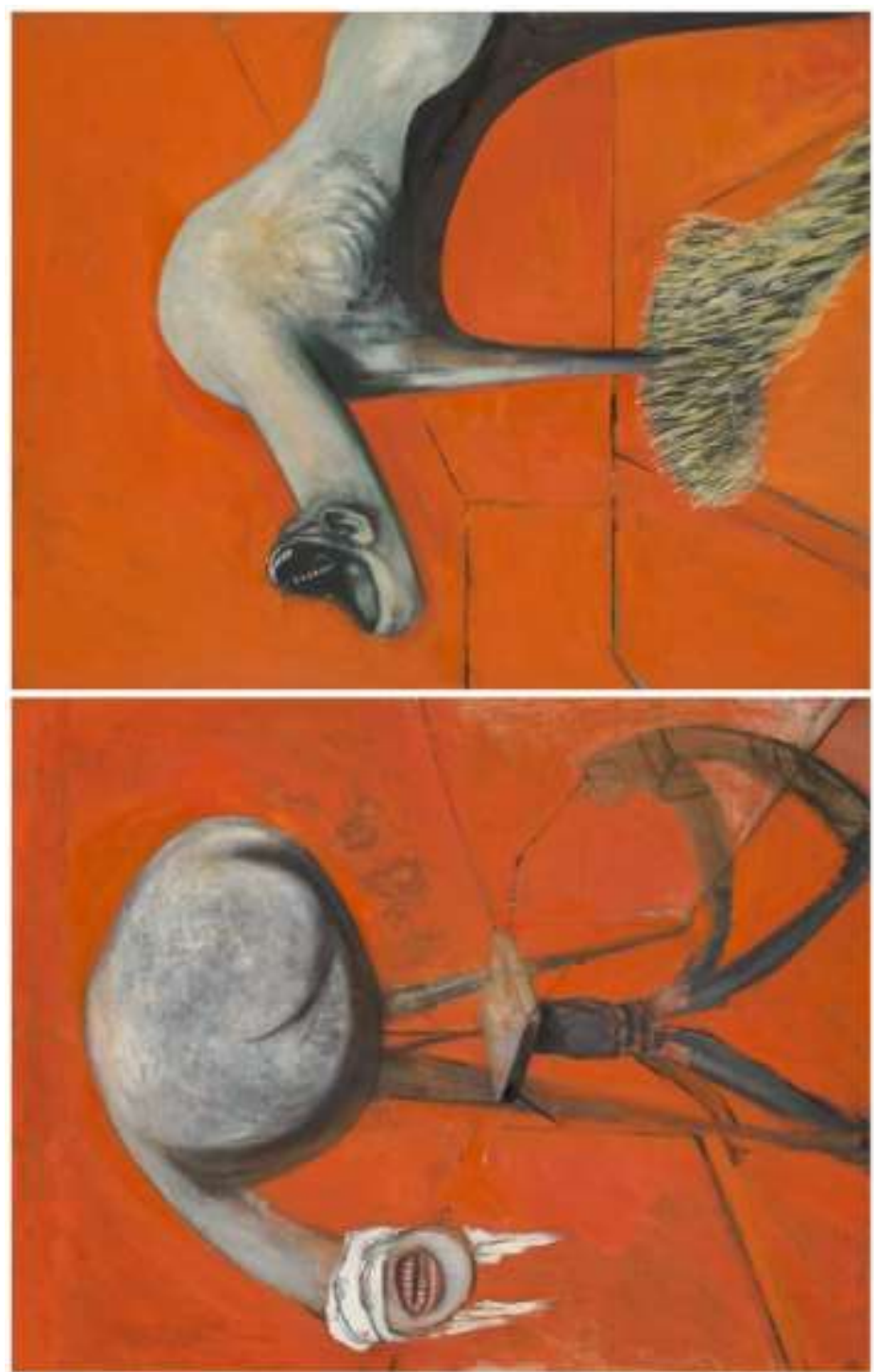

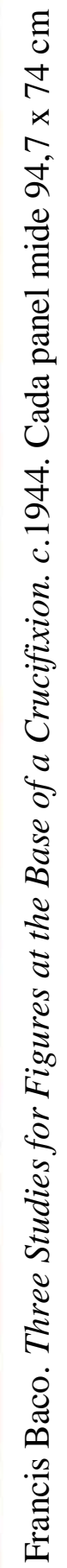

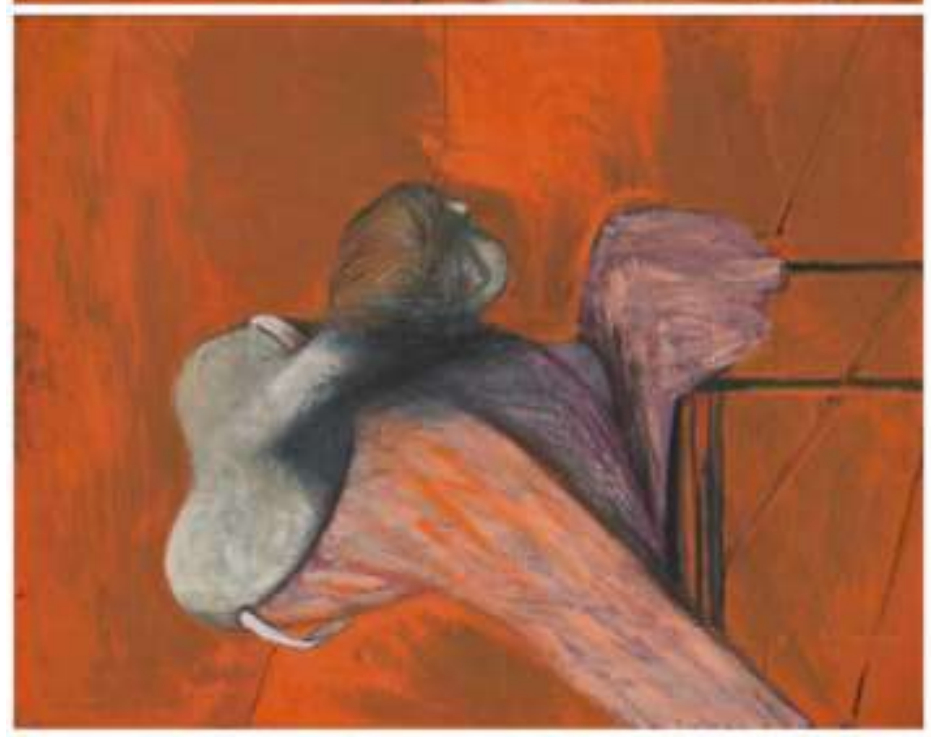




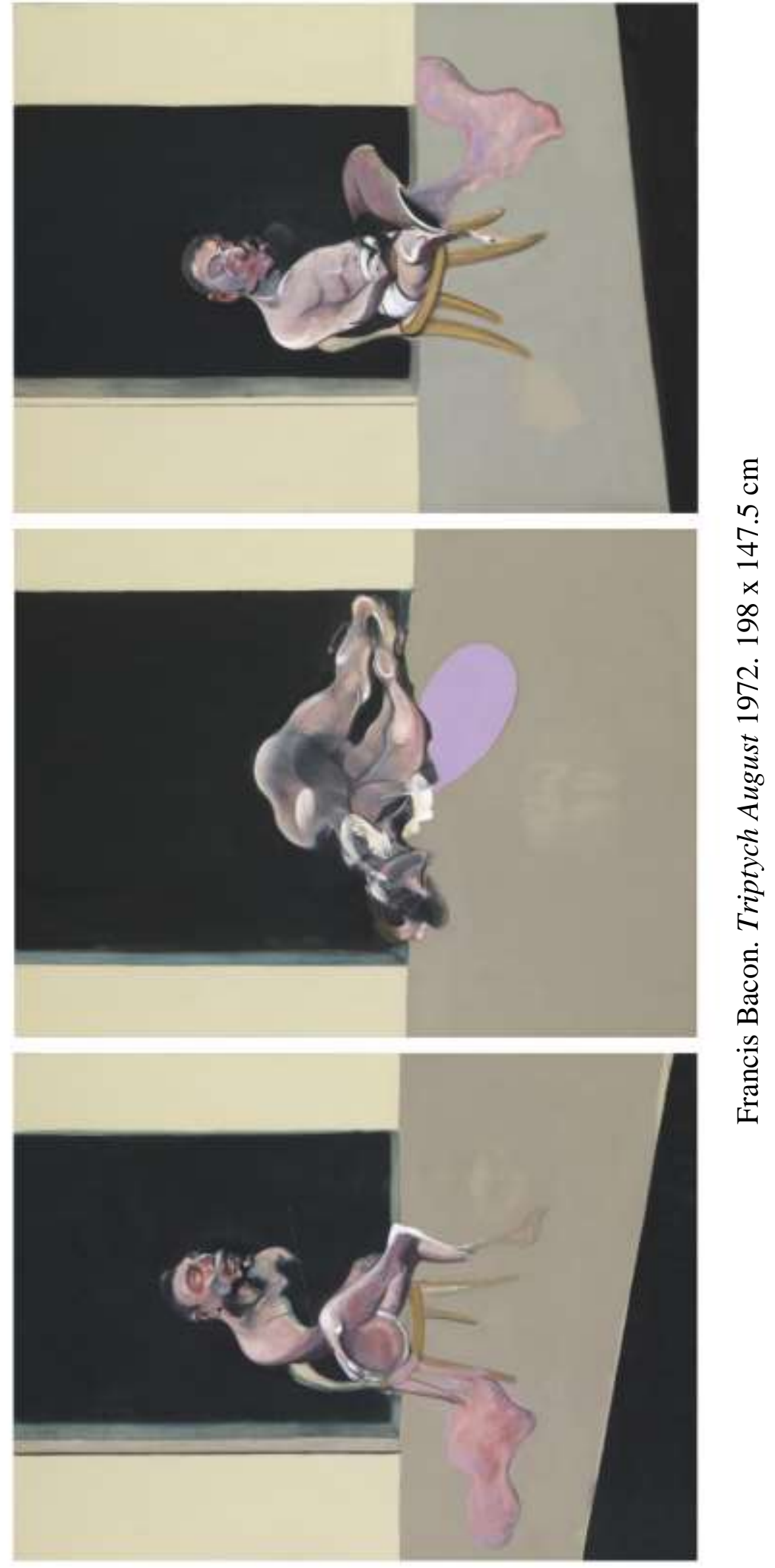




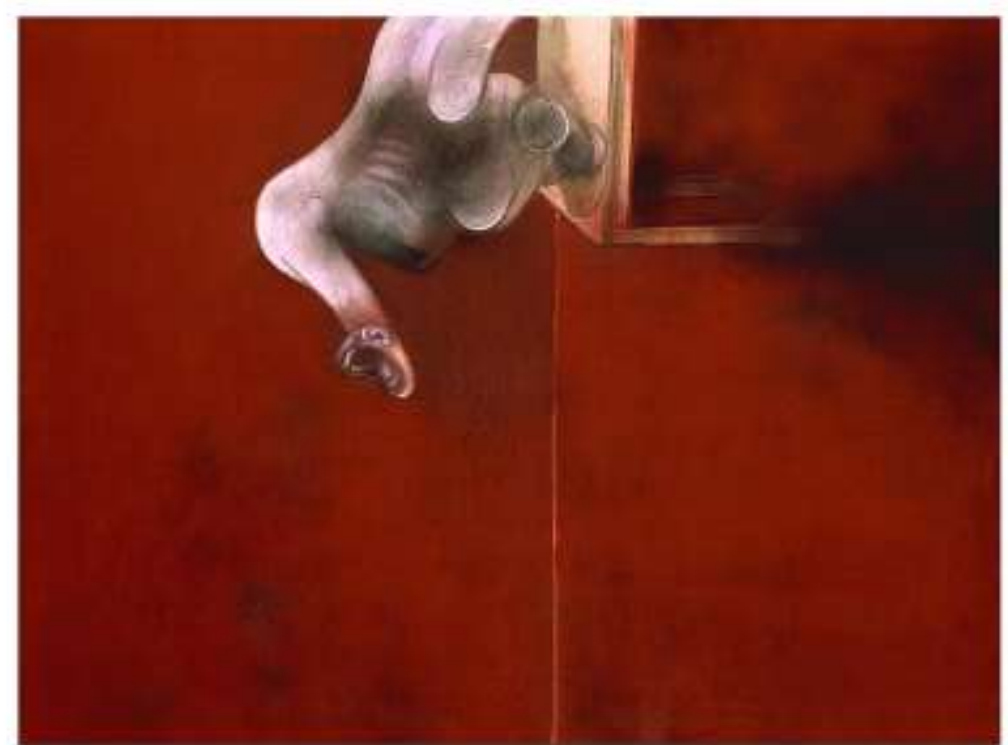

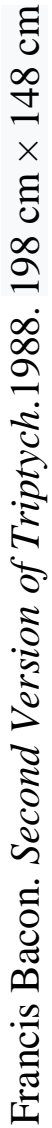
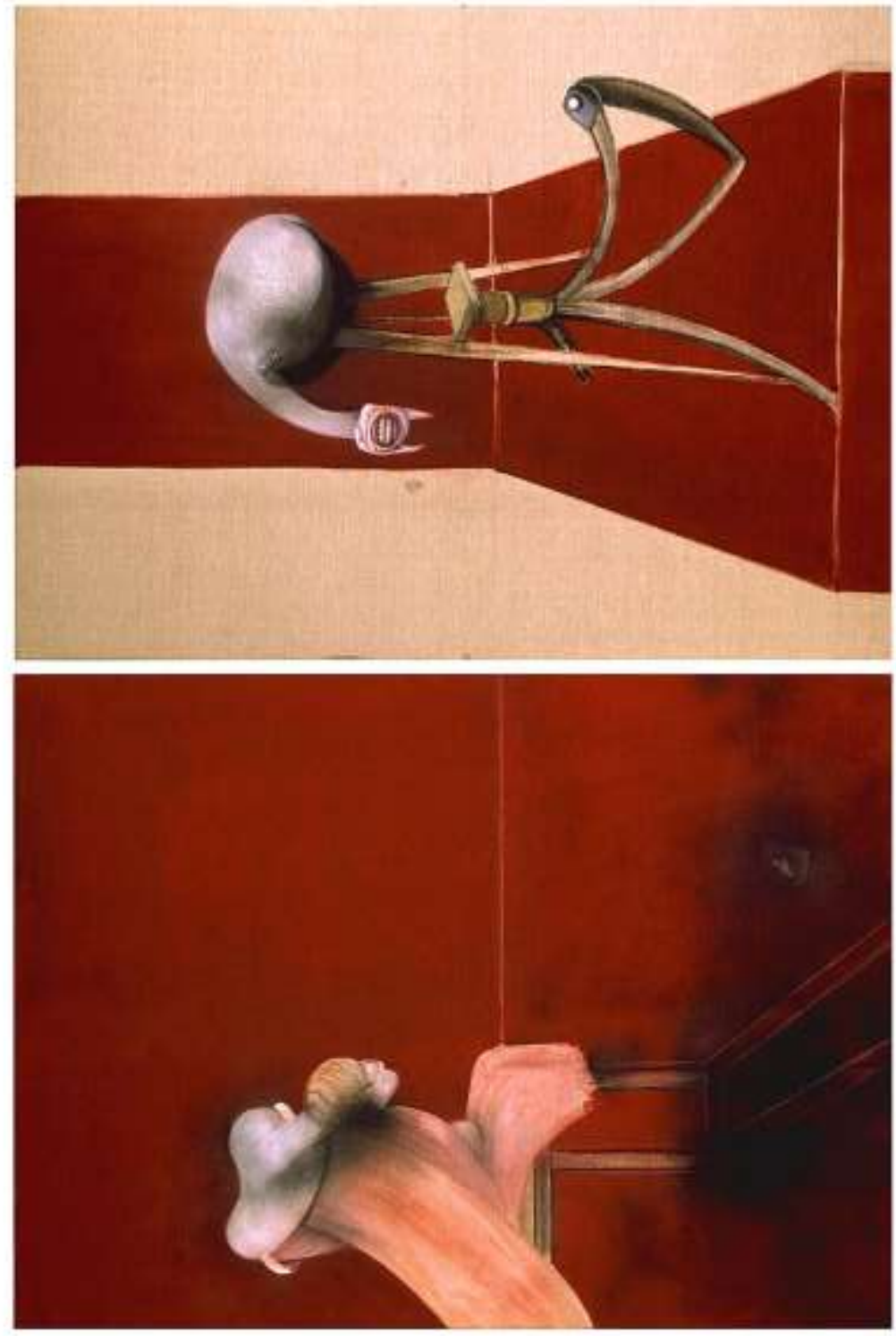
La Horizontalidad de la mirada de Oriente en Occidente 


\section{HIROSHI SENJU}

$\mathrm{P}$

odríamos considerar a Hiroshi Senju como el paradigma de nuestra actualidad globalizada. Pintor japonés afincado en Nueva York, en su obra poseedora de una belleza exquisita y fascinante - aunque con una referencia sólida del expresionismo abstracto - podemos encontrar la combinación del lenguaje visual minimalista con las técnicas de la antigua pintura japonesa. De hecho, Senju es uno de los pocos pintores contemporáneos que utiliza la técnica milenaria nihonga (日本 画), término que designa el estilo y las técnicas de la pintura tradicional japonesa, utilizando pigmentos naturales extraídos de minerales, conchas o corales molidos y aglutinados con adhesivos de origen animal. Pero el aspecto más interesante de su trabajo es, a nuestro juicio, el que está plenamente relacionado con el asunto principal de nuestra tesis: la configuración de su espacio pictórico. Efectivamente, siguiendo los postulados de la tradición japonesa, su pintura es mucho más que el espacio que la delimita a derecha o izquierda o arriba y abajo. Así, en su obra encontramos un espacio pictórico que se comprende dentro del ámbito de la tradición de las pinturas que decoran los fusuma (襖), como sucede con las monumentales pinturas instaladas como tales y realizadas para el templo Kongobuji en Koyasan o, en otro caso, otros paneles pintados en los que se continúa con aquella tradición que representa el espacio exterior al tiempo que lo integra en el interior arquitectónico. Es decir, lo que expresado en palabras de Alfonso Falero sería como: "Crear una interfaz que traduce la identidad daoísta entre interior-exterior en la identidad estética entre mundo natural y mundo artístico" ${ }^{\text {"460 }}$.

Así, en la obra de Senju se perpetuará la naturaleza de un espacio que, desde los pintores chinos de la dinastía Han 漢 hasta los japoneses y coreanos, ha devenido en

\footnotetext{
${ }^{460}$ Alfonso Falero, "El Fūryū como categoría estética", en Gras Balaguer, Menene (ed. 2015) El jardín japonés: Qué es y no es entre la espacialidad y la temporalidad del paisaje, Madrid: Tecnos, 137-154].
} 
secuencial. Por lo tanto entendemos que en su pintura acontece el retorno a unas formas pretéritas de representación. Expresado en palabras de Panofsky:

[...] a partir de premisas aceptadas, parece infructuoso seguir insistiendo en la misma dirección, acostumbran a surgir aquellos grandes retornos al pasado, o mejor aquellos cambios que, a menudo, están relacionados con la asunción del rol conductor por parte de un nuevo sector o de un nuevo género de arte y que crean justamente, a través del abandono de lo ya aceptado, es decir, a través de un retorno a formas de representación aparentemente "más primitivas"

${ }^{461}$ Erwin Panofsky, la perspectiva como forma simbólica, Barcelona, 2003, p. 29. 


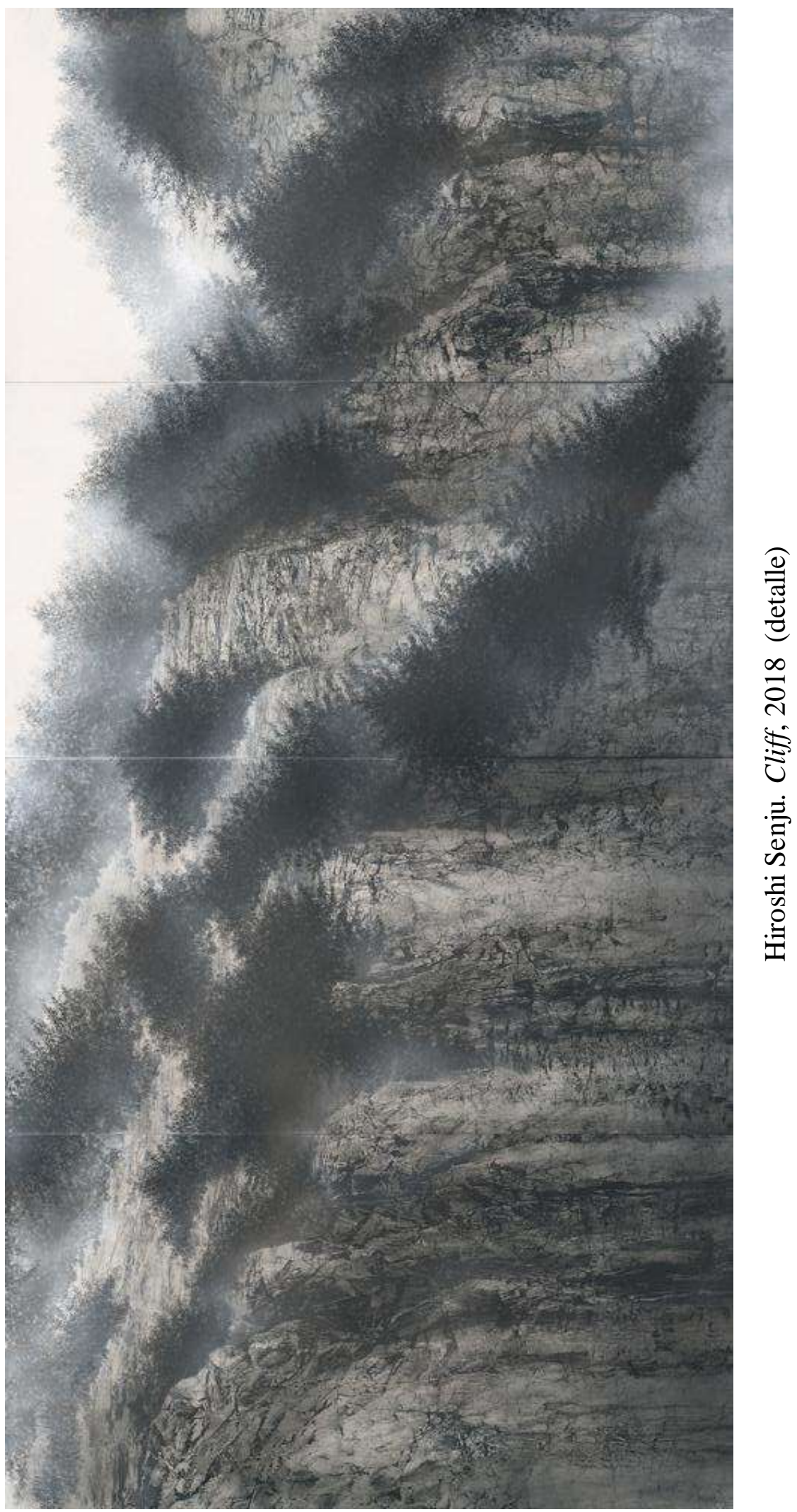




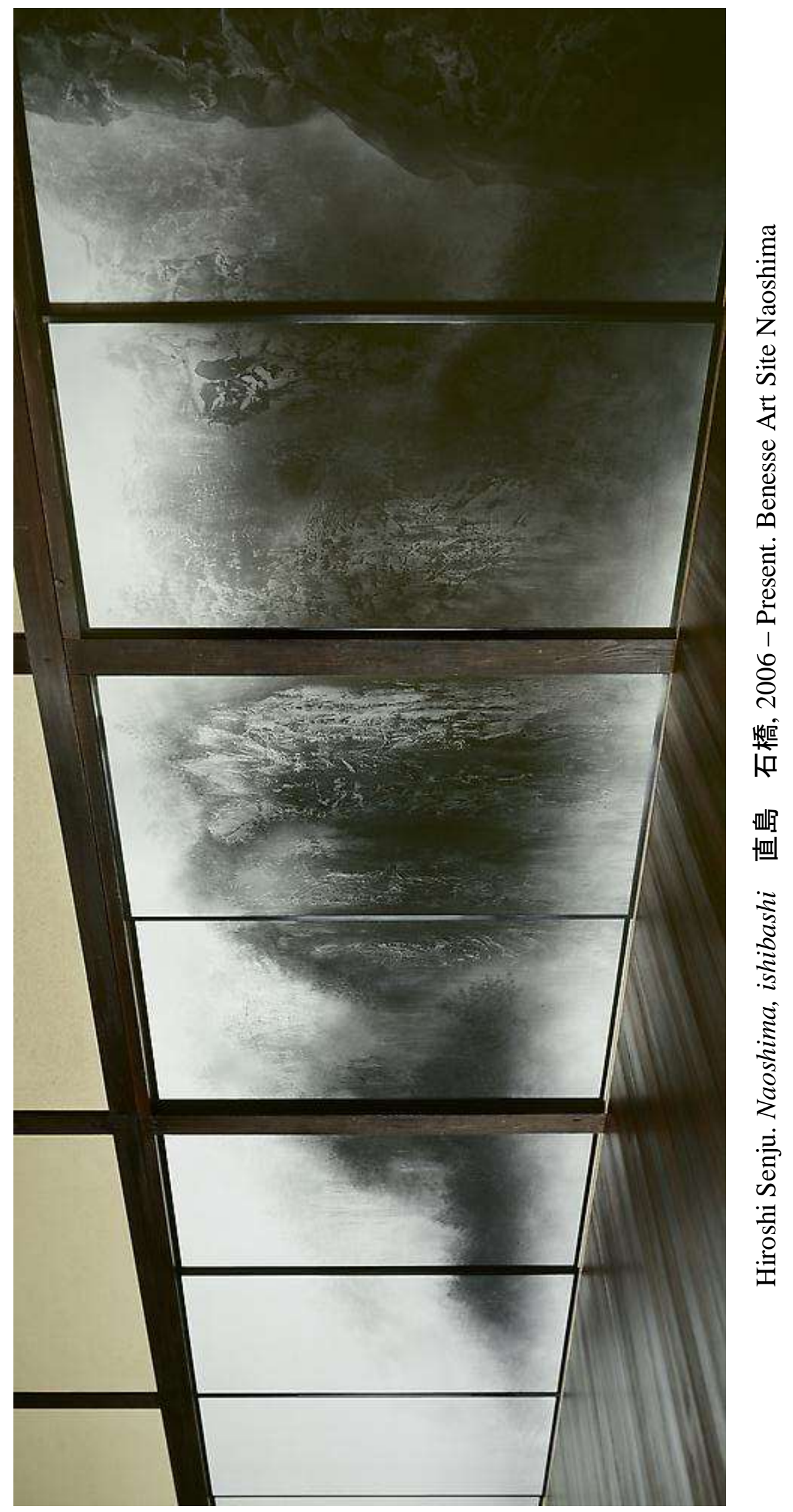




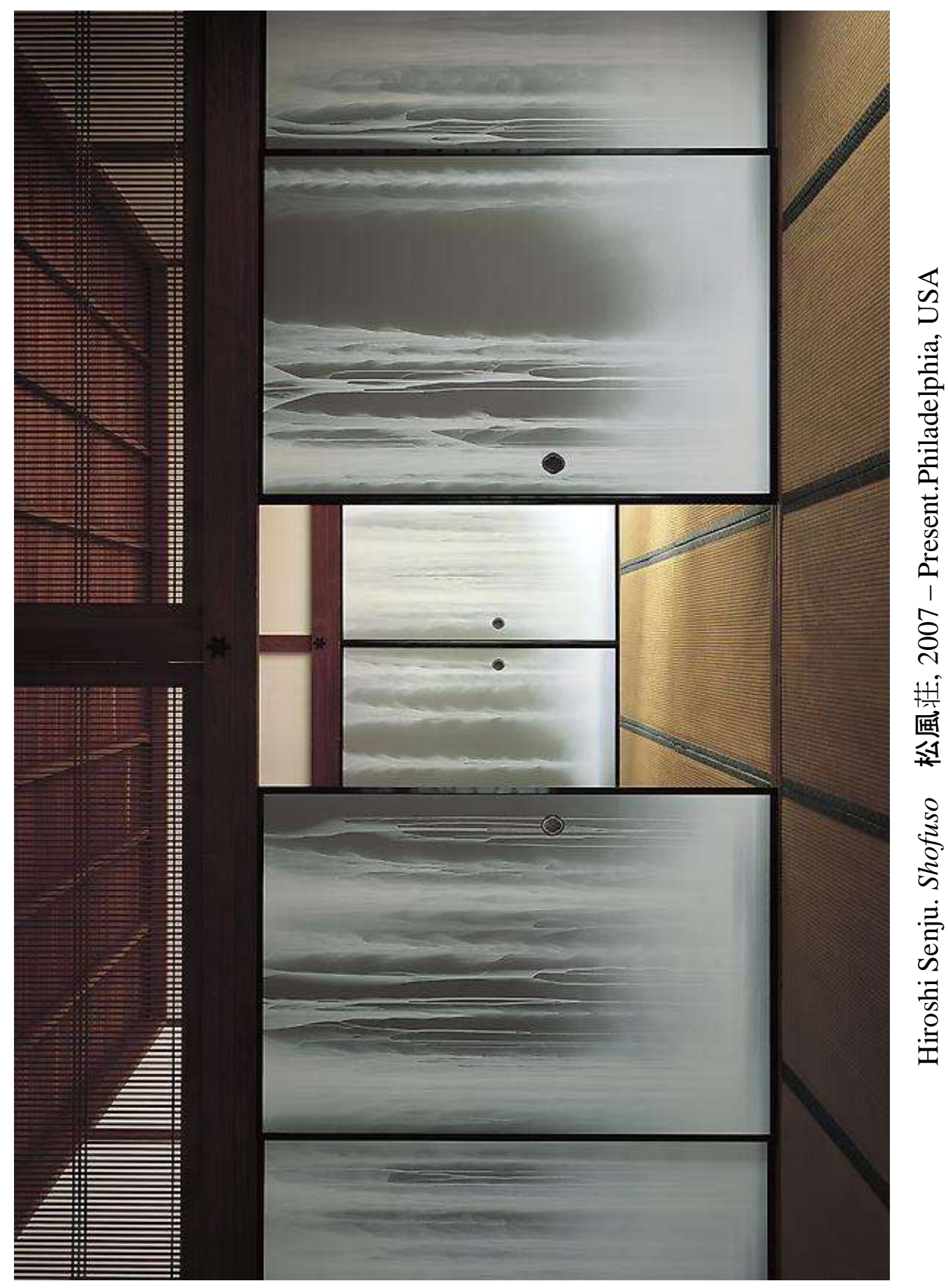




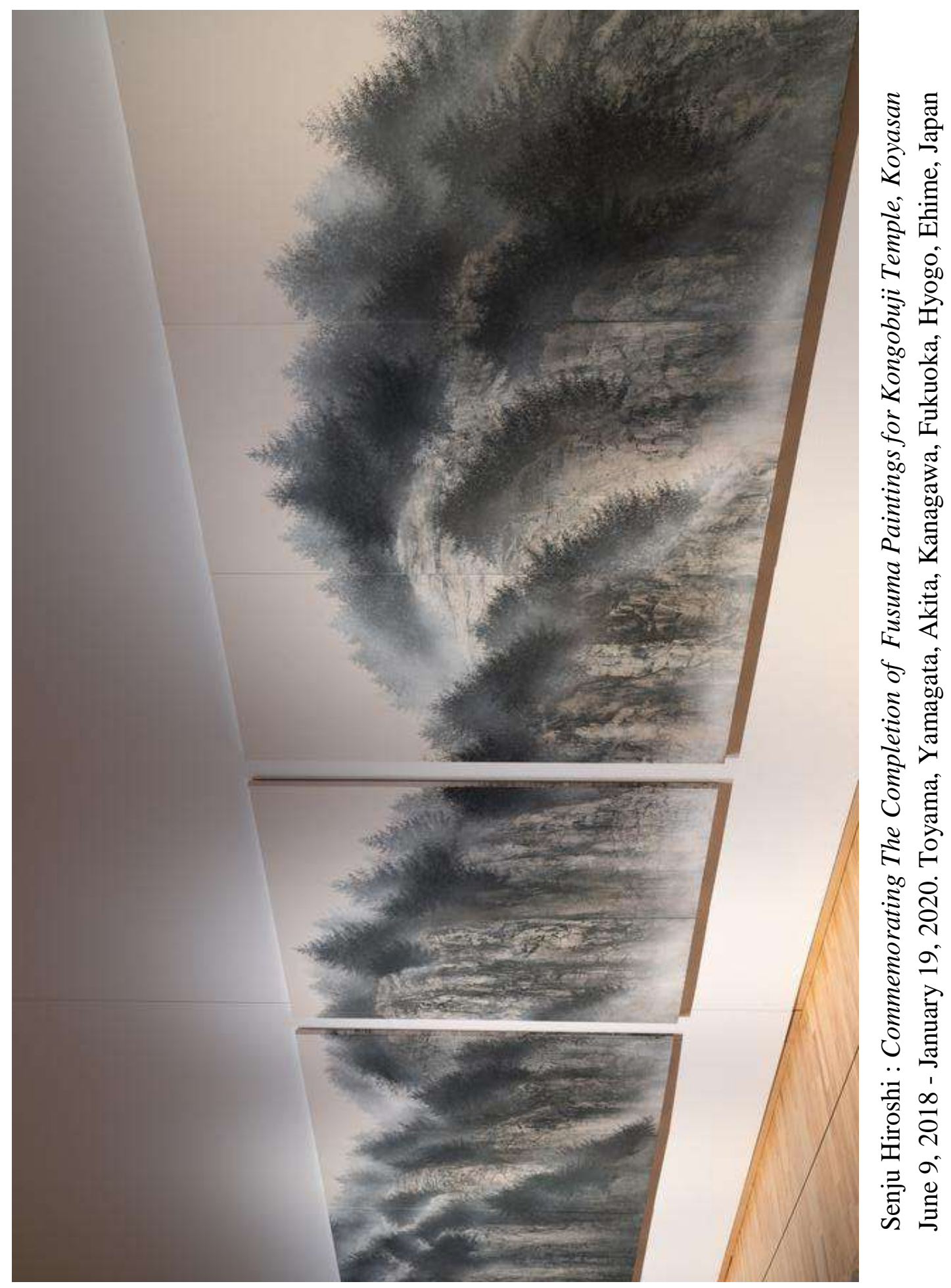


La Horizontalidad de la mirada de Oriente en Occidente 


\section{2.- La Narración Continua en la obra de Cy Twombly, Joan Mitchell,} Antoni Tàpies

Nuestra actualidad contemporánea busca con ahínco destruir las limitaciones con las que cada vez más la sociedad oculta algunos aspectos de nuestro entorno: la belleza, el anhelo de un algo divino, los valores míticos, los rituales. Al amparo de esta idea, entendemos que en cierta medida, al abandonar la perfecta identificación del yo y el mundo, el individuo contemporáneo parece haberse sumido en una profunda melancolía. Es decir que cuando el arte dejó de representar nuestros dramas olvidó también su identificación con lo sagrado. Una idea que nos recuerda Martín Medina:

Como evidencia Gillo Dorfles, en "La desacralización del arte y la pérdida de los valores míticos y rituales”, el arte contemporáneo se ha concienciado de sí mismo. Esta autoconciencia es la gran novedad, tras su largo proceso histórico en Occidente, donde el arte ha sido mezclado, si no confundido, tradicionalmente con la religión, con la belleza, con el saber, con el dominio de cuantos se ejercitaron en los poderes, con la vida social. El arte tradicional era una liturgia, una acción sagrada $[\ldots]^{462}$.

Sin embargo, en el trabajo de muchos pintores que han desarrollado su obra en la segunda mitad del pasado s. XX encontramos el anhelo profundo por reencontrar la poética del espacio pintado. Así, al recuperar la función narrativa y secuencial, en su pintura se regenerará una nueva estructura plástica. Hablamos de grandes cuadros, casi como murales que al carecer de cualquier simulacro de profundidad envuelven la mirada. Nos encontramos entonces ante unas obras donde su condición misma es consecuencia del interés del artista por el proceso mismo de pintar. Es decir, son la pura conciencia de la pintura que, así mismo, ha eliminado cualquier sugerencia de mímesis de la forma o del espacio mensurable y en profundidad. Unas pinturas que resultan ser un reto tanto para el pintor como para un espectador que, por lo tanto, se encontrará ante una realidad primaria, resultante al fin y al cabo del proceso de depositar la pintura sobre la superficie del lienzo.

Por otra parte, es indudable que algunos de estos pintores han acusado en sus obras la influencia de la filosofía zen japonesa: bien explorando su yo a través de la intuición o con un particular sentido del humor transcendental. Unas obras que en muchos casos destacan por su condición de serie - como sucede por ejemplo con las

\footnotetext{
${ }^{462}$ José Marín Medina, Tapies/Meditaciones, Madrid, 1976, p. 144.
} 
pinturas de Twombly - y donde la autorreferencia será una parte esencial de su definición. En cualquier caso, observamos que muchos cuadros - cada uno individual están integrados secuencialmente con otro, mediante el movimiento y el tiempo a la par. Hablamos de unas obras que para su desarrollo precisan de una intuitiva sensibilidad que permita expresar y captar un instante que, como tal, fluye. Su trabajo es el depositario de la creencia de unos valores intemporales que son un reflejo de su particular manera de mirar. Es decir, una selección cultural que ha escapado de los códigos perceptivos tradicionales de Occidente, reinventando su propio lenguaje y adoptando un espacio pictórico mucho más cercano al extremo oriental. En suma, unas obras que por lo tanto nos revelan una concepción del mundo que también parece beber de las obras tardías de Monet.

En cualquier caso, en todas ellas se revela el interés de su autor por los procesos de la pintura, respondiendo con interés a algunos aspectos del arte extremo oriental como por ejemplo la caligrafía - en estrecha comunión con el uso de una yuxtaposición lineal de soportes para sus obras. Es decir, la función comunicativa del ideograma, del signo, que estará en el origen de unas obras donde - mediante un diseño repetido sobre fondos vacíos - se creará un ritmo secuencial, casi musical, como rechazo a cualquier tipo de convenciones formales que puedan sugerir un espacio ilusionista. Entonces, las composiciones quedan suspendidas en equilibrio mediante la interacción de pares de complementarios: llenos/vacíos, movimiento/contramovimiento, atracción/rechazo, desplegándose en unos lienzos horizontales y largos, como frisos, o sobre consecutivos soportes que se leen como una secuencia serial y que permiten la unión de los contrarios. 
Cy TWOMBLY, JOAN MITCHELL, ANTONI TÀPIES 


\section{Cy TWOMBLY}

unque heredero del Expresionismo Abstracto, en su obra encontramos - a
semejanza de aquel equilibrio de tensiones de la pintura china y japonesa - la
extraordinaria cualidad de componer y oponer imágenes abriéndose tanto al mundo exterior como al interior, como pares de opuestos que se complementan, abordando la gestualidad psíquica como objeto y como sujeto para brindarnos un espacio pictórico que a su vez requerirá de la materia. Nos encontramos, pues, con una abrumadora serie de atributos que obligarán a Twombly a recurrir a grandes formatos o, en su caso, a la combinación de varios paneles consecutivos donde su pintura se despliega como una suerte escritura a través de un espacio fluido que se prolonga de manera aparentemente ilimitada. Es decir, unas obras que parecen no tener ni principio ni fin. En esta tesitura, será allá por la segunda mitad de los años cincuenta del pasado s. XX cuando Twombly comience a poner el énfasis en el blanco, suprimiendo en gran medida el color o recurriendo a él o a colores lavados sobre unos fondos blancos, vacíos, silenciosos. Hablamos de unas pinturas que como una caligrafía devienen en bidimensional y donde - como tal en su proceso - confluyen el espacio y el tiempo. Hablamos de unas pinturas en las que - de manera similar a la obra tardía de Monet - el color se vuelve materia, proyectándose a través de un continuo espacial desde el mismo sustrato de su creación, con sus cualidades inherentes al espacio, asociadas a otros sentidos además de los visuales. Nos encontramos pues ante ritmos fluctuantes que a través de superficies múltiples, en el proceso mismo del montaje final, crean superficies episódicas que reflejan con exactitud ese casi oriental enfoque secuencial de la pintura.

Así, podemos decir que la suya es una peculiar manera de escribir - de narrar en el tiempo - mediante un "ritmo fluctuante" como señaló Roland Barthes. 
El arte de Twombly [...] no pretende aferrarse nada, se sostiene, flota, se mueve entre el deseo - que inspira con sutileza la mano - y esa galanadura que constituye una discreta renuncia a todo afán de conquista. Si se quisiera localizar esta moralidad habría que buscarla muy lejos, fuera de la pintura, fuera del mundo occidental, fuera de la época histórica, en el límite de los sentidos. Y habría que decir con el Tao Tê Kung ${ }^{463}$.

Por consiguiente, entendemos que nos encontramos ante unas pinturas que han sido realizadas para ser leídas, utilizando el lenguaje del ritual implícito de su cultura. Un ejemplo que podemos encontrar en su obra Sin título (Panorama), de 1959, donde nos muestra cómo organizar de manera secuencial la pintura mediante la línea. Es decir, mediante un desarrollo lineal, como una serie de episodios independientes que son una especie de reflejo de voces e impulsos. Un equilibrio de tensiones entre palabras e imágenes, que recrea la iconografía de su simbólico universo en una estrecha comunión con el lenguaje y los mitos, formulado todo ello sobre unos lienzos que recurren para su escala monumental al uso de múltiples paneles. Efectivamente, hablamos de una escritura de la imagen que al fin y al cabo determinará la obra. Una imagen que no pretende ser la mímesis de contenido ni comunicar un determinado mensaje. Su despliegue fluctúa en paralelo a su mente, ordenando el lenguaje y el pensamiento secuencial.

\footnotetext{
${ }^{463}$ Roland Barthes, "La sabiduría del arte", prólogo al catálogo de la exposición de Whitney Museum of
} American Art. N.Y. 1979. En, Merve Verlang, Cy Twombly, Berlín, pp 84 y ss y 94 


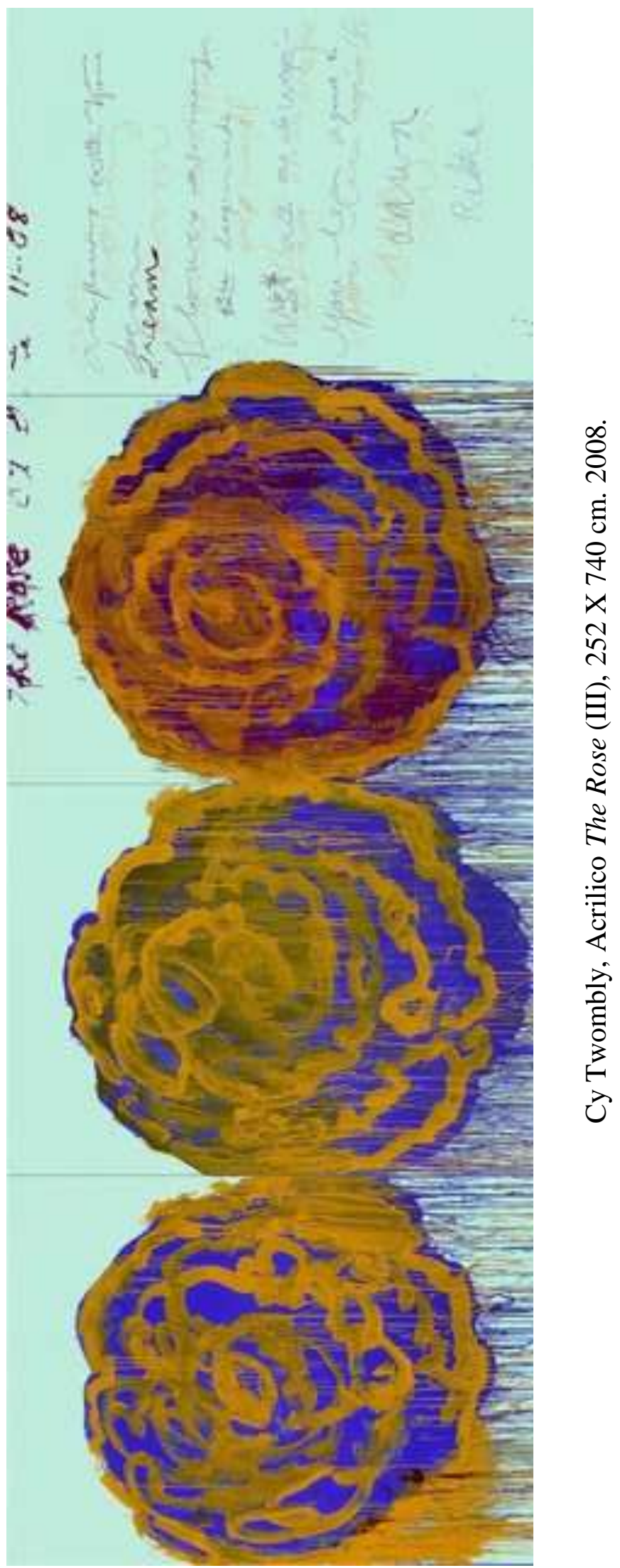



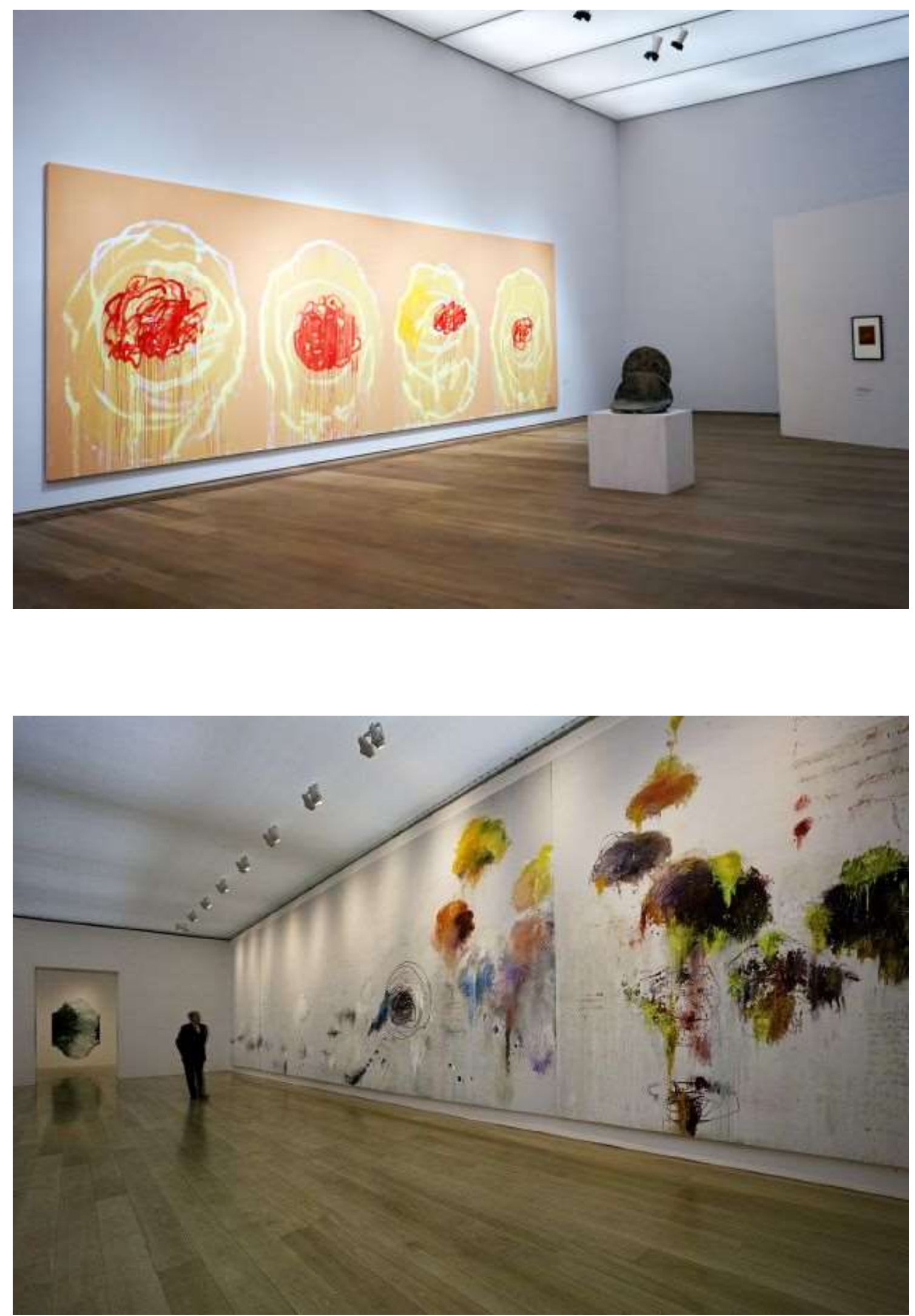

Cy Twombly. Renzo Piano's Pavilion at The Menil Collection in Houston. 400, 1 X $1585 \mathrm{~cm}$. 
La Horizontalidad de la mirada de Oriente en Occidente 


\section{JOAN MITCHELL}

$\mathrm{U}$

na de las figuras más destacadas del grupo de pintores que surgieron al amparo e influencia del Expresionismo Abstracto norteamericano aunque, consideramos, con una personalidad más independiente. En sus propias palabras:

[...] cuando estoy pintando no soy consciente de mi misma [...] es el cuadro el que me dice lo que tengo que hacer. [...] Quiero pintar la sensación de un espacio. Podría ser un espacio cerrado, o podría ser un espacio grande y abierto. [...] La abstracción no es un estilo. Simplemente quiero trabajar en la superficie, que es una manera de usar el espacio y la forma: es una ambivalencia de formas y de espacio. $[\ldots]^{464}$.

Una declaración de principios con la que abiertamente manifiesta que sus pinturas tratan más de sentimientos que de cuestiones artísticas y en las que la naturaleza ha sido precisamente la principal fuente de inspiración. Efectivamente, como si se tratase de aquellos antiguos pintores/letrados de la dinastía Song, Joan Mitchell pinta a partir de la impresión, de la emoción provocada por un determinado paraje. Es decir, sin discriminar entre el orden natural y el orden humano. En sus propias palabras "prefiero dejar la naturaleza tal cual [...] Ya es demasiado bella. No quiero mejorarla [...] Nunca intentaría reflejarla. En cambio, me gustaría pintar aquello que me transmite. La música, algunos poemas, ciertos paisajes [... $]^{\natural 465}$.

\footnotetext{
${ }^{464}$ Joan Mitchell, "Entrevista de Yves Michaud", en Alarcó, et al, Monet y la abstracción, Madrid, p. 302

465 Joan Mitchell, IVAM Centre Julio Gonzalez II-IX/14 XII 1997, Catálogo de la exposición, Generalitat Valenciana. Consellería de Educación i Ciencia, p. 10.
} 
Pero, en lo que compete al asunto del espacio pictórico, tal vez su manifiesta admiración por la obra de de Kooning o Kline haya influido en la característica intensidad de unas pinturas donde destaca especialmente su gran tamaño. Para ello, en muchos casos, recurrirá a formatos alargados o a la yuxtaposición de dos, tres o más paneles, lo que favorecerá el despliegue horizontal de sus pinturas y la secuencia rítmica de colores y formas, mediante el desarrollo espaciotemporal de la obra. A modo de ejemplo, en su obra Ici, del año 1992, parece hacer alusión a esa idea del espacio/tiempo de la pintura extremo oriental. Efectivamente, la palabra francesa ici - "aquî" - parece querer indicar el aquí, el ahora temporal y espacial, el lugar en el tiempo y en el espacio capturado a través de los colores y de los gestos que componen un espacio capaz de expresar una emoción. No por casualidad, para Mitchell, la pintura es la única forma artística que "carece de tiempo [...] nunca acaba, es la única cosa que es al mismo tiempo continua y estática [... $]^{\natural, 466}$. De este modo, nos encontramos de nuevo con una noción del espacio que nos remonta a aquel equilibrio de tensiones que inspirará además los dos grandes motivos de su pintura: el paisaje y la poesía.

De este modo, entendemos que la percepción de esta multivocidad se verá intensificada con el desarrollo horizontal de sus pinturas. Efectivamente, es interesante destacar como en Edrita Frief Mitchell recurre a una lectura secuencial - de derecha a izquierda - mediante el recorrido de unos trazos azules que parecen adquirir un cierto sentido etéreo al ser sustituidos paulatinamente por los amarillos. Así, la secuencia tonal cuasi sinestésica de estos colores establece una pauta musical que - al recurrir de manera intuitiva a la ley de la proporción numérica - logrará hacer ganar intensidad al espacio pintado. Para ello, esta pintura de enormes dimensiones recurrirá a la yuxtaposición de cuatro paneles en los que la abstracción de las líneas y el color fluctúan en una permanente evocación de la memoria, para así, parafraseando a Marshall "[...] usar la pintura para sumergir en ella el pensamiento cognitivo y transformar sus recuerdos de lugares y tiempos pasados en una expresión supernatural $[\ldots]^{467}$. En cualquier caso, no se trata de una memoria en el estricto sentido psicológico del término, ni de una obra pintada según una estricta sucesión que la entiende como una narración en el tiempo. Por el contrario, hablamos de un tiempo que es un todo presente en cada elemento de su espacio. Por lo tanto, una pintura que podemos entender sucesiva y simultánea mediante el despliegue unificado de todos sus elementos. Es decir, un todo espacial que se desarrolla en el tiempo. La expresión de una emoción, indisociable de unas pinturas que son un instrumento para un ejercicio espiritual del arte, del que nacerán acciones,/emociones y vacíos/formas. La contradicción o paradoja que se constituye en sí misma como una unidad, una sola realidad.

\footnotetext{
${ }^{466}$ Richard D. Marshall, Danielle Tilkin, Las pinturas de Joan Mitchell, Valencia, 1997, p. 11.

${ }^{467}$ Ibídem, p. 13
} 


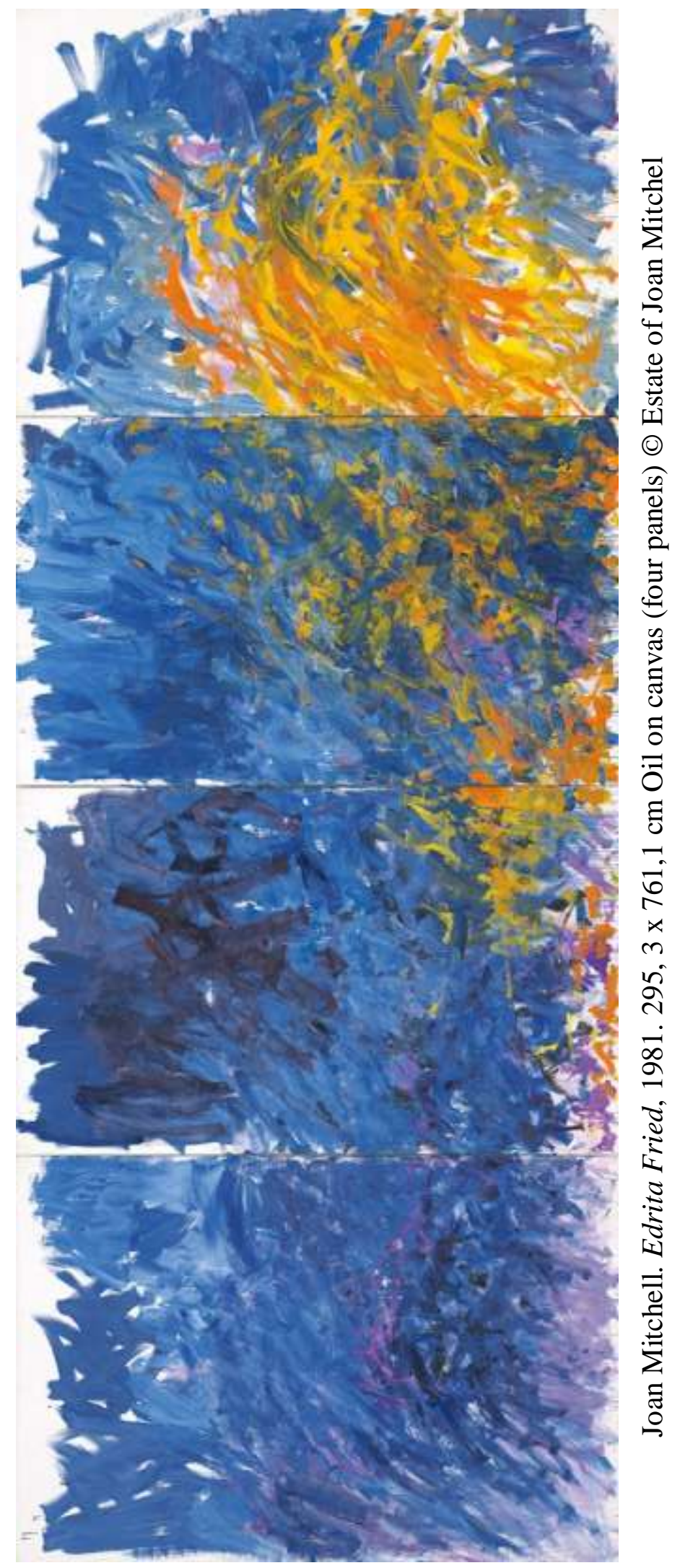




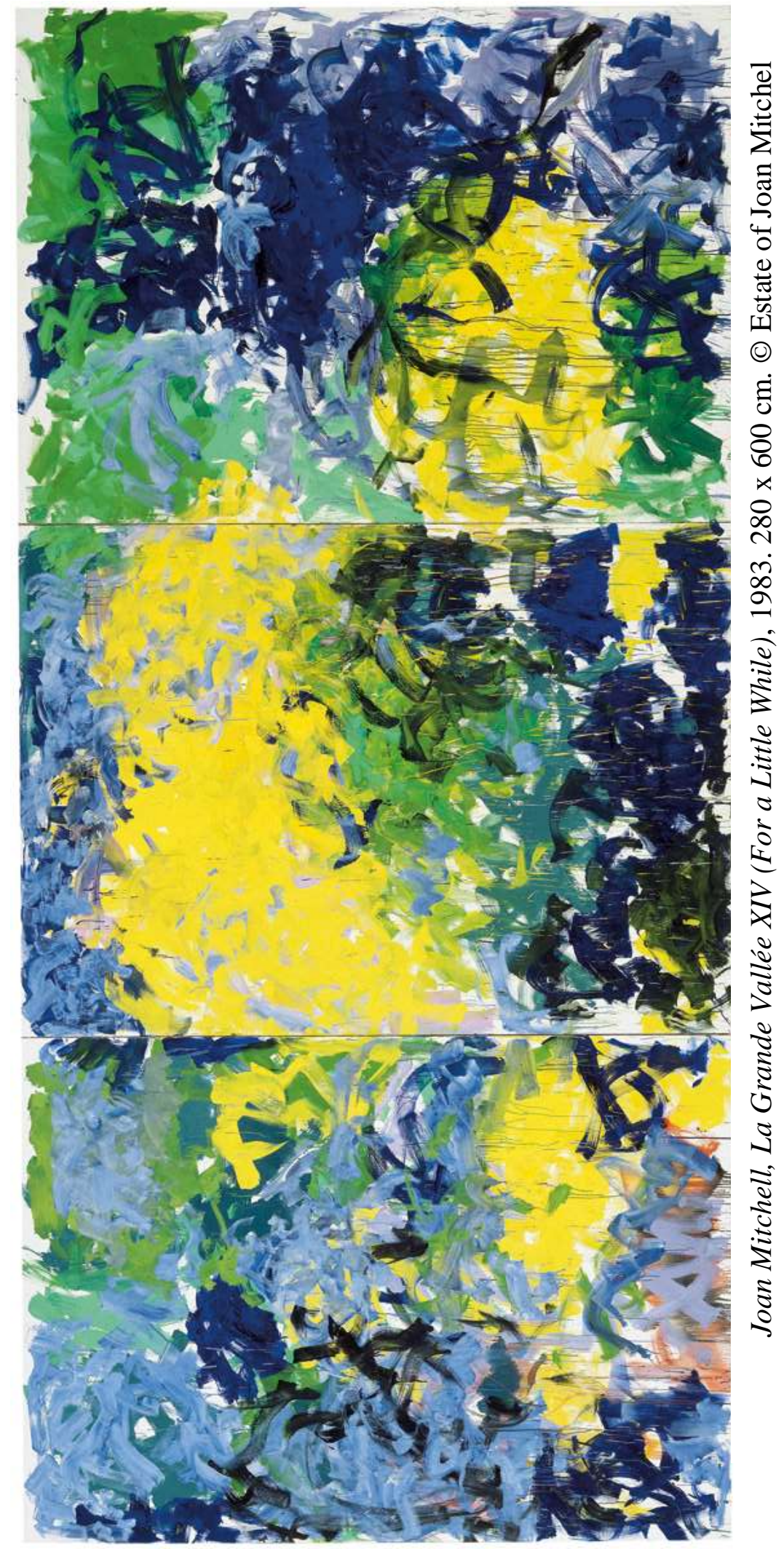




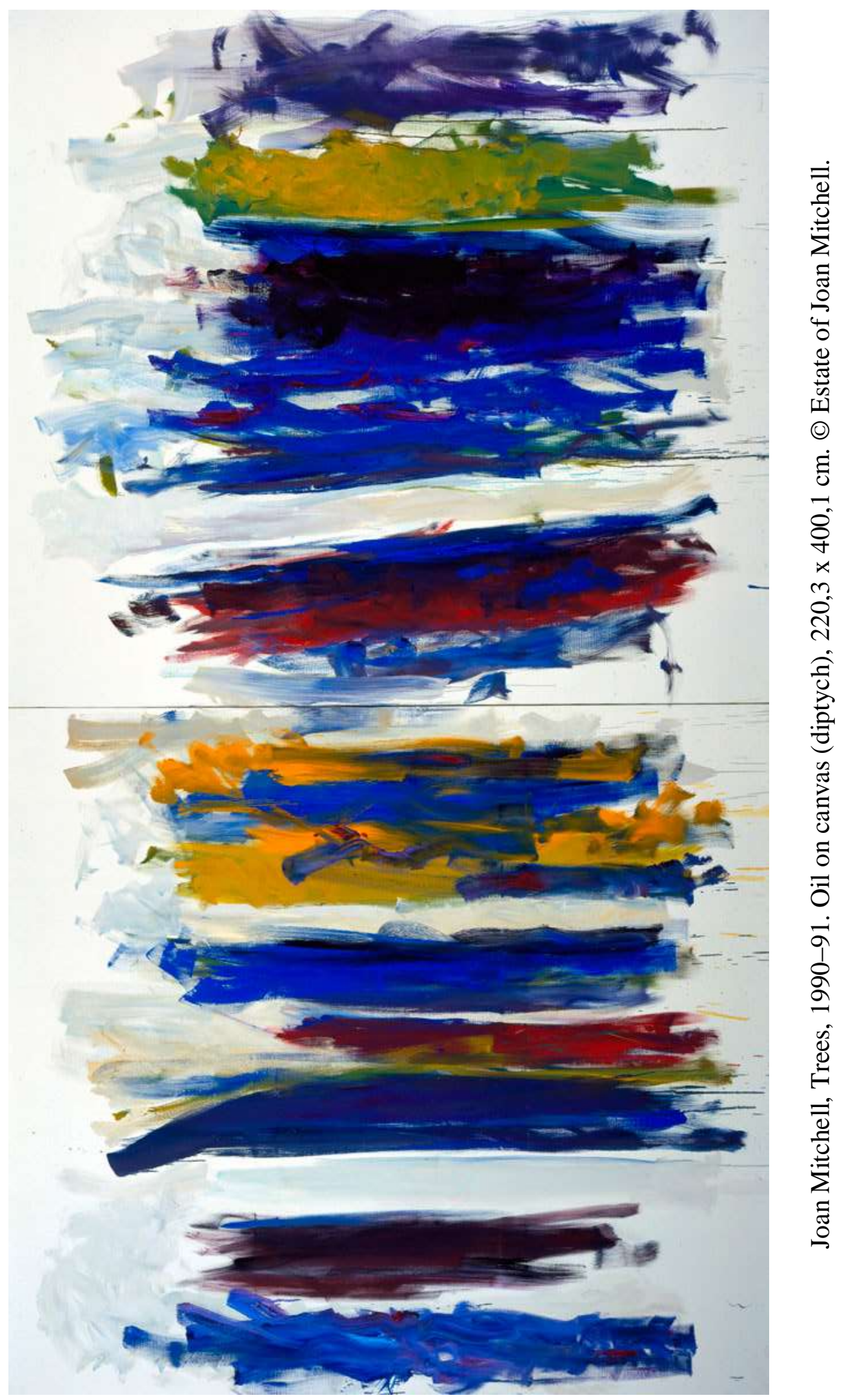




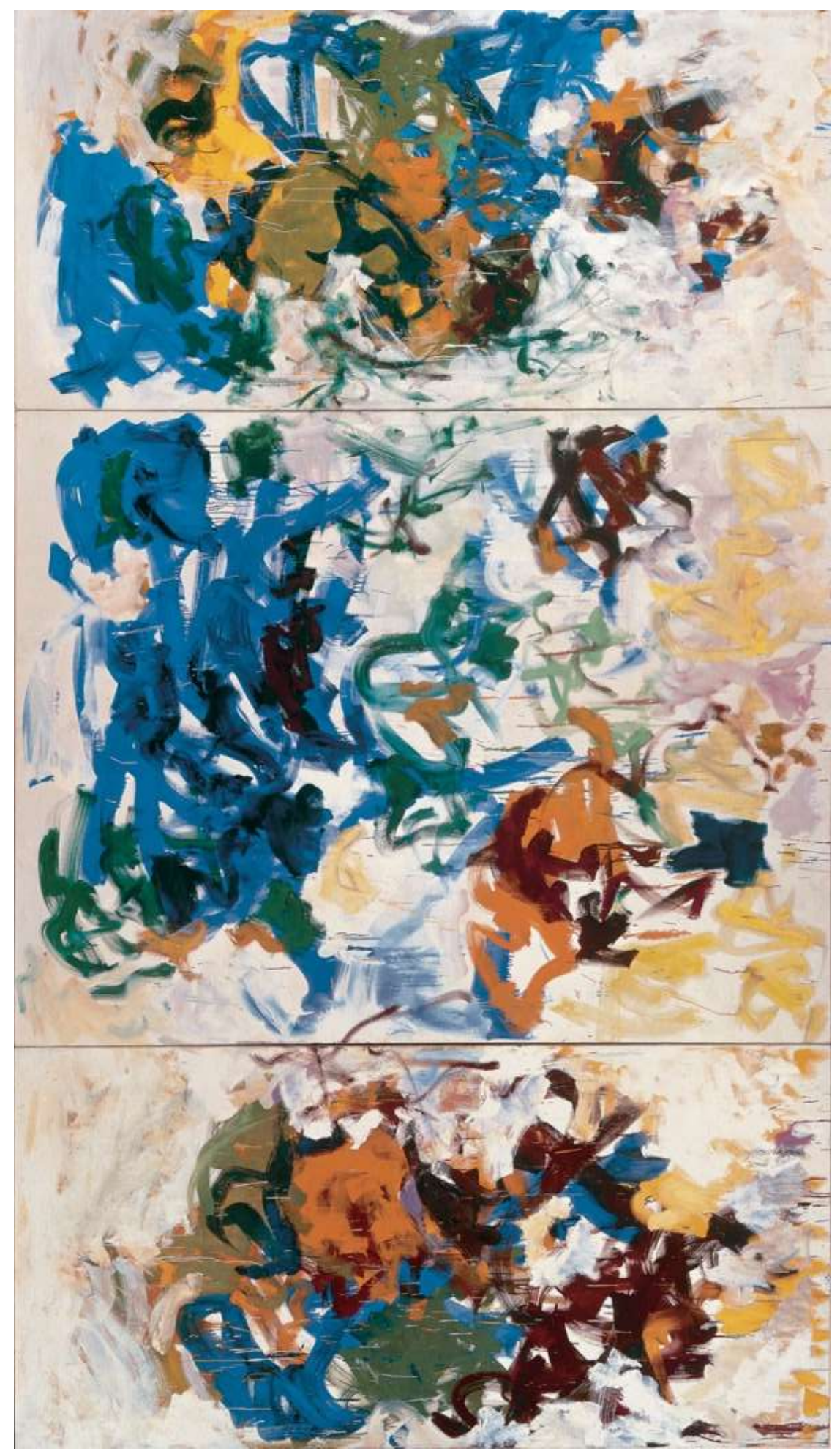

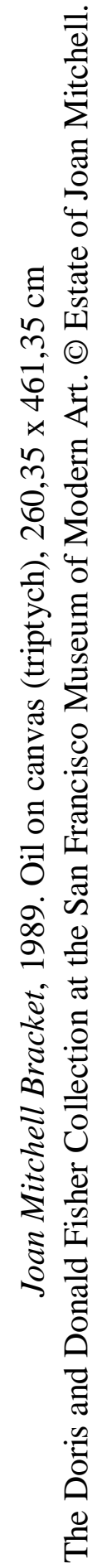




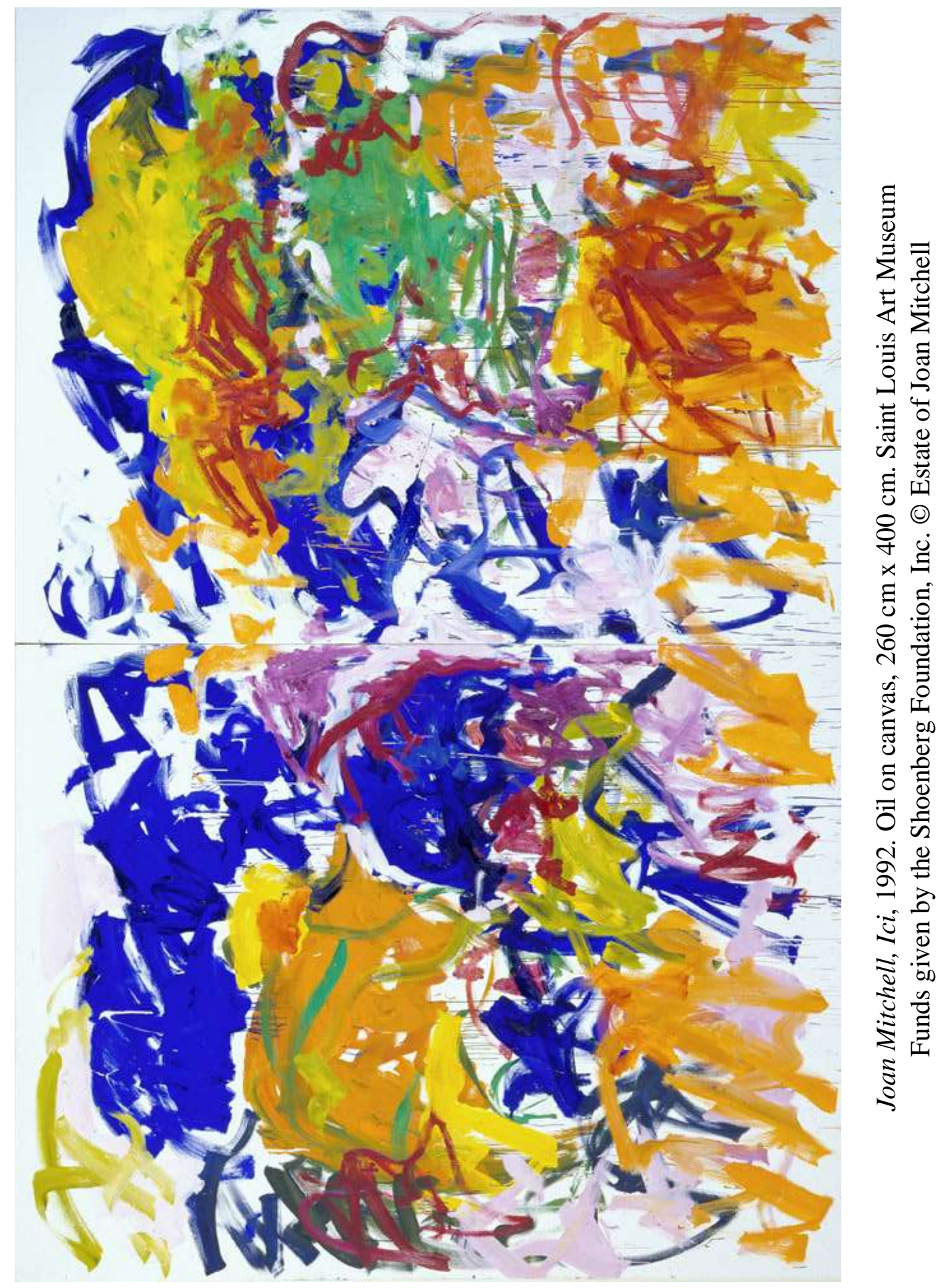


La Horizontalidad de la mirada de Oriente en Occidente 


\section{ANTONI TÀPIES}

$\mathrm{E}$ n su obra podemos encontrar algunos principios de la pintura Zen como, entre otros, la sugerencia de un mundo ajeno a los preceptos euclidianos, la transcendencia o tensión espiritual de la obra o la relación armónica de una cosmovisión expresada a través de una multivocidad no ajena a las cosas humildes, mínimas. De este modo, partiendo del Zen, la obra de Tàpies ni quiere describir ni busca reconstruir un espacio, por el contrario, lo entiende como el medio para que su lenguaje establezca un punto de partida para la comunicación entre el espectador y la obra. Una concatenación de estímulos que hila sutilmente el tejido de diferentes códigos y sobre los que el propio autor ha dicho:

[...] Hay obras de Claude Monet que me parecen tan fuertemente imaginativas, o más, que las del Bosco, que pasa por serlo mucho. ¿Qué diríamos entonces de los paisajes, de los pequeños bodegones o de otras imágenes de la pintura, o de la poesía, chinas o japonesas? Un simple hai-ku de Basho, que tal vez describe la "vulgaridad" de un hombre estornudando, va muy cargado de sugerencias imaginativas, de encadenamientos y asociaciones de ideas, quizá más ricas que la que provoca $E l$ jardín de las delicias ${ }^{468}$.

Una suerte de iluminación interior que penetra en la naturaleza de las cosas por medio de una mirada intuitiva a través de los símbolos de nuestra psique, que se verá expresada sobre una consecución de espacios. Un planteamiento totalmente alejado de una percepción lógico - analítica. Pero ¿ha sido esta una tendencia realmente nueva? Efectivamente, esta novedad ha tenido como un más que evidente referente a la

${ }^{468}$ Tàpies, Antoni. El arte contra la estética, 1986, Barcelona, Editorial Planeta-De Agostini, p. 217. 
caligrafía china y japonesa. En consecuencia, hablamos de una pintura que no se expresa recurriendo al color o que, más bien, se expresa recurriendo a su carencia y al uso de trazos firmes que, a decir de Martín-Medina, retoman una "[...] larga tradición cultural: la letra, el signo alfabético (tanto el signo adquirido o también el inventado con referencia a un alfabeto, o a un sistema de caracteres de comunicación cualquiera). La verdad es que el signo - letra, además de ser un elemento ancestral en la comunicación visual, ha sido utilizado desperdigadamente, a través de tiempos y culturas, con menores o mayores pretensiones de elemento artístico. Pienso más que en los sistemas de ideogramas, más que en los caracteres [... "469. Estamos hablando, por lo tanto, del letrismo de su pintura matérica.

En suma, entendemos que al hilo de la tendencia de la pintura del s. XX, tratando de retomar convenciones preculturales para romper con una tradición dada, la obra de Tàpies volverá su mirada hacia la pintura de otras latitudes y/o de otras épocas, especialmente de la pintura y la caligrafía extremo oriental. Por consiguiente, nos reencontramos con lo que podemos interpretar como un ritual o una "liturgia de los objetos" que, a decir de Marín-Medina nos presenta "[...] el misterio sugeridor de hallar algo en una situación imprevisible hoy pero que pertenece a nuestro propio recuerdo. Tàpies nos propone el hallazgo dentro de la memoria $[\ldots]^{\prime 470}$.

\footnotetext{
469 José Marín-Medina, Tapies/Meditaciones, Madrid, 1976, p 116.

${ }^{470}$ Ibídem, p. 34.
} 


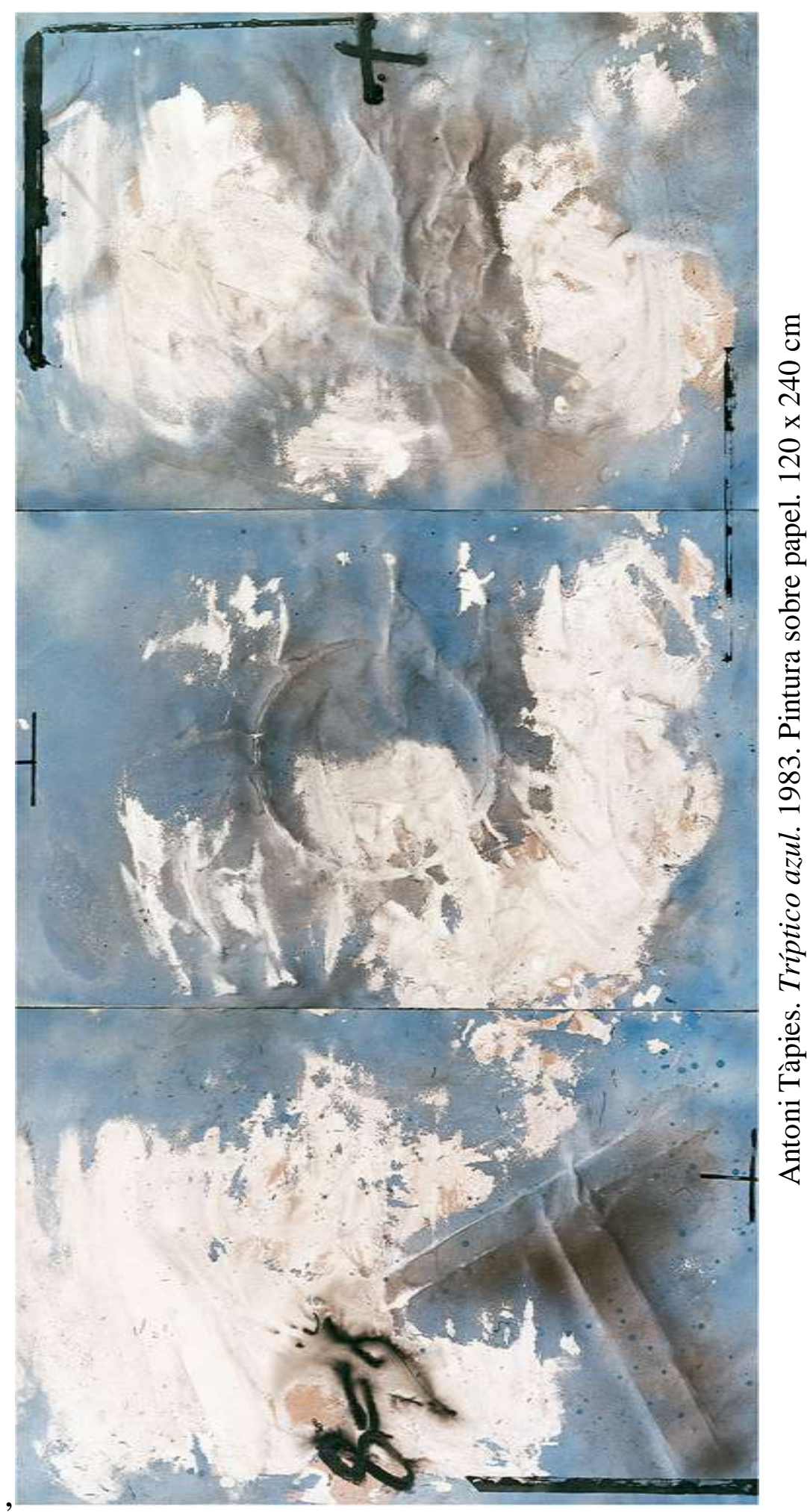




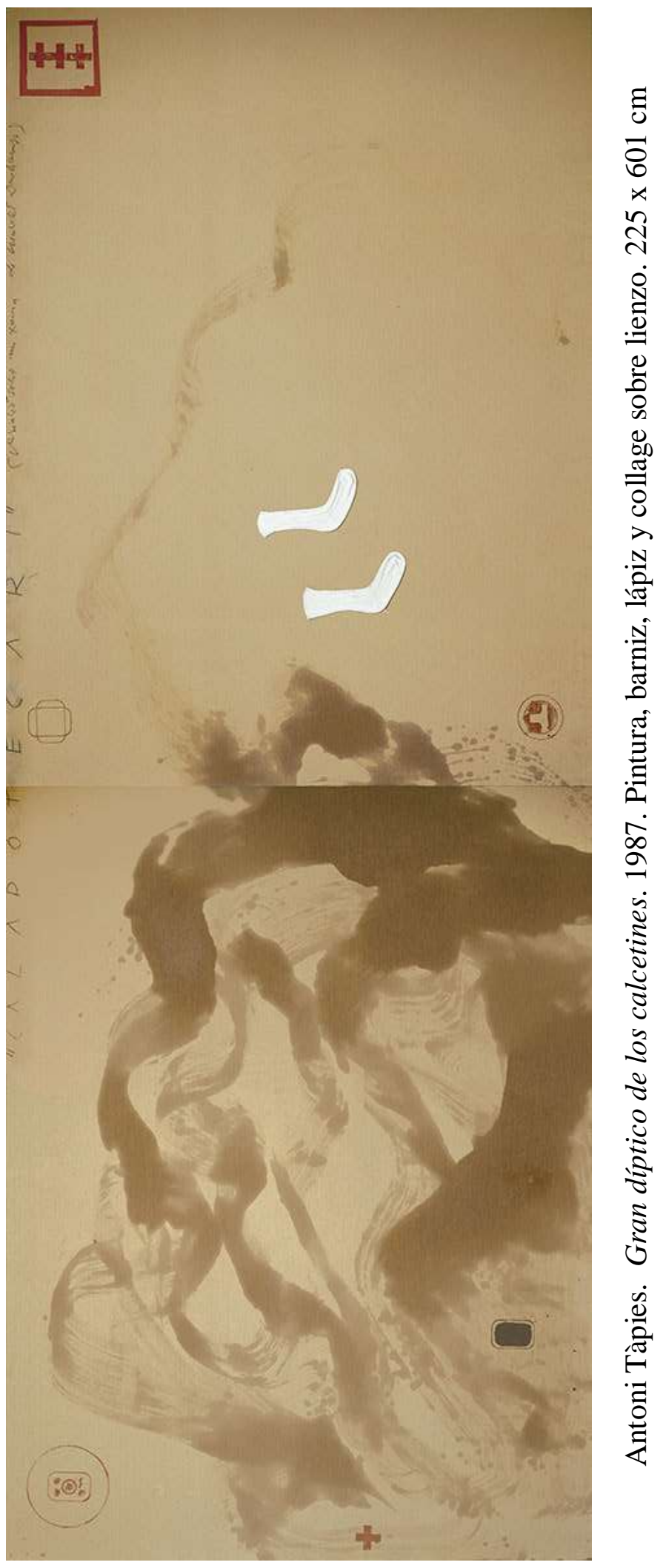




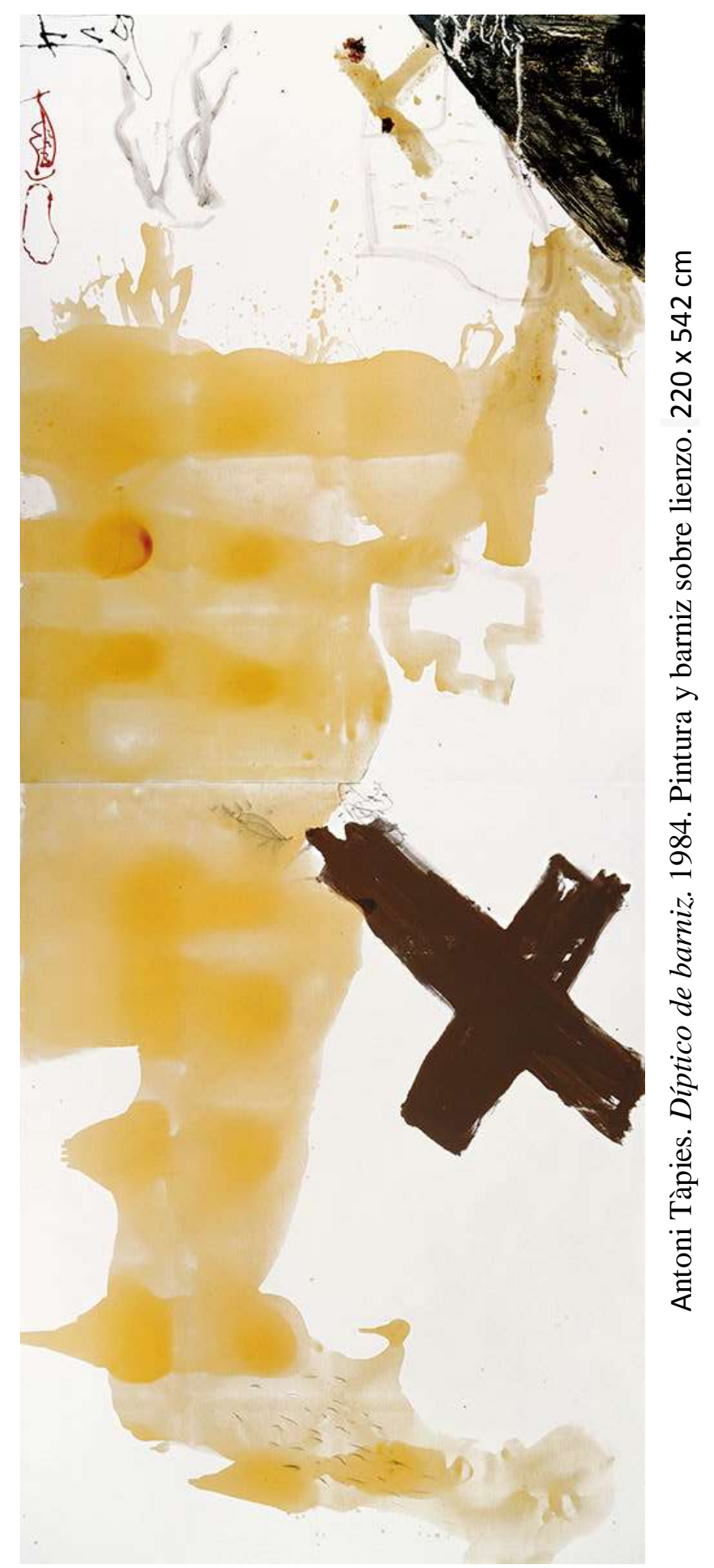




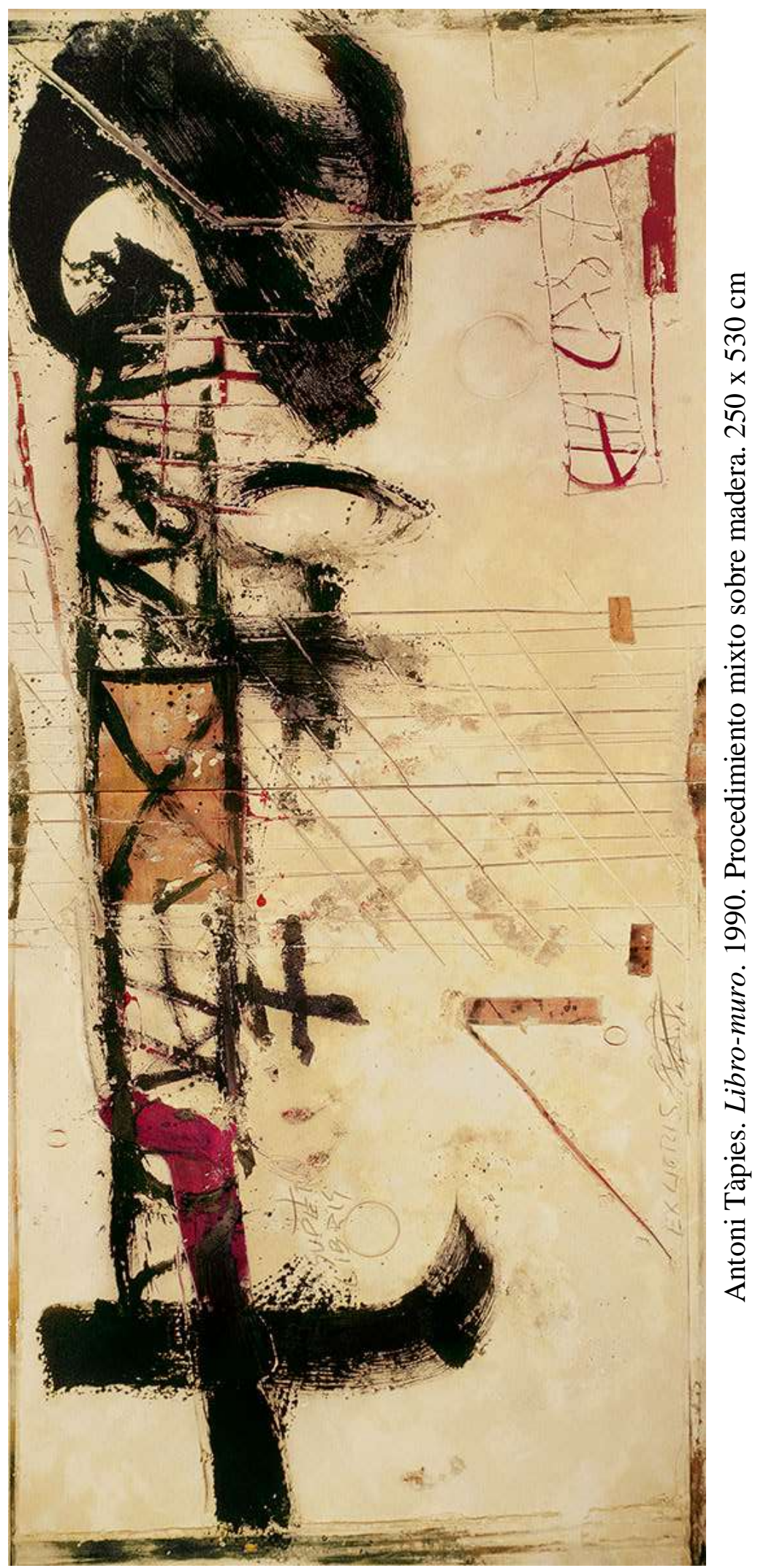


La Horizontalidad de la mirada de Oriente en Occidente 


\section{CONCLUSIONES 471}

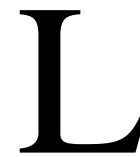

a comprensión del espacio pictórico ha sido desde siempre un tema recurrente tanto en los estudios de Estética como en los de Historia y Sociología del Arte. Se trata de una problemática sujeta a nociones y patrones de creencias profundamente arraigadas que no constituyen una construcción gratuita sino que se corresponden con un cierto tipo de civilización. Por consiguiente, el estudio de sus sistemas de representación nos permite acercarnos a las ideas abstractas del intelecto a través de su materialización como códigos concretos. Para ello, en esta tesis hemos recurrido tanto al uso de determinados conceptos - entendidos desde el contexto semiótico de su cultura - como de comparaciones culturales - donde cada apartado cultural se comprende mirando al otro - para ampliar algunas nociones sobre el concepto del espacio en la pintura y sobre la dialéctica que se establece entre la mirada, la obra y el espectador. Al hilo de esta idea, en el marco de esta investigación hemos estudiado unos modelos perceptivos que han ido evolucionando al amparo de todo un conjunto de creencias, normas y sentimientos que conforman lo que se ha dado en llamar una selección cultural. Como ejemplo, hemos mencionado el término japonés fûkeiga shoshiki (風景画書式) - que podemos traducir como “formato horizontal de escritura al estilo de la pintura de paisaje» - un concepto en el que, en el contexto de esta investigación, podemos deducir la implicación de un determinado sistema oculto de ideas. Efectivamente, aunque etimológicamente se trata de un término relativamente nuevo, en él encontramos unas implicaciones espaciales profundamente arraigadas en la tradición extremo oriental. Por lo tanto, inferimos que su acepción espacial lo enmarca

\footnotetext{
${ }^{471}$ En este último apartado se recoge parcialmente el ensayo "El espacio pictórico europeo y extremo oriental. Una comparativa entre la noción de horizonte y de horizontalidad", publicado en Eurasia: Avances de Investigación, Salamanca: Ediciones Universidad de Salamanca, 2020.
} 
en un determinado nicho cultural que tarde o temprano termina por imponerse y que, parafraseando a Francastel, en el caso de la pintura "ofrece un modelo selectivo de ordenación de selecciones visuales" ${ }^{, 72}$.

Al amparo de esta idea, a lo largo de esta tesis hemos señalado como tanto en el campo pictórico extremo oriental como en el europeo se observa la presencia de un elemento horizontal que, como tal, interviene en la organización de su espacio. Lo que podemos entender como una categoría de horizontalidad que, sin embargo, según las leyes perceptivas difiere en ambos espacios culturales. Así, en Occidente el espacio pictórico se comprende desde una escala humana que precisa de un punto de referencia fijo defendido por la Perspectiva o monoperspectivismo y que argumenta su posicionamiento como una única verdad. De este modo, la mirada se extiende en profundidad hacia un horizonte conceptual, ideado por y para un punto de fuga fijo ubicado sobre una línea horizontal. Nos encontramos aquí con una proyección espacial limitada por el plano del dibujo que mantiene resonancias cartesianas e introduce el cálculo numérico para la construcción de imágenes. Mientras en la pintura extremo oriental la mirada se desplaza de manera lineal, mediante una suma de agregados que secuencializa el espacio. Hablamos de un ensamblaje de grupos organizado mediante el denominado Foco Móvil o Principio de la Narración Gráfica Continua. Un recurso que para el desglose del espacio pictórico recurre a la horizontalidad de los formatos o a la yuxtaposición de un número determinado de soportes: los rollos de mano, que en su versión horizontal se denominan emakimono (絵巻物) en japonés/ chüan (手捲) en chino, los biombos - byôbu (屏風) en japonés, pingfeng (屏風) en chino - y los álbumes plegados - ts'e o ts'e yeh (冊) en chino, gachô (画 帳) en japonés ${ }^{473}$. Por consiguiente, nos encontramos con la lectura de una factura horizontal cuyo espacio comprende una noción de vacío que suscita la impresión de resonancia numinosa y que - en el contexto del formato de estos característicos soportes - entendemos como una "horizontalidad dilatada". Es decir, aquella que Otto define como lo "sublime puesto en sentido horizontal" 474 .

Pero, consignar estas diferencias nos ha obligado a preguntarnos sobre las causas explicativas que han dado lugar al fenómeno de la perspectiva en Europa y al método continuo en el Extremo Oriente, entendiendo ambos en el sentido artístico como modelos de percepción. Sin embargo, asumir ambos como sistemas de representación, nos obliga como tales modelos - con acepciones sociales, artísticas y filosóficas - a deducir unas normas destinadas a la concepción de ambos espacios pictóricos que, a su vez, han estructurado tanto sus modos de representación como de contemplación. Una problemática que atiende al sujeto en tanto en cuanto éste hace suya la imagen a partir de la ya mencionada pulsión escópica, común a todas las épocas y culturas que hayan

\footnotetext{
472 Pierre Francastel, Sociología del arte, Madrid, 1984, p. 34.

${ }^{473}$ Ver, Robert van Gulik, Robert. H. Chinese Pictorial Art. As Viewed by the Connoisseur. Notes on the Means and Methods of Traditional Chinese Connoisseurship of Pictorial Art, based upon a Study of the Art of Mounting Scrolls in China and Japan. New York: Hacker Art Books, 1981.

${ }^{474}$ Rudolf Otto, Lo santo. Lo racional y lo irracional en la idea de Dios. Madrid, 2016, p. 154.
} 
destinado normas colectivas para la mirada que, además, estén históricamente explicadas. Por consiguiente, entendemos que si tanto el Extremo Oriente como Occidente han recurrido a sistemas de representación codificados, ambas son culturas escópicas que, por lo tanto, han desarrollado sus propias normas colectivas de percepción. Pero, inferir este supuesto nos ha permitido utilizar el concepto de "forma simbólica" de la que nos hablaba Panofsky: la perspectiva como forma simbólica y como emblema del Renacimiento, para posteriormente convertirse en el símbolo cultural de autoafirmación de Occidente.

Pero llegados a este punto, hemos tenido que hacernos la siguiente pregunta: ¿podemos interpretar el recurso de la narración gráfica continua como la forma simbólica de Oriente? Pero, ante la presunción de esta categoría cabe preguntarse ¿por qué no se ha encontrado en Oriente ningún término que la defina? Nos consta que ya en el s. V, Hsieh Ho (谢赫) en la Crítica de la pintura o Notas sobre la clasificación de los viejos cuadros (Gǔ Huà Pǐn Lù 古画品录) recoge los cánones que debían regir la pintura en seis principios (Huihuà Liùfă 绘画六法). Además, también conocemos el uso del método de tres distancias Sānyuănfă (三遠法) publicado en el Línquán Gāozhì (林 泉高致), atribuido a Guo Xi (郭熙), un compendio de tres términos chinos para definir los diferentes enfoques en profundidad del espacio de la pintura de paisaje: Gâoyuân ( 高遠), Shênyuân (深遠) y Píngyuân (平遠). Por otra parte, tenemos publicaciones sobre adaptaciones chinas de la perspectiva, como el método Xianfa (線法) - véase el Shixue jingyung (視學精蘊), Esencia de la ciencia de la visión de Nian Xiyao (年希堯 ) ${ }^{475}$, publicado en 1729 - además de las técnicas aotufa (凹凹法) y gougufa (句股法)， como ejemplo del producto resultante de la hibridación visual del Extremo Oriente y Europa. En resumidas cuentas, nos encontramos con una serie de conceptos y publicaciones que nos muestran como los artistas extremo orientales - en estos casos, concretamente de China - han codificado sus propios sistemas visuales, los cuales a su vez son un reflejo de sus sociedades y su filosofía. Sin embargo ¿por qué no encontramos ninguna publicación extremo oriental sobre el sistema de la Representación Gráfica Continua?

Al amparo de esta idea, por una parte nos hemos detenido en el concepto de ventana como origen del formato del cuadro occidental y por otra en el de los formatos antes mencionados de la pintura extremo oriental, que recurren a un desarrollo lineal comprendido como una experiencia continua espacial y temporal. De este modo, en el contexto cultural de estos característicos soportes, si en el caso europeo para la representación del espacio la pintura recurre a la Perspectiva, en el de Asia Oriental se aplicará el denominado Principio de la Narración Gráfica Continua, recurso sobre el que George Rowley (1981) - en Principios de la pintura china - nos explica cómo capta un tiempo que se desarrolla a través de un movimiento lateral de las líneas compositivas y no en profundidad, como ha sucedido a partir del desarrollo de la perspectiva en la

\footnotetext{
${ }^{475}$ Véase Elisabetta Corsi, La fábrica de Ilusiones. Los Jesuitas y la difusión de la perspectiva lineal en China, 1698-1766. México: El Colegio de México, Centro de Estudios de Asia y África, 2004.
} 
pintura del Renacimiento y de la Edad Moderna europea. Por lo tanto, una pregunta importante para esta investigación es la que sigue: ¿Podemos entender la Perspectiva y la Narración Gráfica Continua como dos sistema de representación, constituidos en los sistemas representativos de dos ámbitos culturales? Una cuestión relevante que en el contexto occidental nos remiten al Renacimiento cuando la pintura, al estar necesitada de certezas, terminó por acuñar un nuevo concepto de espacio: métrico y siempre reflexionado desde una escala humana. Efectivamente - al estar necesitado de un punto de referencia fijo en la línea del horizonte - el espacio pictórico moderno occidental permitirá que la mirada se extienda en profundidad, dando lugar a lo que hoy entendemos como el origen del oculocentrismo europeo que, entre otras cosas, ha encontrado su significación cultural en la perspectiva y ha sido el origen de un nuevo formato para la pintura, el cuadro. Es decir, lo que hoy se comprende como un símbolo cultural de autoafirmación que mediante la comprensión de un espacio pictórico unificado alcanzará su correlato teórico en la perspectiva: un sistema de representación convertido en el sistema representativo de Occidente.

No obstante, no podemos ignorar que, igual que en la tradición de la pintura de Asia Oriental, tanto en la Antigüedad Clásica como en la Edad Media del arte europeo se ha recurrido a secuencias espaciales y temporales como estrategia para unir varios elementos mediante agrupaciones rítmicas. Una circunstancia que favorecía planteamientos espaciales más expresivos e intuitivos que - lejos de estar planteados alrededor de un centro unitario - lograban un efecto de unidad mediante la yuxtaposición de espacios, dando así lugar a una sucesión temporal que se perdió en el siglo xv con el Humanismo y el desarrollo científico de la perspectiva. Mientras, en el contexto de la pintura extremo oriental, la pintura ha recurrido a unos soportes que ni a lo alto ni a lo ancho pueden ser aprehendidos de una sola ojeada dando lugar a su característica dimensión espaciotemporal. Así, a diferencia de la pintura europea, su universo no es estático ni está centrado en un punto de vista fijo, lo que ha dado lugar a una relación espacio/tiempo que se expresa a través del concepto $M a$ 間 $^{476}$ que al fragmentar el espacio establece una relación secuencial, yuxtaponiendo los diferentes elementos que intervienen en la pintura y alternando motivos y silencios/vacíos ${ }^{477}$.

Al hilo de esta idea, hemos puesto el énfasis en una cuestión relevante: para estudiar la concepción del espacio en la pintura extremo oriental debemos tener en cuenta que la comprensión de su construcción - como sustrato y como fundamento ontológico - se estructura a partir de la expresión de dos aspectos dentro de un mismo universo. Es decir, su comprensión atañe a una dualidad que sin dejar de serlo conforma una sola realidad. Un equilibrio de tensiones - que entiende que el mundo de los fenómenos descansa sobre una oposición polar de fuerzas asociadas al Yin (陰) y el

\footnotetext{
${ }^{476}$ Concepto budista asociado a un intervalo entre varios objetos que se relacionan en continuidad.

${ }^{477}$ En estas pinturas se denominó $X u$ por los taoístas y shûnyatâ por los budistas a aquel espacio sin contornos donde los objetos pierden su silueta definida. El denominado Ku 空 del budismo zen japonés: una idea del vacío como generador de vida, donde el mundo fenoménico es una sombra, la ilusión del auténtico mundo que es el espiritual. De aquí la categoría del yohaku 余白 o blanco que resta, que define aquel espacio vacío gracias al cual el trazo del pincel adquiere su verdadera razón de ser.
} 
Yang (陽) ${ }^{478}$ - expresadas a través de los binomios espacio/ tiempo, sugestión/ composición y formas/silencios-vacíos, reforzados por la coherencia de la interdependencia de los opuestos. En otras palabras, se trata de una serie de relaciones de áreas de carácter aditivo, que en su movimiento horizontal organizan la composición mediante una secuencia rítmica expresada con el término chino Qifú (起伏) ${ }^{479}$.

Llegados a este punto hemos deducido que, sin duda, uno de los rasgos esenciales que mejor ha definido esta estética ha sido una cierta resistencia a la unidad mediante la búsqueda armónica de los opuestos. Si bien, esto no debe llevarnos a conclusiones demasiado generalistas ya que, por ejemplo - a diferencia de China - en Japón el uno no subsume a lo múltiple y en consecuencia, más que su armonización, se ha valorado la multivocidad y la coexistencia de diferentes planos. Un ámbito, en cualquier caso, donde se da una binaridad de fuerzas que no se excluyen mutuamente y que provocan una mutación constante. Es decir, que el mundo de los fenómenos reposa sobre una interdependencia de opuestos complementarios: lo positivo y lo negativo, la luz y la sombra, lo creador y lo receptor Por consiguiente, el espacio pictórico de Asia Oriental se estructura desde el desarrollo lineal de unas pinturas organizadas a partir del denominado Principio de la Comparación Interna (Rowley. G: 1981), un planteamiento espacial completamente distinto al occidental que recurre a una teoría científica de la visión para construir el espacio. Y de aquí, otro punto esencial para esta investigación que nos depara otra comparativa: construcción y composición. Una composición espacial en la pintura extremo oriental que mantiene profundos vínculos con lo sagrado y la occidental evoluciona desde un estricto sentido cartesiano hacia la mimética construcción de su espacio.

En cualquier caso, este asunto nos ha llevado al siguiente punto de nuestra investigación: señalar la influencia de los sistemas de pensamiento sobre la concepción del espacio pictórico y sobre los códigos perceptivos. En esta tesitura, en el ámbito extremo oriental, es sabida la influencia de China sobre gran parte de las ideas fundamentales de Japón y Corea: la composición de los colores o la ley de la proporción numérica de su pintura ${ }^{480}$, pasando por algunos de sus principales valores culturales o un sincretismo estético y religioso que, en este último caso, comprende también la tradición de unas divinidades relacionadas con los fenómenos y con las fuerzas de la naturaleza. Una representación de todo cuanto hay como sagrado - a las que el sintoísmo denomina kami (神), el taoísmo shen (神) y hotoke (仏) el budismo que están comprendidas dentro de una cosmovisión a la que podemos considerar

\footnotetext{
${ }^{478}$ Los conceptos de Yin 陰 y Yang 陽 son una noción básica dentro de la cosmología china. No se entienden como fuerzas o energías. Son los nombres que reciben las parejas de elementos que están relacionados entre sí por oposición y complementariedad. Es decir, lo Yin existe gracias a lo Yang, y viceversa.

${ }^{479}$ Secuencia rítmica subida-descenso. Es decir, la "disposición de las estructuras en su movimiento horizontal". François Cheng, Vacio-Espíritu. Textos teóricos chinos sobre el arte pictórico. Valencia 2017, p. 55.

${ }^{480}$ También llamado principio del menor número, al que recurre para captar el $Q i$ 氣 (pneuma o soplo vital) a partir del sonido y a través de la obra, establecía una resonancia musical entre el espectador y el artista.
} 
panteísta o animista, caracterizada por una armonía no dualista donde el hombre y el medio natural conforman una unidad ${ }^{481}$. Una dialéctica entre identidades autoafirmativas y exclusivas que desde el punto de vista de la historia de las religiones ha dado lugar a doctrinas individuales como el daoísmo, sintoísmo y budismo, y entre sus hibridaciones de diverso tipo a un fenómeno religioso que llamamos sincretismo. Así, todos ellos han tenido en común la práctica de lo que podríamos denominar un ejercicio espiritual del arte, es decir, la experiencia religiosa a través de la relación armoniosa del hombre, la naturaleza y el arte. Lo que a su vez nos remite a la creencia mutua de la reciprocidad entre el sujeto, los dioses y la naturaleza, estableciendo así una relación horizontal que conserva un indiscutible paralelismo con la armonía que recoge el I Ching (易经) - Libro de las Mutaciones- entre el hombre, la tierra (el espacio) y el cielo (el tiempo). Desde esta perspectiva el cielo y la tierra al mismo tiempo representan el espacio y el tiempo. Una idea fundamental de la mutación que rige todas las cosas y que regula ante todo la relación entre las tres entidades que son el cielo, la tierra y el hombre. Una visión naturalista del cosmos que explica la existencia de múltiples verdades dentro de un sistema horizontal de las relaciones, en el ámbito de un animismo politeísta que ha funcionado como base para una estructura social fundamentada en una idea de colectividad, donde la norma se centra en la idea del grupo y no del individuo ¿Ha favorecido esto una comprensión horizontal en la interpretación de las relaciones?

Una cosmovisión muy diferente a la antropocéntrica característica de Occidente. Es decir, de un conjunto de valores cristianos - cuyo origen monoteísta se encuentra en el Viejo Testamento - planteados desde un punto de vista antropocéntrico y dentro de un sistema vertical de las relaciones, donde Dios y el individuo ocupan el estatus más elevado. De aquí esa comprensión del yo imbuida por aquella idea de un Dios y verdad únicos característicos de la dicotomía occidental. Pero ¿podría esta jerarquía estar relacionada simbólicamente con la tradición de la pintura moderna europea donde el esquema compositivo gira alrededor de un único foco central? ¿Podría encontrar su correlato en una estructura del cuadro - supeditada a un punto de vista homocéntrico que ha puesto el acento en la perpendicularidad del espacio compositivo con respecto a una supuesta línea de un horizonte físico y conceptual? Un pensamiento sistémico caracterizado por una visión monoteísta, origen de una tradicional separación entre la naturaleza, la sociedad, la divinidad y el mismo yo. Una cosmovisión que tiene como referente una figura omnipotente paradigmática de Occidente, que se relaciona simbólicamente con una jerarquía que - con respecto a la sociedad y la naturaleza otorga al hombre el estatus más elevado dentro de un sistema vertical de relaciones. En definitiva, una tradición enmarcada dentro de las grandes religiones de Oriente Medio el cristianismo, el judaísmo y el islam - que entendían el origen de la verdad implícito en la revelación divina y para las que la representación en imágenes de los temas sagrados resultaban particularmente polémicas. Entonces, esta visión que jerarquiza la separación de la divinidad, la naturaleza y el hombre ¿ha podido tener relación con la

\footnotetext{
${ }^{481}$ Una triple tipología de deidades que desde un punto de vista estructuralista - donde sus diferencias son muy relativas - nos revelan una coincidencia fundamental: todas ellas pertenecen a la misma categoría semiótica de "espíritus".
} 
verticalidad compositiva con respecto a la línea del horizonte que encontramos en la pintura europea? Y, en este caso ¿podría, entonces, cada sistema cultural encontrar su correlato en la estructura espacial de sus pinturas? Llegados a este punto, parece inevitable cuestionarse la lógica de si la relación horizontal de cielo/tierra/arte extremo oriental puede plantear la alteralidad de su pintura con respecto a la cosmovisión de sus sociedades.

Así, hemos visto como las supuestas limitaciones que el esquema de la tradición ha impuesto sobre la sintaxis de la imagen, lejos de empobrecerla, han dado lugar a estilos estructurados de expresión que se han ido enriqueciendo en los diferentes lenguajes pictóricos. En lo que compete a este estudio sobre la comprensión del espacio en la pintura, hablamos de una síntesis de las diferencias - en la relación que se establece entre visión y ojo/ sujeto y mundo - de la tradición y cosmovisión de dos culturas distintas. Desde estos planteamientos, en el ámbito extremo oriental encontramos unas pinturas donde se representan motivos planos que dependen de ritmos lineales y donde los diversos elementos se unen mediante una alternancia rítmica basada tanto en planos como aislamientos, en el contexto de una profunda espiritualidad. Una comprensión de un espacio pictórico que discurre de manera homogénea prescindiendo de cualquier nexo mimético - corpóreo o espacial en perspectiva - que se perpetuó en el Extremo Oriente y se perdió en Occidente con la adopción de la perspectiva como sistema de representación y como símbolo. Lo que se ha dado en llamar un "momento estilístico" que, como nos recuerda Belting, en su momento permitió que el hombre dejase de mirar iconos para, paradójicamente, alcanzar una "mirada icónica" que transformó en imagen la propia mirada ${ }^{482}$. Hablamos por lo tanto de una revolución cognitiva que como análogo teorético tuvo una teoría árabe de la visión fundamentada en la óptica griega, lo que explica su autoafirmación artística y filosófica, además de su condición práctico/ teórica y revolucionaria, desde el momento en el que su irrupción hizo que Europa olvidase la condición narrativa implícita en los orígenes de la pintura.

Desde entonces, el secular universo figurativo occidental ha fundamentado y organizado su espacio desde la estricta base de la mímesis de la realidad. Un estándar visual que comenzará a manifestar su agotamiento creativo a partir del s. XVIII con Turner y Courbet, hasta llegar a su más que evidente cuestionamiento con las obras de los pintores impresionistas. Posteriormente, cubistas, fovistas, surrealistas, dadaístas y demás corrientes artísticas del s. XX llegarán más allá de la tradición de una mirada acostumbrada a la mímesis pero, sin embargo, sin que ninguna llegue a cuestionar la comprensión del espacio pictórico vigente hasta entonces en el marco de la pintura europea. Será necesario esperar hasta las obras tardía de Monet y su posterior influencia en la nueva pintura surgida a mediados del s. XX, que con los movimientos de vanguardias norteamericanos - y mediante el binomio básico punto/línea y superficie pictórica - recrearán, a la manera extremo oriental, la abstracción de unas formas

\footnotetext{
${ }^{482}$ Hans Belting, Florencia Bagdad: Una Historia de la Mirada entre Oriente y Occidente, Madrid, 2012, p. 18.
} 
representadas sobre fondos vacíos. Así, a partir de los Nenúfares de Monet, se romperá el estricto marco de la perspectiva geométrica que ceñía la pintura desde el Renacimiento europeo y que mantenía desde entonces la mirada supeditada a una ilusión óptica. A partir de ese momento, el espacio pictórico ofrecerá una realidad mucho más compleja y sugerida, planteando su ámbito desde una dimensión más holística en la que entrarán a formar parte, además de la vista, otros sentidos. Hablamos de una pintura que en su desarrollo horizontal desglosa el tiempo y fragmenta el espacio, para deslizarse en el continuo de un espacio sin tiempo. Hablamos de una pintura que recuperará la yuxtaposición de un determinado número de soportes reintroduciendo de esta manera los dípticos y trípticos en la pintura contemporánea. Hablamos de una pintura que - como la china, coreana o japonesa y su apabullante estética relacionada con la naturaleza - establece un estrecho vínculo con lo sagrado. Una cuestión relevante ya que, a partir de los años 40 del pasado s. XX, la pintura buscará restaurar la conexión con una cierta perspectiva religiosa; con lo mágico. Es decir, con aquella faceta espiritual del proceso artístico que parecía haberse perdido con el espíritu racionalista y cartesiano. El mismo que había empoderado la perspectiva hasta transformarla en la "forma simbólica" de occidente. En consecuencia, podemos decir que la pintura contemporánea ha perdido en parte su cualidad física para alcanzar una cierta cualidad metafísica. Una suerte de metalenguaje donde, desde nuestro punto de vista, el espacio y el tiempo ya no se conciben separados.

Concluimos entonces que desde el Extremo Oriente no se ha concebido el Principio de la Narración Gráfica Continua como un sistema espacial y de pensamiento. Su representación se perpetúa en la tradición de lo numinoso en el orden de las fuerzas naturales. Por lo tanto, de la intuición de una "horizontalidad dilatada", como una dimensión natural exenta de oposición entre logos y natura, donde tradicionalmente el yo no ha precisado de un elemento de autoafirmación. Concluimos en definitiva que la Narración Gráfica Continua no es un proceso intelectual - que, como tal, opera y se expresa dentro de un sistema cultural - por lo tanto, no hay lugar para su comprensión ni como símbolo metafísico ni como meta-histórico; es decir, como sistema. En cierto sentido está totalmente alejado de la comprensión occidental del problema - donde el arte, los mitos, los ritos y el propio lenguaje adquieren el estatus de formas de conocimiento - pues no se da en él el dualismo materia-espíritu.

En definitiva, en esta tesis hemos podido estudiar una diferente tradición de la actividad de la mirada en Oriente y en Occidente. Una tradición de la mirada en la que, en palabras de Belting "[...] solo cuando se ve en ella un problema de la imagen se descubre su significación cultural"483. Es decir, se descubren aquellas señas de identidad - implícitas en las prácticas sociales de la exposición y contemplación de la imagen - de perfiles cada vez más difusos, que nos revelan además de las condiciones del formato una determinada actitud ante la comprensión de su espacio. Pero, mientras tanto, en el proceso - y en contra de las proclamas de muchas voces agoreras - seguirá habiendo

${ }^{483}$ Ibídem, p. 17. 
pintura porque, como los mitos, como la palabra, como la música, la pintura no podrá acabarse nunca. La pintura permanecerá. 
APÉNDICE DE IMÁGENES 


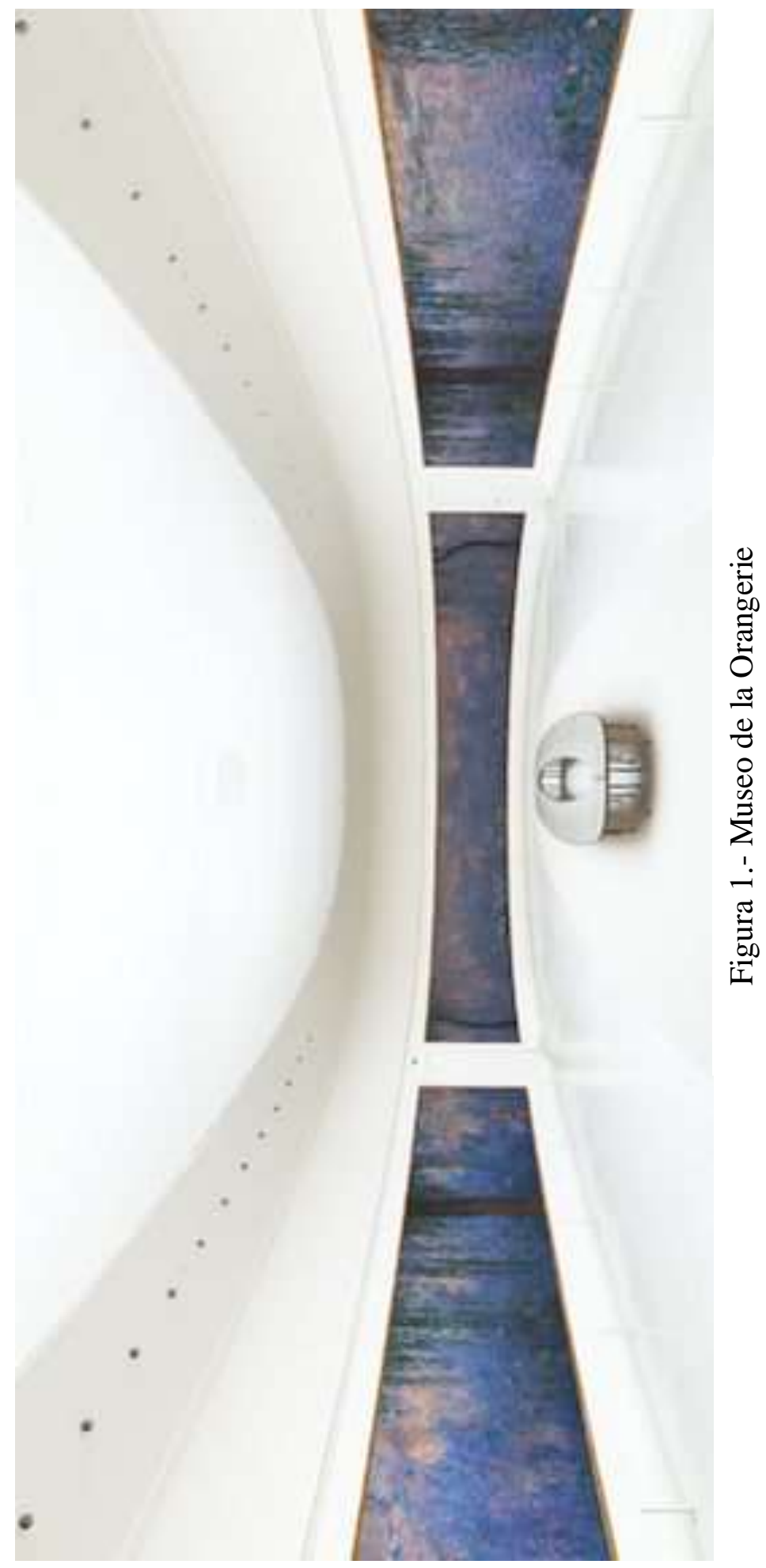




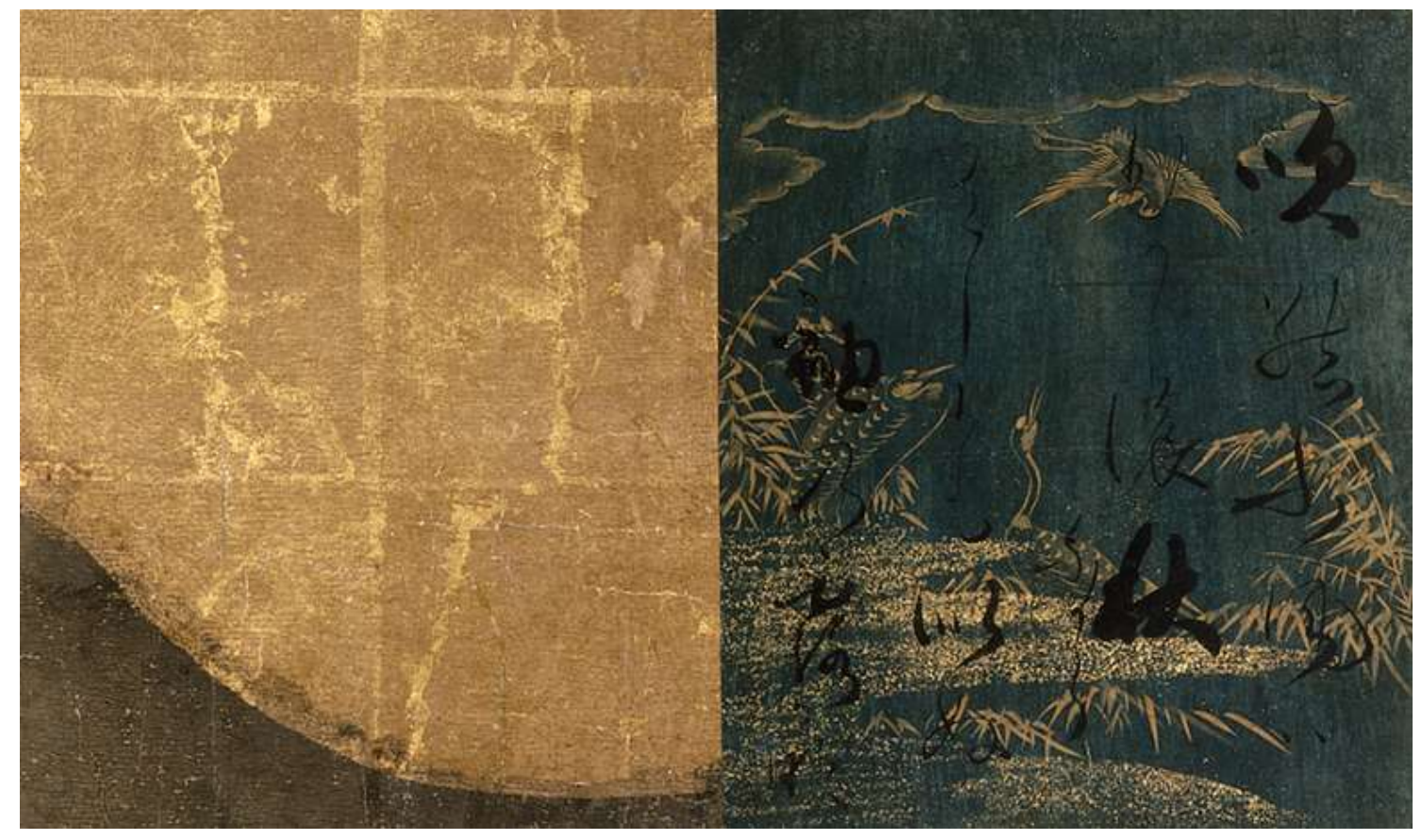

Figura 2.- Hon'ami Koetsu 本阿弥光悦 (1558-1637) Calligraphy: Although the Wind Still Blows

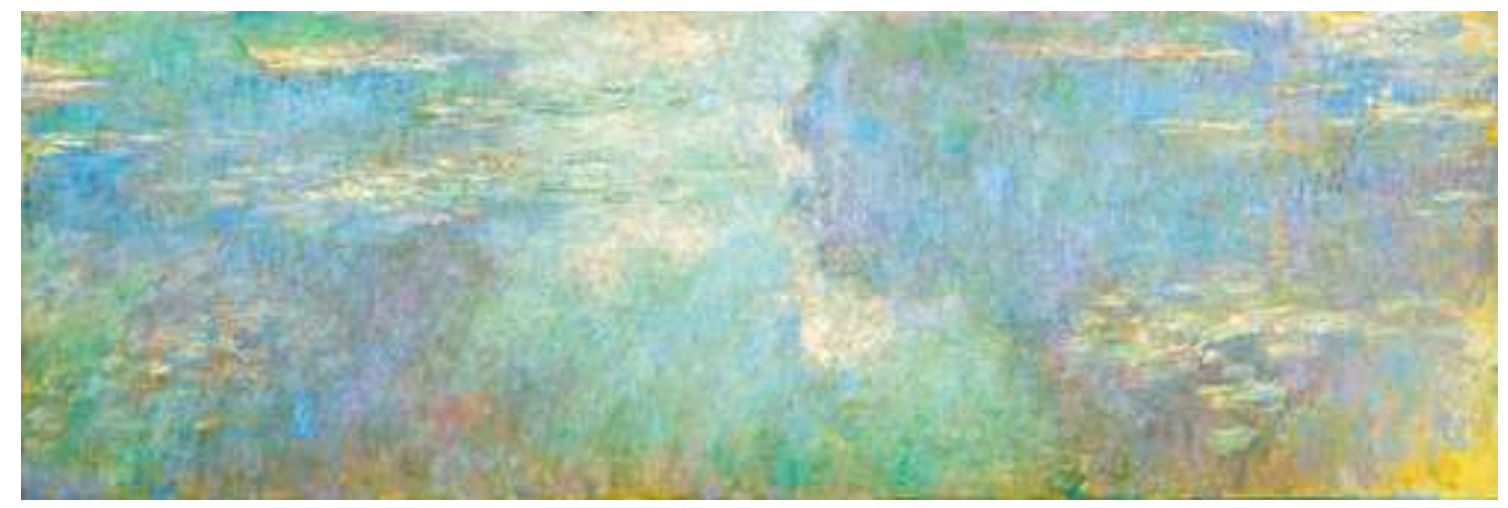

Figura 3.- Claude Monet (1840-1926) Estanque de nenúfares 8. 1917-19. 


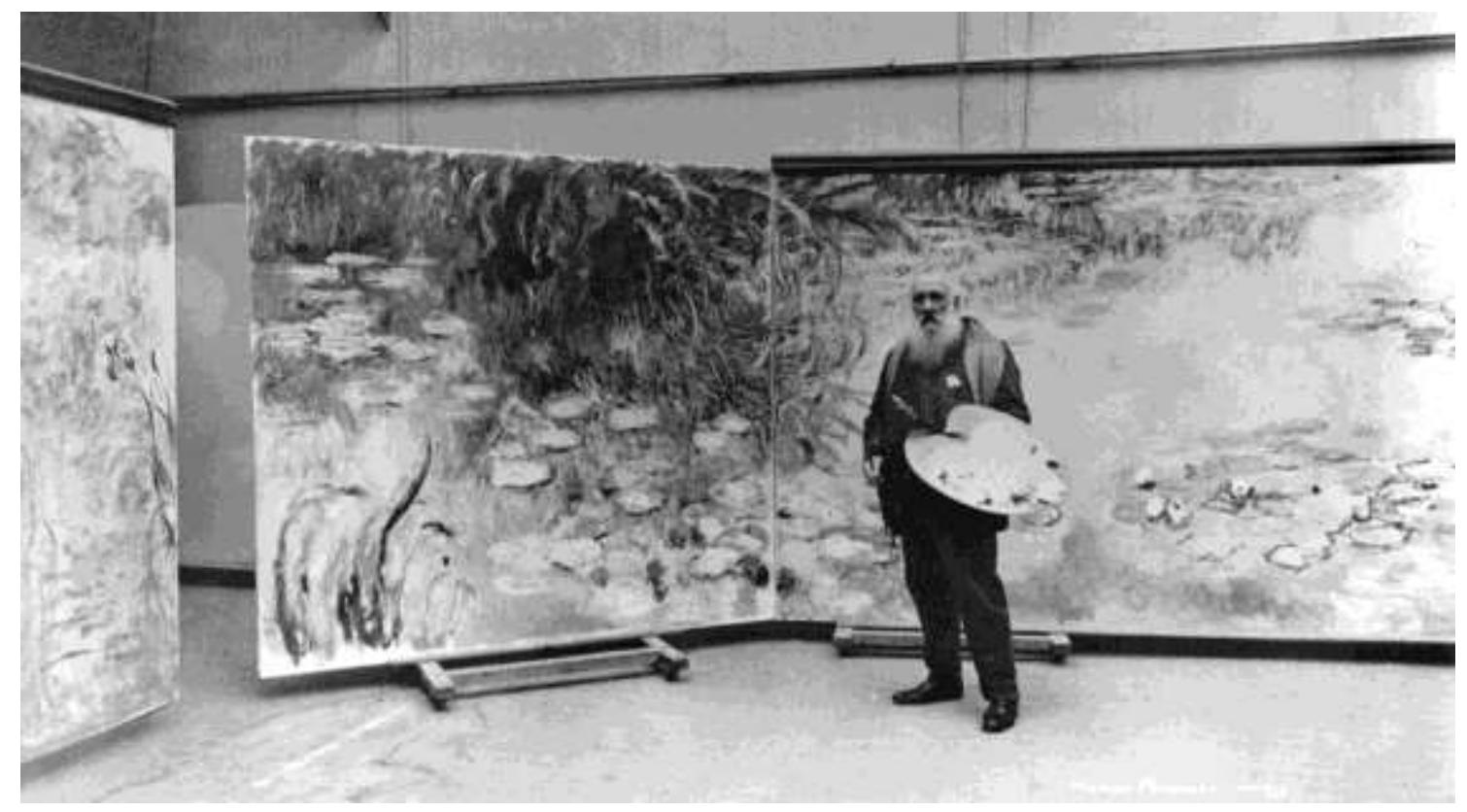

Figura 4.- "Claude Monet pintando algunos de sus Nenúfares (1920-26)

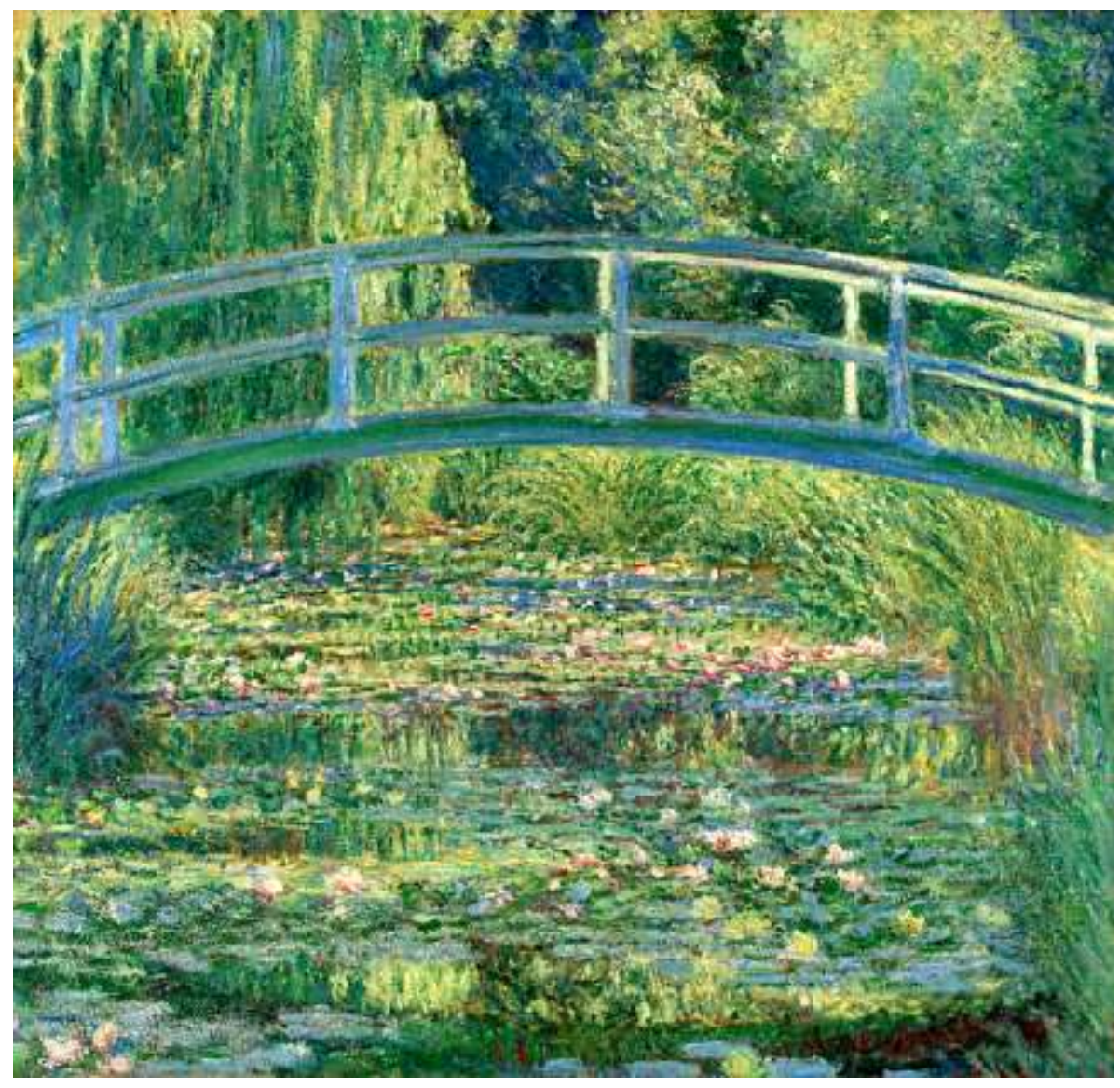

Figura 5.- Claude Monet. Estanque de nenúfares (1899). 88,3 x 93,1cm. 


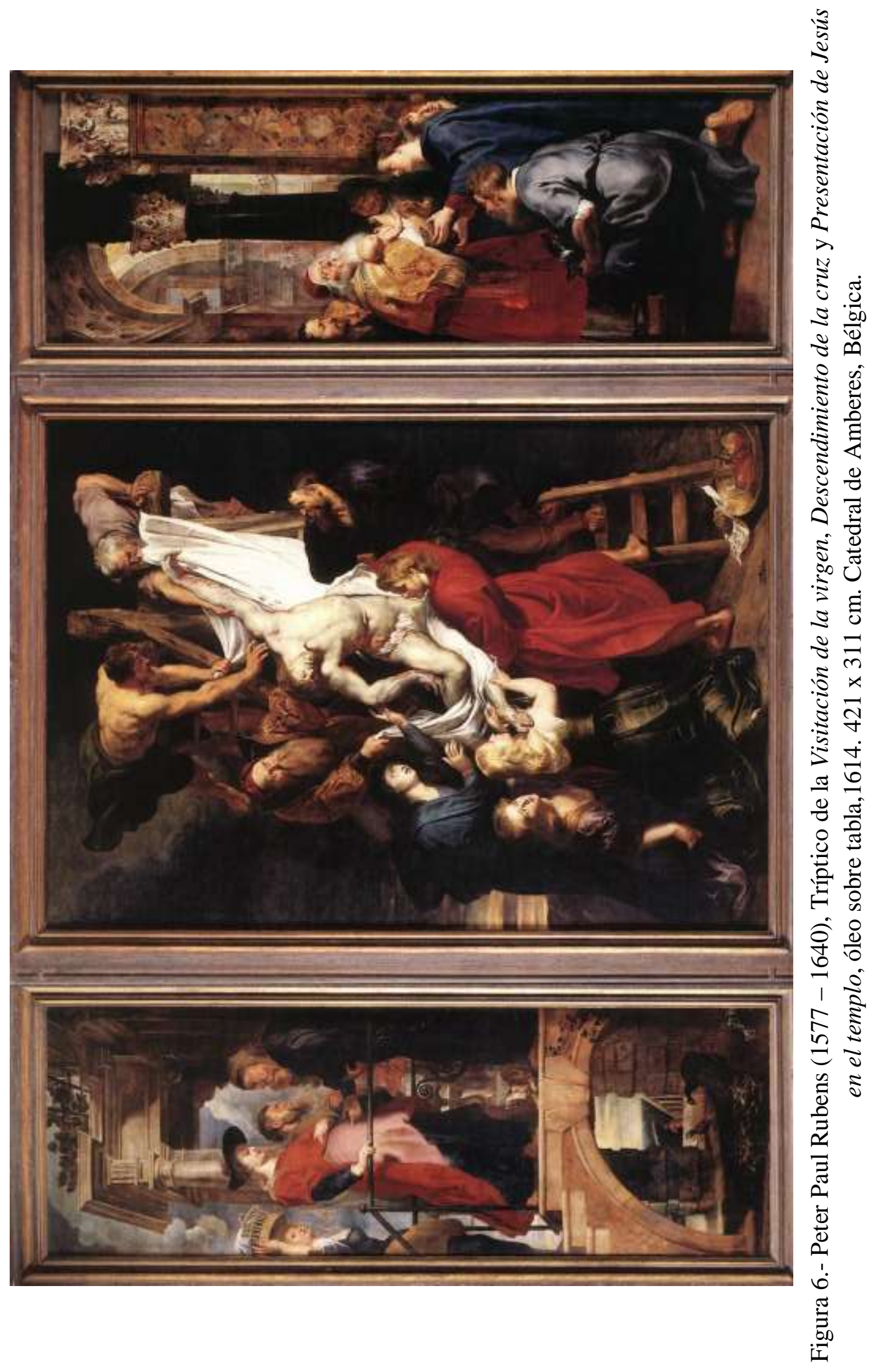




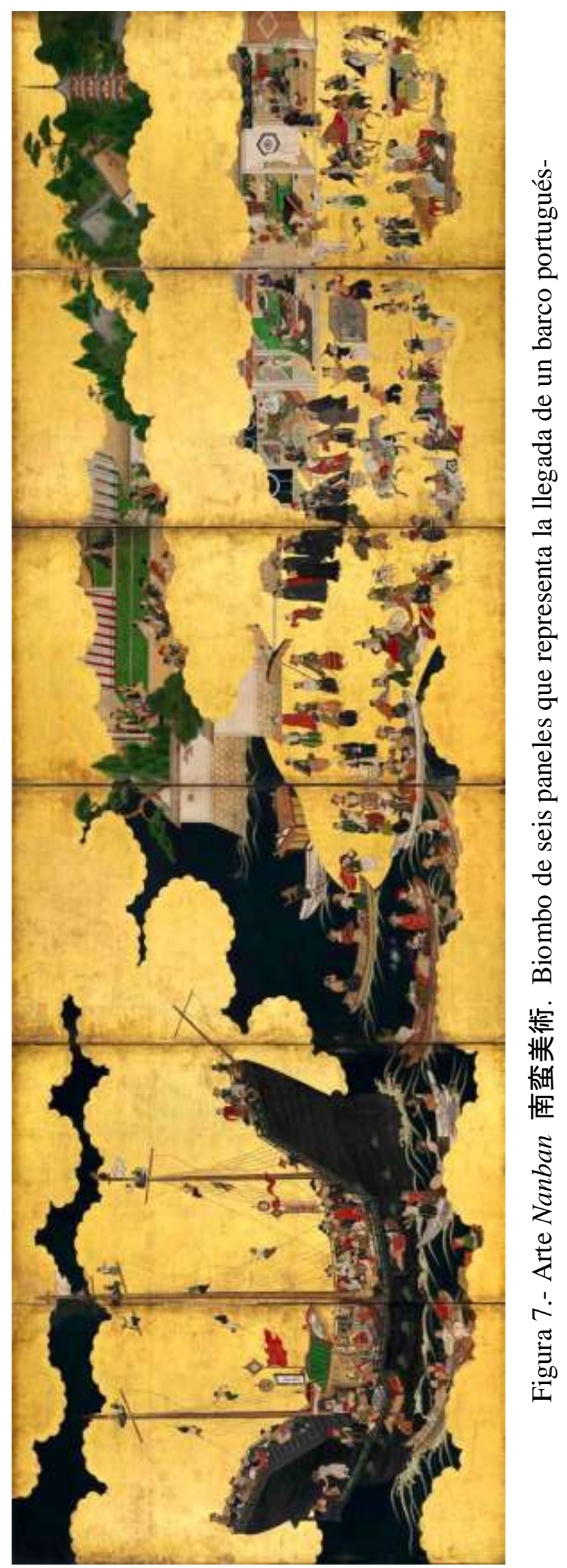




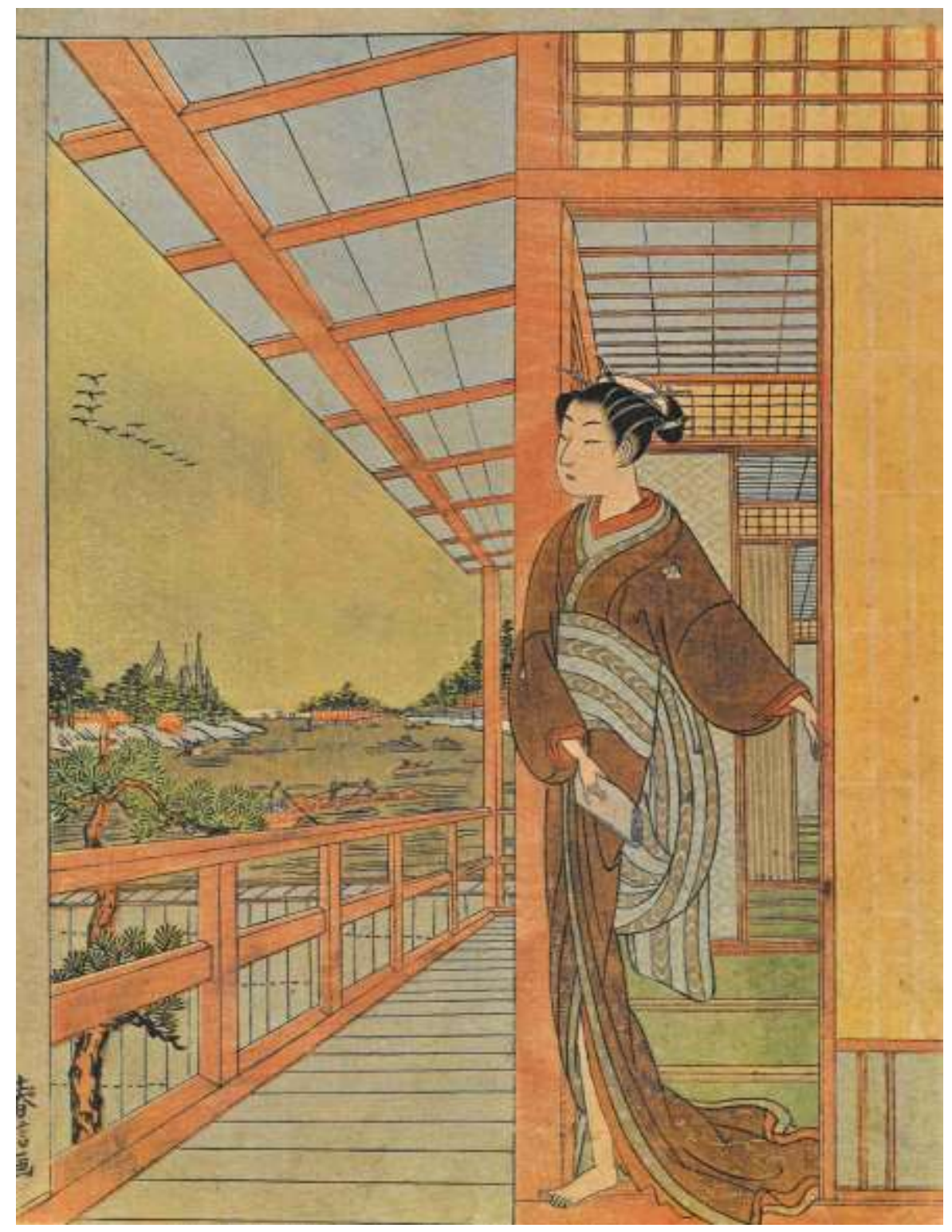

Figura 8.- Shiba Kôkan 司馬 江漢 (1747-1818), Mujer en la terraza. 1770. 


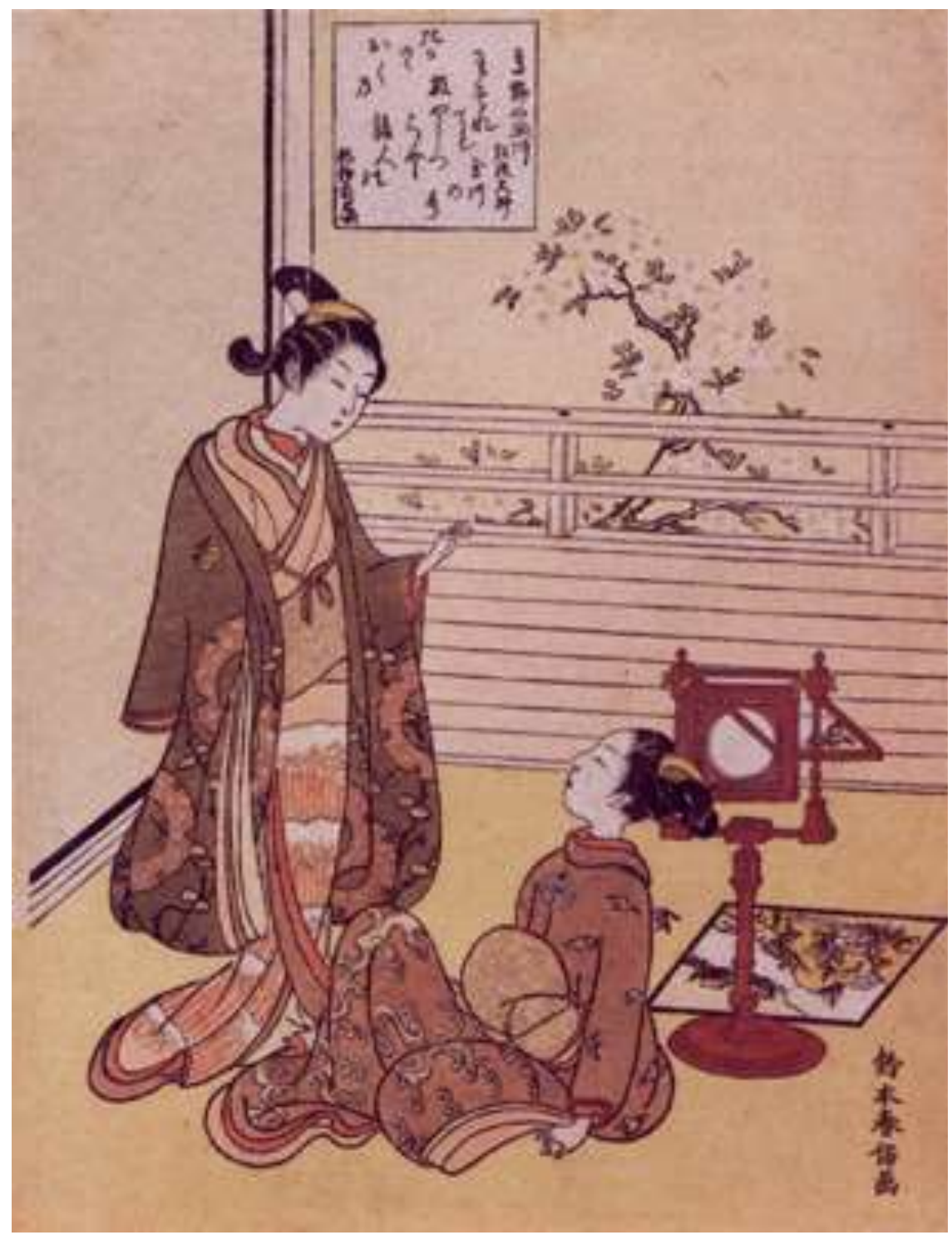

Figura 9.- Harunobu Suzuki 鈴木春信 (1725-1770) Koya no Tamagawa . Grabado ukiyoe en el que aparece un zograscope. 


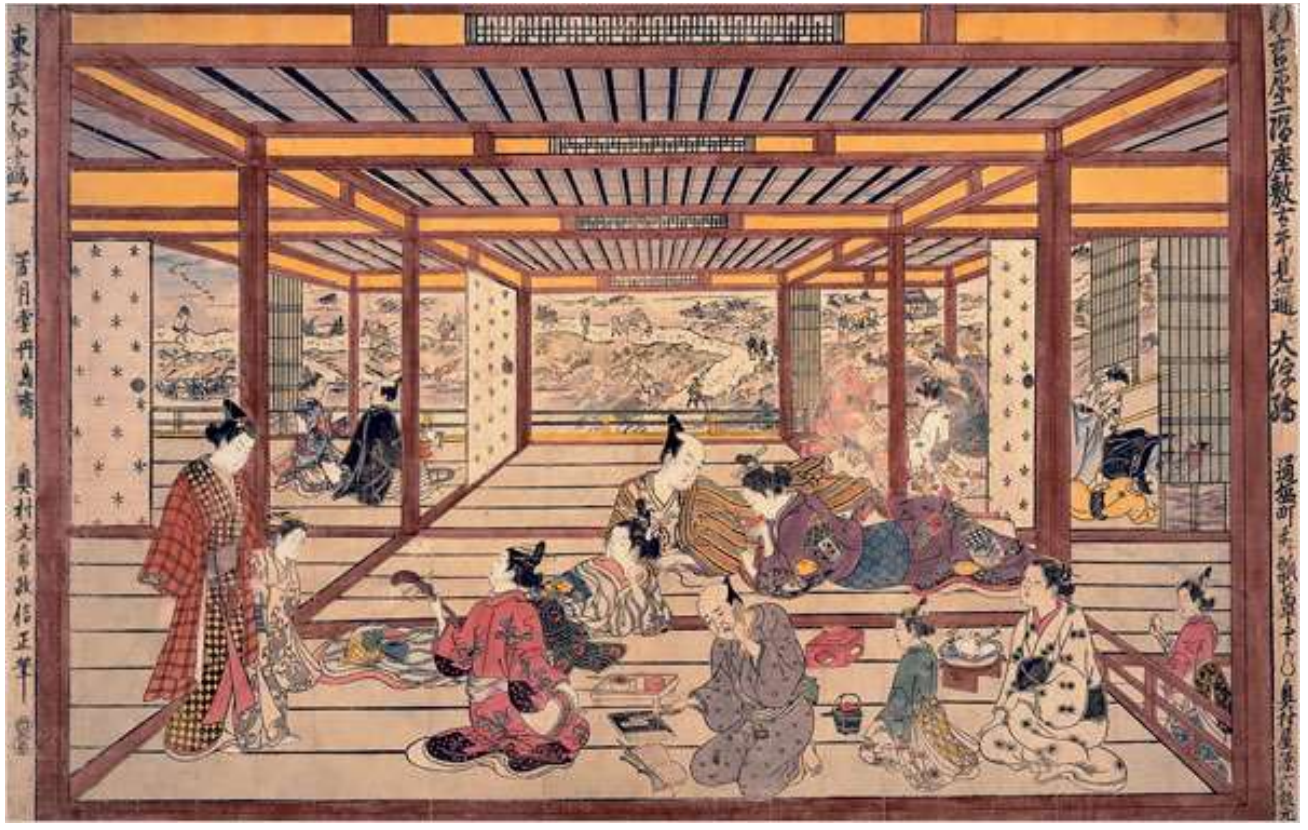

Figura 10.- Okumura Masanobu 奥村 政信 (1686-1764) que utiliza la perspectiva europea de un punto de fuga. Imagen en perspectiva de un gran salón del segundo piso en el nuevo Yoshiwara, mirando hacia el terraplén (1745), grabado en madera coloreado a mano.

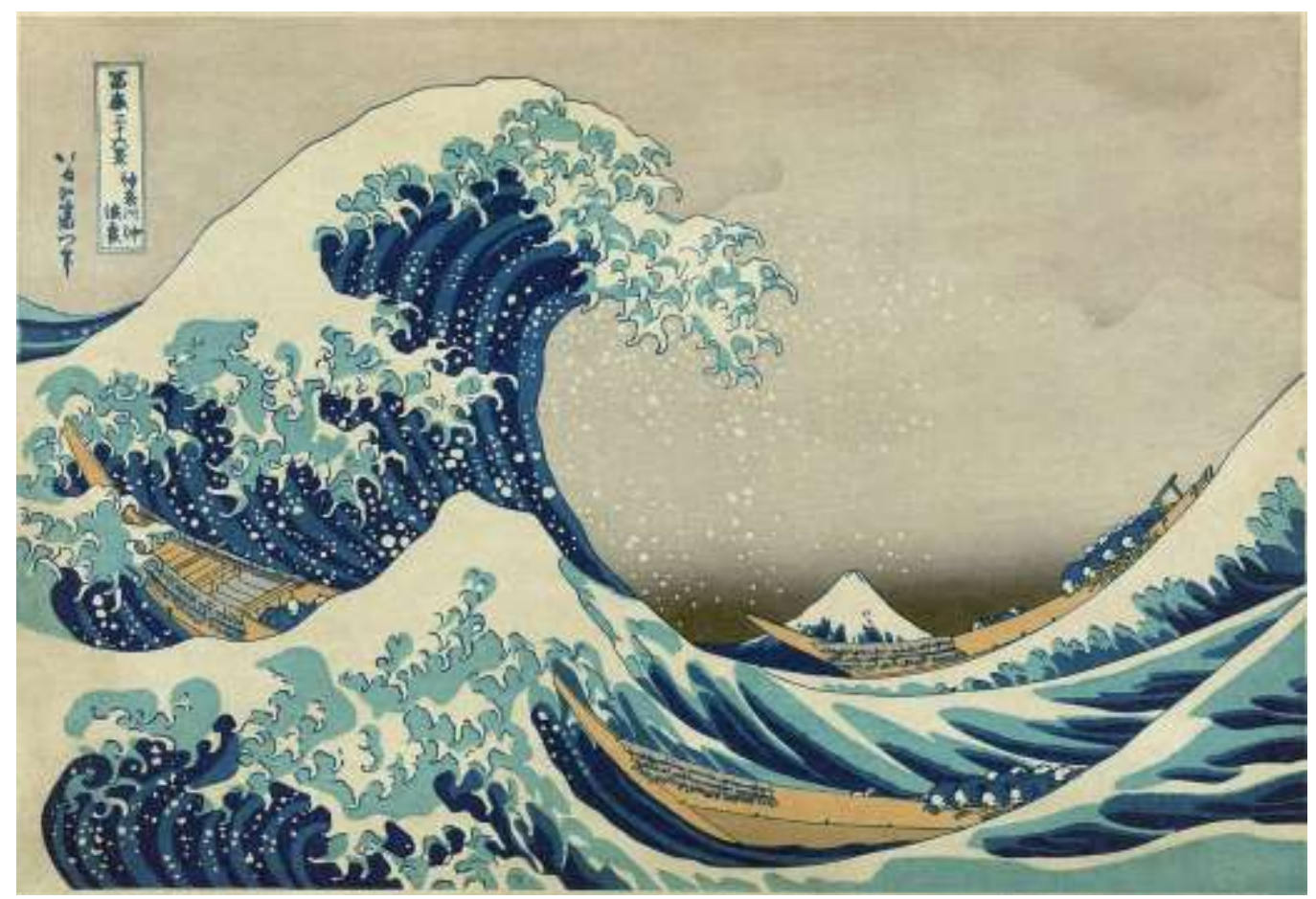

Figura 11.- Katsushika Hokusai 北斎 (1760 - 1849). La gran ola de Kanagawa (18301833), 


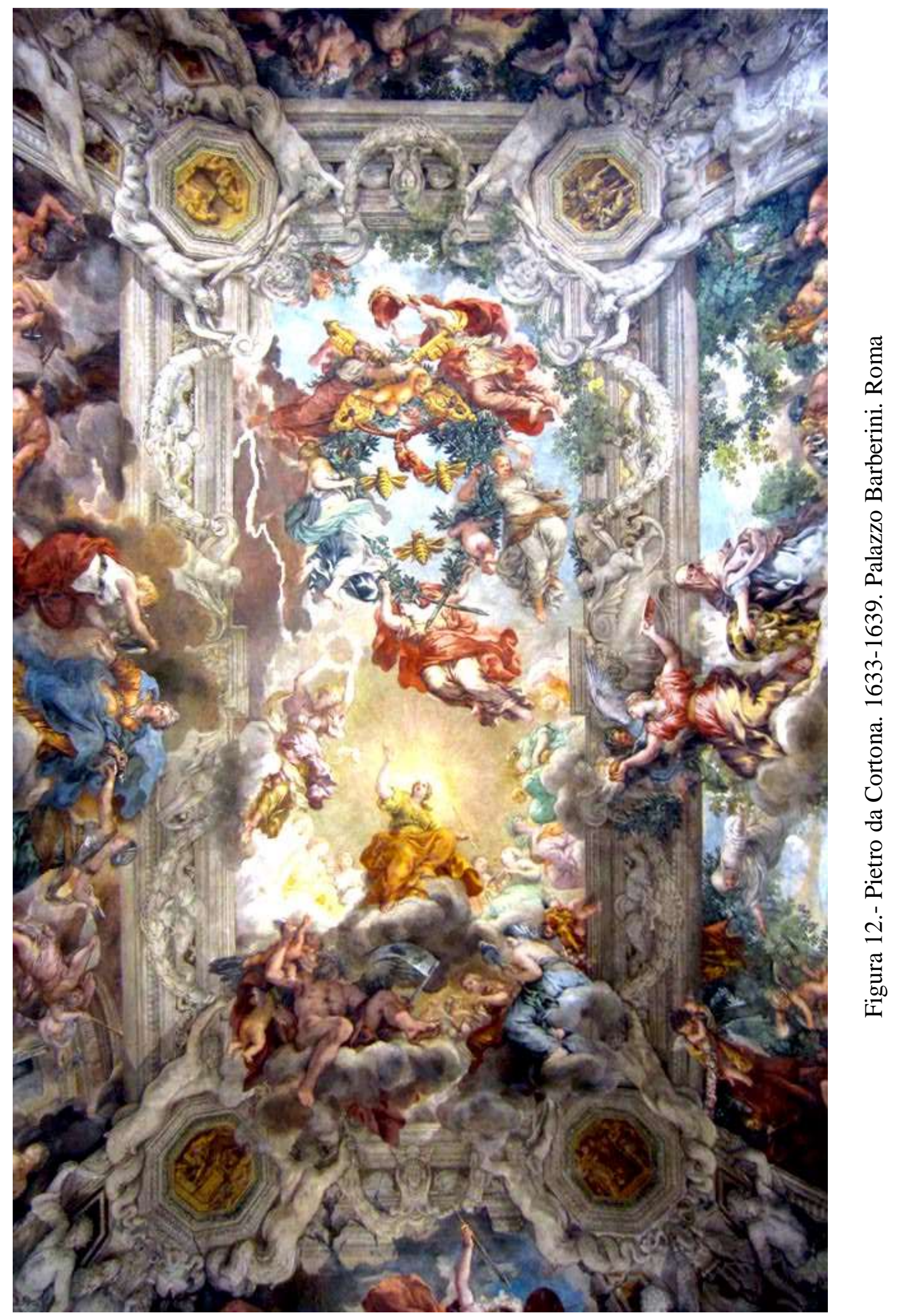




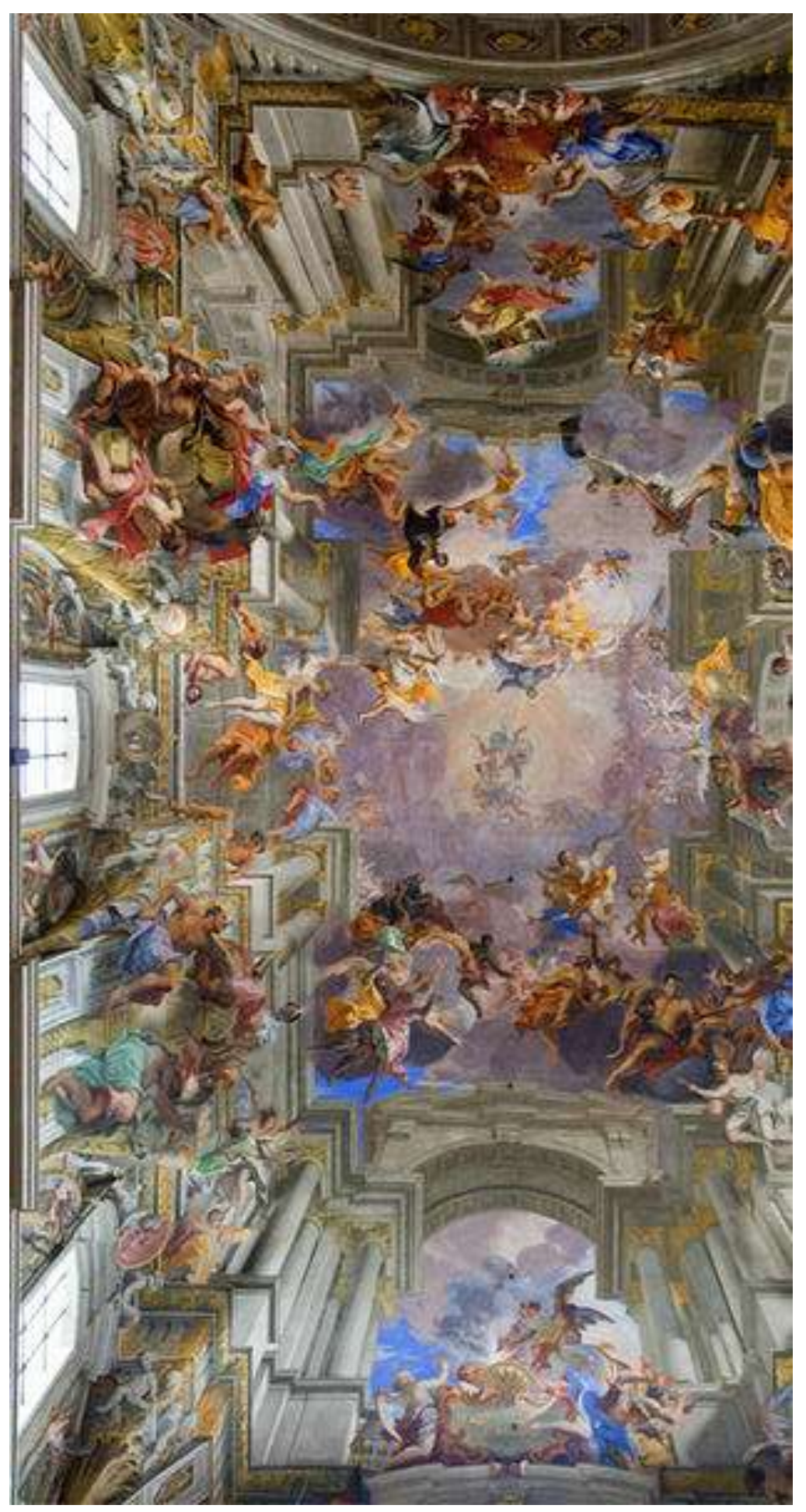

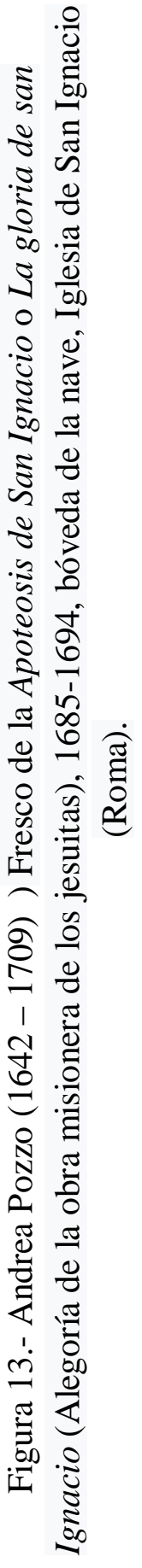




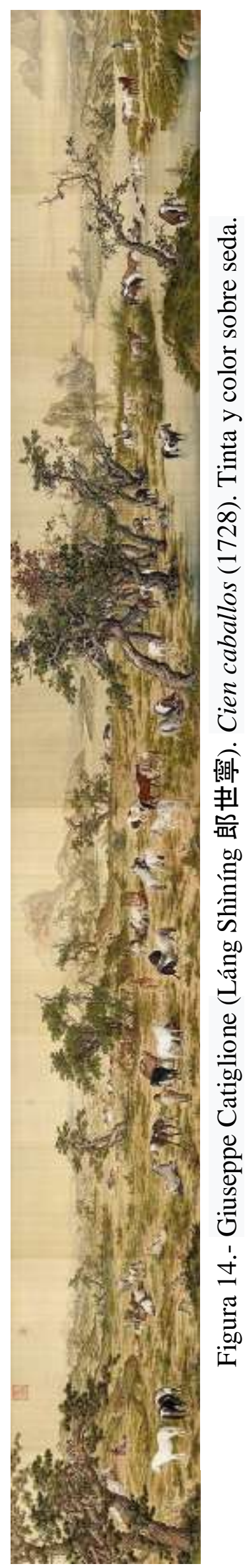




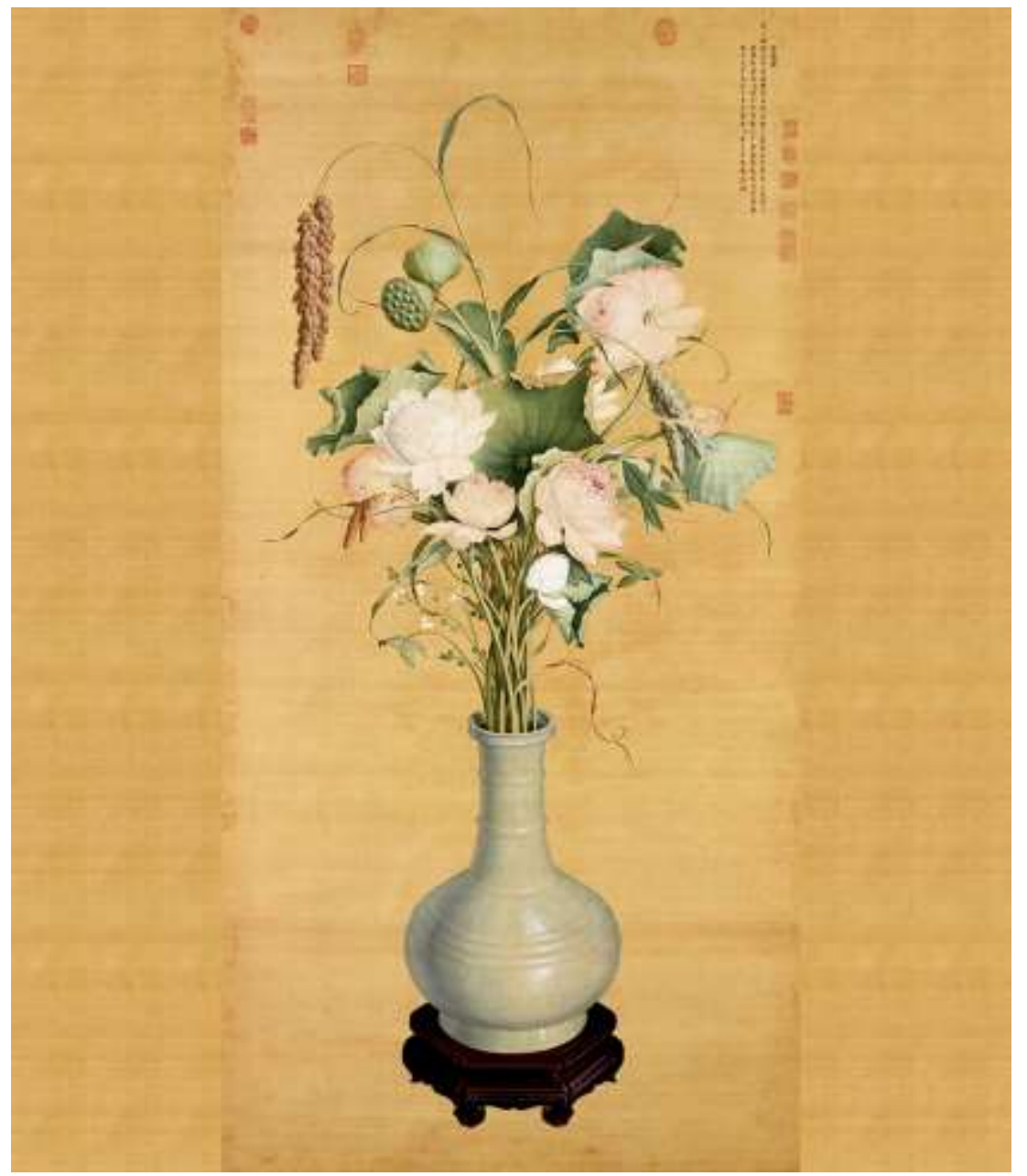

Figura 16.- Giuseppe Castiglione (Láng Shìníng 郎世寧). Bodegón de loto y florero. Tinta china y acuarela sobre rollo de seda. 


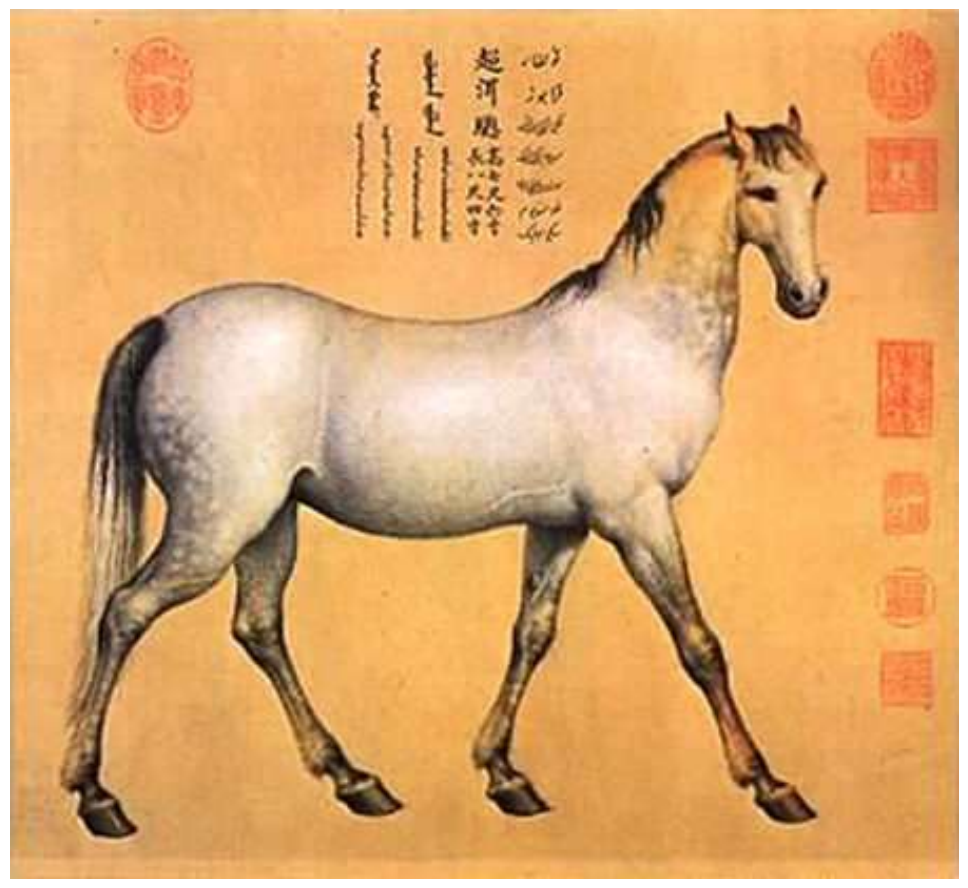

Giuseppe Castiglione (Láng Shìníng 郎世寧). Uno de los Cuatro corceles afganos de, presenta un caballo llamado Chaoni'er.
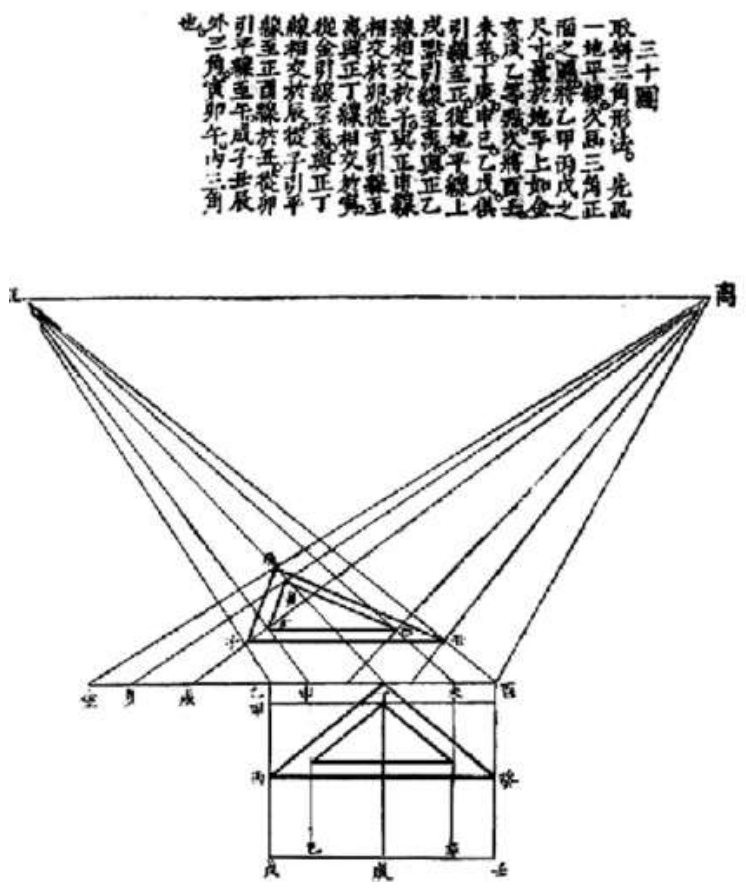

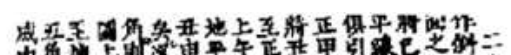

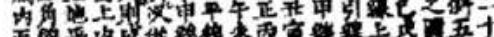

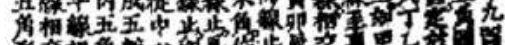

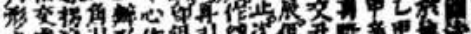

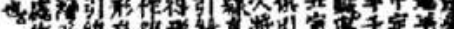

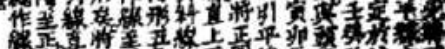

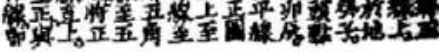

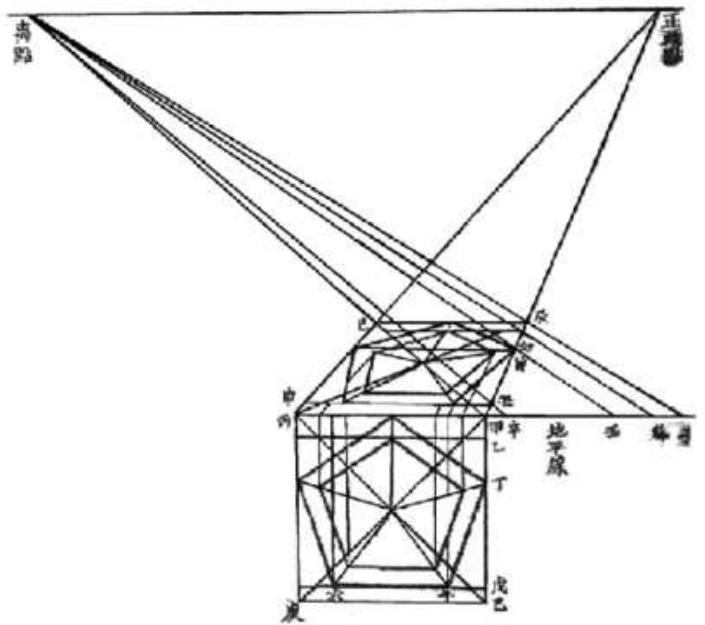

Figura 17.- Principio de proyección discutido en Shi Xue. Fuente: Nian Xiyao. Shi Xue. 1735. Placas XXIX, XXX. 


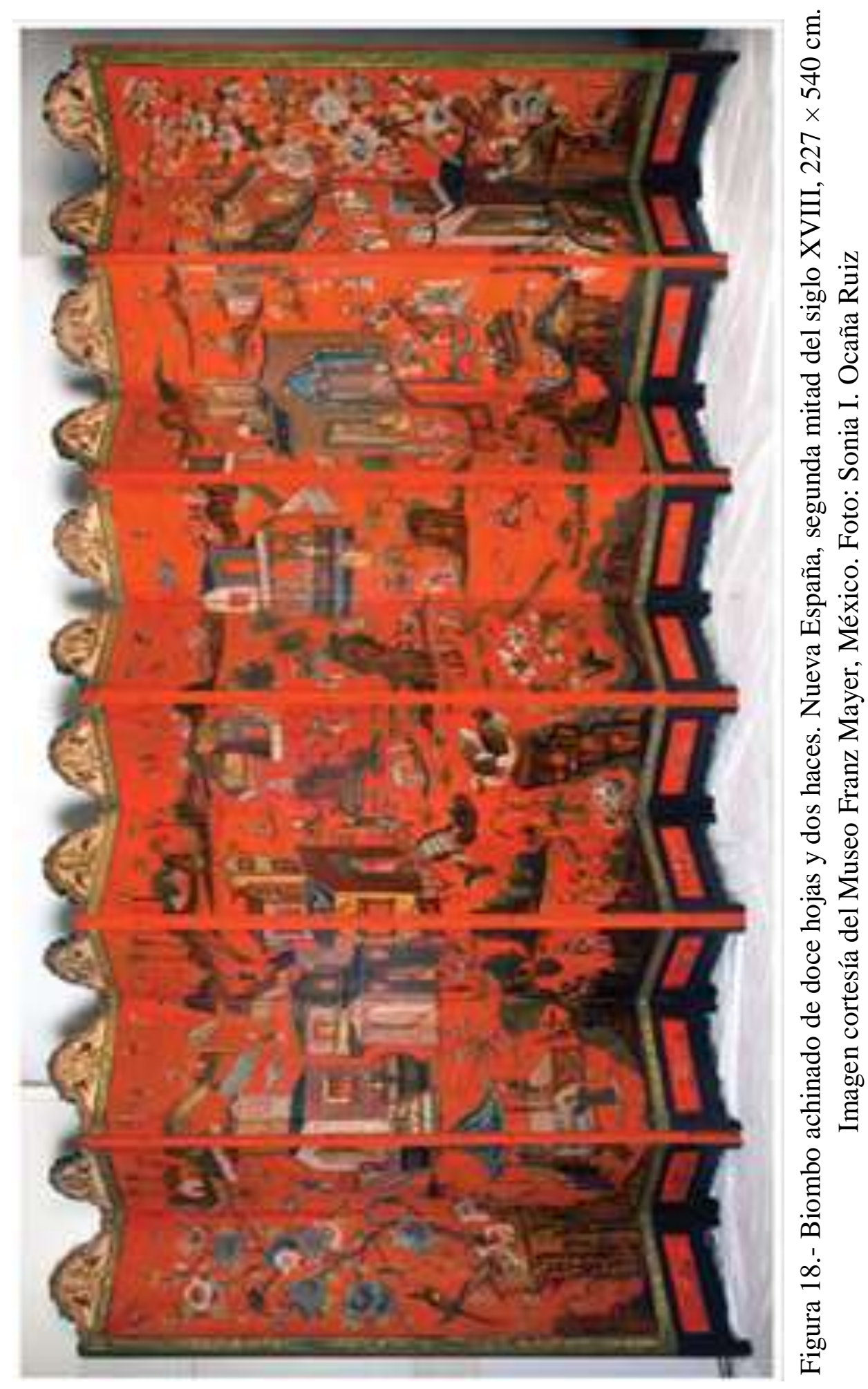



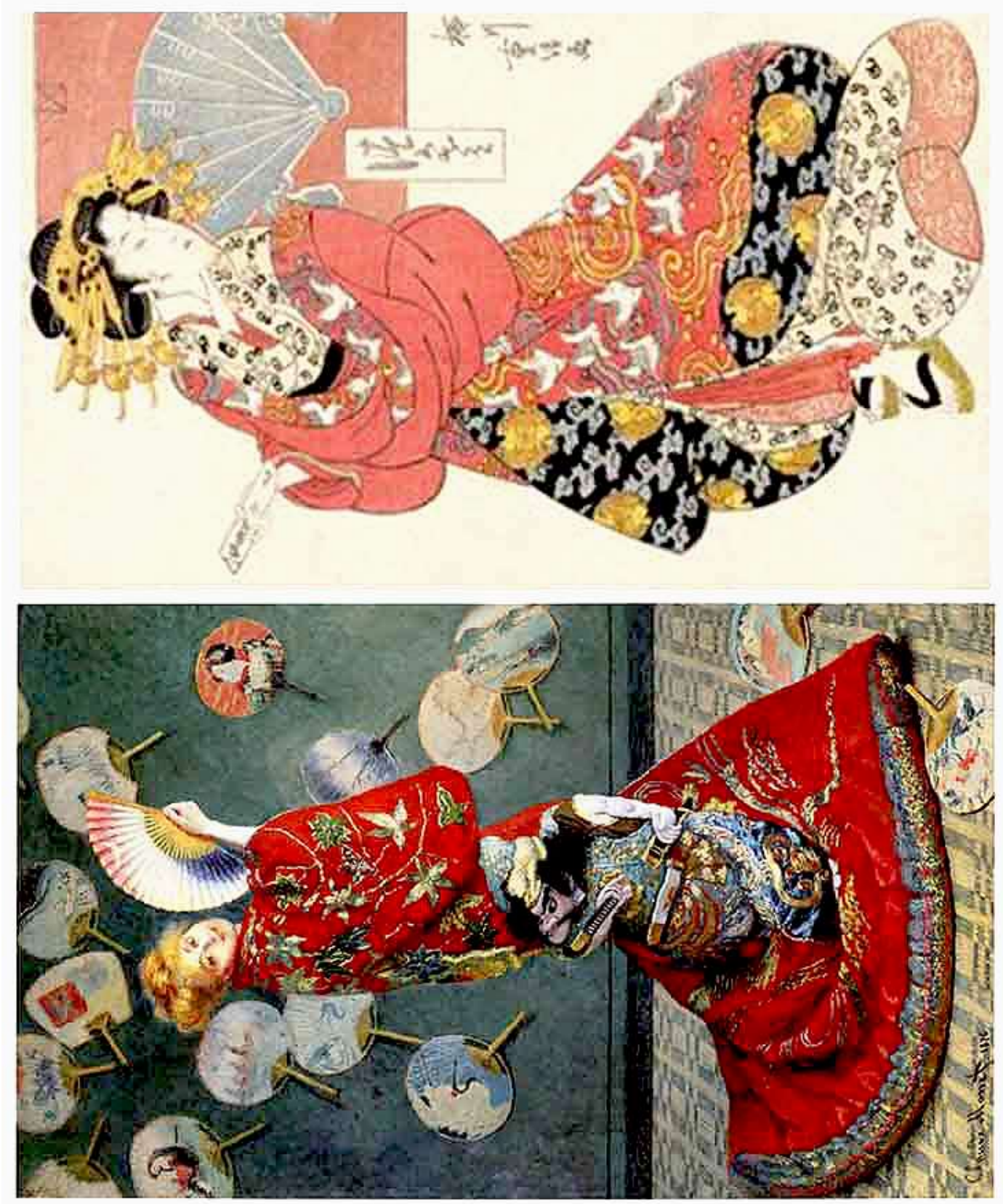


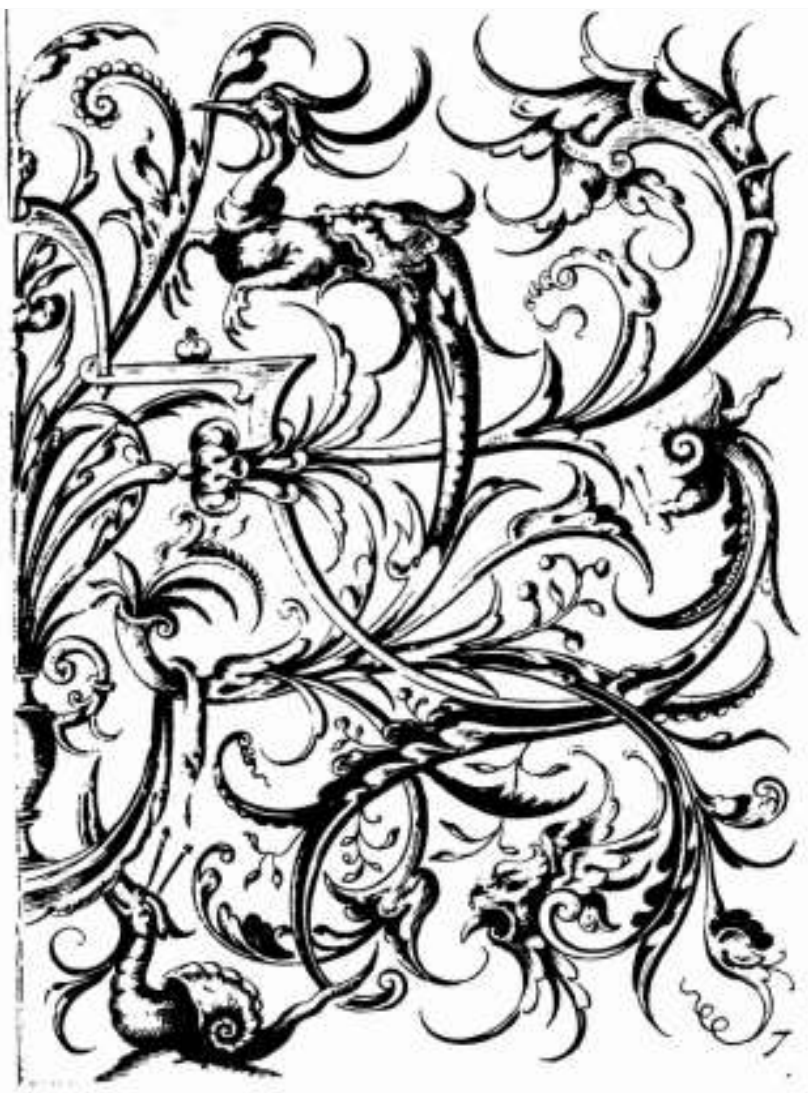

Figura 20.- Nicasius Rousseel (i - 1646). Arabesco de una serie de grotescos,. Grabado de 1623.

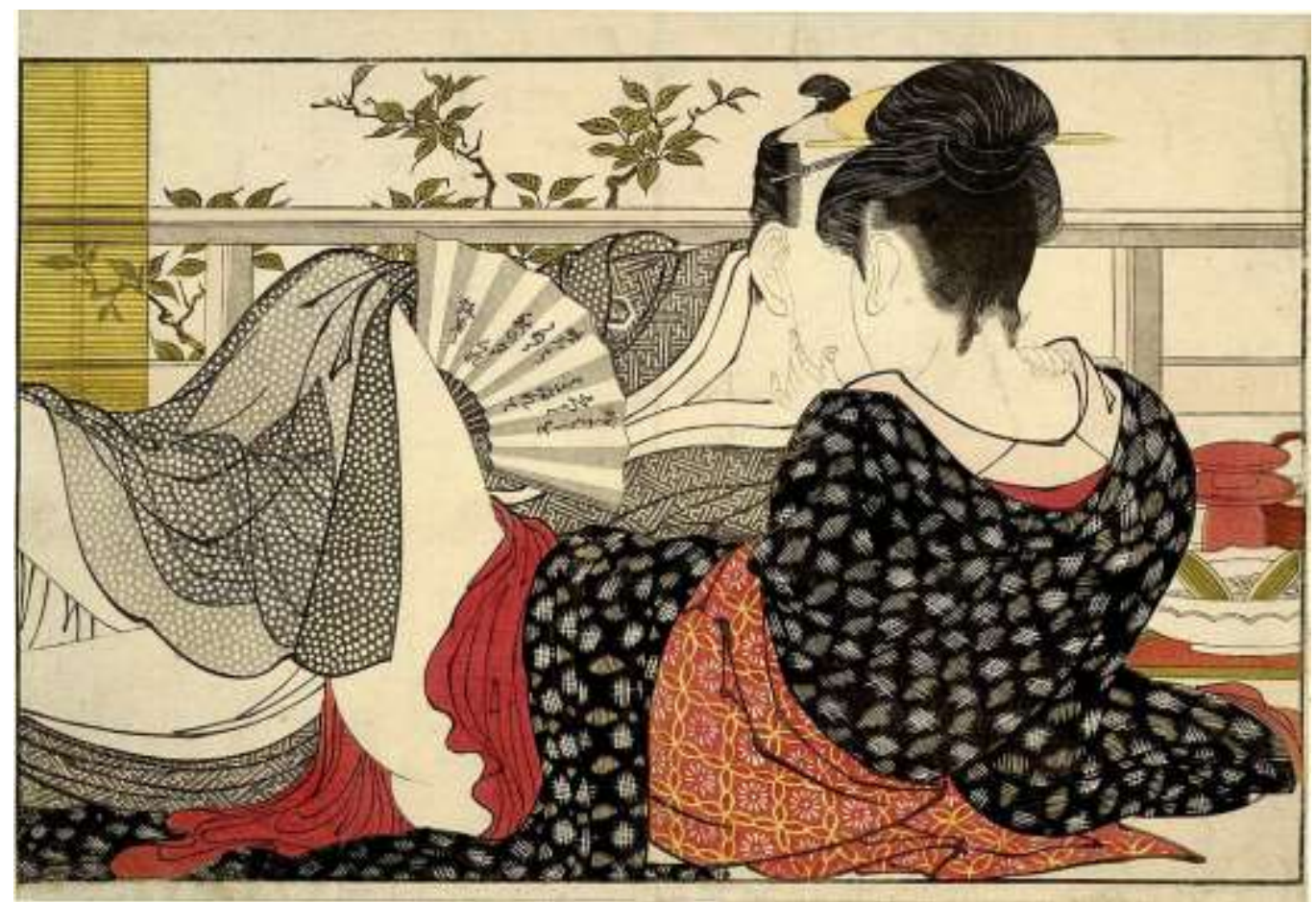

Figura 21.- Kitagawa Utamaro(喜多川 歌麿 (1788) Estampa Shunga No. 10 


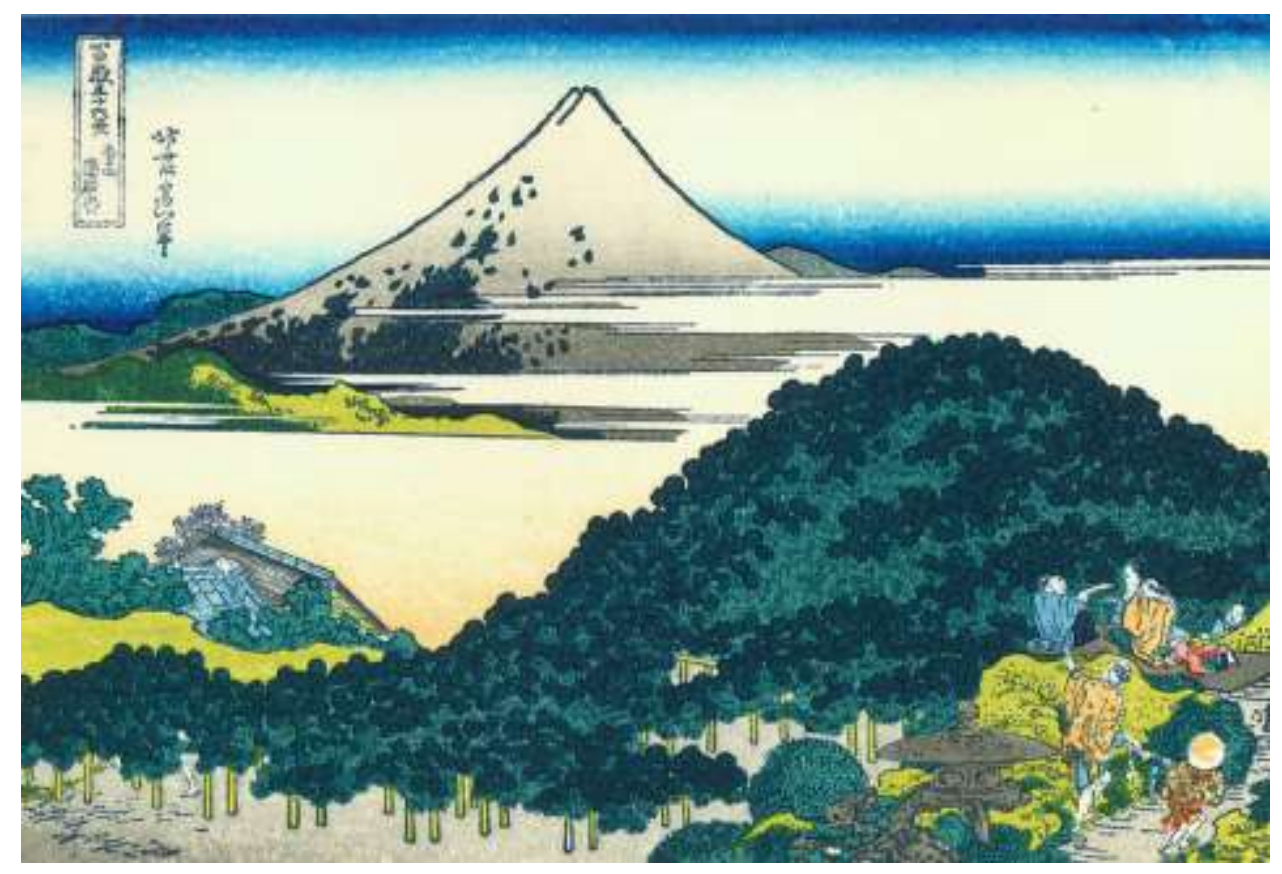

Figura 22.- Katsushika Hokusai - 青山 円座松 - Los pinos circulares de Aoyama. Parte de la serie Treinta y seis vistas del monte Fuji, no. 08. 1823.

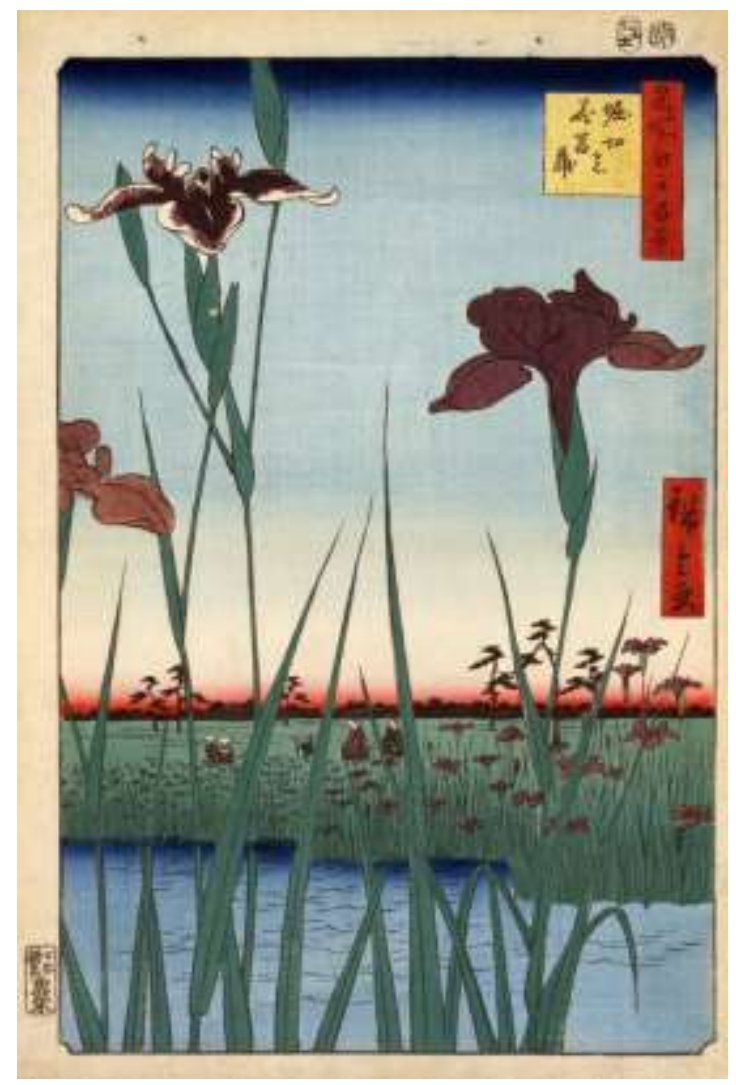

Figura 23.- Utagawa Hiroshige (歌川広重. Jardin de lirios en Horikiri (堀切の花菖 蒲 Horikiri no hanashōbu? ${ }^{?}$ (i5-1857) 

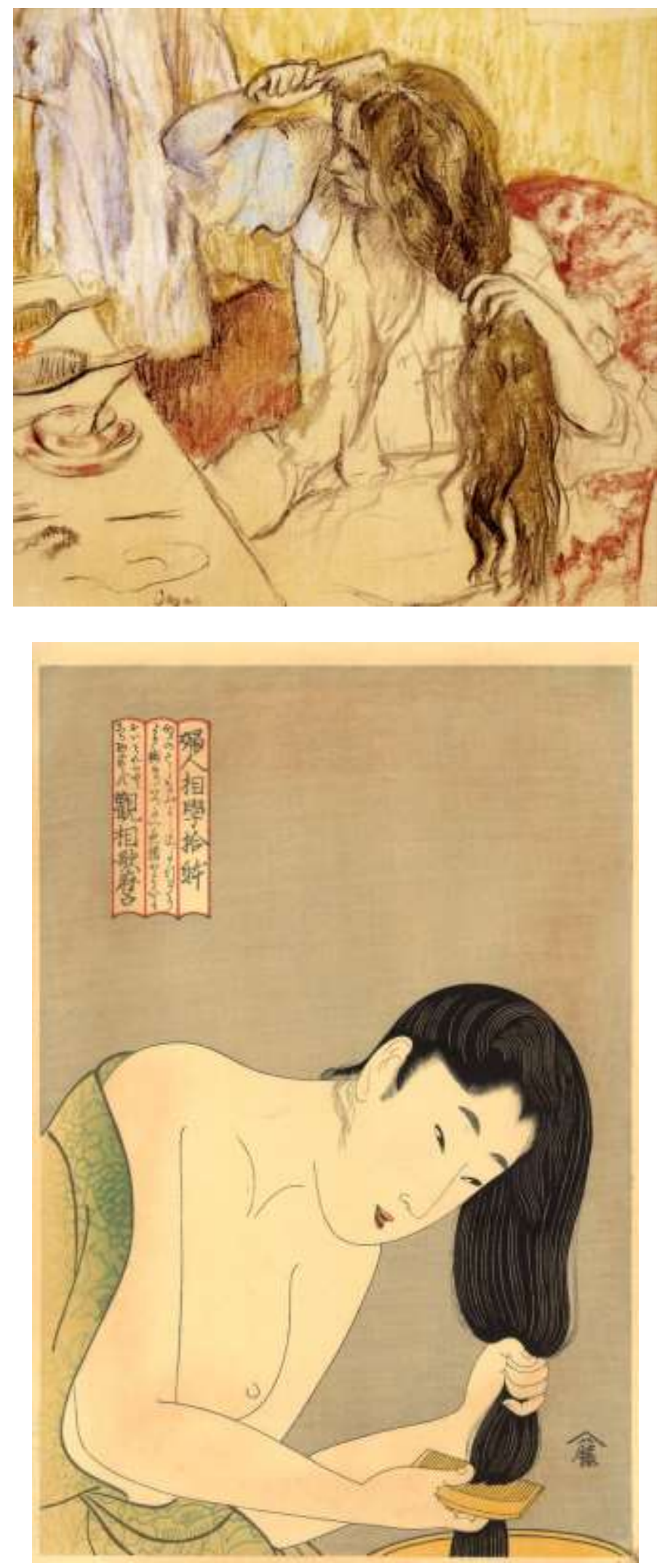

Figura 24.- Edgar Degas. Mujer en su toilette, 1885 (pastel sobre cartón) y grabado Peinándose el pelo de la serie Fujin Sōgaku Jittai 婦人相学十射, "Diez fisonomías de las mujeres", de Kitagawa Utamaro. 

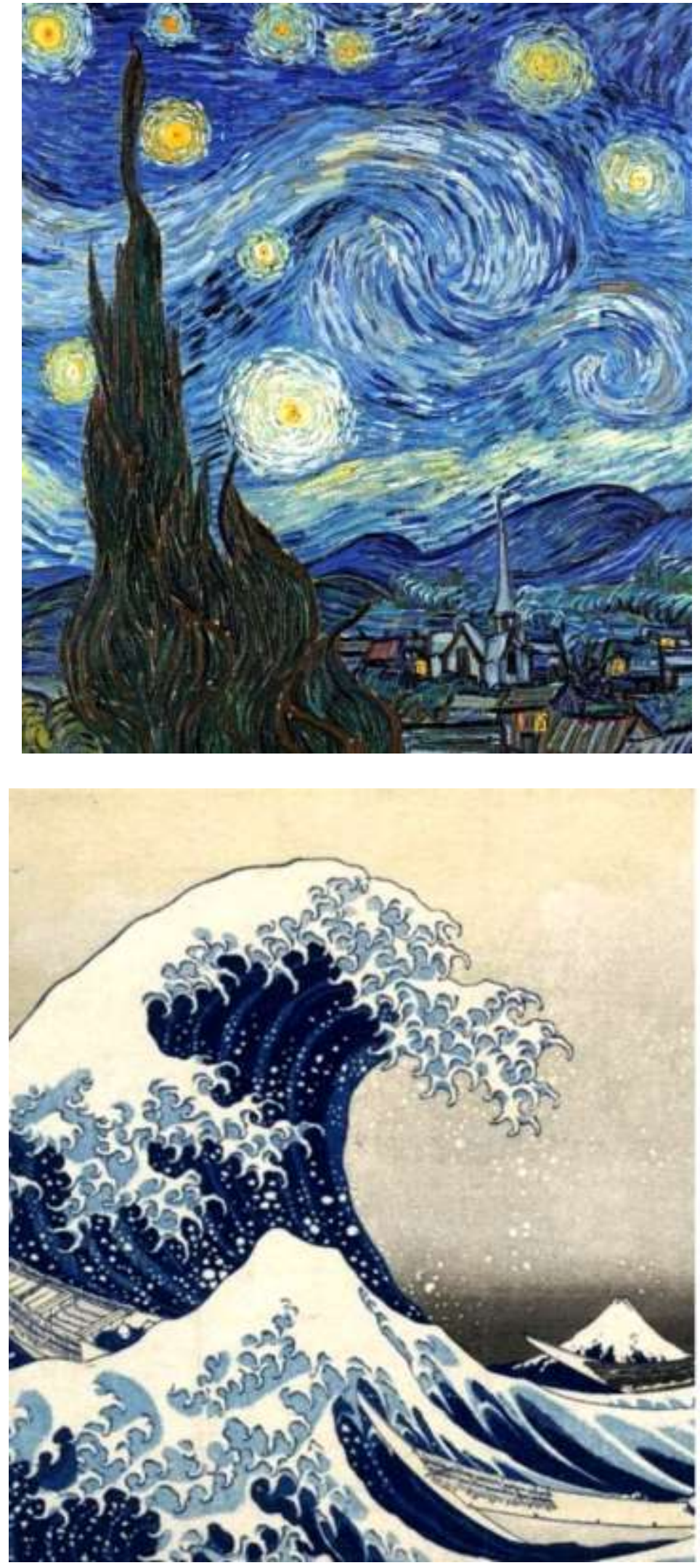

Figura 25.- La noche estrellada de Van Gogh y La gran ola de Kanagawa, de Hokusai. 

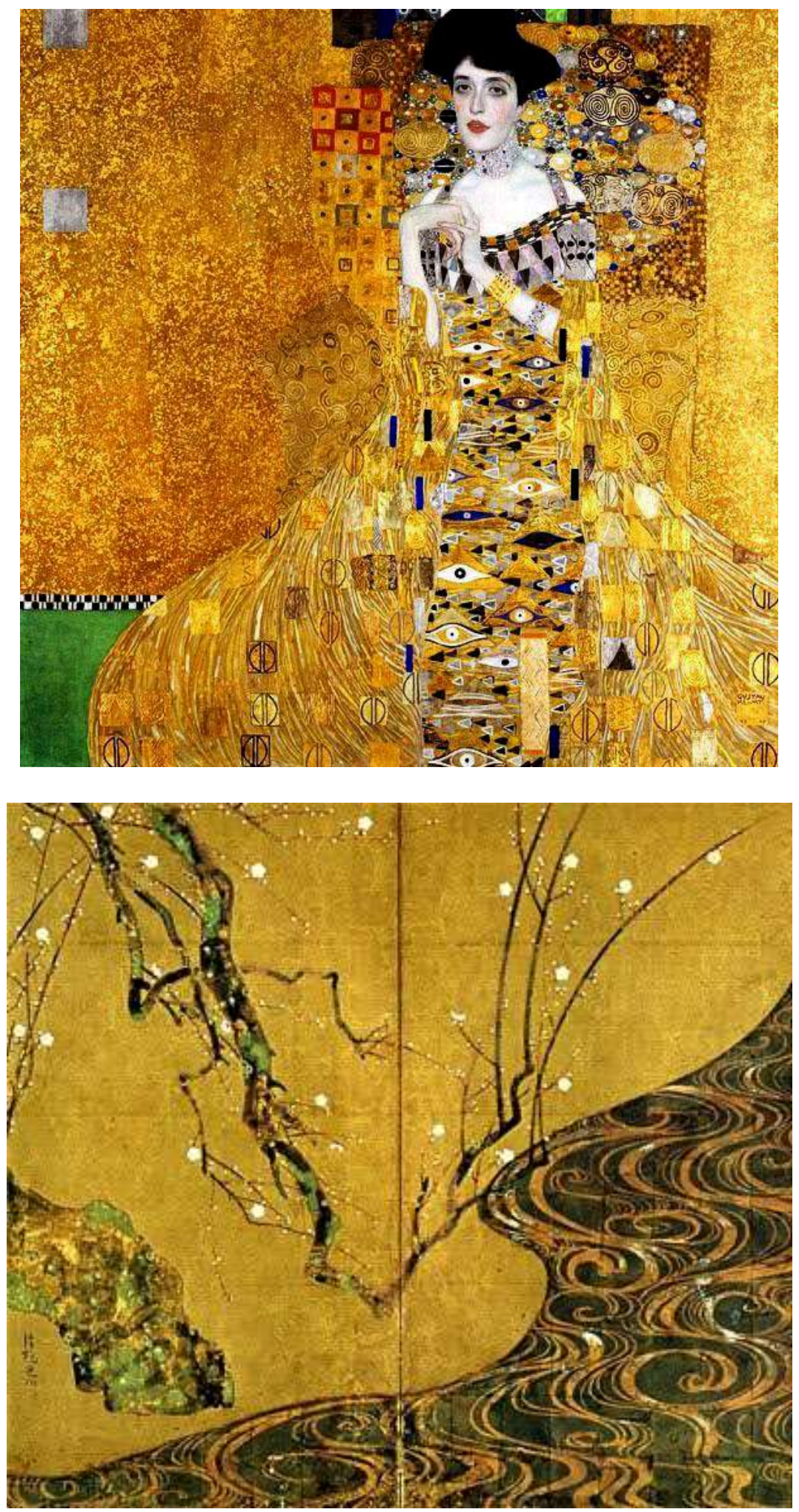

Figura 26.- Retrato de Adele Bloch-Bauer de Gustav Klimt, 1907 y Flores de ciruelo rojo y blanco , Ogata Kōrin , principios del siglo XVIII. 


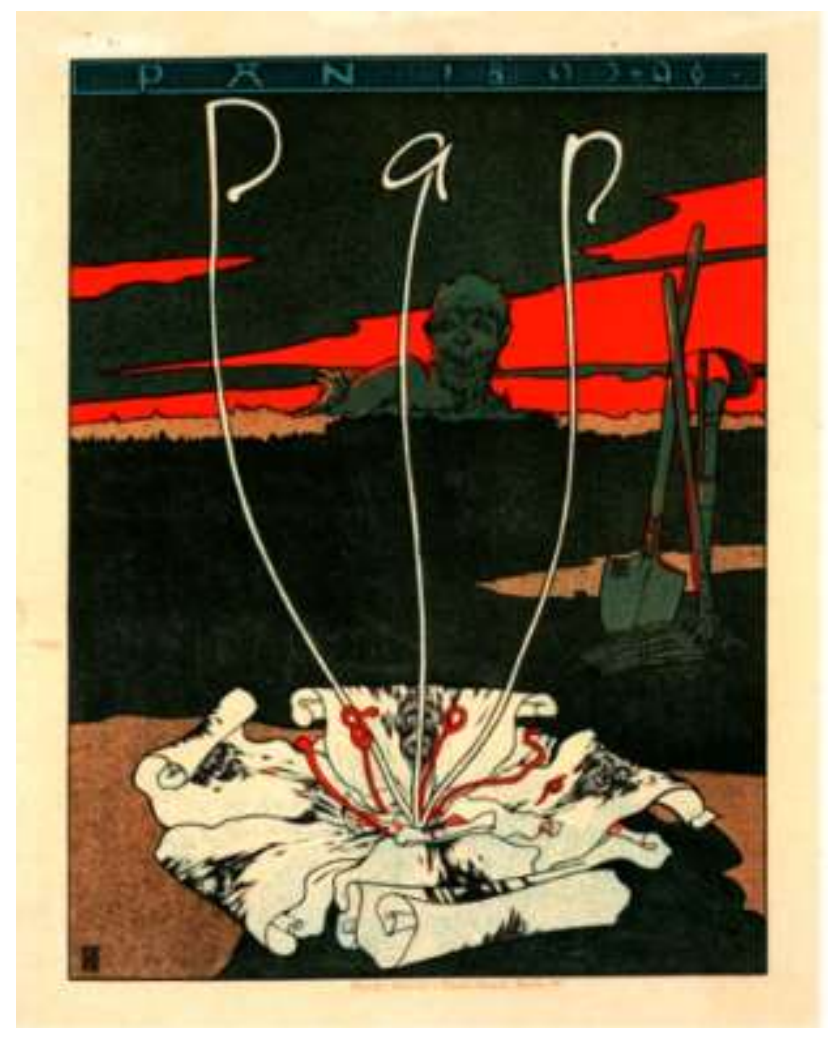

Figura 27.- Joseph Sattler. Portada de la revista 'Pan' (1895).

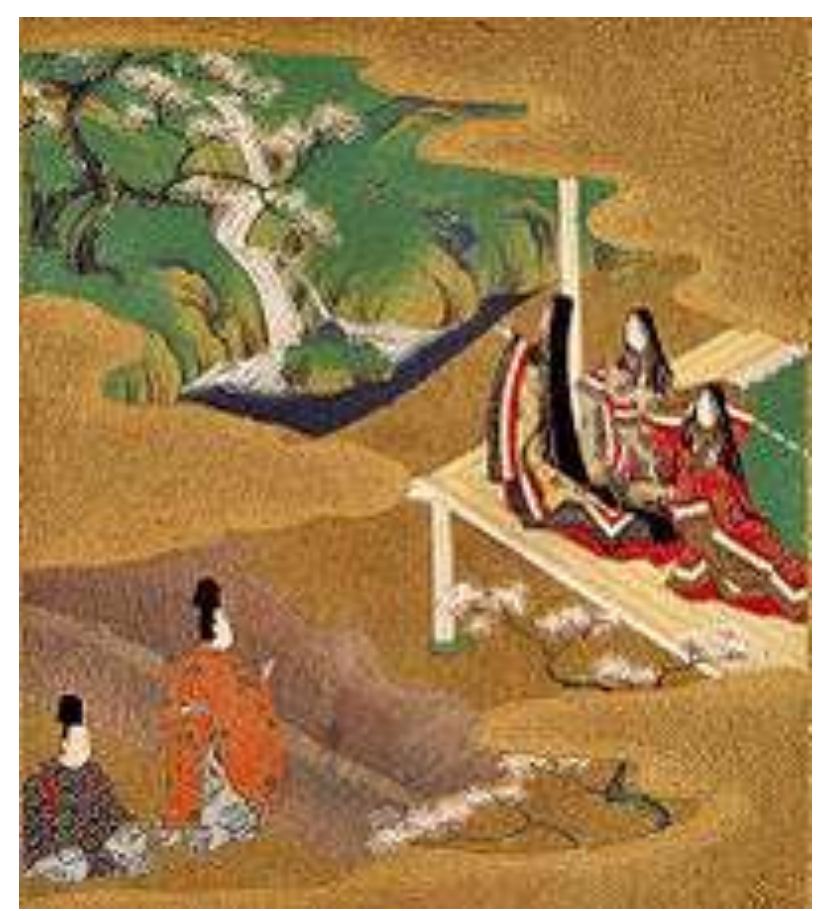

Figura 28.- Tosa Mitsuoki 土佐 光起; (1617 -1691) Escena del Genji Monogatari. 


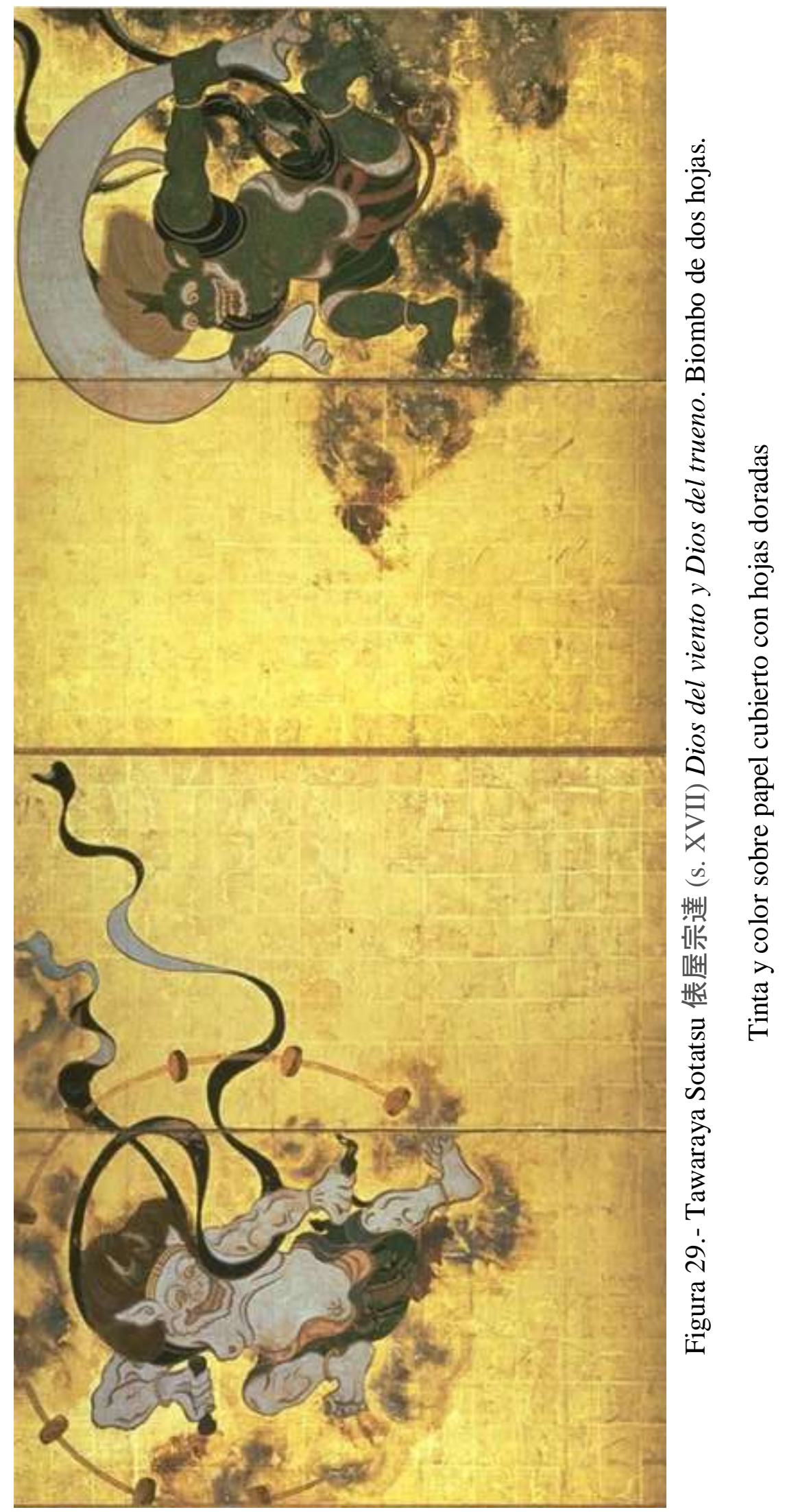




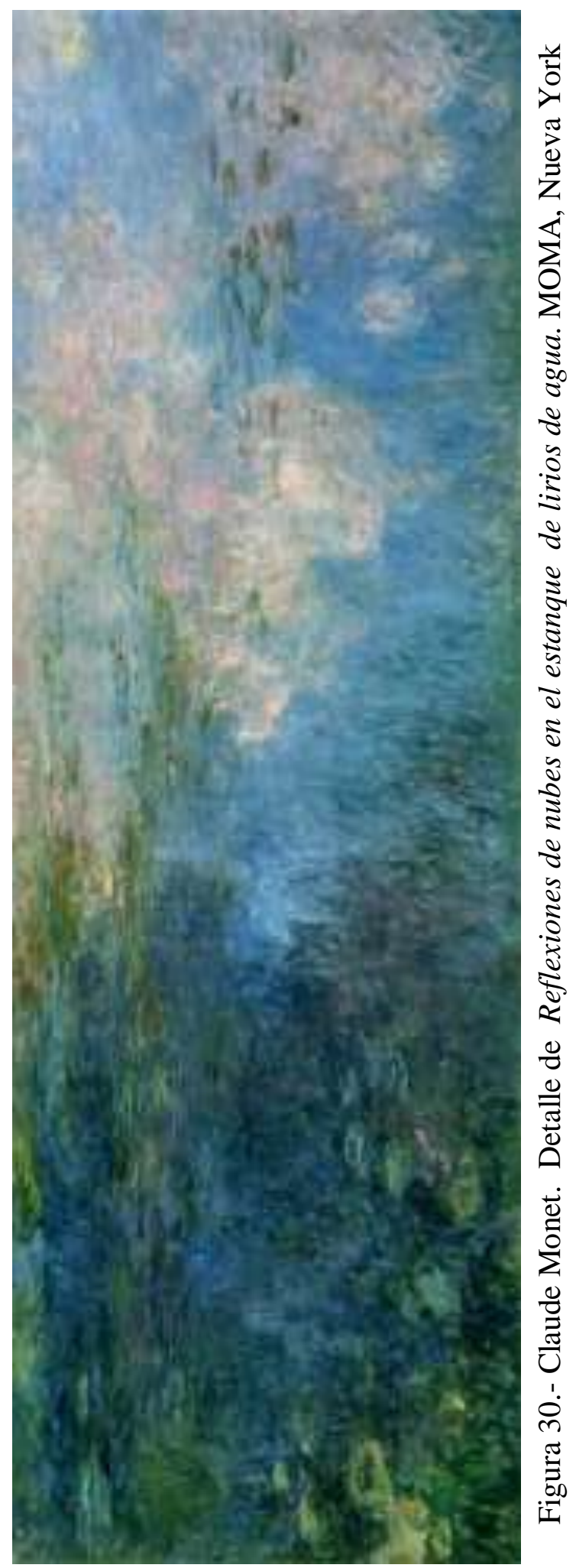




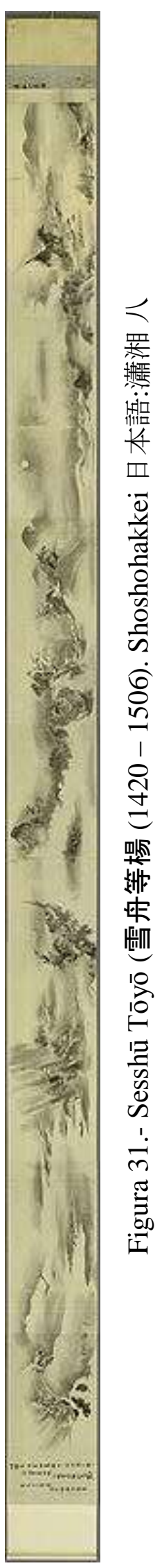




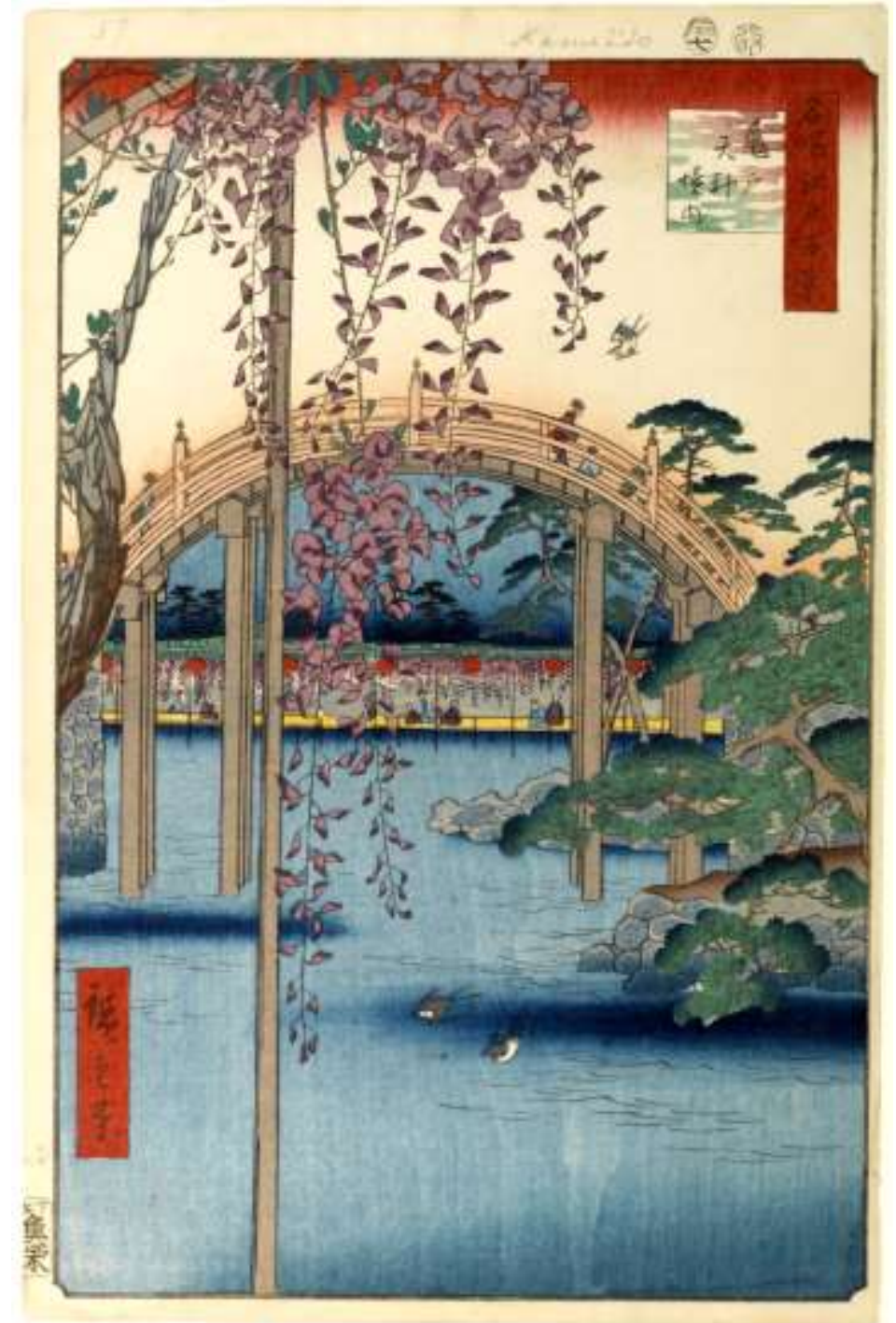

Figura 32.- Utagawa Hiroshige (歌川広重 $(1797$ - 1858). Dentro del Santuario Kameido Tenjin (Kameido Tenjin Keidai) 


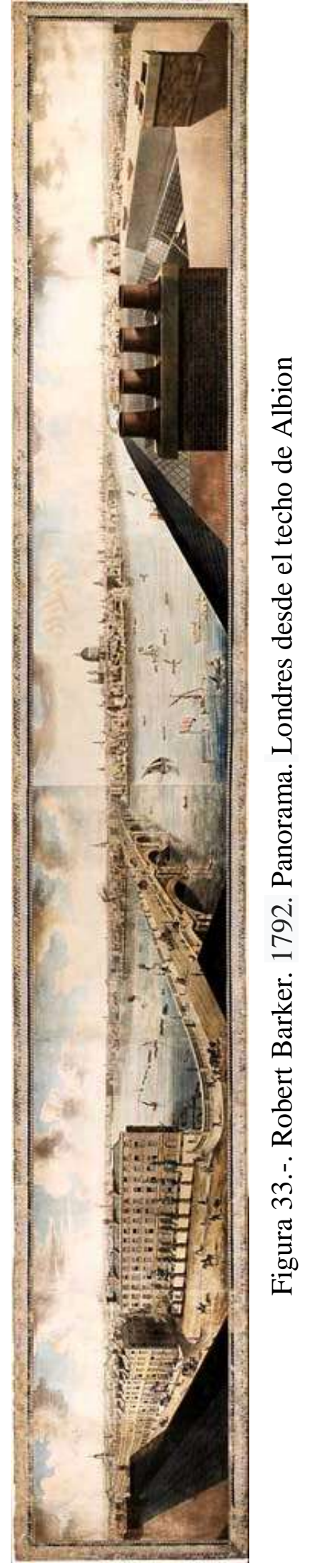




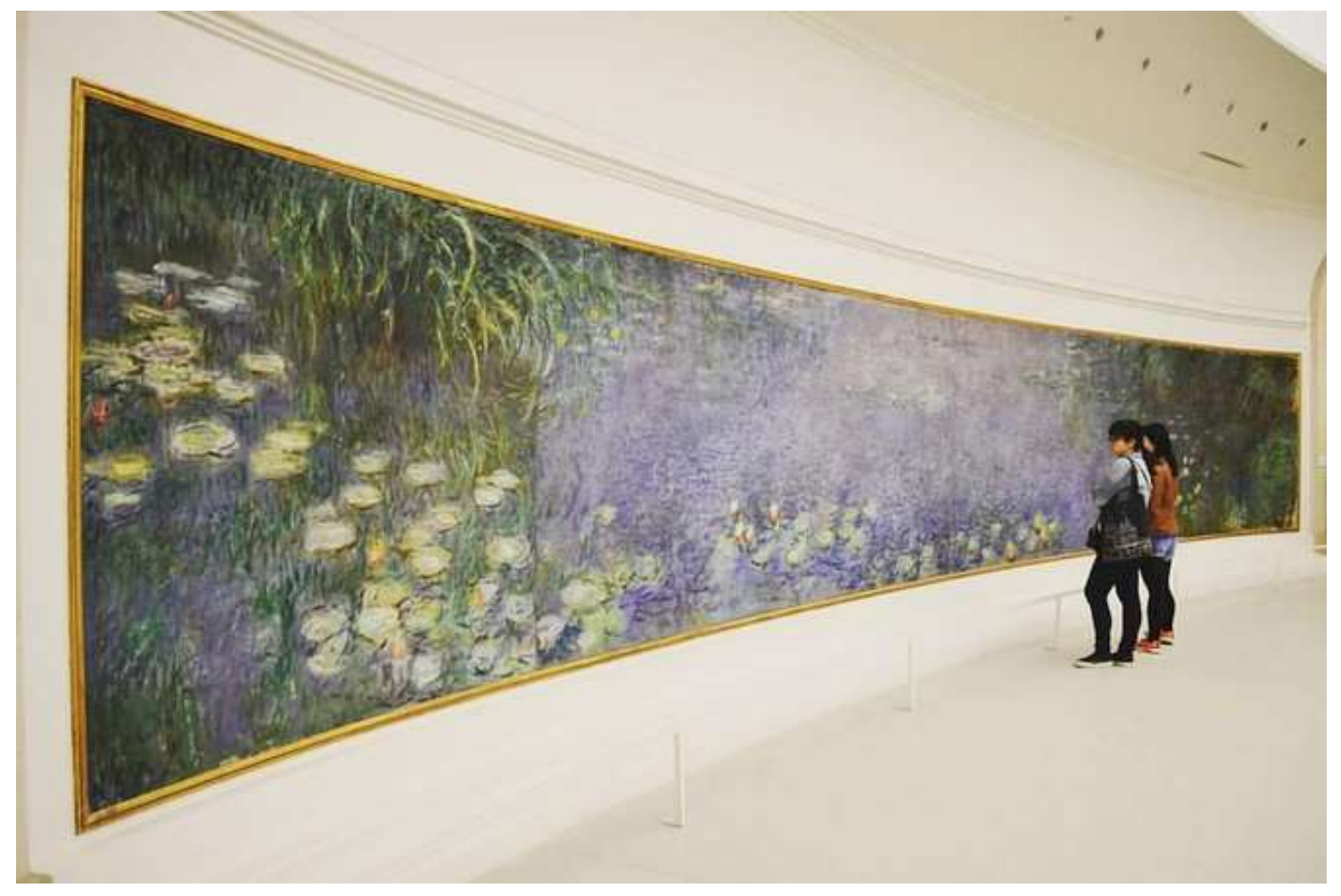

Figura 34.- Museo Orangerie 


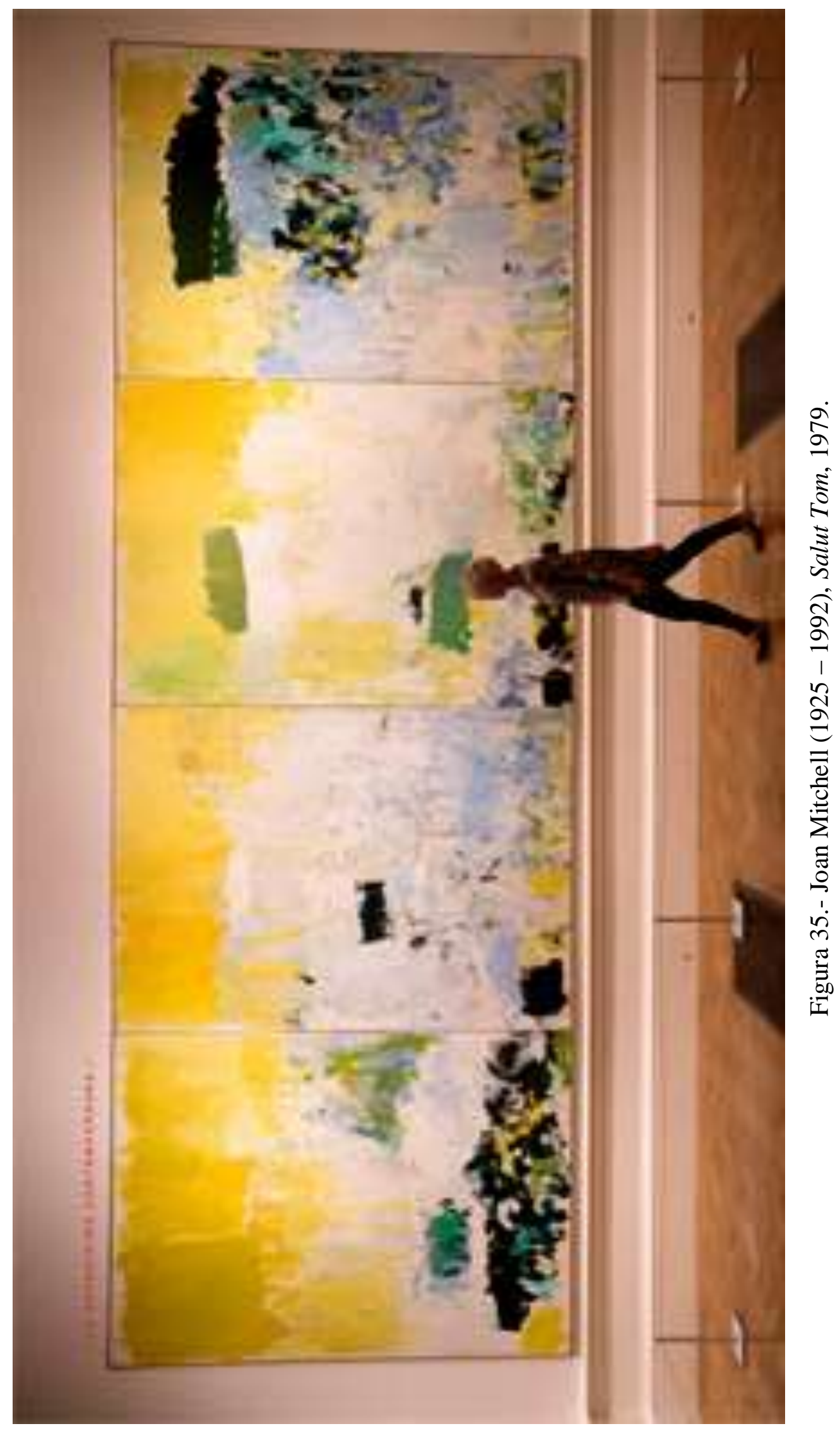




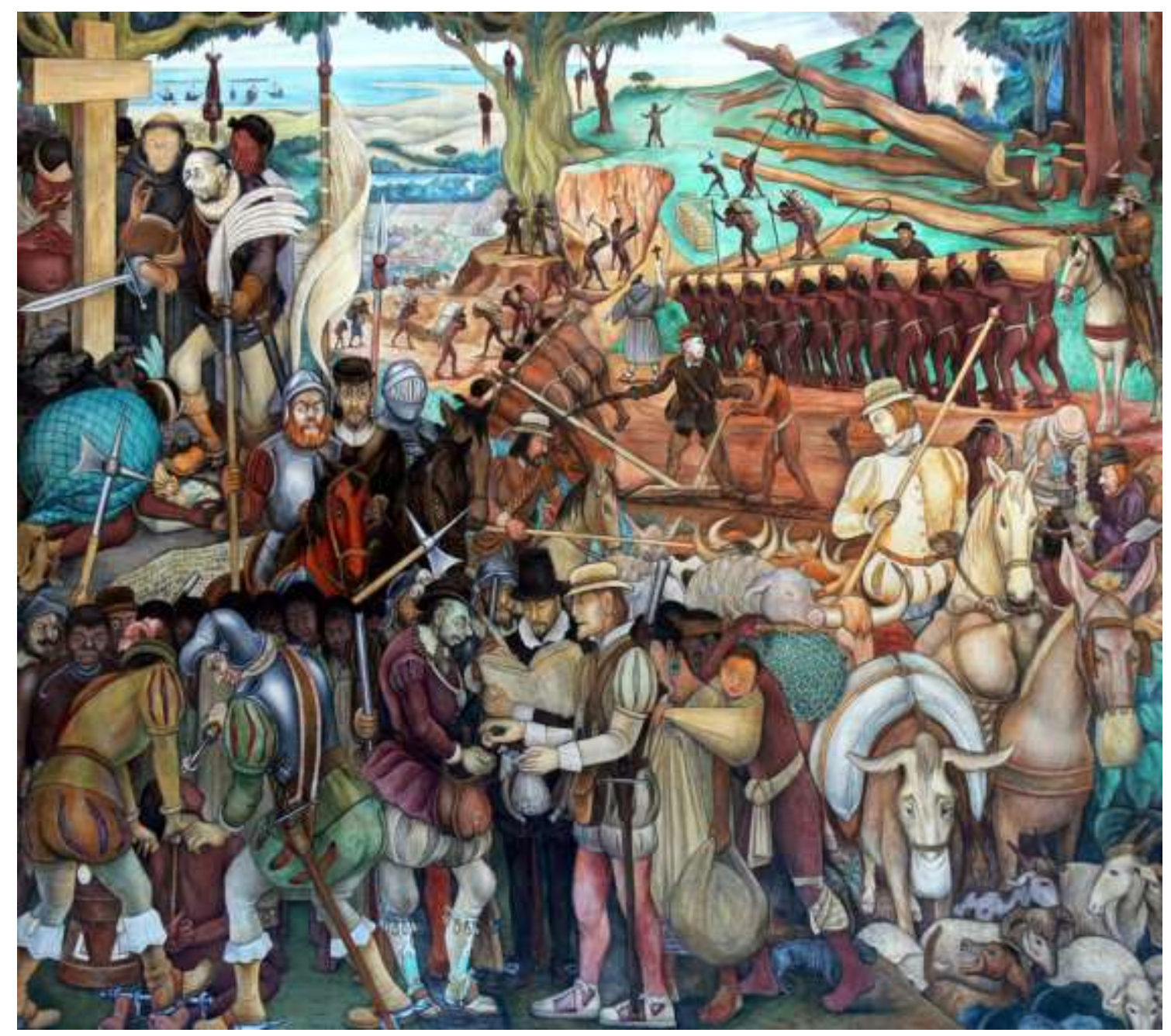

Figura 36.- Diego Rivera (1886 - 1957). Explotación de México por los conquistadores españoles. Palacio Nacional. Mural (1929-1945). 


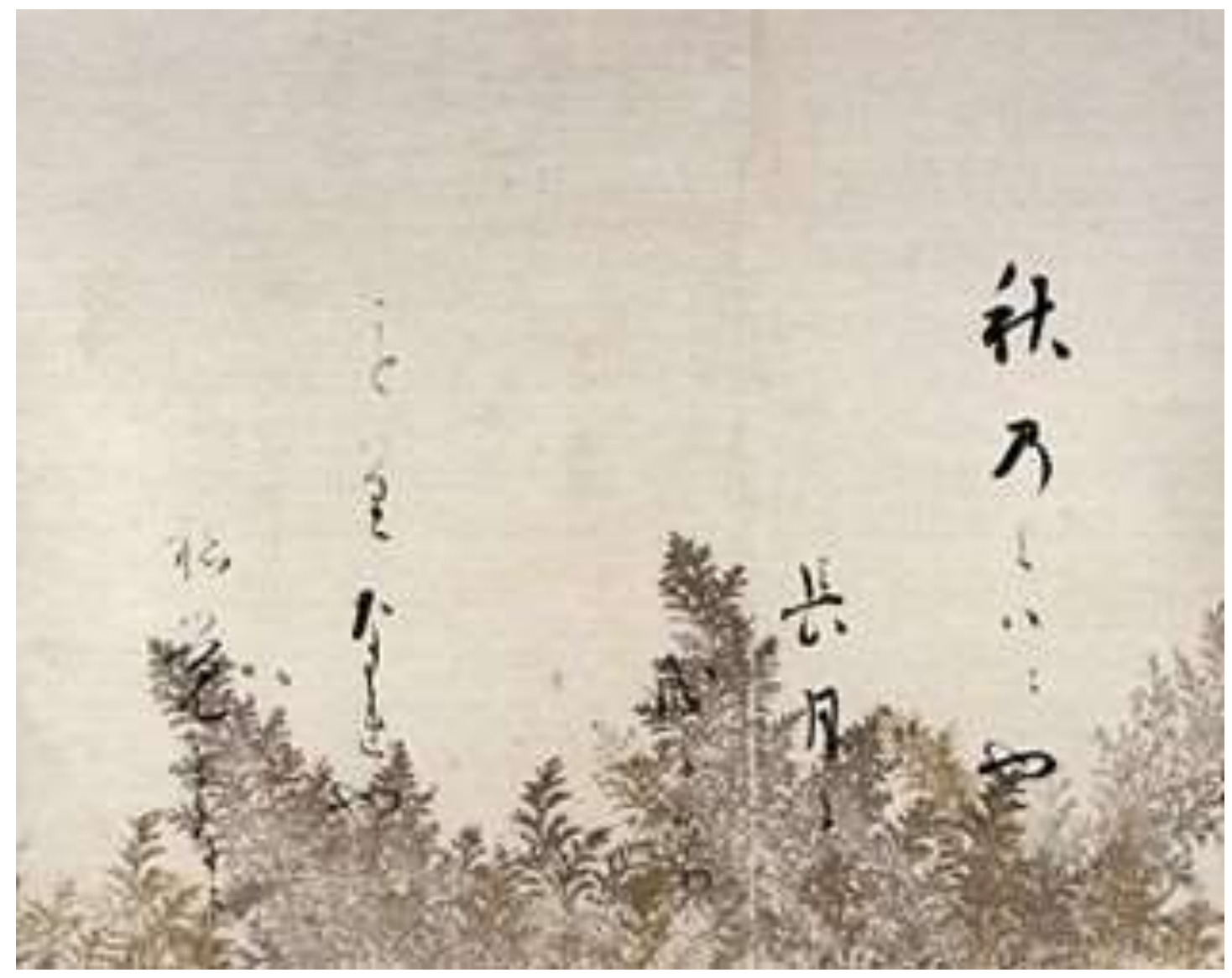

37.- Hon'ami Kôetsu 本阿弥光悦. caligrafía. Tawaraya Sôtatsu 俵屋宗達, papel. Poema Waka. Periodo Edo. 


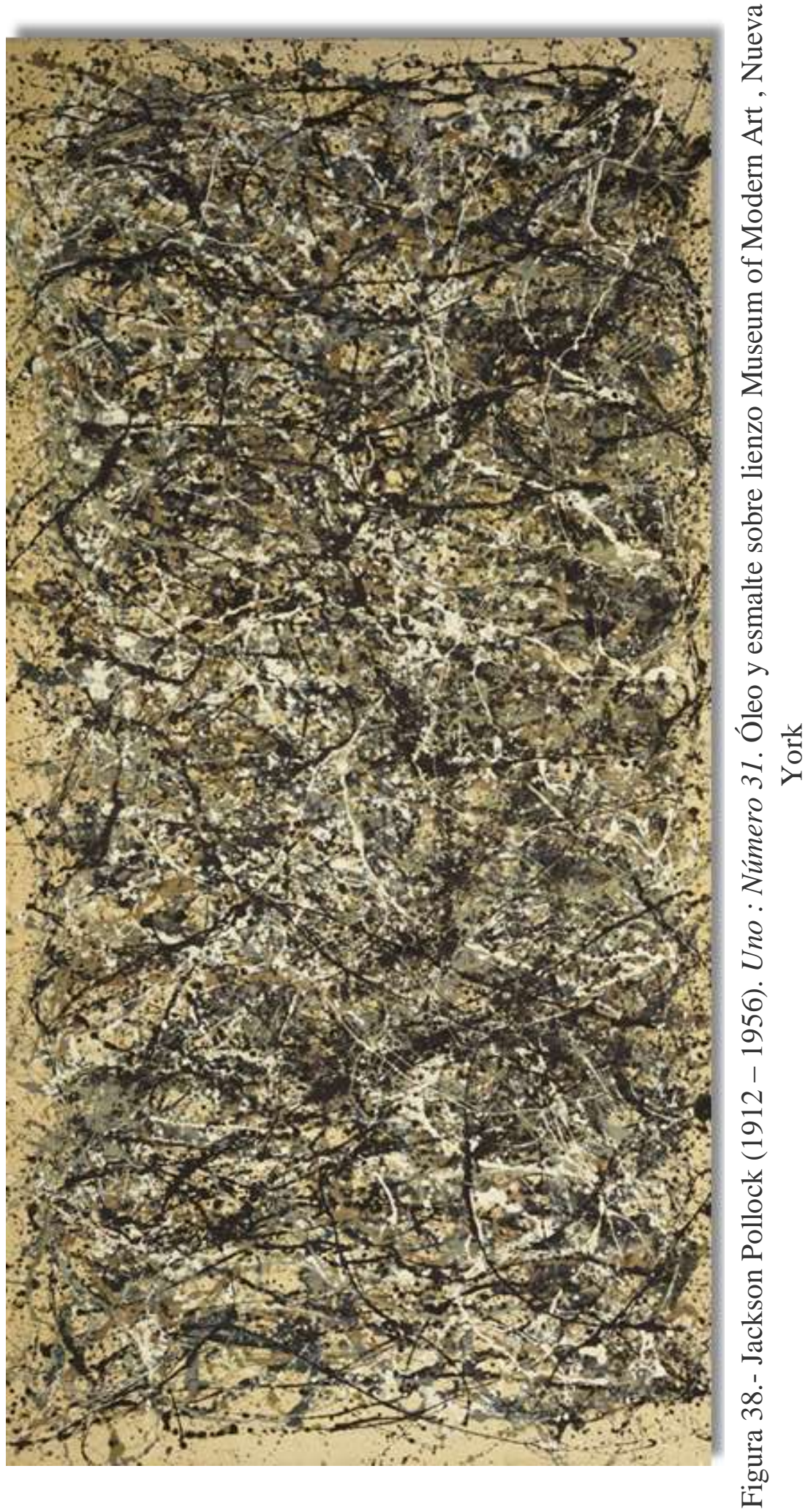




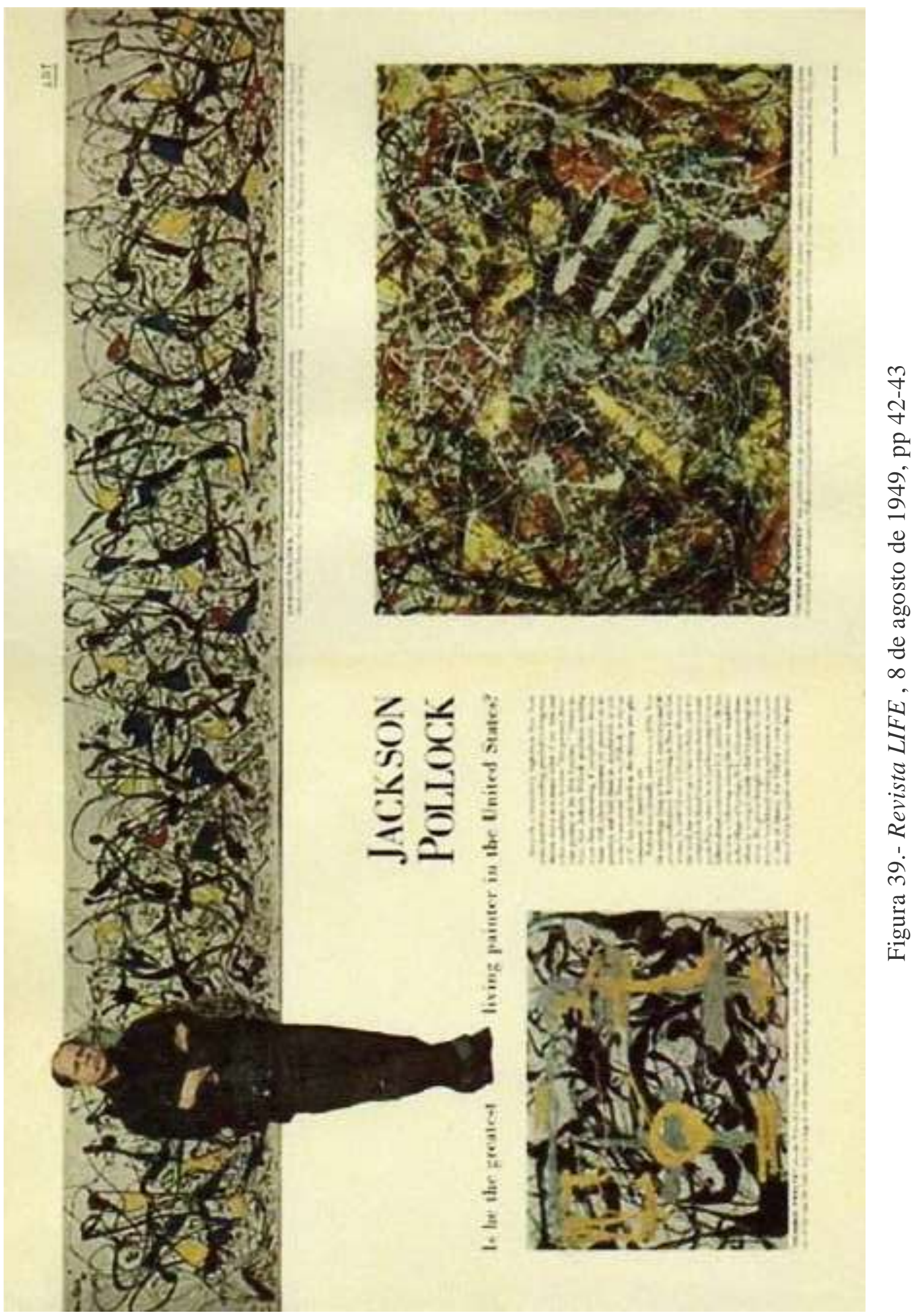




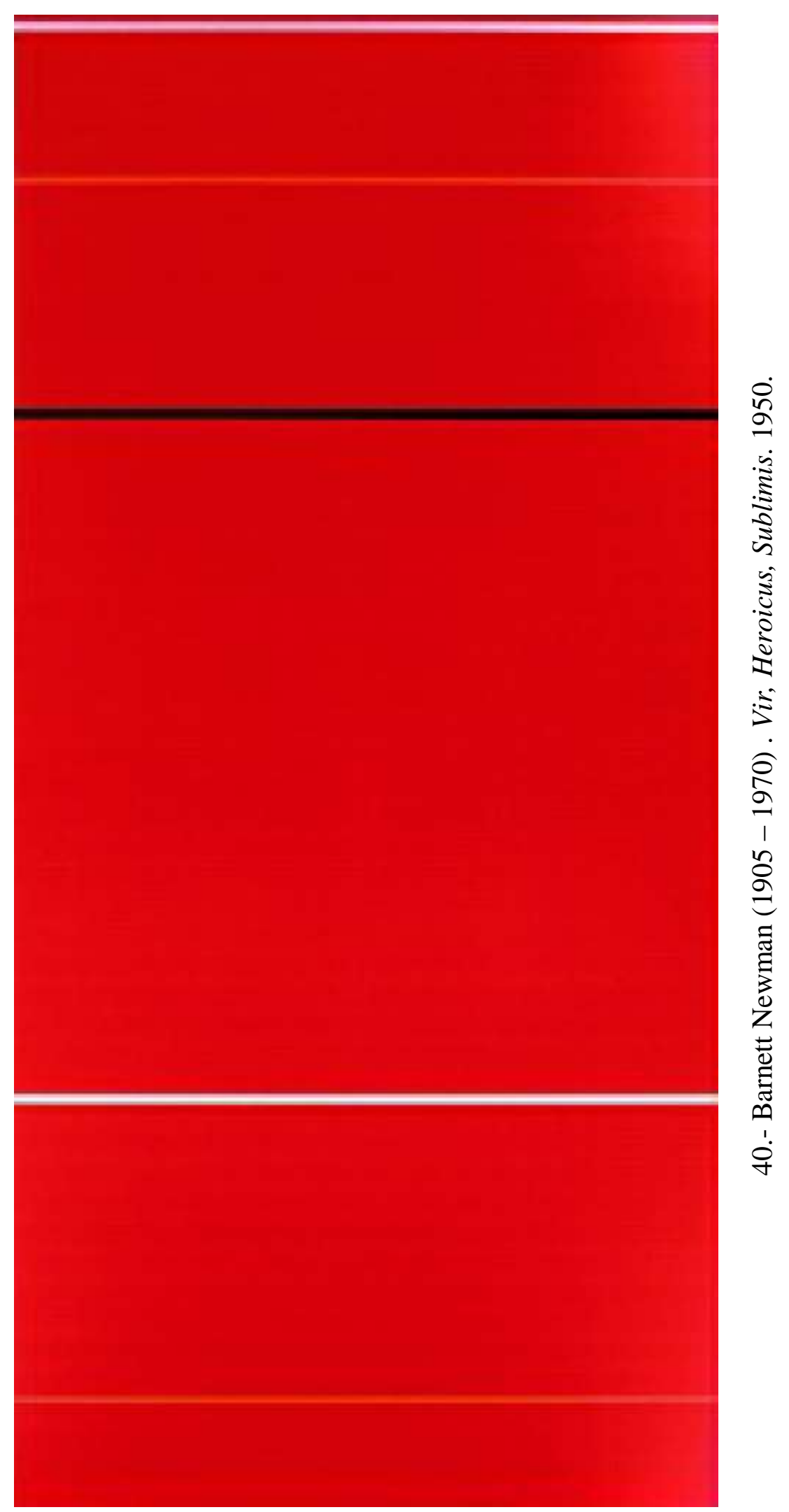




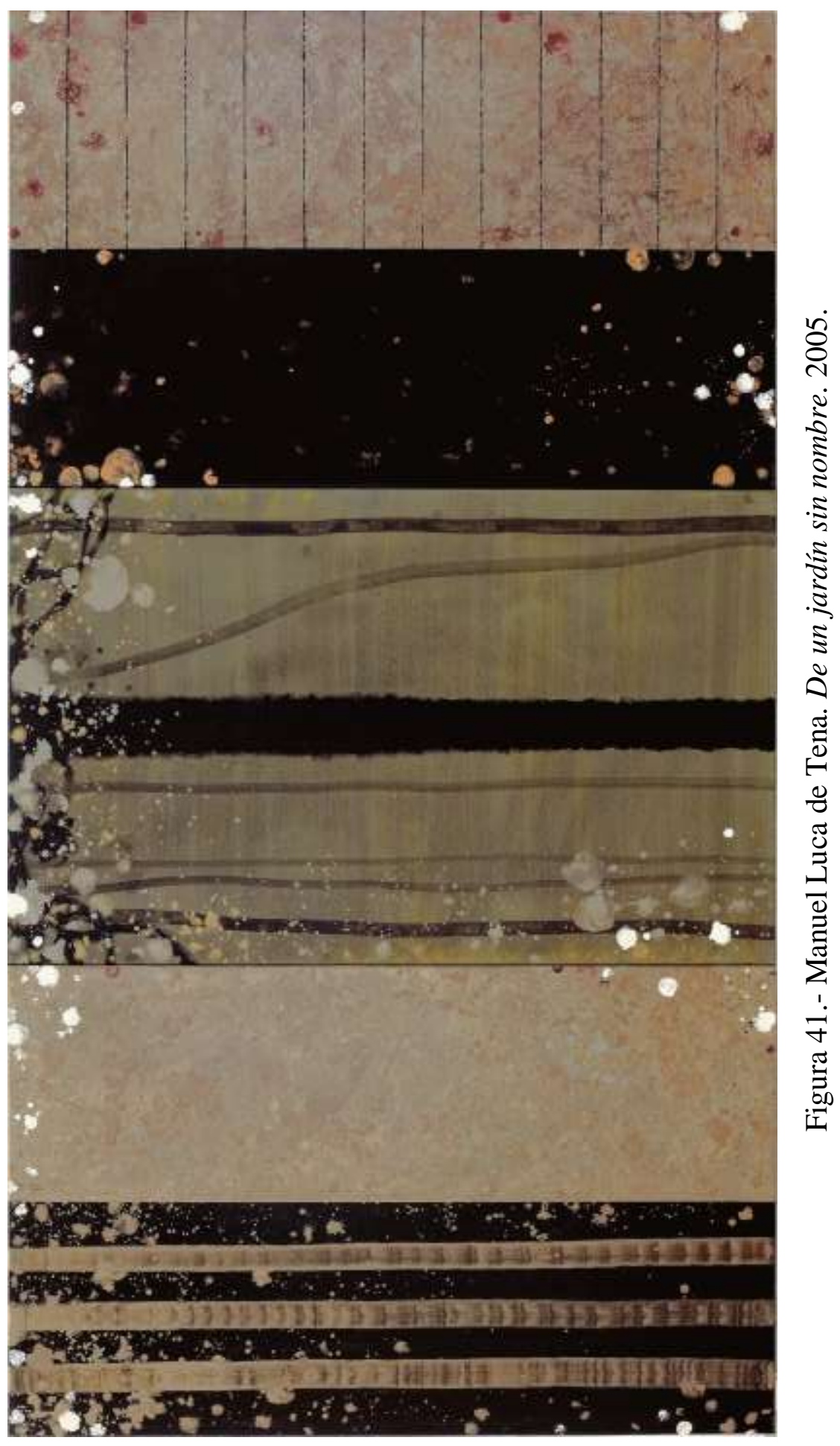




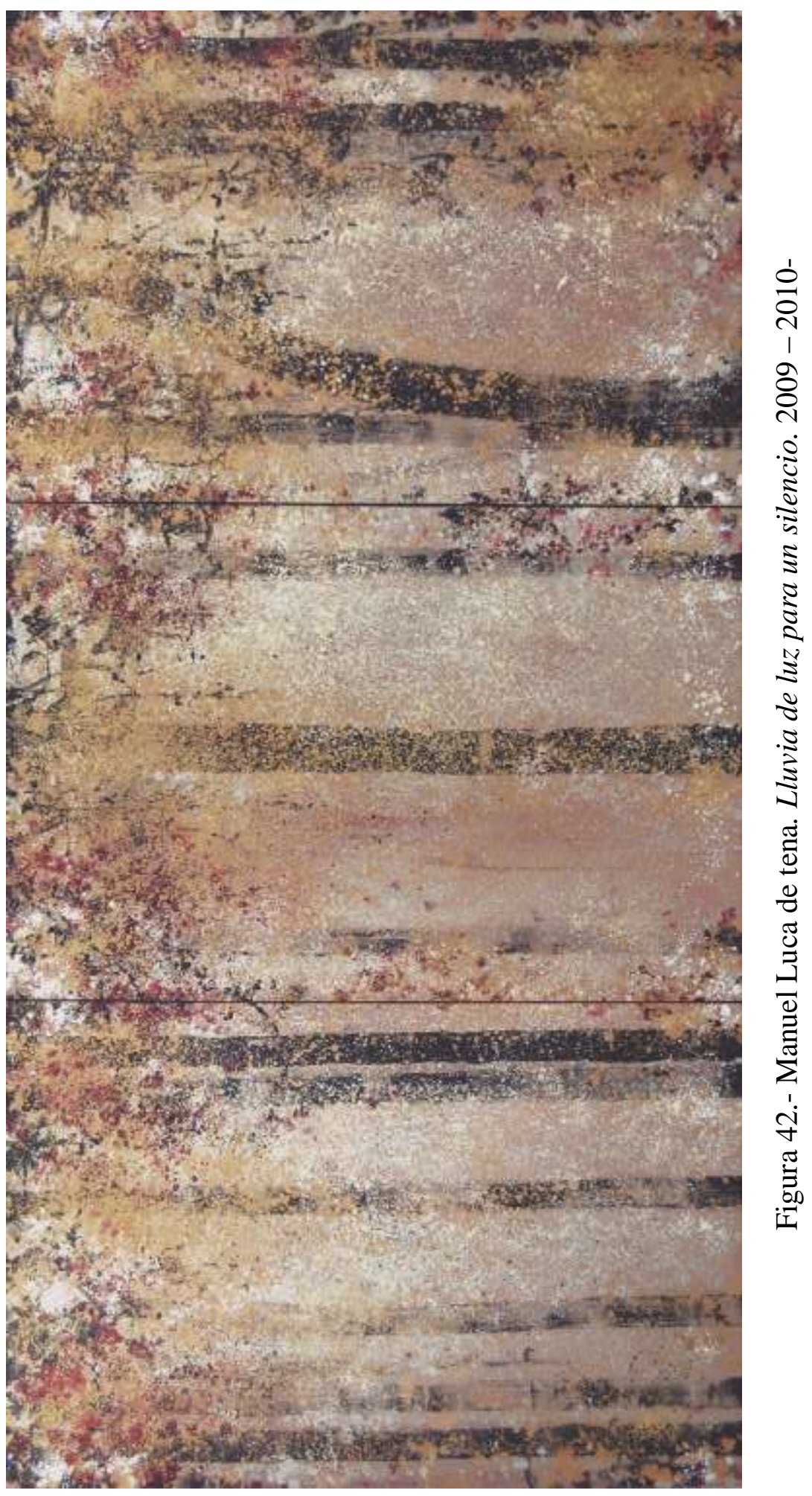




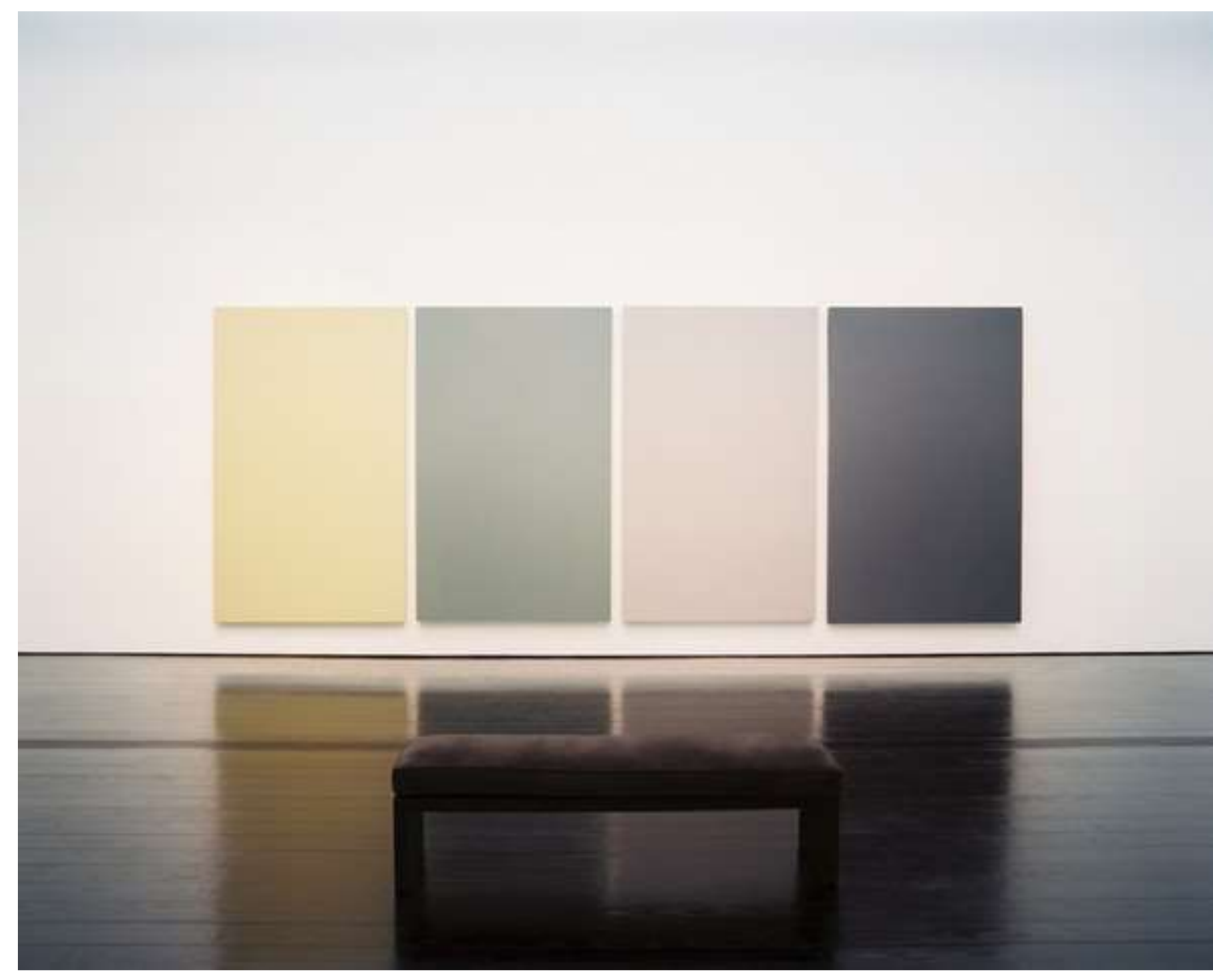

Figura 43.- Brice Marden. The Seasons (1974 - 1975). 


\section{BIBLIOGRAFÍA}




\section{1.- BIBLIOGRAFÍA GENERAL}

\section{Libros}

Barthes, Roland. La Cámara Lúcida. Barcelona: Paidós, 2009.

Barthes, Roland. Lo Obvio y lo Obtuso. Barcelona: Paidós, 2009.

Belting, Hans. Florencia Bagdad: Una Historia de la Mirada entre Oriente y Occidente. Madrid: Akal /Estudios Visuales, 2012.

Berque, Agustín. El Pensamiento Paisajero. Madrid: Biblioteca Nueva, 2009.

Bryson, Norman. Visión y Pintura. La lógica de la mirada. Madrid: Alianza Editorial, S.A, 1991.

Colinas, Antonio. La simiente Enterrada. Un viaje a China. Madrid: Siruela, 2005.

Corsi, Elisabetta. La fábrica de Ilusiones. Los Jesuitas y la difusión de la perspectiva lineal en China, 1698-1766. México: El Colegio de México, Centro de Estudios de Asia y África, 2004.

Cortés, Helena y Leyte, Arturo, trans : Heidegger, Martin, Caminos de bosque, Madrid: Alianza Editorial, S.A. 1996.

Francastel, Pierre. Sociología del arte. Madrid: Alianza Editorial, S.A. 1984.

Frazer, James George. La Rama Dorada. Magia y Religión. México: Fondo de Cultura Económica, México, D.F, 2014.

Gauthier, Guy. Veinte lecciones sobre la imagen y el sentido. Madrid: Cátedra, 1996.

Gombrich, Ernst Hans Josef. Arte e Ilusión. Estudio sobre la psicología de la representación pictórica. Barcelona: Editorial Gustavo Gili, S.A, 1979.

Gombrich, Ernst Hans Josef. La Preferencia por lo primitivo. Episodios de la historia del gusto y el arte de Occidente. Barcelona: Debate 2003.

Han, Byung - Chul. La salvación de lo bello. Barcelona: Editorial Herder, 2018.

Hockney, David and Gayford, Martin. Una historia de las imágenes. Madrid: Ediciones Siruela, 2018. 
Hofmann, Werner. Los fundamentos del arte moderno. Una introducción a sus formas simbólicas. Barcelona: Ediciones Península, 1995.

Kenkô, Yoshida. Tsurezuregusa, ocurrencias de un ocioso. Madrid: Hiperión, 1986.

Lévi-Strauss, Claude. Mito y significado. Madrid: Alianza Editorial, S.A. 1990.

Marcus, George E y Fischer, Michael M J. La antropología como crítica cultural. Un momento experimental en las ciencias humanas. Buenos Aires: Amorrortu Editores, 2000 .

Marina, José .Antonio. Las arquitecturas del deseo. Una investigación sobre los placeres del espíritu. Barcelona: Editorial Anagrama, 2007.

Otto, Rudolf. Lo santo. Lo racional y lo irracional en la idea de Dios. Madrid: Alianza Editorial, S.A, 2016.

Panofsky, Erwin. La Perspectiva como forma simbólica. Barcelona: Tusquets Editores S. A, 2003.

Panofsky, Erwin. Renacimiento y renacimientos en el arte occidental. Madrid: Alianza Editorial, S.A, 1975.

Pérez Infante, Carlos, trans. Tratado de pintura de León Battista Alberti. México: Universidad Autónoma Metropolitana, 1998.

Plinio el Viejo, Historia Natural, (Libro XXXV, 15) tomado de Una Historia de las Imágenes, 2018.

\section{Revistas}

Castilla, Manuel V. "Estatus apostólico de la perspectiva matemática lineal en china durante el siglo XVIII". Orientando Temas de Asia Oriental, Sociedad, Cultura y Economía. Año 10. Número 19. Veracruz: Centro de Estudios APEC, 2018. http://orientando.uv.mx/index.php/orientando/article/view/2100 (Última consulta 12/04/17).

Corsi, Elisabetta." Perspectiva iluminadora e iluminación de la perspectiva. La versión del arte occidental de la perspectiva, de Nian Xiyao (1671-1738) en los prólogos a la 'ciencia de la visión'". Estudios de Asia y África. Vol. XXXVI. Núm. 3, septiembre-diciembre. 375-418 El Colegio de México, A.C. Distrito Federal. 2001. https://www.redalyc.org/articulo.oa?id=58636301 (última consulta 02/03/18) 
Corsi, Elisabetta. "Términos chinos utilizados como sinónimo de 'perspectiva' y ecos del naturalismo en algunos textos sobre pintura del s. XVIII". El Colegio de México.Vol. 32. Núm. 3, México $\quad$ D. $\quad$ F, 1997. https://estudiosdeasiayafrica.colmex.mx/index.php/eaa/article/view/1510 (Última consulta 03/03/18).

Escobar García-Quirós, Ignacio, "Dibutades o el arte de dibujar". Arte, Individuo y Sociedad, 2000, p. 250. file:///C:/Users/Usuario/Downloads/6772Texto\%20de1\%20art\%C3\%ADculo-6856-1-10-20110531.PDF (Última consulta 13/06/2020).

Henckmann, Wolfhart, "Sobre la distinción entre Valores Estéticos y Artísticos" I Enrahonar 32/33, 2001, Universitat de Múnic. Philosophie Department Geschwisterscholl Platz, $\quad 1 . \quad 80539 \quad$ München, 2001. https://ddd.uab.cat/pub/enrahonar/0211402Xn32-33/0211402Xn32-33p67.pdf el (Última consulta 14/06/20)

Kaldenbach, C.J. "Vistas en Perspectiva". Print Quarterly. 1985: 86-104. https://kalden.home.xs4all.nl/auth/perspectiveviews.htm (Última consulta 02/07/20) 


\section{2.- BIBLIOGRAFÍA SOBRE ARTE Y ESTÉTICA ORIENTAL}

\section{Libros}

Aitken, Geneviève y Delafond, Marianne. La collection d'estampes Japonaises de Claude Monet. Lausanne: Bibliothèque des Arts, 2003.

Barlés Báguena, Elena. Lo mejor del Arte del Extremo Oriente. Madrid: Editorial Información e Historia, 1997.

Buisson, Dominique. Temples et Sanctuaries au Japón. París: Editions de Moniteur, 1981.

Buckman, Thomas R. Bibliography y Natural History. Essays presented at a Conference Convened in June 1964 by Thomas R. Buckman. Kansas: University of Kansas Libraries, 1966.

Cabañas, Pilar. La Fuerza de Oriente en la Obra de Joan Miró. Madrid: Electa (Grijalbo Mondadori. S.A), 2000.

Courtois, Michel. Pintura China. Madrid: ed. Aguilar, en la col. "Historia general de la pintura", no 24, 1969.

Cheng, François. La Philosophie de la Nature Dans lárt Déxtême Orient. Paris: Editions You-Feng, 1998.

Cheng, François. Cinco Meditaciones Sobre la Belleza. Madrid: Ediciones Siruela, 2007.

Cheng, François. Vacío-Espíritu. Textos teóricos chinos sobre el arte pictórico. Valencia: Pre- Textos, 2017.

Cheng, François. Vacío y Plenitud. Madrid: Ediciones Siruela, 2004.

Falero, Alfonso. Aproximación a la Cultura Japonesa. Salamanca: Amarú Ediciones, 2006.

Falero, Alfonso. Aproximación al sintoísmo. Salamanca: Amarú, 2007.

Falero, Alfonso. "El Fūryū como categoría estética". En El jardín japonés: Qué es y no es entre la espacialidad y la temporalidad del paisaje, ed Gras Balaguer, Menene, 137154. Madrid: Tecnos, 2015. 
Fenollosa, Ernest. Introducción a la Cultura China. Editorial Melusina. S.L, 2011.

Garcés Gracía, Pilar y Terrón Barbosa, Lourdes (eds).. Itinerarios, Viajes y Contactos Japón-Europa. Bern. Peter Lang AG, International Academic Publishers. 2013.

García Rodriguez, Amaury A. y García Montiel, Emilio (compiladores). Cultura Visual en Japón. Once Estudios Iberoamericanos. México D.F: El Colegio de México, Centro de Estudios de Asia Oriental, 2009.

García Gutiérrez, Fernando. Japón y Occidente. Influencias recíprocas en el Arte. Sevilla: Ediciones Guadalquivir, 1990.

García Gutiérre, Fernando. "Influencias mutuas entre el arte japonés y el occidental". En Gómez Aragón, Anjhara. Japón y "Occidente”. El patrimonio cultural como punto de encuentro. Sevilla: Aconcagua Libros, 2016.

García Gutiérrez, Fernando. El Zen y el arte japonés. Sevilla: Guadalquivir Ediciones, 1998.

Guasch, Anna María et al, Summa Pictórica, de las Vanguardias a la Postmodernidad. Tomo I. Barcelona: Editorial Planeta, 2000.

Guo, Xi (郭熙). Lin Quan Gao Zhi (林泉高致). Jiangsu Phoenix Literature and Art Publishing, LTD, 2015.

Han, Byung - Chul. Ausencia. Acerca de la cultura y filosofía del Lejano Oriente. Buenos Aires: Caja negra Editora, 2019.

Han, Byung - Chul. La salvación de lo bello. Barcelona: Editorial Herder S.A, 2015.

Houghton Brodrick, Alan. La Pintura China. México D.F: Breviarios del Fondo de Cultura Económica, 1954.

Janata, Alfred. Pintura coreana. Barcelona: Editorial Edhasa, 1960.

Jenyns, Soame. A Background to Chinese Painting. New York: Schocken Books, 1972.

Jiayi, Z y Chongzheng, N. Pintura China Tradicional. Historia Cantada en Poemas sin Voz. Beijing: China Intercontinental Press, 2000.

Jordi Vilà, Galvany Albert, trad. Yijing, el libro de los cambios. Girona: Ediciones Atalanta, 2006.

Jullien, François. La Gran Imagen no Tiene Forma o del no Objeto por la Pintura. Barcelon: Alfa Decay, 2008.

Jung, Jae-seo. "Daoism in Korea". En Daoism Handbook. Editado por Livia. Kohn, 792-820. Leiden: Brill, 2000. 
Juniper, Andrew. Wabi Sabi. El "Arte de la Impermanencia” Japonesa. Barcelona: Ediciones Oniro, 2004.

Kawazoe, Noboru. La arquitectura de Japón. Tokio: Int. Society for Educational Information, 1990.

Kitaura, Yasunari. La Plenitud del Vacío. Ensayos sobre el Aikido y Otros Aspectos de la Cultura Japonesa. Madrid: Compañía Literaria, 1999.

Kim, Sue-Hee. El Arte del Extremo Oriente. Madrid: Grupo Anaya, S.A, 1993.

Lanzaco Salafranca, Federico. Los Valores Estéticos de la Cultura Clásica Japonesa. Madrid: Editorial Verbum, 2009.

Lévi-Strauss, Claude. La otra cara de la luna. Escritos sobre Japón, Barcelona: RBA Libros, S.A, 2013.

Luca de Tena, Manuel. La Presencia de lo Ausente. El concepto y la expresión del vacíoen los textos de los pintores contemporáneos occidentales a la luz del pensamiento extremo-oriental. Salamanca: Tesis Doctoral Universidad de Salamanca. 2008.

Menzúa López, A.J. La Experiencia del Paisaje en China. "Shanshui" o cultura del paisaje en la dinastía Song. Madrid: Abada Editores S.L, 2014.

Ono, Sokyo. El sintoísmo. El camino de los kami. Gijón: Editorial Satori, 2009.

Racionero, Luis. Textos de Estética Taoísta. Madrid: Alianza Editorial, S.A. 2014.

Riechmann, Jorge. Un Mundo Vulnerable. Ensayos sobre Ecología, Ética y Tecnología. Madrid: Ediciones Catarata, 2005.

Riviére, Jean. Arte Oriental, Barcelona: Salvat. Biblioteca Salvat de los Grandes Temas n'91, 1973.

Rodriguez Llera, Ramón. Japón en Occidente. Arquitectura y Paisajes del Imaginario Japonés. Del Exotismo a la Modernidad. Valladolid: Secretariado de Publicaciones e Intercambio Editorial. Universidad de Valladolid., 2012

Roncero Mayor, Luis. La tradición esotérica taoísta: Los fundamentos de la alquimia interior taoísta y sus correspondencias en la alquimia medieval española. Madrid: tesis Doctoral Universidad Autónoma de Madrid, 2012.

Rowley, George. Principios de la Pintura China. Madrid: Alianza Editorial, S. A, 1981.

Ruiz de la Puerta, Félix. Lo Sagrado y lo Profano en Tadao Ando. Madrid: Álbum Letras Artes, S. L, 1995. 
Schelling, Friedrich. La Relación del Arte con la Naturaleza. Madrid: Editorial Globus, 2014.

Silbergeld, Jerome. Chinese Painting Style. Media, Methods and Principles of Form. Seattle and London: University of Washington Press, 1982.

Sze, Mai-Mai. The Way of Chinese Painting. Its Ideas and Technique. With Selections from the Seventeenth Century Mustard Seed Garden Manual of Painting. New York: Vintage Books a Division of Random House, 1959.

Sueiras, $\mathrm{M}^{\mathrm{a}}$ del Mar. El espacio pictórico extremo oriental y europeo: Una comparativa entre la noción de Horizonte y de Horizontalidad. En: Eurasia: Avances de Investigación. Salamanca: Ediciones de la Universidad de Salamanca, 2021.

Tregear, Mary. El arte chino. Barcelona: Ediciones Destino, 1991.

Van Gulik, Robert H. Chinese Pictorial Art. As Viewed by the Connoisseur. Notes on the Means and Methods of Traditional Chinese Connoisseurship of Pictorial Art, based upon a Study of the Art of Mounting Scrolls in China and Japan. New York: Hacker Art Books, 1981.

Vives, Javier. El Teatro Japonés y las Artes Plásticas. Gijón: Editorial Satori, 2010.

Watsuji, Tetsuro. Antropología del Paisaje. Climas, Culturas y Religiones. Salamanca: Ediciones Sígueme, 2006.

Y. Yamashita, "Lo que se conoce de Seshû". En: Guasch, Anna María. Summa Pictórica. De la Prehistoria a las Civilizaciones Orientales. 271-281. Barcelona: Editorial Planeta, 2000.

\section{Revistas}

Almazán Tomás, David. "La seducción de oriente: de la chinoiserie al japonismo". Artigrama. No 18. 2003. 83-106.

Bailey, Penny, "La iconografía de Sipjangsaeng de Corea: la búsqueda de la longevidad y la inmortalidad en las artes visuales de la dinastía Joseon", The Asia-Pacific Journal: Japan Focus 18 (8), 2020: 1-18, https://apjjf.org/2020/8/Bailey.html (última consulta $14 / 06 / 20)$

Byung-kil, Chang, "Corrientes espirituales en la Corea tradicional", El correo de la Unesco. Corea "país de la mañana serena”. París, 1978. 
Cabañas Moreno, Pilar. "Ramón Gaya. El Arte de China y Japón, Fuentes de Referencia en sus Obras", Anales de Historia del Arte 10, 2000: :311/332, UCM, Facultad de Geografía e Historia, Departamento de Historia del Arte III. (última consulta 18/06/20).

Choe Sun-u, "Un aporte original a la pintura oriental". El correo de la Unesco. Corea "país de la mañana serena”. París, 1978.

Falero Folgoso, Alfonso. "Filosofía del Camino". Nihon Yûkôkai, Revista de Cultura Japonesa. N 6, 2009:16-19.

García Gutiérrez, Fernando. "El arte del 'siglo cristiano' en Japón (Nanban Geijutsu)". Boletín de la Asociación Española de Orientalistas VII, 1971: 31-37.

García Gutiérrez, Fernando. "La pintura de Hokusai y su influencia en Europa, a los 150 años de su muerte". Boletín de Bellas Artes, Nº 27, 1999: 183 - 198.

García Gutiérrez, Fernando. 'Los 'nanban byobu' de Japón (unas pinturas con temas occidentales)”. Laboratorio de Arte, $\mathrm{N}^{\circ}$ 2, 1989: 61-76.

García Gutiérrez, Fernando. "50 años de una arte: 1945 - 1995. En el 50ªniversario del final de la Guerra Mundial”. Fundación Fondo de Cultura de Sevilla, 1996.

Gutiérrez Machó, Luisa María. "La música como lenguaje y medio de comunicación. Ecos del lejano Oriente en la Vanguardia Musical. Orientalismo y Japonismo musical”. Entreculturas № 5, 2012: 15 - 36. http://www.entreculturas.uma.es/archivo5.html (Última consulta 17/10/15)

Henckmann, Wolfhart. "Sobre la Distinción Entre Valores Estéticos y Artísticos". Enrahonar 32/33, 2002: 67 - 79, https://revistes.uab.cat/enrahonar/article/view/v32-33henckmann/397-pdf-es (última consulta 30/06/20)

Lira espejo, Eduardo. "Los japoneses, su música y su actitud creadora". Revista de Arte, 1 (6). 1935: 25-30.

Naquin, Susan. "Giuseppe Castiglione / Lang Shining Un ensayo de revisión”. T oung Pao, 95(4), 2009: 393-412, https://www.researchgate.net/publication/249577957_Giuseppe_CastiglioneLang_Shini ng A Review Essay (Última lectura 02/03/18)

Prager, Oscar, "El Arte del Paisaje". Revista de Urbanismo. No 6, 2002, https://revistaurbanismo.uchile.cl/index.php/RU/article/view/12905/13189 (última consulta 30/06/20)

Za-yong, Zo, "Los pintores anónimos del alama popular". El correo de la Unesco, Corea “país de la mañana serena”. París, 1978.

Zunzunegui, Santos. "El Perfume del Zen”, Nosferatu. Revista de Cine, vol (11):1993: 18-25, 
https://riunet.upv.es/bitstream/handle/10251/40842/NOSFERATU_011_003.pdf?sequen ce $=4 \&$ isAllowed=y (última consulta, 18/06/20)

Zunzunegui, Santos. "Voces Distantes", Nosferatu. Revista de Cine, vol (25), 1997: 2433,https://riunet.upv.es/bitstream/handle/10251/41047/NOSFERATU_025-

026_004.pdf?sequence=4\&isAllowed=y (última consulta 18/06/20)

Zunzunegui, Santos."La Intertextualidad en el Cine Mudo de Ozu. De los Géneros Clásicos a la Política de lo Efímero", Nosferatu. Revista de Cine, vol (25), 1997: 58-62, Documento descargado de: https://riunet.upv.es/bitstream/handle/10251/41053/NOSFERATU_025026_010.pdf?sequence $=4 \&$ isAllowed $=y$ (última consulta 30/06/20)

\section{Papeles de Trabajo}

Cabañas Moreno, Pilar. "Simplificación de la Forma en el Arte Japonés", Homenaje al Profesor Hernández Perera. Comunidad Autónoma de Canarias y Dirección General del Patrimonio Histórico. 805-811, Madrid: 1992, https://eprints.ucm.es/5972/1/SIMPLificaci\%C3\%B3n de la FORma.pdf

González Linaje, M. Teresa. La Pintura del Paisaje: desde el Taoísmo Chino al Romanticismo Europeo: Paralelismos Plásticos y Estéticos, Universidad Complutense de Madrid, Tesis Doctoral, Madrid, 2005.

Roncero Mayor, Luis, La tradición esotérica taoísta: los fundamentos de la alquimia interior taoísta y sus correspondencias en la alquimia medieval española, Universidad Autónoma de Madrid, Tesis Doctoral, Madrid,

Sawai, Yoshitsugu, "Perspectivas de la naturaleza en culturas de Asia Oriental", Universidad de Tenri, Nara, Galicia y Japón del sol naciente al sol poniente, 2008, https://ruc.udc.es/dspace/bitstream/handle/2183/12905/CC-

98_art_13.pdf?sequence $=1 \&$ isAllowed=y (Última consulta 31/05/20)

Tseng, Huey Chen. Reflexiones sobre el Espacio-Vacío. Un Encuentro entre Occidente y Oriente en el Ámbito del Arte, Universidad de Salamanca, Tesis Doctoral, Salamanca, 2004. 


\section{Páginas Web}

El Perrito Chino, "Fragmentos de estética China". En La dicha Artificial. La Habana Elegante, Segunda Época. http://www.habanaelegante.com/Winter2008/Dicha.html (Última consulta: 01/09/2015)

Gómez de Cadiñanos, P. “Tseng, Huey Chen”. En Vacío y Realidad. Arte Oriental. http://www.espaciotangente.net/Pinceladaunica.html (Última consulta: 01/09/2015)

Bibliodissey. "Japanese Flora". http://bibliodyssey.blogspot.com.es/2007/07/japaneseflora.html (Última consulta: 04/09/15)

JAANUS. Japanese Architecture and Art Net Users System.

http://www.aisf.or.jp/ jaanus/deta/s/sansuiga.htm

Kenneth Spencer Research Library." Art and Science in Japanese Woodblock-Printed Books" en $K \quad U$ Libraries. The University of Kansas. (2010) http://liblamp.vm.ku.edu/spencer/exhibits/easternBotanicals/index.html. (Última consulta 30/06/20)

Khanacademy. "El Arte Japonés: Los formatos de la obras bidimensionales" https://es.khanacademy.org/partner-content/british-museum/Asia1/japan-bm/a/japaneseart-the-formats-of-two-dimensional-works. (Última consulta 04/09/15)

Vives Rego, Javier. "Japón, cultura y arte" https://culturanipon.blogspot.com/ (Última consulta 30/06/20) 


\section{3 - BIBLIOGRAFÍA SOBRE PINTURA CONTEMPORÁNEA}

\section{Libros}

Alarcó, Paloma, Monet y la Abstracción, Catálogo Museo Thyssen Bornemisza. .Madrid: 2010.

Anfam. David. Expresionismo Abstracto. Bilbao: Turner y FMGB Guggenheim Bilbao Museoa, 2017.

Barthes,Roland. Cy Twombly. Berlín: Merve Verlag, 1983.

Calvo Serraller, Francisco. El Arte Contemporáneo. Madrid: Taurus, 2001.

Calvo Serraller, Francisco. El expresionismo Abstracto Americano en las Colecciones Españolas. Museo de Arte Contemporáneo Esteban Vicente, Segovia, 2003.

Costello, Eilenn. Brice Marden. New York: Phaidon Press Inc, 2013.

Dziewier, Yilmaz, Ken Okiishiand Rudolf Sagmeister. Joan Mitchell. Retrospective. Her life and paintings. Verlag der Buchhandlung Walther Konig. 2015.

Emmerling. Leonhard. Jackson Pollock. Köln: Taschen, 2003,

Everitt, Anthony. El expresionismo Abstracto. Barcelona: Editorial Labor S.A. 1984.

Gímenez, Carmen. Cy Twombly, catálogo de la exposición del Museo Guggenheim Bilbao en colaboración con la Tate Modern. Londres. Bilbao: Tf Editores y Museo Guggenheim Bilabo, 2008.

Greenberg, Clement. Arte y Cultura. Barcelona: Paidós Estética, 2016.

Guasch, Anna María et al, Summa Pictórica, de las Vanguardias a la Postmodernidad. Tomo X. Barcelona: Editorial Planeta, 2000.

Marín-Medina, José. Tapies/Meditaciones. Madrid: Ediciones Rayuela, 1976.

Marshall, Richard D. y Tilkin, Danielle. Joan Mitchell, Catálogo de la exposición Ivam Centre Julio Gonzalez, 1997. 
Monet, C. Los Años de Giverny. Correspondencia. Madrid: Turner Publicaciones S.L, 2010.

Sagner- Düchting, Karin. Claude Monet 1840-1926. Una fiesta para la vista. Basilea: Taschen, 1991.

Seitz. W.C. Claude Monet: seasons and moments. Catálogo Exposición del Museum of Modern Art. New York: 1960.

Steinberg, Leo. Other Criteria. Confrontations with Twentieth-Century Art. Chicago: The University of Chicago Press, 2007.

Stuckey, Charles, F. Claude Monet 1840 -1926. Thames and Hudson. The Arte Institute of Chicago. 1995.

Szeemann, Harald. Cy Twombly, Catálogo de la Exposición. Madrid: 1987.

Tàpies, Antoni. El arte contra la estética. Barcelona: Ed Planeta - Agostini. 1986.

Tàpies, Antoni. El Arte y sus lugares. Madrid: Ed Siruela, 1999.

Verlag, Merve. Catálogo de la Exposición de Cy Twombly en el Whitney Museum of Ameican Art. Nueva York. 1979

Wildenstein, Daniel. Monet o el triunfo del Impresionismo. Köln: Taschen/Wildenstein Institute, 2001.

Revistas

Flament, Albert. "Retrospective", en La Revue de Paris, 1930.

Marín-medina, José, "Joan Mitchell. La mujer de Nueva Yorck", Cultural. Diario ABC, Madrid, 1997: 37.

“Old Master's Modern Heirs. The scorned work of Monet's later years inspires a present generation of painters", Revista LIFE, 2 de Diciembre 1957, https://books.google.es/books?id=j1YEAAAAMBAJ\&pg=PA94\&source=gbs toc r\&re dir esc=y\#v=onepage\&q\&f=false en https://www.oldlifemagazines.com/december-021957-life-magazine.html

Sueiras, Ma del Mar. "El espacio en la pintura contemporánea", en ASRI - Arte y Sociedad, Revista de investigación, № 12, 2017 


\section{Páginas Web}

https://www.menil.org/exhibitions/261-works-by-cy-twombly (Última consulta 12/09/20)

Cy Twombly Fundation. http://www.cytwombly.org/ (Última consulta 02/07/20)

Francis Bacon, 1909 - 1992. https://www.tate.org.uk/art/artists/francis-bacon-682 (Última consulta 02/07/20)

Fundación Antoni Tàpies. 30 Anys. https://fundaciotapies.org/la-colleccio/ (última consulta $02 / 07 / 20$ )

Hiroshi Senju Studio, http://www.hiroshisenju.com/exhibitions (última consulta 01/07/20)

\section{Papeles de Trabajo}

The Museum of Modern Art, Exposición Claude Monet: seasons and moments. Notas de prensa, 1960.

Tàpies, Antoni. Los lugares del arte. Fundació Antoni Tàpies. Barcelona: 2010. https://docplayer.es/21323691-Antoni-tapies-los-lugares-del-arte.html (Última consulta 07/05/17) 